\title{
Amancio Amorós Sirvent (1854-1925) y su proyección en la vida musical valenciana
}

\author{
Elena Micó Terol
}

\begin{abstract}
ADVERTIMENT. La consulta d'aquesta tesi queda condicionada a l'acceptació de les següents condicions d'ús: La difusió d'aquesta tesi per mitjà del servei TDX (www.tdx.cat) ha estat autoritzada pels titulars dels drets de propietat intel-lectual únicament per a usos privats emmarcats en activitats d'investigació i docència. No s'autoritza la seva reproducció amb finalitats de lucre ni la seva difusió i posada a disposició des d'un lloc aliè al servei TDX. No s'autoritza la presentació del seu contingut en una finestra o marc aliè a TDX (framing). Aquesta reserva de drets afecta tant al resum de presentació de la tesi com als seus continguts. En la utilització o cita de parts de la tesi és obligat indicar el nom de la persona autora.
\end{abstract}

ADVERTENCIA. La consulta de esta tesis queda condicionada a la aceptación de las siguientes condiciones de uso: La difusión de esta tesis por medio del servicio TDR (www.tdx.cat) ha sido autorizada por los titulares de los derechos de propiedad intelectual únicamente para usos privados enmarcados en actividades de investigación y docencia. No se autoriza su reproducción con finalidades de lucro ni su difusión y puesta a disposición desde un sitio ajeno al servicio TDR. No se autoriza la presentación de su contenido en una ventana o marco ajeno a TDR (framing). Esta reserva de derechos afecta tanto al resumen de presentación de la tesis como a sus contenidos. En la utilización o cita de partes de la tesis es obligado indicar el nombre de la persona autora.

WARNING. On having consulted this thesis you're accepting the following use conditions: Spreading this thesis by the TDX (www.tdx.cat) service has been authorized by the titular of the intellectual property rights only for private uses placed in investigation and teaching activities. Reproduction with lucrative aims is not authorized neither its spreading and availability from a site foreign to the TDX service. Introducing its content in a window or frame foreign to the TDX service is not authorized (framing). This rights affect to the presentation summary of the thesis as well as to its contents. In the using or citation of parts of the thesis it's obliged to indicate the name of the author. 


\title{
AMANCIO AMORÓS SIRVENT (1854-1925) Y SU PROYECCIÓN
}

\author{
EN LA VIDA MUSICAL VALENCIANA
}

\author{
Elena Micó Terol
}

Tesis Doctoral dirigida por:

Dra. D. a María GEMBERO USTÁRROZ 



\title{
AMANCIO AMORÓS SIRVENT (1854-1925) Y SU PROYECCIÓN
}

\section{EN LA VIDA MUSICAL VALENCIANA}

\author{
Tesis Doctoral para optar al Título de Doctora \\ presentada por
}

\section{ELENA MICÓ TEROL}

\author{
Directora: \\ Dra ${ }^{a}$ D. ${ }^{a}$ María Gembero Ustárroz \\ Consejo Superior de Investigaciones Científicas \\ Institución "Milà i Fontanals", Barcelona
}

Tutor:

Dr. D. Jaume Carbonell i Guberna

Departament d' Història de l'Art, Universitat de Barcelona

Barcelona, noviembre de 2011 

A Sixto Micó Revert 



\section{ÍNDICE GENERAL}

\section{Volumen 1}

ESTUDIO

\begin{tabular}{|c|c|}
\hline \multicolumn{2}{|l|}{ Agradecimientos $\ldots \ldots \ldots \ldots \ldots \ldots \ldots \ldots \ldots \ldots \ldots \ldots \ldots$} \\
\hline Abreviaturas y siglas .............. & 7 \\
\hline 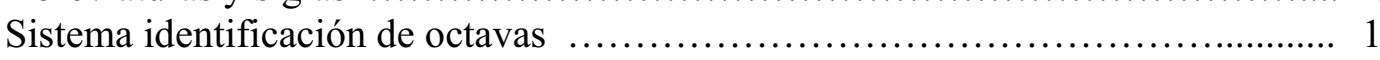 & 11 \\
\hline 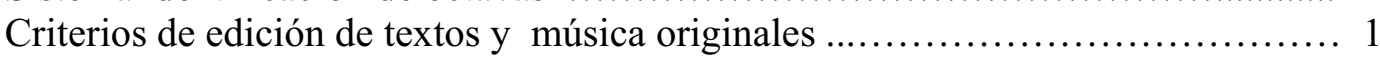 & 11 \\
\hline Introducción ....... & \\
\hline Objetivos y estructura del trabajo & 5 \\
\hline Fuentes empleadas .................. & \\
\hline 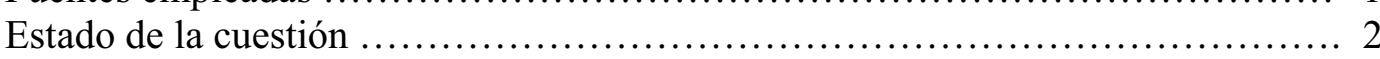 & \\
\hline
\end{tabular}

\section{Capítulo 1}

La actividad musical en Valencia entre 1850 y 1925 ...................... 31

1. El marco urbano, económico y sociopolítico en la Valencia de

Amancio Amorós .................................................. 33

2. El marco cultural y artístico ......................................... 41

2. 1. La Renaixença valenciana ....................................... 41

2. 2. La creación artística ............................................. 47

2. 3. Historiografía e inicios de la Musicología en Valencia ................. 50

3. Enseñanza musical ..................................................... 54

3. 1. Escuelas municipales de música ................................ 56

3. 2. La creación del Conservatorio de Música de Valencia (1879) ............ 58

Los inicios del centro ........................................... 58

Reconocimiento oficial del Conservatorio de Valencia y adscripción de sus enseñanzas al Conservatorio de Madrid (1911) .............. 64

Incorporación del Conservatorio de Valencia a las enseñanzas del Estado (1917) ........................................... 66

3. 3. Academias de música ............................................ 68

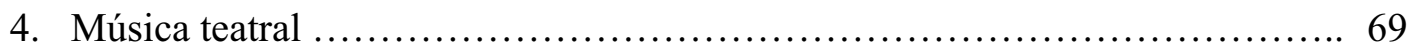

4. 1. Los teatros valencianos ........................................ 69

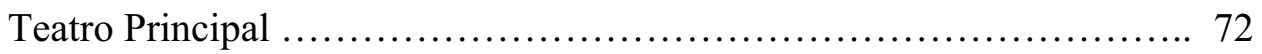

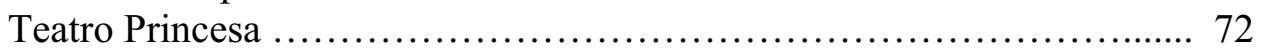

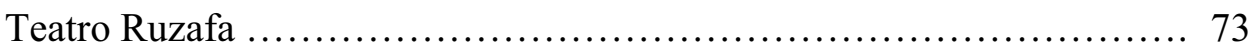

Teatro Apolo .................................................. 74

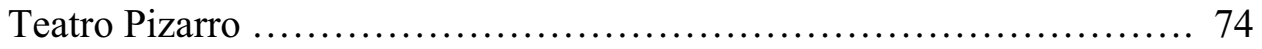

Teatro Circo Colón ............................................ 74

Otros teatros y cafés-teatro .................................... 75

4. 2. Aproximación a las actividades escénicas de los teatros valencianos ..... 76 
5. Sinfonismo y bandas ................................................. 90

5. 1. Actividad sinfónica y orquestas en Valencia ......................... 90

Antecedentes: orquestas de teatro $(1800-1878) \ldots \ldots \ldots \ldots \ldots \ldots \ldots \ldots . \ldots 1$

Orquesta Sociedad de Conciertos de Valencia (1878) ................... 93

Orquesta Goñi (1890) ........................................... 95

Asociación de Profesores de Orquesta de Valencia (1902) ............... 96

Orquesta Sinfónica de Valencia (1916) ............................... 97

5. 2. Bandas de Música .................................................. 98

La Valenciana ..................................................... 102

Banda de 1'Oli [del Aceite] ............................................ 103

Banda de Veteranos de la Libertad .................................... 104

Banda de la Brigada del Cuerpo de Bomberos .......................... 105

Banda Municipal de Valencia ......................................... 106

Otras bandas ...................................................... 107

6. Sociedades culturales valencianas con actividad musical y movimiento coral .. 109

6. 1. Sociedades culturales con actividad musical ........................... 109

El Liceo Valenciano ............................................. 111

La Real Sociedad Económica de Amigos del País de Valencia .......... 112

El Casino/Círculo de Comercio y Fomento o Círculo Valenciano .........117

Ateneo Científico, Artístico y Literario de Valencia ....................... 119

Academia Científico Literaria de la Juventud Católica .................... 120

Ateneo Casino Obrero de Valencia ................................... 122

Lo Rat Penat ................................................................ 125

El Iris ............................................................. 129

Círculo Católico-Obrero Cooperativo de San Vicente Ferrer ..............131

Círculo de Bellas Artes ................................................. 131

Asociación de Profesores Músicos de Santa Cecilia ....................... 132

Círculo Musical/Ateneo Musical ........................................ 134

Centro Escolar y Mercantil ............................................ 135

Centro de Cultura Valenciana o Real Academia de Cultura Valenciana .. 137

6. 2. La Sociedad de Cuartetos Valenciana y otras agrupaciones de cámara .... 139

6. 3. Movimiento coral ...................................................... 142

Orfeón Valenciano (1862) y El Micalet (1893) .......................... 143

Orfeón Republicano La Vega (1893) .....................................149

Francisco Fayos Anthony y la Asociación Coral de la Región

Valenciana $(1895-1897)$..................................... 150

7. Música religiosa ................................................. 155

\section{Capítulo 2}

Amancio Amorós Sirvent (1854-1925): perfil biográfico ................... 173

1. Formación y comienzos profesionales (1854-1889) ......................... 175

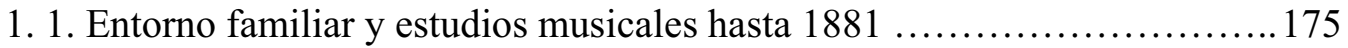

1. 2. Amorós pianista y primeras composiciones $(1882-1889)$............... 180

1. 3. Amorós y la Renaixença valenciana ................................. 192

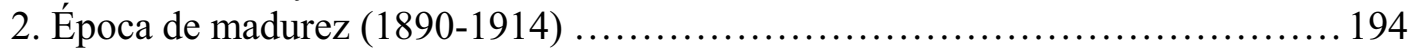


2. 1. Amancio Amorós, figura esencial en la vida musical valenciana ......... 194

2. 2. Amorós y la Comisión de Música Sagrada de Valencia ..................209

3. Nombramientos, honores y últimos años (1915-1925) ........................212

4. La biblioteca personal de Amancio Amorós ................................. 225

\section{Capítulo 3}

1. Centros valencianos en los que trabajó Amorós .............................. 233

1. 1. Institución para la Enseñanza de la Mujer $(1888-1901)$................. 234

1. 2. Colegio-Convento de las Adoratrices (1887-1899) .................... 237

1. 3. Academia Musical Amorós (1890-1893) ...............................246

1. 4. Colegio-Seminario Andresiano de las Escuelas Pías (1906) ............... 247

1. 5. Conservatorio de Música de Valencia (1881-1924) ...................... 249

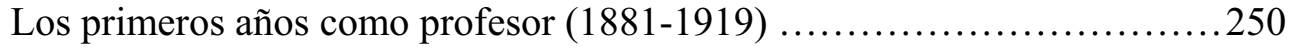

Acceso de Amorós a la dirección del Conservatorio (1919) ................254

Principales logros de Amorós como director (1919-1924) ..................257

a) Solución de los problemas económicos del centro ....................257

b) Gestiones para incorporar el Conservatorio de Música de Valencia al Estado ...............................................259

c) Consolidación y mejora del profesorado ........................... 263

Dimisión de Amorós como Director del Conservatorio ....................... 265

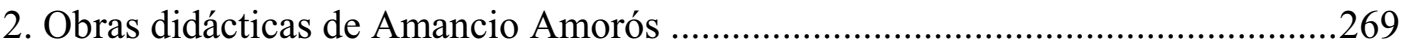

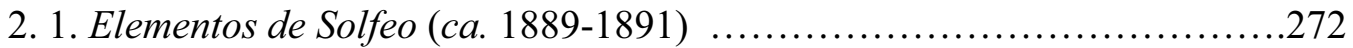

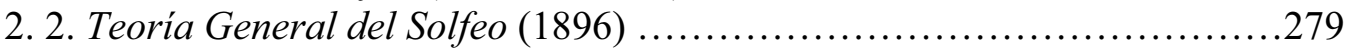

2. 3. Nociones Teóricas de Solfeo (1908-1909) .................................283

2. 4. Lecciones Manuscritas Graduadas (1910) ................................287

2. 5. Lecciones de Solfeo manuscrito a una y dos voces (sf) .................... 292

2. 6. Obras didácticas de armonía, piano y composición ..................... 292

Programa de Amancio Amorós para la asignatura de Armonía del

Conservatorio de Música de Valencia (1916) ........................292

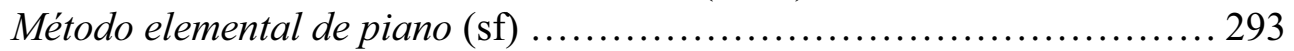

Un posible tratado de composición de Amorós .......................... 294

\section{Capítulo 4}

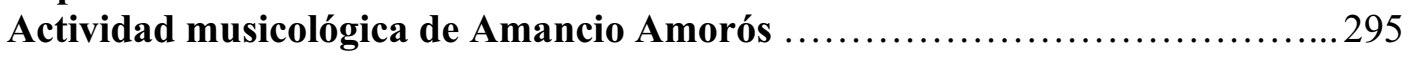

1. Relación entre Amancio Amorós y Felipe Pedrell ..............................297

1. 1. "Impresiones": un homenaje de Amorós a Pedrell ........................297

Circunstancias en las que se conocieron Amancio Amorós y

Felipe Pedrell........................................... 300

Amorós y la Ilustración Musical Hispanoamericana (1888-1896) ...........302

Pedrell, Amorós y la ópera nacional .................................... 303

1. 2. Epistolario entre Felipe Pedrell y Amancio Amorós ....................... 305

2. Creación de la Biblioteca Musical Valenciana (1894-1895) ...................... 310

2. 1. Ejemplares localizados de la Biblioteca Musical Valenciana ................311 
2. 2. Características de la Biblioteca Musical Valenciana .........................313

2. 3. Obras publicadas en la Biblioteca Musical Valenciana ......................318

Obras para canto y piano ................................................. 318

Obras para piano y piano a cuatro manos .............................. 321

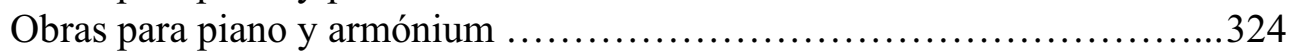

\section{Capítulo 5}

Amorós compositor

1. Coordenadas estéticas de la labor creadora de Amorós: tradición romántica, folklore valenciano y cecilianismo ................................... 329

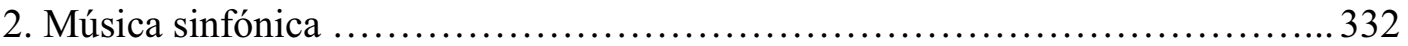

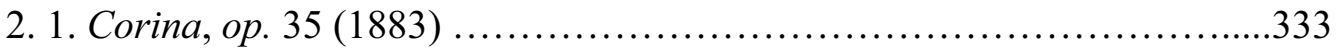

2. 2. Sinfonía para gran orquesta, sobre aires populares de

Valencia y su reino, op. 69 (1890) ................................. 342

3. Música instrumental de cámara ........................................ 348

3. 1. Col.lecció de huit peces per a piano i harmònium sobre motius

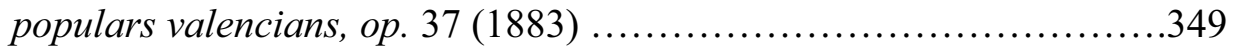

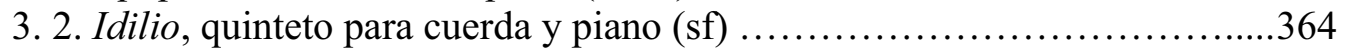

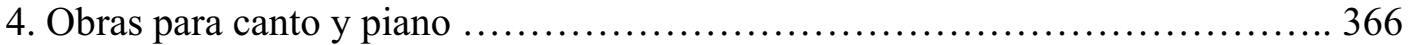

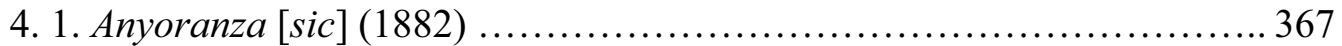

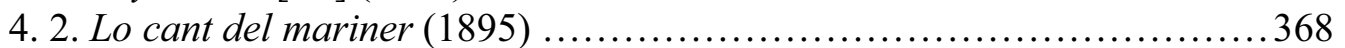

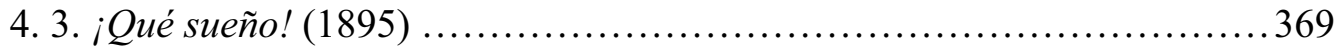

5. Obras para piano ....................................................... 371

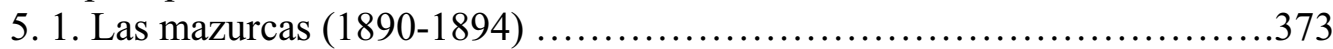

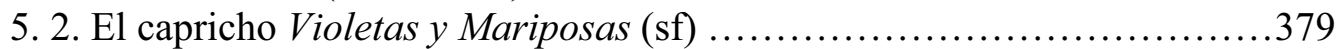

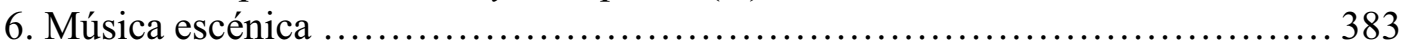

6. 1. Obras no estrenadas: Navegación Submarina (1885) y El tío Sappo (sf) ................................................. 384

6. 2. La zarzuela Los dos esclavos, op. 50 (1886) ............................. 386

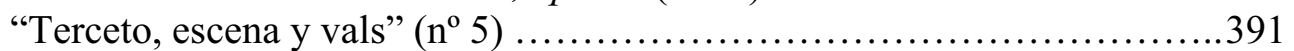

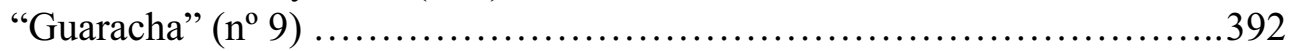

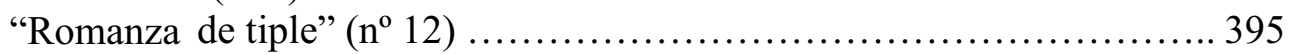

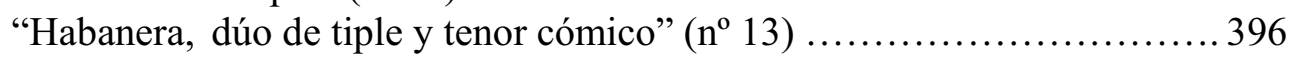

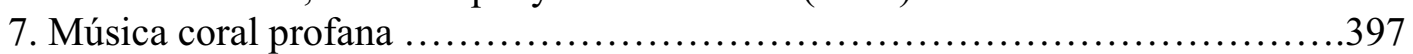

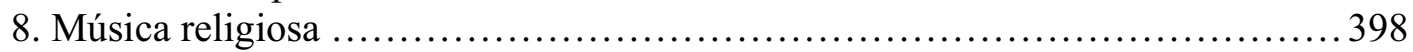

8. 1. La Misa Ceciliana (1912) y otras misas .............................. 400

8. 2. El himno Venid peregrinos, op. 88 (1893) .......................... 407

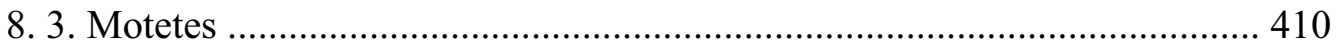

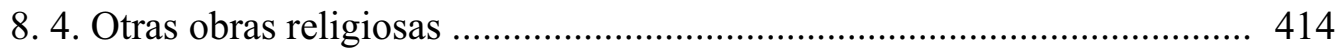

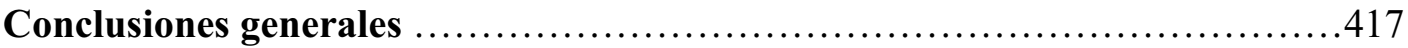


1. Biblioteca de Catalunya (Barcelona) ....................................435

2. Archivo Nacional de Catalunya ......................................... 437

3. Registro Civil de Sant Cugat del Vallés (Barcelona) ....................... 437

4. Archivo Histórico Municipal de Valencia ...................................438

5. Archivo del Conservatorio Superior de Música de Valencia ................. 439

6. Archivo de la Real Sociedad Económica de Amigos del País de Valencia ... 440

7. Archivo Histórico de la Universidad de Valencia .............................441

8. Archivo de la Real Academia de Cultura Valenciana (Centro de Cultura Valenciana) ................................................ 442

9. Archivo del Real Colegio del Corpus Christi de Valencia ...................442

10. Archivo Diocesano de Valencia ..................................... 442

11. Biblioteca Musical de Compositores Valencianos del Ayuntamiento de Valencia ......................................................... 442

12. Biblioteca Municipal de Valencia ..................................... 443

13. Biblioteca Valenciana (antiguo Monasterio de San Miguel de los Reyes de Valencia) .................................................. 443

14. Archivo Municipal de Agullent (Valencia) .............................. 443

15. Archivo Parroquial de San Bartolomé Apóstol de Agullent (Valencia) ....... 443

16. Archivo Parroquial de El Salvador de Cocentaina (Alicante) .................443

17. Archivo particular de Vicente Fuentes (Bétera, Valencia) ....................443

18. Archivo del Real Conservatorio de Música y Declamación de Madrid ....... 444

19. Real Academia de Bellas Artes de San Fernando en Madrid ................. 444

20. Archivo de la Sociedad General de Autores y Editores en Madrid ............445

21. Biblioteca Nacional de España en Madrid ................................... 445

22. Fuentes hemerográficas ............................................... 446

23. Fuentes jurídicas .................................................. 447

Bibliografía

Índice de ilustraciones

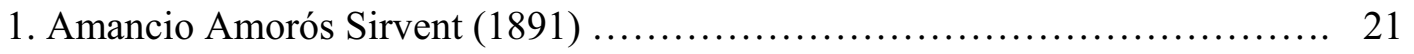

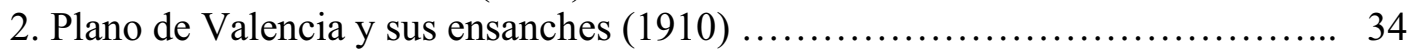

3. Amancio Amorós Sirvent (1911) ....................................... 66

4. Plano de situación de algunos teatros estables y desaparecidos

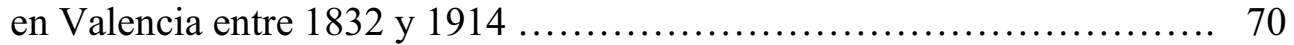

5. Cartel de la Feria de Valencia (1898) ..................................... 128

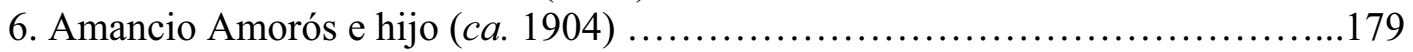

7. La familia Amorós en Bétera, verano de 1916 .............................. 180

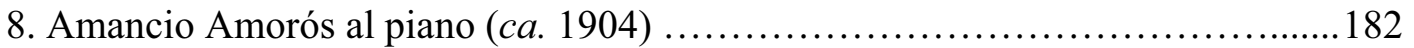

9. Anuncio de la Academia Musical Amorós ...................................... 196

10. Autógrafo de Amancio Amorós explorando combinaciones de su nombre y apellidos para formar el pseudónimo "Marco Antonio Verzenni" 
11. Amancio Amorós en una velada musical del Centro Escolar y

Mercantil (1917) ......................................................... 212

12. Amancio Amorós y su esposa Consuelo Barra (1924) ........................... 219

13. Amancio Amorós jugando al ajedrez y su esposa Consuelo Barra (1924) ......220

14. Amancio Amorós, Consuelo Barra, Teresa Portolés, José Amorós, Teresa Amorós y Consuelo Amorós (1924)...................................2220

15. Teresa Portolés, Consuelo Barra, Amancio Amorós, Teresa Amorós, José Amorós y Consuelo Amorós (1924)............................... 221

16. Monasterio de San Cugat del Vallés ........................................ 222

17. Esquela de Amancio Amorós, 1925 ............................................223

18. Plano de situación de los centros en los que Amorós fue

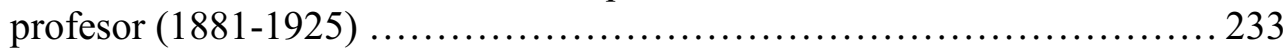

19. Casa de las Adoratrices y Convento de San Gregorio de Valencia, derribados en 1913 ................................................. 238

20. Convento de las Madres Adoratrices, postal de los años 20 (siglo XX) ....... 239

21. Autores de la música y texto de Las Siete Palabras (1890) ..................... 244

22. Anuncio de la Academia Preparatoria de Amancio Amorós .................... 247

23. Amancio Amorós Sirvent, óleo (autor desconocido) ..........................268

24. Amancio Amorós, Elementos de solfeo, $1^{\mathrm{a}}$ ed. (ca. 1889-91) ................... 273

25. Amancio Amorós, Teoría General del Solfeo, $1^{\mathrm{a}}$ ed. (1896) .....................280

26. Amancio Amorós, Nociones Teóricas de Solfeo, primer curso, 2a ed. (1911) ... 284

27. Amancio Amorós, Nociones Teóricas de Solfeo, segundo curso, $1^{\mathrm{a}}$ ed. (1908) 285

28. Amancio Amorós, Nociones Teóricas de Solfeo, tercer curso, $1^{\text {a }}$ ed. (1909) ....285

29. Amancio Amorós, Nociones Teóricas de Solfeo, $2^{\circ}$ curso, p. 11 ................ 286

30. Amancio Amorós, Nociones Teóricas de Solfeo, $2^{\circ}$ curso, pp. 33-34 ........... 286

31. Amancio Amorós, Lecciones Manuscritas Graduadas, segundo curso, $1^{\mathrm{a}}$ ed. (1910)........................................................ 288

32. Amancio Amorós, Lecciones Manuscritas Graduadas, tercer curso, $2^{\mathrm{a}}$ ed. (1914) .............................................................289

33. Amancio Amorós, Lecciones Manuscritas Graduadas, $3^{\text {er }}$ curso, p. 38 ......... 291

34. Decoración de cubierta de la Biblioteca Musical Valenciana (1894-1895) ........ 313

35. Anuncio de Casa Laviña, sucesor Antonio Sánchez Ferrís ..................... 314

Índice de tablas

1. Junta Directiva del Conservatorio de Música de Valencia en 1879 ........... 61

2. Claustro de profesores del Conservatorio de Valencia en 1879 ................ 62

3. Claustro de profesores numerarios del Conservatorio de Música de

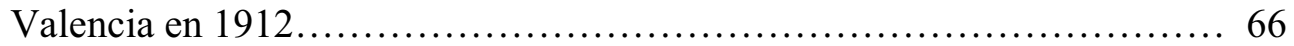

4. Selección representativa de teatros y cafés-teatro de Valencia a finales del siglo XIX y principios del XX .................................. 71

5. Compositores valencianos de música escénica en la primera mitad del siglo XIX ............................................ 77

6. Representaciones operísticas en el Teatro Principal de Valencia. Selección de las temporadas 1890-1924. 
7. Representaciones de zarzuela en el Teatro Princesa. Selección de las

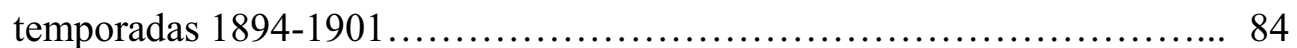

8. Estrenos en el Teatro Ruzafa de Valencia, 1900-1910 (selección) ............... 87

9. Bandas civiles documentadas en Valencia (ca. 1850-1925) ..................... 102

10. Principales sociedades culturales con actividad musical en

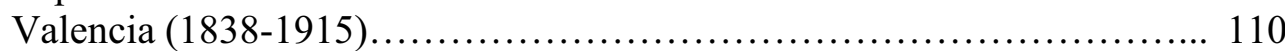

11. Programa de dos conciertos sacros organizados por la Real Sociedad Económica de Amigos del País de Valencia en 1887 ..................... 116

12. Algunos intérpretes y compositores escuchados en los conciertos de la Real Sociedad Económica de Amigos del País de Valencia (1872-1886) ........ 117

13. Presidentes de Lo Rat Penat y de su sección de Música entre 1878 y 1904 ... 129

14. Programa interpretado en el Teatro Principal de Valencia el 29-X-1879, con motivo de una función extraordinaria de la sociedad El Iris........... 130

15. Programa interpretado en las veladas literario-musicales del Centro Escolar y Mercantil de Valencia ..................................... 137

16. Algunas composiciones interpretadas por el Orfeón El Micalet en 1895-97 ...148

17. Coros documentados en la Comunidad Valenciana (1893-1898)............. 153

18. Coros de Valencia activos entre 1898 y 1910 .............................. 155

19. Obras contenidas en el Álbum Musical de Amancio Amorós ...................... 184

20. Obras contenidas en el Álbum Pianístico de Amancio Amorós ................ 185

21. Miembros de la Comisión de Música Sagrada de Valencia en 1913 .............209

22. Compositores de Las Siete Palabras, con texto de José Bau, interpretadas en el Convento de las Adoratrices de Valencia en 1889..... 241

23. Profesores numerarios del Conservatorio de Música de Valencia en 1920 ......264

24. Profesores auxiliares interinos del Conservatorio de Música de

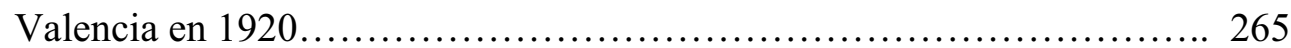

25. Programa Oficial de Solfeo de la Escuela Nacional de Música (1876) ......... 276

26. Programa Oficial de Solfeo de la Escuela Nacional de Música (1898) .......... 281

27. Escritos heortásticos al Maestro Pedrell ......................................... 299

28. Obras publicadas en la Biblioteca Musical Valenciana, revista dirigida por Amancio Amorós................................................ 316

29. Salvador Giner, Balada de Blanca del melodrama El Rayo de Sol (1894). Esquema analítico ...................................................... 319

30. Manuel Chulvi, La prece della giannina (sf). Esquema analítico .............. 320

31. Manuel Penella Raga, Cançoneta de la mare. Esquema analítico ...............321

32. Roberto Segura, Cunera (Canzonetta para piano). Esquema analítico ................322

33. Roberto Segura, Prega (1891-92). Esquema analítico ......................................322

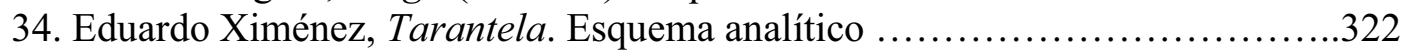

35. Juan Bautista Plasencia, Canzonetta. Esquema analítico ........................323

36. Manuel Penella Raga, La fiesta del trabajo. Esquema analítico .................324

37. José $\mathrm{M}^{\mathrm{a}}$ Úbeda Montés, ¡Illusión!. Esquema analítico ..............................324

38. Francisco J. Blasco, A la Reina de la fiesta. Esquema analítico ..................325

39. Amancio Amorós, Corina, op. 35, Sinfonía para orquesta (1883). Esquema analítico.................................................. 338

40. Amancio Amorós Sirvent, Sinfonía para gran orquesta, op. 69, compuesta sobre aires populares de Valencia y su reino (1890). Esquema analítico.....348 
41. Amancio Amorós, Col.lecció de huit peces per a piano i harmònium sobre motius populars valencians, op. 37 (1883). Esquema analítico............ 350

42. Amancio Amorós, Idilio (sf), quinteto para cuerda y piano.

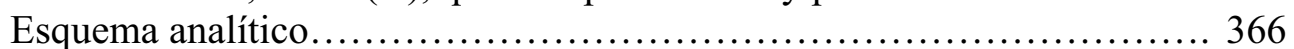

43. Amancio Amorós, Anyoranza [sic] (1882). Esquema analítico ..................368

44. Amancio Amorós, Mazurca en Re bemol Mayor (1890). Esquema analítico ... 374

45. Amancio Amorós, Mazurca en Sol Mayor para piano (1890).

Esquema analítico...................................................... 376

46. Amancio Amorós, Mazurca en Re menor para piano (1891).

Esquema analítico..................................................... 377

47. Amancio Amorós, Mazurca en Fa Mayor. Esquema analítico ...................379

48. Amancio Amorós, Violetas y mariposas, capricho para piano (sf).

Esquema analítico................................................. 382

49. Materiales de la ópera Saffo de Pacini utilizados por Amancio Amorós en la parodia El tío Sappo (sf)........................................386

50. Amancio Amorós, Los dos esclavos, zarzuela en tres actos. Letra de Antonio Roig Civera. Principales personajes de la obra y reparto en su estreno (Valencia, 1886) ....

51. Amancio Amorós. $N^{o} 5$, Terceto, escena y vals de Los dos esclavos, op. 50 (1886). Reducción para piano (Maguncia, Schott, sf).

Esquema analítico

52. Amancio Amorós. $N^{o}$ 9, Guaracha de Los dos esclavos, op. 50 (1886).

Reducción para piano (Maguncia, Schott, sf). Esquema analítico.

53. Amancio Amorós. $N^{o} 12$, Romanza de Los dos esclavos, op. 50 (1886).

Reducción para canto y piano (Maguncia, Schott, sf). Esquema analítico...396

54. Amancio Amorós. $N^{o} 13$, Habanera de Los dos esclavos, op. 50 (1886).

Reducción para canto y piano (Maguncia, Schott, sf). Esquema analítico...397

55. Amancio Amorós, Misa Ceciliana (1912). Esquema analítico ..................403

56. Amancio Amorós, Venid Peregrinos "Pequeño Himno popular religioso", op. 88 (1893). Esquema analítico ......................................... 409

57. Amancio Amorós, O salutaris Hostia, op. 61 (1891), terceto [sic] para voces y órgano. Esquema analítico .................................... 412

58. Amancio Amorós, Acepta Virgen Pura (sf). Esquema analítico ............... 416

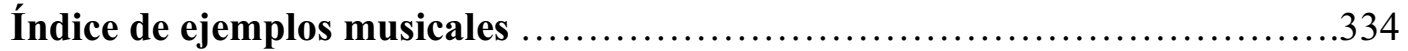

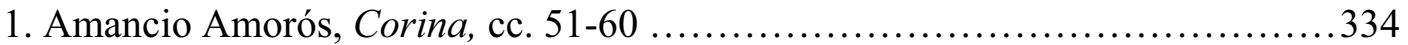

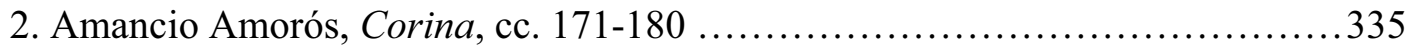

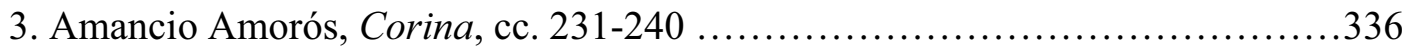

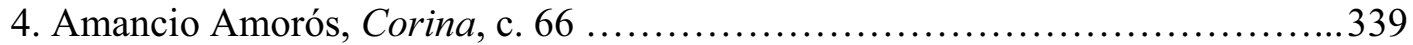

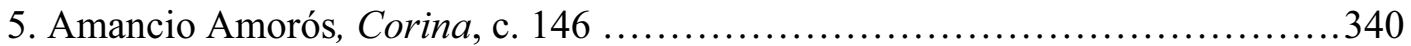

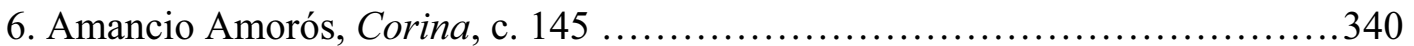

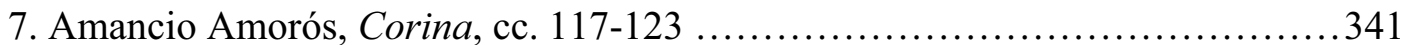

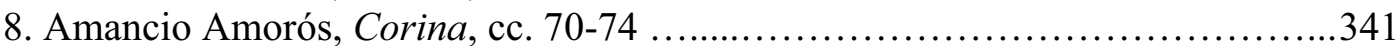

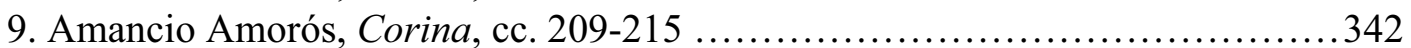


10. Amancio Amorós, Corina, cc. 222-226

11. Amancio Amorós, Sinfonía para gran orquesta, cc. 41-45 .................. 345

12. Amancio Amorós, Sinfonía para gran orquesta, cc. 57-60 ......................345

13. Amancio Amorós, Sinfonía para gran orquesta, cc. 2-4 ........................345

14. Amancio Amorós, Sinfonía para gran orquesta, cc. $92-95$......................346

15. Amancio Amorós, Sinfonía para gran orquesta, cc. 117-121 ...................347

16. Amancio Amorós, Sinfonía para gran orquesta, cc. 125-129 ...................347

17. Amorós, Col.lecció de huit peces per a piano i harmònium sobre motius populars valencians, $\mathrm{n}^{\circ} 1$, Melodía característica del dolçainer valencià davant la processó, cc. $23-27$..................................... 352

18. Melodía para acompañar las imágenes en las procesiones (1873),

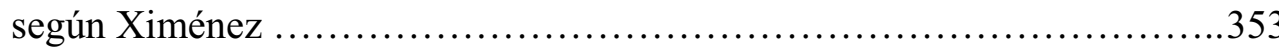

19. Amancio Amorós, Col.lecció de huit peces per a piano i harmònium sobre motius populars valencians, $\mathrm{n}^{\circ} 1$, Melodía característica del dolçainer valencià davant la processó, cc. 12-22

20. Amancio Amorós, Col.lecció de huit peces per a piano i harmònium sobre motius populars valencians, $\mathrm{n}^{\mathrm{o}} 2$, Melodía característica del dolçainer valencià davant la processó, cc. 7-16

21. Amancio Amorós, Col.lecció de huit peces per a piano i harmònium sobre motius populars valencians, $\mathrm{n}^{\mathrm{0}} 2$ Melodía característica del dolçainer valencià davant la processó, cc. 22-29 ...............................354

22. Melodía original de la Mangrana recogida por Eduardo Ximénez 355

23. Amancio Amorós, Col.lecció de huit peces per a piano i harmònium sobre motius populars valencians, $\mathrm{n}^{\mathrm{0}} 3$, Dansa valenciana de la Ribera del Xúquer, cc. 38-46...

24. Amancio Amorós, Col.lecció de huit peces per a piano i harmònium sobre motius populars valencians, $\mathrm{n}^{\circ} 3$, Dansa valenciana de la Ribera del Xúquer, cc. 1-4

25. Amancio Amorós, Col.lecció de huit peces per a piano i harmònium sobre motius populars valencians, $\mathrm{n}^{\mathrm{o}} 3$, Dansa valenciana de la Ribera del Xúquer, cc. 4-8

26. La Xàquera Vella, melodía original recogida por Eduardo Ximénez

27. Amancio Amorós, Col.lecció de huit peces per a piano i harmònium sobre motius populars valencians, $\mathrm{n}^{\circ} 4$, Dansa dels gegants (vulgo Xàquera Vella), cc. 1-2

28. Amancio Amorós, Col.lecció de huit peces per a piano i harmònium sobre motius populars valencians, $\mathrm{n}^{\circ} 4$, Dansa dels gegants (vulgo Xàquera Vella), cc. 2-4

29. Tema original de la Danza dels nanos, recogida por Eduardo Ximénez .........359

30. Amancio Amorós, Col.lecció de huit peces per a piano i harmònium sobre motius populars valencians, $\mathrm{n}^{\circ}$ 5, Dansa dels nanos, cc. 5-9 .......... 360

31. Fandanguet de la Danza dels nanos, recogido por Eduardo Ximénez .......... 360

32. Amorós, Col.lecció de huit peces per a piano i harmònium sobre motius populars valencians, $\mathrm{n}^{\mathrm{o}}$ 5, Dansa dels nanos, cc. 49-53 ........... 360

33. Melodía de la Danza Valenciana de la Vall d'Albaida (ca. 1898-1900), recogida por López-Chavarri 
34. Amancio Amorós, Col.lecció de huit peces per a piano i harmònium sobre motius populars valencians, $\mathrm{n}^{\mathrm{0}} 6$, Dansa valenciana de la Vall d'Albaida, cc. 41-53

35. Amancio Amorós, Col.lecció de huit peces per a piano i harmònium sobre motius populars valencians, $\mathrm{n}^{\circ} 6$, Dansa valenciana de la Vall d'Albaida, cc. 2-4

36. Amancio Amorós, Col.lecció de huit peces per a piano i harmònium sobre motius populars valencians, $\mathrm{n}^{\circ} 5$, Dansa valenciana de la Vall d'Albaida, cc. 70-77

37. Amorós, Idilio, cc. 98-105 ............................................... 365

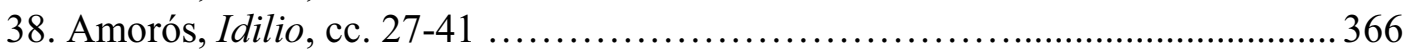

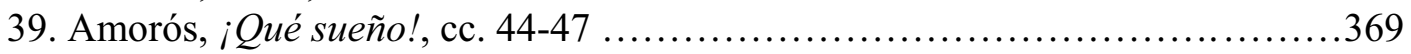

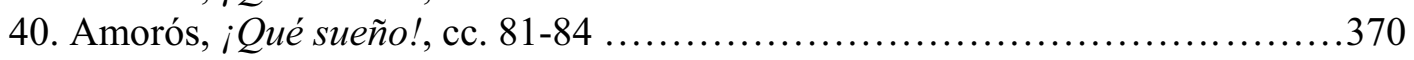

41. Amorós, Mazurca en Re bemol Mayor, cc. 45-49 .............................. 374

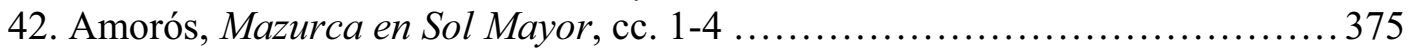

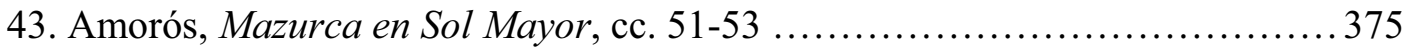

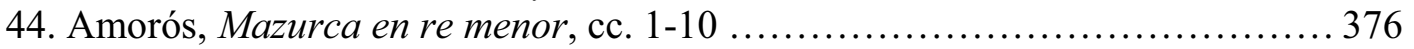

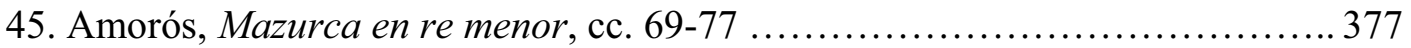

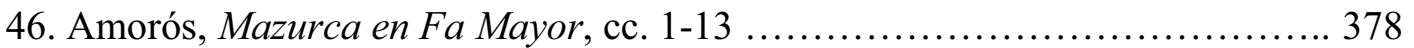

47. Amorós, Mazurca en Fa Mayor, cc. 50-56 ...................................... 378

48. Amorós, Mazurca en Fa Mayor, cc. 70-77 .................................. 379

49. Amorós, Violetas y Mariposas, cc. 21-28 .................................. 381

50. Amorós, Violetas y Mariposas, cc. 62-69 .................................. 381

51. Amancio Amorós, Guaracha de Los dos esclavos, op. 50, cc. 14-16 .......... 394

52. Amancio Amorós, Guaracha de Los dos esclavos, op. 50, cc. 47-50 .......... 394

53. Amorós, Misa Ceciliana, cc. 1-9 ........................................................... 404

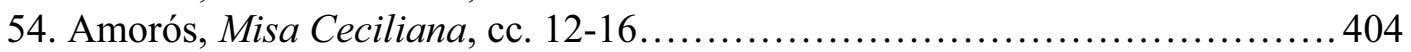

55. Amorós, Misa Ceciliana, Kyrie, cc. 9-12 .................................. 405

56. Amorós, Misa Ceciliana, Gloria, cc. 1-9 .................................................... 405

57. Amorós, Misa Ceciliana, Credo, cc. 1-16 ............................................... 405

58. Amorós, Misa Ceciliana, Credo, cc. 57-62 .............................................. 406

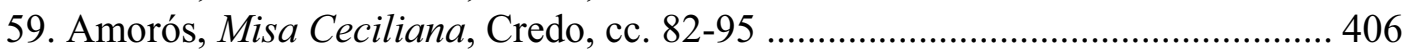

60. Amorós, Venid Peregrinos, cc. 40-48 ............................................................ 410

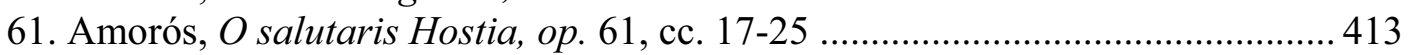

62. Amorós, O salutaris Hostia, op. 61, cc. 42-43 ............................ 413

63. Amorós, O salutaris Hostia, op. 61, cc. 45-48 .............................................. 414 


\section{Volumen 2 \\ (en CD-ROM) \\ CATÁLOGO, EDICIONES MUSICALES, APÉNDICES}

1. Catálogo de la producción musical de Amancio Amorós ................... 1

2. Edición de composiciones de Amancio Amorós (selección) .................. 65

Corina, op. $35(1883)$............................................ 67

Sinfonía para gran orquesta, compuesta sobre aires populares de

Valencia y su reino, op. $69(1890)$....................................113

Col.lecció de huit peces per a piano i harmònium sobre

motius populars valencians, op. 37 (1883) .............................139

Idilio, quinteto para cuerda y piano (sf) …............................ 187

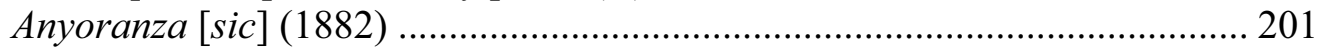

Mazurca en Re bemol Mayor (1890) ...................................... 207

Mazurca en Sol Mayor (1890) .............................................. 213

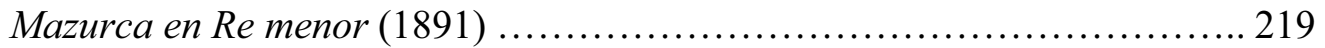

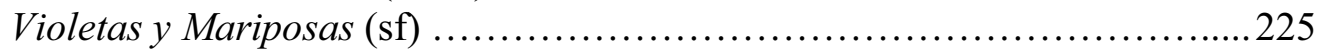

Zarzuela Los dos esclavos, op. 50 (1886)

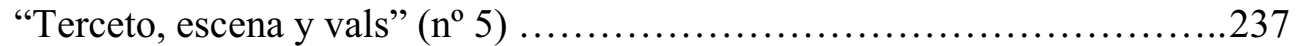

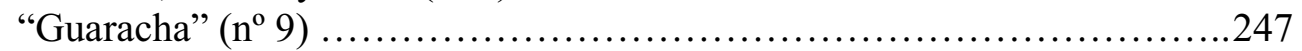

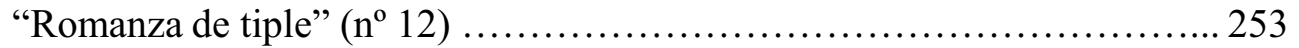

"Habanera, dúo de tiple y tenor cómico" (no 13) ............................261

Misa Ceciliana (1912) .......................................................269

Venid peregrinos, op. 88 "Himno popular religioso" (1893) ...........................321

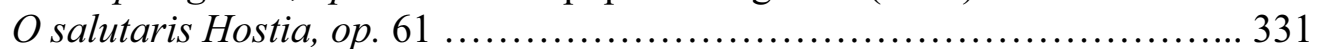

Recibid mil parabienes, "Salutación al Patriarca San José" (sf) ............... 343

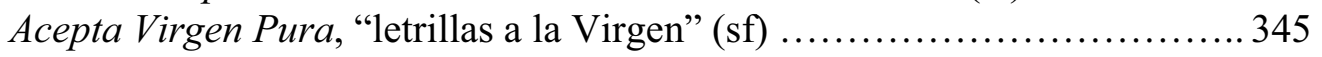

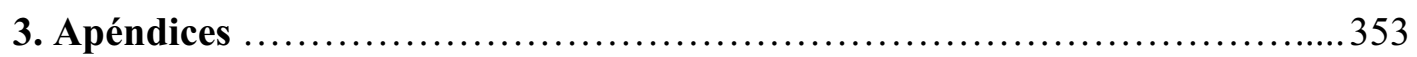

1. Inventario de la biblioteca personal de Amancio Amorós ........................355

2. Obras publicadas en la Biblioteca Sacro Musical, volúmenes 1 y $2(1891-1892)$......................................... 367

3. Texto del artículo "Amancio Amorós” de Eduardo Serrano (1891) ................. 371

4. Crónica de la Conmemoración del X Aniversario del Conservatorio de Valencia $(1890)$.................................................. 377

5. Relación de obras didácticas de Amancio Amorós ............................ 381

6. Lecciones de Solfeo manuscrito a una y dos voces con acompañamiento de armónium y piano (sf) de Amancio Amorós: edición crítica ...............383

7. Elementos de Solfeo, $3^{\mathrm{a}}$ ed., (1901) de Amancio Amorós: resumen del contenido 
8. Teoría General del Solfeo, $1^{\mathrm{a}}$ ed., (1896) de Amancio Amorós:

resumen del contenido

9. Nociones Teóricas de Solfeo, primer curso, de Amancio Amorós,

$2^{\mathrm{a}}$ ed., (1911): resumen del contenido....

10. Nociones Teóricas de Solfeo, segundo curso, de Amancio Amorós,

$1^{\text {a }}$ ed., (1908): resumen del contenido

11. Nociones Teóricas de Solfeo, tercer curso, de Amancio Amorós,

$1^{\text {a }}$ ed., (1909): resumen del contenido

12. Lecciones Manuscritas Graduadas, $2^{\circ}$ curso, de Amancio Amorós,

$1^{\mathrm{a}}$ ed., (1910): resumen del contenido

13. Lecciones Manuscritas Graduadas, $3^{\circ}$ curso, de Amancio Amorós,

$2^{\mathrm{a}}$ ed., (1914): resumen del contenido

14. Método de solfeo y principios de canto, aplicables en las escuelas y colegios de Pascual Pérez Gascón (1857): resumen del contenido

15. Método de solfeo sin acompañamiento, primer curso (1845)

de Hilarión Eslava: resumen del contenido

16. Programa de Amancio Amorós para la asignatura de Armonía del Conservatorio de Música de Valencia (1916)

17. Biblioteca Musical Valenciana: reproducción de los volúmenes 1-3 (1894-1895)

18. Cartas de Amancio Amorós a Felipe Pedrell (1896-1915) 503

19. Hispaniae Schola Musica Sacra: portada y lista de suscriptores de los volúmenes 1-3

20. Texto del artículo "Impresiones" (1911) de Amancio Amorós

21. Sinopsis argumental de la zarzuela Los dos esclavos de Amancio Amorós .

22. Crónicas periodísticas de la peregrinación a la Ermita de San Vicente Ferrer de Agullent (Valencia) en 1893 


\title{
AMANCIO AMORÓS SIRVENT (1854-1925) Y SU PROYECCIÓN
}

\author{
EN LA VIDA MUSICAL VALENCIANA
}

Elena Micó Terol

Volumen I

ESTUDIO

Tesis Doctoral dirigida por:

Dra. D. ${ }^{a}$ María GEMBERO USTÁRROZ 



\section{Agradecimientos}

En primer lugar deseo expresar mi máxima gratitud a la Dra. María Gembero Ustárroz, Científica Titular del CSIC en la Institució Milà i Fontanals de Barcelona y directora de esta Tesis Doctoral, por su confianza en mí, por creer que este proyecto era posible desde sus inicios, por su dedicación, guía constante y palabras de aliento, pero especialmente por su rigor profesional y sus numerosos consejos y sugerencias durante los años de elaboración de esta Tesis, a pesar de la distancia geográfica que separa nuestros lugares de residencia; sin su ayuda este Trabajo no hubiera sido posible. Agradezco al Dr. Xosé Aviñoa, coordinador del Programa de Doctorado Música en la España Contemporánea de la Universidad de Barcelona y al Dr. Jaume Carbonell, Tutor de esta Tesis, su colaboración e inestimable ayuda en cuestiones administrativas. Mi gratitud también al Dr. Emili Casanova Herrero, profesor de la Universidad de Valencia y Académico de la Academia Valenciana de la Lengua por sus consejos para la transcripción de textos valencianos contemporáneos.

Debo un agradecimiento especial a Margarita Amorós Portolés, nieta de Amancio Amorós, por acogerme generosamente en su casa y por ofrecerme valiosa información sobre la familia del compositor, ya que, aunque no conoció a su abuelo, puso a mi disposición diversas fotografías y recuerdos de Amancio Amorós y me transmitió anécdotas e informaciones sobre acontecimientos familiares relacionados con él a los que no habría podido acceder por otras vías.

La ayuda de Joana Crespí (†), directora de la Sección de Música de la Biblioteca de Catalunya, fue esencial en los inicios de esta investigación. Ella me facilitó el inventario de obras manuscritas de Amancio Amorós y me indicó los pasos a seguir para localizar escritos y otras obras impresas del autor en esa institución catalana. Agradezco 
también la constante ayuda recibida de Rosa Montalt, actual directora de la sección de Música de la Biblioteca de Catalunya.

Otras muchas personas me han ayudado directa o indirectamente en la realización de este trabajo, entre ellas Vicente Fuentes, de Bétera (Valencia), que me facilitó la consulta de manuscritos autógrafos de Amancio Amorós conservados en su archivo particular; José María Bru, de Agullent (Valencia), compositor y fundador en 1984 de la Escuela de música "Amancio Amorós Sirvent”, y Salvador Astruells, musicólogo, quienes me ofrecieron material de consulta de sus bibliotecas personales; José Manuel Miñana, Jefe de Estudios del Conservatorio Superior de Música de Valencia, que facilitó mis consultas de documentación en esa institución; Elena Magallanes, Archivera del Real Conservatorio Superior de Música de Madrid, que me atendió amablemente; M ${ }^{\mathrm{a}}$ Luz González Peña, del Archivo de la Sociedad General de Autores y Editores de España, que me facilitó las partituras y métodos de solfeo de Amorós conservados en dicha institución; Inés López Moral, encargada del Archivo Diocesano de Valencia; Vicente Ferrer, del Archivo del Corpus Christi de Valencia; $M^{\mathrm{a}}$ Carmen Boix, de la Real Sociedad Económica de Amigos del País de Valencia; y Mercedes Rojas, encargada de la Hemeroteca de la Biblioteca Valenciana.

Agradezco sinceramente a todo el personal de las bibliotecas, hemerotecas y archivos consultados su paciencia para atender mis peticiones. Deseo mencionar especialmente al personal de la Biblioteca de Catalunya (Barcelona), Archivo Nacional de Catalunya, Biblioteca Valenciana (Valencia), Biblioteca y Hemeroteca Municipal de Valencia, Archivo Histórico Municipal de Valencia, Biblioteca Nacional de Madrid, Biblioteca y Archivo de la Universidad de Valencia, Biblioteca de la Real Academia de Bellas Artes de San Fernando (Madrid) y a los párrocos José Manuel Vidal y Benjamín Olivares de San Bartolomé Apóstol de Agullent (Valencia) y Ramón Micó Colomer de El 
Salvador de Cocentaina (Alicante). Mis amigos filólogos Manuel Requena y Marisol Benavent atendieron mis dudas en cuestiones de gramática latina.

Finalmente, agradezco a mis amigos más cercanos y a mi familia, especialmente a mis hijos Daniel y Raúl, su apoyo y comprensión incondicionales durante el largo proceso de elaboración de esta Tesis. Gracias particularmente a Daniel por solucionar mis problemas informáticos y por animarme a seguir, tanto en los buenos como en los malos momentos. Deseo también recordar aquí de manera especial a mi padre, Sixto Micó Revert, por su sacrificio, entrega y dedicación para que yo pudiese iniciar mis estudios musicales, y por enseñarme el valor del esfuerzo y de la lucha diaria, fruto de los cuales son estas páginas, de las que él estuvo pendiente hasta el último momento. 



\section{Abreviaturas y siglas}

\begin{tabular}{|c|c|}
\hline A & contralto \\
\hline AA.VV & Autores varios \\
\hline ac. & acompañamiento \\
\hline arm. & armónium \\
\hline arp. & arpa \\
\hline b. & bajo ( instrumento) \\
\hline B. & bajo (voz) \\
\hline Bar. & barítono \\
\hline bat. & batería \\
\hline bd. & bombardino \\
\hline bo. & bombo \\
\hline$B O A V$ & Boletín Oficial del Arzobispado de Valencia \\
\hline c. / cc. & compás/ compases \\
\hline C. & carpeta \\
\hline Camp. & campana \\
\hline cb. & contrabajo \\
\hline cl. & clarinete \\
\hline Co. & coro \\
\hline coord. & coordinador \\
\hline Covb. & coro de voces blancas \\
\hline Covi. & coro voces infantiles \\
\hline crn. & cornetín \\
\hline cu. & cuerda \\
\hline dir. & director \\
\hline$D M E H$ & Diccionario de la Música Española e Hispanoamericana \\
\hline$D M V$ & Diccionario de la Música Valenciana \\
\hline$E: A G$ & Archivo de la Parroquia de San Bartolomé Apóstol de Agullent \\
\hline$E: A G m$ & Archivo Municipal de Agullent \\
\hline E:Ban & Archivo Nacional de Cataluña \\
\hline$E: B c$ & Biblioteca de Catalunya (Barcelona) \\
\hline$E: C O s$ & Archivo de la Parroquia El Salvador de Cocentaina (Alicante) \\
\hline$E: M b a$ & Archivo Real Academia de Bellas Artes de San Fernando en Madrid \\
\hline$E: M c$ & Biblioteca y Archivo del Real Conservatorio de Música de Madrid \\
\hline$E: M n$ & Biblioteca Nacional (Madrid) \\
\hline E:Msa & Archivo Sociedad General de Autores y Editores en Madrid \\
\hline$E: V A a$ & Archivo Histórico Municipal de Valencia \\
\hline$E:$ Vaac & Archivo Academia de Cultura Valenciana \\
\hline$E: V A b m$ & Biblioteca Musical de Compositores Valencianos (Valencia) \\
\hline$E: V A b v$ & Biblioteca Valenciana \\
\hline$E: V A c m$ & Archivo Conservatorio Superior de Música de Valencia \\
\hline E:Vacp & Archivo del Corpus Christi (Valencia) \\
\hline E:VAseap & Archivo Real Sociedad Económica de Amigos del País de Valencia \\
\hline$E: V A m$ & Biblioteca Municipal de Valencia \\
\hline$E: V A u$ & Archivo Histórico Universidad de Valencia \\
\hline Ed. & editorial \\
\hline & editor, edición \\
\hline & fagot \\
\hline fi. & figle \\
\hline
\end{tabular}




\begin{tabular}{|c|c|}
\hline fin. & flautín \\
\hline fl. & flauta \\
\hline fsc. & fliscorno \\
\hline$H M C V$ & Historia de la Música de la Comunidad Valenciana \\
\hline$H M C V B$ & Historia de la Música Catalana, Valenciana y Balear \\
\hline$H P V$ & Història del País Valencià \\
\hline$H V$ & Historia de Valencia \\
\hline I. A. & Ildefonso Alier \\
\hline ICCMU & Instituto Complutense de Ciencias Musicales \\
\hline Imp. & Imprenta \\
\hline INAEM & Instituto Nacional de Artes Escénicas y de la Música \\
\hline IVAECM & Instituto Valenciano de Artes Escénicas, Cinematografía y Música \\
\hline leg. & legajo \\
\hline ms. & manuscrito \\
\hline Ms. & manuscrito \\
\hline num. & número \\
\hline ob. & oboe \\
\hline op. & opus \\
\hline órg. & órgano \\
\hline p./pp. & página/ páginas \\
\hline p. & piano \\
\hline perc. & percusión \\
\hline q. D. g. & que Dios guarde \\
\hline qnt. & quinteto \\
\hline q. s. m. b. & que su mano besa \\
\hline rq. & requinto \\
\hline s. & siglo \\
\hline S.A. & Sociedad Anónima \\
\hline s.a. & $\sin$ año \\
\hline s.e. & sin editorial \\
\hline S. & soprano \\
\hline sax. & saxofón \\
\hline $\mathrm{SC}$. & Schott, editorial, Maguncia (Alemania) \\
\hline sf. & sin fecha \\
\hline Sig. & signatura \\
\hline sp. & sin paginar \\
\hline sub. & subsección \\
\hline $\mathrm{T}$. & tenor \\
\hline tbn. & trombón \\
\hline tim. & timbal \\
\hline Tip. & tipografía \\
\hline$T N G$ & The New Grove Dictionary of Music and Musicians \\
\hline tp & trompa \\
\hline UME & Unión Musical Española \\
\hline va. & viola \\
\hline ve. & violoncello \\
\hline Vd. & Usted \\
\hline V. I. & Vuestra Ilustrísima \\
\hline vln. & violón \\
\hline V. M. & Vuestra Majestad \\
\hline
\end{tabular}


vn.

violín

vol., vols. volumen, volúmenes

VV.

voces 



\section{Sistema de identificación de octavas}

$\mathrm{La}^{3}$.

Se ha utilizado el sistema de identificación de octavas franco belga, La $440 \mathrm{~Hz}=$

\section{Criterios de edición de textos y música originales}

En la edición literal de textos he actualizado la ortografía, la acentuación y la puntuación, aunque mantengo la ortografía original de lugares propios y de personas, y las letras en cursiva y mayúsculas en palabras completas. Incluyo traducciones al castellano de los textos originales en valenciano, presentadas o bien a doble columna (izquierda para el original y derecha para la traducción) o en notas a pie de página.

En la edición musical incluyo entre corchetes o en notas las modificaciones realizadas respecto al original (principalmente indicaciones dinámicas introducidas por paralelismo con otros pasajes y corrección de evidentes errores de copia). La indicación de las ligaduras entre notas de adorno y notas principales es siempre editorial. Para adecuar la instrumentación original de las obras de Amorós a los usos orquestales actuales, presento todos los clarinetes en si bemol y las trompas en $\mathrm{Fa}$ (transportando las partes originales en otros tonos cuando ha sido necesario). Por la misma razón, presento las partes originales para cornetín adaptadas a trompetas en si bemol, y las partes originales para figle adaptadas a tuba. 

INTRODUCCIÓN 

Mi primera toma de contacto con la importante labor creadora del compositor Amancio Amorós Sirvent (Agullent, Valencia, 1854- Sant Cugat del Vallés, Barcelona, 1925) tuvo lugar hace once años, cuando reparé en el Fondo Amorós Sirvent de la Biblioteca de Catalunya durante una consulta al catálogo de la misma. Para mí, natural y residente en Agullent, Amancio Amorós había sido hasta entonces una vaga figura que daba nombre a la "Escola Amanci Amorós Sirvent", la escuela de la banda de música “Agrupació Musical d'Agullent". Sabía también que la calle "Germans Amorós" (Hermanos Amorós) de la misma localidad llevaba ese nombre en honor a Amancio Amorós y a su hermano Eugenio, ambos músicos y profesores de música. La constatación del desconocimiento general que había de la figura de Amancio Amorós, en contraste con las numerosas y variadas composiciones conservadas del mismo, estimuló mi interés y me animó a emprender la investigación que ha dado lugar a esta Tesis Doctoral.

\section{Objetivos y estructura del trabajo}

El objetivo de esta investigación es realizar un primer estudio sistemático sobre Amancio Amorós Sirvent en el contexto de la vida musical valenciana de la segunda mitad del siglo XIX y el primer cuarto del siglo XX, revisando la biografía conocida del músico y analizando su intensa labor como pianista, pedagogo y compositor. La Tesis consta de dos volúmenes. El primero de ellos contiene el estudio propiamente dicho, e incluye cinco capítulos y la relación de fuentes y bibliografía consultadas. En el Capítulo 1, para contextualizar adecuadamente la actividad musical de Amancio Amorós, presento un panorama general de la vida musical en la Valencia de finales del XIX y principios del siglo XX en el que, además de revisar y reelaborar los datos tomados de la bibliografía existente, aporto información nueva sobre algunas importantes instituciones musicales valencianas con las que se relacionó el compositor. En el Capítulo 2 reviso, 
actualizo y amplío la información biográfica disponible sobre el músico, abordando sucesivamente su etapa formativa y despegue profesional como pianista y compositor, su vinculación con la sociedad Lo Rat Penat (entidad clave en la Renaixença valenciana), y su etapa de madurez, en la que tuvo gran proyección no sólo en la vida musical valenciana, sino también a nivel nacional. El Capítulo 3 se centra en la importante actividad docente de Amancio Amorós, que dio clases en diversas instituciones y en el Conservatorio de Valencia (del que también fue director), y escribió varias obras didácticas dedicadas al solfeo, la armonía y el piano, algunas de ellas de notable éxito editorial y reconocidas expresamente por la Real Academia de Bellas Artes de San Fernando de Madrid. El Capítulo 4 estudia la actividad musicológica de Amancio Amorós, centrándose en dos aspectos: la creación de la Biblioteca Musical Valenciana (1894-1895), publicación promovida por Amorós que supuso un importante impulso a la difusión de obras de compositores valencianos, y la relación de Amorós con Felipe Pedrell. En el Capítulo 5 presento un primer acercamiento a la labor compositiva de Amorós a partir de una selección representativa de obras suyas de diversos géneros musicales: sinfónico, camerístico, pianístico, escénico y religioso. Tras describir las coordenadas estéticas en las que se enmarcó la creación del compositor, analizo veintiuna piezas musicales suyas, ocho de ellas editadas por primera vez en esta Tesis.

El volumen 2 de la Tesis (en CD-Rom) incluye el catálogo completo de la producción musical de Amorós, la edición musical de las veintiuna composiciones seleccionadas en el estudio y varios apéndices, entre ellos el inventario de la biblioteca personal de Amancio Amorós depositada en la Biblioteca de Catalunya por su hijo, José Vicente Amorós Barra, la edición crítica de tres lecciones de solfeo inéditas de Amorós (Lecciones de Solfeo manuscrito a una y dos voces) y otros materiales y documentos relacionados con la investigación. 


\section{Fuentes empleadas}

Para realizar esta Tesis he consultado numerosas fuentes manuscritas e impresas conservadas en diferentes archivos y bibliotecas. Un listado general de las mismas puede consultarse al final de este volumen 1. A continuación comentaré algunos aspectos de los archivos y documentos más relevantes empleados en mi investigación. Las fuentes manejadas han sido principalmente de cinco tipos:

1) Documentación administrativa procedente de diversas instituciones para reconstruir la biografía y actividad profesional de Amancio Amorós.

2) Prensa periódica de la época de Amancio Amorós (especialmente valenciana), para contextualizar la labor del músico y conocer la recepción de sus obras estrenadas; a través de la prensa he podido documentar tanto composiciones conservadas en la actualidad como algunas hoy desaparecidas.

3) Composiciones musicales manuscritas e impresas de Amancio Amorós.

4) Obras teóricas de Amancio Amorós: métodos de solfeo y otras materias musicales.

5) Publicaciones musicológicas promovidas por Amancio Amorós, en especial su serie Biblioteca Musical Valenciana.

Uno de los fondos documentales más importantes empleados en esta Tesis ha sido el Legado Amorós Sirvent, conservado en la Biblioteca de Catalunya, que comprende las signaturas M 1271 a 1314 y M 1384 a 1386, y está constituido por cuarenta y tres composiciones manuscritas del autor, un Tratado de Composición también manuscrito e incompleto y copias autógrafas de los anónimos Misterio de San Cristóbal, Misterio de Adán y Eva y Misterio del Rey Herodes, así como la música correspondiente a tres números de la también anónima Consueta de la Fiesta de Nuestra Señora de la Asunción de Elche. Este fondo documental ingresó en la Biblioteca de Catalunya el 29 de octubre 
de 1930, y en una nota adjunta al mismo se especifica que quedó en depósito, reservándose "el Sr. Amorós el derecho a su propiedad"1. En la actualidad el Legado Amorós Sirvent sigue en la Biblioteca de Catalunya, pero continúa en depósito y no es propiedad de dicha institución ${ }^{2}$. También en la Biblioteca de Catalunya, aunque no dentro del Legado Amorós Sirvent, se conserva la biblioteca personal de Amancio Amorós, constituida por al menos 240 obras. Entre éstas se conserva parte de la música impresa del propio compositor, que incluye obras para piano, los números editados de su zarzuela Los dos esclavos y varios métodos de solfeo.

La música religiosa de Amancio Amorós que he podido consultar se guarda, además de en la Biblioteca de Catalunya, en diferentes archivos. En el Colegio del Corpus Christi (Patriarca) de Valencia se conservan dos piezas religiosas manuscritas y otras cuatro impresas. En el Archivo Histórico de la Unión Musical Española consulté las partituras de música religiosa publicadas por Amancio Amorós dentro de la colección Obras Religiosas Españolas, editada por Ildefonso Alier y Casa Dotesio, así como las Lecciones Manuscritas Graduadas para segundo y tercer curso de solfeo de Amorós. En la Biblioteca Musical de Compositores Valencianos del Ayuntamiento de Valencia pude localizar ocho obras religiosas de Amorós: Quam dilecta tabernacula tua, Credidi de $4^{o}$ tono, Ave Maria, O salutaris Hostia, op. 61, O salutaris Hostia a solo, Acepta Virgen Pura, la salutación al Patriarca San José Recibid mil parabienes y los gozos a San José

\footnotetext{
${ }^{1}$ El "Sr. Amorós" al que hace referencia la nota era José Vicente Amorós, hijo de Amancio, que es quien depositó el Legado Amorós en la Biblioteca de Catalunya en 1930. E:Bc, Libro de Registro ${ }^{\circ} 24$ (1930$31)$.

2 Algunas obras de este fondo documental depositadas en 1930 en la Biblioteca de Catalunya son actualmente ilocalizables. Por ejemplo, no se han podido localizar actualmente: Ejercicios preliminares de solfeo, de Manuel Penella, con dos registros de entrada (123863 y 123961); Agilidad e independencia de los dedos, de Roberto Segura, $\mathrm{n}^{\circ} 123972$; la edición impresa de Quam dilecta tabernacula tua, $\mathrm{n}^{\circ}$ 123925, de Amancio Amorós; Al atardecer, de Emilio Ramírez, nº 123931; Lectura musical. Colección de obras para piano y solfeo [Anónimo], $\mathrm{n}^{\circ}$ 123940; y Harmonium album, de Chopin, Schumann, Leipzig, $n^{\circ} 123963$ (los números indicados son los de registro de las obras en la Biblioteca de Catalunya).
} 
Pues sois Santo sin igual ${ }^{3}$. He podido comprobar que se trata de copias manuscritas de las partituras impresas de estas obras editadas previamente por Ildefonso Alier en la colección Obras Religiosas Españolas y por Antich y Tena en la revista Biblioteca Sacro Musical.

La Biblioteca Nacional de Madrid conserva una reducción autógrafa del propio Amancio Amorós para voces y piano de su zarzuela Navegación Submarina, además de varias ediciones de sus métodos de solfeo. También localicé cinco métodos de solfeo y teoría musical de Amancio Amorós en la Biblioteca Valenciana, con sede en el antiguo Monasterio de San Miguel de los Reyes; la Biblioteca Valenciana conserva además el libreto impreso de la zarzuela Los dos esclavos de Amorós, el volumen 3 de su Biblioteca Musical Valenciana (1895) y el texto manuscrito de A les Danses d'Agullent, que podría ser una zarzuela en un acto de Amorós cuya música hoy es desconocida.

En el Archivo del Conservatorio Superior de Música de Valencia localicé interesantes datos sobre la labor de Amancio Amorós como profesor y director del mismo en libros de actas de exámenes, actas de la Junta Directiva y actas del Claustro de profesores, entre otras series documentales. El mismo centro conserva también algunos de los tratados pedagógicos del compositor. En el Archivo de la Real Academia de Bellas Artes de San Fernando de Madrid consulté diversas series documentales, como libros de actas y documentación sobre académicos correspondientes; este archivo conserva

\footnotetext{
${ }^{3}$ Estas obras de Amorós fueron recopiladas por el jesuita Vicente Javier Tena Meliá (1905-1985) y un grupo de colaboradores, como Francisco Domingo Francés Cañigueral, Bernardo Alcover, Vicente Pérez y Ricardo Barceló; véase Vicente Tena Meliá, Obras musicales de Amancio y Eugenio Amorós y Ramón Esplugues (Agullent: Ajuntament d'Agullent, inédito, 1978), sp. Vicente Tena, patrocinado por el Ayuntamiento de Valencia, se dedicó desde 1962 a recopilar obras de compositores valencianos por los pueblos de la Comunidad Valenciana. Con los fondos reunidos (mayoritariamente partituras manuscritas originales y copias) abrió en 1981 al público la Biblioteca Musical de Compositores Valencianos, que ocupa el mismo edificio que la Biblioteca Municipal Central de Valencia, a la que está adscrita. Véase Vicente Galbis López, "Tena Meliá, Vicente Javier", en Diccionario de la Música Valenciana (en adelante $D M V$ ), dir. Emilio Casares, 2 vols. (Madrid: Instituto Complutense de Ciencias Musicales, Institut Valencià de la Música), vol. 2 (2006), p. 494.
} 
también dos de los métodos de solfeo de Amorós y, dentro del fondo del pianista Leopoldo Querol, el volumen 1 de la Biblioteca Musical Valenciana editada por Amorós.

\section{Estado de la cuestión}

La figura de Amancio Amorós Sirvent (Agullent, Valencia, 1854-San Cugat del Vallés, Barcelona, 1925) ha tenido hasta ahora escasa presencia en la historiografía musical, a pesar de su prolífica obra compositiva (que abarca prácticamente todos los géneros musicales) y de su enorme influencia en la vida y en la enseñanza musicales de Valencia en las últimas décadas del siglo XIX y primeras décadas del XX. En algunas importantes publicaciones sobre la música española y valenciana de los siglos XIX y XX el compositor ni siquiera es mencionado ${ }^{4}$.

Hasta el momento la investigación científica más importante realizada específicamente sobre Amancio Amorós y su obra es el Trabajo de Investigación Tutelada que sobre este músico presenté en la Universidad de Granada en 2004 para la obtención del Diploma de Estudios Avanzados ${ }^{5}$, trabajo que fue el punto de partida de esta Tesis Doctoral. Antes de este trabajo, y desde finales del siglo XIX, diversas publicaciones habían aportado datos dispersos sobre Amorós, generalmente referidos sólo a algunas de las facetas del músico.

\footnotetext{
4 Amancio Amorós no es mencionado, por ejemplo, en Baltasar Saldoni, Diccionario biográficobibliográfico de efemérides de músicos españoles (Madrid: Imprenta de Antonio Pérez Dubrull, 1880); Adolfo Salazar, La Música contemporánea en España (Madrid: Ediciones La Nave, 1930); Emilio Cotarelo y Mori, Historia de la zarzuela (Madrid: Tipografía de Archivos, 1938); José Subirá, Historia de la Música Española e Hispanoamericana (Barcelona: Salvat, 1958); y Eduardo López-Chavarri Andújar, Compositores Valencianos del siglo XX: del Modernismo a las vanguardias (Valencia: Generalitat Valenciana, 1992).

${ }^{5}$ Elena Micó Terol, Amancio Amorós Sirvent (1854-1925), compositor, pianista y pedagogo. Catálogo de su producción y aproximación a su estilo compositivo, Trabajo de Investigación Tutelada dirigido por María Gembero Ustárroz (Granada: Universidad de Granada, 2004, 239 pp.). Véase también Elena Micó Terol, "Amanci Amorós Sirvent i la seua producció musical profana", Almaig, estudis i documents, 20 (2004), pp. 104-108 y Elena Micó Terol, “Amanci Amorós Sirvent: Compositor i pedagog”, Actas del II Congreso de l'Institut d'Estudis de la Vall d'Albaida, celebrado en Ontinyent en noviembre de 2004 (Ontinyent: Institució Alfons El Magnànim, 2008), pp. 867-886.
} 
La primera referencia bibliográfica que he localizado dedicada expresamente a Amancio Amorós es un artículo publicado por Eduardo Serrano en 1891 en la revista Ilustración Musical Hispano-Americana ${ }^{6}$. Serrano mencionó los profesores de Amorós, las obras de éste y las dificultades que el compositor tuvo para estrenar dos de sus zarzuelas, e hizo una valoración de su estilo musical. En ese mismo número de la revista, en la sección “Álbum musical”, se publicó la Mazurca en re menor para piano que Amorós dedicó a Felipe Pedrell. Un grabado con el retrato de Amorós fue publicado en el siguiente número de la misma revista ${ }^{7}$ (Ilustración 1).

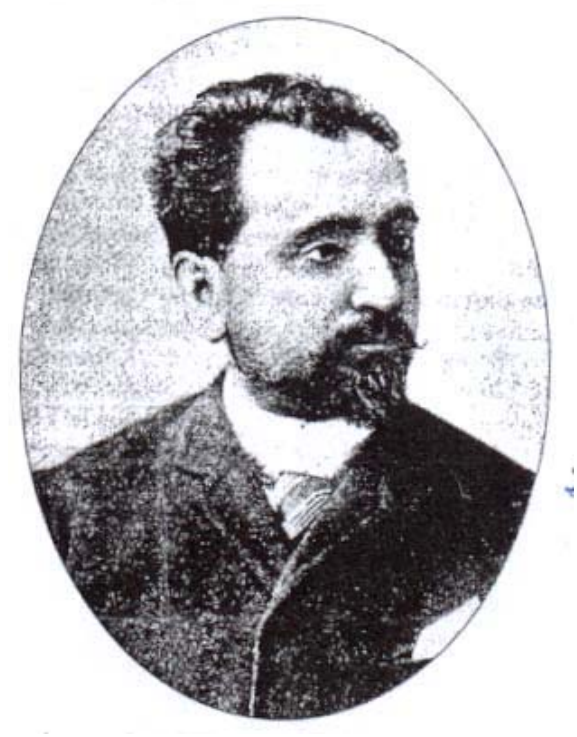

Ilustración 1

Amancio Amorós Sirvent (1891). Ilustración Musical Hispanoamericana, 77 (30-III-1891), p. 489.

Todavía en vida de Amorós aparecieron otras publicaciones que ya lo trataban como un músico importante. Francisco Javier Blasco, en La Música en Valencia (1896), aportó interesantes datos sobre Amorós como compositor y pedagogo, y mencionó por primera vez la academia privada dirigida por el compositor y la publicación de la

\footnotetext{
${ }^{6}$ Eduardo Serrano, “Amancio Amorós", Ilustración Musical Hispanoamericana, 15-III-1891, pp. 477479.

${ }^{7}$ Ilustración Musical Hispanoamericana, 30-III-1891, p. 489.
} 
Biblioteca Musical Valenciana, promovida por él ${ }^{8}$. En su Diccionario de 1897, Pedrell dedicó una breve semblanza a Amorós ${ }^{9}$. En La música en Valencia (1903), José Ruiz de Lihory dio noticia de las actividades de Amancio Amorós como profesor honorario del Conservatorio de Valencia, maestro director de la Capilla de las Adoratrices, profesor del Colegio Andresiano de las Escuelas Pías y colaborador de "revistas profesionales", aunque no mencionó las fechas de estas actividades ni las fuentes en las que se basó ${ }^{10}$.

Leopoldo Querol Rosso, en su discurso de ingreso como académico de número en la Real Academia de Bellas Artes de San Carlos de Valencia (1969), incluyó a Amorós entre los "insignes músicos valencianos" que dieron gloria a la ciudad y alcanzaron fama fuera de ella ${ }^{11}$. El interés por la obra de Amancio Amorós quedó patente en la labor del jesuita Vicente Tena, que recopiló ocho obras religiosas de Amancio Amorós, en el contexto de su labor en pro de la recuperación del patrimonio musical valenciano ${ }^{12}$.

\footnotetext{
${ }^{8}$ Francisco Javier Blasco, La música en Valencia. Apuntes Históricos (Alicante: Imprenta de Sirvent y Sánchez, 1896), pp. 64, 77, 80, 86 y 97.

${ }^{9}$ Felipe Pedrell, Diccionario biográfico y bibliográfico de músicos y escritores de música españoles, portugueses e hispanoamericanos antiguos y modernos (Barcelona: Victor Berdós y Feliu, 1897), vol. 1, p. 63.

10 José Ruiz de Lihory, La música en Valencia, diccionario biográfico y crítico (Valencia: Tip. Doménech, 1903), pp. 24-26.

${ }^{11}$ Leopoldo Querol Rosso, "Estilo y significación del Romanticismo de Chopin", Archivo de Arte Valenciano, 41 (1970), pp. 42-49; esta publicación incluye el discurso leído el 14-XI-1969 por Leopoldo Querol Rosso en su recepción pública como académico de número y la contestación al mismo de José Corts Grau. El mismo año (1969), Javier Goérlich, Presidente de la Real Academia de Bellas Artes de San Carlos de Valencia, consiguió la creación de la Sección de Música de la misma.
}

${ }^{12}$ Tena, Obras musicales, sp. El ejemplar conservado en la Biblioteca Municipal de Agullent contiene copias de las obras recopiladas y transcritas por el jesuita Vicente Javier Tena Meliá (1905-1985) y un grupo de colaboradores, como Francisco Domingo Francés Cañigueral, Bernardo Alcover, Vicente Pérez y Ricardo Barceló. En diciembre de 1978, Vicente Tena, subvencionado por el Ayuntamiento de Agullent, presentó e hizo entrega de este ejemplar al municipio. La obra reúne ocho piezas religiosas de Amancio Amorós (Quam dilecta tabernacula tua, motete a solo y coro a tres voces y órgano; Credidi de $4^{\circ}$ tono a coro, solo de tenor y barítono; Ave Maria a solo, coro y órgano; O salutaris Hostia, op. 61 a tres voces y órgano; O salutaris Hostia, a solo de tiple o tenor y órgano; Acepta Virgen Pura, a dos voces y órgano; la salutación al Patriarca San José Recibid mil parabienes, para coro popular y los gozos a San José Pues sois Santo sin igual, a tres voces y órgano), once de Eugenio Amorós (Letrillas para Comunión, a dos voces iguales y órgano; Gozos al Sagrado Corazón de Jesús, a tres voces y órgano; Himno a San Francisco de Asís, a solo, coro y órgano; Romanza a la Santísima Virgen, para Bajo o Barítono y órgano; Gozos al Glorioso San Blas, a tres voces mixtas y órgano; Oh sol de mis amores, copla de comunión a dos voces y órgano; Dios Excelso, copla de comunión a dos voces y órgano; Panis 
La labor docente y pedagógica de Amorós fue mencionada en el estudio de Dionisio Preciado sobre el método de Solfeo de Eslava ${ }^{13}$. José Climent destacó en 1978 a Amorós como músico de iglesia y autor de composiciones italianizantes publicadas en la Biblioteca Sacro Musical, mencionó sus Elementos de Solfeo (1889) y consideró que su zarzuela Los dos esclavos (estrenada en 1886) fue para el autor una mera distracción ${ }^{14}$.

Dos libros de Eduardo López-Chavarri transmitieron datos sobre Amancio Amorós basados en las publicaciones antes mencionadas de Francisco Javier Blasco y Ruiz de Lihory (aunque sin citarlas y sin contrastar la veracidad de las fuentes) ${ }^{15}$, lo que ha contribuido a transmitir algunos errores que reaparecen en recientes estudios sobre la música valenciana ${ }^{16}$. López-Chavarri reivindicó en otra de sus publicaciones la importancia de las obras para piano de Amorós ${ }^{17}$.

En 1999, la voz sobre Amancio Amorós que publicó Ramón Sobrino en el Diccionario de la Música Española e Hispanoamericana amplió la información que se tenía hasta ese momento sobre el compositor; Sobrino mencionó su labor como profesor de Solfeo y Piano de la Institución para la Enseñanza de la Mujer y como maestro director de la Capilla de las Adoratrices de Valencia e incluyó un primer catálogo de la

\footnotetext{
Angelicus, a solo de tenor-bajete con acompañamiento de órgano; Preces al Sagrado Corazón de Jesús, a dos voces y órgano; Panis Angelicus, motete a solo de Tenor y órgano; Plegaria a la Santísima Virgen María, a solo de Tenor y órgano) y tres de Ramón Esplugues (Misa a dúo y solo con acompañamiento de órgano; Rosario a la Santísima Virgen y Plegaria al Santísimo Sacramento).

13 Dionisio Preciado, "Don Hilarión Eslava y su Método Completo de Solfeo", en Monografia de Hilarión Eslava. Primer Centenario (Pamplona: Diputación Foral de Navarra, Institución Príncipe de Viana, 1978), pp. 227, 244 y 245.

${ }^{14}$ José Climent, Historia de la Música Contemporánea Valenciana, del Cenia al Segura (Valencia: Artes Gráficas Soler, 1978), pp. 34, 54, 55, 71, 140 y 145.

15 Eduardo López-Chavarri Andújar, Cien años de música valenciana, 1878-1978 (Valencia: Caja de Ahorros de Valencia, 1978), pp. 41, 76-79; Eduardo López-Chavarri Andújar, Cien años de historia del Conservatorio de Valencia (Valencia: Conservatorio Superior de Música de Valencia, 1979), pp. 41- 42.

16 Comentaré los mencionados errores a lo largo de esta Tesis.

17 Eduardo López-Chavarri Andújar, "Concierto en el Conservatorio de Música", en Crónica de un centenario (Valencia: Conservatorio Superior de Música de Valencia, 1983), pp. 43-44.
} 
producción musical de Amorós conocida hasta ese momento, que tendré ocasión de actualizar y ampliar en esta Tesis ${ }^{18}$. El mismo autor comentó brevemente tres zarzuelas de Amancio Amorós en el Diccionario de la Zarzuela ${ }^{19}$.

Roberto Loras Villalonga, en su libro sobre La Asociación de profesores músicos de Santa Cecilia desde su fundación a 2002, comentó el papel que tuvo Amorós en esa institución como miembro fundador, secretario (desde 1897) y presidente $(1909-24)^{20}$. El mismo autor, en su estudio de 2008 sobre los métodos españoles de solfeo de finales del siglo XIX y principios del XX, presentó un primer análisis de los Elementos de Solfeo y Lecciones Manuscritas Graduadas para segundo y tercer curso de Amancio Amorós y destacó la adecuación de estos tratados a los programas oficiales de Solfeo de la Escuela Nacional de Música y Declamación, y la magnífica aportación que supusieron para el aprendizaje del solfeo ${ }^{21}$.

Salvador Astruells Moreno, en su estudio sobre la Banda Municipal de Valencia, mencionó el papel de Amancio Amorós como miembro del tribunal en las oposiciones a director de dicha agrupación ${ }^{22}$. En la Tesis Doctoral de Ana Fontestad sobre el Conservatorio de Valencia (el estudio más completo hasta ahora sobre esta institución) se aportaron datos sobre Amorós como alumno y profesor del centro y se comentaron

\footnotetext{
${ }^{18}$ Ramón Sobrino Sánchez, "Amorós Sirvent, Amancio", en Diccionario de la Música Española e Hispanoamericana (en adelante DMEH), dir. Emilio Casares, 10 vols. (Madrid: Sociedad General de Autores y Editores, 1999-2002), vol. 1 (1999), pp. 420-421. Los datos de esta voz se repiten íntegramente en Ramón Sobrino, “Amorós Sirvent, Amancio", en DMV, vol. 1 (2006), pp. 47-48.

${ }^{19}$ Ramón Sobrino Sánchez, "Amorós Sirvent, Amancio", en Diccionario de La Zarzuela. España e Hispanoamérica, dir. Emilio Casares, 2 vols. (Madrid: ICCMU, 2002), vol. 1, p. 90.

${ }^{20}$ Roberto Loras Villalonga, La Asociación de profesores músicos de Santa Cecilia desde su fundación a 2002 (Valencia: Editorial Mare Nostrum, 2003), pp. 22-29.

${ }^{21}$ Roberto Loras Villalonga, Estudio de los métodos de solfeo españoles en el siglo XIX y principios del $X X$, Tesis Doctoral (Valencia: Universidad Politécnica de Valencia, 2008), pp. 425-430, 493-502, 566, $573-574$.

${ }^{22}$ Salvador Astruells Moreno, La Banda Municipal de Valencia (Valencia: Ajuntament de València, 2004), p. 74.
} 
algunas de sus obras didácticas, aunque incurriendo en algunos errores que detallaré en el lugar oportuno ${ }^{23}$.

Victoria Alemany Ferrer, en su estudio sobre el piano en Valencia a finales del siglo XIX y comienzos del $\mathrm{XX}^{24}$, repite los datos sobre Amorós ofrecidos por Sobrino ${ }^{25} \mathrm{y}$ menciona la importancia de Amorós como pianista acompañante, aunque sin aportar datos nuevos. En Romanticismo y música instrumental en Valencia 1832-1916, Manuel Sancho García analiza la actividad sinfónica y de cámara en la ciudad de Valencia, pero no menciona el estreno de las dos sinfonías de Amorós que edito y estudio en la presente Tesis $^{26}$. El mismo autor, en su artículo “Orfeonismo y canto coral en Valencia (18501910)", realiza una primera aproximación al movimiento coral valenciano y menciona dos obras corales de Amorós, que enmarca dentro de la corriente regionalista valenciana $^{27}$.

Elvira Juan Llovet, en su estudio sobre la música religiosa de la comarca valenciana de la Vall d'Albaida ${ }^{28}$, resume brevemente la trayectoria profesional de

\footnotetext{
${ }^{23}$ Ana Fontestad Piles, El Conservatorio de Música de Valencia antecedentes, fundación y primera etapa (1879-1910), Tesis Doctoral (Valencia: Universitat de València. Departament d'Història de l'Art, 2005), pp. 393-399, 560 .
}

${ }^{24}$ Victoria Alemany Ferrer, Metodología de la técnica pianística y su pedagogía en Valencia, 1870-1916, Tesis Doctoral (Valencia: Universidad Politécnica de Valencia, Departamento de Comunicación Audiovisual, Documentación e Historia del Arte, 2006), p. 166. Este estudio fue posteriormente publicado como El piano en Valencia en los años del cambio al siglo XX (1879-1916) (Barcelona: Consejo Superior de Investigaciones Científicas, 2010; Monumentos de la Música Española, 79).

${ }^{25}$ Sobrino, “Amorós Sirvent, Amancio”, en DMEH, vol. 1 (1999), pp. 420-421.

26 Manuel Sancho García, Romanticimo y música instrumental en Valencia 1832-1916 (Valencia: Institució Alfons El Magnànim, 2007), p. 214. Esta obra es un resumen de la Tesis Doctoral del autor, titulada El sinfonismo en Valencia durante la restauración 1878-1916 (Valencia: Universitat de València, Servei de Publicacions, 2003). Sancho sí menciona brevemente a Amorós en el capítulo sobre la música de salón, por su participación en las sesiones musicales organizadas por diversas entidades recreativas valencianas.

\footnotetext{
${ }^{27}$ Manuel Sancho García, “Orfeonismo y canto coral en Valencia (1859-1910)", Revista de Musicología, 30/ 1 (2007), p. 120

${ }^{28}$ Elvira Juan Llovet, Música religiosa en los pueblos del valle de Albaida, del siglo XVII hasta los inicios del siglo XX, Tesis Doctoral (Valencia: Universidad de Valencia, 2009), p. 284.
} 
Amancio Amorós sin citar fuentes, menciona treinta y cuatro obras religiosas del compositor (sin analizarlas), e indica únicamente los títulos de las seis conservadas en el Archivo del Real Colegio del Corpus Christi de Valencia, citando el catálogo de Climent $^{29}$.

Además de las obras ya comentadas, diversas enciclopedias, diccionarios y obras divulgativas incluyen breves resúmenes sobre la figura de Amancio Amorós, en los que generalmente se repiten datos publicados anteriormente, sin aportar informaciones nuevas. Así, Amorós tiene un hueco en el conocido Diccionario de Anglés-Pena ${ }^{30}$, en otros diccionarios $\mathrm{y}$ estudios generales ${ }^{31} \mathrm{y}$ en diversos diccionarios y publicaciones centrados en el ámbito valenciano ${ }^{32}$.

\footnotetext{
${ }^{29}$ José Climent Barber, Fondos Musicales de la Región Valenciana, Real Colegio del Corpus Christi, vol. 2 (Valencia: Institución Alfonso el Magnánimo, 1984), pp. 97-98.

${ }^{30}$ José Pena e Higinio Anglés, Diccionario de la música (Barcelona: Labor, 1954), vol. 1, p. 65.

${ }^{31}$ Josep Ricart Matas, Diccionario biográfico de la música (Barcelona: Iberia, S. A., 1966), p. 37; Santiago Albertí (ed.), Diccionari Biogràfic (Barcelona: Alberti, 1966-1970) vol. 1, p. 118; Gloria Emparán Boada, "El piano en el siglo XIX", Cuadernos de Música. El Romanticismo Musical Español, 2 (1982), p. 67; Mariano Pérez, Diccionario de la Música y los Músicos (Madrid: Ediciones Istmo, 1985), p. 53; Mariano Vázquez Tur, "Piano de salón y piano de concierto en la España del siglo XIX", Revista de Musicología, 14/1-2 (1991), pp. 225-228; Luis Iglesias de Souza, Teatro lírico español (La Coruña: Diputación Provincial de La Coruña, 1991), p. 995 (vol. 1), p. 752 (vol. 2), p. 742 (vol. 3), p. 475 (vol. 4 dedicado a libretistas y compositores); Jesús Giralt (dir.), Gran Enciclopedia de la Música (Barcelona: Fundació Enciclopedia Catalana), vol. 1 (1999), s. p.

32 José Ma Bru Casanova, "Aproximación a Amancio Amorós y Sirvent", en Agullent 1585-1985 IV Centenari de la Segregació jurídica d'Agullent d'Ontinyent (Valencia: Caixa Estalvis d'Ontinyent, 1985), pp. 187-192; Bernardo Adam Ferrero, "Amorós Sirvent, Amancio", en Músicos Valencianos (Valencia: Proip, 1992), p. 28; Ana Galiano Arlandis, "La Renaixença", en Historia de la Música de la Comunidad Valenciana (en adelante $H M C V$ ), dir. Gonzalo Badenes (Valencia: Editorial Prensa Valenciana, 1992), p. 310; Manuel García Franco, "El apogeo de la zarzuela", en $H M C V$, p. 292; José E. Peláez Malagón, "Amorós Sirvent, Amancio", en Historia de la Música Catalana, Valenciana i Balear (en adelante $H M C V B)$, dir. Xosé Aviñoa, 13 vols. (Barcelona: Edicions 62, 1999-2004), vol. 1 (1999), p. 41; Adam Ferrero, "Amorós Sirvent, Amancio", en 1000 Músicos Valencianos (Valencia: Sounds of Glory, 2003), p. 122; Salvador Astruells Moreno, El mestre Eduardo Felip: director i compositor (Albalat de la Ribera: Ajuntament de Albalat de la Ribera, 2005), p. 147; Roberto Loras Villalonga, El Patriarca de la Música Valenciana (Valencia: Universidad Politécnica de Valencia, 2007), p. 186.
} 
Sobre el contexto musical español en época de Amancio Amorós, a las contribuciones generales de Carlos Gómez Amat y Celsa Alonso-Emilio Casares ${ }^{33}$, se suman estudios sobre ciudades o aspectos concretos, como los de $\mathrm{M}^{\mathrm{a}}$ Antonia Virgili y Victoria Cavia sobre Valladolid ${ }^{34}$, Xosé Aviñoa y Monserrat Comellas sobre Barcelona ${ }^{35}$, Lluís-Marc Herrera sobre Lleida ${ }^{36}$, Beatriz Martínez del Fresno, José Antonio Gómez Rodríguez y Fidela Uría sobre Asturias ${ }^{37}$, Luis Costa, Pilar Alén y María García Caballero sobre Galicia ${ }^{38}$, José Ignacio Palacios sobre Soria ${ }^{39}$, Adelaida Muñoz y

33 Emilio Casares y Celsa Alonso (eds.), La música española en el siglo XIX (Gijón: Servicio de Publicaciones de la Universidad de Oviedo, 1995); Carlos Gómez Amat, Historia de la música española. Siglo XIX (Madrid: Alianza Editorial, 1984).

${ }^{34} \mathrm{M}^{\mathrm{a}}$ Antonia Virgili Blanquet, La música en Valladolid en el siglo XX (Valladolid: Ateneo, 1985); $\mathrm{M}^{\mathrm{a}}$ Antonia Virgili Blanquet, "Música y teatro en Valladolid en el siglo XIX", Revista de Musicología, 10/2 (1987), pp. 653-660; Victoria Cavia Naya, "Un músico del siglo XIX y su proyección desde la catedral de Valladolid: Hilario Prádanos", Cuadernos de Música Iberoamericana, 7 (1999), pp. 199-214; Victoria Cavia Naya, La vida musical de la catedral de Valladolid en el siglo XIX (Valladolid: Diputación provincial de Valladolid, 2004).

35 Xosé Aviñoa, La música i el Modernisme (Barcelona: Curial, 1985); Xosé Aviñoa, "Sociedades musicales y modernidad en Cataluña en el primer tercio del siglo XX", Cuadernos de Música Iberoamericana, 8-9 (2001), pp. 277-286; Xosé Aviñoa, "Barcelona, del wagnerismo a la generación de la República”, en España en la música de Occidente, Actas del Congreso Internacional (Salamanca, 1985), eds. Emilio Casares, José López-Calo, Ismael Fernández de la Cuesta (Madrid: INAEM, 1987), vol. 2, pp. 323-340; Montserrat Comellas i Barri, El romanticisme musical a Barcelona. Els concerts (Barcelona: Libros de la Frontera, 2000); Xosé Aviñoa, "Modernisme i música: una reflexió al cap dels anys", Recerca Musicològica, 14-15 (2004-2005), pp. 107-122. Véanse además las siguientes contribuciones de Xosé Aviñoa en $H M C V B$, "L'activitat concertística", vol. 3 (1999), pp. 111-146; "L’activitat musical", vol. 4 (1999), pp. 59-102; "La música religiosa", vol. 4 (1999), pp. 189-209; y "La creació”, vol. 4 (1999), pp. 210-256.

36 Lluís-Marc Herrera i Llop, La Música a Lleida durant la Renaixença $i$ el Modernisme (Lleida: Ajuntament de Lleida, 2002).

${ }^{37}$ Beatriz Martínez del Fresno, "Asturias en la obra de Manuel del Fresno (1900-1936)", en Canciones de dentro. Música asturiana para voz y piano (Oviedo: Caja de Asturias, Fundación Príncipe de Asturias, Consejería de Cultura, 1996), pp. 111-140; José Antonio Gómez Rodríguez (ed.), Canciones de dentro. Música asturiana para voz y piano (Oviedo: Caja de Asturias, Fundación Príncipe de Asturias, Consejería de Cultura, 1996); José Antonio Gómez Rodríguez (ed.), Ecos de Asturias. Música asturiana para piano (Oviedo: Caja de Asturias, Fundación Príncipe de Asturias, Consejería de Cultura, 1997); Fidela Uría Líbano, Música asturiana entre 1860 y 1934. Vida, obra y catálogo de Víctor Sáenz, Anselmo González del Valle, Baldomero Fernández (Oviedo: Servicio de Publicaciones del Principado de Asturias, 1997).

38 Luis Costa Vázquez-Mariño, "As bases do nacionalismo musical galego no entorno da música relixiosa", Actas del Congreso Galicia fai dous mil anos. O feito diferencial galego, coord. Carlos Villanueva (Santiago de Compostela: Museo do Pobo Galego, 1998), vol. 2, pp. 251-292; Pilar Alén Garabato, "La Música en Galicia: del piano de salón a las masas corales", en Galicia e América. Música, Cultura e Sociedade arredor do 98 (Santiago de Compostela: Tórculo Artes Gráficas, 1999), pp. 73-101; Pilar Alén, "La edad de oro de las melodías gallegas (ca. 1890-1915)", en Homenaje a José García Oro, eds. M. Romaní y $\mathrm{M}^{\mathrm{a}}$ Ángeles Novoa (Santiago de Compostela: Servicio de publicaciones de la 
Antonio Cabeza sobre Palencia ${ }^{40}$, María Nagore sobre Pamplona y Bilbao ${ }^{41}, \mathrm{M}^{\mathrm{a}}$ Rosa Martínez Anguita sobre Jaén ${ }^{42}$, Gonzalo Martín Tenllado sobre Málaga ${ }^{43}$, José Miguel Barberá Soler y María del Coral Morales sobre Granada ${ }^{44}$, entre otros. Interesantes referencias para mi trabajo han sido también los estudios que abordan los géneros musicales sinfónico, camerístico, pianístico, escénico y religioso en la época de Amorós ${ }^{45}$.

Universidad de Santiago, 2002), pp. 375-382; Pilar Alén Garabato, "Reflexiones sobre un siglo de música gallega (ca. 1808-1916)", Revista de Musicología, 30/1 (2007), pp. 49-102; María García Caballero, La vida musical en Santiago a finales del siglo XIX (Santiago de Compostela: Alvarellos editora, 2008).

39 José Ignacio Palacios Sanz, “Aproximación histórica a la capilla de música en la catedral de Burgo de Osma durante el siglo XIX: de Bernardo Pérez al Motu Proprio", Revista de Musicología, 14/1-2 (1991), pp. 549-560.

${ }^{40}$ Adelaida Muñoz y Antonio Cabeza Rodríguez, "Algunos aspectos de la vida musical de Palencia en el siglo XIX: Las Bandas de Música”, Revista de Musicología, 14/1-2 (1991), pp. 279-296.

${ }^{41}$ María Nagore Ferrer, "Sociedades filarmónicas y de conciertos en el Bilbao del siglo XIX", Cuadernos de Arte de la Universidad de Granada, 26 (1995), pp. 195-206; María Nagore Ferrer, La revolución coral. Estudio sobre la Sociedad Coral de Bilbao y el movimiento coral Europeo, 1800-1936 (Madrid: ICCMU, 2001); María Nagore Ferrer, "La Escuela Municipal de Música de Pamplona: una institución pionera en el siglo XIX”, Príncipe de Viana, 238 (2006), pp. 537-560.

${ }^{42} \mathrm{M}^{\mathrm{a}}$ Rosa Martínez Anguita, La música civil y religiosa en Jaén en el siglo XIX (Jaén: Universidad de Jaen, 1997); $\mathrm{M}^{\mathrm{a}}$ Rosa Martínez Anguita, La Música y los músicos en el Jaén del siglo XIX (Jaén: Concejalía de Cultura, Servicio de Publicaciones, 2000).

${ }^{43}$ Gonzalo Martín Tenllado, La música en Málaga durante el siglo XIX. Ocón: música nacionalista en la catedral de Málaga (Granada: Universidad de Granada, 1991).

${ }^{44}$ José Miguel Barberá Soler, "La música en Granada durante el siglo XIX", Revista del Centro de Estudios Históricos de Granada y su reino, 7 (1993), pp. 227-250; María del Coral Morales Villar, La agrupación lírica Francisco Alonso (1963-1973): historia de una compañia de zarzuela de Granada (Granada: Junta de Andalucía, Consejería de Cultura, 2003); María del Coral Morales Villar, Los Tratados de canto en España durante el siglo XIX: técnica vocal e interpretación de la música lírica, Tesis doctoral dirigida por Emilio Ros Fábregas (Granada: Universidad de Granada, Departamento de Historia del Arte y Música, 2008).

${ }^{45}$ Ramón Sobrino Sánchez, "La Música sinfónica en el siglo XIX”, en La Música española en el siglo $X I X$, eds. Emilio Casares y Celsa Alonso (Gijón: Servicio de Publicaciones de la Universidad de Oviedo, 1995), pp. 279-323; Ramón Sobrino Sánchez, "La sociedad de conciertos de Madrid, un modelo de sociedad profesional", Cuadernos de Música Iberoamericana, 8-9 (2001), pp. 125-148; Carlos Gómez Amat, "Sinfonismo y música de cámara en la España del siglo XIX", en España en la Música de Occidente, Actas del Congreso Internacional (Salamanca, 1985), eds. Emilio Casares, José López-Calo, Ismael Fernández de la Cuesta (Madrid: INAEM, 1987), vol. 2, pp. 211-223; Mónica García Velasco, "La Sociedad de cuartetos de Madrid (1863-1894)", Cuadernos de Música Iberoamericana, 8-9 (2001), pp. 149-194; Mariano Vázquez Tur, El piano y su música en el siglo XIX en España, Tesis Doctoral (Santiago de Compostela: Universidad de Santiago, Facultad de Geografía e Historia, 1988); Gemma Salas Villar, "Santiago de Masarnau y la implantación del piano romántico en España", Cuadernos de Música Iberoamericana, 4 (1996), pp. 197-222; Ana Vega Toscano, "Métodos españoles de piano en el siglo XIX", Cuadernos de Música Iberoamericana, 5 (1998), pp. 129-145; Emilio Casares Rodicio (dir.), 
Los estudios monográficos sobre músicos españoles de finales del siglo XIX y primera mitad del XX se han centrado sobre todo en figuras bien conocidas como compositores o intérpretes, como Isaac Albéniz, Enrique Granados, Francisco Asenjo Barbieri, Pablo Sarasate, Jaume Pahissa, Ruperto Chapí, Emilio Arrieta, Fernando Remacha, Julio Gómez, Tomás Bretón y Nemesio Otaño ${ }^{46}$. Mi Tesis se enmarca en esta tradición de estudios monográficos sobre compositores, pero poniendo el foco de atención en una figura actualmente casi olvidada, como es Amancio Amorós, y en su entorno histórico y cultural.

Actas del Congreso Internacional La zarzuela en España e Hispanoamérica. Centro y periferia 18001950, Cuadernos de Música Iberoamericana, 2-3 (1996-1997); Emilio Casares Rodicio, "Teatro musical, zarzuela, tonadilla, ópera, revista", en Historia de los espectáculos en España, coord. Andrés Amorós (Madrid: Castalia, 1999), pp. 147-172; Antonio Peña y Goñi, La ópera española y la música dramática en España en el siglo XIX. Apuntes históricos, edición facsímil (Madrid: ICCMU, 2004); Ramón Barce, "La ópera y la zarzuela en el siglo XIX", en España en la Música de Occidente, Actas del Congreso Internacional (Salamanca, 1985), eds. Emilio Casares, José López-Calo, Ismael Fernández de la Cuesta (Madrid: INAEM, 1987), vol. 2, pp. 145-153; Emilio Casares y Álvaro Torrente (eds.), La ópera en España e Hispanoamérica, 2 vols. (Madrid: ICCMU, 2002); Mª Antonia Virgili Blanquet, "La música religiosa en el siglo XIX español”, en La música española en el siglo XIX, eds. Emilio Casares y Celsa Alonso (Gijón: Servicio de Publicaciones de la Universidad de Oviedo, 1995); pp. 375-405; María Nagore Ferrer, "Una aportación al estudio de la reforma de la música religiosa en España: el Congreso Internacional de Música Sacra (Bilbao, 1896)", Revista de Musicología, 20/1 (1997), pp. 605-615; Mariano Lambea (ed.), El Motu Proprio de San Pío X y la Música (1903-2003), Actas del Simposio Internacional (Barcelona, 2003), Revista de Musicología, 27/1 (2004); María Nagore Ferrer, "Tradición y renovación en el movimiento de reforma de la música religiosa anterior al Motu Proprio", Revista de Musicología, 27/1 (2004), pp. 211-233; M Antonia Virgili Blanquet, "La música religiosa en el siglo XIX español", Revista Catalana de Musicología, 2 (2004), pp. 181-202; Francisco Javier Legasa, "Bonifacio Iráizoz (1883-1951) y el modernismo musical en el contexto del Motu Proprio", Príncipe de Viana, 238 (2006), pp. 675-693; José López-Calo, "Hilarión Eslava (1807-1878), precursor del cecilianismo en España", Príncipe de Viana, 238 (2006), pp. 577-607; Ma Antonia Virgili Blanquet, "El canto popular religioso y la reforma litúrgica en España (1850-1915)”, Aisthesis, 47 (2010), pp. 175-186.

${ }^{46}$ Walter Aaron Clark, Retrato de un romántico (Madrid: Turner, 2002); Walter Aaron Clark, Enrique Granados: Poet of the piano (Oxford: Oxford University Press, 2006); Emilio Casares Rodicio, Francisco Asenjo Barbieri, 2 vols. (Madrid: ICCMU, 1994); Luis G. Iberni, Pablo Sarasate (Madrid: ICCMU, 1994); Xosé Aviñoa, Jaume Pahissa: un estudi biogràfic i crític (Barcelona: Biblioteca de Catalunya, 1996); Luis G. Iberni, Ruperto Chapí (Madrid: ICCMU, 2009); Ma Encina Cortizo, Emilio Arrieta. De la ópera a la zarzuela (Madrid: ICCMU, 1998); Marcos Andrés Vierge, Fernando Remacha. El compositor y su obra (Madrid: ICCMU, 1998); Beatriz Martínez del Fresno, Julio Gómez: una época de la música española (Madrid: ICCMU, 1999); Víctor Sánchez Sánchez, Tomás Bretón: un músico de la Restauración (Madrid: ICCMU, 2002); José López-Calo, Nemesio Otaño: medio siglo de música religiosa en España (Madrid: ICCMU, 2010). 



\section{CAPÍTULO 1}

LA ACTIVIDAD MUSICAL EN VALENCIA ENTRE 1850 y 1925 



\section{El marco urbano, económico y sociopolítico en la Valencia de Amancio Amorós}

A mediados del siglo XIX el creciente proceso de urbanización hizo crecer las grandes ciudades europeas por encima de su entorno regional. Valencia es un ejemplo que responde a esta tendencia general. Los 64.186 habitantes registrados en la ciudad a finales del siglo XVIII según el Padrón Municipal en el interior de sus murallas y los 14.757 en la periferia pasaron a convertirse en 1857 en 88.057 habitantes en el interior y 19.382 en los arrabales ${ }^{1}$. La creciente industrialización, la exportación de productos agrícolas, el crecimiento de los mercados, el aumento demográfico, la introducción del ferrocarril en 1852 y el derribo de las murallas a partir de 1865 cambiaron la forma que tenía Valencia de relacionarse con el exterior ${ }^{2}$. La apertura de las grandes vías urbanas previstas en los planes de Ensanche potenció el sector oriental de la ciudad de Valencia, con una trama viaria ordenada, que se pobló de edificios de estilo modernista y ecléctico, muchos de los cuales todavía existen. En el resto de la ciudad y, en especial en la otra orilla del río Turia, la urbanización se retrasó hasta bien avanzado el siglo XX. Otra manifestación del carácter expansivo de Valencia fue la incorporación de municipios periféricos, desde el Grau o el Cabanyal a Patraix, Campanar, Benimaclet, y otros (véase Ilustración 2) $)^{3}$.

\footnotetext{
${ }^{1}$ Joaquín Azagra Ros, "La densificación de la ciudad intramuros", en Historia de Valencia (en adelante $H V$ ), dir. Antoni Furió (Valencia: Prensa Valenciana (Levante) y Universitat de València, 1999), pp. 431433.

2 Josep Vicent Boira, "Los accesos a la ciudad: caminos, carreteras, estaciones y puerto", en $H V$, p. 533; Anaclet Pons y Justo Serna, "La demolición de las murallas", en $H V$, pp. 501-503.

${ }^{3}$ Juan Luis Piñón, "Los ensanches de Valencia”, en $H V$, pp. 503-505; Víctor Algarra Pardo, "La anexión de los poblados periféricos", en $H V$, pp. 507-510.
} 


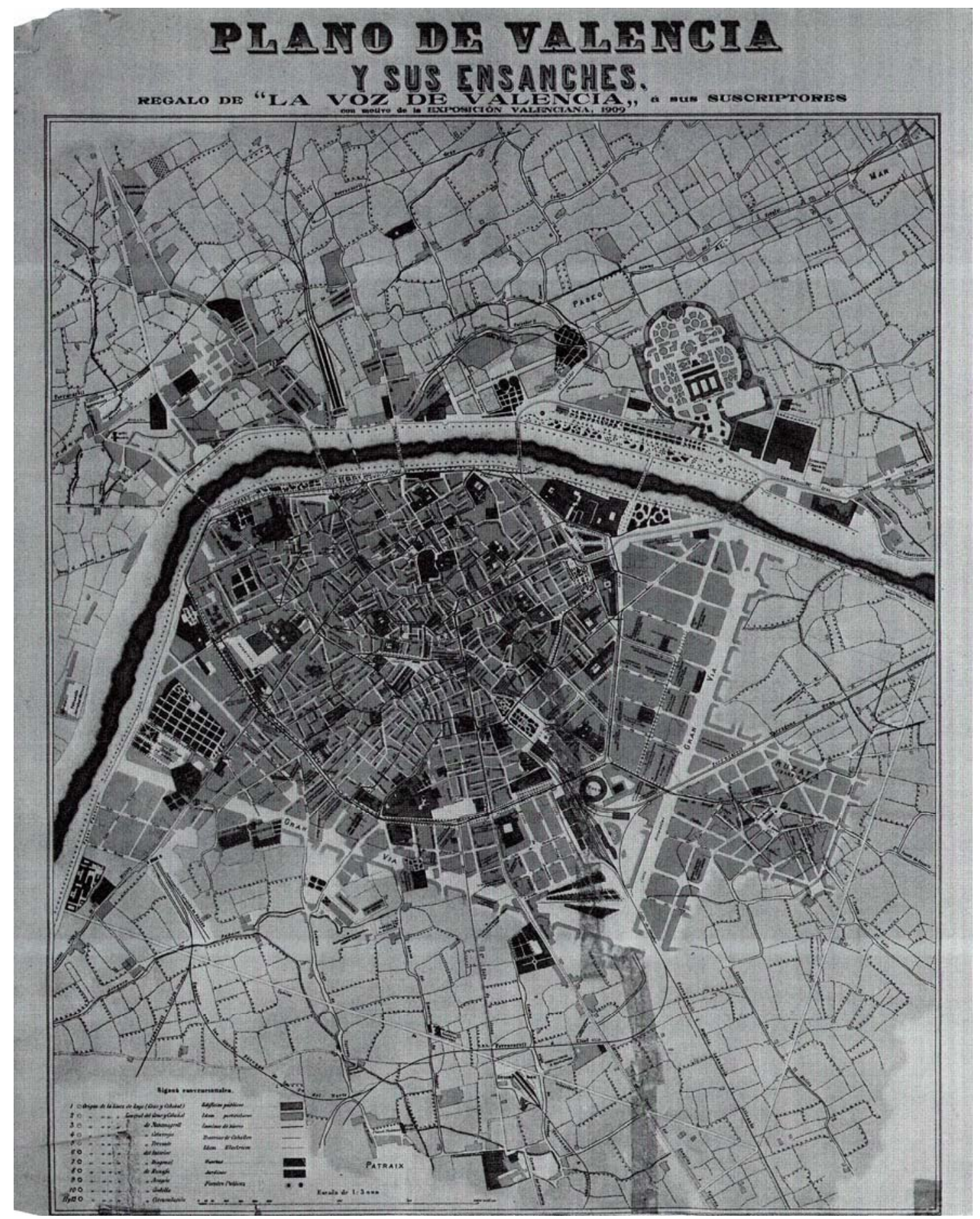

Ilustración 2

Plano de Valencia y sus ensanches (1910).

Cartografía Histórica de Valencia, p. 149. 
Valencia se convirtió en uno de los emporios comerciales e industriales más potentes de la cuenca mediterránea durante el siglo XIX. La burguesía valenciana se volcó en negocios financieros, ferroviarios, comerciales (habilitación del puerto ${ }^{4}$, llegada del ferrocarril $1^{5}$, mejora de las carreteras y caminos) e invirtió en industria y en tierras de regadío entre 1844 y 1865. A principios del siglo XIX en la provincia de Valencia sólo existían una serie de enclaves de industria dispersos (sedería, papel, textil lanero) en los partidos judiciales de Albaida, Alzira, Enguera, Requena y Xátiva ${ }^{6}$. A finales de la centuria, sin embargo, Valencia y su entorno ya ocupaban un lugar destacado en el contexto industrial español. Según Martínez Gallego, la imagen de una burguesía valenciana agrarista, volcada en negocios financieros y poco dispuesta a asumir riesgos en inversión industrial debería revisarse. La entrada del capitalismo provocó la crisis de las industrias manufactureras típicas del Antiguo Régimen. Una vez finalizado el sistema gremial y al decretarse la libertad de industria y eliminarse las patentes, la industria de la sedería, que había ocupado a la mayor parte del artesanado valenciano del setecientos, con una estructura obsoleta, entró en crisis pero no desapareció. Esta incipiente industria valenciana se dedicó a partir de la crisis de la sedería a la confección de prendas y artículos de vestir: sombreros, pieles, paños, abanicos, y surgieron además otro tipo de industrias, las relacionadas con la construcción y la metalurgia ${ }^{7}$.

\footnotetext{
${ }^{4}$ Véase Josep Vicent Boira, "El puerto de Valencia”, en $H V$, pp. 457-459.

${ }^{5}$ Véase Telesforo Hernández, "El impacto del ferrocarril”, en $H V$, pp. 456-457.

${ }^{6}$ Con la estructuración de España en provincias, implantadas en 1833, la provincia de Valencia quedó configurada con límites ligeramente diferentes a los actuales, sin incluir la Huerta de Gandía ni la Vall d' Albaida, que pertenecían a la provincia de Alicante, ni tampoco el Altiplano de Requena, que todavía era de Castilla. Los límites de las provincias de Valencia y Alicante se rectificaron entre 1836 y 1847, y la comarca de Requena-Utiel se anexionó a la provincia de Valencia en 1851.

${ }^{7}$ Francesc Andreu Martínez Gallego, "Vientos de progreso: la industria y el comercio a mediados del Ochocientos", en $H V$, pp. 460-462.
} 
El reinado de Isabel II (1844-1868) constituyó una etapa de relativa estabilidad institucional y de crecimiento para Valencia, sólo alterado por algunos enfrentamientos esporádicos y por el paréntesis del bienio progresista $(1854-1856)^{8}$. A partir de 1844 , los partidos Progresista y Demócrata dejaron de contar para el poder Moderado. El partido Moderado, cuyos miembros ocuparon el poder durante el periodo isabelino, exceptuando el bienio 1854-56, lo nutrían un grupo de propietarios, grandes comerciantes, financieros e industriales. Estos constituían una burguesía moderada, enriquecida con los negocios urbanísticos realizados al amparo de las leyes desamortizadoras 9 , con la prestación de servicios a la comunidad (abastecimiento de agua, pavimentado, gas, trasportes) o con operaciones financieras. Con el alcalde José Campo, que ocupó la alcaldía entre 1845 y 1850, Valencia dio un salto cualitativo hacia la modernidad, ya que mejoró sus infraestructuras y servicios ${ }^{10}$. Casi todos los integrantes de esta burguesía moderada vivían en Valencia, o entre Valencia y Madrid y dedicaban más tiempo a sus negocios que a la política. Su enlace permanente con el poder era el valenciano Luis Mayans, ministro, diputado y presidente de las Cortes. El partido moderado contaba por abajo con

\footnotetext{
${ }^{8}$ Isabel Burdiel, "Revolució Liberal i moderantisme burgés: 1833-1866", en Història del País Valencià (en adelante $H P V$ ), coord. Ernest Belenguer, 6 vols. (Barcelona: Edicions 62, 1988-2006), vol. 5 (1990), pp. 112-114; Pons y Serna, "Ayuntamiento y negocios político", en $H V$, p. 444. Puede consultarse también Joaquín Azagra Ros, El bienio progresista en Valencia. Análisis de una situación revolucionaria a mediados del siglo XIX 1854-65 (Valencia: Universitat de València, 1978).
}

${ }^{9}$ Los edificios desamortizados entre 1836 y 1847 generaron una amplia dotación de suelo urbano. Sus compradores -Reig, Lassala, Carsí, Dotres, Salvá, Cabrerizo, Calvet, Bertrán de Lis y otros- los reconvirtieron o los derribaron, obteniendo magníficos beneficios. Véase Manuel Sanchis Guarner, La ciutat de València, Sintesi d'història i de geografia urbana (Valencia: Generalitat Valenciana, Consell Valencià de Cultura, 1997), p. 448.

\footnotetext{
${ }^{10}$ José Campo Pérez (1814-1889). Político valenciano que fue diputado, senador y Alcalde de Valencia y marqués de Campo (título otorgado por Alfonso XII). Poseía una importante formación económica y financiera, fruto de sus viajes por Europa. En 1846 fundó la Sociedad Valenciana de Crédito y Fomento, el primer banco español de inversiones. Promovió la Sociedad de Conducción de Aguas Potables, el alumbrado de gas, y el adoquinado de la ciudad. En 1850 el marqués de Campo entró en el floreciente y más próspero de sus negocios, la empresa de ferrocarriles, compró los derechos de la línea del Mar a Xàtiva y en 1852 constituyó la Sociedad de Ferrocarriles del Grao a Játiva, primer ferrocarril valenciano. En esta empresa contó con la ayuda de la Real Sociedad Económica de Amigos del País, de la que era socio, y que aportó ayuda financiera y asesoramiento. Véase Vicente Gascón Pelegrí, Prohombres valencianos en los últimos cien años, 1878-1978 (València: Caixa d'Estalvis de València, 1978), pp. 9495.
} 
los caciques comarcales y, por arriba, con la Corona, que se apoyaba en él. Sus éxitos políticos dependían de censos electorales muy reducidos y convenientemente manipulados ${ }^{11}$. Su líder era el general Narváez, que recibió el título de Duque de Valencia en 1844.

En 1854 los progresistas recobraron el poder por dos años e intentaron llevar a cabo un vasto programa de reformas económicas. Desde 1864, y sobre todo a partir de 1866, el reinado de Isabel II conoció una crisis económica sin precedentes. En 1865, la paralización de la industria sedera valenciana era casi total y una epidemia contribuyó al declive final de la sericultura dejando a muchos artesanos sin trabajo. Eso añadió más paro, nuevas dificultades y nuevos problemas sociales a una coyuntura ya por sí misma en crisis. A todos estos problemas hay que añadir el brote de cólera de 1865, una inundación de la ribera del Júcar que hizo caer la producción de arroz valenciano en esos años y las crisis de subsistencias de 1867 y 1868 . La escasez de trigo, que no pudo ser paliada con la importación, ocasionó una subida espectacular del precio del pan. Los alimentos de primera necesidad alcanzaron precios prohibitivos y hubo especulación y hambre. La crisis financiera en Valencia coincidió con la crisis internacional y estuvo relacionada con la marcha defectuosa de los negocios ferroviarios, que precipitó la caída del régimen moderado y preparó la revolución de 1868. En Valencia, además, se produjo un malestar general entre la burguesía comercial y financiera que conllevó el desmoronamiento de la banca autóctona ${ }^{12}$.

Esta situación desembocó en la revolución de 1868, "la Gloriosa”. Se convocaron elecciones municipales que fueron favorables a los republicanos en varias ciudades de

\footnotetext{
${ }^{11}$ Francesc Andreu Martínez Gallego, "Banquete, tertulia y partido. Agentes de la política urbana", en $H V$, p. 443.

12 Pedro Ruiz Torres, "Crisi del sistema moderat i revolució democràtica 1866-1874”, en HPV, vol. 5 (1990), p. 118.
} 
España, entre ellas, Valencia, donde ganaron por mayoría en todos los colegios electorales $^{13}$. Este triunfo republicano continuó con las elecciones a Cortes Constituyentes, pues en la circunscripción de Valencia los cuatro líderes más votados fueron republicanos, pero este éxito fue un caso aislado, ya que el resultado en toda España fue favorable a la candidatura monárquico-democrática. La unidad de los republicanos se fue debilitando en los meses que siguieron a "la Gloriosa", ya que no se integraron en el gobierno provisional de España presidido por el General Prim. Los militantes del partido republicano se organizaron en pactos federales, como el que unió a Zaragoza, Valencia, Barcelona y Mallorca ${ }^{14}$.

La Constitución de 1869 no fue aceptada por los republicanos, ya que institucionalizaba un régimen monárquico e impedía que se introdujera cualquiera otra forma de Estado ${ }^{15}$. El 8 de octubre de 1869 la Milicia Nacional, con el apoyo de una masa de agricultores hambrientos, se sublevó en Valencia aclamando la República Federal. La plaza del Mercado fue el núcleo de la insurrección popular. Se nombró un directorio (presidido por el alcalde republicano Antonio Guerrero), que tuvo la ciudad en su poder nueve días, finalmente Valencia fue sometida con un duro bombardeo de artillería por el gobierno central. Los sucesos de octubre de 1869 en Valencia fueron el intento de conseguir la revolución democrática desde la barricada y la revuelta popular espontánea $^{16}$.

Tras el conflictivo reinado de Amadeo de Saboya (1870-1873), y la proclamación de la Primera República española (1873) un grupo de diputados se retiró de las Cortes e

\footnotetext{
${ }^{13}$ En las elecciones municipales de diciembre de 1868 triunfaron los republicanos en las principales ciudades del País Valenciano: Eleuterio Maisonnave, Josep Antoni Guerrero y Francesc González Cherma fueron elegidos alcaldes de Alicante, Valencia y Castellón respectivamente.

${ }^{14}$ Rosa Montlleó Peris, “La revolución Gloriosa y la Primera República”, en $H V$, pp. 450-451.

${ }^{15}$ Ruiz, "Crisi del sistema”, p. 129.

${ }^{16}$ Sanchis Guarner, La ciutat, pp. 491-492; Montlleó, “La revolución”, p. 451.
} 
instó a todas las provincias a la insurrección cantonal. El cantón de Valencia, proclamado el 19 de julio de 1873, fue anulado con las tropas del general Martínez Campos, que sometió la ciudad a un intenso bombardeo ${ }^{17}$.

El 28 de diciembre de 1874 llegó a Valencia el general Martínez Campos y se puso en contacto con el Marqués de Cáceres, el Marqués de Casa-Ramos, el Conde de Almodóvar, Cirilo Amorós, Teodoro Llorente y otros patricios valencianos partidarios de la restauración monárquica en la persona de Alfonso XII, hijo de Isabel II. Valencia fue, por tanto, cuna de la restauración borbónica, y sus clases acomodadas contribuyeron a construir el soporte político del sistema, el bipartidismo entre conservadores y liberales, mediante el clientelismo y el caciquismo ${ }^{18}$. Fuera del orden constitucional de la Restauración quedaron los carlistas -que eran muy fuertes en ciertos sectores rurales valencianos- y los republicanos federales, herederos de los demócratas -que predominaban en la capital y otras ciudades del País Valenciano-, y así mismo los obreros internacionalistas -cada día más fuertes en los núcleos industriales ${ }^{19}$. La estabilidad de la alternancia pactada empezó a venirse abajo con la concesión del sufragio universal masculino en 1891, a partir del cual el republicanismo, con el escritor Vicente Blasco Ibáñez al frente, ascendió hasta convertirse en la fuerza más votada. Tras la Guerra de 1914 el turno pactado quedó roto y los escaños de Valencia se repartieron entre

\footnotetext{
17 Montlleó, "La revolución", pp. 450-452. El cantonalismo fue la respuesta de los republicanos intransigentes a la lentitud con la que avanzaba el Gobierno en la vía del federalismo, convencidos de que éste sólo podría imponerse de abajo a arriba, y no al revés. El cantón de Valencia fue proclamado con el apoyo de la milicia republicana. Se nombró una Junta revolucionaria en la que convivían sectores tan diversos como los representados por el Marqués de Cáceres, Pascual Caruana o Teodor Llorente, todos ellos monárquicos, el rector de la Universidad, Eduardo Pérez Pujol y el historiador y viejo republicano Vicente Boix. En la primera proclama, la junta difundió la idea de mantener el orden a toda costa, no se planteaba reivindicaciones sociales y económicas como en otros cantones, y se justificaba que se hubiera proclamado el cantón de Valencia por la intranquilidad de la provincia debido a la larga crisis del Ministerio.

${ }^{18}$ Teresa Carnero, "Los partidos dinásticos y el turnismo", en $H V$, pp. 479- 481.

${ }^{19}$ Sanchis Guarner, en La ciutat, p. 505. Véase también Manuel Martí, "La societat valenciana de la Restauració (1875-1814): estabilització del domini burgés i contestació renovada”, en HPV, vol. 5 (1990), pp. 137-166.
} 
la Unión Republicana, los carlistas, el Partido Tradicionalista, la Agrupación Regionalista de Acción Católica, el Partido Socialista Obrero Español y el Partido Radical de España. Valencia ya no respetaba el turno de los partidos iniciado por el "canovismo" en 1876 bajo los borbones ${ }^{20}$.

En Valencia el partido republicano de Blasco Ibáñez recogió durante varias décadas los frutos del descontento popular, obteniendo un enorme respaldo y gobernando el consistorio de manera casi ininterrumpida entre 1901 y $1923^{21}$.

A principios del siglo XX Valencia era una ciudad industrializada. La importancia y el predominio de la industria sedera había disminuido, y subsistía la producción de curtidos y empujaba con fuerza el sector de la madera, la metalurgia y la alimentación, este último con una vertiente exportadora, -en particular de vinos y cítricos-, muy activa. Predominaba la pequeña empresa, pero día a día se introducía la mecanización y la producción se regía por criterios industriales. La mejor expresión de esta dinámica eran las exposiciones regionales, en particular la de 1909, emplazada junto a la Alameda, donde se mostraban los avances de la agricultura y la industria.

La I Guerra Mundial (1914-1918) afectó seriamente a la economía valenciana, colapsando las exportaciones de cítricos y produciendo el alza descontrolada de los precios y el desabastecimiento de los mercados. En 1917 el malestar en la capital se canalizó en forma de huelga general, que se prolongó durante varias semanas, enrareciendo el ya de por sí tenso panorama social. En 1919 y 1920 se repitieron las movilizaciones y se entró en una espiral de violencia en la que se sucedieron las bombas y los asesinatos de civiles y de agentes del orden. La instauración de la dictadura de

\footnotetext{
${ }^{20}$ Alicia Yanini, “La máquina electoral del caciquismo”, en $H V$, pp. 481- 482.

${ }^{21}$ Joan Alcázar, "La primera Guerra Mundial i la Dictadura de primo de Rivera", en HPV, vol. 5 (1990), pp. 261-262.
} 
Primo de Rivera (1923-1930), bien acogida por la burguesía valenciana, frenó durante algunos años la conflictividad social, pero no apagó la creciente radicalización política.

\section{El marco cultural y artístico}

\section{1. La Renaixença valenciana}

La Renaixença fue un movimiento cultural y de concienciación nacionalista surgido en la década de los treinta del siglo XIX, y preocupado por la recuperación de las señas de identidad propias de valencianos, catalanes y mallorquines. Parte esencial del movimiento fue buscar la regeneración y recuperación de la lengua catalana hablada en Cataluña, Baleares y Valencia. La afinidad idiomática relacionó los resurgimientos de estos tres territorios, unidos por otros vínculos de índole histórica: no sólo el nombre Renaixença fue compartido en todos ellos, sino que los protagonistas del proceso fueron mutuos colaboradores, tanto en revistas literarias como en sus respectivos Juegos Florales y otras iniciativas culturales ${ }^{22}$.

Suele considerarse que el origen de la Renaixença valenciana tuvo lugar en 1859, año en que se celebraron en Valencia los primeros Juegos Florales, y que el movimiento se prolongó durante la segunda mitad del siglo XIX y la primera del $\mathrm{XX}^{23}$. Vicent

\footnotetext{
${ }^{22}$ Marc Baldó, "Consolidació de la cultura burgesa”, en HPV, vol. 5 (1990), pp. 189-190; Manuel Jorba i Jorba, "La Renaixença", en Història de la Literatura Catalana, dir. Joaquim Molas, 11 vols. (Barcelona: Ed. Ariel, 1984-1988), vol. 7 (1986), pp. 9-39; Margalida Tomàs, "Renaixença", en Gran Enciclopedia Catalana, dir. Jordi Carbonell, 16 vols. (Barcelona: Enciclopedia Catalana, 1969-1983), vol. 12 (1978), pp. 466-467.

23 Vicent Simbor Roig, Els origens de la Renaixença valenciana (València: Universitat de València, 1980), pp. 13-18. También en Barcelona se celebraron Juegos Florales en 1859 pero, a diferencia éstos, los de Valencia, de ese mismo año, fueron bilingües, en castellano y valenciano (muestra de las dificultades que marcarán todo el proceso de la Renaixença valenciana). Véase Vicent Simbor Roig, "La Renaixença: entre Teodor Llorente y Constantí Llombart", en HV, p. 492. Los Juegos Florales de Valencia fueron patrocinados por el Liceo Valenciano y se celebraron en el paraninfo de la Universidad de Valencia. Nacieron por el empeño del mallorquín Marià Aguiló, bibliotecario de la Universidad de Valencia, ayudado por Teodor Llorente (1836-1911) y Vicente W. Querol (1837-1889), y no tuvieron continuidad, ya que no se repitieron hasta 1879, gracias al esfuerzo del grupo de Constantí Llombart. Manuel Sanchis Guarner, Renaixença al País Valencià (Valencia: Colecció 3 i 4, 1982), pp. 31-33; Lluís Guarner, La Renaixença Valenciana i Teodor Llorente (Barcelona: Edicions 62, 1985), pp. 26-27. Durante el siglo XIX la exaltación del mundo medieval y el deseo de dar una base social y literaria a la lengua catalana hizo surgir la idea de restaurar la antigua fiesta de los Jocs Florals [Juegos Florales]. El 1
} 
Simbor, sin embargo, sitúa el origen de la Renaixença valenciana en 1830, año en que el Diario de Valencia publicó el poema En los dies del nostre rey Fernando de Antoni Maria Peyrolon (administrador de Real Patrimonio de la Albufera), en el que el autor felicitó a Fernando VII el día de su santo. Para Simbor, éste es "el primer poema renaixencista publicado en el territorio de los Países Catalanes"24.

La Renaixença actuó en diversos frentes: literatura culta y popular, música, artes plásticas y folclore, con una atención especial por la recuperación y dignificación de la lengua propia. La Renaixença valenciana ha sido estudiada específicamente desde diferentes puntos de vista ${ }^{25}$.

El prestigio de la lengua castellana, por ser la lengua de la capital española, se reforzó a partir del siglo XVIII con las medidas coercitivas de la monarquía borbónica. El proceso de castellanización de la burguesía valenciana a lo largo del siglo XIX coincide pues, en aparente contradicción, con el desarrollo de la Renaixença que reivindicaba una revaloración de la lengua autóctona. El valenciano no dejó de ser nunca un vehículo de

de mayo de 1859 en el Saló del Cent de Barcelona se restauró esta fiesta con apoyo del Ayuntamiento. Algunos sectores más progresistas la consideraron un anacronismo. Los Juegos Florales se centraron en torno a la tríada temática de Fe, Patria y Amor; véase Antón M. Espadaler, Història de la literatura catalana (Barcelona: Editorial Barcanova, 1993), p. 153.

${ }^{24}$ Simbor, Els origens, pp. 90-93; Simbor, “La Renaixença al País Valencià”, Caplletra, 4 (1988), p. 11.

25 En mi estudio he manejado sobre todo las siguientes aportaciones, que menciono por orden cronológico: Nicolau Primitiu, Renaixença i Romanticisme (València: Edicions Acció, 1935); Alfons Cucó, Aspectes de la política valenciana en el segle XIX (Barcelona: Rafael Dalmau, 1965); Manuel Sanchis Guarner, Les generacions literàries en la Renaixença valenciana (València: Lo Rat Penat, 1968); Alfons Cucó, El Valencianisme polític 1874-1936 (València: Cosmos, 1971); Ricard Blasco, "Lo Rat Penat: periodich lliterari quincenal (1884-1885)", Estudis romànics, 16 (1971-1975), pp. 185-231; Simbor, Els origens (1980); Sanchis Guarner, Renaixença al País Valencià (1982); Manuel Sanchis Guarner, El sector progresista de la Renaixença valenciana (Valencia: Universitat de València, 1985); Guarner, La Renaixença Valenciana (1985); Simbor, "La Renaixença al País Valencià" (1988), pp. 9-43; Ricard Blasco, "Llengua i pàtria al País Valencià durant la Renaixença", Caplletra, 4 (1988), pp. 43-67; Baldó, "Consolidació de la cultura" (1990), pp. 167-220; Espadaler, Història de la literatura, pp. 149172; Joan Gil Barberà [et al.], Lo Rat Penat (Valencia: Consell Valencià de Cultura, 1996); Antoni Furió (dir.), "La Cultura de la Renaixença", en $H V$, pp. 489-500; Simbor, "La Renaixença", pp. 492-494; F. Archilés y M. Martí, “La cultura política de la Renaixença”, en $H V$, pp. 498-500. 
comunicación oral, sobre todo en las clases populares, incluso en las grandes ciudades como Valencia ${ }^{26}$.

El Romanticismo se interesó por la "nación" y por la "patria", buscó sus caracteres específicos, cantó sus gestas y éstas fueron el soporte ideológico y cultural de la Renaixença. El pasado comenzó a verse con nostalgia y la lengua era uno de los componentes más sensibles de los rasgos que caracterizaban al pueblo ${ }^{27}$. Durante la Renaixença se escribieron varios poemas en "llemosí", lengua culta autóctona de la zona catalano-parlante, y se inició un movimiento reivindicativo encaminado a devolver al valenciano su prestigio como lengua vehicular a todos los niveles ${ }^{28}$.

En la Renaixença valenciana hubo dos grupos diferentes: el guant o grupo cultista (poetas burgueses) y l'espardenya o de los poetas populistas o populares ${ }^{29}$. El grupo cultista estuvo integrado además por Vicente W. Querol (1837-1889), Jacinto Labaila (1833-1895), Rafael Ferrer (1836-1892) y Félix Pizcueta (1837-1890). Todos tenían títulos universitarios y propiedades agrícolas, casi todos eran abogados, y eran políticamente conservadores (excepto Pizcueta). El único que mantuvo una dedicación poética fue Llorente. Este grupo no creó ninguna infraestructura cultural. Sus miembros defendieron el apoliticismo y criticaron al sector reivindicativo del movimiento

\footnotetext{
${ }^{26}$ Véase José Luis Sirera, "La cultura de principios de siglo", en Historia del País Valenciano, coord. Pedro Ruiz Torres, 6 vols. (Madrid: Editorial Planeta, 1980-1981), vol. 5 (1981), p. 427. Sobre aspectos sociolinguísticos de la Renaixença véase Rafael Lluís Ninyoles, Conflicte lingüístic valencià (València: Eliseu Climent, 1978). Utilizaré el término valenciano para referirme específicamente al catalán hablado en Valencia.

${ }^{27}$ Primitiu, Renaixença i Romanticisme, pp. 9-15.

${ }^{28}$ Para muchos autores de la época el "llemosín" era el equivalente al catalán culto, y se usaba para designar la lengua común de catalanes, valencianos y mallorquines, que se creía descendía del provenzal. Según Sirera, "La cultura", p. 464, el lemosín es un dialecto occitano utilizado por los trovadores provenzales durante los siglos XII y XIII.

${ }^{29}$ Baldó, “Consolidació de la cultura”, pp. 196-200.
} 
renaixencista catalán (encabezado por Víctor Balaguer) que pretendía no sólo recuperar el uso culto de la lengua sino otros derechos como pueblo con personalidad propia ${ }^{30}$.

La Renaixença valenciana tuvo un impulso mayor a mediados de la década de los setenta con las actividades del grupo populista y progresista, encabezado por Constantí Llombart (1848-1893), que incluía personas de ideología radical y republicana ${ }^{31}$. En 1874 se inició en Valencia la revista anual Lo Rat Penat: Calendari Llemosí, escrita en llemosí, el catalán culto de la Renaixença valenciana. Esta revista fue la primera plataforma aglutinadora de los renaixencistas valencianos y el germen de la nueva sociedad Lo Rat Penat $^{32}$. El grupo de Llombart, a diferencia del grupo anterior promovido por Llorente, defendía el uso vivo de la lengua valenciana y un contacto más estrecho con el pueblo y su mundo literario (sainets, peces valencianes, revistas satíricas y políticas).

El grupo progresista de Llombart creó en 1878 la sociedad Lo Rat Penat, en la que participaron también los integrantes del grupo cultista de Llorente. El acto fundacional de la sociedad, celebrado en el recinto de la Feria de Julio de Valencia el 31 de julio de 1878, puso ya de manifiesto las diferencias esenciales en la concepción del movimiento entre los dos grupos. Mientras el grupo de Llorente declamó sus versos con una retórica vacía y aséptica, el grupo populista de Llombart puso de manifiesto una

\footnotetext{
${ }^{30}$ Guarner, La Renaixença Valenciana, p. 36. Llorente, Ferrer y Bigné, al reivindicar el apoliticismo, defendían la política centralista española, en la que ellos mismos participaban como representantes de las provincias de los partidos monárquico-conservadores. En la Renaixença valenciana los poetas burgueses no estaban en contra del marco conservador y unitarista, su valencianismo podía conciliarse con el proceso centralizador y aceptaban el orden burgués establecido. Los poetas populares, frecuentemente republicanos, estaban en contra de este orden.

${ }^{31}$ Carmelo Navarro Llombart (1848-1893) era hijo de humildes artesanos. Estudió con Macario Asensi y después fue al Colegio de las Escuelas Pías. Fue un republicano federalista que había destacado en la resistencia cantonal de Valencia y que supo reunir a un grupo de colaboradores, que como él, eran de extracción social humilde, autodidactas y políticamente progresistas: Josep d'Orga Piñana (1800-1881), Josep Bodría i Roig (1842-1912), Josep Sanmartín i Aguirre (1848-1901), Antoni Palanca i Hueso (18481905), Víctor Iranzo i Simón (1850-1890), Lluís Cebrián i Mezquita (1851-1934), Ricard Cester (1855?), Josep M. Puig Torralba (1859-1911) y Vicente Blasco Ibáñez (1867-1928), entre otros. Véase Gascón, Prohombres valencianos, pp. 267-270.

${ }^{32}$ Blasco, "Lo Rat Penat", p. 186.
} 
Renaixença políticamente más reivindicativa ${ }^{33}$. El presidente de Lo Rat Penat, Félix

Pizcueta, único miembro progresista del grupo de Llorente, tuvo que tranquilizar los ánimos de la burguesía asistente al acto inaugural, asegurando que Lo Rat Penat no tenía ninguna finalidad de reivindicación política:

Vull previndre els espirits recelosos respecte a les nostres mires i intencions; vull no deixar dubte respecte als propòsits que ens animen.

Tal vegada crega algú que la creació d'aquesta societat obeïx quant menys a alguna mira d'exclusivisme provincial i quant més a alguna idea separatista; i jo, que dec concentrar al meu pit els sentiments de mos dignes companys, tinc que declarar ací, que ans que tot som fills i amants de la noble terra espanyola, que no ressuscitem glòries de l'antic Reialme valencià més que per tenir el goig de que no s'obliden i es perguen com la seua llengua en l'obscuritat del temps $[\ldots]^{34}$.

Se ha atribuido a Llombart un grado notable de reivindicación y conciencia nacional que estaría ausente en el grupo de Llorente. A Constantí Llombart se le ha considerado el pilar básico de la Renaixença valenciana pero políticamente, según Arniches, nada hace suponer que sus ideas pudiesen haber servido para dar el paso desde el federalismo a una articulación explícitamente nacionalista. A Llorente se le ha reprochado que no politizara la Renaixença (únicamente se preocupó de la estricta producción cultural) y que fuese un españolista vinculado a los intereses de Madrid. Su actividad se calificó incluso de antivalencianista y de ser la expresión de los deseos la clase dominante valenciana. Sin embargo, todos los renaixencistas valencianos eran

\footnotetext{
${ }^{33}$ Simbor, "La Renaixença", pp. 492-494; Cucó, El Valencianisme politic, pp. 9-25, pone de relieve la ambigüedad de no pocas ideas del valencianismo político de Llombart, que nunca se pronunció claramente sobre el objetivo político-cultural.

${ }^{34}$ Felix Pizcueta, "Discurs de gràcies del Sr. President en Feliu Pizcueta", en Excel.lències de la llengua llemosina: discurs panegirich llegit en la solemne sessió inaugurativa de Lo Rat Penat per Constantí Llombart (Valencia: Emili Pasqual, 1878), pp. 85-87. [Quiero calmar los espíritus recelosos respecto nuestras miras e intenciones: no quiero dejar ninguna duda respecto a los propósitos que nos animan. Tal vez alguien pueda creer que la creación de esta sociedad obedece a alguna mira de exclusivismo provincial y a alguna idea separatista; y yo, que debo aunar en mi pecho los sentimientos de mis compañeros, tengo que declarar aquí, ante todo somos hijos y amantes de la noble tierra española, que no resucitamos glorias del antiguo reino valenciano más que para tener el placer de que no se olviden y pierdan como su lengua en la oscuridad del tiempo].
} 
españolistas y éste no era el hecho que los diferenciaba. Según Arniches no hubo en realidad ningún planteamiento de identidad nacional valenciana que no fuera al mismo tiempo español, y ni Llombart ni Llorente pueden ser interpretados sin referirnos al doble patriotismo como su rasgo distintivo ${ }^{35}$.

Finalmente el prestigio literario de Llorente y sus compañeros se impuso y Teodoro Llorente fue elegido presidente de la entidad Lo Rat Penat para el año 1879-80. De esta forma la sociedad Lo Rat Penat estuvo desde su nacimiento en manos del grupo burgués. Las presidencias de Llorente, Labaila, Ferrer i Bigné, Vicent Pueyo, Ferran Reig i Garcia no lograron impulsar una dinámica definida e influyente en la calle. En 1884 el grupo de Llombart consiguió que saliera elegido presidente el progresista Félix Pizcueta. Entre diciembre de 1884 y abril de 1885 se publicó la revista Lo Rat Penat: periòdich lliterari quincenal. La publicación, aparecida seis años después de la fundación de la entidad valencianista, estuvo controlada por el grupo de Llombart y contó con la colaboración de renaixencistas valencianos, de Catalunya y de las Islas Baleares, pero sin ninguna intervención del grupo de Llorente (que miró con recelo la publicación) ${ }^{36}$.

Para Llombart la Renaixença sólo tenía sentido si se contemplaba como un movimiento de reivindicación global de la personalidad de los valencianos y no se reducía a una simple dedicación poética nostálgica. Llorente en cambio, como líder del conservadurismo, tuvo que enfrentarse a las presiones de su misma clase social, que no

\footnotetext{
${ }^{35}$ Véase Archilés y Martí, "La cultura política”, pp. 498-500.

${ }^{36}$ Los burgueses valencianos, tributarios políticamente del gobierno central, miraron con recelo algunas composiciones poéticas leídas en el acto de inauguración de la entidad (28-VII-1878) con expresiones anticentralistas. A los recelos políticos que impidieron un normal desarrollo de la recién creada entidad se sumaron disensiones de tipo cultural, como las polémicas surgidas en 1881 entre los valencianistas e intelectuales locales castellanoparlantes. Según Blasco, "Lo Rat Penat", pp. 9-10, los propios fundadores de Lo Rat Penat no sabían qué hacer con la lengua valenciana restaurada. Incluso Teodoro Llorente consideraba que el arcaísmo era un elemento necesario para dar condiciones literarias a un idioma que en el uso vulgar las había perdido por falta de cultivo. La influencia ejercida por Llorente y su menosprecio a los autores populares que utilizaban la lengua viva, produjo una división entre los escritores valencianos.
} 
aceptaba ninguna política que atacara el sistema político de la Restauración, inaugurado recientemente ${ }^{37}$.

Desde el punto de vista musical, la Renaixença revalorizó las tradiciones populares y subrayó la necesidad de formar una conciencia musical valenciana. Uno de los puntos principales en los que se afirmó la Renaixença musical fue la utilización del folclore en el lenguaje creativo ${ }^{38}$. La Renaixença actuó además como activadora de la investigación musicológica. Tradicionalmente la historiografía valenciana afirma que tres nombres sustentaron musicalmente este movimiento cultural en Valencia: Juan Bautista Guzmán (1846-1909), José María Úbeda (1839-1909) y Salvador Giner (1832-1911) ${ }^{39}$. A estos podrían añadirse otros como Vicente Peydró, Amancio Amorós, Eduardo Ximénez o Manuel Penella Raga. Desarrollaré más adelante las conexiones de Amorós con la Renaixença.

\section{2. La creación artística}

La arquitectura de la Restauración, fundamentalmente ecléctica, como la arquitectura modernista que se da desde 1900 a 1915 son fenómenos ligados al proceso de formación de la ciudad. En la Valencia de la Restauración, dentro de los historicismos, el neogótico fue el más importante. Este estilo se adoptó en edificios públicos de carácter religioso como capillas e iglesias, en establecimientos benéficos y asistenciales (casa de la Beneficiencia, de la Misericordia, Colegio Imperial de Huérfanos, asilo de San Juan Bautista y del Marqués de Campo) y algunos teatros valencianos como el Teatro Apolo (1876) y el Teatro Ruzafa (1880), estilo que contrastará con el neoclásico o académico

\footnotetext{
${ }^{37}$ Simbor, "La Renaixença", pp. 495-496; David Cervera, La prensa valenciana y su aportación a la Renaixença (Valencia: Ayuntamiento de Valencia, 1976), pp. 60-61.

${ }^{38}$ Galiano, "La Renaixença", p. 302.

${ }^{39}$ Climent, Historia de la música, p. 29.
} 
del Teatro Principal $(1832)^{40}$. Desde comienzos del siglo XX, el Modernismo ofreció nuevos repertorios decorativos y efectos a unos arquitectos que buscaban un estilo propio y definitorio de su época. Aunque la recepción del modernismo en Valencia fue tardía, su lenguaje se mantuvo en los medios populares después de desaparecer como arquitectura culta. El modernismo se utilizó para edificios monumentales de carácter público que todavía hoy caracterizan el paisaje urbano de Valencia, como los Mercados de Colón y Central y la estación del Norte ${ }^{41}$.

En el campo de las artes plásticas, la escultura valenciana del período tuvo poca importancia y osciló entre la supervivencia de una imaginería populista y el desarrollo de la escultura neoclásica, que se mantuvo hasta bien entrado el siglo XX. Por el contrario, la pintura valenciana del momento adquirió gran importancia y desde mediados del siglo XIX existió una Escuela Valenciana de pintura que ejerció una gran influencia posterior. En ella se han señalado tres grupos: 1) La escuela romántica valenciana que desarrolla la pintura de historia, cuyo máximo representante fue Antonio Gisbert (1834-1901), con obras como El Fusilamiento de Torrijos y sus compañeros y Los comuneros de Castilla. En esta etapa también destacan Martínez Cubells (1845-1917), autor de la pintura de las cúpulas de San Francisco El Grande de Madrid y F. Domingo Marqués, más cercano al impresionismo, y autor de La expulsión de los moriscos. Además de las pinturas de historia, en esta escuela se desarrolló una pintura costumbrista que enlaza con los presupuestos teóricos de la Renaixença valenciana, con artistas como Bernardo Ferrándiz (1825-1885) autor del El Tribunal de las Aguas; A. Fillol (1870-1930) y P. Francés

\footnotetext{
${ }^{40}$ Trinidad Simó, “Arquitectura y urbanismo, 1874-1920”, en Historia del Arte Valenciano, dir. Vicente Aguilera Cerni, 6 vols. (Valencia: Consorci d'editors valencians, 1986-1990), vol. 5 (1987), pp. 46, 51 y 53. Véase también Daniel Benito Goérlich, La arquitectura del eclecticismo en Valencia. Vertientes de la arquitectura valenciana entre 1875-1925 (Valencia: Ajuntament de València, 1983).

${ }^{41}$ Daniel Benito Goérlich, "Del historicismo al modernismo: la arquitectura valenciana entre dos siglos", en $H V$, pp. 513-515; Simó, “Arquitectura y urbanismo”, en $H V$, pp. 65- 73.
} 
(1854-1902), entre otros ${ }^{42}$; 2) Pintores que desean renovar la técnica y se adentran en el Impresionismo, tomando como maestros a Rosales y Fortuny. En esta tendencia se alternaba la pintura de historia, la de costumbres, el paisaje y el retrato. Destacaron en ella Joaquín Agrasot (1836-1919), Josep Benlliure Gil (1855-1937), Antonio Muñoz Degraín (1840-1924), e Ignacio Pinazo (1949-1916); 3) Joaquín Sorolla (1863-1923), representante del luminismo costumbrista en cuya producción se distinguen tres etapas: la primera de connotaciones naturalistas y temática social que conecta con la obra de su amigo Blasco Ibáñez (Aún dicen que el pescado es caro, Triste herencia); una etapa en la que acentúa la temática costumbrista y reproduce escenas de la vida cotidiana del Cabanyal de Valencia (Sol de la mañana, Sol de la tarde) y finalmente, a partir de 1910, la última etapa con predominio de una mayor serenidad y clasicismo en sus obras. Joaquín Sorolla recopiló entre 1911 y 1919 escenas del folklore y el costumbrismo español en catorce gigantescos óleos, encargo del mecenas y erudito Archer Milton Huntington para la Hispanic Society de Nueva York ${ }^{43}$.

La creación literaria valenciana de finales del XIX y comienzos del XX estuvo polarizada por dos grandes fenómenos: la Renaixença y el naturalismo. En ambos casos los escritores se interesaron por el tema local o regional. En la Renaixença, el grupo cultista (Renaixença de guant) produjo poemas de excelente factura en los que se crearon tópicos locales, mientras que el grupo popular (Renaixença d'espardenya), añadió a la producción de poesías y ensayos una reivindicación popular y autóctona (prensa satírica y sainete en valenciano). Suele considerarse que Teodoro Llorente ejerció el monopolio

\footnotetext{
${ }^{42}$ La pintura de historia, especialmente demandada en los encargos de instituciones y los concursos académicos, era aparatosa y teatral, y se insertaba dentro de la sensibilidad romántica y nacionalista. El costumbrismo valenciano exaltó la pluralidad española y contribuyó a forjar una imagen de Valencia tópica, muy parecida a la descrita en los versos de Llorente. Véase Baldó, "Consolidació de la cultura", pp. 218-220; Enrique Tormo, “L'Art valencià del segle XX", en HPV, vol. 5 (1990), p. 414.

${ }^{43}$ Sirera, "La cultura", pp. 442-445; Baldó, "Consolidació de la cultura", pp. 218-220; Tormo, "L’Art valencià", pp. 411-413.
} 
de la poesía de la Renaixença. Eduard J. Verger constata sin embargo, que su poesía representa sólo una parte, abundante, pero no la mejor de toda la producida. Prácticamente todos los poetas valencianos produjeron obras para los Juegos Florales a cambio de prestigio. Pero la aceptación de las convenciones retóricas de los Juegos Florales no siempre afectó toda la obra de cada escritor, y después de la fundación de Lo Rat Penat se desarrolló, en las dos últimas décadas del s. XIX, otra corriente poética menos academicista y tradicionalista con poetas como Josep Bodría, Víctor Iranzo, Constantí Llombart y Antoni Palanca ${ }^{44}$.

Los temas locales y regionales valencianos eran también esenciales en la novela naturalista valenciana. Vicente Blasco Ibáñez, comprometido con la causa republicana, fue uno de los máximos exponentes de esta corriente naturalista ${ }^{45}$. En sus novelas se propuso mostrar la nueva sociedad, en la que convivían tradiciones (sin añorarlas) y el inevitable progreso y cambio social. Blasco Ibáñez incluyó aspectos desagradables y denuncia social en sus obras, en contraste con la temática idílica e irreal que plasmaba Llorente en sus poemas.

\section{3. Historiografía e inicios de la Musicología en Valencia}

El ensalzamiento de lo propio, propugnado por la Renaixença, potenció el desarrollo de la historiografía local valenciana, ejercida por profesionales liberales (abogados, periodistas, propietarios, políticos, archiveros, médicos). Surgió así la

\footnotetext{
${ }^{44}$ Eduard J. Verger, "La poesia valenciana de la Restauració (1874-1902)", en La Ilustració poètica metropolitana \& continental, Versos $i$ altres escrits, Articles i notes de crítica literaria. Artículo online perso.wanadoo.es/lipmic/verger/, consultado el 10-IV-2009. Véase también José Luis Sirera, Història de la literatura valenciana (Valencia: Edicions Alfons el Magnànim, 1995), pp. 400-415.

45 Destacan sus novelas Arroz y tartana (1894), Flor de Mayo (1895), La Barraca (1898), Entre naranjos (1900) y Cañas y Barro (1902). Véanse Alborg, J. L., Realismo y Naturalismo. La novela III. A. Palacio Valdés - V. Blasco Ibáñez (Madrid: Gredos, 1999); J. Oleza y J. Lluch (eds.), Vicente Blasco Ibáñez 1898-1998. La vuelta al siglo de un novelista. Actas del Congreso Internacional (Valencia, 1998), 2 vols. (Valencia: Direcció General del Llibre i Coordinació Bibliotecària, 2000); Joan Oleza, "Novelas mandan. Blasco Ibáñez y la musa realista de la modernidad”, en Vicente Blasco Ibáñez, pp. 19-51.
} 
denominada "escuela histórica valenciana", que focalizó su interés en la documentación de aspectos concretos de la historia de Valencia ${ }^{46}$. También se desarrolló en Valencia la escuela Krausista que fue seguida por los llamados "institucionistas". El interés por lo local de este grupo fue escaso y sus inquietudes intelectuales se definían en el marco nacional español; se interesaron por el progreso, el cultivo de la ciencia y el europeísmo. Los "institucionistas" eran profesores universitarios, librepensadores y republicanos que se hallaban en las antípodas del conservadurismo que dominó la Renaixença y cultivaron la filosofía y las ciencias jurídicas, sociales y humanas ${ }^{47}$.

En el marco general de desarrollo de la historiografía valenciana, surgieron también las primeras aportaciones de Valencia a la Musicología, entre ellas la de Amancio Amorós, que trataré en el Capítulo 4 de esta Tesis.

Según Ana Galiano, la musicología valenciana nació con los estudios de Juan Bautista Guzmán (1846-1909) que, durante el periodo que ejerció como maestro de capilla en la catedral de Valencia, trabajó en la ordenación y catalogación de su archivo musical y en 1888 publicó en Madrid algunas obras de Juan Bautista Comes, compositor valenciano del siglo XVII ${ }^{48}$. Guzmán localizó en la catedral de Valencia gran cantidad de obras autógrafas de Comes, en un estado tan lastimoso que "muchas parecían encajes por la acción de la tinta sobre el papel y los estragos de la polilla»" ${ }^{\text {" }}$. El trabajo de Guzmán

\footnotetext{
${ }^{46}$ En ella destacan historiadores como Roque Chabás, Manuel Dancila, Teodor Llorente, Josep Serrano y Josep E. Serrano Morales, entre otros.

${ }^{47}$ Marc Baldó, "La cultura: entre el naturalismo y el positivismo", en $H V$, pp. 521-522.

48 Juan Bautista Guzmán, compositor y musicólogo, inició su formación en la parroquia y banda de Aldaia (Valencia), donde estudió solfeo y órgano con Mariano Vera. Posteriormente estudió armonía con José Piqueras y José María Úbeda. Obtuvo por oposición las plazas de organista en la catedral de Salamanca (1872) y Real Monasterio de Nuestra señora de Covadonga (1872). Fue maestro de capilla en la catedral de Ávila (1875), Valladolid (1876) y finalmente en la catedral de Valencia (1879) en donde permaneció doce años. Merece destacarse su papel al frente de la Escolanía de Montserrat, entidad a la que dio un fuerte impulso durante los últimos años del siglo XIX y primeros del XX. Véase Joan Gay i Puigbert, “Guzmán Martínez, Juan Bautista [Manuel]”, en DMEH, vol. 6 (2000), pp. 172-173.

${ }^{49}$ Galiano, "La Renaixença”, p. 303.
} 
supuso ya un interés por el archivo musical de la catedral valenciana y por sus $\operatorname{maestros}^{50}$.

Más conocida y relevante que la de Guzmán fue la aportación musicológica de Vicente Ripollés Pérez, que en su primer trabajo de investigación se propuso estudiar las fuentes musicales más antiguas conservadas en los archivos catedralicios de Valencia, centrándose en las epístolas farcidas de Navidad y de San Esteban, copiadas en el Epistolare Valentinum, un manuscrito del siglo XIV (códice 110 de la catedral de Valencia). El resultado de esta investigación fue presentado por Ripollés en el Congreso Internacional de Musicología celebrado en Basilea en 1924, con el título "Breves anotaciones a la Epístola Farçida de San Esteban"51. El segundo trabajo de investigación de Ripollés fue "Dramas litúrgicos que tienen por aumento la parábola evangélica de las Virgenes prudentes et fatuae y el hecho real de la Resurrección de Jesucristo", publicado en los Anales del Centro de Cultura Valenciana, que fue una ampliación del discurso del autor en la inauguración del curso 1928 del Centro de Cultura Valenciana ${ }^{52}$.

Otros relevantes trabajos musicológicos de Ripollés fueron la transcripción de la Visitatio Sepulchri de Gandía, la publicación de "Fragmentos del epistolario de Pedrell” y El Villancico i la cantata del segle XVIII a Valencia (1935) que, según Miguel A. Picó es la obra más rigurosa de toda la musicología valenciana de la primera mitad del siglo XX;

\footnotetext{
${ }^{50}$ El mal estado de los papeles fue mencionado por Guzmán en una carta a F. A. Barbieri. Véase Daniel Codina, "Felip Pedrell i la música religiosa. La seva relació amb el monestir de Montserrat", Recerca Musicològica, 11-12 (1991-1992), pp. 357-358.

${ }^{51}$ Vicente Ripollés Pérez, "Breves anotaciones a la epistola farçida de San Esteban", Boletín de la Sociedad Castellonense de Cultura, 22 (1946), pp. 127-166.

${ }^{52}$ Vicente Ripollés Pérez, "Dramas litúrgicos que tienen por aumento la parábola evangélica de las Virgenes prudentes et fatuae y el hecho real de la Resurrección de Jesucristo", en Anales de la Real Academia de Cultura Valenciana, 1 (1928), pp. 47-80. En 1920 Ripollés presentó su discurso de recepción como director de arte de esta institución valenciana. Miguel A. Picó Pascual, "La aportación musicológica del canónigo Vicente Ripollés Pérez", Revista de Musicología, 27/1 (2004), pp. 289-290. Vicente Ripollés ingresó en esta institución valenciana en 1920. Véase Almanaque de las Provincias para 1923, p. 116. Las actas del Congreso Ripollés (1878-1943) y la historiografía musical de su tiempo celebrado en Valencia en diciembre de 2005 no han sido, de momento, editadas.
} 
y Músicos castellonenses. Monografía documentada laureda con el premio de la Excelentísima Diputación de Castellón en los Jocs Florals de Lo Rat Penat de Valencia en $1935^{53}$

También deben tenerse en cuenta las aportaciones musicológicas de Mariano Baixauli (1861-1923) ${ }^{54}$ y Eduardo Ximénez (1824-1900). El interés por el folklore animó la actividad musicológica del jesuita Baixauli. Los manuscritos originales de la Colección de Baixauli, recuperados del archivo del Colegio de Jesuitas de Valencia por el organista Roberto Hurtado, y editados en 1980 por Salvador Seguí, incluyen una colección de tocatas de danza y procesionales propias de la festividad del Corpus valenciano. El legado de Baixauli se completa con diversas variantes de les Albaes valencianes [Alboradas valencianas] y otras melodías de danza, como la Xàquera de Torrent, la danza dels Alcides de Silla y las de otras localidades de las provincias de Valencia y Alicante como señaló Salvador Giner en 1976:

Se incluyen también en estos papeles manuscritos otras tocatas de danza dictadas por los mismos comunicantes [los dulzaineros Pedro "Pauet" y los hermanos Vicente y Salvador Díaz] y otra, la Xàquera de Torrent (distinta a la Xàquera Vella), dictà i ballà per la senyora Concepció, tía de Joaquín $\mathrm{Vid}^{55}[\mathrm{sic}$. Aparece también la danza dels Alcides (dels Porrots, u hòmens de la força), de Silla, y además, toda una serie de tocatas de danzas de Algemesí, Alcudia, Alcira, Alfarp, Llombay, Catadau, Turís, Bocairent, Beniarrés, siendo de destacar la encomiable minuciosidad del trabajo realizado por el padre Baixauli al incluir la cita de "Pascual Escobar, dolçainer de Quart de les Valls (Morverdre) 1894", dando cuenta así, del lugar, fecha y comunicante de una nueva serie de tocatas propias de los pueblos de la Vega Baja del Palancia. Se completa esta parte de la colección, la que parece más acabada e interesante, con diversas variantes de Albaes valencianes, anotándose hasta cinco versiones distintas, entre las que destacamos

\footnotetext{
${ }^{53}$ Picó, “La aportación musicológica”, pp. 291-292.

${ }^{54}$ Maestro de capilla. Fue niño de coro en la catedral de Valencia y alumno de Salvador Giner. Ganó por oposición la plaza de maestro de capilla de la catedral de Tortosa y en 1892 la de la primada de Toledo. En 1896 ingresó en la Compañía de Jesús y ejerció como organista de la casa de la orden en Valencia. En su música se distinguen dos periodos claramente definidos, en el primero muestra un estilo sinfónicooperístico, con abundante acompañamiento orquestal y después entró en el camino de la reforma propugnada por Pío X y se convirtió en uno de los máximos defensores del nuevo estilo de música religiosa. Véase José López-Calo, "Baixauli Biguer, Mariano”, en DMEH, vol. 2 (1999), pp. 61-62.
}

55 [Dictada y bailada por la señora Concepción, tía de Joaquín Vid]. 
estas dos: a) la més senzilla, com la que canten els xiquets la vespra de Nadal acompanyant-se de "simbombes"56, b) en tabalet i dolçaina, com es canten en els pobles de l'Horta" ${ }^{57}$.

La vieja carpeta hallada por el padre Roberto Hurtado contiene otros materiales, quizá de menor interés que los hasta aquí referidos, pero dejaremos el hablarles de ellos para una nueva ocasión ${ }^{58}$.

La faceta musicológica de Eduardo Ximénez, centrada también en la investigación folklórica valenciana, es comentada en el capítulo 5 de esta Tesis. El compositor Eduardo López-Chavarri Marco destacó también por sus trabajos bibliográfico-musicales, como El Anillo del Nibelungo (1902), Historia de la Música (en dos volúmenes 1914-1916), el tratado sobre folklore Música Popular Española (1927) y Chopin (1950). Colaboró además en varias revistas especializadas españolas y extranjeras, como La Guide Musical, Ritmo (1930-1966) y Revista Musical Catalana (1905-1931) e investigó sobre el folklore musical valenciano. La Biblioteca Valenciana conserva un manuscrito inédito de Eduardo López-Chavarri Marco, Cantos y danzas populares de la región valenciana, que según el propio autor eran "coleccionados en mis excursiones y tomados por mí al oído directamente, en su mayoría"59.

\section{Enseñanza musical}

Antes de la creación del Conservatorio de Valencia en 1879, la enseñanza musical se impartía en centros religiosos, colegios privados, capillas de música y casas particulares. La música era una asignatura considerada complementaria, de adorno y con

\footnotetext{
${ }^{56}$ [La más sencilla, como la que cantan los niños la víspera de Navidad acompañandose de zambombas].

${ }^{57}$ [En tabalet y dulzaina, como se cantan en los pueblos de la huerta].

58 Salvador Seguí, "Por las rutas de nuestro folklore musical. Un valioso legado del padre Baixauli", Levante, 9-XII-1976.

$59 E: V A b v$, AELCH/pro 491. Vicente Galbis y Rafael Díaz, "López-Chavarri Marco, Eduardo", en $D M E H$, vol. 6 (2000), pp. 1043-1047; Vicente Galbis y Rafael Díaz, "Homenaje a la familia LópezChavarri, figuras de la historia musical valenciana", en Anales de la Real Sociedad Económica de Amigos del País de Valencia, 1993-94, pp. 344-346.
} 
carácter voluntario $^{60}$. Hubo colegios en Valencia que ofrecían la opción de estudiar música, con el pago de una cuota especial; entre ellos destacaron el Colegio Real de San Pablo (antiguo Real Seminario de Nobles Educandos de Valencia), las Educandas de la Real Casa Enseñanza, el Colegio Valentino y el Colegio Edetano. La Ley Moyano de 9 de septiembre de 1857 no contempló la música ni en la primera ni en la segunda Enseñanza, aunque en Valencia, en la segunda mitad del siglo XIX, aumentó el número de colegios en los que se impartió música: Colegio de Loreto, San Rafael, Santa Rosa, Ibérico, Casa Enseñanza y Escuelas Pías ${ }^{61}$.

Las distintas sociedades recreativas valencianas mostraron gran interés por la música y en sus sedes organizaban clases de escritura, lectura, aritmética, dibujo y música (véase apartado 6 de este mismo capítulo sobre las sociedades con actividad musical). Estas corporaciones cumplieron una función recreativa, pero además difundieron la educación musical entre las clases obreras. Entre ellas destacó particularmente la Sociedad Económica de Amigos del País de Valencia, que inauguró en 1851 una Escuela Popular de Música Vocal dirigida por Pascual Pérez Gascón, organista de la catedral de Valencia, autor de Método de solfeo y principios de canto aplicables en la escuela y colegios. Guía para la Enseñanza que, según el informe del Conservatorio de Madrid, era la primera obra concebida para la enseñanza musical colectiva ${ }^{62}$. El sistema pedagógico de Pérez Gascón se basaba en el sistema simultáneo de solfeo y canto

\footnotetext{
${ }^{60}$ Vicente Galbis López, "La educación musical española en el siglo XIX: el caso valenciano”, Eufonía, 17 (1999), pp. 79-87; Fontestad, El Conservatorio de Música, p. 30.

${ }^{61}$ La Ley Moyano sí incluyó sin embargo la enseñanza musical en el nivel superior, dentro de la carrera de Bellas Artes; Fontestad, El Conservatorio de Música, pp. 35-39.

${ }^{62}$ El Método de solfeo y principios de canto de Pérez Gascón, editado inicialmente en 1848, era el que utilizó el autor para sus alumnos del colegio privado de San Pablo según Blasco, La música en Valencia, p. 95. Pérez Gascón adaptó el método de 1848 a las nuevas exigencias derivadas de la procedencia social de los alumnos, y así salió a la luz en 1857 el Método de solfeo y principios de canto aplicables en la escuela y colegios. Guía para la Enseñanza. El método incluye treinta y ocho carteles, veinticinco con la parte elemental y los trece restantes con cantos a dos y tres voces. Los carteles eran reproducciones a gran escala que se podían colgar en las paredes del aula para facilitar la lectura a todos los alumnos.
} 
del francés Bocquillon-Wilhem ${ }^{63}$. Con la fundación de la Escuela Popular de Música, el arte musical empezó a difundirse y popularizarse entre la clase baja con escasos recursos económicos. Esta Escuela se puso en funcionamiento con veinte alumnos pobres seleccionados para recibir enseñanza simultánea por un solo profesor, que pronto mostraron sus progresos. La contribución de la Real Sociedad Económica de Amigos del País de Valencia fue decisiva para fomentar el interés por la música en el entorno social, y gracias a su iniciativa nació en 1879 el Conservatorio de Música de Valencia. La Sociedad Económica no disponía de los recursos económicos suficientes para poner en marcha el centro y sostener su funcionamiento, pero buscó subvenciones y las obtuvo finalmente de la Diputación Provincial y Ayuntamiento de Valencia (véase "La creación del Conservatorio de Música de Valencia (1879)"

\section{1. Escuelas municipales de música}

Según Ana Fontestad, gracias a la labor de difusión musical de las sociedades culturales y recreativas valencianas, el Ayuntamiento de Valencia empezó a asumir responsabilidades en materia educativo-musical. Varios profesores de música ofrecieron sus servicios al Ayuntamiento de forma altruista y se fundaron así las primeras escuelas municipales de música ${ }^{65}$. La primera petición para crear una escuela musical para niños pobres fue de Manuel Penella Raga en 1867, quien se ofreció para dar clases de música

\footnotetext{
${ }^{63}$ Véase Bernarr Rainbow, "Wilhem, Guillaume Louis Bocquillon" (1781-1842), en The New Grove Dictionary of Music and Musicians, Second Revised Edition (en adelante TNG), ed. Stanley Sadie, 29 vols. (London: MacMillan, 2002), vol. 27 (2002), p. 387.

${ }^{64}$ Fontestad, El Conservatorio de Música, pp. 53-55 y 104-115; Manuel Bas Carbonell, "Conservatorio de Música de Valencia", en 225 años de la Real Sociedad Económica de Amigos del País de Valencia (Valencia: Fundación Bancaja, 2003), p. 137.

${ }^{65}$ Las primeras Escuelas Municipales al principio no generaron gastos, pero con el tiempo los maestros solicitaron un salario y una indemnización por alquiler del local en donde se emplazaba la escuela. Fontestad, El Conservatorio de Música, pp. 27 y 71. Para el caso de Pamplona véase María Nagore Ferrer, "La Escuela Municipal de Música de Pamplona: una institución pionera en el siglo XIX", Príncipe de Viana, 238 (2006), pp. 537-560. Nagore señala que poco después de Pamplona, y en concreto, a partir de 1868, comenzaron a crearse escuelas o academias municipales de música en otras ciudades españolas.
} 
gratuitamente en el Colegio de San Nicolás a niños pobres escolarizados en las escuelas municipales. La Comisión de Instrucción Pública emitió un informe favorable a esta $\operatorname{propuesta}^{66}$.

En diciembre de 1868 el Ayuntamiento valenciano creó la primera escuela pública de música para niñas, dirigida por la profesora Consuelo del Rey, situada en la Escuela Normal de Maestras, lo que originó problemas por la ocupación del espacio del edificio $^{67}$. También se creó en 1869 el denominado "Instituto Musical Público" para que cursaran estudios musicales niños pobres mayores de siete años. El Ayuntamiento encargó la dirección de este centro a Manuel Penella. Este Instituto parecía estar encaminado a ofrecer una enseñanza más profesional de la música, pero la precariedad de los fondos municipales hizo que el centro no dejara de ser una escuela municipal de música más ${ }^{68}$.

En 1873, a petición de varios padres de niñas pobres de escuelas públicas, el Ayuntamiento creó otra escuela pública de música para niñas además de la ya existente y nombró profesora a Emilia Lacombe. El Ayuntamiento, que en un principio no puso obstáculos a la creación de estas escuelas municipales, empezó a poner objeciones y denegar estas iniciativas altruistas cuando los presupuestos para mantenerlas se incrementaron. La escasez de medios para hacer frente a la demanda social de enseñanza musical hizo que el Ayuntamiento acordara en enero de 1879 destinar una subvención

\footnotetext{
${ }^{66}$ E:VAa, Sección III, Sub. G Instrucción Pública, Clase III (Enseñanza Artística y Literaria), Subclase B, Escuelas de música (1865-1902), nº 2, Petición de D. Manuel Penella, profesor de música en el Colegio de S. Nicolás, ofreciendo enseñanza a niños pobres de las Escuelas del Ayuntamiento (1867).

${ }^{67}$ E:VAa, Sección III, Sub. G Instrucción Pública, Clase III (Enseñanza Artística y Literaria), Subclase B, Escuelas de música (1865-1902), n ${ }^{\circ}$, Sobre el establecimiento de la sección de música en la escuela normal de niñas de esta ciudad (1867).

${ }^{68}$ E:VAa, Sección III, Sub. G Instrucción Pública, Clase III (Enseñanza Artística y Literaria), Subclase B, Escuelas de música (1865-1902), n ${ }^{\circ}$ 1, Carta de Manuel Penella a la Comisión de Instrucción de esta provincia sobre la puesta en funcionamiento del Instituto Musical Público (1869); Fontestad, El Conservatorio de Música, p. 66.
} 
anual de 2500 pesetas a la Sociedad Económica de Amigos del País si ésta ponía en marcha el Conservatorio de Música de Valencia ${ }^{69}$. La creación de este centro en 1879 no supuso la desaparición de las tres escuelas municipales de música existentes entonces (las de Penella, Lacombe y Rey). En 1880, a petición del profesor de solfeo Eduardo Senís, el Ayuntamiento aprobó la creación de una nueva escuela municipal ${ }^{70}$. Así pues, el Ayuntamiento continuó costeando por un lado los gastos de sus escuelas de música y por otro subvencionando a la Sociedad Económica de Amigos del País para sostener el Conservatorio de Música ${ }^{71}$.

Las Escuelas de Artesanos también ofrecieron la música en su plan de enseñanza en 1873 en dos centros: la Escuela Central, dirigida por Manuel Penella ${ }^{72}$ y la Escuela San Nicolás, donde impartió clases de música Francisco Javier Blasco ${ }^{73}$.

\section{2. La creación del Conservatorio de Música de Valencia (1879)}

\section{Los inicios del centro}

El trabajo más completo de los realizados hasta ahora sobre el Conservatorio de Valencia es la tesis de Ana Fontestad que, junto con otros estudios, he utilizado para dar la visión de conjunto que sigue, en la que empleo además informaciones procedentes de

\footnotetext{
${ }^{69}$ E:VAa, Sección III, Sub. G Instrucción Pública, Clase III (Enseñanza Artística y Literaria), Subclase B, Escuelas de música (1865-1902), nº 1, Expediente relativo a la creación del Conservatorio de música de Valencia (1879).

${ }^{70}$ E:VAa, Sección III, Sub. G Instrucción Pública, Clase III (Enseñanza Artística y Literaria), Subclase B, Escuelas de música (1865-1902), nº 4, D. Eduardo Senís Zafrané, profesor de música solicita establecer una escuela de música y enseñar gratis a los niños que le mande el Ayuntamiento si éste le concede local (1880).

${ }^{71}$ E:VAa, Sección III, Sub. G Instrucción Pública, Clase III (Enseñanza Artística y Literaria), Subclase B, Escuelas de música (1865-1902), en estos legajos se pueden consultar las peticiones que los distintos profesores dirigieron al Ayuntamiento de Valencia. Véase también Fontestad, El Conservatorio de Música, pp. 62-82; Blasco, La música en Valencia, p. 63.

${ }^{72}$ Vicente Galbis López, “Penella, Manuel”, en DMEH, vol. 8 (2001), pp. 574-575.

${ }^{73}$ Blasco, La música en Valencia, p. 63.
} 
la abundante documentación que sobre el Conservatorio generaron la prensa y diversas instituciones valencianas, que he consultado personalmente ${ }^{74}$.

Al poco tiempo de crearse los Conservatorios de Madrid (1830) y el Liceo de Barcelona (1838), empezaron a surgir centros similares en otras capitales de provincia españolas. Muchos de estos nuevos conservatorios nacieron bajo el amparo de las Sociedades de Amigos del País. El caso del Conservatorio valenciano, aunque más tardío, fue uno de ellos ${ }^{75}$.

El ambiente musical en Valencia a finales del XIX era propicio para la creación del conservatorio de música y las necesidades de la ciudad así lo reclamaban. Según Gayano, fue en el Instituto Musical Público (también denominado Sociedad Instituto Musical) donde se gestó la idea de fundar el conservatorio valenciano, pero la Real Sociedad Económica de Amigos del País de Valencia fue la que impulsó activamente la idea $^{76}$. Desde que se creó la sección de Bellas Artes en la Sociedad Económica de

\footnotetext{
${ }^{74}$ Fontestad, El Conservatorio de Música. Pueden consultarse además: E:VAseap, Libro de Actas de la Sección de Bellas Artes, sesiones de 30-V-1878, 20-VII-1878, 4-II-1879; Anónimo, "Conservatorio de Música", en Anales de la Real Sociedad Económica de Amigos del País de Valencia, 1878, pp. 78-82; Anónimo, "El Conservatorio de Música de Valencia", Almanaque de las Provincias para 1880, pp. 131133; Amparo Ranch Sales, "La música en la Real Sociedad Económica de Amigos del País de Valencia", en Anales de la Real Sociedad Económica de Amigos del País de Valencia, 1987-88, pp. 61-80; LópezChavarri, Cien años de historia; Antonio Botella Jáudenes, Memoria del Conservatorio de Música (Valencia: Imprenta V. Gay, 1892); Bas, "Conservatorio de Música", pp. 137-141; Blasco, La música en Valencia, pp. 63-64; José Martínez Aloy, Geografia General del Reino de Valencia. Provincia de Valencia (Barcelona: A. Martins, 1920), vol. 1, pp. 619-620; López-Chavarri Andújar, Cien años de Música, pp. 125-138; José Climent, "Conservatorio de Música de Valencia”, en Gran Enciclopedia de la Región Valenciana, dir. Manuel Mas, 12 vols. (Valencia: Graphic 3, 1973), vol. 3, p. 230; Manuel Llorens (dir.), "Conservatorio de Música de Valencia", en Gran Enciclopedia Valenciana, 10 vols. (Valencia: Difusora de Cultura Valenciana, 1990-1991), vol. 3 (1991), p. 155.
}

${ }^{75}$ Mariano Pérez Gutiérrez, "Los Conservatorios españoles. Historia, Reglamentaciones, planes de estudio, centros, profesorado y alumnado", Música y Educación, 15/6 (1993), pp. 26-28. Existen estudios monográficos de los conservatorios de Madrid y Barcelona; véanse Federico Sopeña Ibáñez, Historia crítica del Conservatorio de Madrid (Madrid: Ministerio de Educación y Ciencia, Dirección General de Bellas Artes, 1967); Joaquín Zamacois, De la Escuela Municipal de Música del año 1886 al Conservatorio Superior Municipal de Música del año 1963 (Barcelona: Ayuntamiento de Barcelona, 1963); Xosé Aviñoa, "Conservatori Superior de Música del Liceu”, en HMCVB, vol. 9 (2003), p. 169; Xosé Aviñoa, "Escola Municipal de Música. Conservatori Municipal de Barcelona", en $H M C V B$, vol. 9 (2003), p. 195; Xosé Aviñoa, Cent anys del Conservatori (Barcelona: Ajuntament de Barcelona, 1986).

${ }^{76}$ Rafael Gayano Lluch, "El Conservatorio de Música y Declamación de Valencia. Apuntes Históricos", Almanaque de las Provincias para 1945, p. 488; La Verdad, 1-I-1869; Galiano, "La Renaixença”, p. 318. 
Amigos del País, su actividad musical se incrementó con la celebración de concursos y conciertos y esta circunstancia hizo que surgiese la idea de fundar un conservatorio ${ }^{77}$. En abril de 1874, Enrique Aguilar, socio de la Sociedad Económica, propuso la creación de una Academia de música en Valencia y la sección de Bellas Artes nombró una comisión formada por los socios Jaime Sales, José Espí, José Frasquet, Ricardo Andrés, Eduardo Serrano, Facundo Cortadella, José $\mathrm{M}^{\mathrm{a}}$ Úbeda y el propio Aguilar, a fin de que la propuesta fuese estudiada, pero en ese momento se desestimó porque la Sociedad no podía mantener la academia ${ }^{78}$. Cuatro años después, el 30 de mayo de 1878, Eduardo Serrano planteó a la sección de Bellas Artes de la Sociedad Económica la creación de una nueva comisión, formada por Enrique Aguilar, José $\mathrm{M}^{\mathrm{a}}$ Sales, Eduardo Serrano, Arturo Lliberós y José Ma Úbeda, para retomar el tema de la fundación de un Conservatorio. La Sociedad Económica, que no tenía ingresos suficientes, buscó subvenciones de la Diputación Provincial y el Ayuntamiento de Valencia ${ }^{79}$.

La sección de Bellas Artes de la Sociedad Económica aprobó el 20 de julio de 1878 el reglamento y presupuestos del Conservatorio de Valencia, que fueron ratificados y aprobados definitivamente por la Sociedad en pleno el 29 de enero de 1879, una vez obtenidas las subvenciones y el local necesario para impartir las clases ${ }^{80}$. El Reglamento Orgánico preveía la constitución de una Junta General ${ }^{81}$ y una Junta Directiva y el 30 de

\footnotetext{
${ }^{77}$ Fontestad, El Conservatorio de Música, p. 215.

78 Jaime Sales y José Espí, “Creación de un Instituto o Escuela de Música”, en Boletín de la Real Sociedad Económica de Amigos del País de Valencia, 16 (1874), pp. 366-368.

${ }^{79}$ La Diputación Provincial concedió 1500 pesetas y el Ayuntamiento de Valencia 2500 pesetas. Véase Fontestad, El Conservatorio de Música, p. 221; Bas, "Conservatorio de Música”, p. 138.

${ }^{80}$ E:VAseap, Libro de Actas de la Sección de Bellas Artes, 20-VII-1878; Anónimo, "Conservatorio de Musica”, en Anales de la Real Sociedad Económica de Amigos del País de Valencia, 1878, pp. 78-79.

81 La Junta General estuvo integrada por tres concejales del Ayuntamiento de Valencia, tres representantes de la Diputación, siete socios de la sección de Bellas Artes, los socios suscriptores, el secretario y el director de la Real Sociedad Económica. Fontestad, El Conservatorio de Música, p. 221.
} 
septiembre quedó constituido el primer claustro de profesores (véanse Tablas 1 y 2).

Tabla 1. Junta Directiva del Conservatorio de Música de Valencia en 1879.

Fuente: E:VAcm, Acta de la Junta Directiva del Conservatorio de Música de Valencia, 8-III-1879.

\begin{tabular}{|c|c|}
\hline Miembros de la Junta & Cargos \\
\hline \hline Antonio Rodríguez de Cepeda & Presidente de la Sociedad Económica \\
\hline José Ma Sales, Eduardo Serrano & $\begin{array}{r}\text { Vicepresidentes de la Sociedad } \\
\text { Económica }\end{array}$ \\
\hline Enrique Aguilar & $\begin{array}{c}\text { Vocal representante de la Sociedad } \\
\text { Económica }\end{array}$ \\
\hline Angelino Estellés & Vocal representante de la Diputación \\
\hline Emilio Borso & Vocal representante del Ayuntamiento \\
\hline Urbano Lolumo & $\begin{array}{c}\text { Vocal representante de los socios de la } \\
\text { Sociedad Económica }\end{array}$ \\
\hline Arturo Lliberós & Secretario de la Sociedad Económica \\
\hline Santiago Miracle & Tesorero de la Sociedad Económica \\
\hline Eduardo Covarrubias & Vicesecretario de la Sociedad Económica \\
\hline
\end{tabular}

El primer Director del Conservatorio de Valencia fue José $\mathrm{M}^{\mathrm{a}}$ Úbeda y la sesión inaugural del nuevo centro se celebró en la Academia de Bellas Artes de San Carlos el 9 de noviembre de $1879^{82}$. Durante el primer año de funcionamiento las clases se impartieron en la sede de la Sociedad Económica y en el piso bajo del edificio conocido como Na Monforta ${ }^{83}$.

Según el primer Reglamento del Conservatorio (1879), las asignaturas que se instauraron en 1879 fueron Solfeo, Canto, Piano, Órgano y Armónium, Violín y Viola, Violoncello, Contrabajo, Armonía y Composición. Este primer Reglamento de 1879 constaba de 9 capítulos y 34 artículos $^{84}$. El gran número de alumnos en el curso 1880-81 hizo que se buscara otro edificio, situado en la plaza de San Esteban, que fue cedido por Pedro Gómez, sucesor de pianos Gómez de Valencia.

\footnotetext{
${ }^{82}$ La prensa calificó la elección de Úbeda de "irreprochable y de interés supremo"; véase Crónica de la Música, 21-X-1880, p. 5.

${ }^{83}$ Luis Iváñez de Lara, "Memoria de los trabajos de la Sociedad Económica de Amigos del País de Valencia durante el año 1879", en Anales de la Real Sociedad Económica de Amigos del País de Valencia, 1879, p. 5. Este edificio estaba ocupado por un Instituto de Segunda Enseñanza, antiguo Colegio de la Asunción.

${ }^{84}$ Anónimo, "Reglamento del Conservatorio de Música de Valencia de 1878", en Anales de la Real Sociedad Económica de Amigos del País de Valencia, 1878, pp. 82-86.
} 
Tabla 2. Claustro de profesores del Conservatorio de Valencia en $1879^{\mathbf{8 5}}$.

Fuentes: E:VAcm, Acta de la Junta Directiva del Conservatorio de Música de Valencia, 18-X-1879; López-Chavarri, Cien años de historia, p. 10.

\begin{tabular}{|c|c|}
\hline Asignatura & Profesores \\
\hline \hline Armonía & Antonio Marco $^{86}$ \\
\hline Órgano/ Armónium/ Composición & ${\text { José M } \text { Úbeda }^{87}}^{\text {Ro }}$ \\
\hline Piano & Roberto Segura $^{88}$ \\
\hline Solfeo & $\begin{array}{c}\text { Antonio Marco } \\
\text { Manuel Coronado }\end{array}$ \\
\hline Cello/ Contrabajo/Canto & Manuel Soriano $^{90}$ \\
\hline Violín/ Viola & Quintín Matas $^{91}$ \\
\hline
\end{tabular}

${ }^{85}$ Salvador Giner no formó parte del claustro de profesores en el año fundacional ya que, aunque fue nombrado profesor, renunció al cargo. E:VAcm, Acta de la Junta Directiva del Conservatorio de Música de Valencia, 18-X-1879.

${ }^{86}$ Antonio Marco fue profesor y violinista. Entre 1872 y 1882 colaboró en diversos recitales interpretados en la Real Sociedad Económica de Amigos del País de Valencia. Además de ser profesor del Conservatorio también lo fue en la Academia Liceo Artístico-Musical de Santa Cecilia, creada en torno a 1895, en la que impartió enseñanzas tan variadas como solfeo, armonía, composición, preparación para oposiciones a bandas militares y dirección de bandas civiles. Algunas de sus obras se encuentran recopiladas en la Biblioteca Sacro Musical. Véase Vicente Galbis López, "Marco Belloch, Antonio", en DMEH, vol. 7 (2000), pp. 155-156.

87 José María Úbeda (1839-1909), se había formado en la Capilla Musical de Santa María de Ontinyent con Francisco de Paula Bonastre. A los 15 años se trasladó a Valencia completando su formación con Pascual Pérez Gascón en armonía, composición y órgano. Aunque fue organista de la parroquia de San Andrés y de la capilla de Nuestra Señora de los Desamparados, donde verdaderamente ejerció su ofició fue en la iglesia del Corpus Christi. Fue el primer profesor de órgano del Conservatorio de Valencia y primer director de la institución. Entre su producción religiosa, publicada en su mayor parte en la Biblioteca Sacro Musical, destaca su Sacerdotes Domini, ofertorio de la fiesta de Corpus Christi, y su Método de órgano. Véase José Climent, "Úbeda Montés, José María”, en DMEH, vol. 10 (2002), pp. 545546 y Bernardo Adam Ferrero, “Úbeda Montés, José María”, en 1000 Músicos Valencianos, pp. 809-810.

${ }^{88}$ Roberto Segura Villalba (1849-1902) fue compositor y primer profesor de piano del Conservatorio de Valencia y, su director desde 1894 hasta el inicio del siglo XX. Su Método de Piano estuvo vigente en la enseñanza oficial desde su publicación en 1892 hasta la década de 1950. Casi todos los profesores de piano que hubo después de él en el Conservatorio de Valencia y otros centros de enseñanza musicales fueron alumnos suyos. Como compositor dedicó sus mayores esfuerzos al instrumento del que era profesor, destacando sus piezas para piano creadas al estilo de la música de salón que estaba de moda en la época. Véase Vicente Galbis López, “Segura Villalba, Roberto”, en DMEH, vol. 9 (2002), p. 911.

${ }^{89}$ Manuel Coronado fue profesor auxiliar de piano y de solfeo en el Conservatorio de Valencia desde 1880 y profesor de Música de las Escuelas de Artesanos de Valencia en sustitución de Manuel Penella. Publicó una Teoría de la Música. Véase José Ma Vives, "Coronado Cervera, Manuel”, en DMEH, vol. 3 (1999), p. 21.

${ }^{90}$ Manuel Soriano natural de Valencia. Se trasladó en 1893 a Ciudad de México, donde dirigió la orquesta de un teatro y residió hasta su fallecimiento. Véase Bernardo Adam Ferrero, "Soriano, Manuel", en 1000 Músicos Valencianos, p. 769.

${ }^{91}$ Quintín Matas (1857-1883) fue alumno de Salvador Giner y completó sus estudios en Madrid con José de Monasterio en 1873 y 1875 . Acaparó primeros premios en distintos concursos de la Escuela Nacional de Música, participó en las sesiones musicales de la Real Sociedad Económica y fue profesor de violín y viola del Conservatorio de Música de Valencia desde su fundación hasta su muerte prematura en 1883. Véase Blasco, La música en Valencia, p. 93; Vicente Pérez Jorge, La Música en Ontinyent (Ontinyent: Caixa d'Estalvis d'Ontinyent, 1979), pp. 97-98 
Los objetivos del Conservatorio de Valencia se repitieron en el nuevo Reglamento de 1884: "El conservatorio se propone la Enseñanza de dicho arte [la música] en la mayor extensión posible, y el fomento de la afición al mismo". Ese año se impartían estudios de Solfeo, Canto, Piano, Órgano y Armónium, Violín y Viola, Violoncello, Contrabajo, Flauta, Clarinete, Armonía y Composición ${ }^{92}$. Los estudios de Solfeo y Armonía duraban tres cursos cada uno; los de Composición, Órgano, Armónium, Violoncello, Contrabajo, Flauta y Clarinete, cinco cursos; los de Canto y Violín, seis cursos, y los de Piano siete $\operatorname{cursos}^{93}$. En el posterior Reglamento de 1893 hubo ligeras modificaciones en la duración de los estudios ${ }^{94}$. Para ingresar en las clases de instrumentos, era necesario tener aprobados dos cursos de Solfeo; el tercero de Solfeo se podía simultanear con uno de los dos primeros cursos de instrumento. Para ingresar en Canto debía tenerse aprobado el primer curso de Solfeo y para comenzar Armonía debía tenerse aprobado todo el Solfeo. Para el ingreso en la clase de Composición debían tenerse aprobados los estudios de Armonía y no podía matricularse ningún alumno de Órgano sin tener aprobados el segundo curso de Piano y el primero de Armonía ${ }^{95}$.

\footnotetext{
92 Reglamento Orgánico del Conservatorio de Música de Valencia de 1884, p. 1, Capítulo I, artículos 1 y 2, "Fines del Conservatorio". El Reglamento de 1884 constaba de 18 capítulos y 125 artículos.

${ }^{93}$ Reglamento Orgánico del Conservatorio de Música de Valencia de 1884, pp. 11-12, 17, Capítulo X, artículo 46, "De la Junta de profesores", Capítulo XIII, artículo 86, “Del orden de los estudios".

${ }^{94}$ Los estudios de Armonía y Solfeo se dividían en tres cursos, los de Contrabajo, Flauta, Clarinete, Armónium, Órgano y Composición en cinco, los de Canto, Arpa, Viola y Violoncello en seis, los de Piano en siete y los de Violín en ocho. Véase Reglamento Orgánico del Conservatorio de Música de Valencia de 1893, pp. 25-26, Capítulo XVI, artículo 110, "Del orden de los estudios"; Fontestad, El Conservatorio de Música, p. 754.

95 Reglamento Orgánico del Conservatorio de Música de Valencia de 1884, pp. 17-18, Capítulo XIII, artículos 86, 87, "Del orden de los estudios". Estas normas seguían vigentes en el Reglamento de 1893.
} 
Había profesores numerarios y auxiliares o supernumerarios y la Junta General podía nombrar Profesores Honorarios a personas que se distinguieran por sus conocimientos musicales en cualquiera de sus manifestaciones ${ }^{96}$.

Reconocimiento Oficial del Conservatorio de Valencia y adscripción de sus enseñanzas al Conservatorio de Madrid (1911)

Durante muchos años el conservatorio valenciano fue una institución de carácter particular y sus enseñanzas no tuvieron validez oficial hasta $1911^{97}$. En 1905, los alumnos del Conservatorio de Valencia solicitaron al Rey la validez académica de los estudios realizados en el centro. El 16 de junio de ese año el Ministerio de Instrucción Pública y Bellas Artes publicó un Real Decreto por el cual se facultaba a las Diputaciones y Ayuntamientos españoles para crear Escuelas de Música, que podían tener carácter oficial si su profesorado cumplía determinados requisitos. Los profesores de solfeo, piano y violín debían tener al menos alguno de estos requisitos: ser titulados por el Conservatorio de Madrid, haber sido premiados en concursos convocados por dicho centro $\mathrm{u}$ otros de prestigio $\mathrm{y}$ haber ingresado por oposición. Las corporaciones municipales y provinciales debían asignar una retribución no inferior a $2000 \operatorname{pesetas}^{98}$. El

\footnotetext{
${ }^{96}$ Reglamento Orgánico del Conservatorio de Música de Valencia, p. 16, Capítulo XI, artículo 76.

${ }^{97}$ E:VAcm, Acta de la Junta Directiva del Conservatorio de Música de Valencia, 8-IV-1905; Pérez, "Los Conservatorios españoles", p. 29; Gayano, "El Conservatorio de Música", p. 488.

98 Real Decreto disponiendo que las Corporaciones provinciales que sostengan Conservatorios y Escuelas de Música y deseen que los estudios en ellos cursados tengan validez académica soliciten su incorporación al Conservatorio de Madrid, Gaceta de Madrid, 17-VI-1905, p. 1108; E:VAcm, Acta de la Junta Directiva del Conservatorio de Música y Declamación de Valencia, 8-IV-1905; Pérez, "Los Conservatorios españoles", p. 29; Gayano, "El Conservatorio de Música", p. 488. En 1900 se creó el Ministerio de Instrucción Pública y Bellas Artes que quedó desgajado del Ministerio de Fomento y suponía la primera intervención del Estado en materia de educación. Las propuestas de Tomás Bretón entre 1901 y 1911 como Comisario Regio, y como Director del Real Conservatorio Superior de Música de Madrid en el periodo 1913-1921, inspiraron parcialmente el Decreto de 16-VI-1905. En 1904 Bretón consideró que era el momento de iniciar un cambio en la formación profesional del músico, fomentado desde el Estado. Véase Victor Sánchez Sánchez, "Tomás Bretón y el regeneracionismo. Una reflexión sobre la valoración de la música en el contexto cultural de la España de 1898", Cuadernos de Música Iberoamericana, 6 (1998), pp. 46-48; Fernando Delgado García, "La construcción del sistema nacional de conservatorios en España (1892-1942)", Cuadernos de Música Iberoamericana, 12 (2006), p. 122.
} 
Conservatorio valenciano inició las gestiones para acogerse al mencionado Real Decreto de 16 de junio de 1905, pero la Diputación negó la necesaria financiación. Una comisión intentó obtener subvención de los Ministerios de Hacienda, Instrucción Pública y Bellas Artes, pero no se obtuvieron resultados favorables ${ }^{99}$.

En septiembre de 1910 Ramón Martínez ocupó la dirección del centro. Según Ana Fontestad, fue un director con muchas aspiraciones y dotes persuasivas, lo que explica que poco tiempo después de acceder al cargo, el Ayuntamiento y la Diputación Provincial de Valencia ofrecieran una subvención para el Conservatorio de 12.000 pesetas cada una. Con esta cantidad el Conservatorio ya estaba en condiciones de solicitar la tan esperada oficialidad de sus estudios y a partir de ese momento, el Ayuntamiento y la Diputación de Valencia se encargaron del sostenimiento y administración del centro.

El paso siguiente fue la disolución de las Juntas General y Directiva. La Junta Directiva dejó el Conservatorio en manos del Ayuntamiento y Diputación Provincial de Valencia para que pudieran solicitar al Ministro de Instrucción Pública la validez oficial de los estudios ${ }^{100}$. Este derecho le fue reconocido al Conservatorio de Valencia el 26 de abril de 1911: se declaró la validez académica de los estudios de Solfeo y elementales de Piano y Violín que se hubiesen cursado en el conservatorio valenciano, que quedaba incorporado al de Madrid $^{101}$. Un año después de reconocerse la oficialidad de sus estudios, el Conservatorio de Valencia contaba con siete profesores numerarios en su plantilla, entre ellos Amancio Amorós (ver Tabla 3 e Ilustración 3).

\footnotetext{
${ }^{99}$ Fontestad, El Conservatorio de Música, pp. 440-446.

${ }^{100}$ Fontestad, El Conservatorio de Música, p. 447; López-Chavarri, Cien años de historia, pp. 51-55.

${ }^{101}$ Real Orden de 26-IV-1911 concediendo validez académica a los estudios de Solfeo y elementales de Piano y Violín, que se cursen en el Conservatorio de Música de Valencia, como incorporado al de Madrid, Gaceta de Madrid, 29-IV-1911, p. 219; La Educación, 10-VI-1911; Delgado, "La construcción del sistema”, pp. 109-134; Fontestad, El Conservatorio de Música, p. 448.
} 


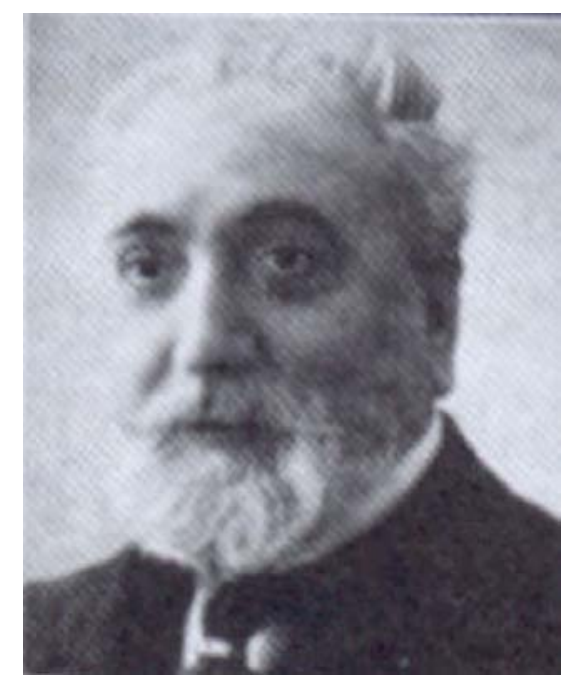

Ilustración 3

Amancio Amorós Sirvent.

Letras y Figuras, 17 (1911).

Tabla 3. Claustro de profesores numerarios del Conservatorio de Música de Valencia en 1912. Fuente: López-Chavarri Marco, Cien años de Música, p. 134.

\begin{tabular}{|c|c|c|}
\hline Asignatura & Profesor & Antigüedad \\
\hline \hline Solfeo y Armonía & Amancio Amorós Sirvent & 22 de junio de 1902 \\
\hline Piano & $\begin{array}{c}\text { José Bellver Abellá } \\
\text { Ramón Martínez Carrasco }\end{array}$ & $\begin{array}{c}20 \text { de enero de } 1903 \\
24 \text { de septiembre de } 1910\end{array}$ \\
\hline Canto & Lamberto Alonso Torres & 3 de diciembre de 1905 \\
\hline Violín & Benjamín Lapiedra Cherp & 12 de octubre de 1907 \\
\hline Declamación & Juan Colom Sales & 13 de octubre de 1910 \\
\hline Estética e Historia de la Música & Eduardo López-Chavarri Marco & 13 de octubre de 1910 \\
\hline
\end{tabular}

Incorporación del Conservatorio de Valencia a las enseñanzas del Estado (1917)

Una vez conseguido el reconocimiento oficial del grado elemental de Piano, Violín y Solfeo, Ramón Martínez, Director del Conservatorio de Valencia, continuó las gestiones en Madrid para obtener la validez oficial de los estudios superiores del centro y su incorporación al Estado ${ }^{102}$. El Ministerio de Instrucción Pública y Bellas Artes emitió un informe favorable y, por Real Decreto de 16 de noviembre de 1917, incorporó el

${ }^{102}$ E:VAcm, Actas de la Junta de Gobierno del Conservatorio de Música de Valencia, 31-X-1914, 9-I1916. Véase también El Imparcial, 23-XI-1917. 
Conservatorio valenciano a las enseñanzas del Estado. El sostenimiento del centro, sin embargo, siguió a cargo de la Diputación y el Ayuntamiento de Valencia hasta que las Cortes aprobaran un proyecto de presupuestos del Ministerio de Instrucción Pública que incluyera el mantenimiento del centro:

El Conservatorio de Música y Declamación de Valencia, de ya larga y brillante historia artística y docente, pretende que se le incorpore al Estado. La pretensión está bien fundada y es perfectamente legítima y digna de tomarse en consideración.

Nada se opone, en efecto, a tan natural deseo. En su parte económica, la incorporación a que aspira, lejos de significar un gravamen, entrañaría un beneficio para el Estado, pues el prestigio de esta Escuela de Música y Declamación, cada vez más creciente, ha dado por resultante un aumento progresivo en su matrícula, que habría, a no dudarlo, de seguir en tal gradación ascendente, una vez que el Conservatorio de Valencia figurara entre los Establecimientos docentes que el Estado directamente patrocina. Ya hoy, sin contar con las subvenciones con que la Diputación Provincial y el Ayuntamiento de dicha capital coadyuvan a sostenerlo, cubre holgadamente todas sus atenciones con sólo sus ingresos naturales de exámenes y matrículas.

En otro orden de consideraciones, la incorporación solicitada es el coronamiento supremo de toda su labor cultural como Centro docente, y habida cuenta de que el Conservatorio de Valencia posee las condiciones didácticas exigidas por el Real Decreto de 16 de Junio de 1905 y la cultura de la capital en que radica es acreedora a que su Establecimiento filarmónico pueda ofrecer las mayores garantías de éxito, el Ministro que suscribe, de acuerdo con el Consejo de Ministros, y con el dictamen del Consejo de Instrucción Pública, tiene la honra de someter a la aprobación de V. M. el adjunto proyecto de Decreto.

Real Decreto

Conformándome con las razones expuestas por el Ministro de Instrucción Pública y Bellas Artes, de acuerdo con el Consejo de Ministros y con el Dictamen del Consejo de Instrucción Pública. Vengo en decretar lo siguiente:

Artículo $1^{\circ}$. Se declara incorporado el Conservatorio de Música y Declamación de Valencia a las Enseñanzas del Estado con todos los derechos correspondientes.

Artículo $2^{\circ}$. Mientras las Cortes no voten la cantidad necesaria para el sostenimiento de dicho Centro docente, continuará éste a cargo de la Diputación y Ayuntamiento de aquella capital.

Artículo $3^{\circ}$. En el próximo proyecto de Presupuestos y gastos del Ministerio de Instrucción Pública, se propondrá al Parlamento la inclusión de los créditos correspondientes, todos los servicios $\mathrm{y}$ atenciones del expresado Conservatorio.

Dado en Palacio a 16 de Noviembre de $1917^{103}$.

${ }^{103}$ Real Decreto de 16-XI-1917 declarando incorporado a las enseñanzas del Estado el Conservatorio de Música y Declamación de Valencia, Gaceta de Madrid, 17-XI-1917, p. 340; E:VAcm, Acta del Claustro de profesores del Conservatorio de Música de Valencia, 25-XI-1917. 


\section{3. Academias de música}

En la segunda mitad del siglo XIX hubo en Valencia diversas academias de música privadas que se anunciaban en revistas de la época. Algunas pertenecían a entidades culturales que sólo permitían el acceso de sus socios, como la Academia Filarmónica del Liceo Valenciano ${ }^{104}$ y otras eran escuelas privadas abiertas a todo el público. En 1852 abrió la Academia de Música Vocal e Instrumental dirigida por el compositor Carlos Llorens ${ }^{105}$. Otras Academias que existieron en Valencia durante las dos últimas décadas del siglo XIX fueron la Academia de Música de Manuel Penella ${ }^{106}$, la Academia Vocal Spitzer-Sola ${ }^{107}$ y la Academia dirigida por Amancio Amorós, conocida como Academia Musical Amorós, de la que daré más detalles en el Capítulo $3^{108}$. En 1895 Ramón Martínez creó una nueva Academia, el Liceo Artístico Musical, que según él no pretendía crear rivalidad con el Conservatorio, como supusieron algunos, sino acoger a los alumnos que no pudieran acceder al mismo. El Liceo impartía Solfeo, Piano, Violín, Violoncello, Canto, Armonía y Contrapunto, Declamación, Estética y Cultura general aplicada a la música, Italiano, Preparación para oposiciones a bandas militares y Dirección de bandas civiles, Guitarra, Bandurria y Laúd. Algunos de sus profesores enseñaban también en el Conservatorio ${ }^{109}$.

\footnotetext{
${ }^{104}$ Esta Academia empezó a impartir clases en febrero de 1841 según Galbis, "La educación”, p. 86.

${ }^{105}$ Diario Mercantil de Valencia, 27-VIII-1853. Según el anuncio, Llorens garantizaba la enseñanza de la música o instrumento en cuatro meses.

${ }^{106}$ Boletín Musical, 31-XII-1892, p. 37.

${ }^{107}$ La Spitzer Sola estaba situada en el Paseo de la Alameda 1. Véase El Mercantil Valenciano, 1-V-1895; Boletín Musical, 31-III-1893, pp. 59-62; Boletín Musical, 31-V-1893, pp. 79-80.

${ }^{108}$ Blasco, La música en Valencia, p. 64; El Mercantil Valenciano, 20 y 26-XI-1890.

${ }^{109}$ Boletin Musical, 30-IX-1895, pp. 503-504.
} 
En 1898 abrió al público otra Academia de música dirigida por Pascual Faubel en la que se impartía Solfeo, Armonía y Violín ${ }^{110}$. Todas las entidades pedagógicas mencionadas, además de ocuparse del aspecto didáctico, organizaban conciertos y colaboraban con otras entidades corales y teatros. Con frecuencia se organizaban veladasconcierto (en las sedes de las instituciones o en salones particulares), además de las habituales audiciones de fin de curso, que mostraban los avances del alumnado y la labor de los profesores $^{111}$.

\section{Música teatral}

\section{1. Los teatros valencianos}

He localizado información sobre diecinueve teatros que funcionaron en Valencia durante la época estudiada (véase Tabla 4). La Ilustración 4 muestra una selección de Teatros estables y desparecidos en Valencia entre 1832 y 1914 que ejercieron influencia en la vida teatral y musical de la ciudad. Presentaré a continuación los datos más relevantes sobre algunos de ellos, en parte fruto de mi investigación en fuentes de la época.

\footnotetext{
${ }^{110}$ Boletín Musical, 20-II-1898, p. 1142.

${ }^{111}$ Como señala M A Antonia Virgili Blanquet, "El pensamiento musical y la estética de salón en la España del siglo XIX", Música Iberoamericana de Salón, Actas del Congreso Iberoamericano de Musicología, coord. José Peñín (Caracas: Fundación Vicente Emilio Sojo, 2000), vol. 1, pp. 28-29, a partir de los años 50 del siglo XIX, además de en los salones aristocráticos y burgueses, comenzaron a imponerse veladas musicales celebradas en casas de reconocidos compositores y pianistas en las que se daban a conocer nuevas obras y se mostraban las habilidades de los discípulos aventajados.
} 


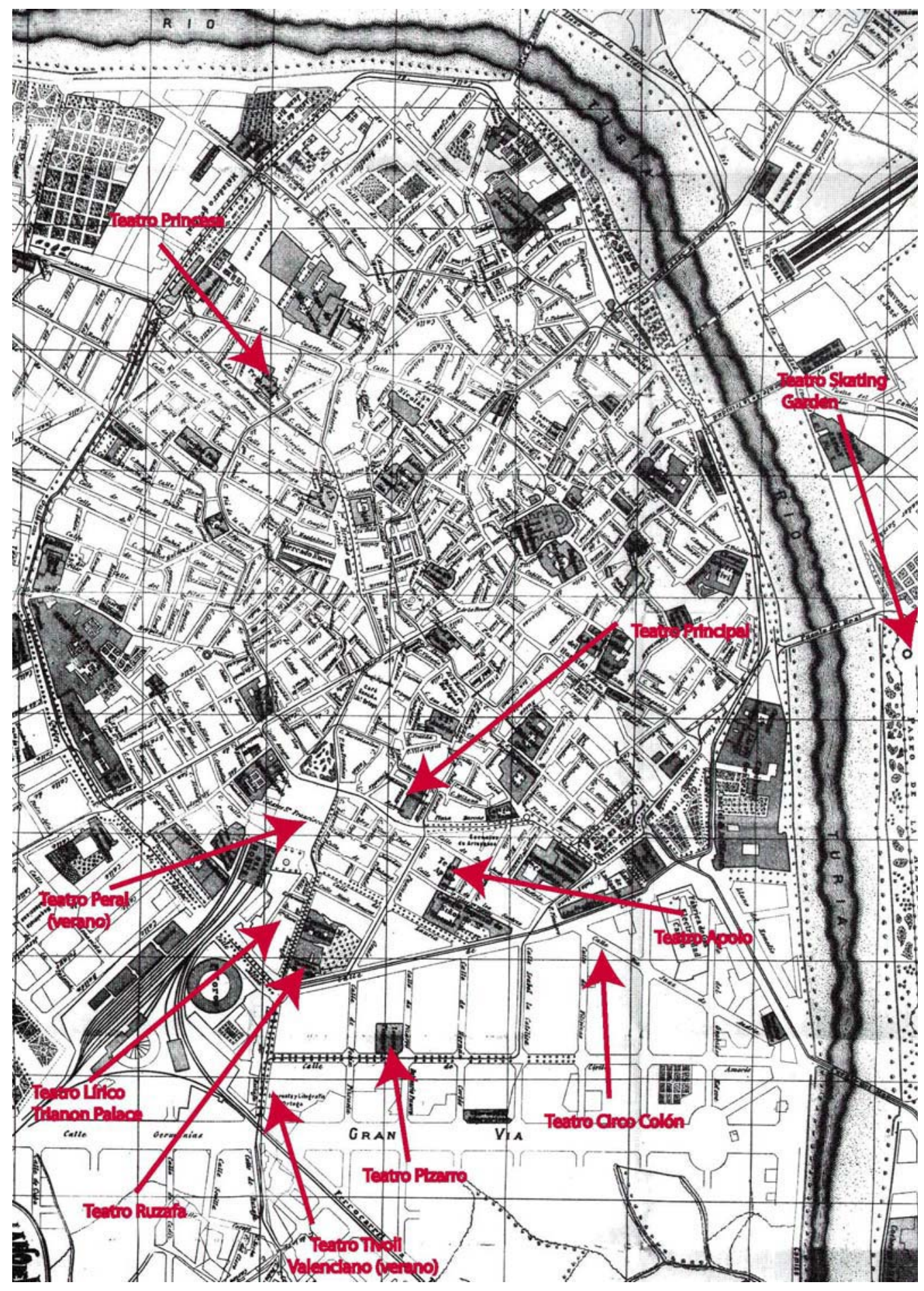

Ilustración 4

Plano de situación de algunos teatros estables y desaparecidos en Valencia entre 1832 y 1914. 
Tabla 4. Selección representativa de teatros y cafés-teatro de Valencia a finales del siglo XIX y principios del $\mathrm{XX}$.

Fuentes: Anónimo, “Centuria teatral”, Almanaque de las Provincias para 1899, pp. 299-304; Anónimo, “Los Teatros en Valencia durante el siglo XIX”, pp. 141-145; Martínez Aloy, Geografía General, pp. 686687; Olmedo, Callejeando por Valencia, pp. 170-172.

\begin{tabular}{|c|c|c|c|}
\hline Nombre Teatro & $\begin{array}{c}\text { Fecha primera } \\
\text { noticia }\end{array}$ & Fecha última noticia & Localización \\
\hline Principal & $\begin{array}{l}24-V I I-1832 \text { con la } \\
\text { representación de la } \\
\text { comedia Luis XIV el } \\
\text { Grande y un acto de } \\
\text { la ópera } L a \\
\text { Cenicienta }\end{array}$ & sigue funcionando & Calle de las Barcas \\
\hline Princesa & $\begin{array}{c}1-\mathrm{X}-1853 \text { con la } \\
\text { representación de la } \\
\text { comedia El arte de } \\
\text { hacer fortuna }\end{array}$ & $\begin{array}{l}\text { 1989. Un incendio lo } \\
\text { destruyó en febrero } \\
\text { de } 2009\end{array}$ & Calle Rey D. Jaime \\
\hline $\begin{array}{c}\text { Café-teatro Príncipe } \\
\text { Alfonso }\end{array}$ & $25-I I-1865$ & $?$ & Plaza del Príncipe \\
\hline $\begin{array}{c}\text { Café-teatro } \\
\text { Ruzafa/Teatro de la } \\
\text { calle Ruzafa/Ruzafa }\end{array}$ & $9-\mathrm{VI}-1868 / 1880$ & Derribado en 1973 & Calle Ruzafa \\
\hline $\begin{array}{c}\text { Café-teatro Circo } \\
\text { Español }\end{array}$ & 4-VII-1869 & septiembre 1875 & En el Parterre \\
\hline $\begin{array}{c}\text { Café-teatro de la } \\
\text { Zarzuela/ Teatro de } \\
\text { la Corona }\end{array}$ & $\begin{array}{c}\text { 21-IV-1870, con la } \\
\text { zarzuela El Dominó } \\
\text { azul } \\
\end{array}$ & $?$ & Calle Corona \\
\hline Apolo & 28-IX-1876 & 1969 & $\begin{array}{c}\text { Calle D. Juan de } \\
\text { Austria }\end{array}$ \\
\hline $\begin{array}{c}\text { Tívoli Valenciano } \\
\text { (de verano) }\end{array}$ & 10-VII-1877 & 1892 & $\begin{array}{c}\text { Calle Ruzafa } \\
\text { (esquina Gran Vía) }\end{array}$ \\
\hline $\begin{array}{c}\text { Jardín del Santísimo } \\
\text { o Skating-Garden (de } \\
\text { verano) }\end{array}$ & $23-V I-1883$ & 1889 & $\begin{array}{c}\text { Calle Severo Ochoa } \\
\text { (manzana Periodista } \\
\text { Badía y Artes } \\
\text { Gráficas) }\end{array}$ \\
\hline Teatro Circo Colón & $\begin{array}{l}6 \text {-XII-1883 con la } \\
\text { representación de la } \\
\text { comedia Lo positivo }\end{array}$ & 1890 & $\begin{array}{l}\text { Calle Colón (manzana } \\
\text { calle Jorge Juan y } \\
\text { Conde Salvatierra) }\end{array}$ \\
\hline $\begin{array}{l}\text { Café-teatro de } \\
\text { Madrid }\end{array}$ & $\begin{array}{c}\text { 5-II-1887 con las } \\
\text { piezas Ya somos tres, } \\
\text { Torear por lo fino y } \\
\text { Maruja }\end{array}$ & otoño de 1887 & Calle de las Barcas \\
\hline Peral (de verano) & 10-VI-1890 & demolido 1891 & $\begin{array}{l}\text { Solares del convento } \\
\text { de San Francisco }\end{array}$ \\
\hline Pizarro & 27-VII-1891 & 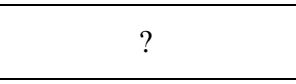 & $\begin{array}{l}\text { Calle Pizarro (esquina } \\
\text { Cirilo Amorós) }\end{array}$ \\
\hline Eslava & 24-XII-1908 & $\begin{array}{c}\text { destruido en } 1959 \\
\text { para construir el cine } \\
\text { Eslava }\end{array}$ & $\begin{array}{l}\text { Sobre el solar del } \\
\text { Hospital d'En Bou }\end{array}$ \\
\hline Novedades & 1908 & 1933 & $?$ \\
\hline $\begin{array}{l}\text { Trianon Palace o } \\
\text { Teatro Lírico }\end{array}$ & 5-XII-1914 & 11-1-1948 & $\begin{array}{c}\text { Calle Ruzafa } \\
\text { (entonces Pi y } \\
\text { Margall, esquina } \\
\text { Santa Clara) }\end{array}$ \\
\hline Benlliure & 29-IX-1915 & 1968 & Avenida del Puerto \\
\hline Olimpia & 1916 & $?$ & $?$ \\
\hline Serrano & 1920 & ? & $?$ \\
\hline
\end{tabular}




\section{Teatro Principal}

A principios del siglo XIX, Valencia sólo contaba con un teatro provisional, instalado en un antiguo caserón, que había pertenecido a Pedro Balda y hasta 1832 no tuvo un edificio de nueva planta. En 1807 el Hospital General de Valencia, que ejercía el monopolio de las representaciones teatrales en Valencia desde 1582, adquirió para la construcción del teatro la casa de los Ballesteros del Centenar de la Ploma y otras contiguas, y encargó al italiano Felipe Fontana la construcción de un edificio para representar ópera italiana, tal y como demandaba la burguesía del momento. La obra se inició en 1808, pero se suspendió por la Guerra de la Independencia. Las obras se reanudaron en 1831, promovidas por el intendente militar Manuel Fidalgo. El teatro abrió sus puertas, sin estar totalmente acabado, el 24 de julio de 1832, con la representación de la comedia Luis XIV el Grande, un acto de la ópera La Cenicienta y lectura de poesías. La fachada del teatro no quedó concluida hasta 1854, que proyectó José Zacarías Camaña. Este teatro, que no tenía nombre especial, no se llamó Principal hasta 1853, cuando dejó de ser el único que existía en la ciudad de Valencia ${ }^{112}$.

\section{Teatro Princesa}

El Teatro Princesa comenzó sus representaciones el 1 de septiembre de 1853 con la comedia El arte de hacer fortuna de Rodríguez Rubí y fue inaugurado el 20 de diciembre del mismo año, día del segundo cumpleaños de la princesa de Asturias, hija de Isabel II, motivo por el cual recibió ese nombre. El teatro, edificado según los planos de José Zacarías Camaña, se situó en uno de los solares del Convento de la Puridad (calle Rey Don Jaime $\mathrm{n}^{\mathrm{o}}$ 3). Su distribución y decorado eran similares a los del Teatro Principal,

\footnotetext{
112 Anónimo, "Centuria teatral", Almanaque de las Provincias para 1899, pp. 300-301; Anónimo, "Los Teatros en Valencia durante el siglo XIX", Almanaque de las Provincias para 1902, p. 142; José Enrique Peláez Malagón, “Teatros", en DMV, vol. 2 (2005), p. 485; Martínez Aloy, Geografia General, pp. 686687; $\mathrm{M}^{\mathrm{a}}$ Francisca Olmedo de Cerdá, Callejeando por Valencia (Valencia: Carena editors, 2003), pp. $170-171$
} 
pero de dimensiones más pequeñas. Desde el año 1868 (año de la revolución que destronó a la reina Isabel II) hasta 1875, tomó el nombre de Teatro de la Libertad; durante la Restauración recuperó su primitivo nombre hasta el advenimiento de la Segunda República ${ }^{113}$.

\section{Teatro Ruzafa}

El Teatro Ruzafa fue inaugurado como teatro propiamente dicho en 1880, aunque su origen se remonta al 9 de junio de 1868 como café-teatro. Fue uno de los primeros cafés-teatro de Valencia, instalado en la calle Ruzafa bajo la dirección de los hermanos Bernardos. En su interior tenía un pequeño escenario, mesas para la venta de bebidas y un espacio para baile. En este local, esencialmente popular, como destaca la prensa del momento, hubo toda clase de representaciones, desde la Pasión y Muerte de Nuestro Señor Jesucristo hasta bailes “cancanescos”, en pleno auge entre 1869 y 1870. El caféteatro Ruzafa cerró al público en mayo de 1880, pero el 15 de septiembre de ese mismo año abrió de nuevo sus puertas como teatro, con un salón en forma de herradura, butacas de rejilla en la primera planta y dos pisos de palcos ${ }^{114}$. Fue el primer teatro de Valencia en el que se instaló luz eléctrica en la temporada $1888-89^{115}$.

\footnotetext{
${ }^{113}$ Un incendio lo destruyó el 29-II-2009. Anónimo, "Centuria teatral”, Almanaque de las Provincias para 1899, p. 301; Anónimo, "Los Teatros en Valencia durante el siglo XIX”, p. 143; Martínez Aloy, Geografía General, p. 687; Olmedo, Callejeando, pp. 171-172; Rafael Solaz Albert, Guía de las guías de Valencia, 1700-1975: fragmentos de historia popular de la ciudad (Valencia: Ayuntamiento de Valencia, 2002), pp. 422-423; Peláez, “Teatros”, p. 486.

114 El Teatro Ruzafa fue derribado en 1973 y en su lugar se construyeron unos grandes almacenes. Anónimo, "Centuria teatral", pp. 301-302; Martínez Aloy, Geografía General, p. 687; Olmedo, Callejeando, p. 172; Peláez, “Teatros”, p. 486.

115 Anónimo, "Los Teatros en Valencia", Almanaque de las Provincias para 1889, p. 137.
} 


\section{Teatro Apolo}

El Teatro Apolo, inaugurado el 28 de octubre de 1876, y actualmente desaparecido, estaba situado en la antigua calle Sequiola (actual calle Don Juan de Austria). El edificio tenía forma de herradura y poseía dos plantas y un amplio vestíbulo de entrada. El patio de butacas era circular y se podía transformar en pista. En ocasiones la sala de teatro se convertía en local de espectáculos en el que se realizaban funciones de circo y actuaciones variadas entre enero y marzo. En la prensa se anunciaba como "Teatro Apolo Circo" $" 116$.

\section{Teatro Pizarro}

El Teatro Pizarro, inaugurado el 27 de junio de 1891, estuvo situado en la calle del mismo nombre, haciendo esquina con la calle Cirilo Amorós ${ }^{117}$. Nació como un teatro de verano y sin cubrir. En 1892 se obtuvo el permiso pertinente para cubrir el recinto y por él pasaron varias compañías de zarzuela y opereta ${ }^{118}$.

\section{Teatro Circo Colón}

El Teatro Circo Colón se edificó en la calle Colón y se inauguró el 6 de diciembre de 1883 con la representación de la comedia Lo positivo. Tenía planta circular en su exterior y el salón interior era oval para poder ofrecer espectáculos ecuestres. Disponía de treinta y seis palcos y un espacioso escenario ${ }^{119}$.

\footnotetext{
116 Anónimo, "Centuria teatral", pp. 302-303; Martínez Aloy, Geografia General, p. 687; Peláez, "Teatros", p. 486; Boletín Musical, 31-XII-1892, p. 34; Anónimo, "Los Teatros en Valencia", Almanaque de las Provincias para 1893, p. 175; Solaz, Guía de las guías, p. 193.

${ }^{117}$ Anónimo, "Centuria teatral”, p. 303, Peláez, "Teatros”, p. 486.

${ }^{118}$ Consúltense por ejemplo Almanaques de las Provincias desde 1893 a 1902.

${ }^{119}$ Anónimo, “Centuria teatral”, p. 303.
} 
Otros teatros y cafés-teatro

En el periodo 1880-1900 estuvieron también activos varios teatros de verano: el Tívoli Valenciano inaugurado el 10 de julio de 1877 con la representación de la zarzuela La Mascotta, que funcionó hasta 1892; el Teatro Peral, que sólo funcionó durante 1890, y en cuya inauguración se representaron las zarzuelas Chateau Margaux y Marina; y el Teatro de verano del Jardín del Santísimo, conocido también como "Skating-Garden", que abrió al público el 23 de junio de 1883 con las zarzuelas El Caballero particular, Canto de ángeles y Música clásica, y estuvo en funcionamiento hasta 1889.

En 1865 se introdujo en Valencia una nueva clase de representaciones escénicas, la de los cafés-teatro. Los primeros locales de este tipo fueron el Café Comercio, el Caféteatro Príncipe Alfonso y a él siguieron otros, como el Café-teatro Ruzafa, el Café-teatro Circo Español, el Café-teatro de la Zarzuela y el Café-teatro de Madrid ${ }^{120}$.

En el siglo XX aparecieron nuevos locales, como el Teatro Eslava (1908) ${ }^{121}$ y el Trianon Palace o Teatro Lírico (1914) ${ }^{122}$. En 1916 se inauguraron dos nuevos teatros, el Benlliure y el Olimpia, en 1920 el Teatro Serrano y en 1921 el Teatro Novedades.

\footnotetext{
${ }^{120}$ Anónimo, "Centuria teatral", pp. 301-303; Anónimo, "Los Teatros en Valencia”, Almanaque de las Provincias para 1887, p. 165.

121 El Teatro Eslava era conocido popularmente como "la Bombonera". De estilo mudéjar, fue construido por el arquitecto José Manuel Cortina Pérez sobre el solar del Hospital de En Bou. Véase Martínez Aloy, Geografia General, p. 687. Fue destruido en 1959 para construir el cine Eslava.

${ }^{122}$ Estuvo situado en la calle Ruzafa (entonces Pi y Margall esquina a calle Santa Clara) se alzó en el solar del Convento de Santa Clara, el de religiosas capuchinas de clausura, que tuvieron que abandonarlo con la Desamortización de Mendizábal en 1835. Fue inaugurado el 5 de diciembre de 1914, celebrándose tres conciertos dirigidos por el maestro Lasalle. Al principio funcionó como circo y variedades, en 1916 José Serrano reformó la sala y el escenario, cambiándole el nombre a Teatro Lírico, donde estrenó con éxito varias de sus obras. El aforo del Trianon Palace era de 1.548 espectadores. En la temporada 1920-21 problemas administrativos provocaron su conversión en cine. Fue derribado en enero de 1948. Véase Solaz, Guía de las guías, p. 195; Martínez Aloy, Geografía General, p. 687.
} 


\section{2. Aproximación a las actividades escénicas de los teatros valencianos}

En este apartado comentaré la actividad de cuatro teatros valencianos que fueron estables durante el periodo estudiado: Principal, Princesa, Apolo y Ruzafa. Desde principios del siglo XIX, la tonadilla escénica, que estuvo presente hasta ese momento en las representaciones teatrales valencianas, fue sufriendo la influencia de la ópera italiana. La vida operística valenciana entre 1820 y 1830 estuvo dominada por la influencia de Rossini. La década 1830-1840 coincidió con los últimos años de gran éxito de Rossini y el predominio de Bellini y Donizetti, y con una fuerte presencia de óperas de Verdi en la segunda mitad de la década de los cuarenta ${ }^{123}$. La década de los cincuenta fue, según Sirera, una "década negra” para la ópera, ya que la zarzuela irrumpió con fuerza. En los teatros valencianos Principal y Princesa se formaron compañías específicas de zarzuela, según Galbis López, la zarzuela de más popularidad representada en Valencia en la década 1850-1860 fue El Tío Caniyitas, de Soriano Fuertes, con letra de Sanz Pérez. A partir de 1852, las zarzuelas El valle de Andorra y Catalina de Gaztambide, y Jugar con Fuego y Galanteos en Venecia de Barbieri fueron las más representadas en la escena valenciana. Entre los autores valencianos de música escénica de la primera mitad del siglo XIX Galbis señala a José Valero Peris (1868-?), Carlos Llorens Robles (18211862), Juan Bautista Plasencia Valls (1816-1855), José Vidal Casanova (1838-?) y Eduardo Ximénez Cos (1824-1900). Fueron libretistas de este repertorio algunos de los principales escritores valencianos del momento, como Vicente Boix, Josep Bernat y Baldoví, José $\mathrm{M}^{\mathrm{a}}$ Bonilla. Algunos de ellos colaboraron también como libretistas de las

\footnotetext{
${ }^{123}$ Como sucedería en otras ciudades españolas, véase para el caso gallego, Pilar Alén, "Reflexiones sobre un siglo de música gallega (ca. 1808-1916)”, Revista de Musicología, 30/1 (2007), p. 60.
} 
primeras zarzuelas en valenciano que surgieron a mediados del siglo XIX (véase Tabla $5)^{124}$.

A partir de la década 1860, Galbis señala un aumentó en el número de zarzuelas en valenciano que habría que relacionar con el sainete, un género de temática costumbrista y en lengua vernácula. Esta tendencia se complementó en las últimas décadas del siglo XIX y principios del XX con el movimiento de la Renaixença que intentó recuperar la lengua y cultura valenciana y mantiene semejanzas con lo que sucedió en otras zonas de la península coincidiendo con el auge del Nacionalismo ${ }^{125}$.

Tabla 5. Compositores valencianos de música escénica en la primera mitad del siglo XIX. Fuentes: Galbis, "La zarzuela", pp. 331-332, Galbis, “Ópera”, en DMV, vol. 2 (2006), p. 178.

\begin{tabular}{|c|c|c|}
\hline Compositor & Obras representativas & Años de estreno \\
\hline \hline \multirow{7}{*}{ José Valero Peris } & $\begin{array}{c}\text { Angélica (ópera en dos } \\
\text { actos) }\end{array}$ & 1839 \\
\cline { 2 - 3 } & $\begin{array}{c}\text { La Esmeralda (ópera en } \\
\text { tres actos) }\end{array}$ & 1843 \\
\cline { 2 - 3 } & $\begin{array}{c}\text { Donde menos se espera } \\
\text { salta la liebre (zarzuela) }\end{array}$ & 1850 \\
\hline \multirow{7}{*}{ Carlos Llorens Robles } & $\begin{array}{c}\text { El Cuerno de Oro (ópera } \\
\text { en tres actos) }\end{array}$ & 1850 \\
\cline { 2 - 3 } & $\begin{array}{c}\text { La herencia de las } \\
\text { jorobas (zarzuela) }\end{array}$ & 1854 \\
\cline { 2 - 3 } & $\begin{array}{c}\text { Federico II El Grande } \\
\text { (ópera en tres actos) }\end{array}$ & 1854 \\
\hline Eduardo Ximénez Cos & Barba azul (zarzuela) & 1855 \\
\hline \multirow{2}{*}{ Juan Bautista Plasencia } & Muzio Scávola & No se estrenó \\
\cline { 2 - 3 } & Fernan El Aventurero & No se estrenó \\
\hline
\end{tabular}

124 José L. Sirera, El Teatre Principal de València (València: Institució Valenciana d'Estudis i Investigació, 1986), pp. 83-88. Véase Vicente Galbis López, "La zarzuela en el área mediterránea", en La zarzuela en España e hispanoamérica. Centro y periferia, 1800-1950, Actas del congreso internacional (Madrid, 1995), Cuadernos de Música Iberoamericana, 2-3 (1996-97), pp. 328, 330-332.

${ }^{125}$ Galbis, "La zarzuela", pp. 334-335. Existen trabajos sobre el desarrollo de la zarzuela en otras zonas geográficas, véanse Actas del congreso internacional La zarzuela en España e Hispanoamérica. Centro y periferia 1800-1950, Cuadernos de Música Iberoamericana, 2-3 (1996-1997), en particular, Francesc Cortés, "La zarzuela en Cataluña y la zarzuela en catalán”, pp. 289-317; Antonio Álvarez Cañibano, "La zarzuela en Andalucía", pp. 351-362; Nagore Ferrer, "La vida zarzuelística en Bilbao (1850-1936)", pp. $399-408$. 
En la segunda mitad del siglo XIX, los teatros activos en Valencia presentaban una cierta diferenciación en cuanto a los géneros representados en ellos, una realidad a la que hubo de adaptarse Amancio Amorós en su faceta de compositor teatral.

El Teatro Principal mostró siempre predilección por la ópera italiana. La prensa valenciana en 1888 señaló que el público asiduo a ese teatro era poco aficionado a las zarzuelas:

Los autores de Cádiz y La Gran-vía, Sres. Burgos, Pérez y el maestro Chueca, vinieron de Madrid para asistir a alguna de las representaciones, pero el escaso éxito que obtuvo el espectáculo, debido a lo flojo de la compañía, y a que el público de este teatro gusta poco de las zarzuelas, obligó a suspender las funciones antes de celebrar las 20 ofrecidas al abono $[\ldots]^{126}$.

Entre 1861 y 1877 tuvo lugar el triunfo absoluto de la ópera en el Teatro Principal. La base del repertorio seguían siendo sobre todo óperas de Rossini, Donizetti, Bellini y Verdi, junto a algunas de Meyerbeer, Gounod, Halévy y Flotow ${ }^{127}$. En 1878 en el Principal se representaron las óperas españolas Marina de Arrieta y Guzmán el Bueno de Bretón. En la temporada 1887 se dio a conocer en Valencia la zarzuela en tres actos La Bruja de Chapí, y este mismo año se estrenó El Recluta, ópera de los valencianos Antonio Chocomeli y José Espí ${ }^{128}$. La novedad de la temporada de 1888-89 fue Lohengrin de Wagner, representada por primera vez en Valencia con gran éxito por una compañía de ópera italiana dirigida por Spetrino ${ }^{129}$. Desde 1891 hasta final de siglo, el Teatro Principal fue el local habitual que acogía óperas y operetas en Valencia (véase Tabla 6).

\footnotetext{
${ }^{126}$ Anónimo, "Los Teatros en Valencia”, Almanaque de las Provincias para 1889, p. 131.

${ }^{127}$ Sirera, El Teatre Principal, pp. 86-87.

128 Anónimo, “Los Teatros en Valencia”, Almanaque de las Provincias para 1889, pp. 131-132.

${ }^{129}$ Anónimo, "Los Teatros en Valencia”, Almanaque de las Provincias para 1890, p. 307.
} 
Aunque el Teatro Principal siempre mostró predilección por el género operístico, en general, durante las dos primeras décadas del siglo XX, para atraer a un número mayor de gente, contrató diversas compañías de zarzuela, compañías de declamación y "varietés" y se incluyeron sesiones de cinematógrafo ${ }^{130}$.

Tabla 6. Representaciones operísticas en el Teatro Principal de Valencia. Selección de las temporadas 1890-1924.

Fuentes: Almanaque de las Provincias para 1891 (pp. 273, 276), 1893 (pp. 173-174), 1894 (p. 81), 1895 (p. 147), 1896 (p. 241), 1897 (p. 247), 1898 (p. 231), 1899 (p. 263), 1900 (pp. 89-90), 1902 (pp. 380-381), 1904 (pp. 193-195), 1906 (pp. 291-292), 1908 (pp. 159, 162), 1910 (pp. 175-176), 1916 ( pp. 209-210), 1918, (pp. 205-207), 1924 (p. 345), Boletín Musical, 22-XI-1893 (p. 150).

\begin{tabular}{|c|c|c|c|}
\hline Temporada & Título & Autor & Compañía \\
\hline \multirow[b]{2}{*}{$1890-91$} & El pescador de perlas & [George] Bizet & $\begin{array}{l}\text { Compañía de ópera } \\
\text { italiana } \\
\text { Director: Bonicioli }\end{array}$ \\
\hline & Los amantes de Teruel & [Tomás] Bretón & $\begin{array}{c}\text { Compañía de ópera } \\
\text { italiana } \\
\text { Director: Goula } \\
\end{array}$ \\
\hline \multirow{12}{*}{$1891-92$} & La sonámbula & [Vincenzo] Bellini & \multirow{6}{*}{$\begin{array}{c}\text { Compañía de ópera } \\
\text { italiana Director: } \\
\text { Bach Subeyas }\end{array}$} \\
\hline & Lucia di Lamermoor & [Gaetano] Donizetti & \\
\hline & El Barbero de Sevilla & $\begin{array}{c}\text { [Gioacchino] } \\
\text { Rossini }\end{array}$ & \\
\hline & Aida & [Giusseppe] Verdi & \\
\hline & Faust & [Charles] Gounod & \\
\hline & Hugonotes & $\begin{array}{l}\text { [Giacomo] } \\
\text { Meyerbeer }\end{array}$ & \\
\hline & Tannhauser & [Richard] Wagner & \multirow{6}{*}{$\begin{array}{c}\text { Compañía de ópera } \\
\text { italiana } \\
\text { Director: Goula }\end{array}$} \\
\hline & Lucrecia & [Gaetano] Donizetti & \\
\hline & Lohengrin & [Richard] Wagner & \\
\hline & $\begin{array}{c}\text { Bella Fanciulla di } \\
\text { Perth }\end{array}$ & [George] Bizet & \\
\hline & Der Freischutz & $\begin{array}{c}\text { [Carl Maria von] } \\
\text { Weber }\end{array}$ & \\
\hline & La Hebrea & [Fromental] Halévy & \\
\hline \multirow{3}{*}{$1892-93$} & Otello & [Giusseppe] Verdi & \multirow{3}{*}{$\begin{array}{l}\text { Compañía de ópera } \\
\text { italiana } \\
\text { Director: Palminteri }\end{array}$} \\
\hline & Lohengrin & [Richard] Wagner & \\
\hline & Faust & [Charles] Gounod & \\
\hline
\end{tabular}

130 Anónimo, "Teatros", Almanaque de las Provincias para 1904, pp. 193-195; Anónimo, "Teatros", Almanaque de las Provincias para 1906, pp. 291-292. 


\begin{tabular}{|c|c|c|c|}
\hline & La Africana & $\begin{array}{l}\text { [Giacomo] } \\
\text { Meyerbeer }\end{array}$ & \\
\hline & Aida & [Giusseppe] Verdi & \\
\hline & Carmen & [George] Bizet & \\
\hline \multirow{4}{*}{$1893-94$} & $\begin{array}{c}\text { Le Damigelle de } \\
\text { Saint-Cyr [opereta] }\end{array}$ & $\begin{array}{c}\text { [Carlos María] } \\
\text { Bachini }\end{array}$ & \multirow{4}{*}{$\begin{array}{c}\text { Compañía de opereta } \\
\text { italiana Director: } \\
\text { Gaetano Tani }\end{array}$} \\
\hline & $\begin{array}{c}\text { Don Pedro de } \\
\text { Medina }[\text { opereta] }\end{array}$ & [Paolo] Lanzini & \\
\hline & $\begin{array}{c}\text { I diavoli Della corte } \\
\text { [opereta] }\end{array}$ & [Oreste] Carlini & \\
\hline & $\begin{array}{c}\text { Un matrimonio fa due } \\
\text { donne [opereta] }\end{array}$ & Gambino & \\
\hline \multirow{4}{*}{$1894-95$} & Cavallería Rusticana & [Pietro] Mascagni & \multirow{4}{*}{$\begin{array}{c}\text { Compañía de ópera } \\
\text { italiana } \\
\text { Director: Tomba }\end{array}$} \\
\hline & La sonámbula & [Vincenzo] Bellini & \\
\hline & La hija del Regimento & [Gaetano] Donizetti & \\
\hline & I pagliacci & $\begin{array}{c}\text { [Ruggero] } \\
\text { Leoncavallo } \\
\end{array}$ & \\
\hline \multirow{6}{*}{$1895-96$} & La Africana & $\begin{array}{l}\text { [Giacomo] } \\
\text { Meyerbeer }\end{array}$ & \multirow{4}{*}{$\begin{array}{c}\text { Compañía de ópera } \\
\text { italiana } \\
\text { Director: Vehils }\end{array}$} \\
\hline & Carmen & [George] Bizet & \\
\hline & Lohengrin & [Richard] Wagner & \\
\hline & Cavalleria Rusticana & [Pietro] Mascagni & \\
\hline & La Dolores & [Tomás] Bretón & Compañía de \\
\hline & Aurora & [José] Espí & $\begin{array}{c}\text { zarzuela } \\
\text { Director: Juan Elías }\end{array}$ \\
\hline \multirow{9}{*}{$1897-98$} & Carmen & [George] Bizet & \multirow{9}{*}{$\begin{array}{l}\text { Compañía de ópera } \\
\text { y opereta italiana } \\
\text { Director: Giovanni }\end{array}$} \\
\hline & El barbero de Sevilla & $\begin{array}{c}\text { [Gioacchino] } \\
\text { Rossini }\end{array}$ & \\
\hline & Dinorah & $\begin{array}{l}\text { [Giacomo] } \\
\text { Meyerbeer }\end{array}$ & \\
\hline & La Traviata & [Giusseppe] Verdi & \\
\hline & Rigoletto & [Giusseppe] Verdi & \\
\hline & Marta & $\begin{array}{l}\text { [Friederich von] } \\
\text { Flotow }\end{array}$ & \\
\hline & $\begin{array}{c}\text { El dúo de la Africana } \\
\text { [zarzuela] }\end{array}$ & [Ruperto] Chapí & \\
\hline & $\begin{array}{c}\text { El Monaguillo } \\
\text { [zarzuela] }\end{array}$ & [Miguel] Marqués & \\
\hline & $\begin{array}{c}\text { Música Clásica } \\
\text { [zarzuela] }\end{array}$ & [Ruperto] Chapí & \\
\hline \multirow{10}{*}{$1898-99$} & Caballería Rusticana & [Pietro] Mascagni & \multirow{5}{*}{$\begin{array}{l}\text { Compañía de ópera } \\
\text { y opereta italiana } \\
\text { Director: Giovanni }\end{array}$} \\
\hline & Marina & [Emilio] Arrieta & \\
\hline & Carmen & [George] Bizet & \\
\hline & $\begin{array}{c}\text { Las campanas de } \\
\text { Corneville }\end{array}$ & [Robert] Planquette & \\
\hline & I pagliacci & $\begin{array}{c}\text { [Ruggero] } \\
\text { Leoncavallo } \\
\end{array}$ & \\
\hline & Aida & [Giusseppe] Verdi & \multirow{5}{*}{$\begin{array}{l}\text { Compañía ópera } \\
\text { Director: Vehils }\end{array}$} \\
\hline & Lohengrin & [Richard] Wagner & \\
\hline & Sansón y Dalila & $\begin{array}{c}\text { [Camile] } \\
\text { Saint-Saëns } \\
\end{array}$ & \\
\hline & Lohengrin & [Richard] Wagner & \\
\hline & Caballeria Rusticana & [Pietro] Mascagni & \\
\hline \multirow{3}{*}{1901} & El Soñador & \multirow{3}{*}{ [Salvador] Giner } & \multirow{3}{*}{-} \\
\hline & El Fantasma & & \\
\hline & Morel & & \\
\hline
\end{tabular}




\begin{tabular}{|c|c|c|c|}
\hline & Sagunto & & \\
\hline & Tosca & [Giacomo] Puccini & $\begin{array}{l}\text { Compañía de ópera } \\
\text { Director: Goula }\end{array}$ \\
\hline \multirow[b]{2}{*}{$1902-1903$} & Don Giovanni & [W. A] Mozart & \multirow{2}{*}{$\begin{array}{c}\text { Compañía } \\
\text { Director: Baratta }\end{array}$} \\
\hline & Hansel y Gretel & $\begin{array}{c}\text { [Engelbert] } \\
\text { Humperdinck }\end{array}$ & \\
\hline \multirow{3}{*}{ 1906-1907 } & Bohemios & [Amadeo] Vives & \multirow{3}{*}{$\begin{array}{c}\text { Compañía de } \\
\text { zarzuela } \\
\text { Director: Blay }\end{array}$} \\
\hline & La Bruja & [Ruperto] Chapí & \\
\hline & Los Mosqueteros & [Vicente] Lleó & \\
\hline 1907-1908 & La Valkyria & [Richard] Wagner & $\begin{array}{l}\text { Compañía de ópera } \\
\text { italiana } \\
\text { Director: Mascheroni }\end{array}$ \\
\hline 1908-1909 & Aida & [Giusseppe] Verdi & \begin{tabular}{|c|} 
Compañía de \\
zarzuela grande \\
Director: Gorgé \\
\end{tabular} \\
\hline \multirow{4}{*}{1915} & $\begin{array}{c}\text { Las Golondrinas } \\
\text { [opereta] }\end{array}$ & $\begin{array}{c}\text { [José María] } \\
\text { Usandizaga }\end{array}$ & $\begin{array}{c}\text { Compañía de } \\
\text { zarzuela } \\
\text { y opereta } \\
\end{array}$ \\
\hline & $\begin{array}{l}\text { La España de } \\
\text { pandereta }\end{array}$ & [Manuel] Penella & \multirow{3}{*}{$\begin{array}{c}\text { Compañía de } \\
\text { zarzuela } \\
\text { Director: Beltrán }\end{array}$} \\
\hline & $\begin{array}{l}\text { Los cadetes de } \\
\text { la reina }\end{array}$ & [Pablo] Luna & \\
\hline & La revoltosa & [Ruperto] Chapí & \\
\hline \multirow{3}{*}{1917} & El gato montés & \multirow{3}{*}{$\begin{array}{c}\text { [Manuel] Penella } \\
\text { Moreno }\end{array}$} & \multirow{3}{*}{$\begin{array}{c}\text { Compañía de } \\
\text { opereta, zarzuela y } \\
\text { revista } \\
\text { Director: Penella }\end{array}$} \\
\hline & $\begin{array}{c}\text { La historieta de } \\
\text { Margot }\end{array}$ & & \\
\hline & La cara del ministro & & \\
\hline \multirow{6}{*}{1924} & Bodas de Juanita & [Luis Olona] & \multirow{6}{*}{$\begin{array}{c}\text { Compañía de óperas } \\
\text { di camera } \\
\text { Director: Crabbé }\end{array}$} \\
\hline & El maestro de capilla & $\begin{array}{c}\text { [Domenico } \\
\text { Cimarosa }] \\
\end{array}$ & \\
\hline & La serva padrona & $\begin{array}{c}\text { [Giovanni Battista] } \\
\text { Pergolesi }\end{array}$ & \\
\hline & Luisa y Federico & - & \\
\hline & Fantochines & $\begin{array}{c}\text { [Conrado] del } \\
\text { Campo y Zabaleta }\end{array}$ & \\
\hline & El secreto de Susana & $\begin{array}{c}\text { [Ermanno Wolf- } \\
\text { Ferrari] }\end{array}$ & \\
\hline
\end{tabular}

Las representaciones escénicas del Teatro Princesa se centraron en la zarzuela, con especial predilección por tres autores: Ruperto Chapí y los valencianos Salvador Giner y Vicente Peydró. Los éxitos de Chapí fueron continuos en Valencia con los estrenos de Mujer y Reina, El cura del regimiento, Las Bravías, La chavala, El estreno y María de los Angeles ${ }^{131}$. Las zarzuelas representadas de Giner, Foch en l'era [sic] y Nit d'albaes, fueron, según Galbis, el máximo exponente de la zarzuela regionalista

${ }^{131}$ Almanaque de las Provincias para 1896, p. 16. Las dos últimas zarzuelas fueron estrenadas en octubre de 1900; véase Almanaque de las Provincias para 1901, p. 121. 
valenciana $^{132}$. Vicente Peydró fue también uno de los autores más prolíficos de zarzuela valenciana y destacó por su permanencia en las programaciones con títulos como La ciudad de porvenir o desde Valencia al sel [sic], El mosquetero y Todos al baile. Las carceleras, también de Peydró, fue la obra que más se puso en escena según la prensa ${ }^{133}$. En sus zarzuelas más populares (Chent de Tró y Les Barraques), Peydró colaboró con el libretista Eduardo Escalante ${ }^{134}$.

En la década de 1880-1890 triunfaron en el Teatro Princesa Los sobrinos del Capitan Grant de Fernández Caballero (que alcanzó treinta representaciones en 1883) y La Gran Vía de Chueca ${ }^{135}$. Tomás Rico, empresario del Teatro Princesa, remodeló la decoración del local, lo iluminó con luz eléctrica y supo darle nuevo impulso a una programación que funcionaba con frecuentes interrupciones ${ }^{136}$. Según Galbis, los diez años finales del siglo XIX fueron la época dorada de este teatro ${ }^{137}$. En noviembre de 1894 destacaron las representaciones de Marina, de Arrieta; El molinero de Subiza, de Oudrid y en el género chico El Moro Muza, de Chapi ${ }^{138}$. En 1895, la compañía de ópera que dirigía Tomás Bretón llegó a Valencia, representó La Dolores del propio Bretón y estrenó Aurora del valenciano José Espí ${ }^{139}$. A partir de 1895 los estrenos de obras del género chico fueron constantes, destacando las de Tomás López Torregrosa, Federico Chueca,

\footnotetext{
${ }^{132}$ Galbis, "La zarzuela", p. 337; Anónimo, "Los teatros en Valencia", Almanaque de las Provincias para 1901, pp. 120-121.

${ }^{133}$ Anónimo, “Los teatros en Valencia”, Almanaque de las Provincias para 1902, p. 381.

${ }^{134}$ Anónimo, "Los teatros en Valencia", Almanaque de las Provincias para 1901, p. 90; Anónimo, "Los teatros en Valencia", Almanaque de las Provincias para 1899, pp. 264-265.

${ }^{135}$ Anónimo, “Teatros”, Almanaque de las Provincias para 1884, p. 66.

${ }^{136}$ Anónimo, "Teatros”, Almanaque de las Provincias para 1890, pp. 308-311.

${ }^{137}$ Galbis, "La zarzuela”, p. 337.

${ }^{138}$ Boletín Musical, 30-XI-1894, pp. 349-350.

${ }^{139}$ Boletín Musical, 15-X-1895, p. 516.
} 
Apolinar Brull y la zarzuela Gigantes y Cabezudos, de Manuel Fernández Caballero (con más de cien representaciones) ${ }^{140}$. En 1898, la prensa valenciana destacó el rotundo éxito de Portfolio de Valencia, de Vicente Peydró con libreto de Maximiliano Thous y Vicente Fe. A este estreno siguieron La Revoltosa, de Chapí, con texto de Fernández Shaw y López Silva y El Santo de la Isidra, de Arniches y Torregrosa ${ }^{141}$. En 1901, la compañía de Valls y Talavera estrenó con gran éxito diversas obras de autores valencianos ${ }^{142}$. Lo mismo sucedió en la temporada 1908-09 y siguientes, la compañía cómico-lírica dirigida por Rafael Lara y Ricardo Sendra pusieron en escena varias obras de autores valencianos: L'entrà de la Murta, de Giner; La cuarta plana, de Antich; La enramà, de Francisco J. Blasco; Al rayar el día del maestro Fayos, entre otros, que alternaron con autores ya consagrados como Chapí ${ }^{143}$. Entre 1910 y 1925 se sucedieron etapas de cierto declive con otras en las que se combinaron compañías de ópera, zarzuela y opereta, con otras de género chico ${ }^{144}$.

En la Tabla 7 presento una selección de las representaciones documentadas en el Teatro Princesa referente a las temporadas 1894-1901.

\footnotetext{
140 Anónimo, "Los teatros en Valencia", Almanaque de las Provincias para 1887, p. 166; Almanaque de las Provincias para 1898, p. 232; Almanaque de las Provincias para 1901, p. 120.

${ }^{141}$ Boletín Musical, 20-I-1898, pp. 1112-1113.

${ }^{142}$ Anónimo, "Los teatros en Valencia”, Almanaque de las Provincias para 1902, p. 381.

${ }^{143}$ Anónimo, "Los teatros en Valencia", Almanaque de las Provincias para 1910, pp. 176, 179.

${ }^{144}$ Galbis, "La zarzuela", p. 341
} 
Tabla 7. Representaciones de zarzuela en el Teatro Princesa. Selección de las temporadas 1894-1901. Fuentes: Almanaque de las Provincias para 1895 (p. 148), 1896 (pp. 241, 243), 1898 (p. 232), 1899 (p. 264), 1900 (pp. 90-91), 1901 (pp. 120-121), 1902 (p. 381), 1903 (p. 236), Boletín Musical, 15-I-1895 (pp. 369-370), 30-I-1895 (pp. 378-379), 20-I-1897 (p. 825), 30-I-1897 (p. 833).

\begin{tabular}{|c|c|c|c|}
\hline Temporada & Título & Compositor & Libretista \\
\hline \multirow{19}{*}{ 1894-1895 } & El moro Muza & [Ruperto] Chapí & [Federico] Jaques \\
\hline & La Marsellesa & $\begin{array}{c}\text { [Manuel] Fernández } \\
\text { Caballero }\end{array}$ & [Miguel] Ramos Carrión \\
\hline & El anillo de hierro & $\begin{array}{c}\text { [Pedro Miguel }] \\
\text { Marqués }\end{array}$ & [Marcos] Zapata \\
\hline & El rey que rabió & [Ruperto] Chapí & [Miguel] Ramos Carrión \\
\hline & Pepe Hillo & [Guillermo] Cereceda & [Ricardo] Puente Brañas \\
\hline & $\begin{array}{l}\text { El dúo de la } \\
\text { Africana }\end{array}$ & $\begin{array}{c}\text { [Manuel] Fernández } \\
\text { Caballero }\end{array}$ & [Miguel] Echegaray \\
\hline & La hija del barba & [Julián] Romea Parra & [Julián] Romea Parra \\
\hline & La Bruja & [Ruperto] Chapí & [Miguel] Ramos Carrión \\
\hline & Los Mostenses & [Ruperto] Chapí & $\begin{array}{l}\text { [Carlos] Arniches, [Celso] } \\
\text { Lucio y [Gonzalo] Cantó }\end{array}$ \\
\hline & $\begin{array}{l}\text { Las campanas de } \\
\text { Carrión }\end{array}$ & [Robert] Planquette & [Luis Mariano] de Larra \\
\hline & Cádiz & $\begin{array}{l}\text { [Federico] Chueca y } \\
\text { [Joaquín] Valverde }\end{array}$ & [Javier] de Burgos \\
\hline & $\begin{array}{c}\text { El tambor de } \\
\text { Granaderos }\end{array}$ & [Ruperto] Chapí & [Emilio] Sánchez Pastor \\
\hline & Mujer y reina & [Ruperto] Chapí & [Mariano] Pina Domínguez \\
\hline & $\begin{array}{l}\text { El cura del } \\
\text { regimiento }\end{array}$ & [Ruperto] Chapí & [Emilio] Sánchez Pastor \\
\hline & La tempestad & [Ruperto] Chapí & [Miguel] Ramos Carrión \\
\hline & Marina & [Emilio] Arrieta & [Francisco] Camprodon \\
\hline & La Dolores [ópera] & [Tomás] Bretón & [Tomás] Bretón \\
\hline & Salto del Pasiego & $\begin{array}{c}\text { [Manuel] Fernández } \\
\text { Caballero }\end{array}$ & [Luis de Eguilaz] \\
\hline & Las dos princesas & $\begin{array}{c}\text { [Manuel] Fernández } \\
\text { Caballero }\end{array}$ & $\begin{array}{l}\text { [Mariano] Pina Domínguez } \\
\text { y [Miguel] Ramos Carrión }\end{array}$ \\
\hline \multirow{13}{*}{$1896-1897$} & $\begin{array}{c}\text { La ciudad del Porvenir } \\
\text { o Desde Valencia al } \\
\text { sel }[\text { sic }]\end{array}$ & [Vicente] Peydró & $\begin{array}{c}\text { [Eduardo] Navarro } \\
\text { Gonzalvo }\end{array}$ \\
\hline & Las bravias & [Ruperto] Chapí & $\begin{array}{c}\text { [José] López Silva y } \\
\text { [Carlos] Fernández Shaw }\end{array}$ \\
\hline & La banda de trompetas & $\begin{array}{c}\text { [Tomás] López } \\
\text { Torregrosa }\end{array}$ & $\begin{array}{c}\text { [Carlos] Arniches y } \\
\text { [Celso] Lucio }\end{array}$ \\
\hline & El cortejo de la Irene & [Ruperto] Chapí & [Carlos] Fernández Shaw \\
\hline & La boda de Luis Alonso & [Jerónimo] Jiménez & [Javier de Burgos] \\
\hline & El ángel caído & [Apolinar] Brull & [Federico] Jacques \\
\hline & La madre abadesa & $\begin{array}{l}\text { [Apolinar] Brull y } \\
\text { [Tomás] López } \\
\text { Torregrosa }\end{array}$ & [Isidro] Sinesio Delgado \\
\hline & $\begin{array}{c}\text { Agua, azucarillos y } \\
\text { aguardiente }\end{array}$ & [Federico] Chueca & [Miguel] Ramos Carrión \\
\hline & La viejecita & $\begin{array}{c}\text { [Manuel] Fernández } \\
\text { Caballero } \\
\end{array}$ & [Miguel] Echegaray \\
\hline & Portfolio de Valencia & [Vicente] Peydró & $\begin{array}{c}\text { [Maximiliano] Thous y } \\
\text { [Vicente] Fe }\end{array}$ \\
\hline & La Revoltosa & [Ruperto] Chapí & [Carlos] Fernández Shaw \\
\hline & El santo de la Isidra & $\begin{array}{l}\text { [Tomás] López } \\
\text { Torregrosa }\end{array}$ & [Carlos] Arniches \\
\hline & Pepe Gallardo & [Ruperto] Chapí & [Guillermo] Perrín y [Miguel] \\
\hline
\end{tabular}




\begin{tabular}{|c|c|c|c|}
\hline \multirow{10}{*}{ 1898-1899 } & & & $\begin{array}{l}\text { Palacios } \\
\end{array}$ \\
\hline & La chavala & [Ruperto] Chapí & $\begin{array}{c}\text { [José] López Silva y } \\
\text { [Carlos] Fernández Shaw }\end{array}$ \\
\hline & $\begin{array}{l}\text { Gigantes y } \\
\text { Cabezudos }\end{array}$ & $\begin{array}{c}\text { [Manuel] Fernández } \\
\text { Caballero }\end{array}$ & [Miguel] Echegaray \\
\hline & El mosquetero & [Vicente] Peydró & [Eduardo] Navarro Gonzalvo \\
\hline & Todos al baile & [Vicente] Peydró & [Eduardo] Navarro Gonzalvo \\
\hline & La olla de grillos & [José] Valero & [Josep] Fillol \\
\hline & $\begin{array}{c}\text { El primer día de } \\
\text { Pascua front al moli } \\
\text { de Nou Moles }\end{array}$ & [José] Fayos Pascual & Comes \\
\hline & Los borrachos & [Jerónimo] Jiménez & $\begin{array}{c}\text { [Serafín y Joaquín] Álvarez } \\
\text { Quintero }\end{array}$ \\
\hline & Les barraques & [Vicente] Peydró & Eduardo Escalante (hijo) \\
\hline & $\begin{array}{c}\text { El Don Juan de } \\
\text { Mozart }\end{array}$ & [José] Fayos Pascual & [Eduardo] Navarro Gonzalvo \\
\hline \multirow{8}{*}{$1899-1900$} & $\begin{array}{l}\text { Gigantes y } \\
\text { Cabezudos }\end{array}$ & $\begin{array}{c}\text { [Manuel] Fernández } \\
\text { Caballero }\end{array}$ & [Miguel] Echegaray \\
\hline & El último chulo & $\begin{array}{c}\text { [Tomás] López } \\
\text { Torregrosa }\end{array}$ & $\begin{array}{l}\text { [Carlos] Arniches y [Celso] } \\
\text { Lucio }\end{array}$ \\
\hline & $\begin{array}{c}\text { Foch en l'era } \\
{[\mathrm{sic}]}\end{array}$ & [Salvador] Giner & [Maximiliano] Thous \\
\hline & El traje de luces & $\begin{array}{c}\text { [Manuel] Fernández } \\
\text { Caballero }\end{array}$ & $\begin{array}{c}\text { [Serafín y Joaquín] Álvarez } \\
\text { Quintero }\end{array}$ \\
\hline & María de los Ángeles & [Ruperto] Chapí & $\begin{array}{c}\text { [Carlos] Arniches y } \\
\text { [Celso] Lucio }\end{array}$ \\
\hline & $\begin{array}{c}\text { Mala lluna [zarzuela } \\
\text { valenciana] }\end{array}$ & Martínez & [Antonio] Palanca Hueso \\
\hline & El estreno & [Ruperto] Chapí & $\begin{array}{c}\text { [Serafín y Joaquín] Álvarez } \\
\text { Quintero } \\
\end{array}$ \\
\hline & Nit d'albaes & [Salvador] Giner & [José] Guzmán Guallar \\
\hline \multirow{8}{*}{$1900-1901$} & $\begin{array}{c}\text { Les viudes de la } \\
\text { plaseta y els festeros } \\
\text { de la } \\
\text { guasa o Catarrocha } \\
\text { [sic }]\end{array}$ & $\begin{array}{c}\text { [Josep] García Solá y } \\
\text { [Eduardo] Senís }\end{array}$ & [Vicente] Fe \\
\hline & Les enramaes & [Salvador] Giner & [Maximiliano] Thous y Cerdá \\
\hline & La senserrà & [José] Bellver & $\begin{array}{c}\text { [Lluís] Bernat y [Teodoro] } \\
\text { Santoncha [sic] }\end{array}$ \\
\hline & La pau del poble & [José] Fayos Pascual & [Estanislao] Alberola \\
\hline & Las carceleras & [Vicente] Peydró & [Ricardo] Flores \\
\hline & La sonámbula & [José] Bellver & $\begin{array}{c}\text { [Lluís] Bernat y [Teodoro] } \\
\text { Santoncha [sic] }\end{array}$ \\
\hline & El presilari & [Vicente] Peydró & [Eduardo] Escalante \\
\hline & El palleter & [José] Bellver & [Gaspar] Thous \\
\hline
\end{tabular}

El Teatro Ruzafa mostró también predilección por la zarzuela. En la temporada 1885-86 la compañía de Rigoberto Cortina estrenó en él la zarzuela en tres actos Los dos esclavos, de Amancio Amorós ${ }^{145}$. En noviembre de 1894 se representaron en el Ruzafa

${ }^{145}$ Anónimo, "Los teatros en Valencia”, Almanaque de las Provincias para 1887, p. 164. 
las zarzuelas La madre del cordero, El señor de rabanillo, El dúo de la Africana, La Verbena de la paloma, Un casament del Dimoni, El trovador de Belchite y Los Africanistas, entre otras, bajo la batuta de Vicente Lleó, titular de la orquesta del local entre 1894 y $1896^{146}$. También en noviembre del 1894 se estrenó el juguete cómico-lírico en un acto Los tenorios, de José Bellver ${ }^{147}$. El estudio de la programación a partir de 1900 permite observar la gran variedad de estrenos de zarzuelas de género chico. Entre 1905 y 1923 merecen destacarse, por su permanencia durante varias temporadas, las obras de los compositores y directores valencianos Vicente Peydró y Vicente Lleó. Otros compositores destacados cuyas obras se escucharon en el Ruzafa fueron Miguel Asensi, Luis Foglietti y Amadeo Vives ${ }^{148}$. En la Tabla 8 presento una selección representativa de los estrenos de las temporadas 1900-1910.

\footnotetext{
${ }^{146}$ Boletín Musical, 30-XI-1894, p. 358; Galbis, "La zarzuela", p. 337.

${ }^{147}$ Boletín Musical, 30-XI-1894, p. 249.

${ }^{148}$ Galbis, "La zarzuela”, pp. 342-343.
} 
Tabla 8. Estrenos en el Teatro Ruzafa de Valencia, 1900-1910 (selección).

Fuentes: Almanaque de las Provincias para 1901 (pp. 121-122), 1903 (pp. 236-237), 1904 (pp. 196-197), 1906 (pp. 293-294), 1908 (pp. 161, 163), 1910 (pp. 177, 180).

\begin{tabular}{|c|c|c|c|c|}
\hline Temporada & Título & Compositor & Libretista & Compañía \\
\hline \multirow{13}{*}{ 1900-1901 } & Los buenos mozos & [Ruperto] Chapí & $\begin{array}{c}\text { [José] López Silva y } \\
\text { [Carlos] Fernández } \\
\text { Shaw }\end{array}$ & \multirow{13}{*}{$\begin{array}{l}\text { Compañía de } \\
\text { zarzuela de } \\
\text { género chico } \\
\text { Director: Miró }\end{array}$} \\
\hline & $\begin{array}{l}\text { La flor de la } \\
\text { montaña }\end{array}$ & $\begin{array}{c}\text { [Arturo] Saco } \\
\text { del Valle }\end{array}$ & [José] Jackson Veyán & \\
\hline & $\begin{array}{c}\text { Los hijos de la calle } \\
\text { de Toledo } \\
\end{array}$ & $\begin{array}{l}\text { [Manuel] Penella } \\
\text { (hijo) }\end{array}$ & [Amable] Carrión & \\
\hline & \begin{tabular}{|c|} 
El martes de \\
carnaval \\
\end{tabular} & [José] Bellver & $\begin{array}{l}\text { [Antonio] Sotillo y } \\
\text { [Juan Bautista] Pont }\end{array}$ & \\
\hline & La señá Frasquita & [Ruperto] Chapí & $\begin{array}{l}\text { [Guillermo] Perrín y } \\
\text { [Miguel de] Palacios }\end{array}$ & \\
\hline & $\begin{array}{l}\text { El galope de los } \\
\text { siglos }\end{array}$ & [Ruperto] Chapí & $\begin{array}{c}\text { Sinesio }] \\
\text { Delgado }\end{array}$ & \\
\hline & $\begin{array}{l}\text { La alegría de la } \\
\text { huerta }\end{array}$ & [Federico] Chueca & $\begin{array}{c}\text { [Enrique] García } \\
\text { Álvarez y [Antonio] } \\
\text { Paso }\end{array}$ & \\
\hline & Curro López & $\begin{array}{l}\text { [Tomás] López } \\
\text { Torregrosa }\end{array}$ & [José] Jackson Veyán & \\
\hline & Ligerita de cascos & $\begin{array}{c}\text { [Tomás] López } \\
\text { Torregrosa }\end{array}$ & $\begin{array}{l}\text { [Sinesio] } \\
\text { Delgado }\end{array}$ & \\
\hline & La balada de la luz & [Amadeo] Vives & [Eugenio] Sellés & \\
\hline & El Missisipi & [Vicente] Lleó & $\begin{array}{c}\text { [Enrique] García } \\
\text { Álvarez y [Antonio] } \\
\text { Paso Paso }\end{array}$ & \\
\hline & $\begin{array}{l}\text { La noche de la } \\
\text { Tempestad }\end{array}$ & $\begin{array}{c}\text { [Jerónimo] } \\
\text { Jiménez }\end{array}$ & [Fiacro] Iráizoz & \\
\hline & El barquillero & [Ruperto] Chapí & [José] Jackson Veyán & \\
\hline \multirow{9}{*}{ 1901-1902 } & El olivar & $\begin{array}{l}\text { [José] Serrano y } \\
\text { [Tomás] Barrera }\end{array}$ & $\begin{array}{c}\text { [Gregorio] } \\
\text { García Arista y } \\
\text { [Atanasio] } \\
\text { Melantuche } \\
\end{array}$ & \multirow[t]{2}{*}{$\begin{array}{l}\text { Compañía de } \\
\text { zarzuela } \\
\text { Director: } \\
\text { Asensio }\end{array}$} \\
\hline & En la vía & [Manuel] Chulvi & [Gaspar] Thous & \\
\hline & La Boheme & [Giacomo] Puccini & $\begin{array}{c}\text { [Luigi] Illica y } \\
\text { [Giuseppe] Giacosa }\end{array}$ & \multirow{4}{*}{$\begin{array}{l}\text { Compañía de } \\
\text { ópera } \\
\text { Director: Arturo } \\
\text { Baratta }\end{array}$} \\
\hline & Carmen & [George] Bizet & $\begin{array}{c}\text { [Ludovic] } \\
\text { Halévy y } \\
\text { [Henri] Meilhac }\end{array}$ & \\
\hline & $\begin{array}{l}\text { Caballería } \\
\text { Rusticana } \\
\end{array}$ & [Pietro] Mascagni & $\begin{array}{c}\text { [Giovanni] Targioni- } \\
\text { Tozzetti } \\
\end{array}$ & \\
\hline & I Pagliacci & $\begin{array}{c}\text { [Ruggero] } \\
\text { Leoncavallo }\end{array}$ & $\begin{array}{c}\text { [Ruggero] } \\
\text { Leoncavallo }\end{array}$ & \\
\hline & La mazorca roja & [José] Serrano & $\begin{array}{c}\text { [Francisco] Tristán } \\
\text { Larios } \\
\end{array}$ & \multirow{3}{*}{$\begin{array}{l}\text { Compañía de } \\
\text { zarzuela chica } \\
\text { Director: } \\
\text { Santiago Lope }\end{array}$} \\
\hline & Lola Montes & [Ruperto] Chapí & [Fiacro] Iráizoz & \\
\hline & San Juan de luz & $\begin{array}{c}\text { Torregrosa y } \\
\text { Quintín Valverde }\end{array}$ & $\begin{array}{c}\text { [Carlos] Arniches y } \\
\text { [José] Jackson }\end{array}$ & \\
\hline \multirow{4}{*}{$1902-1903$} & El presidario & [Vicente] Peydró & [Eduardo] Escalante & \multirow{4}{*}{$\begin{array}{l}\text { Compañía de } \\
\text { zarzuela chica } \\
\text { Director: } \\
\text { Santiago Lope }\end{array}$} \\
\hline & Los granujas & $\begin{array}{c}\text { [Joaquín] Valverde } \\
\text { Sanjuán y [Tomás] } \\
\text { López Torregrosa }\end{array}$ & $\begin{array}{c}\text { [Carlos] Arniches y } \\
\text { [José] Jackson }\end{array}$ & \\
\hline & Alboradas & [Salvador] Giner & $\begin{array}{c}\text { [José] Guzmán } \\
\text { Guallar } \\
\end{array}$ & \\
\hline & $\begin{array}{l}\text { Abanicos y } \\
\text { panderetas }\end{array}$ & [Ruperto] Chapí & $\begin{array}{c}\text { [Serafín y Joaquín] } \\
\text { Álvarez Quintero } \\
\end{array}$ & \\
\hline
\end{tabular}




\begin{tabular}{|c|c|c|c|c|}
\hline & Los zapatos blancos & Lope y Liñan & Aparicio y Colom & \\
\hline \multirow{9}{*}{ 1904-1905 } & La puñalada & [Ruperto] Chapí & $\begin{array}{c}\text { [Carlos] Fernández } \\
\text { Shaw }\end{array}$ & \multirow{6}{*}{$\begin{array}{l}\text { Compañía de } \\
\text { zarzuela de } \\
\text { género chico } \\
\text { Director: Pepe } \\
\text { Talavera y } \\
\text { Santiago Lope }\end{array}$} \\
\hline & $\begin{array}{c}\text { La polka de los } \\
\text { pájaros }\end{array}$ & [Ruperto] Chapí & $\begin{array}{l}\text { [Benjamín] Ibarrola y } \\
\text { [Ricardo] Monasterio }\end{array}$ & \\
\hline & El túnel & $\begin{array}{c}\text { [Arturo] Saco del } \\
\text { Valle }\end{array}$ & $\begin{array}{c}\text { [Enrique] Prieto } \\
\text { y [Ramón] Rocabert }\end{array}$ & \\
\hline & $\begin{array}{l}\text { El cisne de } \\
\text { Lohengrin }\end{array}$ & [Santiago] Lope & $\begin{array}{l}\text { [Antonio] Sotillo y } \\
\text { [Juan Bautista] Pont }\end{array}$ & \\
\hline & La muñeca & [Santiago] Lope & $\begin{array}{l}\text { [Antonio] Sotillo y } \\
\text { [Juan Bautista] Pont }\end{array}$ & \\
\hline & $\begin{array}{l}\text { La corte de } \\
\text { Trasmania }\end{array}$ & [Santiago] Lope & $\begin{array}{c}\text { [Antonio] Sotillo y } \\
\text { [Juan Bautista] Pont }\end{array}$ & \\
\hline & Calabazas & [Ruperto] Chapí & $\begin{array}{c}\text { [Antonio] Ramos } \\
\text { Martín }\end{array}$ & \multirow{3}{*}{$\begin{array}{l}\text { Compañía de } \\
\text { zarzuela del } \\
\text { género chico } \\
\text { Director: } \\
\text { Vicente Peydró }\end{array}$} \\
\hline & El alma del pueblo & [Ruperto] Chapí & $\begin{array}{c}\text { [Carlos] Fernández } \\
\text { Shaw y [José] } \\
\text { López Silva }\end{array}$ & \\
\hline & El príncipe ruso & [Amadeo] Vives & $\begin{array}{l}\text { [Luciano] Boada y } \\
\text { [Manuel de] Castro }\end{array}$ & \\
\hline \multirow{5}{*}{ 1906-1907 } & La guedeja rubia & [Vicente] Lleó & [Fiacro] Iráizoz & \multirow{5}{*}{$\begin{array}{l}\text { Compañía de } \\
\text { zarzuela } \\
\text { Director: } \\
\text { Vicente Peydró }\end{array}$} \\
\hline & Ruido de campanas & [Vicente] Lleó & $\begin{array}{c}\text { [Antonio Martínez] } \\
\text { Viérgol }\end{array}$ & \\
\hline & La pesadilla & [Ruperto] Chapí & $\begin{array}{l}\text { [Luciano] Boada y } \\
\text { [Manuel de] Castro }\end{array}$ & \\
\hline & El galleguito & $\begin{array}{l}\text { [Tomás] López } \\
\text { Torregrosa }\end{array}$ & [José] Jackson Veyán & \\
\hline & $\begin{array}{c}\text { Los bárbaros del } \\
\text { Norte }\end{array}$ & [Ruperto] Chapí & [Sinesio] Delgado & \\
\hline \multirow{8}{*}{ 1907-1908 } & Ninon & [Amadeo] Vives & [Miguel] Echegaray & \multirow{8}{*}{$\begin{array}{l}\text { Compañía de } \\
\text { zarzuela } \\
\text { Director: } \\
\text { Vicente Peydró }\end{array}$} \\
\hline & La rabalera & [Amadeo] Vives & [Miguel] Echegaray & \\
\hline & La edad de hierro & [Vicente] Lleó & $\begin{array}{c}\text { [Antonio] Fernández } \\
\text { Lepina y [Antonio] } \\
\text { Plañiol }\end{array}$ & \\
\hline & La fea del olé & [Vicente] Lleó & $\begin{array}{c}\text { [Antonio] Fernández } \\
\text { Lepina y [Antonio] } \\
\text { Plañiol }\end{array}$ & \\
\hline & $\begin{array}{c}\text { La hostería del } \\
\text { laurel }\end{array}$ & [Vicente] Lleó & $\begin{array}{c}\text { [Antonio] Paso y } \\
\text { [Joaquín] Abati }\end{array}$ & \\
\hline & Apaga y vámonos & [Vicente] Lleó & $\begin{array}{l}\text { [José] Jackson Veyán } \\
\text { y [José] López Silva }\end{array}$ & \\
\hline & Rejas y votos & [Vicente] Peydró & [Ricardo] Flores & \\
\hline & La bella Lucerito & $\begin{array}{c}\text { [Arturo] Saco del } \\
\text { Valle }\end{array}$ & $\begin{array}{c}\text { [Serafín y Joaquín] } \\
\text { Álvarez Quintero }\end{array}$ & \\
\hline \multirow{8}{*}{ 1908-1909 } & La regadera & $\begin{array}{l}\text { [Vicente] Lleó y } \\
\text { [Luis] Foglietti }\end{array}$ & $\begin{array}{c}\text { [Antonio] Casero y } \\
\text { [Alejandro] } \\
\text { Larrubiera }\end{array}$ & \multirow{4}{*}{$\begin{array}{l}\text { Compañía de } \\
\text { zarzuela } \\
\text { Director: } \\
\text { Vicente Peydró }\end{array}$} \\
\hline & $\begin{array}{l}\text { El talismán } \\
\text { prodigioso }\end{array}$ & [Amadeo] Vives & $\begin{array}{c}{[\text { Sinesio }]} \\
\text { Delgado } \\
\end{array}$ & \\
\hline & $\begin{array}{l}\text { iSi las mujeres } \\
\text { mandasen! }\end{array}$ & $\begin{array}{l}\text { [Vicente] Lleó y } \\
\text { [Luis] Foglietti }\end{array}$ & $\begin{array}{c}\text { [Manuel] Fernández } \\
\text { de la Fuente }\end{array}$ & \\
\hline & Alma andaluza & [Miguel] Asensi & Pérez Manglano & \\
\hline & $\begin{array}{c}\text { Los tres maridos } \\
\text { burlados }\end{array}$ & [Vicente] Lleó & $\begin{array}{l}\text { [Joaquín] Dicenta y } \\
\text { [Pedro de] Repide }\end{array}$ & \\
\hline & \begin{tabular}{|c|}
$\begin{array}{c}\text { La alegría del } \\
\text { batallón }\end{array}$ \\
\end{tabular} & [José] Serrano & $\begin{array}{c}\text { [Carlos] Arniches y } \\
\text { Quintana }\end{array}$ & \\
\hline & La mujer de Boliche & [Amadeo] Vives & $\begin{array}{c}\text { Fernández de la } \\
\text { Fuente }\end{array}$ & \\
\hline & El garrotín & [Luis] Foglietti & [Ramón] Asensio Mas & \\
\hline
\end{tabular}




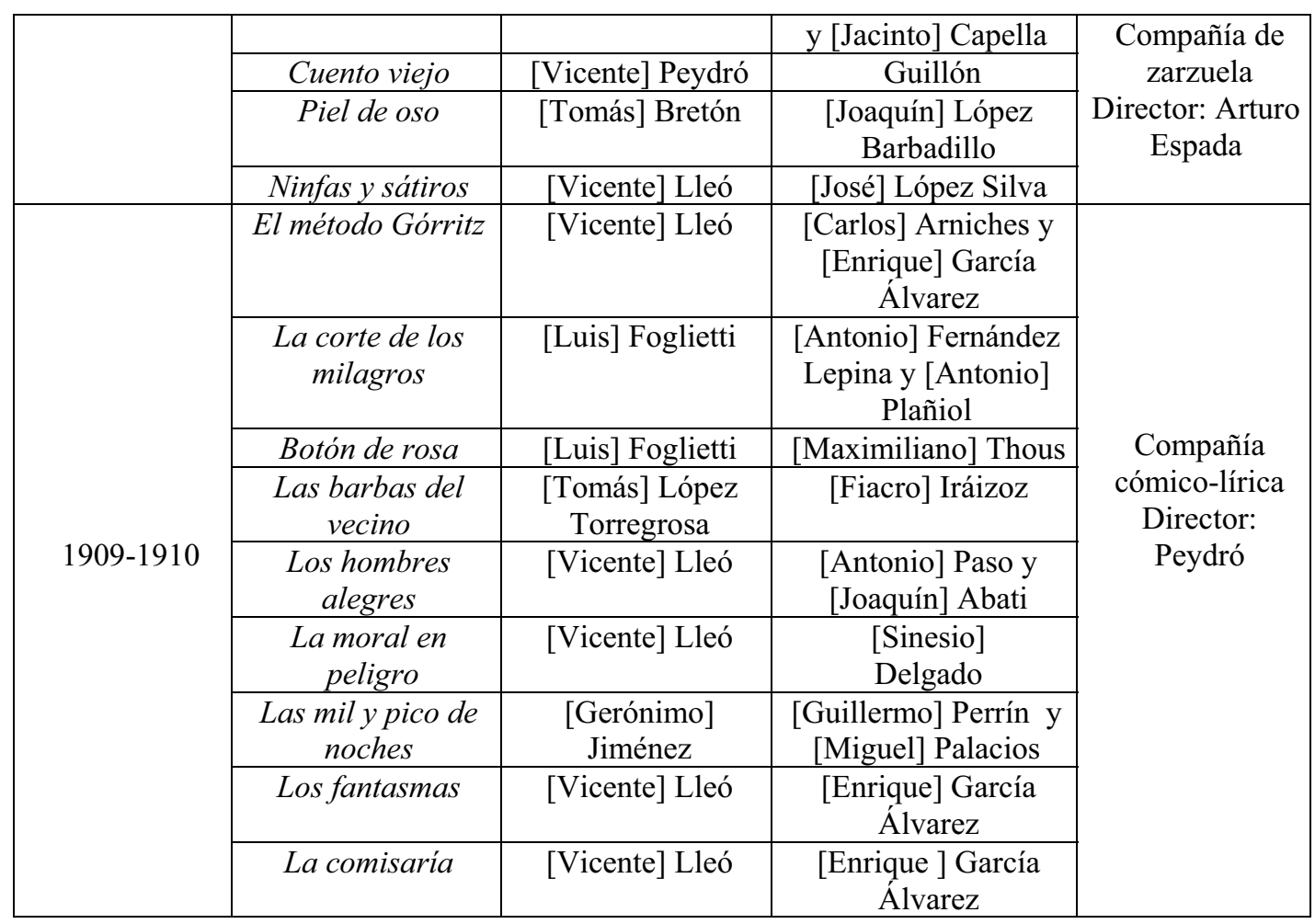

El Teatro Apolo se especializó en la zarzuela pero también acogió representaciones de ópera preferentemente italiana. En octubre de 1893 se estrenó en él la zarzuela en cuatro números El queso de bola de Manuel Penella, con libreto de Edmundo de C. Bonet y Pascual Montagud. En noviembre del mismo año se estrenó la zarzuela en cuatro actos Sidi-Aguariach, con libreto de Edmundo de C. Bonet y Pascual Montagud y música del valenciano Manuel Penella, bajo la dirección de Eduardo Senís ${ }^{149}$. En 1894 la cantante Josefina Huguet, de gira por Valencia, actuó en el Apolo en la representación de las óperas Lucia di Lammermoor, La Sonámbula y El Barbero de Sevilla ${ }^{150}$.

En la temporada 1899-1900, la empresa del Apolo contrató la compañía de zarzuela y ópera española del teatro Parish de Madrid, que presentó la ópera Maria del Carmen, de Granados; la zarzuela en tres actos Curro Vargas, de Chapí; D. Lucas del

\footnotetext{
${ }^{149}$ Boletín Musical, 30-X-1893, p. 442, Boletín Musical, 22-XI-1893, p. 450.

${ }^{150}$ Boletín Musical, 30-IX-1894, p. 313.
} 
Cigarral, de Vives y el melodrama lírico El clavel rojo, de Bretón ${ }^{151}$. Junto con Chapí, a partir de 1905, los autores que alcanzaron más éxito en el Apolo fueron los valencianos José Serrano (con Moros y Cristianos, La noche de Reyes, La banda nueva, La gente seria, Alma de Dios y Barbarroja) y Manuel Penella Moreno con éxitos de El gato Montés, la opereta La muñeca del amor, la revista de costumbres argentinas $P$. B. Ty Corpus Christi, entre otros ${ }^{152}$.

\section{Sinfonismo y bandas}

En este epígrafe presento una visión de conjunto sobre la música instrumental en Valencia entre 1850 y 1925, partiendo de la bibliografía existente y de aportaciones nuevas que he localizado en el curso de mi investigación. Me centraré en dos apartados: 1) Actividad sinfónica y orquestas valencianas; y 2) Bandas de música.

\section{1. Actividad sinfónica y orquestas en Valencia}

El estudio más completo realizado hasta el momento sobre el tema es el de Manuel Sancho García sobre el sinfonismo en Valencia durante la Restauración ${ }^{153}$. El panorama descrito por Sancho se completa por otros estudios de diversos autores ${ }^{154}$. A lo

\footnotetext{
${ }^{151}$ Anónimo, "Los teatros en Valencia”, Almanaque de las Provincias para 1900, pp. 89-93.

152 Anónimo, "Los teatros en Valencia", Almanaque de las Provincias para 1906, pp. 294-295; Almanaque de las Provincias para 1908, pp. 161, 163; Almanaque de las Provincias para 1910, pp. 177178, 180; Almanaque de las Provincias para 1918, p. 209; Galbis, "La zarzuela”, pp. 343-344.
}

153 Sancho, en su estudio, analiza pormenorizadamente el origen, funcionamiento y repertorio de las agrupaciones orquestales del momento pero no dedica ningún apartado al análisis musical de la producción sinfónica valenciana. Véase Sancho, El sinfonismo; Sancho, Romanticismo; Manuel Sancho, "Los inicios del sinfonismo en Valencia: La Sociedad de Conciertos de José Valls", Revista de Musicología, 27/2 (2004), pp. 979-997.

154 Blasco, La música en Valencia, pp. 66-77; Ruiz de Lihory, La música en Valencia, pp. 39, 42; Climent, Historia de la música, pp. 53-55, 58, 141 y 146 y José Climent, Historia de la música valenciana (Valencia: Rivera Mota, 1989), pp. 89, 91, 151 y 152; López-Chavarri, Cien años de música, pp. 24, 61, 73; Eduardo López-Chavarri, Breviario de Historia de la música valenciana (Valencia: Editorial Piles, 1985), pp. 49-87; Vicente Galbis López, "La música instrumental y vocal de la primera mitad del siglo XIX", en HMCV, pp. 271-272; Galiano, "La Renaixença”, p. 319; Galiano, "La transición del siglo XIX al XX”, en $H M C V$, p. 333; José Luis García del Busto, "La generación musical de 1890", en $H M C V$, p. 355; Xosé Aviñoa, "L'activitat concertística", p. 132; Xosé Aviñoa, "L'activitat musical", 
largo de este estudio presentaré información nueva sobre las dos sinfonías de Amancio Amorós, que no fueron descritas, ni mencionadas en la bibliografía citada.

Antecedentes: orquestas de teatro (1800-1878)

La vida musical valenciana, desde principios del siglo XIX, estuvo dominada por la ópera italiana y la música sinfónica quedó en un plano subordinado a ella ${ }^{155}$. Según Sancho, hasta 1875 el teatro era el escenario habitual de actividad sinfónica en Valencia y escasearon los conciertos orquestales basados en un programa de piezas sinfónicas ${ }^{156}$. La música orquestal solía utilizarse como apoyo en las representaciones escénicas, alternando con bailes, dramas, comedias y distintos números teatrales ${ }^{157}$. Hasta la creación en 1878 de la Sociedad de Conciertos de Valencia, las orquestas valencianas, vinculadas a compañías de ópera o zarzuela, formaban un conjunto que podía oscilar entre los treinta y cinco y los sesenta profesores.

La actividad sinfónica también estuvo presente en bailes de sociedad, festividades y actos solemnes, serenatas, y determinados conciertos sacros y funciones religiosas. En los denominados "bailes de máscaras", celebrados preferentemente en los salones de entidades culturales valencianas, a las danzas europeas como valses, polkas y mazurcas podían añadirse diversos arreglos orquestales de fragmentos operísticos. Las orquestas

pp. 91-94; Casimiro González, "La música orquestal”, en Un siglo de música en la Comunidad Valenciana (Valencia: Unidad Editorial S. A., 1998), pp. 39- 40.

${ }^{155}$ Lo mismo sucedía en otras áeras geográficas, Xosé Aviñoa señala en "A propòsit del consum musical tardoromàntic barceloní", Revista de Catalunya, 35 (1989), p. 80, que la sensibilidad derivada del gusto musical de los barceloneses de mediados del XIX era tardoromántica y operística; véase también García Caballero, La vida musical en Santiago, p. 216.

${ }^{156}$ Sancho, Romanticismo, p. 25.

${ }^{157}$ El desarrollo normal de una función mantenía el orden siguiente: 1. La orquesta abría el espectáculo con una sinfonía de un compositor local o extranjero ya consagrado; 2. Puesta en escena de la pieza más importante, que servía de base al programa, y que constaba, como mínimo, de tres actos; 3 . La compañía de baile representaba una pieza ligera ("baile con argumento"), o una serie de bailes a modo de "suite"; 4. Obra teatral corta: comedia o sainete; 5 . El espectáculo concluía con otro baile, de menor duración que el anterior. Véase Sirera, El Teatre Principal, p. 78; Comellas, El Romanticisme musical, p. 79. 
que amenizaban estas veladas se formaban básicamente con músicos procedentes de los teatros de la ciudad ${ }^{158}$.

En la sociedad Liceo Valenciano, fundada en 1836, empezó a funcionar en 1841 una orquesta de treinta instrumentistas dirigida por José Valero, constituida por socios aficionados a los que se agregarían más tarde algunos instrumentistas profesionales. En 1859 se interpretaron en el Liceo las sinfonías Romeo y Julieta [de Berlioz] y la de $I l$ Pirata de Bellini, junto a fragmentos de ópera italiana y una comedia ${ }^{159}$.

Según Ramón Sobrino, 1860 marcó en España el nacimiento de las primeras orquestas surgidas de la iniciativa privada como la Sociedad Artístico-Musical de Socorros Mutuos, en 1860 y la Sociedad de Conciertos, en 1866, ambas en Madrid. Se amplió, por influencia del pensamiento europeo, el concepto de "sinfonismo", que hasta entonces hacía referencia exclusivamente a oberturas operísticas y bailes de salón, y comenzaron a aparecer en los programas formas orquestales mayores, como sinfonías y conciertos. Pero la situación en Valencia no era comparable, según Sancho, a la de capitales como Madrid o Barcelona ${ }^{160}$. La orquesta sinfónica del Teatro Principal de Valencia ofreció en 1863, por ejemplo, un concierto en la inauguración de los baños flotantes de La Florida, constituido todavía exclusivamente por piezas operísticas: la sinfonía de La Gazza Ladra, de Rossini; el dúo de Rigoletto, de Verdi; la sinfonía de la ópera Marta, de Flotow; el aria de la ópera Semiramis, de Rossini; unos valses de La reina de la flores y la sinfonía de Los diamantes de la Corona, de Francisco Asenjo Barbieri $^{161}$. La orquesta no era además sino una agrupación de músicos contratados ex

\footnotetext{
${ }^{158}$ Sancho, El sinfonismo, pp. 33, 36-37.

${ }^{159}$ Diario Mercantil de Valencia, 6-II-1859.

${ }^{160}$ Sobrino, "La Música sinfónica", pp. 301-302; Sobrino, "La Sociedad de conciertos", p. 125; Aviñoa, La música i el modernisme, analiza la evolución de la actividad sinfónica en Barcelona en el periodo modernista; Sancho, Romanticismo, p. 33.

${ }^{161}$ Diario Mercantil de Valencia, 19-VII-1863.
} 
profeso para las temporadas líricas y se disolvía al concluir éstas ${ }^{162}$.

En 1864 se convocó en el Teatro Principal de Valencia al colectivo de músicos de orquesta para crear la Sociedad Artístico-Musical de Socorros Mutuos de Valencia, a imitación de la de Madrid, fundada en 1860. La idea tuvo una buena acogida, pero por problemas organizativos se suspendió el proyecto $^{163}$. No fue hasta la década de los 70 cuando las orquestas del Teatro Principal y del Teatro Princesa de Valencia mostraron un creciente interés por el género sinfónico ${ }^{164}$.

\section{Orquesta Sociedad de Conciertos de Valencia (1878)}

En 1878 José Valls Enguix (1850-1909) fundó junto con otros sesenta profesores la Sociedad de Conciertos de Valencia con el propósito de impulsar la música sinfónica en la ciudad ${ }^{165}$. La Sociedad de Conciertos de Madrid, fundada en 1866, pudo servir, según Sancho, de modelo para el nuevo proyecto valenciano. La Sociedad de Conciertos de Valencia pasó a denominarse desde julio de 1879 Sociedad Artístico-Musical ${ }^{166}$. La Sociedad de Conciertos valenciana funcionó entre 1878 y 1888 y después se convirtió en una orquesta teatral vinculada a compañías líricas. Esta Sociedad de Conciertos fue la primera asociación de profesores músicos legalmente constituida en Valencia surgida de la iniciativa privada y que tenía la finalidad de proteger los intereses del músico

\footnotetext{
${ }^{162}$ García del Busto, “La generación musical”, p. 355.

${ }^{163}$ Antonio Vidal Guillen y Vicent Torrent, “Sociedades Musicales”, en DMV, vol. 2 (2006), p. 459.

${ }^{164}$ Sancho, Romanticismo, pp. 35-36.

165 Galiano, "La Renaixença”, p. 319. Véase Sancho, "Los inicios del sinfonismo”, pp. 979-997. José Valls, que había estudiado en el Conservatorio de Madrid y conocía el ambiente musical de esta capital, contó con la ayuda de Pascual Rodríguez y José Guallar, profesores de la orquesta del Teatro Principal. Véase un resumen sobre José Valls en Rafael Díaz, "Valls, José”, en DMEH, vol. 10 (2002), p. 707.

${ }^{166}$ En el E:VAa, sección III, Asociaciones culturales, Sociedad Artístico-Musical (1878-1883). En esta sección, actualmente en proceso de catalogación, pueden consultarse diversos programas de conciertos de la Sociedad de Conciertos valenciana con los precios de las localidades, entre otros datos.
} 
profesional de orquesta. Su plantilla instrumental (con cincuenta y nueve músicos) era similar a la de otros conjuntos sinfónicos decimonónicos europeos ${ }^{167}$.

Los instrumentistas de la orquesta de la Sociedad de Conciertos valenciana tenían prohibido adquirir compromisos artísticos con otra empresa o sociedad sin el consentimiento de su presidente; con esta medida se pretendía alcanzar una cierta estabilidad en la composición de la orquesta. La Memoria de la Sociedad de Conciertos presentada en 1881 describió la situación del colectivo de instrumentistas y detalló los conciertos en sus tres primeros años de existencia. En 1879 hubo cuatro conciertos, con cuarenta y cuatro ensayos; en 1880, seis conciertos y cincuenta y tres ensayos; en 1881, cuatro conciertos y cincuenta ensayos ${ }^{168}$. El concierto inaugural de la Orquesta de la Sociedad de Conciertos se celebró en el Teatro Skating-Ring ${ }^{169}$ de Valencia el 5 de mayo de 1878 y el programa incluyó las oberturas operísticas de Poete y Faisan, de Franz von Suppé; Aurora, valses de N. Toledo; Raimond, de A. Thomas; Oberon, de Weber; Emancipation, polka-mazurka de F. Wohanka y el vals Au revoir, del compositor francés Émile Waldteufel ${ }^{170}$.

\footnotetext{
${ }^{167}$ Anónimo, La Sociedad de Conciertos de Valencia ante el público (Valencia: Imp. Manuel Alufre, 1881), pp. 7-9; Sancho, Romanticismo, pp. 48-51.

${ }^{168}$ Anónimo, La Sociedad de Conciertos, pp. 8, 21, 22; García del Busto, "La generación musical”, p. 355.

${ }^{169}$ El Skating-Ring fue un establecimiento de ocio, creado en Valencia en 1877, provisto de pista de patinaje, picadero, tiro de pistola y teatro.

${ }^{170} E: V A a$, Sección III, Asociaciones Musicales, programa del concierto inaugural del 5-V-1878, en proceso de catalogación. Según esta referencia, el concierto inaugural se celebró el 5 de mayo y no el 12 del mismo mes como afirma Sancho. Véase Sancho, Romanticismo, p. 46. Sancho analiza el repertorio interpretado por la Sociedad de Conciertos de Valencia. Los compositores españoles y valencianos con representación en los programas de la Sociedad de Conciertos de Valencia fueron Tomás Bretón, Ruperto Chapí, Pedro Miguel Marqués, Salvador Giner, José Espí, Eduardo Ximénez, Manuel Chulvi, Juan Bautista Plasencia, José Medina, Manuel Penella, Pascual Galiana y Manuel Soriano; véase Sancho, Romanticismo, pp. 63-66.
} 
Orquesta Goñi (1890)

Otra iniciativa que fomentó la música sinfónica en Valencia fue la orquesta de Andrés Goñi (1865-1906), violinista que en 1890 firmó un contrato con la Junta General de la Feria de Julio de Valencia para ofrecer una serie de conciertos en el Paseo de la Glorieta de Valencia con una orquesta compuesta por sesenta y cinco ejecutantes (jóvenes profesores y alumnos del conservatorio valenciano) ${ }^{171}$. El número de músicos osciló entre los sesenta y cinco de 1890 y los noventa de 1897. El 1 de junio de 1890 la orquesta Goñi hizo su presentación con un programa integrado por Les Vergers-Wateau de Grieg, Meditación de Gounod, Valses de Espí, obertura de la ópera Cleopatra de Mancinelli, Minueto de Bozoni y Marcha de la Antorchas $n^{o} 1$ de Meyerbeer. Como ocurrió con la Sociedad de Conciertos, la Orquesta Goñi fue una asociación profesional de músicos de orquesta que pretendían asegurarse una estabilidad laboral y económica, de ahí que participasen, al margen de la temporada anual de conciertos, en serenatas, funciones religiosas, festivales benéficos o patrióticos y bailes de carnaval. La trayectoria artística de la Orquesta Goñi abarca una década, entre 1890 y 1899, aunque la formación siguió ofreciendo conciertos, ya sin la presencia de Goñi, hasta la creación de la “Asociación de Profesores de Orquesta de Valencia” en 1902, en la que ingresaron la mayor parte de sus miembros ${ }^{172}$.

\footnotetext{
${ }^{171}$ El Mercantil Valenciano, 21-V-1890. Andrés Goñi (1864-1906) nació en Barcelona, pero desde los diez años se trasladó a Pamplona, donde inició su formación musical. Pensionado por la Diputación de Navarra fue a Madrid y continuó sus estudios con José Pinilla, José Aranguren y Jesús Monasterio. En 1881 ocupó el cargo de primer violín del Teatro Real y poco después ingresó en la Sociedad de Conciertos de Madrid. Ocupó por oposición la plaza de profesor de violín en el Conservatorio de Música de Valencia en sustitución de Quintín Matas; véase Vicente Galbis López, "Goñi Otermin, Andrés", en DMEH, vol. 5 (1999), p. 791.
}

172 Sancho, Romanticismo, pp. 90-93. Sancho señala que la orquesta Goñi supuso un cambio de orientación estética con respecto a la etapa de la Sociedad de Conciertos. Véanse López-Chavarri, Cien años de música, p. 73; Gómez Amat, "Sinfonismo y música", p. 215. Del repertorio español y valenciano interpretado por la Orquesta Goñi destacan En la Alhambra, de Bretón; la Fantasía de Pan y Toros, de Barbieri; los poemas sinfónicos de Salvador Giner: Una nit d'albaes y Es xopà hasta la Moma. La Orquesta Goñi dio a conocer dos nuevas obras de Giner de carácter programático: Las fases del campo y El festín de Baltasar. Otros autores valencianos con obras interpretadas por la orquesta Goñi fueron 
Asociación de Profesores de Orquesta de Valencia (1902)

Entre 1900 y 1916 surgieron en Valencia varias orquestas de vida efímera que representaron un poderoso estímulo para la constitución de la Orquesta Sinfónica de Valencia en 1916. El movimiento sinfónico en Valencia se mantuvo activo con los conciertos organizados en marzo de 1903 en el Círculo de Bellas Artes por Eduardo López-Chavarri (1871-1970) y los organizados por la Asociación de Profesores de Orquesta, fundada en $1902^{173}$. El objetivo de esta última era velar por la situación laboral y económica de los profesores de orquesta ${ }^{174}$. Valencia no disponía de una orquesta profesional estable de conciertos y esta Asociación ofreció instrumentistas a cuantas iniciativas privadas iban surgiendo en favor del género sinfónico durante esos años. La Asociación de Profesores de Orquesta de Valencia celebró su concierto inaugural el 1 de abril de 1903 en el Teatro Principal con la obertura y marcha de Tannhäuser, de Wagner; la Danza Macabra y varios fragmentos de Sansón y Dalila, de Saint-Saëns; Reverie, de Schumann; la obertura Der Freischütz, de Weber y algunas páginas orquestales de Guiraud, Moszkowski y Dunkler ${ }^{175}$.

\footnotetext{
Vicente Peydró (Gavota), Enrique Bru (Danzas satíricas), Desamparados Chavarría (Plácida noche), José Espí (Vals) y Manuel Penella (A orillas del Turia). Véase Sancho, Romanticismo, pp. 100-104.

173 Sancho, Romanticismo, p. 127; Véase también Díaz y Galbis, "López-Chavarri Marco, Eduardo", pp. 1043-1047. En 1904 el propio López-Chavarri intentó crear la Sociedad Filarmónica de Valencia, constituida por dieciocho instrumentistas de cuerda de la Asociación de Profesores de Orquesta, aunque el proyecto no cuajó. Véase Sancho, Romanticismo, p. 137.

${ }^{174}$ Su continuidad hasta 1914 fue irregular. En esa fecha accedió a la presidencia Pedro Sosa López. En 1922 la Asociación de Profesores se fusionó con el Ateneo Musical de Valencia y nació así la Asociación Benéfica y Montepío de Profesores de Música de Valencia. Véase Vidal y Torrent, "Sociedades Musicales", en $D M V$, vol. 2 (2006), p. 456.

175 Algunas iniciativas en las que colaboró la Asociación de profesores de Orquesta de Valencia fueron: sesiones orquestales en el Teatro Principal y La Glorieta (1903); conciertos organizados por la Sociedad Filarmónica en el Salón Sánchez-Ferrís (1904 y 1905) y Teatro Principal (1906); conciertos celebrados en el Conservatorio, dirigidos por José Valls (1905); conciertos del Teatro Principal, bajo la dirección de Enrique Granados y con el pianista Stéphane Pugno (1907); conciertos Bellver-Vergé en el Conservatorio (marzo, 1908); dos ciclos de conciertos en la Exposición Regional (1909); conciertos de la Feria de julio de 1913; conciertos en el Teatro-cine Libreros y Teatro Trianon-Palace (1914); festival artístico organizado por el Teatro Principal (mayo, 1915). Véase Sancho, El sinfonismo, p. 171.
} 
Orquesta Sinfónica de Valencia (1916)

La Exposición Regional de Valencia en 1909 reactivó el movimiento sinfónico, que había sido muy pobre en los cinco años anteriores ${ }^{176}$. En el evento actuó un conjunto orquestal formado por músicos valencianos pertenecientes a la Asociación General de Profesores de Orquesta. José Lassalle (1876-1932) organizó una orquesta profesional de artistas valencianos y contribuyó decisivamente a renovar las programaciones de concierto en Valencia ${ }^{177}$. Las visitas a Valencia desde 1910 de la Orquesta Sinfónica de Madrid y la Orquesta Sinfónica de Barcelona ${ }^{178}$, la fundación a finales de 1911 de la Orquesta Filarmónica de Valencia, y la Orquesta de Cámara de Valencia en 1915 ayudaron a impulsar el proyecto de creación de una orquesta sinfónica valenciana.

Con la creación de la Orquesta Sinfónica de Valencia en 1916 se abre una nueva etapa caracterizada por la normalización de la actividad sinfónica en Valencia ${ }^{179}$. La Orquesta Sinfónica de Valencia nació por iniciativa del Ateneo Musical, con una plantilla instrumental de más de ochenta músicos. Esta orquesta hizo su debut en el Teatro Principal y aportó savia nueva al, según Sancho García, "mediocre y desfasado panorama sinfónico local, definible por su carácter provinciano" ${ }^{180}$.

\footnotetext{
${ }^{176}$ Sancho, Romanticismo, pp. 127, 136-144 y 183.

${ }^{177}$ La historiografía musical valenciana, hasta las investigaciones de Sancho García, había considerado que la orquesta que intervino en los conciertos de la Exposición Regional de 1909 fue la "TonkünstlerOrchester” de Munich, bajo la dirección de José Lassalle. Sancho, Romanticismo, pp. 146, 153 y 183.

${ }^{178}$ Revista Musical, 11 (1911), pp. 272-273.

${ }^{179}$ Sancho, Romanticismo, p. 153; Aviñoa, "L’activitat musical”, p. 94. El interés por la música sinfónica fue creciendo a lo largo del siglo XX, de manera semejante a como ocurrió en otras ciudades españolas como por ejemplo La Coruña ó Barcelona; véase Ma Pilar Alén, "Reflexiones sobre el ambiente musical en La Coruña (1920-1980) a través del Fondo Bugallal”, en Campos Interdisciplinares de la musicología, Quinto Congreso de la Sociedad Española de Musicología (Barcelona, 2000), ed. Begoña Lolo, 2 vols. (Madrid: Sociedad Española de Musicología, 2002), vol. 1, p. 215; Aviñoa, "Modernisme i música", pp. 112-113, 118.

${ }^{180}$ Sancho, El sinfonismo, p. 275.
} 


\section{2. Bandas de Música}

Las bandas de música valencianas fueron particularmente activas durante la segunda mitad del siglo XIX y la primera del XX. A continuación daré una visión de conjunto sobre estas agrupaciones con el fin de situar el contexto en el que se desarrolló la actividad de Amancio Amorós relacionada con ellas.

Entre las primeras interpretaciones que intentan aproximarse al origen de las bandas de música, Pedrell, en 1894, sugirió su vinculación con el estamento militar ${ }^{181}$. Bernardo Adam Ferrero afirma también que el origen y desarrollo de las bandas de música en Valencia tiene su punto de arranque en la milicia. Desde comienzos del siglo XIX se habían creado muchas bandas militares en España, asociadas a los distintos bandos políticos durante la invasión napoleónica (1808-1814) y los posteriores conflictos entre conservadores y liberales. Adam señala para el caso valenciano:

Históricamente, las bandas valencianas arrancan de los primeros años del siglo XIX, con las músicas militares francesas que llevaba el ejército de Napoleón en su guerra contra España. Igualmente ocurre después en las guerras carlistas ${ }^{182}$.

Frente a esta hipótesis preferentemente militar, José Climent sugirió el papel desempeñado por la Iglesia Católica en la formación de las bandas civiles, y en concreto, por el organista de la parroquia:

[...] La mayor parte de pueblos tienen una plaza de organista, que se proveía por oposición, y que además, era también el maestro del lugar. Era, por tanto, un músico que vivía del pueblo y para el pueblo; que tenía en sus manos la parte cultural-musical de los ciudadanos y en sus manos estaba la abundancia y dignidad de manifestaciones culturales que, al mismo tiempo, podría proporcionarle una consideración moral y material entre los ciudadanos [...]. Y bien podía este músico preparar un grupo de instrumentistas que atendieran las

\footnotetext{
${ }^{181}$ Felipe Pedrell, Diccionario Técnico de la Música, 2a ed. (Barcelona: Isidro Torres Oriol, 1894), pp. 41-42.

182 Bernardo Adam Ferrero, Las bandas de música en el mundo (Madrid: Sol, 1986), p. 80.
} 
necesidades de esparcimiento y diversión, al mismo tiempo que las culturales que tuviera el pueblo $[\ldots]^{183}$.

A finales del siglo XIX y principios del XX, comenzaron a formarse además

bandas de carácter civil, que adoptaron algunas características de las formaciones

militares en cuanto a plantilla instrumental, partituras patrióticas, uniformes y modos de

desfilar. Ruiz Monrabal destacó tres elementos en la génesis de las bandas de música

valencianas, la influencia de las bandas militares, de la Iglesia y de los gremios:

Las convulsiones políticas y revolucionarias de la primera mitad del siglo XIX llenaron de conjuntos militares la geografía de las tierras valencianas, desde Vinaroz a Orihuela. Cuando no eran las tropas napoleónicas, eran los Ejércitos Españoles o las Milicias Valencianas; y cuando no era la contienda entre liberales y conservadores, eran las tropas carlistas contra las "cristianas", pero siempre, en todos estos conflictos, cada facción iba acompañada de su agrupación musical para dar solemnidad a la victoria [...].

Cuando estas músicas militares fueron disolviéndose 0 retirándose de los pueblos, estaba sembrada la semilla para imitarlas y despertado el deseo de crear grupos bandísticos locales para dar solemnidad a los actos cívicos y religiosos. Algún componente de las bandas militares se quedaba en el pueblo o era invitado a quedarse para iniciar la preparación musical de algunos vecinos de profesiones humildes que, sin estudio alguno, reunían aptitudes para tocar un instrumento $[\ldots]$.

A este origen de carácter militar hay que añadir la otra vía de formación de nuestras Bandas de Música en esta época. Hubo bandas cuyo origen se debe a los "ministriles" o instrumentistas que, de manera estable, servían en capillas, catedrales, colegiatas, maestros de coro y parroquias distribuidas por toda la Región. De manera principal los organistas, maestros de coro y curas párrocos que, necesitados de acompañamientos musicales que dieran solemnidad a los actos litúrgicos y a las procesiones, impartían clases de música para preparar feligreses en quienes se percibía aptitudes musicales para estos menesteres.

Cuando se trata de los orígenes de nuestras Bandas, no podemos tampoco olvidar a las organizaciones gremiales que, con sus "tabalots", atabales y dulzainas ponían su nota alegre en sus fiestas y conmemoraciones $[\ldots]^{184}$.

${ }^{183}$ Climent, Historia de la música, pp. 143-144.

${ }^{184}$ Vicente Ruiz Monrabal, Historia de las sociedades musicales de la Comunidad Valenciana: Les Bandes de Música i la seua Federació (Valencia: Federación de Sociedades Musicales de la Comunidad Valenciana, 1993), vol. 1, pp. 31-33. 
Cucó explicó el origen de estas agrupaciones en Valencia, como un fenómeno propio de la sociedad liberal urbana ${ }^{185}$. La música de banda adquirió una gran significación dentro del ambiente de la sociedad burguesa decimonónica valenciana, en concreto en los núcleos urbanos. Diversos actos políticos, civiles, militares y religiosos demandaban la presencia del acompañamiento musical que proporcionaban las bandas de música. Las bandas participaban además en diversas festividades de la ciudad en las que ofrecían conciertos y serenatas ${ }^{186}$. Éstas últimas eran actuaciones musicales en honor de algún personaje relevante (político, militar, religioso, o miembro de la casa real) para celebrar onomásticas, bodas o festividades, o también podían tener un origen religioso, como el Corpus ${ }^{187}$.

Al igual que en otras ciudades de España, las bandas acudían a los paseos, parques y plazas determinados días de la semana, contribuyendo al esparcimiento de la población ${ }^{188}$. Era habitual durante la temporada estival que las bandas amenizaran las noches de los jueves y domingos en el paseo de la Glorieta de la capital valenciana ${ }^{189}$. La prensa ofrece numerosas descripciones de los conciertos que se celebraban en la Glorieta, como la siguiente:

Esta noche promete verse muy favorecido el paseo de la Glorieta. La brillante música que con tanta inteligencia dirige el Sr. Rueda, de nueve y media a once y media, amenizará el citado paseo. La entrada costará dos reales, y el producto se destina a socorrer a los

\footnotetext{
185 Josepa Cucó, Músicos y festeros valencianos (Valencia: IVAECM, 1993), p. 15.

${ }^{186}$ Vicente Galbis López, "Les bandes valencianes: història, activitats i projecció social”, en HMCVB, vol. 6 (2001), pp. 165-166; El Mercantil Valenciano, 5-VI-1881, 7-VI-1882.

${ }^{187}$ Un ejemplo de serenata en Valencia se describe en El Mercantil Valenciano, 7-VI-1882. Para el caso de Murcia, véase Esperanza Clares, "Bandas y Música en la calle: una visión a través de la prensa en las ciudades de Murcia y Cartagena (1800-1975), Revista de Musicología, 28/1 (2005), pp. 550-553.

188 Muñoz y Cabeza, "Algunos aspectos de la vida musical”, p. 283; Uría, Música Asturiana, p. 61; Héctor-Luis Suárez Pérez, "Panorama musical del último cuarto del siglo XIX en una pequeña ciudad del Noroeste Ibérico", Revista de Musicología, 14/1-2 (1991), p. 298; García Caballero, La vida musical en Santiago, pp. 275-305.
}

${ }^{189}$ Boletín Musical, 31-VIII-1892, p. 7. 
pobres. El programa, por su mérito, es un estímulo a la caridad. He aquí las obras que lo componen: $1^{\circ}$ Pasodoble alemán, $2^{\circ}$ a) Leyenda valaca (melodía), por Braga, b) Marcha fúnebre Marionette, Gounod, $3^{\circ}$ Gran fantasía de zarzuela El salto del pasiego, del maestro Caballero, $4^{\circ}$ Gran final primero de La Africana de Meyerbeer, $5^{\circ}$ Almer, Boire y Chanter (valses) de Strauss, $6^{\circ}$ Pasodoble ${ }^{190}$.

El repertorio interpretado por las bandas era muy ecléctico, y estaba constituido por arreglos de música teatral (fantasías sobre temas de óperas, operetas y zarzuelas), transcripciones de páginas orquestales, pasodobles, marchas, valses y otras piezas de baile (mazurcas, polkas, habaneras, pasodobles, malagueñas, etc.). Es decir, coexistían arreglos de música lírica con piezas originales para banda ${ }^{191}$.

En el siglo XIX en Valencia existían diversas bandas de música. Junto a las militares (banda del regimiento de Sevilla, banda del regimiento de Saboya, de Guadalajara, de Vizcaya, Mallorca, Vizcaya, Tetuán, Iberia, entre otras), surgieron bandas civiles como las que muestro en la Tabla 9, que comentaré en los apartados siguientes.

${ }^{190}$ El Mercantil Valenciano, 7-VIII-1890.

${ }^{191}$ El Mercantil Valenciano, 25-VII, 7-VIII y 8-VIII-1890. La tendencia a crear un repertorio específico para bandas se fue consolidando progresivamente. Como representante de esta tendencia Galbis destaca el compositor valenciano Carlos Llorens Robles (1821-1862), que trabajó en Valencia y Murcia; véase Galbis, "La música instrumental”, p. 274; Galbis, "Les bandes valencianes”, pp. 162-163. 
Tabla 9. Bandas civiles documentadas en Valencia (ca. 1850-1925).

Fuentes: $E: V A a$, Sección I, sub. LL Banda Municipal, clase I (Músicas municipales), subclase A Creación, Reglamentación, Disolución (1859-1869); Ruiz de Lihory, La Música en Valencia, p. 39; La Música Ilustrada Hispano-Americana, 15-VII-1900, p. 163; Álvarez [et al.], 150 Años, pp. 85-91.

\begin{tabular}{|c|c|c|}
\hline Banda & Cronología & Director \\
\hline \hline $\begin{array}{c}\text { Banda Asilados de la Casa de la } \\
\text { Misericordia }\end{array}$ & $c a$. 1800 & Nicolás García \\
\hline La Unión & 1861 & Agustín Llorens \\
\hline $\begin{array}{c}\text { Banda de vecinos de Patraix } \\
\text { Banda de la casa de la } \\
\text { Beneficencia }\end{array}$ & 1861 & No consta \\
\hline $\begin{array}{c}\text { La Valenciana } \\
\text { Banda de l'Oli }\end{array}$ & 1875 & Puis Tárrega \\
\hline $\begin{array}{c}\text { Bablo Zapata } \\
\text { Banda de la Brigada de Bomberos }\end{array}$ & Mediados s. XIX-1869 & Ramón Izquierdo \\
\hline Patronato Juventud Obrera & $1876-1923$ & Pablo Zapata \\
\hline Banda de la Asociación de & Finales s. XIX & José Sánchez \\
\hline $\begin{array}{c}\text { Veteranos de la Libertad/Batallón } \\
\text { de Veteranos }\end{array}$ & Finales s. XIX/continuaba en & Ginés Gómez/ Francisco Lozano \\
\hline Lira Valenciana & Finales s. XIX & Alfredo Clavel \\
\hline Banda Municipal de Valencia & Desde 1903 & Santiago Lope \\
\hline
\end{tabular}

\section{La Valenciana}

Esta banda, constituida a mediados del siglo XIX por unos 40 músicos, estuvo dirigida, al menos hasta 1869 , por el profesor y primer cornetín de la orquesta del Teatro Principal de Valencia Pablo Zapata y Grajales. Zapata solicitó el 31 de enero de 1861 a la corporación municipal que "La Valenciana" pudiera denominarse "Música del Excelentísimo Ayuntamiento", lo que suponía representar al Ayuntamiento y estar bajo sus órdenes. El Ayuntamiento le concedió lo solicitado y desde 1861 a 1869 la banda quedó vinculada, por contrato, a tocar, entre otras actuaciones, en las revistas de la Brigada de Bomberos de Valencia el primer domingo de cada mes. Además el Ayuntamiento utilizaría sus servicios (sin retribuirle por ello) en las festividades del Corpus, santos patronos y actos de tomas de posesión. El Ayuntamiento se reservaba utilizar la banda en casos extraordinarios, como la visita de los reyes de España y demás 
actos que tuviera que solemnizar la Corporación, en cuyo caso los músicos serían gratificados $^{192}$. Parece ser que la banda dirigida por Zapata no cumplió con las obligaciones convenidas con el Ayuntamiento, ya que en abril de 1869, Ramón Izquierdo y Ginés Gómez presentaron sendas solicitudes al Ayuntamiento de Valencia para obtener la plaza de Músico Mayor del Ayuntamiento, con la finalidad de organizar una nueva banda de música militar titular del mismo ${ }^{193}$.

\section{Banda de l'Oli [del Aceite]}

Su denominación parece derivar del local que utilizaban para sus ensayos, en la hoy desaparecida Lonja del Aceite ${ }^{194}$. Esta agrupación musical era dirigida por el músico mayor del ejército Ramón Izquierdo y estaba compuesta por treinta profesores, todos ellos de formación militar. Izquierdo presentó el 27 de octubre de 1860 una propuesta al Ayuntamiento para que éste le concediese el título de banda del Excelentísimo Ayuntamiento de Valencia, pero su propuesta fue desestimada a favor de la presentada por Pablo Zapata ${ }^{195}$. Parece ser que la banda dirigida por Zapata no cumplió con las obligaciones convenidas con el Ayuntamiento y, el 3 de abril de 1869 Ramón Izquierdo presentó una nueva propuesta al Ayuntamiento de Valencia para ser Músico Mayor del Ayuntamiento y organizar una nueva banda de música militar titular del mismo ${ }^{196}$. Se

\footnotetext{
192 E:VAa, Sección I, sub. LL Banda Municipal, clase I (Músicas municipales), subclase A Creación, reglamentación, Disolución (1859-1869), nº 1, Música de la ciudad (1860).

193 E:VAa, Sección I, sub. LL Banda Municipal, clase I (Músicas municipales), subclase A Creación, reglamentación, Disolución (1859-1869), $\mathrm{n}^{\circ}$ 1, Creación de una banda militar de música titular del Ayuntamiento (1869).

${ }^{194}$ Ruiz de Lihory, La música en Valencia, p. 39.

195 E:VAa, Sección I, sub. LL Banda Municipal, clase I (Músicas municipales), subclase A Creación, Reglamentación, Disolución (1859-1869), nº 1, Música de la ciudad (1860).

196 E:VAa, Sección I, sub. LL Banda Municipal, clase I (Músicas municipales), subclase A Creación, Reglamentación, Disolución (1859-1869), n 1, Creación de una banda militar de música titular del Ayuntamiento (1869).
} 
presentaron otras candidaturas (entre ellas la de Ginés Pérez) y la Comisión de fiestas del Ayuntamiento de Valencia propuso celebrar un concurso oposición público y nombrar un tribunal para elegir entre las propuestas presentadas ${ }^{197}$. Según Ruiz de Lihory, la banda de l'Oli, dirigida por Ramón Izquierdo, fue la que recibió autorización del Ayuntamiento de Valencia para anunciarse como Banda titular del Ayuntamiento, aunque no he podido por el momento documentar este dato ${ }^{198}$.

\section{Banda de Veteranos de la Libertad}

La banda de Veteranos por la Libertad, dirigida por Ginés Gómez, procedía de antiguas milicias encargadas de velar por la defensa de la Constitución. A finales del siglo XIX un grupo de militares veteranos constituyeron esta agrupación, conocida jocosamente como "Banda de la Tos" por la edad ya avanzada y delicado estado de salud de sus componentes, que vestían traje militar con espadín y acompañaban en procesiones, fiestas populares y corridas de toros. Al menos desde 1898, y dirigida por el joven Francisco Lozano, inició un periodo de reconstitución como muestra la crónica que a continuación trascribo y en 1900, cambió su denominación a Batallón de Veteranos ${ }^{199}$.

La de Veteranos, aunque de larga vida, puede decirse que está en los albores de su renacimiento desde que al encargarse de la dirección el joven ya citado profesor Sr. Lozano, comenzó una nueva era de reconstitución, un periodo de organización que deja sentir sus efectos $^{200}$.

197 E:VAa, Sección I, sub. LL Banda Municipal, clase I (Músicas municipales), subclase A Creación, Reglamentación, Disolución (1859-1869), n ${ }^{\circ}$ 1, Creación de una banda militar de música, titular del Ayuntamiento, Acta Municipal de la sesión celebrada por el Ayuntamiento Popular de Valencia, 16-IV1869.

198 Ruiz de Lihory, La música en Valencia, p. 39; Vicente Vidal Corella, El maestro Santiago Lope (Valencia: Conservatorio Superior de Música de Valencia, 1979), pp. 24-25.

199 Véase La Música Ilustrada Hispano-Americana, 15-VII-1900, p. 163 y Astruells, La Banda Municipal, p. 66.

${ }^{200}$ Boletín Musical, 10-VIII-1898, p. 1272. 


\section{Banda de la Brigada del Cuerpo de Bomberos}

El 2 de enero de 1876 hizo su presentación en Valencia la Banda de la Brigada de Bomberos $^{201}$. Desde ese momento intentó formalizar un contrato con el Ayuntamiento para conseguir que éste la declarase con el título de "Música Municipal", cosa que consiguió el 17 de julio de 1879. El objetivo con el que se creó la banda era acompañar en las revistas y actos oficiales de la brigada de Bomberos, pero desde el principio se pretendió que el conjunto fuese conocido por la ciudad y se solicitó permiso al Ayuntamiento para poder tocar en el Paseo de la Glorieta los días festivos de invierno, permiso que se les concedió en julio de $1877^{202}$. La banda de los Bomberos actuó también en procesiones, serenatas a altos cargos del Ayuntamiento, celebraciones de diversa índole (festividades de barriadas de la ciudad, espectáculos deportivos) y actuaba como banda invitada desde el nacimiento en 1886 del Certamen de Bandas organizado por el Ayuntamiento de Valencia. El director de esta agrupación entre 1876-1907 fue Pablo Zapata. Le sucedieron en el cargo José Castro Miralles, Carmelo Sainz Artigues, Antonio Torres Olmos y Francisco Lozano. La plantilla estuvo integrada por:

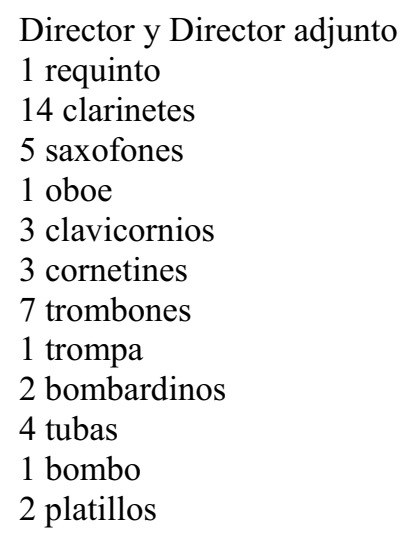

\footnotetext{
${ }^{201}$ Según Ángeles Álvarez esta formación parece haber derivado de "La valenciana”. Ángeles Álvarez [et al.], 150 Años del cuerpo de Bomberos de Valencia 1857-2007 (Valencia: Ajuntament de València, $2007)$, pp. 85,88 . No he podido localizar ningún dato que corrobore esta hipótesis, el único vínculo que puedo establecer entre estas agrupaciones es la figura del director Pablo Zapata, que dirigió entre 18611869 la banda "La Valenciana" y desde 1876 hasta 1907, la banda de la Brigada de Bomberos.

${ }^{202}$ La Banda de la Brigada de Bomberos del Ayuntamiento de Valencia obtuvo el 7-VII-1877 licencia municipal del Ayuntamiento para tocar durante dos horas los días festivos de invierno en el Paseo de La Glorieta y recibía una gratificación de 250 reales por día.
} 
Algunos músicos de la banda de Bomberos formaron parte de la primera promoción de músicos de la Banda Municipal de Valencia que se creó en 1903. La presentación de la Banda Municipal de Valencia supuso el principio del fin de la banda de la Brigada de Bomberos, que en 1914 se disolvió temporalmente por problemas de insubordinación de los músicos respecto a su director Carmelo Sainz, y desapareció definitivamente en 1923 por discrepancias entre sus componentes ${ }^{203}$.

\section{Banda Municipal de Valencia}

En agosto de 1902, el concejal republicano del Ayuntamiento de Valencia, Vicente Ávalos Ruiz, presentó a la corporación municipal la propuesta de creación de la Banda Municipal de Valencia ${ }^{204}$. Tras su aprobación, se inició el proceso de organizar la banda, que fue presentada el 8 de diciembre de 1903, bajo la batuta de Santiago Lope ${ }^{205}$. Su plantilla instrumental inicial fue:

Una flauta de primera, otra de segunda, con obligación de flautín; un oboe solista, otro de segunda, con obligación de corno; un requinto solista; un clarinete solista; diez clarinetes: cuatro de primera, tres de segunda y tres de tercera; un clarinete bajo de segunda; dos saxofones tenores, otro barítono; dos trompas en Sib; dos trompas en Fa; una trompa bajo; un clarinete alto tercero; dos fliscornos bajos; dos cornetines; cuatro trompas; cuatro trombones en Do y Sib; un trombón bajo en Fa; dos fliscornos; dos fagotes; dos bombardinos en Do y Sib; cuatro contrabajos en Do y Sib; dos contrabajos de cuatro cuerdas; un redoblante; una caja, con obligación de lira, triángulo, pandereta, etc; dos pares de platillos; un bombo y un par de timbales ${ }^{206}$.

\footnotetext{
203 Álvarez [et al.], 150 Años, pp. 85-91.

${ }^{204}$ E:VAa, Sección I, sub. LL Banda Municipal, en proceso de catalogación, 45 cajas (1901-1942), caja 2 (1902), Libro de Actas Comisión especial de creación de una Banda Municipal, sesiones de 12-VIII1902, 11-I-1903，11-II-1903，31-III,1903，15-IV-1903，13-V-1903，18-VII-1903; Expediente sobre Reglamento de la Banda Municipal (1902).

${ }^{205}$ E:VAa, Sección I, sub. LL Banda Municipal, en proceso de catalogación, 45 cajas (1901-1942), caja 4 (1903), Oficio de la Alcaldía comunicando al Presidente de la Comisión de Personal el nombramiento de Santiago Lope para Director de la Banda Municipal (1903).
}

${ }^{206}$ El Mercantil Valenciano, 20-V-1903. 
La Banda Municipal de Valencia ha sido estudiada monográficamente por Astruells $^{207}$.

\section{Otras bandas}

Otras bandas activas en Valencia en época de Amancio Amorós fueron: la de los "Asilados de la Casa de la Misericordia"208, la de la Casa de la Beneficencia"209, la banda del Patronato de la Juventud Obrera (dirigida por Pascual Rodríguez), la banda de la Asociación de Católicos (dirigida por José Sánchez), y la Lira Valenciana (dirigida por Alfredo Clavel) ${ }^{210}$. La prensa del momento comentó la juventud y el potencial de La Lira Valenciana:

La banda La Lira Valenciana es naciente, está constituida de poco tiempo, pero es numerosa y tiene elementos para llegar a buena altura $^{211}$.

En 1886 el Ayuntamiento de Valencia creó un Certamen de Bandas de Música de Valencia, que en los primeros años se denominó "concurso" y estuvo ligado al contexto festivo de la Feria de Julio de Valencia ${ }^{212}$. Tuvo sus precedentes en los conciertos y bailes que se programaban para la Feria, como el Gran Festival organizado en 1872, en el

207 Astruells, La Banda Municipal, pp. 71-75. Emilio Vega dirigió la banda entre 1907-1912 y Luis Ayllón entre 1913-1940. Amancio Amorós formó parte en 1903 del tribunal para las oposiciones a la plaza de director de la Banda Municipal de Valencia. La convocatoria de estas oposiciones puede consultarse en el Boletín Oficial de la Provincia de Valencia, 10-IV-1903, pp. 2-3.

${ }^{208}$ Según Ruiz de Lihory, La Música en Valencia, p. 39, en 1800, y por iniciativa del inquisidor Fiscal Nicolás Rodríguez Lazo se creó la banda de los “Asilados de la Casa de la Misericordia” dirigida por Nicolás García.

${ }^{209}$ La banda de la Beneficencia se creó en 1875 dirigida por Luis Tárrega, según consta en La Música Ilustrada Hispano-Americana, 15-VII-1900, p. 163

${ }^{210}$ Blasco, La música en Valencia, p. 86; La Música Ilustrada Hispano-Americana, 15-VII-1900, p. 163.

${ }^{211}$ Boletín Musical, 10-VIII-1898, p. 1272.

212 Según Elvira Asensi, "El certamen de bandas", pp. 12-13, la competitividad que se creaba entre las bandas participantes constituía un elemento clave para que estas bandas mejoraran su nivel y progresaran en su tarea formativa. 
que ochocientos cantantes e instrumentistas interpretaron la cantata La Feria de Valencia de Salvador Giner con texto de García Bravo ${ }^{213}$.

En 1886 la primera edición del Certamen de Bandas se celebró en el paseo de la Alameda de Valencia, delante del Pabellón Municipal (desaparecido a causa de un incendio en 1981). Con la consolidación del Certamen, su ubicación se trasladó desde 1888 a la Plaza de Toros. Las bandas concursaban por secciones según su tipología (bandas civiles y bandas militares) y según el número de componentes. Conforme avanzaba el siglo XIX se produjo un progresivo declive de las bandas militares frente a las civiles, lo que explica la desaparición de la sección para bandas militares en el Certamen de Bandas de Valencia ${ }^{214}$.

En 1898 únicamente se inscribieron en la primera sección dos bandas de la ciudad de Valencia, la banda de Veteranos, dirigida por Francisco Lozano y la Lira Valenciana dirigida por Alfredo Clavel. La prensa valenciana del momento criticó a la Corporación Municipal por no conceder subvenciones para que estas agrupaciones se desarrollasen:

Nosotros hemos de decir con lealtad que nos place esta lucha entre las dos bandas, porque creemos fundadamente que si esa competencia es noble, de ella nacerá el estímulo y la emulación, el trabajo y el perfeccionamiento, factores que han de concluir [sic] por hacer que Valencia tenga una o dos bandas dignas de su importancia. Estamos seguros que sin el poderoso acicate de la competencia, seguiríamos en ese estado de postración musical que da vergüenza sólo al pensar que cualquier banda de los pueblos importantes de la provincia podía figurar con ventaja al lado de las de la capital, y todavía sube a mayor punto el rojo de la vergüenza al saber que miserables municipios ayudan, fomentan y subvencionan sus bandas, mientras que la Excma. Corporación Municipal de Valencia permanece impávida sin conceder importancia alguna a estas agrupaciones siendo el pito que menos les molesta.

Bien a las claras hemos visto lo nutridas que se han presentado las dos bandas de referencia, el número de elementos que cuentan y la calidad de los ejecutantes, pues negar que en nuestra población hay

\footnotetext{
${ }^{213}$ Véase Eduardo López-Chavarri Andújar, 100 años del Certamen Internacional de Bandas de Música (València: Ajuntament de València, 1986); Astruells, La Banda Municipal, pp. 231-234; Blasco, La música en Valencia, pp. 83-91; Galbis, "Les bandes valencianes”, pp. 175-177.
}

${ }^{214}$ Vicente Galbis López, "Bandas”, en $D M V$, vol. 1 (2006), p. 90. 
muchos y buenos músicos, y que es susceptible la creación y mantenimiento de una o dos bandas buenas, equivaldría a negar la evidencia $^{215}$.

En sus primeras ediciones el certamen tuvo un carácter provincial, aunque fue ampliando su campo de acción hasta convertirse en el Certamen Internacional de Bandas de Música Ciudad de Valencia, que sigue existiendo en la actualidad. La Banda de la Brigada del Cuerpo de Bomberos, desde 1886, actuó como invitada, hasta la aparición de la Banda Municipal de Valencia en 1902.

\section{Sociedades culturales con actividad musical y movimiento coral}

\section{1 . Sociedades culturales con actividad musical ${ }^{216}$}

Desde mediados del ochocientos, la burguesía valenciana impuso un modo de vida que incluía actividades lúdicas vinculadas al conocimiento y que le llevó a habilitar lugares de esparcimiento y diversión. Durante la Feria de Julio eran zonas de paseo la Alameda y La Glorieta. En invierno, el ocio se refugiaba en los recintos cerrados, como los salones de sociedades recreativas y culturales, donde se organizaban bailes, así como en los cafés y teatros ${ }^{217}$.

\footnotetext{
${ }^{215}$ Boletin Musical, 10-VIII-1898, p. 1272.

${ }^{216}$ Las primeras aproximaciones al tema de las sociedades culturales con actividad musical en Valencia son: López-Chavarri, Cien años de música, pp. 69-80; Ranch, "La música", pp. 61-80; Galiano, "La Renaixença", pp. 305-306; Vicente Galbis López, La música escénica en Valencia: 1832-1868. Del modelo del Antiguo Régimen a la organización musical del Estado burgués, Tesis Doctoral (Valencia: Universidad de Valencia, 1998), pp. 460-465; Alemany, Metodología de la técnica, pp. 127-132, Sancho, Romanticismo, pp. 209-227. Entidades similares surgieron en otras ciudades de la península ibérica; véase Sociedades Musicales en España. Siglos XIX-XX, Actas del Curso de Musicología (Granda, 1997), Cuadernos de Música Iberoamericana, 8-9 (2001).
}

${ }^{217}$ Los bailes de máscaras eran los más concurridos y se extendían de enero a mayo. Los cafés propiamente dichos sólo estaban al alcance de unos pocos (El León de Oro, El Siglo, Habana, La Escocesa, Cayol, Ambos Mundos, De La Paz, Novedades, Unión, Universal, Valenciano, Imperial). Los denominados "cafés económicos", más numerosos y asequibles eran el principal centro de esparcimiento popular. Sobre los Teatros valencianos, véase apartado 4 de este capítulo. Los palcos y los salones del teatro se convirtieron es espacios para entablar amistades, galantear e incluso proyectar negocios. Véase Marc Baldó, "Entre el confort y el ocio: la sociabilidad ciudadana en la segunda mitad del siglo XIX, en $H V$, pp. 518-520. 
La Real Orden de 28 de febrero de 1839 promulgada por la reina $\mathrm{M}^{\mathrm{a}}$ Cristina de Borbón, regente a la muerte de Fernando VII, liberalizó y reguló el derecho de reunión y asociación en España, lo que hizo que en todo el país y también en Valencia proliferaran las sociedades culturales y recreativas de impronta burguesa ${ }^{218}$. En la Valencia de finales del XIX hubo numerosas sociedades que organizaban actividades musicales, como expondré en sucesivos apartados. En la Tabla 10 incluyo las principales sociedades que he documentado en mi estudio. Hubo además música en otras instituciones culturales y recreativas como el Círculo Industrial, Casino Instructivo, Sociedad Valenciana de Agricultura, Casino Nacional, El Micalet ${ }^{219}$.

Tabla 10. Principales sociedades culturales con actividad musical en Valencia (1838-1915). Fuentes: Boix, Manual del viajero, pp. 193-194, 229-230; Martínez Aloy, Geografia general, pp. 621-622; Díaz, Guía Novísima, p. 76; Roig Condomina, "El Ateneo", p. 107; Almanaque de las Provincias para 1880, p. 159; Sala, Història de Lo Rat, pp. 65-66; Roig Condomina, "El Iris", p. 239; E:VAseap, C. 222, III-Educación $\mathrm{n}^{\circ} 16$, Documentación relativa a las escuelas públicas y privadas que existen en la ciudad de Valencia; Roig, “Algunes notes”, pp. 240-241; Loras, La Asociación, pp. 11, 15-16; Revuelta, Compañía de Jesús, vol. 3, p. 569; Almanaque de las Provincias para 1916, pp. 137-140.

\begin{tabular}{|c|c|}
\hline Nombre & Fecha fundación \\
\hline \hline $\begin{array}{c}\text { Liceo Valenciano } \\
\text { Amigos del País de Valencia }\end{array}$ & 1838 \\
\hline $\begin{array}{c}\text { El Casino/Círculo de Comercio y } \\
\text { Fomento/ Círculo Valenciano }\end{array}$ & 1776 \\
\hline $\begin{array}{c}\text { Ateneo Científico, Artístico y } \\
\text { Literario de Valencia }\end{array}$ & 1869 \\
\hline $\begin{array}{c}\text { Academia Científico Literaria de } \\
\text { la Juventud Católica }\end{array}$ & 1871 \\
\hline Ateneo Casino Obrero de Valencia & 1876 \\
\hline Lo Rat Penat & 1878 \\
\hline El Iris & 1879 \\
\hline $\begin{array}{c}\text { Círculo Católico-Obrero } \\
\text { Cooperativo de San Vicente Ferrer }\end{array}$ & 1881 \\
\hline Círculo de Bellas Artes & 1894 \\
\hline $\begin{array}{c}\text { Asociación de Profesores } \\
\text { Músicos de Santa Cecilia }\end{array}$ & 1897 \\
\hline Círculo Musical/ Ateneo Musical & 1900 \\
\hline Centro Escolar y Mercantil & 1912 \\
\hline $\begin{array}{c}\text { Centro de Cultura/ Real } \\
\text { Academia de Cultura Valenciana }\end{array}$ & 1915 \\
\hline
\end{tabular}

\footnotetext{
${ }^{218} \mathrm{M}^{\mathrm{a}}$ Encina Cortizo y Ramón Sobrino, "Asociacionismo musical en España", Cuadernos de Música Iberoamericana, 8-9 (2001), pp. 11-16.

${ }^{219}$ Sancho, El sinfonismo, p. 268.
} 
Las sociedades recreativas programaban conciertos y daban clases de música a sus $\operatorname{socios}^{220}$. Estas sociedades se organizaron en secciones, y la sección de música, que solía estar presidida por músicos influyentes, era una de las secciones con más vitalidad. Los socios podían exhibir sus aptitudes artísticas en sesiones en las que se recitaban poesías, se leían discursos, se cantaba y se podía incluso representar alguna obra dramática. La sección de música de cada sociedad, en colaboración con las secciones de literatura y declamación, organizaba periódicamente conciertos, denominados "veladas literariomusicales" o "sesiones artístico-literarias" en las que la música jugaba un papel protagonista, aunque como mero entretenimiento, como excusa para el encuentro social $^{221}$. También había sesiones musicales en casas particulares de la burguesía y la nobleza valencianas. Entre los promotores de estas veladas estuvieron el banquero y violoncellista Jaime Manent, el político Vicente Salvá, el abogado Jaime Sales, el impresor Benito Monfort, el Marqués de Dos Aguas y el empresario Paulino Sanchis ${ }^{222}$.

En los apartados que siguen describiré las sociedades culturales valencianas más relevantes a partir de la segunda mitad del siglo XIX.

\section{El Liceo Valenciano}

El Liceo Valenciano fue la entidad cultural valenciana con más peso durante el segundo tercio del siglo XIX, inaugurada en 1838. Tuvo desde 1841 una sección de música y declamación para sus socios entre los que figuraban, entre otros, Antonio Rodríguez de Cepeda, Manuel Benedito Calzada, Mariano Roca Togores, Antonio

\footnotetext{
${ }^{220}$ Según Virgili, "El pensamiento musical", p. 22, estas sociedades se autofinanciaban con las cuotas de sus socios y con la organización de actividades diversas como conciertos, exposiciones y concursos, entre otras.

${ }^{221}$ Celsa Alonso, "Los salones: un espacio musical para la España del XIX”, Anuario Musical, 48 (1993), pp. 167-169.

${ }^{222}$ Ruiz de Lihory, La Música en Valencia, p. 283; Sancho, Romanticismo, pp. 209-210, 220.
} 
Aparisi Guijarro, Pascual Pérez Rodríguez, Vicente Wenceslao Querol y Teodoro Llorente. El Liceo editó una revista con el nombre de la sociedad, concedió una especial importancia a los bailes y a la representación de zarzuelas y creó una orquesta en la que participaron socios aficionados y músicos profesionales ${ }^{223}$. El Liceo desempeñó un papel de gran importancia en la difusión de la música sinfónica en Valencia. Sus veladas solían comenzar con una obertura operística a la que seguían diversas composiciones vocales (arias, dúos, cavatinas, coros operísticos) entre las que se intercalaban la lectura de poesías o la puesta en escena de algún sainete. También incluían variaciones y fantasías para piano sobre temas de ópera o piezas concebidas para el lucimiento personal de algunos aficionados ${ }^{224}$.

\section{La Real Sociedad Económica de Amigos del País de Valencia}

Esta institución se fundó en 1776 con el objetivo de impulsar el desarrollo de la industria y el comercio, y fue una de las sociedades valencianas más activas en la enseñanza y propagación de la música ${ }^{225}$. La Real Sociedad Económica fomentó la creación de importantes instituciones valencianas, como la Caja de Ahorros y Monte de Piedad de Valencia (1842 y 1877), el Conservatorio de Música de Valencia (1879), el Instituto Taquigráfico (1881), la Escuela de Comercio para Señoras (1884), el Patronato de la Juventud Obrera (1884), la Cámara de Comercio (1886) y la organización de las Exposiciones Regionales de 1867 y 1883 , entre otras ${ }^{226}$.

\footnotetext{
${ }^{223}$ Vicente Boix, Manual del viajero y guía de los forasteros en Valencia (Valencia: Imprenta de José Rius, 1849), pp. 193-194.

${ }^{224}$ Véase Galbis, La música escénica, pp. 460-465; Alemany, Metodología de la técnica, pp. 127-132.

${ }^{225}$ Martínez Aloy, Geografia general, pp. 621-622.

${ }^{226}$ Manuel Llorens (dir.), "Sociedad Económica de Amigos del País de Valencia", en Gran Enciclopedia Valenciana, vol. 9 (1991), p. 99; Boix, Manual del viajero, pp. 191-193.
} 
La Real Sociedad Económica tomó el relevo del desaparecido Liceo Valenciano en cuanto a actividad musical se refiere. Según Jimeno Lassala, de todas las manifestaciones musicales que se organizaron en Valencia, las más importantes eran las organizadas por la Sociedad Económica ${ }^{227}$, que además promovía otras artes, fomentaba escuelas de música (véase "Enseñanza musical" en este mismo Capítulo), y organizaba certámenes musicales anuales de ámbito nacional, para premiar a los mejores músicos. El Archivo de la Real Sociedad Económica de Amigos del País de Valencia conserva cinco obras musicales manuscritas de Felipe Pedrell presentadas bajo lema al certamen convocado en 1876 en el centenario de la fundación de la entidad. De estas cinco obras, cuatro obtuvieron el primer premio: Misa de Réquiem a capella, para cuatro voces mixtas y coro, Misa de Gloria para voces solistas de tiple, tenor, bajo, coro, gran orquesta y órgano, un Te Deum para cuatro voces y coro con acompañamiento de orquesta, órgano y arpa, y el motete Bone Pastor a tres voces y coro, con acompañamiento de orquesta. Pero hubo otra misa de Pedrell, premiada también con un accésit, titulada Misa de Gloria a grande orquesta y órgano, con solos y coros que, según Amparo Ranch, no se menciona en toda la bibliografía sobre Pedrell y no aparece ni siquiera en la catalogación de manuscritos de Pedrell que recopiló Higinio Anglés en $1921^{228}$.

En 1871, la Real Sociedad Económica valenciana aprobó un proyecto de su sección de Bellas Artes para organizar diez y seis "veladas-musicales" al año, con dos conciertos por mes durante los ocho meses de la temporada, aunque los conciertos no comenzaron hasta 1872. A partir de 1872 se acordó que pudieran asistir a estas veladas musicales todos los interesados, es decir tanto socios como cualquier otra persona que

\footnotetext{
227 José Jimeno Lassala, "Los conciertos de la Real Sociedad Económica de Amigos del País. Primera época 1872-84”, en Las Provincias, 8-I-1946.

${ }^{228}$ Referencia citada por Ranch, "La música", p. 63; E:VAseap, C. 196, VII-Varios, nº 1, Premios que ofrece la Real Sociedad Económica de Amigos del País de Valencia en el Certamen extraordinario de su primer centenario (1875); E:VAseap, C. 201, $\mathrm{n}^{\circ} 1, \mathrm{n}^{\circ} 2$; C. 202, $\mathrm{n}^{\mathrm{o}} 1, \mathrm{n}^{\mathrm{o}} 2$, Obras musicales premiadas por la Sociedad en el Certamen extraordinario conmemorativo de su primer centenario (1876).
} 
contara con la recomendación de un socio. Estas veladas musicales se transformaron desde 1875 en sesiones literario-musicales, con un desarrollo parecido, según Victoria Alemany, a las "sesiones públicas" que se ofrecían en el Liceo valenciano. A partir de la fundación del Conservatorio de Música de Valencia en 1879 los profesores de este centro participaban en los conciertos de la Real Sociedad Económica y desde 1884 empezaron a colaborar en estos conciertos alumnos aventajados, como el pianista José Bellver (18691945) y Concepción Asenjo Vilar ${ }^{229}$. En estos conciertos se interpretaba repertorio camerístico y piezas para intérpretes solistas.

Los conciertos de la Real Sociedad Económica se iniciaron, según Jimeno Lassala, en 1872 y fueron suspendidos temporalmente en $1886^{230}$. Era frecuente la actuación del dúo de Ricardo Benavent al piano y José Ma Úbeda o José Espí al armónium. Los violinistas Quintín Matas y Pascual Faubel, los violoncellistas Manuel Soriano y Calvo y la arpista Petra Tormo eran acompañados al piano por Benavent, Iborra, Úbeda, Serrano o Goérlich. Actuaron en varias ocasiones Petra Tormo (arpa) y Quintín Matas (violín). Los tríos eran poco frecuentes y se formaban con algunos de los profesores ya mencionados. Muy frecuente era el cuarteto de cuerda con piano y armónium, al que podían añadirse según la ocasión el contrabajo (Medina o Beltrán), clarinete (Adlert), trompa (Asensi), y fagot (Galiana) para formar una pequeña orquesta. En estos casos los directores podían ser Salvador Giner o José Espí ${ }^{231}$.

\footnotetext{
${ }^{229}$ Alemany, Metodología de la técnica, pp. 132-137. Según Alemany los profesores no cobraban por su participación en los conciertos; el dinero que la Sociedad Económica pagaba al director, José $\mathrm{M}^{\mathrm{a}}$ Úbeda, servía para sufragar gastos del Conservatorio. El pianista Roberto Segura actuaba sólo en los conciertos dados por los profesores del Conservatorio o para acompañar al piano a sus alumnas. Véase Vicente Galbis y José Climent, "Bellver Abells, José", en DMEH, vol. 2 (1999), pp. 342-343; José Climent, “Asenjo Vilar, María de la Concepción”, en DMEH, vol. 1 (1999), p. 790.

${ }^{230}$ La Sociedad Económica organizó en 1883 veintidós conciertos durante la celebración de la Exposición Regional; Jimeno, "Los conciertos", 8-I-1946.

${ }^{231}$ Jimeno, “Los conciertos", 8-I-1946.
} 
El 18 de noviembre de 1888 la Escuela de Comercio, dependiente de la Real

Sociedad Económica, celebró la apertura de curso con un concierto en el que actuaron un

doble cuarteto de instrumentos de cuerda, piano y armónium, bajo la batuta de Amancio

Amorós, profesor de la escuela de música de esa institución ${ }^{232}$.

Los conciertos celebrados en la Real Sociedad Económica podían aparecer bajo la denominación de "clásicos" o "sacros", según sus características o época del año en que se hacían. Las sesiones "clásicas" se celebraban sin una periodicidad concreta e incluían obras de cámara, piezas pianísticas y páginas concertantes de salón para diversos instrumentos $^{233}$ :

Notable fue el concierto clásico que tuvo lugar en los salones de la Económica, y en el que tomaron parte los profesores del Conservatorio de música, dirigidos por Salvador Giner. Las escogidas piezas que constituían el programa alcanzaron una ejecución inmejorable. La primera parte estaba formada por el Allegro del Cuarteto, obra 12, de Mendelssohn; Lento del Trío, obra 110, de Schumann, y el Lento y Allegro agitado de la obra Promenades d'un solitaire, de Heller. La ejecución fue brillante y los aplausos de la distinguida concurrencia premiaron a los distinguidos profesores, señores Marco, Rodríguez, Segura, Valls, Soriano, Matas y Giner, bajo cuya inteligente batuta alcanzaron notable valor las sublimes concepciones de los maestros clásicos [...].

No era menos variada y escogida la segunda parte. Tres composiciones gustaron extremadamente. El Nocturno, para violín y piano, de Chopin, ejecutado divinamente por el señor Matas, con acompañamiento de piano por el Sr. Segura; El Niño que se duerme y la Canción de caza de Schumann, arregladas para quinteto de cuerda, piano y armónium por el señor Giner [...].

Tanto los señores profesores que en el concierto tomaron parte, como la Junta de gobierno de la Económica, merecieron sinceros aplausos por sus esfuerzos en propagar el conocimiento de la música clásica, organizando audiciones tan notables como la de ayer ${ }^{234}$.

Los conciertos "sacros" solían celebrarse los viernes durante la temporada cuaresmal y sus programas mezclaban obras religiosas y de cámara. En casi todos ellos

\footnotetext{
${ }^{232}$ Ilustración Musical Hispanoamericana, 30-XII-1888, p. 184.

${ }^{233}$ Los programas de los conciertos presentan una estructura similar a los que se ofrecían en la Real Sociedad Económica de Amigos del País de Santiago; véase García Caballero, La vida musical en Santiago, pp. 350-353.

${ }^{234}$ Crónica de la Música, 29-III-1892, p. 4.
} 
tomaban parte cantantes miembros de conocidas familias valencianas. En Tabla 11 presento el detalle de dos de estos conciertos sacros celebrados en marzo de 1887.

Tabla 11. Programa de dos conciertos sacros organizados por la Real Sociedad Económica de Amigos del País de Valencia en 1887.

Fuentes: Las Provincias, 4-III-1887 y 18-III-1887.

\begin{tabular}{|c|c|c|c|}
\hline Autor & Título & Plantilla & Intérpretes \\
\hline [Salvador] Giner & Preludio & $\begin{array}{l}\text { Quinteto de cuerda, piano } \\
\text { y armónium }\end{array}$ & - \\
\hline [Salvador] Giner & Sub tuum praesidium & - & Esperanza Torres \\
\hline [Félix] Mendelssohn & $\begin{array}{l}\text { Intermedio y final del } \\
\text { Cuarteto } n^{\circ} 2\end{array}$ & Cuerda y piano & - \\
\hline [F. J.] Haydn & Sancta Maria & Trío & $\begin{array}{c}\text { Trinidad Puchol, } \\
\text { Esperanza Torres } \\
\text { Pedro Varvaró }\end{array}$ \\
\hline & $\begin{array}{c}\text { L'abbandono (melodía de } \\
\text { Mariano) }\end{array}$ & Violoncello & Raimundo Calvo \\
\hline [Félix] Mendelssohn & Adagio del Cuarteto $n^{\circ} 2$ & Cuerda y piano & - \\
\hline [Manuel] Chulvi & La prece della Giannina & & Josefa Soriano \\
\hline [Franz] Behr & Melodía & Cuerda y piano & 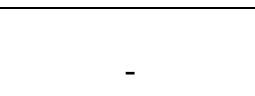 \\
\hline \multicolumn{4}{|c|}{ 18-III-1887 } \\
\hline [Henri] Kowalski & Dolor & Elegía para cuerda y piano & - \\
\hline [Giacomo] Rossini & O salutaris & & Josefa Soriano \\
\hline [Félix] Mendelssohn & $\begin{array}{c}\text { Intermedio y final del } \\
\text { Cuarteto } n^{\circ} 2\end{array}$ & Cuerda y piano & - \\
\hline [Pedro] Varvaró & Ave Maria & - & Esperanza Torres \\
\hline [Salvador] Giner & Preludio & Cuerda, piano y armónium & - \\
\hline [Charles] Gounod & Ave Maria & - & Trinidad Puchol \\
\hline [Félix] Mendelssohn & Adagio del Cuarteto $n^{\circ} 2$ & Cuerda y piano & - \\
\hline [Giuseppe] Verdi & $\begin{array}{c}\text { Ave Maria (de la ópera } \\
\text { Otello) }\end{array}$ & 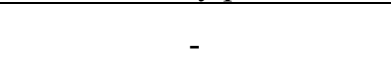 & Josefa Soriano \\
\hline
\end{tabular}

El repertorio vocal era de diversa índole, desde el Vorrel morire o Lamentos de amor, hasta las arias de Lucia di Lamermoor, de Gaetano Donizetti o de El Barbero de Sevilla, de Gioacchino Rossini y las Variaciones de Prock. Las que más asiduamente se interpretaban eran las arias o romanzas de óperas conocidas en aquella época. Entre las intérpretes, frecuentemente mujeres, hubo damas de las familias Arnau, Casa Ramos, Dorda, Lozano, Peset y Sales. Entre los cantantes masculinos estuvieron Blanquells, Cubells, Dalmau, Domínguez, Varvaró, Losada, Payá y Rodríguez. Los acompañantes al 
piano solían ser Segura, Soriano, Goérlich y Lacomba ${ }^{235}$. En la Tabla 12 muestro los intérpretes y compositores más escuchados en los conciertos de la Real Sociedad Económica de Amigos del País de Valencia.

Tabla 12. Algunos intérpretes y compositores escuchados en los conciertos de la Real Sociedad Económica de Amigos del País de Valencia (1872-1886).

Fuente: Jimeno, "Los conciertos", 8-I-1946.

\begin{tabular}{|c|c|c|}
\hline \multicolumn{2}{|c|}{ Intérpretes } & Compositores \\
\hline Pianistas & $\begin{array}{c}\text { Emilio Iborra } \\
\text { Ricardo Benavent } \\
\text { José Espí } \\
\text { José Úbeda } \\
\text { Manuel Soriano } \\
\text { Francisco Goérlich } \\
\text { Roberto Segura }\end{array}$ & \multirow{4}{*}{$\begin{array}{l}\text { L. Van Beethoven } \\
\text { Félix Mendelssohn } \\
\text { F. J. Haydn } \\
\text { Gioachino Rossini } \\
\text { Charles Gounod } \\
\text { Robert Schumann } \\
\text { J. S. Bach } \\
\text { Hilarión Eslava } \\
\text { Johann N. Humel } \\
\text { Felipe Pedrell } \\
\text { Salvador Giner } \\
\text { José Espí }\end{array}$} \\
\hline Violinistas & $\begin{array}{c}\text { Quintín Matas } \\
\text { Salvador Giner } \\
\text { Pascual Faubel } \\
\text { Enrique Vidal } \\
\text { José Rodríguez }\end{array}$ & \\
\hline Violoncellistas & $\begin{array}{c}\text { Manuel Soriano } \\
\text { Raimundo Calvo } \\
\text { José Medina } \\
\text { Francisco Zurita }\end{array}$ & \\
\hline Directores & $\begin{array}{c}\text { Salvador Giner } \\
\text { Roberto Segura } \\
\text { Manuel Coronado } \\
\text { José Valls } \\
\text { José Bellver } \\
\text { Ricardo Benavent }\end{array}$ & \\
\hline
\end{tabular}

\section{El Casino, Círculo de Comercio y Fomento o Círculo Valenciano}

Esta sociedad nació el 9 marzo de 1847 con la denominación de Casino y estuvo situada en la plaza de San Francisco no 9 de Valencia. En marzo de 1848 cambió su nombre a Círculo de Comercio y Fomento y posteriormente, al menos desde 1867, fue conocido como Círculo Valenciano. El Casino disponía de salones de recreo, sala de

\footnotetext{
${ }^{235}$ Como muestra de los programas ofrecidos e intérpretes, Véanse Las Provincias 1, 4, 5, 11, 18 y 31-III-
} 1887. 
lectura, de café, sala de juegos y salón para bailes ${ }^{236}$. Contaba con una sección de música que organizaba bailes, conciertos vocales-instrumentales y, en Cuaresma, los habituales conciertos "sacros". El repertorio que pudo escucharse en esta entidad era el típico de los salones: arias, dúos y conjuntos operísticos, caprichos, variaciones, fantasías para piano sobre temas de ópera, reducciones para piano de sinfonías de ópera, dúos camerísticos y piezas pianísticas. Sus intérpretes solían ser socios del Casino, aunque también en alguna ocasión hubo recitales de concertistas famosos, como las violinistas Julia Blechsdmid (1874) y Egeria Antonini (1881), el guitarrista Francisco Tárrega (1900) e instrumentistas como José Ma Úbeda, Vicente Peydró, Manuel Penella, Emilio Iborra, Manuel Soriano, José Medina, Pascual Faubel y Antonio Marco. En los conciertos sacros del Casino se mezclaban géneros tan dispares como arias y oberturas operísticas, dúos y tercetos instrumentales y obras $\operatorname{sacras}^{237}$. La prensa de la época describe algunas veladas musicales del Círculo, como una de 1893:

Esta distinguida sociedad, dando preferencia a las agradables sensaciones del arte, ha dado entrada en sus elegantes salones a la música Di Camera, representada por un doble sexteto confiado a la hábil dirección del inteligente maestro D. Andrés Goñi. La reputación de tan respetable artista y el admirable trabajo que los excelentes profesores elaboran, excusan todo elogio y dan la medida del solaz y esparcimiento conseguido en estas artísticas fiestas. Todas las obras pueden figurar dignamente entre los más selectos programas: entre los números que más han cautivado, podemos citar un idilio musical del maestro austriaco Czibulka, titulado Un bel sogno, nuevo en Valencia, siendo tanto el frenesí que esta obra produjo en el auditorio, que llegó a pedir en su entusiasmo la tercera repetición.

También el Angelus de las Escenas pintorescas de Massenet y En el Molino, de Gillet, han sido obras que reclamaron los honores de la repetición, lo propio que la gran fantasía de Faust.

La audición de una Gavota de Echevarria; Polonesa de concierto de Brull; una obra de Coelli, Plan de Erey y una fantasía de Roberto el Diablo de Meyeerbeer, todas ejecutadas por primera vez, fueron muy del agrado de los amantes a la buena música.

Nuestro aplauso a los profesores del doble sexteto y a su maestro el Sr. Goñi, y nuestra cordial felicitación al Círculo de Comercio y Fomento por el recreo que ofrece a sus socios ${ }^{238}$.

\footnotetext{
236 Boix, Manual del viajero, pp. 229-230; Filiberto Abelardo Díaz, Guía Novísima de Valencia (Valencia: Imprenta de El Valenciano, 1867), p. 76.

${ }^{237}$ Sancho, Romanticismo, pp. 212-213.

${ }^{238}$ Boletín Musical, 31-III-1893, p. 61.
} 
Ateneo Cientifico, Artístico y Literario de Valencia

Esta sociedad fue el órgano director de la actividad artística en Valencia durante las décadas de los setenta y ochenta del siglo XIX. El origen del Ateneo Científico, Literario y Artístico de Valencia hay que buscarlo en las reuniones semanales que organizaron un grupo de estudiantes durante el curso 1868-69, en el domicilio de Francisco Mata Sanz, en el número 13 de la calle Adresadors. El grupo creció con tanta rapidez que en 1869 decidieron establecer una academia científico-literaria, que recibió el nombre de "La Antorcha" y fue inaugurada el 6 de enero de 1870 en una casa de la plaza de los Murcianos. Tras una primera reforma del reglamento en febrero del mismo año, y sucesivos cambios de nombre -Ateneo de la Juventud Valenciana, "La Antorcha", Ateneo de Valencia- se adoptó el que sería el nombre definitivo: Ateneo Científico, Artístico y Literario $^{239}$. Su actividad artística se difundió mediante El Boletín del Ateneo de Valencia y la organización de exposiciones, debates, conferencias y discursos ${ }^{240}$.

El Ateneo valenciano se dividió inicialmente en tres secciones: ciencias exactas, físicas y naturales; ciencias sociales; y literatura y bellas artes (éstas últimas se separaron en 1875). La entidad editó el discurso pronunciado por Ricardo Benavent en la Real Sociedad Económica del País de Valencia, en el que reflexionaba sobre la importancia de la música clásica y los principales artistas que en ella se habían distinguido ${ }^{241}$.

\footnotetext{
${ }^{239}$ Vicente Roig Condomina, "El Ateneo Científico, Literario y Artístico de Valencia y su aportación a las artes en el último tercio del siglo XIX”, Ars Longa, 6 (1995), p. 107. Fueron también muchos los locales en los que estuvo instalada la sede social de la institución. En febrero de 1872, la sociedad se trasladó al primer piso del $\mathrm{n}^{\circ} 1$ de la calle de la Raposa (junto a Serranos); en 1877, pasó a la calle Cañamás, en el antiguo palacio de la Bailía, y en 1884 a la casa del marqués de Mirasol. De aquí pasó, en 1891, a causa de las dificultades económicas por las que atravesaba, a un local más económico, situado en la calle del Arzobispo Mayoral 11, donde tuvo que convivir, entre 1894 y 1899 con el Ateneo Mercantil. En 1899 se trasladó a un local, propiedad de Emeterio Albors, en la calle del Mar, $\mathrm{n}^{\circ} 57$.

240 La Ilustración Valenciana: ciencias, letras y artes, 15-I-1887. Véase también Martínez Aloy, Geografia general, pp. 604-605.

${ }^{241}$ Roig, "El Ateneo Científico, Literario", pp. 108-114; Véase Celsa Alonso, "Benavent, Ricardo", en $D M E H$, vol. 2 (1999), p. 352. El discurso de Benavent publicó en El Arte (Madrid), 18-I-1874.
} 
El Ateneo de Valencia promovió veladas literario-musicales en colaboración con el Conservatorio de Música. La celebrada en 1878, dedicada a las mujeres, tuvo una magnífica acogida por parte de sus socios. Payá, Goérlich, Faubel y Martínez interpretaron algunos números de Faust de Charles Gounod, Il Trovatore y La Traviata de Giuseppe Verdi y La Africana de Giacomo Meyerbeer ${ }^{242}$. En 1893 el Ateneo organizó un homenaje a Zorrilla en el que los socios leyeron piezas del escritor y se interpretaron varias obras musicales: La marcha fúnebre de Bertini (a doble quinteto de cuerda y piano); una Romanza sin palabras de Beethoven arreglada para quinteto de cuerda, piano y armónium; y la Melodía elegíaca de Salvador Giner, con letra de Rodríguez Guzmán, obra estrenada ese día y compuesta para la ocasión ${ }^{243}$.

\section{Academia Científico Literaria de la Juventud Católica}

Esta Academia se creó en 1871 con una finalidad cultural y recreativa, fue clausurada por el gobierno de la primera República en 1873 y retomó su actividad en 1880, año en el que empezó a publicar el Boletín-Revista de la Juventud Católica de Valencia $^{244}$. La Academia tuvo su sede en el palacio Parcent y, según su reglamento, se proponía trabajar "en la propaganda de las ideas religiosas y en la difusión de las sanas doctrinas científicas y literarias" 245 .

Entre los actos que organizaba la Academia fueron habituales las veladas literariomusicales de los sábados, fomentadas por las secciones de literatura y música y las celebradas en festividades señaladas como Santo Tomás de Aquino, San José, la

\footnotetext{
${ }^{242}$ Valencia Ilustrada, 24-III-1878, p. 90.

${ }^{243}$ Boletín Musical, 31-III-1893, p. 59.

244 Boletín-Revista de la Juventud Católica de Valencia, n ${ }^{\mathrm{o}} 1$ (Valencia: Imprenta de Carlos Verdejo, 1880).

245 E:VAseap, C. 231, XII-Correspondencia de Sociedades, $\mathrm{n}^{\circ}$ 2, Documentación relativa al reglamento por el que ha de regirse la Academia de la Juventud Católica de Valencia (1884).
} 
Inmaculada, San Vicente Ferrer y la Virgen de los Desamparados ${ }^{246}$. En 1892 la Academia convocó un concurso para premiar el mejor Himno a Colón para tenor, barítono y coro a cuatro voces con acompañamiento de quinteto de cuerda, piano y $\operatorname{armónium}^{247}$ :

En el certamen celebrado en honor a Cristóbal Colón por la Academia de la Juventud Católica de esta capital, fue premiado el himno a cuatro voces y coro, con acompañamiento de quinteto de cuerda, piano y armónium, cuyo autor resultó ser D. Mariano Baixauli, mereciendo el accésit el otro himno de análogo instrumental y coral, de nuestro amigo el joven pianista D. José Pascual.

Estas dos obras fueron ejecutadas en la sesión solemne que con este motivo tuvo lugar, en la cual se cantó también una salve del señor Varvaró para bajo y voces con acompañamiento de quinteto de cuerda y armónium, interpretada por su autor ${ }^{248}$.

El Conservatorio de Valencia cedía su salón de actos a la Academia para que ésta celebrara sus veladas musicales ${ }^{249}$. En 1890 la Academia celebró la festividad de la Inmaculada con una misa solemne en la que se interpretó la Gran Misa de Rigoberto Cortina para orquesta y coro, bajo la dirección del profesor José $\mathrm{M}^{\mathrm{a}}$ Medina. Por la noche se celebró una velada literario-musical en el salón de actos del Conservatorio valenciano en la que se recitaron poesías dedicadas a la Inmaculada y Pascual, Lluch, Sáez y Puig interpretaron piezas para piano, armónium y canto ${ }^{250}$.

La prensa menciona algunos de los participantes en las sesiones literariomusicales de la Academia celebradas en 1891:

\footnotetext{
246 Anónimo, “Academia Científico Literaria de la Juventud católica de Valencia", Almanaque de las Provincias para 1890-91, p. 246; Boletín-Revista de la Juventud Católica de Valencia, 1 (1880), pp. 613.

${ }^{247}$ Ilustración Musical Hispanoamericana, 15-VI-1892.

${ }^{248}$ Boletín Musical, 31-X-1892, p. 23.

249 E:VAseap, C. 246, Música $\mathrm{n}^{\circ}$ 5, Documentación del Conservatorio y la Academia de la Juventud Católica de Valencia relativa a la cesión, a dicha Academia del salón de audiciones para una velada musical (1888).

250 Anónimo, “Academia Científico Literaria de la Juventud católica de Valencia”, Almanaque de las Provincias para 1890, pp. 245-246.
} 
Celebraron sesiones todos los sábados [...] ejecutándose variadas piezas a piano, armónium, violín, violoncello y flauta por los señores Goñi, Medina, Cortés, Pascual Lluch, Martí y Boscá, Moltó y Marco, Sanchis, Roig, Huguet y Estrems; y sentidas composiciones de canto por los señores Llorens, Sáez, Alonso, Cabedo y Ballester, Cabedo y Español, Amorós (D. Eugenio), Coscollá, Pastor, Ivancos y Cidón ${ }^{251}$.

En 1893, la entidad celebró una velada dedicada al Sagrado Corazón de Jesús en cuya parte musical se interpretaron una fantasia de Aida, para piano y armónium, ejecutada por Pascual y Tomás; Jesús Nazareno de Gounod, interpretada por el tenor Llorens de Bonilla; Un sogno fa de Caracciolo para barítono, cantada por Cabedo; La Rondinella de Gounod y el Ave María de Schubert cantadas por Llorens ${ }^{252}$.

\section{Ateneo Casino Obrero de Valencia}

Esta Asociación cultural fue fundada en 1876 por Francisco Vives Mora, junto con cuarenta y cuatro obreros. Su primera sede estuvo instalada en la casa-palacio del conde de Albalat, situado en la plaza Mosen Sorell ${ }^{253}$. Este centro ofrecía clases de primera enseñanza, dibujo, solfeo, francés y contabilidad y estableció una biblioteca pública y gabinete de lectura, así como una sección de música y declamación "a cuyo efecto se levantará un bonito teatro" ${ }^{, 54}$, según se anunciaba días después de la inauguración ${ }^{255}$. La actividad docente y recreativa del centro prosiguió con normalidad hasta que en marzo de 1878 un incendio destruyó el palacio del conde de Albalat. El

\footnotetext{
251 Anónimo, “Academia Científico Literaria de la Juventud católica de Valencia", Almanaque de las Provincias para 1891, p. 307.

${ }^{252}$ El Valenciano, 13-VI-1893.

${ }^{253}$ Manuel Llorens (dir.), “Ateneo Casino Obrero”, en Gran Enciclopedia Valenciana, vol. 1 (1991), p. 290.

${ }^{254}$ Las Provincias, 26-XI-1876.

${ }^{255}$ E:VAseap, C. 222, III-Educación $\mathrm{n}^{\mathrm{o}} 16$, Documentación relativa a las escuelas públicas y privadas que existen en la ciudad de Valencia (1883). En este mismo legajo se puede consultar el Reglamento del Ateneo Casino Obrero de Valencia.
} 
origen del fuego, según la prensa del momento, había estado en el teatrito que la sociedad había construido en el salón principal de la casa ${ }^{256}$. Después de la catástrofe, el Ateneo

Obrero se estableció en un local que había pertenecido a la administración militar y en 1888 se trasladó a la antigua sede de la Sociedad Económica de Amigos del País de Valencia, situada en la calle del $\mathrm{Mar}^{257}$.

El Ateneo Obrero celebraba anualmente un Certamen Artístico y Literario cuyo cartel anunciador en 1885 decía así:

Tema Primer. Himno a l'Ateneo. Composició coral a tres veus, la primera per a xiquetes, $\mathrm{i}$ la segon $\mathrm{i}$ tercera per a xiquets, $\mathrm{ab}$ acompanyament d'orquestra completa $\mathrm{i}$ ab subjecció a la lletra que oportunament se donarà a conéixer. Premi: una batuta d'ébano ab caps d'argent e inscripció corresponent i títol de Soci de mèrit d'esta corporació.

Tema Segon. Barcarola, a dos veus de xiquetes i xiquets, ab acompanyament d'orquestra, sent la lletra de lliure elecció. Premi: un objecte d'art.

Advertència. Les estrofes de l'himne podran ser a soles, duo o tercet de tenor, tiple, barítono o baix.

Tema Tercer. La madre en la familia obrera. Composició poètica de metro i extensió lliures [...].

Tema Quart [...].

Observacions. Tots los treballs que se presenten hauran de ser precisament inèdits, i los relatius al Tercer i Quart tema estar escrits en castellà $[\ldots]^{258}$.

\footnotetext{
${ }^{256}$ Las Provincias, 17-III-1878.

${ }^{257}$ Las Provincias, 14-VIII-1878.

${ }^{258}$ Lo Rat Penat: periodich lliterari quincenal, 15-I-1885, p. 22. [Tema Primero. Himno al Ateneo. Composición Coral a tres voces, la primera para niñas, la segunda y tercera para niños con acompañamiento de orquesta completa y con sujeción a la letra que previamente se dará a conocer. Premio: una batuta de ébano con remates de plata e inscripción correspondiente y título de socio de mérito de esta corporación.

Tema Segundo. Barcarola, a dos voces de niñas y niños con acompañamiento de orquesta completa y letra de libre elección. Premio: un objeto de arte.

Advertencia: Las estrofas del himno podrán ser a solo, dúo o trío de tenor, tiple, barítono o bajo.

Tema Tercero. La madre en la familia obrera. Composición poética de metro y extensión libres [...].

Tema cuarto [...].

Observaciones. Todos los trabajos que se presenten deberán ser inéditos y los relativos al Tercer y Cuarto tema estar escritos en castellano].
} 
El Ateneo Obrero organizó además conciertos de música religiosa y otras veladas musicales. En una de ellas, en la que actuaron los jóvenes profesores Josep García Solá, Vicente Peydró y Eduardo Senís, celebrada en 1880 interpretó el siguiente programa:

Primera Parte

Marcha de las Antorchas de Meyerbeer, en versión para piano a cuatro manos y armónium.

Indiferencia de Penella para coro con acompañamiento de piano y armónium.

La Ausencia, romanza para canto y piano de Penella.

Segunda parte

Paragraph $3^{\circ}$, sinfonía de Suppé para a piano y armónium.

Cavatina de Linda de Chamonix.

Romanza para tenor de Luisa Miller.

Cavatina para soprano de la ópera Betty de Donizetti.

Tercera parte

Sinfonía de la ópera Mignon de Thomas.

La preghe della Sera de Mariano.

Romanza de tiple de la zarzuela El Anillo de hierro

Serenata para coro de Jordá ${ }^{259}$.

En un concierto sacro del Ateneo Obrero celebrado en 1888, se incluyeron, además de la lectura de poesías las siguientes composiciones:

\author{
Angelus de Massenet \\ Oregina de Luzzaschi \\ Gesú Nazareno de Gounod \\ Salve de Goberna \\ ¿Quién és esta? de Ximénez \\ Ave María de Verdi \\ Mater Dolorosa de Luizzi \\ Plegaria de tiple de la ópera I Lombardi de Verdi \\ Ave María de Penella ${ }^{260}$.
}

${ }^{259}$ El Mercantil Valenciano, 16-XI-1880.

${ }^{260}$ E:VAseap, C. 246, Música $\mathrm{n}^{\circ}$ 6, Documentación relativa a conciertos celebrados por la Económica (1888). Incluye invitaciones y programas. 
Lo Rat Penat ${ }^{261}$

El escritor y republicano federal Carmelo Navarro Llombart, conocido como

Constantí Llombart ${ }^{262}$, fundó en 1878 la sociedad conocida como Lo Rat Penat a raíz del

éxito de un recital poético celebrado en el Ateneo Casino Obrero de Valencia con motivo

de la festividad de San Pedro Apóstol. La presentación de la sociedad Lo Rat Penat tuvo

lugar el 31 de julio de 1878 en el pabellón del Ayuntamiento de Valencia instalado para

la celebración de la Feria de Julio. Según se anunció en la prensa, en el acto se guardó el

siguiente orden:

\begin{abstract}
Una magnifica sinfonía por la Sociedad de Conciertos, que tan dignamente dirige el joven y distinguido maestro D. José Valls.

Discurso inaugural, Excel.lències de la llengua llemosina, por el celoso iniciador de la Sociedad D. Constantino Llombart.

Intermedio por la Sociedad de Conciertos.

Lectura de poesías lemosinas de los Sres. Pascual y Genís, Llorente, Serrano, Cañete, Arroyo y Almela, Iranzo y Simón y otros.

Himno Lo Pendó del Rat Penat, letra del Sr. Llombart, música del Sr. Penella, cantado por los alumnos de la escuela del Ayuntamiento que dirige este último y por los de la del Ateneo Casino Obrero, que dirige el Sr. Senís.

Discurso de gracias por el presidente efectivo de la sociedad, Sr. Pizcueta.

Las señoras que honren con su asistencia esta solemnidad, serán obsequiadas con preciosos bouquets.

Todo hace, pues, esperar que la inauguración de la patriótica Sociedad Lo Rat Penat dejará un grato y profundo recuerdo en nuestra bella y amada Valencia ${ }^{263}$.
\end{abstract}

Lo Rat Penat nació como una entidad para defender la cultura valenciana, y reunía a literatos, artistas y amantes de la historia y cultura valencianas. Su finalidad básica era estudiar, investigar, conservar y fomentar el progreso de la lengua y cultura

\footnotetext{
${ }^{261}$ La historia de Lo Rat Penat ha sido estudiada por Daniel Sala Giner, Història de Lo Rat Penat, dir. Federico Martínez Roda (Valencia: Lo Rat Penat, 2000). En esta Tesis aporto algunos datos nuevos, aunque no he podido acceder a los fondos del Archivo y Biblioteca de Lo Rat Penat en Valencia, ya que están en proceso de catalogación, según información que me facilitó su Junta de Gobierno en 2008.

${ }^{262}$ Llombart participó en la Revolución de Septiembre de 1868 y publicó diversos poemas políticos (Cantos republicanos), que más tarde recogió en alguno de sus dramas posteriores. Fundó la sociedad "Lo Rat Penat" que pretendía aglutinar a valencianos de todas las clases, aunque fue controlada por la burguesía conservadora que impuso sus decisiones y paralizó el proyecto inicial de su fundador.
}

${ }^{263}$ Valencia Ilustrada, 28-VII-1878, p. 240. 
valencianas $^{264}$. Esta sociedad recuperó los Juegos Florales en la ciudad de Valencia en 1879, que en realidad eran un acto de sociedad celebrado en el contexto de la Feria de Julio $^{265}$. La creación de la sociedad Lo Rat Penat cumplió una de las aspiraciones de los intelectuales de aquel momento: contar con un órgano que pudiera expresar los ideales de la Renaixença en Valencia (véase en este mismo capítulo apartado sobre la Renaixença).

La primera sede definitiva de Lo Rat Penat estuvo en una antigua casona propiedad del Conde de Casal, Luis Iváñez de Lara, situada en la placeta Conde de Casal 2, $1^{\text {a }}$ de la calle del Molí de Na Rovella ${ }^{266}$. Desde sus inicios Lo Rat Penat se estructuró en cuatro secciones: 1) literatura, 2) arqueología, 3) música y pintura y 4) escultura y $\operatorname{artes~menores~}^{267}$. La sección de música, muy activa durante los primeros años, organizaba frecuentemente veladas literario-musicales semanales o quincenales ${ }^{268}$. Un gran número de compositores valencianos estuvieron afiliados a Lo Rat Penat en los primeros años de actividad de la sociedad, como Amancio Amorós, Salvador Giner, Manuel Penella, Vicente Peydró, Raimundo Calvo, Pascual Faubel, Francisco Goérlich, Eduardo Senís, Juan Bautista Plasencia, José Jordá y otros. Los compositores daban a conocer sus obras en las veladas organizadas por la entidad y entregaban las partituras a la sección de

\footnotetext{
${ }^{264}$ Joan Gil Barberá, Lo Rat Penat (Valencia: Generalitat Valenciana, Consell Valencià de Cultura, 1996), p. 39; Martínez Aloy, Geografia general, pp. 606-607; Vidal y Torrent, "Sociedades Musicales", en $D M V$, vol. 2 (2006), p. 461.

${ }^{265}$ Según Sanchis, Renaixença al País Valencià, p. 50, los Juegos Florales de Valencia eran un certamen literario con "poesía de escasa calidad y gran monotonía". Según Gil Barberá, los Juegos Florales, de origen medieval, se habían celebrado por primera vez en Toulose hacia 1323. En España, fue Barcelona la primera ciudad que los organizó en 1393. En Valencia se promovió, en 1474, a instancias de Luis Despuig, un certamen poético en el que participaron Jaume Gasull, Joan Moreno, Joan Vidal. Los poemas que presentaron a este certamen están recogidos en el libro Les Trobes en Lahors de la Verge Maria, que fue el primero impreso en Valencia en 1474, y también en España. Véase Gil, Lo Rat Penat, pp. 133-134.

${ }^{266}$ Las primeras actividades de la sociedad se desarrollaron en los locales de la Universidad de Valencia y del Ateneo Casino Obrero. Almanaque de las Provincias para 1880, p. 159; Sala, Història de Lo Rat, pp. 65-66.

${ }^{267}$ Sala, Història de Lo Rat, p. 69.

${ }^{268}$ La Ilustración Valenciana: ciencias, letras y artes, 15-I-1887; Anónimo, "Lo Rat Penat", Almanaque de las Provincias para 1882, p. 229; Sala, Història de Lo Rat, pp. 80-81.
} 
música $^{269}$. Especialmente concurrida y animada fue una sesión celebrada en marzo de 1885 en la que se leyeron poesías de Llombart, Bodría, Ruiz Carruana, Cruz Martí, Gascó, Barber, Algarra y en cuyos intermedios se interpretaron al piano y armónium selectas composiciones de autores mayoritariamente valencianos, entre otras algunas de Amancio Amorós:

En los intermitjos s'eixecutaren al piano i harmònium selectes composicions, cridant l'atenció lo Impromtuo [sic], que interpretà admirablement lo jove Sr. Plasència; lo Trémolo de Gottschalk, que sostingué ab gran igualtat i delicadesa l'inteligent artiste Sr. Benavent; la Barcarola sense paraules de Mendelsshon, en sol menor, que interpretaren ab gust exquisit lo Sr. Espí i lo citat Sr. Benavent, així com la graciosa Serenata d'Espí, quals composicions foren molt aplaudides, obtenint l'honor de la repetició.

Los Srs. Amorós i Plasència donaren a conéixer tres números dels huit quadros que sobre motius d'aires populars premià Lo Rat Penat $[\ldots]^{270}$.

El traslado de la sede social de Lo Rat Penat la entidad a la calle Embajador Vich en 1896 se celebró con una solemne sesión inaugural en la que se leyeron diversas poesías $^{271}$ y se escucharon composiciones de Manuel Penella, Amancio Amorós, José Ma Úbeda, Lamberto Alonso e Higinio Vives, con las intervenciones del Orfeón Infantil y la Cámara Obrera. En junio de 1906 Lo Rat Penat volvió a cambiar de sede social y de nuevo lo celebró con una velada literario-musical en la que se recitaron poesías ${ }^{272}$. La sociedad organizaba cada año en la Feria de Julio de Valencia, dentro de los Juegos

\footnotetext{
269 Almanaque de las Provincias para 1882, p. 230; Almanaque de las Provincias para 1883, p. 140;
} Almanaque de las Provincias para 1884, p. 309.

${ }^{270}$ Lo Rat Penat: periodich lliterari quincenal, 15-III-1885, p. 48. [En los intermedios se ejecutaron al piano y armónium selectas composiciones, llamó la atención el Impromptu, que interpretó admirablemente el joven Sr. Plasencia, el Trémolo de Gottschalk, que mantuvo con gran igualdad y delicadeza el inteligente artista Sr. Benavent; la Barcarola sin palabras de Mendelsshon, en sol menor, que interpretaron con gusto exquisito el Sr. Espí y el Sr. Benavent, así como la graciosa Serenata de Espí, todas estas composiciones fueron muy aplaudidas, obteniendo el honor de la repetición. Los señores Amorós y Plasencia dieron a conocer tres números de los ocho cuadros que sobre aires populares premió Lo Rat Penat].

${ }^{271}$ Las poesías eran de Llorente, Palanca i Hueso, Puig Torralba, Cebrián, Bodría, Espiau, Cabrelles, Roig Bataller, Bonet Alcantarilla, Epila, Trénor, Serrat, Gimeno y Alufre.

${ }^{272}$ Sala, Història de Lo Rat, pp. 111, 127. 
Florales, un Certamen de Composición del que daré más detalles al estudiar la figura de Amancio Amorós (ver Ilustración 5).

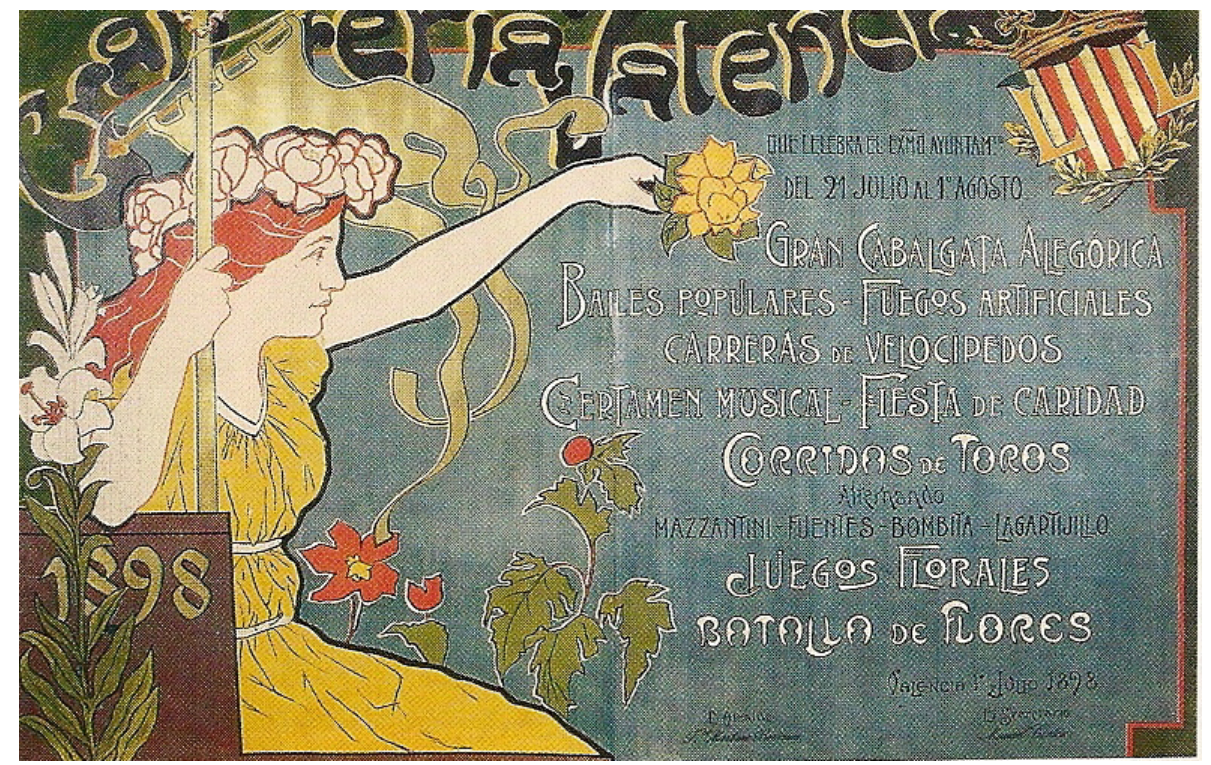

Ilustración 5

Cartel de la Feria de Valencia (1898).

Historia de Valencia, p. 524.

En la Tabla 13 presento los presidentes de Lo Rat Penat y de su sección de música entre 1878 y 1904, Amancio Amorós estuvo al frente de la misma en 1883-84 y 1892-95. 
Tabla 13. Presidentes de Lo Rat Penat y de su sección de Música entre 1878 y 1904.

Fuentes: Almanaque de las Provincias para 1880, p. 162; 1882 (p. 233); 1883 (p. 143); 1884 (p. 311 ); 1893 (p. 117); 1894 (pp. 129-132); 1895 (pp. 215-218); 1896 (p. 124); 1902 (p. 304); Sala, Història de Lo Rat, pp. 105-107, 114-116.

\begin{tabular}{|c|c|c|}
\hline Años & Presidente entidad & Presidente sección música \\
\hline $1878-79$ & Félix Pizcueta & - \\
\hline $1879-80$ & Teodoro Llorente & Manuel Penella \\
\hline $1880-81$ & Jacinto Labaila & Salvador Giner \\
\hline $1881-82$ & Rafael Ferrer i Bigné & José Jordá \\
\hline $1882-83$ & Vicente Pueyo Ariño & Agustín Payá \\
\hline $1883-84$ & Fernando Reig García & Amancio Amorós \\
\hline $1884-86$ & Félix Pizcueta & José Espí \\
\hline $1886-87$ & Cirilo Amorós & José Espí \\
\hline $1887-88$ & Pascual Frígola (Barón de Cortes) & Eduardo Ximénez \\
\hline $1888-89$ & Barón de Cortes & Salvador Giner \\
\hline $1889-90$ & Luis Cebrián Mezquita & Ignacio Vidal Teruel \\
\hline $1890-91$ & Luis Cebrián & José Espí \\
\hline $1891-92$ & Pascual Frívola (Barón de Cortes) & Ignacio Vidal Teruel \\
\hline $1892-93$ & Barón de Cortes & Amancio Amorós \\
\hline $1893-94$ & Honorato Berga Garcías & Amancio Amorós \\
\hline $1894-95$ & Honorato Berga Garcías & Amancio Amorós \\
\hline $1895-96$ & $\begin{array}{c}\text { Honorato } \\
\text { Berga Garcías }\end{array}$ & $\begin{array}{c}\text { Ignacio Vidal Teruel } \\
\text { Salvador Giner (honorario) }\end{array}$ \\
\hline $1896-97$ & $\begin{array}{c}\text { Honorato } \\
\text { Berga Garcías } \\
\end{array}$ & Manuel Penella \\
\hline $1897-98$ & $\begin{array}{c}\text { Honorato } \\
\text { Berga Garcías }\end{array}$ & Manuel Penella \\
\hline $1898-99$ & $\begin{array}{c}\text { Honorato } \\
\text { Berga Garcías }\end{array}$ & Manuel Penella \\
\hline 1899.1900 & Teodoro Llorente & Manuel Penella \\
\hline 1900-1901 & Teodoro Llorente & Manuel Penella \\
\hline 1901-1902 & Honorato Berga Garcías & Manuel Penella \\
\hline $1902-1903$ & Honorato Berga Garcías & Ignacio Vidal? \\
\hline 1903-1904 & José Ruiz de Lihory & Eduardo López-Chavarri \\
\hline
\end{tabular}

El Iris

La Sociedad recreativa El Iris, creada en 1879, se proponía cultivar el arte, la literatura y las ciencias: "Será objeto de esta Sociedad el cultivo de las bellas letras, ciencias y artes, y cuantos objetos puedan servir de honesto solaz para los socios y sus familias"273. La sociedad se definía como "familiar recreativa-artística-literaria" y tenía su sede en la calle Libreros, donde llegó a disponer de un salón de teatro y uno de baile,

${ }^{273}$ Vicente Roig Condomina, "El Iris (1878-1882): Un ejemplo de Sociedad Recreativa valenciana del siglo XIX promotora del arte”, Ars Longa, 9-10 (2000), p. 239. 
un pequeño casino y un jardín de invierno para celebrar tertulias de señoras ${ }^{274}$. El Iris organizaba sesiones literario-musicales periódicamente, así como representaciones teatrales y conciertos. Un ejemplo de la estructura y repertorio de estas funciones puede verse en la Tabla 14, que muestra el programa de una velada extraordinaria organizada por El Iris en el Teatro principal de Valencia en 1879.

Tabla 14. Programa interpretado en el Teatro Principal de Valencia el 29-X-1879, con motivo de una función extraordinaria de la sociedad $E$ l Iris.

Fuente: E:VAa, Sección III, Asociaciones Culturales, Sociedad Artístico-Musical (1878-1883).

\begin{tabular}{|c|c|c|}
\hline Título & Autor & Intérpretes \\
\hline Marcha del Profeta & No consta & $\begin{array}{c}\text { Sociedad de Conciertos y Banda } \\
\text { del Regimiento de Otumba }\end{array}$ \\
\hline Schotis & No consta & $\begin{array}{c}\text { Coros del Ateneo Casino Obrero } \\
\text { acompañados por la Sociedad de } \\
\text { Conciertos }\end{array}$ \\
\hline \multicolumn{3}{|c|}{ Lectura de poesías } \\
\hline Capricho elegante & Colomer & Consuelo del Rey de Fambuena \\
\hline Romanza de la ópera Aida & & $\begin{array}{l}\text { Adela Montagud (voz), Francisco } \\
\text { Goérlich (Piano) }\end{array}$ \\
\hline $\begin{array}{c}\text { Marcha fúnebre en el entierro de } \\
\text { una marioneta }\end{array}$ & [Charles] Gounod & Sociedad de Conciertos \\
\hline El Grumete (zarzuela en un acto) & $\begin{array}{l}\text { [Emilio] Arrieta, con texto de } \\
\text { [Antonio] García Gutiérrez }\end{array}$ & Compañía de Cereceda \\
\hline La Primavera & No consta & $\begin{array}{l}\text { Coro de niños de la Escuela de } \\
\text { Artesanos acompañados por la } \\
\text { Sociedad de Conciertos }\end{array}$ \\
\hline \multicolumn{3}{|c|}{ Lectura de poesías } \\
\hline $\begin{array}{c}\text { Aria de las joyas de la ópera } \\
\text { Faust }\end{array}$ & No consta & $\begin{array}{c}\text { Adela Montagud (voz) } \\
\text { acompañada por la Sociedad de } \\
\text { Conciertos }\end{array}$ \\
\hline $\begin{array}{c}\text { Fantasía sobre motivos del Faust } \\
\text { para piano y armónium }\end{array}$ & No consta & $\begin{array}{c}\text { Consuelo del Rey y Francisco } \\
\text { Goérlich }\end{array}$ \\
\hline Concierto en Sol menor & [Félix] Mendelsshon & Rafael Gil \\
\hline $\begin{array}{c}L^{\prime} \text { Estasi, vals brillante para canto } \\
\text { y piano }\end{array}$ & [Luigi] Arditi & $\begin{array}{c}\text { Adela Montagud (voz), Consuelo } \\
\text { del Rey (piano) }\end{array}$ \\
\hline Gran polonesa de Concierto & Sánchez Madrid & $\begin{array}{l}\text { Sociedad de Conciertos y Banda } \\
\text { del Regimiento de Otumba }\end{array}$ \\
\hline
\end{tabular}

La sociedad El Iris también organizó un certamen musical en 1880, aunque en una línea diferente a los de la Sociedad Económica, ya que El Iris premiaba habaneras, valses y rigodones. La obra más destacada de este certamen fue la polonesa a voces solas

${ }^{274}$ Roig, "El Iris", p. 239. 
titulada Inspiración, de Eduardo Ximénez ${ }^{275}$. El Iris se disolvió en 1882 por desavenencias entre sus socios ${ }^{276}$.

\section{Círculo Católico-Obrero Cooperativo de San Vicente Ferrer}

Sociedad creada en 1881, establecida en la Plaza de Correo Viejo 1 cuyo objeto era propagar entre la clase obrera la instrucción, buenas costumbres y proporcionarle medios para su distracción. El Círculo disponía de un salón de recreo y una biblioteca y celebraba veladas literario-musicales en honor a San Vicente Ferrer y conferencias dominicales religiosas, científicas, literarias, sociales, de industria y artes. La Sociedad contaba con varias escuelas: dos de instrucción primaria, una para adultos y otra para niños, una de música con cincuenta alumnos y otra de dibujo con cincuenta y tres ${ }^{277}$.

\section{Círculo de Bellas Artes}

Esta sociedad surgió en 1894, cuando un grupo de artistas decidió crear un centro de reunión, estudio, trabajo, exposición y venta de obras de arte. El Círculo de Bellas Artes tuvo cuatro secciones: exposiciones, clase, veladas y fiestas, y excursiones. La sociedad tuvo una excelente acogida y contó con el apoyo de artistas como Joaquín Sorolla y Emilio Sala, entre otros. El Círculo organizó exposiciones y conferencias, y editó diversas publicaciones ${ }^{278}$. En la década de los 90 , los actos de inauguración de las exposiciones organizadas por el Círculo contaban con la participación del sexteto Goñi,

\footnotetext{
275 Almanaque de las Provincias para 1881, pp. 256-257.

${ }^{276}$ Roig, “E1 Iris”, p. 239.

${ }^{277}$ E:VAseap, C. 222, III-Educación n ${ }^{\circ} 16$, Documentación relativa a las escuelas públicas y privadas que existen en la ciudad de Valencia (1883).

${ }^{278}$ Vicente Roig Condomina, "Algunes notes sobre els inicis del Cercle de Belles Arts de València i la seua activitat en el segle XIX”, Ars Longa, 7-8 (1996-97), pp. 240-241.
} 
que solía interpretar obras de Giacomo Meyerbeer, Charles Gounod, Pietro Mascagni, Jules Massanet, Georges Gillet y Carlo Pedroti, entre otros ${ }^{279}$.

En 1900 el Círculo de Bellas Artes convocó un concurso para premiar la mejor zarzuela en un acto que se presentara. Resultó ganadora Tute de Caballos, cuyo autor no consta $^{280}$. En la sede del Círculo de Bellas Artes se celebraron, en 1903, conciertos sinfónicos organizados por Eduardo López-Chavarri Marco. En 1911 el Círculo convocó un concurso de composición orquestal, en el que se ofrecía un premio a la mejor suite sinfónica sobre temas populares valencianos y otro a la mejor rapsodia también inspirada en cantos populares valencianos ${ }^{281}$.

\section{Asociación de Profesores Músicos de Santa Cecilia}

La Asociación surgió cuando algunos profesores músicos comenzaron a reunirse anualmente en la Capilla de Nuestra Señora de la Seo (ó del Milagro) el día de Santa Cecilia (22 de noviembre) para celebrar una misa por invitación del comité de redacción de la Biblioteca Sacro Musical. En 1895 los asistentes a la misa decidieron redactar un reglamento para fundar una asociación de profesores músicos bajo la advocación de Santa Cecilia ${ }^{282}$. La Asociación perseguía fines religiosos: honrar a su patrona y mejorar las costumbres católicas de los profesores músicos de la ciudad de Valencia, visitar y ayudar moralmente a los enfermos, celebrar comuniones mensuales, evangelizar a los músicos en general y ayudar a los músicos con menos recursos económicos ${ }^{283}$. En 1896

\footnotetext{
${ }^{279}$ Las Provincias, 12-V-1894; Las Provincias, 18-V-1895.

${ }^{280}$ Boletín Musical, 20-III-1900, p. 1684.

${ }^{281}$ Aviñoa, "La creació”, pp. 245-246.

${ }^{282}$ Loras, La Asociación, pp. 11, 15-16.

${ }^{283}$ Podrían establecerse ciertas similitudes entre la Asociación de profesores de Santa Cecilia de Valencia y las nacidas en España a mediados del siglo XVI; véase José López-Calo, "Cien años de asociaciones de música religiosa”, Cuadernos de Música Iberoamericana, 8-9 (2001), p. 288.
} 
asistieron a la misa de Santa Cecilia muchos más músicos que en celebraciones anteriores, invitados por Salvador Giner. Esa misma noche los profesores reunidos leyeron el Reglamento (redactado por José Ma Úbeda, Manuel Sacanelles, Antonio Pastor y el presbítero Miguel Sarrió) que fue expuesto en el Conservatorio de Música de Valencia y en la casa de los editores Antich y Tena para que se sugirieran posibles modificaciones.

El 22 de enero de 1897 la Asociación de Santa Cecilia celebró su Primera Asamblea en el Salón de Juntas de la Real Capilla de la Seo de Valencia, que fue la sede de la Asociación hasta 1948. En esta Asamblea se aprobó el Reglamento y se procedió al nombramiento de la Junta Directiva de la Asociación por un periodo de cuatro años. La Junta la integraron: Salvador Giner (Presidente), Vicente Ripollés (Vicepresidente), Amancio Amorós (Secretario), Antonio Pastor (Vicesecretario), José Medina y Matías Guillén (Visitadores), José Ma Úbeda (Tesorero) y Miguel Sarrió (Consiliario) ${ }^{284}$.

La Asociación contaba con dos clases de socios, los numerarios (a la que pertenecían los músicos), quienes tenían la obligación de cumplir con lo preceptuado en el Reglamento) y los supernumerarios, que sólo tenían la obligación de pagar las cuotas. En 1897 la entidad contaba con 49 socios numerarios y 26 supernumerarios y en 1900 estas cifras eran de 69 numerarios y 60 supernumerarios. La Asociación celebraba sus juntas generales en la Sala de Juntas del Milagro, y las juntas directivas se celebraban en casa del presidente o en la de cualquier otro directivo. Desde su fundación la precariedad económica fue una constante, ya que la entidad se mantenía con las cuotas de sus socios, de ahí la necesidad de atraer más socios, y organizar rifas de libros u otros objetos en los

\footnotetext{
${ }^{284}$ La Música Religiosa en España, 15 (1897), p. 238, este boletín comentó que la Asociación, creada en Valencia, bajo la advocación de Santa Cecilia, estaba destinada a "moralizar" la música en el templo; Las Provincias, 17-II-1897; Loras, La Asociación, pp. 3-9. El cardenal Ciriaco M Mancha concedió 100 días de indulgencia a cada uno de los asociados y fieles que, con limosnas o de cualquier otro modo, contribuyeran a los fines de la Asociación.
} 
actos que organizaba la asociación (conferencias, comuniones, la festividad de Santa Cecilia y en las Misas de Réquiem por los asociados difuntos). En el funcionamiento de esta sociedad hubo tensiones, ya que los músicos católicos practicantes, lamentaban que los músicos anticatólicos vivieran a expensas de la iglesia. En 1900 se acordó que sólo podrían tocar en las funciones religiosas de la asociación los músicos practicantes, aunque el acuerdo llegó finalmente a desestimarse. Como hubo muchas bajas de socios, se pensó en fusionar la Asociación de Santa Cecilia con otra asociación valenciana, la Hermandad y Congregación de Profesores Músicos bajo la protección de San Vicente Ferrer y Nuestra Señora de los Desamparados. Esta fusión al final no llegó a $\operatorname{producirse}^{285}$.

\section{Círculo Musical/ Ateneo Musical}

El Círculo Musical se creó en 1900 y pretendía agrupar a la "nobilísima clase de profesores músicos, estrechar los lazos de amistad y compañerismo [...] y al mismo tiempo fomentar los intereses propios de la clase"286. La sesión inaugural de esta entidad se celebró en el Conservatorio de Música y Declamación de Valencia y a ella acudieron profesores de las orquestas Goñi y Valls y del Teatro Ruzafa, pianistas, organistas, maestros compositores, cantantes y editores de música. Para dar forma al proyecto que pretendían constituir se nombraron las siguientes comisiones:

1) Por las voces: Vicente Chulvi, Francisco López, Facundo Domínguez, Juan Bautista Pons, Álvaro Llario y Miguel Gea.

\footnotetext{
${ }^{285}$ Loras, La Asociación, pp. 16-17. Véase Reglamento de la Hermandad y Congregación de Profesores Músicos bajo la protección de San Vicente Ferrer y Nuestra Señora de los Desamparados (Valencia: La Hermandad, 1863).

${ }^{286}$ Boletín Musical, 20-III-1900, pp. 1680-1681. Reglamento para el régimen y buen gobierno del Círculo Musical de Valencia, p. 2, Capítulo I, artículo $1^{\circ}$ "Del objeto del Círculo".
} 
2) Por los instrumentistas (no pianistas): Francisco García, Matías Guzmán, Raimundo Calvo, Antonio Montesinos, José Marís Martel, Luis Tárrega, Juan Llana, Tomás Martínez y José Peiró.

3) Por los pianistas: Juan Tomás, Eugenio Úbeda, Miguel Benllonch y Bernardo Úbeda.

4) Por los editores: Francisco Antich y Antonio Sánchez Ferrís.

5) Por los maestros compositores: Rigoberto Cortina, Amancio Amorós y Francisco Calabuig.

En la sesión inaugural se eligió una Junta Directiva interina que presentó un proyecto de Reglamento $^{287}$. Finalmente el Reglamento para el régimen y buen gobierno del Círculo Musical de Valencia se aprobó el 24 de marzo de $1902^{288}$. El número de músicos adheridos al Círculo Musical Valenciano en 1900 era de 148 y al cabo de dos meses eran ya $248^{289}$. En 1911 el Círculo Musical cambió su denominación por el de Ateneo Musical y gracias a la iniciativa de éste, surgió en 1916 la Orquesta Sinfónica de Valencia $^{290}$.

\section{Centro Escolar y Mercantil}

Este centro, núcleo del asociacionismo católico valenciano, ubicado en la calle Libreros 2 de Valencia, fue fundado por el jesuita José Conejos en $1912^{291}$. Aunque se llamó escolar y mercantil, se dedicó más a actividades educativas y culturales que a

\footnotetext{
${ }^{287}$ Boletín Musical, 30-III-1900, p. 1687.

${ }^{288}$ Reglamento para el régimen y buen gobierno del Círculo Musical de Valencia (Valencia: Papelería de José Ferrándis, 1902).

${ }^{289}$ Boletín Musical, 30-III-1900, pp. 1681 y 1687.

${ }^{290}$ Sancho, Romanticismo, pp. 168, 230.

${ }^{291}$ Manuel Revuelta González, Compañía de Jesús en la España Contemporánea (Madrid: Universidad Pontificia Comillas, 1984), vol. 3, p. 569; Enrique Lull Martí, Jesuitas y pedagogía: El Colegio de San José en la Valencia de los años veinte (Madrid: Universidad Pontificia Comillas, 1997), p. 632.
} 
mercantiles. Desde 1916 hasta 1931 el centro editó una revista propia, Oro de ley, publicación semanal ilustrada desde la que se potenciaban sus actividades ${ }^{292}$.

El Centro Escolar y Mercantil se organizó en secciones, conocidas también como academias: academia de medicina y derecho, filosofía y letras, ciencias, bellas artes, academia de literatura y declamación, de música (conservatorio), industria y comercio, bachillerato, taquigrafía, correos, fomento industrial y mercantil, prensa y aduanas. Las sesiones de apertura y clausura de estas academias revestían una cierta solemnidad y eran presididas por personalidades relevantes ${ }^{293}$.

La sección de música integrada por Facundo Domínguez, Francisco Salomón, Vicente Carrión, Juan Sánchez Roglá, Juan Salvador, Martínez Ercilla y Vilana, entre otros, dispuso de un coro y una orquesta propia desde 1917 y celebraba veladas literariomusicales en honor a Santa Cecilia ${ }^{294}$. En la Tabla 15 incluyo el programa dos veladas literario-musicales presididas por Amancio Amorós y dirigidas por el director de la sección de Música, Emilio Martí Alonso. El programa incluía además discursos y lectura de poesías.

\footnotetext{
292 María Fernanda Mancebo, La Universidad de Valencia: de la monarquía a la república, 1919-1939 (Valencia: Universitat de Valencia, 1994), p. 79; Almanaque de las Provincias para 1928, p. 167.

${ }^{293}$ Mancebo, La Universidad de Valencia, p. 80. Mariano Peset Reig (coord.), Historia de la Universidad de Valencia (Valencia: Servei de Publicacions de la Universitat de València, Patronat Cinc Segles, 19992000), vol. 3, p. 112.

${ }^{294}$ Oro de ley, 8-12-1917, p. 429; Oro de ley, 6-VI-1919, p. 352.
} 
Tabla 15. Programa interpretado en las veladas literario-musicales del Centro Escolar y Mercantil de Valencia.

Fuentes: Oro de ley, 29-IV-1917, p. 211; Oro de ley, 6-V-1917, pp. 220-222; Oro de ley, 10-II-1918, p. 103.

\begin{tabular}{|c|c|c|}
\hline Autor & Título & Intérpretes \\
\hline \multicolumn{3}{|c|}{29 abril de 1917} \\
\hline [Giacomo] Meyerbeer & $\begin{array}{c}\text { Marcha de la Coronación de la } \\
\text { ópera El profeta }\end{array}$ & $\begin{array}{c}\text { Violinistas: Burgos, Goerlich y } \\
\text { Sánchez clarinetista: Río Cosa } \\
\text { piano: Rafael Burgos }\end{array}$ \\
\hline No consta & Canción Napolitana & Juan Salvador \\
\hline No consta & L'emigrant & Coro de la sección musical \\
\hline Salvador Giner & $\begin{array}{l}\text { Romanza del tercer acto de la ópera } \\
\text { Sagunto }\end{array}$ & Facundo Domínguez \\
\hline No consta & Fantasía para clarinete & $\begin{array}{c}\text { Clarinete: no consta } \\
\text { Piano: Pérez del Río-Cosa }\end{array}$ \\
\hline Paolo Tosti & Povera Rosa & Francisco Salomón \\
\hline [Edvard] Grieg & Patria Nueva & No consta \\
\hline $\begin{array}{c}\text { [Miguel] Asensi, letra } \\
\text { M. Thous }\end{array}$ & Cançons del poble & No consta \\
\hline \multicolumn{3}{|c|}{ Febrero 1918} \\
\hline Juan Sánchez Roglá & Sección Musical & Grupo instrumental \\
\hline No consta & O paraíso de La Africana & No consta \\
\hline No consta & $\begin{array}{c}\text { Himno del Centro Escolar y } \\
\text { Mercantil }\end{array}$ & No consta \\
\hline [Paul] Lincke & Lysistrata & No consta \\
\hline $\begin{array}{l}\text { [José María] } \\
\text { Usandizaga }\end{array}$ & Romanza & No consta \\
\hline [Juan] Sesé & Viva Aragón & No consta \\
\hline Facundo Domínguez & Serenata & No consta \\
\hline [Giuseppe] Verdi & Credo de Otello & No consta \\
\hline [Giuseppe] Verdi & Dueto de la Forza del Destino & No consta \\
\hline [Jules] Massenet & Escenas Pintorescas & No consta \\
\hline [Gioachino] Rossini & La Caridad & No consta \\
\hline $\begin{array}{c}\text { [Miguel] Asensi, letra } \\
\text { M. Thous }\end{array}$ & Cançons del poble & No consta \\
\hline
\end{tabular}

\section{Centro de Cultura Valenciana / Real Academia de Cultura Valenciana}

El 7 de enero de 1915, el presidente de la Diputación Provincial de Valencia, José Martínez Aloy creó el núcleo del Centro de Cultura, denominado "Directorio", constituido por doce "directores" de número vitalicios (dos diputados, dos concejales, el cronista de la provincia, el cronista de la ciudad y seis eruditos valencianos) ${ }^{295}$. El diputado valenciano Pérez de Lucía describió así la nueva institución:

\footnotetext{
295 Inicialmente había sólo seis miembros independientes $\mathrm{y}$, debido a ese origen público, tenía representación de las dos entidades públicas que apoyaban institucional y económicamente al Centro,
} 
Se crea por la Diputación un Centro de Cultura Valenciana que tendrá por objeto el de realizar la superior investigación en todos los órdenes de la cultura general y en especial de la valenciana [...]. Este centro, al que se le reconocerá toda la independencia necesaria para cumplir su elevada misión, tendrá plena capacidad jurídica, se dividirá en tantas secciones como exija su propio desenvolvimiento y se regirá por los Estatutos y Reglamentos formados por una comisión que designe la Diputación, la que quedará facultada para designar a las personas peritas que estime nombrar ${ }^{296}$.

Desde diciembre de 1915 el centro experimentó diversas reestructuraciones internas. El presidente de la entidad era denominado Director Decano. Los socios de la entidad eran de varias categorías y todos recibían también la denominación de "directores":

a. Directores numerarios (seis eruditos, dos cronistas, dos diputados provinciales y dos concejales del Ayuntamiento valenciano, a los que se añadieron desde diciembre de 1915 tres delegados).

b. Directores consiliarios (que habían sido anteriormente directores efectivos por razón de sus cargos provinciales y ya habían dejado de serlo).

c. Directores honoris causa u honorarios: personalidades eminentes de cualquier procedencia que hubiesen demostrado interés en beneficio de las ciencias o artes en el antiguo Reino de Valencia.

d. Directores Correspondientes (cronistas de las Diputaciones y Ayuntamientos valencianos y eruditos residentes en la comunidad valenciana).

e. Directores Corresponsales (eruditos residentes fuera de la Comunidad Valenciana).

como eran la Diputación y el Ayuntamiento, de manera que a los seis miembros de hecho se sumaron dos diputados y dos concejales, más los cronistas tanto de la provincia como del Ayuntamiento de Valencia.

296 Anónimo, "Los L años del Centro de Cultura Valenciana, crónica de la conmemoración jubilar", Anales del Centro de Cultura Valenciana, 50, pp. 9-10; véase también Almanaque de las Provincias para 1916, pp. 137-140. 
f. Directores a dignitate numeris, creados en abril de 1920, que eran, personas que habían ejercido cargos públicos o habían cooperado en la obra cultural del Centro.

g. Directores artistas, categoría a la que perteneció Amancio Amorós Sirvent desde 1921 hasta su muerte ${ }^{297}$.

\section{2. La Sociedad de Cuartetos Valenciana y otras agrupaciones de cámara}

A imitación de la Sociedad de Cuartetos madrileña, creada en febrero de 1863 por el maestro santanderino Jesús de Monasterio, Salvador Giner organizó en 1868 en Valencia una primera "Sociedad de Cuartetos", para promover la música de cámara entre los valencianos ${ }^{298}$. El conjunto de cuerda estaba formado por Salvador Giner (violín), Enrique Prosper (violín), Antonio Marco (viola) y Salvador Girona (violoncello). Durante los meses de marzo y abril de 1868, la Sociedad de Cuartetos ofreció dos conciertos en el Círculo Valenciano en los que, junto a la interpretación de obras religiosas, se interpretaron obras de cámara de Beethoven, Mozart, Krommer y una transcripción para septeto de la sinfonía $n^{o} 5$ de Beethoven. Esta Sociedad de Cuartetos valenciana tuvo una vida efímera, ya que desapareció el mismo mes de abril de 1868, tras participar en unos funerales celebrados en la iglesia de San Bartolomé de Valencia. El principal motivo para su desaparición, a pesar del éxito obtenido en los dos conciertos celebrados fue, según Sancho, la falta de un espacio idóneo para celebrar los $\operatorname{conciertos}^{299}$.

En 1890, el violinista Andrés Goñi y el profesor de piano del Conservatorio de Valencia Roberto Segura crearon una segunda Sociedad de Cuartetos de Valencia que

\footnotetext{
${ }^{297}$ Anónimo, “Los L años del Centro”, pp. 11-12.

${ }^{298}$ En Barcelona, l'Ateneu Català desde 1860 y el Centre Artístic desde 1866, fueron dos entidades que tuvieron un importantísimo papel en la difusión de la música de cámara; véase Comellas, El Romanticisme musical, pp. 126-133.

${ }^{299}$ Sancho, Romanticismo, pp. 220-221.
} 
continuó activa hasta $1901 \mathrm{y}$, con actuaciones intermitentes, hasta 1911. La nueva sociedad la integraron además de Andrés Goñi, como director y primer violín, los alumnos de cuerda del Conservatorio de Valencia Luis Sánchez (violín), José Lluch (viola) y Raimundo Calvo (violoncello) y el citado pianista Roberto Segura. El primer concierto de esta Sociedad de Cuartetos tuvo lugar en el Conservatorio de Valencia el 21 de febrero de 1890, como destacó la prensa del momento:

Con mucha brillantez inauguró anoche los conciertos de música clásica la Sociedad de Cuartetos de reciente constituida [sic] en esta capital bajo la dirección de los distinguidos profesores del Conservatorio Sres. Segura y Goñi, a quienes secundan los aventajados discípulos de dicho centro Sres. Sánchez, Lluch y Calvo, que tocan respectivamente el violín, la viola y el violoncello ${ }^{300}$.

La Sociedad de Cuartetos valenciana actuó asiduamente en los conciertos "clásicos" que se organizaron en Conservatorio de Valencia durante los cursos 1891, 1892 y $1894^{301}$ y participó en veladas y sesiones inaugurales de apertura de curso de diversas instituciones valencianas, como el Instituto para la Enseñanza de la Mujer (véase Capítulo 3 “Actividad Docente de Amancio Amorós"), la Academia de la Juventud Católica y el Ateneo Casino Obrero. Un ejemplo del seguimiento que la prensa del momento hacía de la Sociedad de Cuartetos es la siguiente reseña:

La sesión inaugural de la Institución para la enseñanza de la Mujer tendrá lugar a las seis de la tarde en su local, calle de D. Juan de Villarrasa, 12, segundo.

Se halla encargada del discurso la señorita doña Julia Alarcón, profesora de dibujo en el citado establecimiento de enseñanza. El secretario general, D. Aniceto Sela, dará cuenta de los trabajos realizados por dicha Institución en el pasado curso.

Un cuarteto compuesto por los reputados profesores Sres. Goñi, Muní, Lluch y Calvo, ejecutará durante el acto las siguientes obras: Andante para instrumentos de cuerda, de Haydn; Adagio cantabile, de Mozart; Canzonetta, de Mendelssohn; y Minueto, de Mozart $^{302}$.

\footnotetext{
${ }^{300}$ El Mercantil Valenciano, 22-II-1890.

${ }^{301}$ Boletín Musical, 28-II-1894, pp. 204-205.

${ }^{302}$ El Mercantil Valenciano, 16-XI-1890.
} 
En ocasiones el cuarteto se ampliaba por necesidades interpretativas y pasaba a denominarse Quinteto Goñi o Sexteto Goñi, o incorporaba a otros músicos, como Doñate (viola), Luis Gallego (violoncello), Matías Guzmán (contrabajo) y José Bellver (piano). Estas agrupaciones de cámara participaban en todo tipo de funciones, desde conciertos, veladas literario-musicales y exposiciones hasta veladas nocturnas en cafés valencianos como el Café España, Café Eslava o Café París, entre otros ${ }^{303}$.

A partir de 1900 surgieron en Valencia nuevos conjuntos de cámara: Cuarteto Calvo, Trío Casanovas y varios dúos de piano y violín, y piano y violoncello. El mismo año 1900 Valencia recibió la visita de importantes concertistas internacionales (Pau Casals, Enrique Granados, Telmo Vela, Raoul Pugno, Mathieu Crickboom) que actuaron en algunas sociedades culturales. En 1901 se inauguró el salón de audiciones "Sánchez Ferrís" para impulsar la música de cámara. Otros escenarios valencianos en los que se ofrecieron conciertos de cámara fueron el Círculo de Bellas Artes, el Teatro Principal, el Salón Eslava y el Ateneo Musical (antiguo Círculo Musical) ${ }^{304}$.

En diciembre de 1911 se fundó la Sociedad Filarmónica de Valencia, entidad privada financiada con las cuotas periódicas de sus socios, y cuyo objetivo básico era la promoción de la música de cámara. En 1912 la Sociedad Filarmónica organizó sus audiciones en el salón de actos del Conservatorio de Valencia, y después pasó a celebrarlos en el Teatro Principal, pero también organizó actuaciones en otros escenarios, como los teatros Apolo, Ruzafa, Eslava y Olimpia. Entre los socios de la Filarmónica

\footnotetext{
${ }^{303}$ Sancho, Romanticismo, p. 227.

${ }^{304}$ Sancho, Romanticismo, pp. 228-230.
} 
había aficionados, artistas y profesores de música de Valencia, entre ellos Amancio Amorós $^{305}$.

\section{3. Movimiento Coral}

Manuel Sancho ha publicado una primera aproximación al movimiento coral valenciano desde sus orígenes en 1850 hasta su consolidación en la primera década del siglo $\mathrm{XX}^{306}$. Basándome en él y en algunas otras fuentes inéditas que he podido manejar, describiré brevemente el contexto coral en el que Amancio Amorós desarrolló su producción.

El desarrollo del movimiento coral español estuvo directamente relacionado con el interés romántico por la expresión del sentimiento nacional y el folklore autóctono, la democratización burguesa de la vida (que permitió el acceso a la cultura de la clase media), el espíritu asociativo propio de la época y el prestigio social que tenía la música en ese momento ${ }^{307}$.

Vicente Galbis sitúa los precedentes del movimiento coral valenciano entre 1840 y 1860, con las actividades corales organizadas en Valencia por aficionados

\footnotetext{
305 A. Vicente Salvá, "La Sociedad Filarmónica. Su vida y su estado actual”, Almanaque de las Provincias para 1924, pp. 86-87; Anónimo, Sociedad Filarmónica de Valencia: Cincuenta años de misión artística, 1912-1962. Memoria (Valencia: Talleres Tipográficos de Semana Gráfica, 1962), pp. 17-19; Las Provincias, 14-I-1912.
}

306 Sancho, "Orfeonismo y canto", pp. 103-126. Otros estudios analizan el fenómeno del movimiento coral en diferentes zonas geográficas del Estado español, véase Jon Bagües, "El coralismo en España en el siglo XIX", en España en la Música de Occidente, Actas del Congreso Internacional (Salamanca, 1985), eds. Emilio Casares, José López-Calo, Ismael Fernández de la Cuesta (Madrid: INAEM, 1987), vol. 2, pp. 173-198; Jaume Carbonell i Guberna, "Las sociedades corales en Cataluña. Visión historiográfica y estado de la cuestión”, Revista de Musicología, 14/1-2 (1991), pp. 113-124; María Nagore Ferrer, "Orígenes del movimiento coral en Bilbao", Revista de Musicología, 14/1-2 (1991), pp. 125-134; María Nagore Ferrer, "La música coral en España en el siglo XIX”, en La música española en el siglo XIX, eds. Emilio Casares y Celsa Alonso (Gijón: Servicio de Publicaciones de la Universidad de Oviedo, 1995), pp. 425-462; Luis Costa, "Coralismo, etnicidad y nacionalismo en Galicia", Cuadernos de Música Iberoamericana, 6 (1998), pp. 49-63.

307 María Nagore Ferrer, "Un aspecto del asociacionismo musical en España: las sociedades corales", Cuadernos de Música Iberoamericana, vol. 8-9 (2001), pp. 211-212. 
pertenecientes a diversas sociedades. El máximo esplendor del movimiento coral valenciano se alcanzó en la década de $1890-1900^{308}$.

La Real Sociedad Económica de Amigos del País de Valencia potenció desde 1850 la actividad coral, impulsando la enseñanza del canto en las Escuelas de instrucción primaria. El pedagogo y compositor valenciano Pascual Pérez Gascón utilizó desde 1850 en el Colegio Real de San Pablo de Valencia su Método de solfeo y principios de canto, basado en el francés Bocquillon-Wilhem y que, según el informe del Conservatorio de Madrid, era la primera obra concebida para la enseñanza musical colectiva ${ }^{309}$. La Sociedad Económica de Amigos del País de Valencia inauguró en febrero de 1851 la Escuela de Música Popular bajo la dirección del mismo Pérez Gascón ${ }^{310}$. El alumnado de esta Escuela Popular estaba constituido por veinte niños pobres, algunos procedentes de los tres orfanatos que existían en Valencia: Misericordia, Beneficencia y Niños de San Vicente. El repertorio interpretado por los grupos corales infantiles de la Escuela Popular en los actos promovidos por la Sociedad Económica estaba formado por obras a dos y tres voces, creadas por el propio Pérez Gascón, himnos patrióticos, canciones infantiles de carácter moralizante, plegarias religiosas y cánones ${ }^{311}$.

\section{Orfeón Valenciano (1862) y Orfeón El Micalet (1893)}

En la década de 1860-70 aparecieron los primeros coros valencianos propiamente dichos. El primero de ellos fue el Orfeón Valenciano. La idea de constituir un coro de

\footnotetext{
${ }^{308}$ Vicente Galbis López, “Coros”, en $D M V$, vol. 1 (2006), pp. 253-260.

${ }^{309}$ Rainbow, "Wilhem, Guillaume Louis Bocquillon”, p. 387.

${ }^{310}$ Según ha constatado Sancho, "Orfeonismo y canto", p. 105, Valencia se convirtió en la primera capital española que implantó el método de enseñanza musical Bocquillon-Wilhem, precediendo a Cádiz (1851) y a Barcelona (1853); Vicente Galbis López, "Un referent per als orfeons Valencians", El Temps, 787, pp. 48-49.

${ }^{311}$ Sancho, “Orfeonismo y canto”, pp. 103-107.
} 
este tipo en Valencia estuvo presente desde mediados de siglo XIX en las sociedades filarmónicas valencianas, según Ruiz de Lihory ${ }^{312}$. En 1861 hubo un intento fustrado de crear un orfeón, pero no fue hasta octubre de 1862 cuando, reunido un número suficiente de voces, y con el apoyo institucional, debutó el Orfeón Valenciano en una serenata ofrecida al Gobernador y Alcalde de Valencia:

Anteayer nos sorprendió agradablemente a las altas horas de la noche, el encuentro con un inesperado coro, compuesto de veinticinco o treinta jóvenes, algunos de ellos muy conocidos en esta ciudad, que hacían resonar en sus calles los primeros cantos orfeónicos que ha escuchado Valencia ${ }^{313}$.

Según Sancho, el fundador del Orfeón Valenciano fue su primer presidente y director, Antonio Serra Montseny; Francisco Javier Blasco, Ruiz de Lihory y más recientemente Vicente Galbis, afirman, sin embargo, que el fundador fue Manuel Penella $^{314}$. El número de componentes del Orfeón valenciano osciló entre veinticuatro y aproximadamente ciento cincuenta cantantes, que en su mayoría eran obreros y artesanos. El Orfeón participaba en serenatas, veladas y sesiones en diversas entidades culturales. En mayo de 1867, actuó en el concierto por la celebración del segundo centenario de la coronación de la Virgen de los Desamparados. A imitación del Orfeón Barcelonés y con el precedente de la Escuela Popular de Música de Valencia, el Orfeón Valenciano inauguró el 9 de mayo de 1863, en la Casa-Enseñanza, una Escuela gratuita elemental de música para las clases trabajadoras, que desapareció en septiembre del mismo año por

\footnotetext{
${ }^{312}$ Ruiz de Lihory, La música en Valencia, p. 39.

${ }^{313}$ La Opinión, 26-X-1862.

${ }^{314}$ La afirmación de Sancho resulta más convincente, ya que se apoya en la prensa del momento (Diario Mercantil de Valencia, 10-III y 13-X-1863), Sancho, "Orfeonismo y canto", pp. 109-110; Blasco, La música en Valencia, p. 84; Ruiz de Lihory, La Música en Valencia, p. 355; Galbis, "La educación musical", p. 84.
} 
falta de apoyo municipal ${ }^{315}$. El Orfeón Valenciano siguió también el modelo del Orfeón Barcelonés en cuanto a repertorio y funcionamiento interno ${ }^{316}$. En su repertorio, el Orfeón Valenciano incluyó obras de músicos locales como José Vidal y José Jordá, obras de sus directores Antonio Serra, Juan García y, sobre todo, Juan Tolosa, fragmentos corales de ópera y zarzuela, y títulos de Josep A. Clavé y Laurent de Rillé. La mayoría de estrenos y actuaciones del Orfeón Valenciano tuvieron lugar en sus primeros años de creación (1862-1864). Tras una etapa de crisis y pocas actuaciones (1864-1866) el grupo se reorganizó en 1867 para participar en las Fiestas del Centenario de la Virgen e interrumpió sus actuaciones en $1868^{317}$.

El Orfeón Valenciano sirvió de modelo para la aparición de otras agrupaciones valencianas, como el Orfeón Apolo y el Orfeón Ceciliano en la misma década de los 60. En 1862 la prensa constató el éxito del movimiento coral valenciano:

La creación de las sociedades corales valencianas es ya un hecho realizado, el público acude con avidez a escuchar sus cantos y los aplaude con entusiasmo; que esta animación no decaiga, que se fomente tan buen espíritu, que se aumenten los individuos del actual Orfeón, que se creen otras sociedades análogas, que se funden otras escuelas de canto, y podremos llegar un día a la altura en que hoy se encuentra Barcelona. Si esto sucede, como lo esperamos, la gloria de la iniciativa pertenecerá siempre a la primera sociedad coral establecida en esta población, al Orfeón Valenciano ${ }^{318}$.

El Orfeón Apolo, constituido por treinta coralistas bajo la batuta de Jaime Puchades, se presentó el 15 de noviembre de 1862 en una serenata con acompañamiento

\footnotetext{
${ }^{315}$ E:VAa, Sección III, Sub. G Instrucción Pública, Clase III (Enseñanza Artística y Literaria), Subclase B, Escuelas de música (1865-1902), nº 1, Circular del Sr. Gobernador relativa a las escuelas de música existentes en esta ciudad y el estado y progreso de las mismas (1865).

${ }^{316}$ Jaume Carbonell i Guberna, "El cant coral”, en HMCVB, vol. 3 (1999), p. 183.

${ }^{317}$ Sancho, “Orfeonismo y canto", pp. 110-112.

${ }^{318}$ Diario Mercantil de Valencia, 29-XII-1862.
} 
de banda de música ante las autoridades municipales. También a finales de 1862 nació el Orfeón Ceciliano, pero ambas entidades desaparecieron en $1863^{319}$.

Valencia, como el resto de España vivió una crisis del movimiento coral entre 1868 y $1892^{320}$. El Orfeón Valenciano se disolvió en 1868 y en la década de 1870-1880 los coros de las escuelas de música de la Escuela de Artesanos y el Ateneo CasinoObrero participaron en diversos actos (veladas literario-musicales, conciertos, funciones religiosas, serenatas, carnavales y festivales benéficos), paliando la ausencia de orfeones propiamente dichos. En 1880 volvió a constituirse el Orfeón Valenciano, que tuvo actuaciones hasta 1883 , pero de nuevo su trayectoria fue muy irregular, con fases de completa inactividad. Hubo también actuaciones corales de los alumnos de las escuelas municipales de música y de las instituciones benéficas valencianas (Colegio San Vicente Ferrer, Misericordia, Casa de Beneficencia) y las de la Academia de la Juventud Católica, el Iris y la Amistad Artística ${ }^{321}$.

En 1893 se inicia, según el Boletín Musical, la consolidación del movimiento orfeonístico valenciano. La llegada a Valencia de cantores de los Coros de Clavé los días 24,25 y 26 de junio de 1893 supuso un revulsivo para el movimiento coral valenciano ${ }^{322}$. El acto central de esta visita fue un concierto celebrado en la Plaza de Toros de Valencia que reunió mil ciento treinta cantantes de treinta y ocho sociedades corales catalanas y ciento treinta instrumentistas dirigidos por Juan Goula. En la primera parte del concierto se interpretó la cantata para coro y banda Gloria a España de Clavé, Arre Moreu para voces solas de Ventura, una pieza instrumental para banda, la pastorela a voces solas Les

\footnotetext{
${ }^{319}$ Sancho, "Orfeonismo y canto", pp. 113-114.

${ }^{320}$ La situación socio-política que atravesaba España en estos momentos (crisis económica, revolución de 1868, sexenio revolucionario) explica la crisis, según Nagore Ferrer, La revolución coral, p. 78.

${ }^{321}$ Sancho, "Orfeonismo y canto", pp. 115-116.

${ }^{322}$ Anónimo, “Los orfeones en España”, Boletín Musical, 15-II-1895, p. 387.
} 
Flors de maig de Clavé, y el vals-jota Las Galas del Cinca para coro y banda de Clavé. En la segunda parte sonaron la cantata Lo cantor del poble para coro y banda de Goula padre, una pieza instrumental para banda, la barcarola El Mar de Clavé, la pieza instrumental La Sardana de Bretón y el rigodón Los Nets dels Almugavers para coro y banda de Clavé e $^{323}$.

La visita de los coros de Clavé a Valencia conllevó la reorganización en septiembre de 1893 del Orfeón Valenciano, convertido en Orfeón El Micalet, bajo la presidencia de José Cros y la dirección artística de Joaquín Pallardó ${ }^{324}$. La prensa subrayó la mejora perceptible en el Orfeón:

El Orfeón Valenciano, titulado El Micalet, ha hecho su debut en público, con motivo de los días del Gobernador Civil. La víspera de S. Rafael, obsequió a la mencionada autoridad con una serenata que hizo patente los visibles progresos de la agrupación coral con la ejecución de sentidos coros perfectamente interpretados, que arrancaron aplausos al entusiasta auditorio que les escuchaba ${ }^{325}$.

La sede social del Orfeón El Micalet fueron unos locales cedidos por el Ayuntamiento valenciano "que aunque modestísimos en sí, sirven para los fines que persigue esta institución, celebrando en él sus ensayos, sus academias, sus clases de solfeo y sus reuniones" ${ }^{\prime 26}$.

El Orfeón El Micalet ingresó en la Asociación de Coros de de Clavé en 1893, y realizó con ellos varias excursiones artísticas: en mayo de 1894 viajó a Barcelona y

\footnotetext{
323 Boletín Musical, 23-VI-1893, pp. 87-88. La actuación mencionada de mil doscientos sesenta ejecutantes en total, fue un espectáculo masivo. Según Nagore Ferrer, esta vertiente espectacular de la música coral se vio potenciada a partir de la década de los 80 del siglo XIX debido a varios factores: la expansión del movimiento coral en casi todas las regiones españolas, la mayor facilidad para las comunicaciones y el auge del espíritu competitivo con la proliferación de concursos de orfeones. Véase Nagore Ferrer, "Un aspecto del asociacionismo", p. 222.

${ }^{324}$ Anónimo, "Los orfeones en España", Boletín Musical, 15-II-1895, p. 387; [Justo], "Los Orfeones El Micalet y La Vega”, Boletín Musical, 15-V-1895, p. 434; Blasco, La música en Valencia, p. 84.

${ }^{325}$ Boletín Musical, 30-X-1893, p. 147.

${ }^{326}$ [Justo], “Los Orfeones El Micalet y La Vega”, Boletín Musical, 15-V-1895, pp. 434-435.
} 
Zaragoza para participar en un festival ${ }^{327}$ y en julio y agosto de 1895 a Bilbao y San Sebastián. En 1895 El Micalet tenía 80 socios protectores y 130 cantantes, todos ellos obreros que acudían a la academia de la sociedad coral y a los ensayos que tenían lugar tres veces por semana, salvo excepciones ${ }^{328}$.

Dos años después de la reorganización del Orfeón El Micalet y aunque su director titular seguía siendo Joaquín Pallardó ${ }^{329}$, Salvador Giner era su principal impulsor y, uno de los principales compositores de su repertorio, además de director artístico y socio honorario. La Tabla 16 muestra algunas de las obras que formaban parte del repertorio de El Micalet en 1895 y 1897.

Tabla 16. Algunas composiciones interpretadas por el Orfeón El Micalet en 1895-97. Fuentes: Boletín Musical, 15-V-1895, pp. 434-435 y 20-III-1897, p. 878.

\begin{tabular}{|c|c|}
\hline Compositor & Obras \\
\hline No consta & La verbena de San Juan \\
\hline No consta & Dormint \\
\hline No consta & Fa la do \\
\hline No consta & La cachita \\
\hline No consta & La caída de la tarde \\
\hline [Salvador] Giner & $\begin{array}{l}\text { El alba, Barcarola, El desfile, La maquinista, } \\
\text { La festa del poble, La Tempestad (letra Benito Busó) }\end{array}$ \\
\hline No consta & Adiós a Granada \\
\hline No consta & El marinerito \\
\hline No consta & La Aurora \\
\hline [Josep A.] Clavé & $\begin{array}{c}\text { El mar, Las Galas del Cinca, Gloria a España, Los nets } \\
\text { dels Almugavers, Arre Moreu, Flors de Maig }\end{array}$ \\
\hline No consta & Veladas de Aragón \\
\hline No consta & La Hija del Vergel \\
\hline No consta & Los pescadors \\
\hline No consta & Himno al Arte \\
\hline No consta & El peixcaor \\
\hline No consta & La peixcaora \\
\hline No consta & La Marsellesa \\
\hline No consta & Salve Regina \\
\hline No consta & Albada \\
\hline No consta & La filadora \\
\hline [José] Fornet & Quiéreme niña (letra de Rue) \\
\hline
\end{tabular}

\footnotetext{
${ }^{327}$ [Justo], “El Orfeón Valenciano El Micalet”, Boletín Musical, 30-V-1894, pp. 247-251.

${ }^{328}$ [Justo], “Los Orfeones El Micalet y La Vega”, Boletín Musical, 15-V-1895, pp. 434-435.

329 Blasco, La música en Valencia, p. 84; [Justo], "El Orfeón Valenciano El Micalet", Boletín Musical, 15-V-1894, p. 240; [Justo], "El Orfeón Valenciano El Micalet", Boletín Musical, 30-V-1894, p. 249.
} 
Orfeón Republicano La Vega (1893)

Bienvenido Marí, Basilio Moncayo y Mateo Colás presentaron en julio de 1893 a la Junta Directiva del Casino Republicano La Vega la propuesta de creación de un orfeón. La propuesta fue aceptada, constituyéndose el Orfeón Republicano la Vega, cuya primera actuación tuvo lugar la noche del 7 de octubre de 1893 en el Casino Republicano de Valencia bajo la dirección de Baltasar Martínez Martín ${ }^{330}$. El Orfeón Republicano solicitó ayuda al Orfeón Valenciano y al periodista Francisco Fayos, para redactar sus estatutos y conseguir repertorio coral, como se desprende de la carta de respuesta, enviada por Francisco Fayos a Bienvenido Marí: (Valencia).

Sr. D. Bienvenido Marí, del Orfeón Republicano de la Vega

Mi distinguido amigo y paisano: hace algunos días me pidió Vd. le transmitiese datos y noticias referentes a la organización de las sociedades corales catalanas, a fin de poder constituir el Orfeón Republicano de la Vega.

Respecto a los reglamentos o estatutos por que éstas se rigen, poco más, poco menos, todos tienen un mismo fin. En ellos, por regla general y en sus bases generales, va envuelto un consejo de moralidad y un ofrecimiento de instrucción. Al ocuparse de sus socios coristas, tratan de las cualidades y requisitos que deben reunir los aspirantes, prohibiendo terminantemente la admisión a los pendencieros, jugadores y de otras malas costumbres, estableciéndose asimismo la forma en que deben ser propuestos y admitidos.

Entusiasta de la obra de Clavé, siempre admiraré el colosal pensamiento de todos ustedes y siempre trataré de secundarle, aconsejando con nuestra voz débil, pero llena de buena fe y entusiasmo a los más que procuren ser partícipes de la influencia social y moralizadora de las sociedades corales, y a otros que las fomenten con su influencia y saber [...]. Dios quiera amigo mío, que esta carta sirva como de primer eslabón para formar una cadena que una el naciente Orfeón republicano de la Vega con los demás de Valencia y de toda España $^{331}$.

Por conflictos políticos entre sus miembros, el Orfeón Republicano cambió su nombre y pasó a denominarse Orfeón Valenciano de La Vega. En su primera etapa, la formación estuvo constituida por treinta voces, que llegaron a cincuenta dos años más

\footnotetext{
${ }^{330}$ [Justo], "Los Orfeones El Micalet y La Vega”, Boletín Musical, 30-V-1895, p. 439; Carbonell, "El cant coral", p. 184.

${ }^{331}$ [Justo], “Las Sociedades Corales”, Boletín Musical, 30-XI-1893, pp. 159-160.
} 
tarde. Este orfeón organizaba conciertos, serenatas e incluso la representación de alguna zarzuela $^{332}$.

Francisco Fayos Anthony y la Asociación Coral de la Región Valenciana (1895-1897)

La actividad de coros y orfeones atrajo la atención de autores y la prensa ligados al regionalismo ${ }^{333}$. El periodista Francisco Fayos Anthony, redactor y corresponsal en Barcelona de la publicación valenciana Boletín Musical y representante del Orfeón El Micalet en la Asociación de Coros claverianos, desempeñó un importante papel en beneficio del movimiento coral valenciano. Fayos Anthony, quien firmaba sus escritos con el pseudónimo "Justo", fue nombrado Socio de Mérito de la sociedad coral El Micalet en $1894^{334}$. Uno de los ideales que perseguía Francisco Fayos era dejar instituida la Asociación Coral de la Región Valenciana, federación de sociedades corales de la Comunidad Valenciana, a semejanza de la que existía en Cataluña, con unos estatutos y reglamento propios, tal como expuso en sus escritos publicados en el Boletín Musical ${ }^{335}$ :

Contribuyamos todos con nuestro esfuerzo a tan humanitaria obra, propaguémosla sin descanso, que quizás en ninguna época como en la actual será tan necesaria. Patriotismo, amor a Valencia, cariño $a$ les coses de casa [a las cosas de casa], y dentro de poco será un hecho la Asociación Coral de la Región Valenciana ${ }^{336}$.

Fayos animó a los orfeones valencianos a cantar en valenciano, afirmando que "el deber de los orfeones valencianos, es entonar cantos entusiastas donde brolle [sic] el

\footnotetext{
332 [Justo], “Los Orfeones El Micalet y La Vega”, Boletín Musical, 30-V-1895, pp. 439-440.

${ }^{333}$ El desarrollo del movimiento coral a través de la creación de nuevos orfeones coincidió con el auge que iba tomando la Renaixença en Valencia, véase para el caso de Galicia Costa, "Coralismo, etnicidad y nacionalismo en Galicia”, pp. 58-59.

${ }^{334}$ Boletín Musical 30-I-1894, p. 190.

335 [Justo], "Los Orfeones Valencianos", Boletín Musical 15-XI-1894, pp. 342-343; [Justo], "Carta abierta", Boletín Musical, 15-XII-1894, pp. 358-360; [Justo], "Los orfeones El Micalet y La Vega", Boletín Musical, 30-IV-1895, pp. 426-428.

${ }^{336}$ Boletín Musical, 15-XII-1894, p. 360.
} 
santo amor a la tierra valenciana" y hace una defensa, a ultranza, de los cantos populares valencianos:

\begin{abstract}
Distinguidos poetas que han hecho alarde de valencianismo, que han ocupado importantísimos cargos en corporaciones esencialmente valencianas, escriben para nuestros orfeones composiciones castellanas, y nuestros músicos, que los hay de primer orden, por compromiso se ven muchas veces precisados a componer música para aquella letra, perdiendo un tiempo precioso que podría dedicar en darnos a conocer música popular, música del país, aquella música fácil y sencilla que se pega al oído del que la oye [...] que los orfeones deben emplear en sus cantos ${ }^{337}$.
\end{abstract}

Estas aspiraciones de Fayos hay que entenderlas en un marco de influencia nacionalista que defendía la lengua, la tradición y evocación de glorias pasadas, ideales que enlazan con los postulados de la Renaixença, corriente regionalista que aportó al repertorio de los orfeones valencianos una producción nueva de partituras en valenciano en las que se utilizó la cita directa o indirecta del folklore local. Francisco Fayos mencionó a poetas y músicos que compusieron obras corales de carácter esencialmente valenciano, entre ellos el prolífico compositor Salvador Giner, autor de con títulos como La festa del poble, Barcarola, Ecos del Turia, El Alba, La Trilla, Matinada de maig, La valenciana, Himne a València; Amancio Amorós, con Costum de l’horta y Alborada; José Morató con La valenciana; Pallardó, con Balada; José María Fayos con Amor a la nostra terra; Juan Grau con La plegà de les olives; Juan Mas con Sempre valencians; y Manuel Penella con Albada. El poeta valenciano José Bodría colaboró en la mayor parte de estas composiciones ${ }^{338}$.

Además de sus escritos en prensa, Francisco Fayos, con el objetivo de propagar la Asociación Coral Valenciana, realizó desde 1894 numerosas visitas a pueblos de la provincia de Valencia para proclamar los beneficios del canto coral y constituir

\footnotetext{
${ }^{337}$ [Justo], "Los Orfeones Valencianos”, Boletín Musical, 15-XI-1894, p. 343.

338 [Justo], “Carta abierta”, Boletín Musical, 15-XII-1894, pp. 358-359.
} 
comisiones encargadas de organizar sociedades corales locales ${ }^{339}$. El 20 de febrero de 1897 había visitado ya catorce pueblos ${ }^{340}$ :

En todos fue recibido con entusiasmo por las personas que de antemano conocían su viaje; como numerosas fueron las reuniones que al efecto convocó, a las cuales asistieron personas de valía, arraigo y posición que, convencidos ante la fácil palabra de Justo, de la conveniencia y utilidad de las sociedades corales, como medio de educar e instruir al obrero, prestáronse gustosos a coadyuvar a tan noble pensamiento, constituyéndose en comisiones de propaganda, para la organización de nuevos orfeones, que no dudamos darán los resultados que todos esperamos ${ }^{341}$.

La prensa nacional anunció en junio de 1895 que la Asociación Coral Valenciana estaba ya constituida:

Se ha constituido en Valencia la Asociación Coral de la Región Valenciana, de la cual formarán parte todos los orfeones y sociedades corales de la región que acepten los Estatutos publicados al efecto $^{342}$.

Para solemnizar la sesión inaugural de la Asociación Coral Valenciana, prevista para septiembre de 1895, Francisco Fayos encargó a Jose Bodría y Salvador Giner la composición de un Himno a Valencia ${ }^{343}$.

Los fines que perseguía la Asociación Coral de la Región Valenciana eran artísticos pero también educativos y patrióticos, "llevando en sí la idea de educar, moralizar y dignificar al obrero, fomentando al propio tiempo, el amor a nuestra materna lengua y el arte musical valenciano" ${ }^{\text {344 }}$. Sin embargo, según sus estatutos, no podía

\footnotetext{
339 Boletín Musical, 30-I-1897, p. 837 y 10-V-1897, p. 913.

340 Sancho, “Orfeonismo y canto”, p. 119.

${ }^{341}$ Anónimo, “La Institución coral valenciana”, Boletín Musical, 20-II-1897, p. 850.

${ }^{342}$ Ilustración Musical Hispanoamericana, 30-VI-1895, p. 287.

${ }^{343}$ Boletín Musical, 15-V-1895, p. 436.

${ }^{344}$ Boletín Musical, 30-II-1897, pp. 859-860.
} 
pertenecer a la Asociación ninguna agrupación coral con una marcada tendencia política $^{345}$.

La Asociación Coral de la Región Valenciana fue un respaldo a la consolidación del movimiento coral valenciano que entre 1893 y 1898 contaba con más de treinta coros en la Comunidad Valenciana (véase Tabla 17).

Tabla 17. Coros documentados en la Comunidad Valenciana (1893-1898).

Fuentes: Boletín Musical, 30-XI-1894 (p. 354), 15-V-1895 (p. 436), 30-V-1895 (p. 442), 20-I-1897 (p. 831), 30-I-1897 (pp. 835-836), 20-II-1897 (pp. 850-851), 30-II-1897 (pp. 859-860), 10-I-1898 (p. 1105), Sancho, “Orfeonismo y canto”, p. 120.

\begin{tabular}{|c|c|}
\hline Coros & Localidad \\
\hline Coro del Regimiento de Infantería de Vizcaya & \multirow{13}{*}{ Valencia } \\
\hline Orfeón de la Punta & \\
\hline Sociedad Musical La Infantil & \\
\hline Lo Turia & \\
\hline El Cid & \\
\hline Orfeó Valencià & \\
\hline L'Antigor & \\
\hline $\begin{array}{l}\text { Orfeón de la Academia de la Juventud } \\
\text { Católica }\end{array}$ & \\
\hline Orfeón de Villanueva del Grao & \\
\hline Orfeón de la Juventud Republicana & \\
\hline Orfeón del Patronato de la Juventud Obrera & \\
\hline Orfeón de la Cámara Obrera & \\
\hline Coro de la Asociación de Obreros & \\
\hline Orfeón el Iris & Requena \\
\hline Orfeón La Unión & $\begin{array}{l}\text { Tavernes de } \\
\text { la Valldigna }\end{array}$ \\
\hline Orfeón Lo Xúquer & Carcaixent \\
\hline Orfeón Gomis & Ontinyent \\
\hline Orfeón Saguntino & \multirow{2}{*}{ Sagunto } \\
\hline Sociedad Orfeonista Saguntina & \\
\hline El Bellveret & \multirow{3}{*}{ Xàtiva } \\
\hline La Lira & \\
\hline Orfeón Españoleto & \\
\hline Coro del Centro Artístico & Cullera \\
\hline Orfeón de Segorbe & Segorbe \\
\hline Orfeón de Manuel & Manuel \\
\hline Orfeón de la Font d'En Carròs & $\begin{array}{l}\text { Font d'En } \\
\text { Carròs }\end{array}$ \\
\hline Orfeón de Moncada & Moncada \\
\hline Orfeón de Paiporta & Paiporta \\
\hline Orfeón de Almàcera & Almàcera \\
\hline Orfeón de Buñol & Buñol \\
\hline Orfeón de Castellón & Castellón \\
\hline Orfeón de Vinaroz & Vinaroz \\
\hline
\end{tabular}

\footnotetext{
345 [Justo], "Proyecto de Estatutos Generales para la Asociación Coral de la Región Valenciana", Boletín Musical, 15-VI-1895, pp. 449-450.
} 
Los primeros años de vida de la Asociación Coral Valenciana vieron surgir desavenencias entre los coros que constituían la federación:

\begin{abstract}
Como todo organismo que se crea y en su desarrollo adolece de alguna más o menos ligera dolencia, hemos de convenir, pues la práctica nos lo demuestra, que al constituirse la Federación Coral Valenciana, se ha ido demasiado aprisa o se camina muy lentamente. Los buenos y justos deseos de Justo, la inspiración del Sr. Bodría, continuo campeón de vivir nuestras costumbres, el genio de nuestro queridísimo maestro Giner, y otros muchos que coadyuvan a tan grandiosa finalidad, han de considerarse de tan precisado valor, que nuestra Federación ha de asegurarse, mucho antes de emprender algo práctico, para que todas aquellas halagüeñas esperanzas y sacrificios, no cedan ante el mal comprendido estímulo de unos y el deseo de prevalecer de otros ${ }^{346}$.
\end{abstract}

Se consideraba difícil crear una directiva general para todos los coros "cuando el desinterés y el patriotismo no se imponen como deber inexcusable", prevalecían distintos puntos de vista entre sus delegados "por temor egoísta de alguna agrupación de que las demás obscureciesen su justa fama y nombre conquistados [...]" y se quería que la federación buscara el apoyo de centros de cultura y sociedades valencianas "al igual que

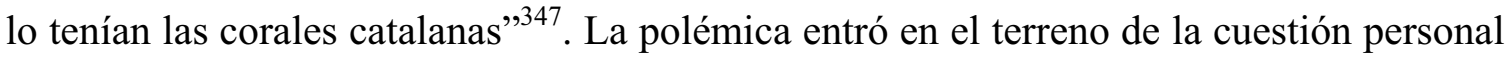
y las descalificaciones, y el problema quedó zanjado con una nota de la redacción del Boletín Musical, poco antes de la disolución de la sociedad ${ }^{348}$.

Entre 1898 y 1910 se constata, según Sancho, una estabilización de la vida coral valenciana. Aún sin la eclosión orfeonística del periodo anterior, en estos años siguieron

\footnotetext{
${ }^{346}$ [Mido], "La Federación Coral Valenciana”, Boletín Musical, 20-IV-1897, p. 899.

347 [Sol-La], "La Federación Coral Valenciana", Boletín Musical, 30-IV-1897, pp. 904-905; [Mido], "La Federación Coral Valenciana", Boletín Musical, 10-V-1897, p. 912.

348 “ [...] Visto el carácter personal y agresivo que esta contienda va tomando; teniendo en cuenta la misión de nuestro periódico y singularmente no perdiendo de vista que estas lamentables escenas vienen a redundar en perjuicio de los intereses de los orfeonistas a cuya causa estamos ligados por vínculos del más acendrado entusiasmo, nos decidimos a pedir en nombre de la prudencia, de la corrección y del comedimiento, cese esta serie de diatribas que lamentamos muy de veras y que no conducen a ninguna parte, ni menos interesan al público, que al informarse ha de juzgar de una manera poco favorable estas interioridades propias del hogar y de ninguna manera pasto de la voracidad pública. La cordura jamás desmentida de los orfeonistas de la Vega y del Sr. Francisco Fayos, nos anima a creer darán por terminado este vidrioso asunto", Boletín Musical, 20-VIII-1897, p. 994 y 30-VIII-1897, p. 1001. Según Galbis, "Coros", p. 255, la Asociación no cuajó debido a su ineficacia y acabó disolviéndose.
} 
naciendo nuevas formaciones corales (véase Tabla 18). Los orfeones que mostraron mayor actividad fueron El Micalet (convertido desde 1905 en Sociedad Coral El Micalet) y l'Antigor.

El orfeón l'Antigor participó en la solemne fiesta celebrada por Lo Rat Penat con ocasión de su traslado a una nueva sede y la celebración del XXV aniversario de sus Juegos Florales $^{349}$. El Orfeón El Micalet participó en el estreno de óperas de Salvador Giner en 1901, realizó excursiones artísticas a Málaga y Granada (1904), Madrid (1905) y Zaragoza (1908), nuevamente bajo la influencia de los Coros Clavé y participó en los conciertos organizados con motivo de las Exposiciones Regional y Nacional de 1909 y $1910^{350}$.

Tabla 18. Coros de Valencia activos entre 1898 y 1910.

Fuente: Sancho, “Orfeonismo y canto", p. 122.

Sociedad Coral El Micalet

L'Antigor

Orfeón Unión Republicana

Coro de la Sociedad Nuevo Liceo

Orfeón Giner

Orfeón sociedad humorística la Rialla

Coro de la sociedad Los XX

Orfeón de la Sociedad El Arte

Escolanía Pompiliana

Juventud Carlista

Orfeón Carlista Valenciano

Orfeón Círculo Instructivo de San Francisco de Asís

Orfeón de la Casa de Obreros de San Vicente Ferrer

Escolanía del Patronato de la Juventud Obrera

El Júcar

\section{Música religiosa}

A pesar del proceso desamortizador iniciado por Mendizábal en 1836, la Catedral de Valencia pudo mantener un grupo de veinte beneficiados y algunos músicos seglares,

\footnotetext{
349 Almanaque de las Provincias para 1907, pp. 227-232.

${ }^{350}$ Sancho, “Orfeonismo y canto”, p. 123.
} 
como el organista Pascual Pérez Gascón. Las iglesias valencianas siguieron siendo el lugar en el que se formaban la mayor parte de los músicos valencianos en la segunda mitad del siglo XIX. En instituciones eclesiásticas estudiaron música por ejemplo, Salvador Giner, José Ma Úbeda, los hermanos Plasencia, Roberto Segura y Vicente Peydró, entre otros ${ }^{351}$.

La música religiosa, en un proceso iniciado ya en el siglo XVIII, fue recibiendo influencias de la lírica italiana, y se alejaba del espíritu de sobriedad que preconizaban los defensores de la tradición renacentista española. En 1904, el compositor valenciano Mariano Baixauli describía así ese proceso:

Comenzaron los cantores a lucir las habilidades de su privilegiada garganta, introdujeron en la Iglesia melodías escritas ad hoc, que iban perdiendo hasta el interés armónico, se siguió con la introducción de la orquesta, y con ella el corte de las piezas propio de la música teatral ${ }^{352}$.

La crítica al estilo operístico en la iglesia estaba presente también en parte de la prensa valenciana. El estreno de una misa en la parroquia de Santa Catalina en 1845 fue comentado así en el periódico El Fénix:

La misa de este día [en Santa Catalina de Valencia] no fue más que un conjunto de reminiscencias teatrales, y en las que los distinguidos autores del Nabuco, de Norma y la Gazza-ladra podían justamente reivindicar gran parte de sus derechos [...]. Dos cosas distintas son la Música profana y la religiosa ${ }^{353}$.

En 1898 seguían publicándose en prensa acusaciones en la misma línea, considerando que debía desterrarse de la iglesia "esa plaga de obras, verdaderamente

\footnotetext{
${ }^{351}$ Climent, Historia de la música, p. 28.

${ }^{352}$ Mariano Baixauli, “La música religiosa”, Razón y Fe, 9/33 (1904), p. 33.

${ }^{353}$ El Fénix, 14-XII-1845. Sobre las críticas negativas hacia el italianismo operístico en la iglesia, véase también Francesc Cortés i Mir, "La música religiosa", en HMCVB, vol. 3 (1999), pp. 195-197; y los artículos con el título "La Música religiosa tal como la quiere la Iglesia", en la publicación valenciana Boletín Musical de los años 1898, 1899 y 1900.
} 
profanas e indignas"354. El periodista Francisco Fayos afirmaba haber oído "el dúo del último acto de Aida, Morire si pura e bella-morire per me de amore, convertida en Benedictus [...] Más aún, hasta a las Hijas de María [...] les hemos oído cantar la Salve [...] con música de la ópera Lucia" ${ }^{, 355}$.

Estas reiteradas críticas que denunciaban la influencia de lo profano en lo religioso fueron creando el ambiente propicio para que se iniciara un intento de renovación. El problema no era exclusivo de Valencia ni de España, sino que la reforma de la música religiosa fue emprendida por diversos países europeos para restaurar el estilo polifónico sacro del siglo XVI y el retorno del canto gregoriano a sus formas primitivas, en lo que se denominó cecilianismo o movimiento ceciliano ${ }^{356}$. Uno de los mayores impulsos para encauzar la restauración de la música religiosa fue dado por la Santa Sede con la publicación de los Reglamentos para la Música Sagrada de 1884 y 1894, precedentes del Motu Proprio ${ }^{357}$. En España la reforma de la música religiosa contó con figuras destacadas como Hilarión Eslava (1807-1878) autor de la Lira SacroHispana y el Museo Orgánico Español ${ }^{358}$, Eustoquio de Uriarte con su Tratado teórico-

\footnotetext{
${ }^{354}$ Boletín Musical, 20-II-1898, p. 1135.

355 Boletín Musical, 28-II-1898, p. 1148. El texto parece referirse a la adaptación a la iglesia de fragmentos de las óperas Aida (1871) de Giuseppe Verdi y Lucia di Lammermoor (1835) de Gaetano Donizetti.

${ }^{356}$ El cecilianismo tuvo como principal objetivo restablecer la tradición de la polifonía palestriniana y del canto llano y nació al sur de Alemania gracias al esfuerzo de un grupo de sacerdotes como Caspar Ett (1788-1847), Kart Proske (1794-1861), Franz Xaver Witt (1834-1888) y Franz Xaver Haberl (18401910). Este movimiento se extendió rápidamente a Estados Unidos e Irlanda, pero la Asociación más importante, después de la germánica, fue la italiana, por su influjo en la Santa Sede y por tanto en la promulgación de "Reglamentos" para la Música Sagrada, como el Motu Proprio. Véase López-Calo, "Hilarión Eslava", pp. 581-585; Siegfried Gmeinwieser, "Cecilian Movement", en TNG, vol. 5 (2001), pp. 333-334; José López-Calo, “Cecilianismo”, en DMEH, vol. 3 (1999), pp. 459-462; José López-Calo, "Congresos de Música Religiosa”, en DMEH, vol. 3 (1999), pp. 876-878; Vicente Ripollés, Memoria sobre la reforma de la Música religiosa en la Capilla de Corpus Christi de Valencia (Madrid: Imprenta y Litografía de la Viuda e Hijos de Terceño, 1897), pp. 5-7.

${ }^{357}$ Ripollés, Memoria sobre la reforma, pp. 7-9; Nagore Ferrer, “Tradición y renovación”, p. 212.

${ }^{358}$ Eslava publicó un artículo en la revista Gaceta Musical de Madrid, dirigida por él mismo, que clarifica las ideas para comprender qué entendía él por reforma y mejora de la música religiosa y cuales serían los
} 
práctico de Canto Gregoriano según la verdadera tradición y Felipe Pedrell, fundador de varias revistas sobre música religiosa y autor de la antología Hispaniae Schola Musica Sacra $^{359}$. En 1895, el arzobispo de Madrid-Alcalá, José María de Cos creó la “Asociación Isidoriana para la reforma de la música religiosa en España". La Asociación divulgó sus ideas regeneracionistas con la creación de una publicación mensual, dirigida por Pedrell, titulada La música religiosa en España (1896-1899) y con la organización del Congreso de Música Religiosa de Bilbao en agosto de $1896^{360}$.

En el ámbito valenciano destacaron como reformistas de la música religiosa Juan Bautista Guzmán (que inició el estudio del repertorio histórico con la publicación de las obras de Juan Bautista Comes), José $\mathrm{M}^{\mathrm{a}}$ Úbeda y Salvador Giner ${ }^{361}$. Con Giner y Úbeda se formaron toda una generación de compositores de música religiosa que abrieron Valencia al siglo XX, entre ellos Amancio Amorós (1854-1925), formado como organista por el agustino Pedro García; José Espí (1849-1905), autor entre otras de una Misa de Gloria, un Stabat Mater y una Salmodia para órgano premiada por la Sociedad de Amigos del País de Valencia; Juan García Navarro (1820-1903), organista de la parroquia de los Santos Juanes y autor de la colección de piezas religiosas titulada Aureola Musical; José Jordá (1838-1918), organista de las iglesias de San Esteban y de Nuestra Señora de los Desamparados, autor de tres misas de Gloria y un Miserere; y José Valero (¿-1868), autor también de obras religiosas ${ }^{362}$. La recuperación y difusión del medios prácticos para alcanzar ese objetivo; Véase López-Calo, "Hilarión Eslava", pp. 600-601; LópezCalo, "Cien años de asociaciones", pp. 293-296.

${ }^{359}$ Véase José López-Calo, "Felip Pedrell y la reforma de la música religiosa", Recerca Musicològica, 11-12 (1991-1992), pp. 157-209; Nagore Ferrer, "Tradición y renovación”, pp. 211-233; Ripollés, Memoria sobre la reforma, p. 6.

\footnotetext{
${ }^{360}$ Ripollés, Memoria sobre la reforma, pp. 6-7; Nagore Ferrer, "Tradición y renovación”, pp. 217-224; Nagore Ferrer, "Una aportación al estudio", pp. 605-615.

${ }^{361}$ Climent, Historia de la música, pp. 29-33; Sancho, El compositor Salvador Giner, Vida y obra musical (Valencia: Ajuntament de València, 2002), p. 61; Cortés, "La música religiosa", p. 245.

${ }^{362}$ Cortés, "La música religiosa", p. 246.
} 
gregoriano y la polifonía del Renacimiento en Valencia fueron potenciados por Vicente

Ripollés, maestro de capilla del Real Colegio de Corpus Christi de Valencia y Juan

Bautista Pastor, maestro de capilla de la Catedral de Valencia. En la Semana Santa de 1897, Juan Bautista Pastor dirigió en la Catedral de Valencia las siguientes obras:

Misa de Plagis, a 5, de Cotes (Ambrosio); Pasiones de Comes (Juan Bautista); las Lamentaciones correspondientes a los oficios de maitines de los tres días, de Pastor (Juan Bautista), Pérez Gascón (Pascual), Eslava, Piqueras, Andreví y Guzmán; Benedictus de Pérez (Juan Ginés); Kyries y Gloria, de Nebra y Credo, Sanctus y Agnus, de Palestrina; un Miserere, de Piqueras y otros dos de Eslava; Antífonas del Mandato de Babán (Gracián); Improperios de Babán ${ }^{363}$.

En 1897, Vicente Ripollés promovió la reforma de la música religiosa en la Capilla del Corpus Christi. Las medidas propuestas por Ripollés para restaurar la "buena música religiosa" se inspiraron en las Constituciones del fundador del Real Colegio de Corpus Christi (el Beato Juan de Ribera) y en los Reglamentos de la Sagrada Congregación de Ritos (1884 y 1894) ${ }^{364}$. Ripollés propuso las siguientes normas para que la Capilla del Corpus Christi sirviese de ejemplo a las demás:

$1^{\circ}$. Se reformará el canto llano según los principios contenidos en el Tratado de canto gregoriano del P. Eustoquio Uriarte, siguiendo la práctica de los monasterios donde florezca la restauración gregoriana.

$2^{\mathrm{o}}$. En las fiestas Dobles de $1^{\mathrm{a}}$ y $2^{\mathrm{a}}$ clase de fundación particular se celebrarán los Oficios divinos según la forma prescrita por el Beato Fundador en el capítulo 40, números 8, 13 y 14 de las Constituciones: esto es, haciendo uso de los fabordones y de la riquísima colección de música polifónica existente en el archivo; cantándose el Credo de la misa a canto llano, según lo dispone el capítulo 54 de las Constituciones en su número 7, y era práctica seguida en la antigua disciplina eclesiástica.

$3^{\mathrm{o}}$. Para las festividades de $1^{\mathrm{a}}$ y $2^{\mathrm{a}}$ clase, dotadas por el Beato Fundador y señaladas en los números 8 y 13 del capítulo 40 de las Constituciones, se podrán tomar composiciones de la segunda y tercera época que no desdigan de la devoción y gravedad peculiares de esta Capilla; podrán también cantarse composiciones de autores modernos

\footnotetext{
${ }^{363}$ La Música Religiosa en España, 16 (1897), p. 250.

${ }^{364}$ Ripollés, Memoria sobre la reforma, pp. 7-10.
} 
siempre que se sujeten al Reglamento publicado por la Santa Sede en $1894^{365}$

$4^{\circ}$. A tenor de lo dispuesto en los artículos 17 y 18 del Reglamento de 1884 arriba citados, sería muy conveniente que para la revisión de las obras musicales que en adelante hayan de admitirse en esta Capilla, se nombrará una comisión de tres Maestros a quienes hicieran respetables sus obras y reconocido celo a favor de la restauración de la música religiosa.

$5^{\circ}$. Atiéndase en la celebración de los Oficios divinos de Semana Santa, en el Miserere de los Viernes y en la Salve de los Sábados, a lo dispuesto por el Beato Fundador en los números 21, 27 y 30 del capítulo 40 de las Constituciones de esta Capilla ${ }^{366}$.

En 1898 un pequeño artículo aparecido en el Boletín Musical se hacía eco de los comentarios que circulaban sobre la inminente reforma:

Se asegura que el Papa se propone dirigir a los obispos una instrucción relativa a la música sagrada, y principalmente al violín, cuyo uso aconsejará proscribir tanto en solos como en orquesta.

Altas dignidades parece que le han inspirado esta idea, con la cual se halla ahora muy preocupado. Hallando en la música sagrada de hoy un exceso teatral y sensualista, quisiera conseguir resucitar los antiguos tiempos en que campeaba la música grave y severa.

Desde este punto de vista, solamente condena la música de Mozart y de Haydn que está muy en boga en las iglesias. En la instrucción mencionada, el Papa no se limitará a hacer el análisis de las distintas clases de música, sino que hablará también acerca de algunos instrumentos ${ }^{367}$.

El proceso de renovación culminó con la publicación por Pío X en 1903 de la instrucción sobre música sagrada Motu Proprio "Tra le sollecitudini”, en veintinueve $\operatorname{artículos}^{368}$. Este documento papal fue publicado en el Boletín del Arzobispado de

\footnotetext{
365 Según Ripollés la segunda época está representada en la escuela valenciana por los maestros Inojosa, Ortells, Baylón, Ríos, Hernández, Vidal, Noguera, Babán, Rabassa, Fuentes, Morera, Melchor Martínez, Martínez Olivares, Martínez de Orgambide, Conejos, Narro y Veana. En la tercera época Ripollés incluye a Montesinos, Morata, Andreví, Piqueres, Mariano y Lamberto Plasencia, entre otros; véase Ripollés, Memoria sobre la reforma, p. 4.

${ }^{366}$ Ripollés, Memoria sobre la reforma, pp. 17-18. Véase [Juan de Ribera], Constituciones de la Capilla del Colegio y Seminario del Corpus Christi, Capítulo 40, pp. 63-70, "De la orden que se ha de guardar en la Cantoría, y música de los divinos oficios".

${ }^{367}$ Boletín Musical, 10-I-1898, pp. 1109-1110.

${ }^{368}$ Véanse las Actas del simposio internacional celebrado en Barcelona en 2003, El Motu Proprio de San Pío X y la Música (1903-2003), Revista de Musicología, 27/1 (2004); en particular Ma Antonia Virgili Blanquet, "Antecedentes y contexto ideológico de la recepción del Motu Proprio en España”, Revista de Musicología, 27/1 (2004), pp. 23-39; Ismael Fernández de la Cuesta, "La reforma del canto gregoriano en el entorno del Motu Proprio de Pío X”, Revista de Musicología, 27/1 (2004), pp. 43-73.
} 
Valencia en $1904^{369}$. Para el compositor valenciano Mariano Baixauli, el Motu Proprio no dejaba lugar a dudas sobre cual era la música religiosa que debía servir al culto. En un artículo de 1904, Baixauli subrayó que Pío X recomendaba las obras de Palestrina y los autores clásicos del siglo XVI, pero sin excluir la música moderna con sus legítimos progresos, a la que exigía que, a imitación del canto gregoriano y polifonía clásica, se acomodara a las condiciones propias de la música religiosa: "santidad, buenas formas y universalidad". La música religiosa debía alejarse de toda extravagancia tanto en ideas, desarrollo, armonía y acompañamientos ${ }^{370}$.

Pío X mandó que en todas las diócesis se creara una Comisión de Música Sacra para velar por la música que se ejecutaba en las iglesias. En concreto, el título VIII del Motu Proprio, artículo 24, dice así:

Para el puntual cumplimiento de cuanto aquí queda dispuesto, nombren los obispos, si no las han nombrado ya, comisiones especiales de personas verdaderamente competentes en cosa de música sagrada, a las cuales, en la manera que juzguen más oportuna, se encomiende el encargo de vigilar cuanto se refiere a la música que se ejecuta en las iglesias. No cuiden sólo de que la música sea buena de suyo, sino que responda a las condiciones de los cantores y sea buena la ejecución ${ }^{371}$.

En Valencia, como en otras diócesis españolas, se creó en abril de 1904 una Comisión de Música Sagrada para vigilar el cumplimiento del Motu Proprio. La Comisión valenciana estuvo formada originalmente por trece miembros ${ }^{372}$ :

\footnotetext{
${ }^{369}$ Boletín Oficial del Arzobispado de Valencia (en adelante BOAV), 1459 (17-II-1904), pp. 49-59. Según Climent, el documento papal se conoció en Valencia ya en 1903. Climent, Historia de la Música, p. 38.

${ }^{370}$ Baixauli, "La música religiosa”, p. 35.

${ }^{371} B O A V, 1459$ (17-II-1904), pp. 57-58.

${ }^{372} B O A V, 1463$ (25-IV-1904), p. 126; BOAV, 1464 (14-V-1904), p. 143.
} 
1. Roque Chabás (1844-1912), canónigo de la Catedral de Valencia, presidente.

2. Joaquín Navarro (?-1904), canónigo de la Catedral de Valencia, vicepresidente.

3. José Vila (1866-1932), canónigo de la Catedral de Valencia, vicepresidente.

4. Eduardo Serrano Pla (1843-1909), secretario.

5. Vicente Lliso (catedrático del Seminario), secretario.

6. José María Úbeda (1839- 1909) (organista del Patriarca), vocal.

7. Juan Bautista Pastor (1859-1927), maestro de capilla de la Catedral de Valencia, vocal.

8. Juan Redó (1866-1931), sochantre de la catedral de Valencia, vocal.

9. José Ferri, cura de la parroquia de San Nicolás de Valencia, vocal.

10. Antonio Femenía, cura de la parroquia de San Valero de Valencia, vocal.

11. Francisco Damiá (1855-1914), colegial del Patriarca, vocal.

12. Mariano Baixauli (1861-1923), jesuita, compositor y maestro de capilla en Tortosa y Toledo, vocal.

13. Ricardo Benavent Feliu (1848-1929), compositor y escritor, vocal.

El primer decreto de la Comisión de Música Sagrada de Valencia fue prohibir las misas llamadas "pastoriles" y el uso de los instrumentos con que solían acompañarse, así como las "pastorelas" en todo acto litúrgico. También se invitó a todos los maestros compositores a presentar a dicha Comisión sus obras para comprobar si se ajustaban a las disposiciones del Motu Proprio ${ }^{373}$.

\footnotetext{
${ }^{373}$ Climent, Historia de la música, pp. 39-40; Oriola, "L'article 24 de Pius X: La Comissió de Música Sagrada a València (1904-1936)", Anales Valentinos, 68 (2008), p. 345. Sobre la tradición pastoril en la música religiosa española, véase Pilar Ramos López, "Pastorelas and the pastoral tradition in 18thcentury Spanish villancicos", en Devotional Music in the Iberian World, 1450-1800: The Villancico and related genres, eds. Tess Knighton y Álvaro Torrente (Aldershot: Ashgate, 2007), pp. 283-306.
} 
Muestra de la vitalidad que tenía la música religiosa valenciana en este periodo es la aparición de la Biblioteca Sacro Musical, revista quincenal de música religiosa valenciana que se publicó desde diciembre de 1890 hasta al menos 1906, y que aparecía “con arreglo a las disposiciones de S. S. Pio X, bajo la invocación de Santa Cecilia". La publicación incluía una entrega de ocho páginas de partituras musicales en tamaño folio con papel satinado y correcto grabado, y entre cuatro y ocho páginas de texto con biografías, artículos, anuncios de vacantes, certámenes y noticias. En el Apéndice 2 incluyo el título de las obras publicadas en los volúmenes 1 y 2 de la Biblioteca Sacro Musical (1891-1892). En la propia revista se indicaron los objetivos:

\begin{abstract}
Animada esta publicación de los mejores deseos, ha escogido entre el caudal inmenso que poseemos, aquellas composiciones que reúnan a la verdad en el género, sencillez en la ejecución y buen efecto en el conjunto; formando un completo y variado repertorio apropiado a los diversos actos o festividades del culto divino, compuesto de Misas, Motetes, Reservas, Te Deum, Himnos, Letrillas, Trisagios, Rosarios, Salves, Letanías, Plegarias, Misereres, Dolores, Gozos, Salutaciones, Despedidas y Villancicos, etc., a 1, 2, 3 y 4 voces con acompañamiento de órgano y en determinadas circunstancias pondremos pequeña orquesta. También intercalaremos algunas obras esencialmente orgánicas, como salmodias para Misas y Vísperas, versos para Himnos, Ofertorios, Elevaciones, Fugas y Pastorelas ${ }^{374}$.
\end{abstract}

Entre los compositores que publicaron obras en la Biblioteca Sacro Musical estuvieron, además de los miembros de la Comisión de Música Sagrada ya citados anteriormente, Amancio Amorós, Eugenio Amorós, Salvador Giner, Francisco Antich, Rigoberto Cortina, José Medina, Manuel Chulvi, Vicente Perales, Facundo Domínguez, José Jordá y José Fornet, entre otros.

La Comisión de Música Sagrada valenciana solicitó en junio de 1904 a todos los compositores de música religiosa de la diócesis que desde ese momento presentasen las obras para su censura y análisis ${ }^{375}$. En marzo de 1905 comenzaron a publicarse en el

\footnotetext{
${ }^{374}$ Biblioteca Sacro Musical, 15-VIII-1893, p. 72.

${ }^{375}$ BOAV, 1467 (23-VI-1904), p. 182.
} 
Boletín del Arzobispado de Valencia los listados de las obras seleccionadas como aptas para poderse interpretar en las iglesias, aclaraciones sobre la utilización de los instrumentos en el templo, así como las obras que la Comisión Diocesana consideraba no aptas. Las composiciones publicadas en los volúmenes 1 y 2 (1891-1892) de Biblioteca Sacro Musical coinciden en su mayoría con las que fueron declaradas idóneas según el Motu Proprio, aunque es interesante constatar que también se publicaron algunas de las obras calificadas como "no aptas",376.

El Motu Proprio de 1903 sólo permitía el acompañamiento de órgano en el canto litúrgico. Las orquestas y bandas de música podrían actuar únicamente en condiciones especiales y el piano e instrumentos de percusión quedaban totalmente prohibidos:

Está prohibido en las iglesias el uso del piano, como asimismo de todos los instrumentos fragorosos o ligeros, como el tambor, el chinesco, los platillos y otros semejantes.

Está rigurosamente prohibido que las llamadas bandas de música toquen en las iglesias, y sólo en algún caso especial, supuesto consentimiento del Ordinario, será permitido admitir un numero juicioso escogido, corto y proporcionado al ambiente, de instrumentos de aire, que vayan a ejecutar composiciones o acompañar al canto, con música escrita en estilo grave, conveniente y en todo parecida a la del órgano $^{377}$.

Pero la realidad era muy distinta, según publicaba irónicamente el Boletín Oficial del Arzobispado de Valencia en 1905: "Se han llegado a cantar trisagios en la misma iglesia con órgano, timbales y contrabajo para acompañar un nutrido coro de cuatro voces"378. También en 1905 la Comisión de Música Sagrada de Valencia emitió un informe sobre las composiciones musicales que podían permitirse en los templos, en el

\footnotetext{
${ }^{376} B O A V, 1485$ (17-III-1905), pp. 84-89; BOAV, 1486 (1-IV-1905), pp. 111-112, BOAV, 1502 (4-XII1905), pp. 357-360.

${ }^{377} B O A V, 1459$ (17-II-1904), p. 57.

${ }^{378}$ BOAV, 1502 (4-XII-1905), p. 356.
} 
que daba detalles sobre la instrumentación mínima exigible tanto para orquestas como

para bandas que actuaran en iglesias:

También entiende la Comisión que en las funciones religiosas [...] nunca debe permitirse la orquesta, si ésta no está convenientemente formada según las reglas del arte. Razón por la cual se establece que el número de instrumentos, y la clase de ellos, según la distinta capacidad de las iglesias, sea como mínimum [sic] el siguiente. En las iglesias de pequeña capacidad no se admitirá orquesta que no conste por lo menos del quinteto completo de instrumentos ce cuerda. Para las iglesias de mediana capacidad la orquesta se compondrá de 2 violines primeros, 2 violines segundos, viola, violoncello, contrabajo, flauta, clarinete y fagot, y una trompa. En las iglesias de gran capacidad, si poseen buen órgano, no debe admitirse orquesta que no cuente al menos de 3 violines primeros, 2 segundos, viola, violoncello, 2 contrabajos, cuarteto de viento-madera y una o dos trompas. Estas combinaciones requieren que el número de voces no sea menor de 3, 6 y 12 respectivamente. Si por la mayor solemnidad se quiere aumentar el número de instrumentos, téngase presentes las reglas de concertación, y no se olvide que han de llevar la parte principal en la música religiosa, y han de ser por tanto las que dominen.

De la banda no debe hacerse uso en las funciones religiosas, si no es en las poblaciones rurales, cuyas iglesias no pueden disponer de órgano o armónium. En este caso tomarán de la banda los instrumentos más similares a la orquesta, y en número tal que no ahogue las voces. Con la flauta, 2 clarinetes primeros, 2 segundos, 2 terceros, 2 saxofones o trompas, bombardino y trombón bajo, resultaría una combinación suave y llena al propio tiempo. Si de esto no se dispone, puédase tomar la flauta, clarinetes primeros y segundos, cornetín o fliscorno, 2 trombones y bombardino, o trombón bajo ${ }^{379}$.

El jesuita Mariano Baixauli participó como representante de la Comisión de Música sagrada del arzobispado de Valencia en el Primer Congreso de Música Sagrada celebrado el 26 y 27 de abril de 1907 en Valladolid. En febrero de 1908 el arzobispo de Valencia, Victoriano Guisasola Menéndez, ordenó la recomposición de la Comisión de Música Sagrada valenciana, cuyos trabajos se habían interrumpidos durante algún tiempo, y exigió que se cumpliera con lo acordado en el citado Congreso de Música Sagrada de Valladolid: la música gregoriana debía ser prioritaria en la Iglesia ${ }^{380}$. Sin duda por ello, en 1908 se organizó en Valencia un curso teórico-práctico de canto gregoriano

${ }^{379}$ BOAV, 1502 (4-XII-1905), pp. 355.

${ }^{380}$ Virgili, "El canto popular”, pp. 175-186; Virgili, "La música religiosa en el siglo XIX”, pp. 375-405; M Antonia Virgili Blanquet, "La reforma de la música sacra en España", en La musique entre France et Espagne, comp. Luis Jambou (París: Presses de l'Université de Paris-Sorbonne, 2003), pp. 153-163. 
impartido por monjes de Solesmes, y, dirigido a miembros de la Catedral, del Colegio del Corpus Christi y del resto de parroquias valencianas. El arzobispo Guisasola Menéndez pidió también que se recuperaran obras de Ambrosio Cotes, Ginés Pérez y Juan Bautista Comes y recomendó que la música religiosa moderna se adecuara al Motu Proprio y a las disposiciones de la Comisión de Música Sagrada de Valencia ${ }^{381}$.

Entre 1909 y 1913 la Comisión de Música Sagrada de Valencia sufrió diversas modificaciones. Se produjeron varias bajas de sus miembros por defunción, entre éstas, las de José Ma Úbeda y Eduardo Serrano (1909), Salvador Giner (1911), Roque Chabás (1912). Otros miembros de la Comisión salieron voluntariamente de ella (Femenía, Lliso y Damián) y fue en ese periodo cuando Amancio Amorós ingresó en la misma ${ }^{382}$.

En noviembre de 1912 se celebró en Barcelona el Tercer Congreso Nacional de Música Sagrada y a él acudió una representación de la diócesis de Valencia con Amancio Amorós entre sus miembros ${ }^{383}$. En el congreso se decidió crear la Asociación Ceciliana Española, (que fue presidida por el valenciano Vicente Ripollés) y la primera Escuela Superior de Música Sagrada (que, según Aviñoa, no llegó a funcionar nunca), y se remarcó el importante papel de las comisiones en sus respectivas diócesis como guardianas del Motu Proprio ${ }^{384}$.

\footnotetext{
381 Oriola, "L'article 24 de Pius X", pp. 347-348; Xosé Aviñoa en su artículo "Los congresos del Motu Proprio (1907-1928). Repercusión e influencias", Revista de Musicología, 27/1 (2004), pp. 386-387, resume las principales conclusiones del Primer Congreso de Música Sagrada celebrado en Valladolid.

382 Oriola, "L'article 24 de Pius X”, pp. 349-350; Anónimo, "Estadística General de la Diócesis de Valencia”, Almanaque Eclesiástico de la Diócesis de Valencia (1913), p. 298.

383 Asistieron al Congreso de Barcelona, Amancio Amorós, José Vila (Canónigo doctoral), Vicente Ripollés (Beneficiado director de canto litúrgico), Juan Bautista Pastor (Beneficiado, maestro de capilla), Mariano Baixauli (S. J.), Francisco Peñarroja (Presbítero), Miguel María Cavanillas, Luis Gallego y Eduardo López-Chavarri (Vocales). Véase BOAV, 1659 (16-VI-1912), pp. 232-235. El discurso pronunciado por el Arzobispo de Valencia en la sesión de clausura del III Congreso Nacional de Música Sagrada puede consultarse en el BOAV, 1671 (16-XII-1912), pp. 435-440.

${ }^{384}$ Tercer Congreso Nacional de Música Sagrada celebrado en Barcelona del 21 al 24 de noviembre de 1912. Crónica y actas oficiales (Barcelona: La Hormiga de Oro, 1913), pp. 230 y 242-243; Aviñoa, "Los Congresos del Motu Proprio", pp. 389-392; López-Calo, "Cien años de asociaciones”, p. 302. Puede consultarse también el Almanaque Eclesiástico de la Diócesis de Valencia (1913), pp. 208-213.
} 
La comisión de Música Sagrada de Valencia, por mandato arzobispal, solicitó a

finales de 1912 a los presbíteros de la diócesis que enviaran copia de los cantos religiosos que se cantaban en sus parroquias, con el objetivo de confeccionar un cancionero diocesano:

La Comisión encarecidamente ruega a todos los Rdos. Curas de la Archidiócesis que, por sí, o por persona competente, trascriban en notación moderna y sin preocuparse de los acompañamientos, los cantos religiosos-populares que hayan estado, o actualmente estén en uso en sus respectivas parroquias, sin omitir aquellos que al parecer, presenten el más mínimo interés, ya por la forma pobre de su melodía, ya por el insignificante valor literario de su texto que debe reproducirse fiel e íntegramente con todas sus estrofas y en su forma y versión original propia, castellana o valenciana $[\ldots]$ La Comisión, contando con la cooperación de los Rdos. Señores párrocos, confiadamente espera poder formar rica colección de cantos religiosos regionales, en la que figuren buen número de gozos, cantos para el rosario, vía crucis, difuntos, dolores de la Virgen y San José, y otros que indudablemente han de desenterrarse, mediante el auxilio de las personas entradas ya en años, que recuerden las costumbres y prácticas religiosas de la antigua y sólida piedad valenciana ${ }^{385}$.

Esta disposición abrió el camino para una interesante recuperación del patrimonio musical popular valenciano, cuyo alcance real está por estudiar. En 1913 la Comisión de Música Sagrada recomendó en un informe "estudiar y proponer nuevos medios con que fomentar y purificar el ejercicio del canto y música sagrada en los actos de culto”. Este informe se convirtió en precepto de obligado cumplimiento en toda la diócesis y sus recomendaciones estaban influenciadas, según Oriola, por las conclusiones del Tercer Congreso de Música Sagrada celebrado en Barcelona y por el Reglamento para la música sagrada de Roma publicado en el Boletín del Arzobispado de Valencia en $1913^{386}$.

\footnotetext{
${ }^{385}$ BOAV, 1672 (2-I-1913), pp. 4-6.

${ }^{386}$ Oriola, “L'article 24 de Pius X”, pp. 351-352.
} 
Las recomendaciones principales fueron:

1. Que se adoptaran las ediciones vaticanas del Gradual y Antifonario ${ }^{387}$.

2. Que el clero diocesano valenciano cantara los recitativos litúrgicos según la edición oficial del "Cantorino" y que interpretara adecuadamente los salmos.

3. Que los sochantres y salmistas tuvieran los conocimientos y la práctica necesaria para realizar su labor.

4. Que se asociasen los sochantres y salmistas de la ciudad bajo la presidencia del sochantre de la Catedral Metropolitana, y que, en caso de reunión de más de seis sochantres para el canto, fuera necesaria la dirección del sochantre presidente o de otro previamente designado para casos de ausencia o enfermedad.

5. Que el pueblo tomase parte activa en el canto de las melodías gregorianas.

6. Que se restablecieran las obras del periodo clásico de la polifonía sagrada en las capillas musicales de la Catedral de Valencia, Colegio del Corpus Christi y la Schola Cantorum del Seminario valenciano.

7. Que no se interpretaran obras sin el visto bueno de la Comisión de Música Sagrada, a excepción de la polifonía clásica y las obras recomendadas por las Asociaciones de Santa Cecilia de Alemania, Francia y España.

8. Que cada Parroquia creara su propio archivo musical.

9. Que nadie ejerciera como maestro-director, organista, concertador o cantor ni se realizasen obras de organería sin el informe de la Comisión de Música Sagrada y aprobación del arzobispado.

\footnotetext{
${ }^{387}$ Hubo competencia entre la antigua edición Medicea, de Ratisbona y los Antifonarios de San Gregorio, editados en Solesmes. Véase Baixauli, "La música religiosa", p. 27; Fernández de la Cuesta, "La reforma del canto", pp. 55-58.
} 
10. Que se evitase la profanidad en las composiciones musicales. Para ello los organistas, directores y cantores habían de procurar ejercer su labor con moderada expresividad, para no turbar la quietud y calma del culto cristiano.

11. Que los organistas respetasen siempre "el género ligado" y el contrapunto imitativo y se resistiesen a la "tentación de improvisar".

12. Ninguna reparación ni obra nueva de organería había de comenzar sin la aprobación del Prelado diocesano, ni a falta del previo examen e informe de la Comisión de Música Sagrada.

13. Que siempre que tuviesen que participar en la liturgia instrumentos distintos al órgano tuvieran la aprobación del Arzobispo.

14. Que la orquesta sólo estuviera integrada por el quinteto de cuerda, flauta, oboe, clarinetes, fagotes y trompas.

15. Con el fin de proveer buenas organistas y cantoras para las iglesias y conventos de religiosas, la Comisión de Música Sagrada juzgó necesario crear una Escuela Diocesana de Música Sagrada que impartiera clases de solfeo gregoriano y moderno de órgano, y de lectura e interpretación de obras polifónicas y modernas ${ }^{388}$.

De las recomendaciones citadas, resultó conflictiva la referente a la participación musical de las mujeres en las iglesias. El Motu Proprio, en el Capítulo 5, artículo 13, prohibía la intervención de las mujeres en las capillas musicales de las iglesias con estas palabras:

Del mismo principio se deduce que los cantores desempeñan en la Iglesia un oficio litúrgico; por lo cual las mujeres, que son incapaces de desempeñar tal oficio, no pueden ser admitidas a formar parte del coro o de la capilla musical. Y si se quiere tener voces agudas de tiples y contraltos, deberán ser niños, según uso antiquísimo de la Iglesia $^{389}$.

\footnotetext{
${ }^{388}$ BOAV, 1679 (16-IV-1913), pp. 183-188.

389 BOAV, 1459 (17-II-1904), p. 56.
} 
Sin embargo, el mismo Motu Proprio en el Capítulo 2, artículo 3 recomendaba la intervención del pueblo, y por tanto también de las mujeres, en el canto gregoriano:

Procúrese que el pueblo vuelva a adquirir la costumbre de usar el canto gregoriano para que los fieles tomen de nuevo parte más activa en el oficio litúrgico, como solían antiguamente ${ }^{390}$.

Esta última disposición, en la cual las mujeres podían intervenir musicalmente "como pueblo" creó diversas dudas que se intentaron aclarar en los decretos Angelopolitana y Neo-Elaboracensis ${ }^{391}$. El maestro Vicente Ripollés, por mandato del arzobispo de Valencia Guisasola, expuso en 1914 a la Congregación de Ritos que, en diversas iglesias de la diócesis de Valencia, existía la costumbre de formar coros y capillas de mujeres (fuera de los colegios), con exclusión absoluta de hombres. Ripollés formuló siete preguntas sobre lo que debía permitirse en relación al canto de las mujeres en la iglesia:

1. ¿Se permite, por virtud del decreto referido [Angelopolitana, 17-I1908], a los coros o capillas, formados de mujeres, solamente cantar en todas las funciones eclesiásticas y en cualesquiera iglesias?

2. ¿Puede confiarse a los mismos coros el canto de las partes invariables y variables de la Misa y del Oficio Divino en todas las iglesias?

3. ¿Está permitido que las capillas de que se trata canten en las funciones extralitúrgicas, por ejemplo, en la bendición del S. S., en el mes de María, en las novenas, etc?

4. Dichas capillas, ¿se permiten en los actos litúrgicos y extralitúrgicos de las cofradías o asociaciones de mujeres, cuando se celebran a puerta abierta y asisten hombres?

5. En las iglesias, ya sean seculares, ya de regulares, en las que hay obligación de coro, ¿es lícito a las mujeres alternar con los sacerdotes o religiosos en el canto de la Misa solemne o del Oficio divino?

6. Los coros mixtos de hombres y mujeres, ¿pueden tolerarse en las funciones sagradas, si, establecida consiguiente separación, no se ven mutuamente hombres y mujeres?

7. En los casos en que se permiten coros de mujeres solas, ¿es conveniente ocultarlas (por medio de celosías) a las miradas del pueblo? ${ }^{392}$.

\footnotetext{
390 BOAV, 1459 (17-II-1904), p. 53.

${ }^{391}$ La legislación eclesiástica sobre el canto de las mujeres en la iglesia fue analizada en Nemesio Otaño, "El canto de las mujeres en la iglesia”, Razón y Fe, 61/244 (1921), pp. 451-472.

392 Otaño, "El canto de las mujeres", pp. 466-467.
} 
La respuesta de la Sagrada Congregación de Ritos a las dudas expuestas por Ripollés fue el conocido como "Decreto Valentina” (1914), que en realidad no aclaró las cosas y se remitió a anteriores disposiciones:

A las siete preguntas sobre el canto especialmente de las mujeres en la iglesia, propuestas para su oportuna resolución por el actual maestro de canto gregoriano de la ciudad y Diócesis de Valencia, en España, con consentimiento de su Rm. Arzobispo, a la Sagrada Congregación de Ritos el día 14 de marzo próximo pasado [sic], la Sagrada Congregación de Ritos, oído el parecer de una especial Comisión, juzgó deber responder así:

Obsérvese el Motu Proprio de S. S. N. Papa Pio X (no 4121) Inter Pastorales officii, sobre la Música Sagrada, del 22 de noviembre de 1903, y los decretos Angelopolitana (n $\left.{ }^{\circ} 4210\right), 17$ de enero de 1908 y Neo-Eboracensis ( $\mathrm{n}^{\circ}$ 4231), de 18 de diciembre de 1908, conforme constan en el volumen VI de Decreta Authentica; S. R. C.

Martinelli, prefecto ${ }^{393}$.

Y así lo rescribió el día 4 de abril de 1914, Fr. Seb. Card.

En diciembre de 1916 fue nombrado arzobispo de Valencia José Ma Salvador

Barreda, quien confirmó en su cargo a los miembros de la Comisión de Música Sagrada

de Valencia y prohibió que a partir de 1920 se interpretasen composiciones sin la aprobación de la Comisión:

\begin{abstract}
Confirmamos, pues, en sus cargos a todos los señores que forman la Comisión diocesana de Música Religiosa, a la que conferimos toda la autoridad y atribuciones que sean precisas para el desempeño de su misión, y disponemos que, a partir del $1^{\circ}$ de enero de 1920 , no se ejecute en las iglesias obra musical alguna que no haya sido sometida a la censura y aprobación correspondiente.

Durante los cuatro últimos meses de año se recibirán en nuestra Secretaria de Cámara las obras que hayan de someterse a la censura; advirtiendo que deben presentarse numeradas, en partitura, con el título de la obra, nombre del autor y firma del remitente. En las obras para orquesta deberá también incluirse la reducción para órgano ${ }^{394}$.
\end{abstract}

El 22 de abril de 1920 fue nombrado arzobispo de Valencia Enrique Reig Casanova, natural de Agullent (Valencia) y paisano de Amorós, que puso de manifiesto

\footnotetext{
${ }^{393}$ Otaño, "El canto de las mujeres", p. 467.

${ }^{394}$ BOAV, 1835 (15-VII-1919), p. 237.
} 
en una circular que la normativa vaticana seguía sin cumplirse en la diócesis valenciana, y añadió nuevas recomendaciones: era necesario cumplir las normas oficiales; para la participación de orquestas en la iglesia había que solicitar permiso; los instrumentos de percusión y los coros femeninos estaban prohibidos; se permitían los cánticos a solo e instrumentos como el violoncello, el contrabajo y el fagot ${ }^{395}$.

Según Oriola, la Comisión de Música Sagrada valenciana, que emitió su último informe en 1913, fue bastante inoperante y, aunque no llegó a desaparecer, vio disminuir el número de sus componentes. La Comisión sufrió seis bajas entre 1920 y 1927, entre ellas la de Amancio Amorós, que fueron cubiertas sólo con dos altas, la de Juan Belda Pastor (1889-1936) y Francisco J. Lauzuruca Torralba (1890-1964) quien fue nombrado presidente de la Comisión a partir de $1925^{396}$.

Desde 1923 fue arzobispo de Valencia Prudencio Melo y Alcalde. Entre esa fecha y el anuncio del IV Congreso de Música Sagrada, celebrado en Vitoria en 1928, la cuestión musical y el papel de la Comisión de Música Sagrada de Valencia desaparecieron de las páginas del Boletín Arzobispal de Valencia ${ }^{397}$.

\footnotetext{
395 Oriola, “L'article 24 de Pius X”, p. 354.

396 Causaron baja por defunción Francisco Peñarroja (†1920), Mariano Baixauli (†1923), Amancio Amorós $(\dagger 1925)$, Juan Bautista Pastor $(† 1927)$. Juan Bautista Redó marchó a Toledo como sochantre en 1923 y José Vila fue nombrado obispo de Gerona en 1925.

${ }^{397}$ Oriola, "L’article 24 de Pius X”, p. 355.
} 
CAPÍTULO 2

AMANCIO AMORÓS SIRVENT (1854-1925): PERFIL BIOGRÁFICO 

En este capítulo presento la información biográfica disponible hasta el momento sobre el compositor Amancio Amorós, fruto de una exhaustiva revisión bibliográfica y de las investigaciones que he realizado en diferentes archivos, bibliotecas y hemerotecas.

\section{Formación y comienzos profesionales (1854-1889)}

\section{1. Entorno familiar y estudios musicales hasta 1881}

Amancio Amorós Sirvent nació en Agullent (Valencia) el 16 de septiembre de

1854, según consta en su partida de bautismo, hasta ahora inédita:

En la Iglesia Parroquial de San Bartolomé Apóstol, Provincia y Arzobispado de Valencia, yo, Don Antonio de Padua Dufour, cura de la misma, hoy día 16 de septiembre de 1854, bauticé solemnemente y según rito de la Santa Iglesia Católica y Apostólica Romana a Amancio Amorós Sirvent que ha nacido hoy entre las cinco y seis de la tarde. Hijo legítimo de Tomás [Amorós] y Vicenta Sirvent, consortes, mercaderes, naturales y vecinos de Agullent. Abuelos paternos José Amorós y Francisca Espí. Maternos Bartolomé Sirvent y Vicenta Espí, todos naturales y vecinos de Agullent. Fueron padrinos Vicente Esplugues y Vicente Casanova, naturales y vecinos de la misma a quienes previne el parentesco espiritual que contrajeron y la obligación y la obligación de enseñarle la doctrina cristiana. Fueron testigos José Casanova y Soler y Vicente Espí Sacristán, ambos de esta Villa $[\ldots]^{1}$.

Amancio era el tercer hijo del matrimonio, que tenía otros dos hijos mayores,

Paulina y Timoteo. Según el mismo compositor, recibió su primera formación musical de su padre, que era mercader, pero también gran aficionado a la música:

Recuerdo yo que en la aurora de mis días, en esa edad llena de encantos infantiles, en esa época, la más feliz de la vida, en la cual se ven deslizar los días como por arte mágico recibía de mi buen padre, aficionado entusiasta por la música, los primeros conocimientos prácticos de solfeo, los cuales a su debido tiempo, me sirvieron de base sólida para ensanchar los conocimientos necesarios que debía utilizar al ejercer la alta misión del profesorado ${ }^{2}$.

\footnotetext{
${ }^{1}$ E:AG, Quinque Libri, Libro IX, 55v, 16-IX-1854, $\mathrm{n}^{\circ} 35$. El nacimiento se produjo en la calle del Marqués, 4, según Bru, “Aproximación a Amancio Amorós”, p. 187.

${ }^{2}$ Amancio Amorós, Teoría General de Solfeo razonada en forma de diálogo y con un programa teórico de la asignatura (Valencia: Manuel Alufre, $1^{\mathrm{a}}$ ed., 1896), p. 5. Aunque según consta en la partida de bautismo, antes transcrita, el padre de Amancio Amorós era mercader, en el Padrón Municipal de Habitantes de Valencia consta como músico, E:VAa, Sección I, Sub. A Estadística. Clase I (Estadística de población), Padrón Municipal de Valencia 1875, legajo 274, nº cédula 17229.
} 
La familia Amorós Sirvent cambió en varias ocasiones de residencia y siempre hubo una relación directa entre los destinos que el Arzobispado de Valencia asignaba a José Amorós Espí, sacerdote y tío de Amancio, y las localidades en donde se instaló la familia Amorós Sirvent ${ }^{3}$. En 1862 los padres de Amancio Amorós se instalaron en la localidad de Bétera, próxima a Valencia capital, donde ese mismo año nació Eugenio, hermano menor de Amancio que, como él, fue también compositor y profesor de música ${ }^{4}$.

Posteriormente la familia se trasladó a Cocentaina (Alicante), donde el tío de Amancio, José Amorós Espí, que en 1867-68, era cura regente de la parroquia El Salvador, buscó el primer profesor de piano y órgano del joven, el agustino fray Pedro García, organista de dicha parroquia, "hasta el punto de confiársele a él la plaza de organista, apenas terminados los años de recibidas las primeras lecciones del padre García"5.

En 1871, Tomás Amorós Espí y Vicenta Sirvent Espí con sus cuatro hijos se trasladaron a Valencia. Vivieron primero en la calle Hospital y en julio de 1878 se trasladaron a la calle San Vicente $\mathrm{n}^{\mathrm{o}} 129^{6}$. En esta etapa Amancio Amorós contó con la tutela musical de Justo Fuster, conocido profesor de la ciudad:

\footnotetext{
${ }^{3}$ José Amorós Espí estuvo en 1854-1863 en la parroquia de Bétera (Valencia), posteriormente fue cura regente de la Parroquia El Salvador de Cocentaina (con toda seguridad entre 1867-1868). Posiblemente estuvo en esta parroquia hasta su muerte en 1871, ya que según el Quinqui Libri de la Parroquia El Salvador, a partir de 1872 fue cura regente Antonio Sorolla. E:COs, Quinque Libri 1867-1872, 12v, 19v, $20 \mathrm{v}, 39 \mathrm{v}, 40 \mathrm{v}, 53 \mathrm{v}, 201,325 \mathrm{v}$.

${ }^{4}$ Eugenio Amorós ingresó como infantillo en la Catedral de Valencia el 12 de octubre de 1871, cuando tenía nueve años. Fue durante mucho tiempo profesor de música del Colegio de San José de los jesuitas en Valencia. Sus obras se conservan en E:VAcp y E: VAbm. Véase José López-Calo, "Amorós Sirvent, Eugenio", en DMEH, vol. 1 (1999), p. 421.

${ }^{5}$ Serrano, “Amancio Amorós”, Ilustración Musical Hispanoamericana, 15-III-1891, p. 478.

${ }^{6} E: V A a$, Sección I, Sub. A Estadística. Clase I (Estadística de población), Índice de varones letra "T", legajo 307, $\mathrm{n}^{\circ}$ folio 17229; Padrón Municipal de Valencia 1875-80, legajo 274, $\mathrm{n}^{\circ}$ cédula 17229; Padrón Municipal de Valencia 1875-80, legajo 276, ${ }^{\circ}$ folio 19834.
} 
Trasladóse toda la familia, después de otras residencias, a Valencia, en cuya capital encontró otra robusta protección en la persona del distinguido maestro D. Justo Fuster, de imperecedera memoria [...]. Ningún músico ni aficionado de la época, desde 1860 hasta la actualidad dejó de conocer en sus días, como hoy recuerda después de ellos, las eminentes cualidades del distinguido profesor de piano y antiguo director de la escuela de música de los Escolapios ${ }^{7}$.

Es muy posible que Amancio Amorós estudiara en el Colegio Andresiano de las Escuelas Pías de Valencia, donde Justo Fuster fue profesor de solfeo y piano, aunque no he podido documentar esta suposición ${ }^{8}$. Parece ser que en Valencia Amancio Amorós estudió piano con Roberto Segura y armonía con Antonio Marco y Justo Fuster ${ }^{9}$. El propio Amorós indicó que: “en 1876 ya había finalizado mis estudios de piano”, aunque no he podido constatar si obtuvo alguna titulación oficial ${ }^{10}$.

\footnotetext{
${ }^{7}$ Eduardo Serrano, “Amancio Amorós”, p. 478. Justo Fuster Carceller nació en Tronchón (Teruel) el año 1815 y fue, según Ruiz de Lihory, el maestro más conocido y popular del segundo tercio del siglo XIX en Valencia. Trabajó en el Colegio Andresiano de las Escuelas Pías, y entre sus alumnos estuvieron Amancio Amorós, Roberto Segura, José Valls, Ricardo Benavent, Blas María Colomer y otros. Murió en Valencia en julio de 1876. Véase Ruiz de Lihory, La Música en Valencia, p. 264 y Saldoni, Diccionario biográfico, vol. 3 (1880), pp. 16-17.
}

${ }^{8}$ En el Archivo Histórico de la Universidad de Valencia (en adelante $E: V A u$ ) y en el Archivo de la Curia de Valencia, centros que conservan documentación de los Escolapios, no he podido localizar datos sobre Amancio Amorós. Los Escolapios dirigían en Valencia el Real Colegio de San Joaquín, las "Escuelas Pías de la Plaza", que eran gratuitas, y el Seminario Andresiano; véase Vicente Faubell, Diccionario Enciclopédico Escolapio, dir. Luis M ${ }^{\text {a }}$ Bandrés Rey (Madrid: Publicaciones ICCE, 1990), vol. 1, pp. 831, 836. Según Pascual Madoz, Diccionario Geográfico-estadístico-histórico de Alicante, Castellón y Valencia (Valencia: Edicions Alfons El Magnànim, 1987), vol. 2, p. 270, en el Colegio-Seminario Andresiano, se podía estudiar música, francés y dibujo, además de las asignaturas propias de la primera y segunda enseñanza. Los alumnos podían ser pensionistas o medio-pensionistas y los propios seminaristas pagaban al profesor de música.

${ }^{9}$ Según Serrano, “Amancio Amorós”, p. 478, Justo Fuster reunía a un número escogido de discípulos las tardes de jueves y domingos "distrayéndoles con las improvisaciones y repentizaciones de obras clásicas de los mejores maestros de piano" (véase Apéndice 3); Sobrino, “Amorós Sirvent, Amancio", p. 421. Roberto Segura estuvo matriculado en 1873 como alumno de quinto curso de piano en la clase del profesor E. Compta en el Conservatorio de Madrid; E:Mc, Actas de exámenes, generales y extraordinarios 1865-1878 (microfilm). Segura estudió también en París con Georges Mathias (18261910), un discípulo directo de Chopin, según López-Chavarri, Cien años de historia, pp. 36-42. Sobre Mathias, véase Jean-Jacques Eigeldinger, "Mathias, Georges-Amedée Saint Clair", en Chopin vu pour ses élèves (Suiza: ed. de la Baconnière, 1988), pp. 246-248.

${ }^{10}$ En Valencia no era posible obtener el título de Piano en esa época. No he localizado a Amorós entre los inscritos para los exámenes por libre en el Conservatorio de Madrid. E:Mc, Libros de pago derechos de matrícula y exámenes entre 1865-1877, 1877-1887, 1887-1899, 1899-1906; Actas de exámenes 18721880; Enseñanza Libre, Exámenes extraordinarios desde 1875 a 1879; Enseñanza Libre, Pagos de matrícula 1901-1909; Actas de exámenes, generales y extraordinarios 1865-1878; Actas de exámenes, generales y extraordinarios 1878-1880. 
En el curso 1879-80 Amancio Amorós fue admitido en el recién creado conservatorio de Valencia como alumno oficial de $1^{\mathrm{o}}$ de Composición, junto con Francisco Antich Carbonell y Enrique José García Muní ${ }^{11}$.

Durante los cursos 1879-80 y 1880-81 Amorós estudió $1^{\circ}$ y $2^{\circ}$ de Composición con los profesores José M $\mathrm{M}^{\mathrm{a}}$ Úbeda y Antonio Marco, respectivamente. Amorós obtuvo la calificación de "Bueno" en $1^{\circ}$ de Composición y "Sobresaliente" en $2^{\circ}$, pero no prosiguió sus estudios de composición en el centro, ya que su nombre no aparece en las actas posteriores de los exámenes ordinarios y extraordinarios ${ }^{12}$. Según Serrano, Amorós estudió con Salvador Giner, quizás en el domicilio de éste en la calle Liria de Valencia, a la que acudían muchos alumnos ${ }^{13}$.

Es posible que Amorós interrumpiera su formación como compositor al empezar a desempeñar tareas profesionales. El 11 de enero de 1882 el músico envió una carta a José $\mathrm{M}^{\mathrm{a}}$ Úbeda, director del conservatorio, comunicando que para atender a sus muchas ocupaciones se veía obligado a darse de baja como alumno de las clases de composición ${ }^{14}$.

El 11 de febrero de 1880 Amancio Amorós se casó con la joven de 19 años $\mathrm{M}^{\mathrm{a}}$ del Consuelo Barra Escat y el matrimonio se instaló en la calle Las Monjas $n^{\circ} 8$ de Valencia.

\footnotetext{
${ }^{11}$ En 1879, año de fundación del Conservatorio de Valencia, el centro convocó pruebas de ingreso para acreditar los conocimientos de su alumnado. Para comenzar el estudio de cualquier instrumento, el alumnado tenía que acreditar el conocimiento de dos cursos de solfeo; para canto, uno; para órgano y armónium, un curso de piano; para composición todos los cursos de armonía. E:VAcm, Acta del Claustro de profesores del Conservatorio de Música de Valencia, 19-X-1879 y Libro de Actas de los Exámenes de ingreso del Conservatorio 1879-80, acta 7-XI-1879. Los tribunales para estas pruebas de ingreso estuvieron formados por los profesores que impartirían las clases objeto de examen. Las Provincias, 31X-1879. Véase José Climent, "Antich Carbonell, Francisco", en DMEH, vol. 1 (1999), pp. 487-488; J. Pasqual Hernàndez Farinós, "Francesc Antich Carbonell, músic de Silla", Algudor, 3 (2004), pp. 73-86, Ernesto Valor Calatayud, “García Muñí, Enrique José”, en DMEH, vol. 5 (2001), p. 481.

${ }^{12}$ E:VAcm, Actas Exámenes Ordinarios de Junio Conservatorio de Música de Valencia. Cursos 1879-80 y 1880-81; Pedrell, Diccionario biográfico, p. 63.

${ }^{13}$ Serrano, "Amancio Amorós", p. 478; Vicente Vidal Corella, "El humorista Don Salvador Giner", en Las Provincias, 14-XI-1971.

${ }^{14}$ E:VAcm, Acta del Claustro de profesores del Conservatorio de Música de Valencia, 15-I-1882.
} 
Tuvieron tres hijos: $\mathrm{M}^{\mathrm{a}}$ del Consuelo, $\mathrm{M}^{\mathrm{a}}$ de la Purificación y José Vicente. La Ilustración

6 muestra la imagen de un joven José Vicente Amorós Barra junto a su padre.

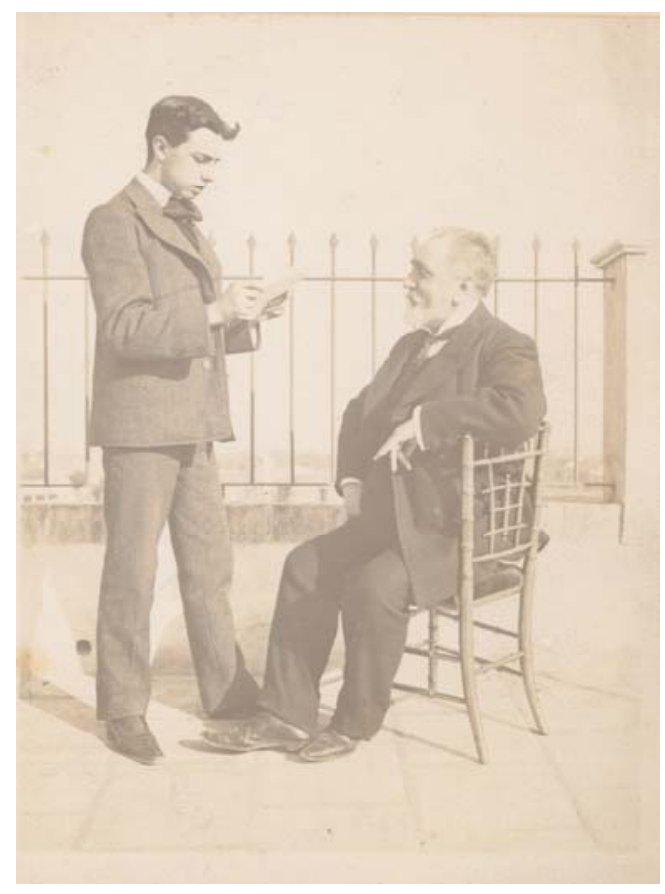

Ilustración 6

Amancio Amorós e hijo (ca. 1904).

Archivo familiar Margarita Amorós Portolés.

Con la familia vivían además Ascensión Belda Revert, natural de Ontinyent

(Valencia) y Remedios Claramunt Montañés, de Puzol (Valencia) que posiblemente eran

el servicio doméstico ${ }^{15}$. Todo parece indicar que el compositor pasaba sus temporadas

estivales en una masía de Bétera, a pocos kilómetros de la capital valenciana. Todavía en

${ }^{15}$ E:VAa, Sección I, Sub. A Estadística. Clase I (Estadística de población), Padrón Municipal de Valencia 1875-80, legajo 268, $\mathrm{n}^{\circ}$ folio 11136; E:VAa, Sección I, Sub. A Estadística. Clase I (Estadística de población), Índice de Varones letra “A”, legajo 429; Padrón Municipal de Valencia 1889, legajo 657, $\mathrm{n}^{\circ}$ folio 13758. Según datos de este último padrón, $\mathrm{M}^{\mathrm{a}}$ del Consuelo Amorós nació el 22-XI-1880; $\mathrm{M}^{\mathrm{a}}$ de la Purificación Amorós el 28-I-1882; y José Vicente Amorós el 31-XI-1887. Por el testimonio oral de la nieta de Amorós, Margarita Amorós Portolés, sé que $\mathrm{M}^{\mathrm{a}}$ del Consuelo Amorós fue monja en la Congregación de Adoratrices de Sevilla. $\mathrm{M}^{\mathrm{a}}$ de la Purificación obtuvo el título de maestra en la Escuela Normal de Maestras de Valencia en 1899, E:VAu, Sección Expedientes académicos, caja 932, legajo 25. En 1908-09 ejerció de maestra en Silla (Valencia) y posteriormente en Sevilla; véase Juan Manuel Fernández Soria y Carmen Agulló, Los temas educativos en las memorias del magisterio valenciano 1908-1909 (Valencia: Universitat de Valencia, 2002), p. 261. José Vicente Amorós Barra se licenció en Filosofía y Letras (sección de Historia) por la Universidad de Valencia en el curso 1907-1908, según consta en el E:VAu, Sección Expedientes, caja 1214, legajo 1. Su trayectoria posterior puede verse más adelante en este mismo capítulo. 

año ${ }^{16}$ (Ilustración 7).

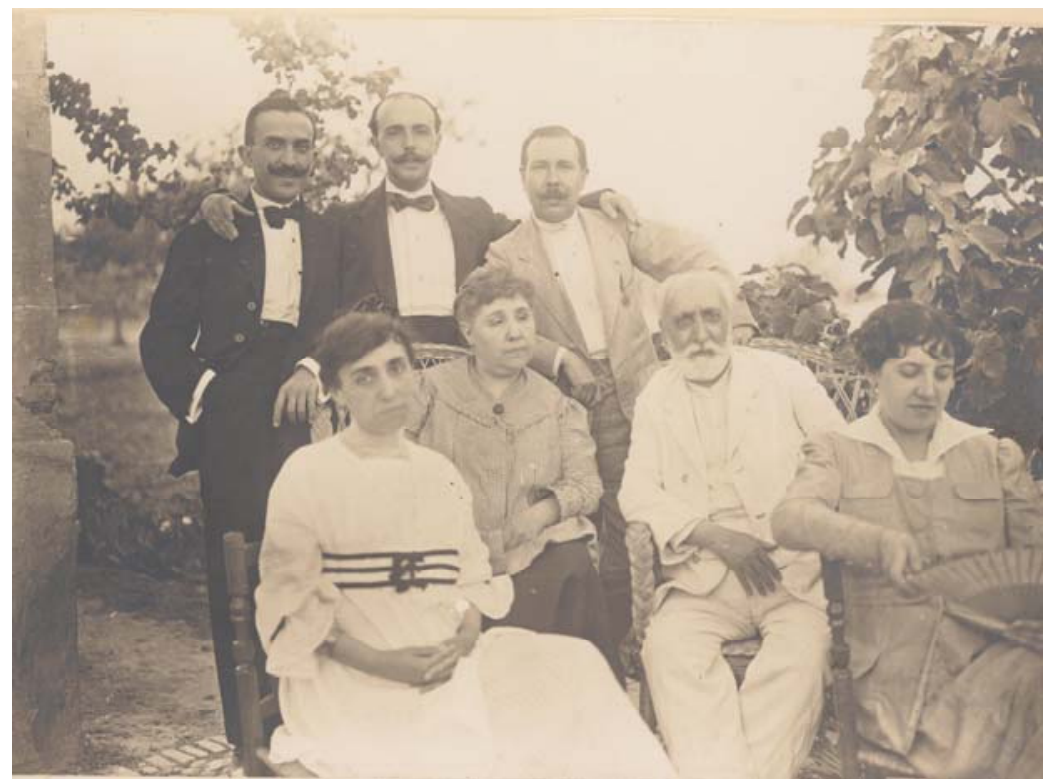

Ilustración 7

La familia Amorós en Bétera, verano de 1916.

De pie de izquierda a derecha: un amigo de la familia, José Vicente Amorós y Emilio Ramírez ${ }^{17}$ (marido de Purificación)

Primera fila, sentados de izquierda a derecha: Purificación Amorós, Consuelo Barra, Amancio Amorós y Teresa Portolés

Archivo familiar Margarita Amorós Portolés.

\section{2. Amorós pianista y primeras composiciones (1882-1889)}

Cuando Amancio Amorós finalizó sus estudios de piano en 1876 se convirtió en un pianista de gran fama en Valencia ${ }^{18}$. Tenía gran facilidad para la repentización y era

\footnotetext{
${ }^{16}$ En algunos manuscritos de sus obras, Amorós escribía lugar y fecha de composición, por lo que me inclino a pensar que la masía "Les Aleretes" de Bétera fue la residencia veraniega de la familia. A finales del siglo XIX y primer cuarto del siglo XX, fue frecuente que la burguesía de la ciudad de Valencia veraneara en el pueblo de Bétera. Posiblemente la inauguración de la línea de tren Bétera-Valencia en 1891, favoreció esta tendencia. Las nuevas construcciones que la burguesía hizo edificar destacaron por las comodidades que todavía no habían llegado a las casas del pueblo. En la actualidad todavía se pueden contemplar algunas de estas viviendas, unas en uso, otras ya abandonadas.

17 Emilio Ramírez (1878-1956), yerno de Amancio Amorós, fue compositor, docente y folklorista murciano. Véase Antonio Oliver, Medio siglo de artistas murcianos (1900-1950) (Murcia: Patronato de Cultura de la Diputación, 1952) p. 171. Enrique Encabo, "Los Cuadros Murcianos de Emilio Ramírez", Revista de Musicología, 32/2 (2009), p. 126, lo adscribe a la escuela casticista y regionalista murciana previa a las vanguardias.
} 
muy solicitado para participar en conciertos y veladas que se celebraban en los salones de las clases burguesas y aristocráticas valencianas y en las principales sociedades culturales de la ciudad ${ }^{19}$.

Entre 1881 y 1884 fue profesor auxiliar de piano en el Conservatorio valenciano $^{20}$. En una foto tomada años después podemos ver a Amancio Amorós al piano (Ilustración 8) y se recordaban así sus primeros pasos profesionales:

Desde los diecisiete años que se consagró a la enseñanza del piano y a dar conciertos de este instrumento, su vida ha sido altamente laboriosa, pues primeramente como pianista y luego como compositor, y en ambos casos como pedagogo, ha realizado una labor intensísima. Fue muy solicitado para dar conciertos, siendo muy aplaudido por el público inteligente.

Creó, actuando como pianista o como director, varias agrupaciones consagradas al fomento de la buena música, como tercetos, cuartetos, quintetos [...] tanto antiguos como modernos ${ }^{21}$.

\footnotetext{
${ }^{18}$ Amancio Amorós Sirvent, "Impresiones", en Escritos heortásticos al Maestro Pedrell (Tortosa: Casa Social del Orfeó Tortosí, 1911), 2 vol., p. 259. A la edad de 23 años ya figura como pianista en los datos del Padrón de Valencia, E:VAa, Sección I, Sub. A Estadística. Clase I (Estadística de población), Padrón Municipal de Valencia 1875-80, legajo 274, $\mathrm{n}^{\circ}$ fol. 17229.

${ }^{19}$ Sobrino, “Amorós Sirvent, Amancio”, p. 421.

20 E:Mba, legajo 5-2-2, Expediente de nombramiento de Amancio Amorós como Académico Correspondiente, elaborado en 1921 por los Académicos de la Real Academia de San Fernando de Madrid, Pedro Fontanilla, Narciso Sentenach y Joaquín Larregla.
}

$21 E: M b a$, legajo 5-2-2, Expediente de nombramiento de Amancio Amorós como Académico Correspondiente (1921). 


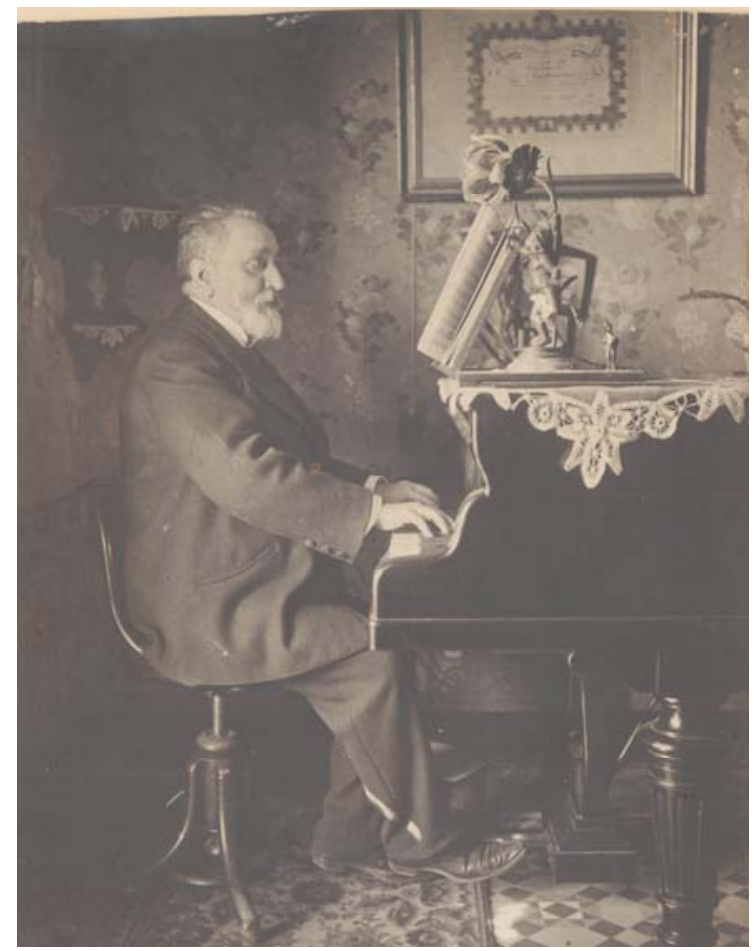

Ilustración 8

Amancio Amorós al piano (ca. 1904). Archivo familiar Margarita Amorós.

Era también muy reconocida la técnica pianística de Amorós:

Puede decirse que la Escuela de su mecanismo ocupa el medio entre la de Compta y Mendizábal del Conservatorio de Madrid, cuyos representantes en el de Valencia son hoy Segura y Valls. Posición elegante, pulsación y digitación, huyendo de las exageraciones mímicas, con las que se pretende por los exaltados lograr del instrumentos ciertos detalles del colorido, que pugnan abiertamente con el mecanismo de aquel; corrección en el fraseo, apartándose de las censurables corruptelas de forzar el ritmo, limpieza en la ejecución y acabada seguridad, he ahí los caracteres del pianista Amorós; por lo que se le venían confiando las empresas más difíciles en la obras clásicas di camera ${ }^{22}$.

Amorós fue un intérprete habitual en las reuniones literario-musicales organizadas periódicamente por la sociedad Lo Rat Penat desde 1882, lo que sin duda le hizo contactar con todo el ambiente cultural de la Renaixença valenciana. Este mismo año estrenó en una de estas veladas su obra Gemechs del cor, con letra de Ramón Oltra, obra

\footnotetext{
${ }^{22}$ Serrano, “Amancio Amorós”, p. 478. Sobre los músicos Compta y Mendizábal, véase Emilio Casares Rodicio, "Compta Torres, Eduardo", en DMEH, vol. 3 (1999), pp. 858-859; Ramón Sobrino Sánchez, “Mendizábal de Sagastume, Manuel A.”, en DMEH, vol. 7 (2000), pp. 433-434.
} 
en la actualidad desaparecida ${ }^{23}$. Actuó también en las celebradas por la Academia

Científico Literaria de la Juventud Católica al menos desde $1885-86^{24}$. En diciembre de 1885, por ejemplo, los hermanos Timoteo, Amancio y Eugenio Amorós participaron en un concierto de esta Academia con el siguiente programa:

1. Melodía para piano y armónium de Giacomo Meyerbeer.

2. El Trapeuse, melodía para barítono de Giacomo Meyerbeer.

3. Capricho Brillante de Félix Mendelssonhn.

4. Serenata de Charles Gounod.

5. Ave María de Saverio Mercadante ${ }^{25}$.

Según Astruells Moreno, Amorós participó también al piano en veladas de cafés $^{26}$. El legado de obras de Amancio Amorós que su hijo depositó en la Biblioteca de Catalunya en 1930, incluye dos colecciones o álbumes con diversas obras impresas para piano de mediados del siglo XIX, probablemente encuadernadas por el propio Amancio Amorós, y tituladas Álbum Musical y Álbum Pianístico (véanse Tablas 19 y 20) que seguramente reflejan el tipo de repertorio que el músico interpretaba en sus actuaciones juveniles $^{27}$. Esta actividad como pianista fue compaginada con la enseñanza de piano en diversos centros valencianos como mostraré más adelante.

\footnotetext{
${ }^{23}$ Almanaque de las Provincias para 1882, p. 230. Posiblemente la obra se conserva en el archivo de Lo Rat Penat al cual no he tenido acceso. Otros autores que participaron en las veladas de los años 1882 y 1883 fueron José Jordá, Manuel Penella, Francisco Goérlich, Vicente Peydró, Facundo Domínguez, Eduardo Senís, véase también Almanaque de las Provincias para 1883, p. 140.

${ }^{24}$ La memoria del curso 1885-86 menciona el éxito ofrecido por la sección de música en las sesiones celebradas por la entidad, en las que participaron Salvador Giner, Amancio Amorós y sus hermanos Eugenio y Timoteo, José $\mathrm{M}^{\mathrm{a}}$ Úbeda, José $\mathrm{M}^{\mathrm{a}}$ Medina, Mariano Baixauli, José Bellver, Facundo Domínguez, José Alfaro, Lamberto Alonso, Massó, Vicente Sanchis y Juan B. Pastor; véase BoletínRevista de la Juventud Católica de Valencia, 56 (1885), p. 405.

${ }^{25}$ Boletín-Revista de la Juventud Católica de Valencia, 54 (1885), p. 26.

${ }^{26}$ Astruells, La Banda Municipal, p. 66.

${ }^{27}$ El Álbum Pianístico ingresó en la $E: B c$ con el no de registro 123976 (E:Bc, M 4128), está encuadernado con tapas de color azul y mide 35 x $27 \mathrm{cms}$. El Álbum Musical ingresó en la $E: B c$ con el n ${ }^{\circ} 123975$ (E:Bc, M 4220) y está encuadernado con tapas rígidas de color azul oscuro y lomo rojo con unas medidas de 35 x 27'5 cms. El Álbum Pianístico contiene unas danzas del compositor cubano Ignacio Cervantes, con una dedicatoria manuscrita en la portada de éstas, firmada en 1889 que dice: "Dedica este recuerdo a su afectuoso amigo el maestro compositor D. Amancio Amorós".
} 
Tabla 19. Obras contenidas en el Álbum Musical de Amancio Amorós. Fuente: Álbum Musical, E:Bc, M 4220.

\begin{tabular}{|c|c|c|c|}
\hline Compositor & Título & Género/Forma & $\begin{array}{l}\text { Editor/Páginas } \\
\text { Observaciones }\end{array}$ \\
\hline $\begin{array}{c}\text { Amancio Amorós } \\
(1854-1925)\end{array}$ & $\begin{array}{l}\text { Terceto, Escena y Vals de } \\
\text { la zarzuela Los dos esclavos }\end{array}$ & $\begin{array}{l}\text { Arreglos de piezas } \\
\text { teatrales }\end{array}$ & Schott, 6 pp. \\
\hline [Concha] Díaz Castro & María & Polca-mazurca & Zozaya $^{28}, 3$ pp. \\
\hline [Albert] Encrois & Fleurs des Champs & Mazurca & Zozaya, 4 pp. \\
\hline [Albert] Encrois & Langage des fleurs & Polka & Zozaya, 5 pp. \\
\hline $\begin{array}{c}\text { [Philipp] Fahrbach } \\
(1815-1885)\end{array}$ & Rêves de Printemps & Vals & Zozaya, 8 pp. \\
\hline $\begin{array}{c}\text { Anónimo, arreglada por } \\
\text { [E.] Ferrer }\end{array}$ & Tango Sevillano & Canción popular & Zozaya, 3 pp. \\
\hline $\begin{array}{l}\text { [Eduardo] López Juarranz } \\
\text { (1844-1897) }\end{array}$ & Lazo nupcial & Mazurca & Zozaya, 5 pp. \\
\hline $\begin{array}{c}\text { [Ignace] Leybach } \\
(1817-1891)\end{array}$ & Bolero Brillant & Bolero & Zozaya, 6 pp. \\
\hline $\begin{array}{c}\text { [Gustave] Lange } \\
(1830-1889)\end{array}$ & Valse Champêtre & Vals & Zozaya, 7 pp. \\
\hline [Blanca] Llisó y Martínez & Celia & Mazurca de salón & Zozaya, 6 pp. \\
\hline $\begin{array}{c}\text { [George] Pfeiffer } \\
(1835-1908)\end{array}$ & $4^{a}$ Mazurca de salón & Mazurca & Zozaya, 7 pp. \\
\hline $\begin{array}{c}\text { [Carl] Millöcker } \\
(1842-1899) \\
\end{array}$ & $\begin{array}{c}\text { Gasparone } \\
\text { Carlotta-Walzer }\end{array}$ & Vals de la opereta & Zozaya, 8 pp. \\
\hline $\begin{array}{c}\text { [Ruperto] Ruiz de } \\
\text { Velasco (1858-1897) }\end{array}$ & Aurora & Mazurca & Zozaya, 4 pp. \\
\hline [Luke] Wheeler & Loyauté & 4valses & Zozaya, 8 pp. \\
\hline \multirow{9}{*}{$\begin{array}{l}\text { [Emile] Waldteufel } \\
\quad(1837-1915)\end{array}$} & Pres de toi & 4 valses & Zozaya, 8 pp. \\
\hline & Joie Envolée & 4 valses & Zozaya, 8 pp. \\
\hline & Nuit d'amour & 4 valses & Zozaya, 8 pp. \\
\hline & Sentiers fleuris & Tanda de 4 valses & Zozaya, 8 pp. \\
\hline & Les souries & Suite de valses & Zozaya, 8 pp. \\
\hline & Les fleurs & Suite de valses & Zozaya, 8 pp. \\
\hline & Lune de miel & Tanda de valses & Zozaya, 8 pp. \\
\hline & Ma voisine & Polka & Zozaya, 6 pp. \\
\hline & Camarada & Polka & Zozaya, 5 pp. \\
\hline $\begin{array}{l}\text { [Philipp] Fahrbach } \\
\text { (junior) }\end{array}$ & Lozanía & Galop & Zozaya, 1 pp. \\
\hline Amancio Amorós & Los dos esclavos $\mathrm{n}^{\circ} 9$ & Guaracha & Schott, 4 pp. \\
\hline Amancio Amorós & Los dos esclavos $\mathrm{n}^{\circ} 13$ & Habanera & Schott, 5 pp. \\
\hline Amancio Amorós & Los dos esclavos $\mathrm{n}^{\circ} 12$ & Romanza & Schott, 6 pp. \\
\hline Manuel Chulvi & La Ricamatrice & $\begin{array}{l}\text { Melodía para canto y } \\
\text { piano }\end{array}$ & $\begin{array}{l}\text { Propiedad del autor, } \\
\text { no especifica datos } \\
\text { editoriales, } 6 \text { pp. Con } \\
\text { una dedicatoria } \\
\text { autógrafa del autor a } \\
\text { Amancio Amorós. }\end{array}$ \\
\hline
\end{tabular}

28 Las obras editadas por Benito Zozaya aparecieron en La Correspondencia Musical: Semanario Artístico y Biblioteca Musical, publicada por el editor Zozaya. Suscripciones en Almacén de Música y pianos de Madrid, Carrera de San Jerónimo, 34. 


\begin{tabular}{|c|c|c|c|}
\hline $\begin{array}{c}\text { [J.] Goula (letra de A. de } \\
\text { Sanctis) }\end{array}$ & Rendez-Vous-Controcambio & $\begin{array}{c}\text { Stornello para canto y } \\
\text { piano }\end{array}$ & Zozaya, 5 pp. \\
\hline $\begin{array}{c}\text { Vicent] Costa i Nogueras } \\
(1853-1919)\end{array}$ & La Muñeca & Mazurca & Zozaya, 2 pp. \\
\hline $\begin{array}{c}\text { [Franz von] Suppé } \\
(1819-1895)\end{array}$ & $\begin{array}{c}\text { Boccacio } \\
\text { Célebre vals de las Cartas }\end{array}$ & $\begin{array}{c}\text { Vals para canto y } \\
\text { piano }\end{array}$ & Zozaya, 6 pp. \\
\hline
\end{tabular}

Tabla 20. Obras contenidas en el Álbum Pianístico de Amancio Amorós.

Fuente: Álbum Pianístico, E:Bc, M 4128

\begin{tabular}{|c|c|c|c|}
\hline Compositor & Título & Género/Forma & $\begin{array}{l}\text { Editor/Páginas } \\
\text { Observaciones }\end{array}$ \\
\hline $\begin{array}{c}\text { Amancio Amorós } \\
(1854-1925)\end{array}$ & Violetas y Mariposas & Capricho & $\begin{array}{l}\text { Casa editorial Salvador } \\
\text { Prosper (sf), } 9 \text { pp. }\end{array}$ \\
\hline \multirow{5}{*}{$\begin{array}{l}\text { [Isaac] Albéniz } \\
\text { (1860-1909) }\end{array}$} & $\begin{array}{l}\text { Scherzo de la Primera } \\
\text { Serenata }\end{array}$ & Scherzo & Zozaya $^{29}, 6$ pp. \\
\hline & Barcarola & Barcarola & Zozaya, 5 pp. \\
\hline & $\begin{array}{l}\text { Suite Espagnole, } \mathrm{n}^{\circ} 1 \\
\text { Granada }\end{array}$ & Serenata & Zozaya, 4 pp. \\
\hline & Pavana-Capricho & Pavana & Zozaya, 4 pp. \\
\hline & $\begin{array}{l}\text { Suite Espagnole, } \mathrm{n}^{\circ} 3 \\
\text { Sevilla }\end{array}$ & Sevillana & Zozaya, 7 pp. \\
\hline $\begin{array}{c}\text { [Ignacio] Cervantes } \\
(1847-1905)\end{array}$ & Danzas & 6 danzas & $\begin{array}{c}\text { Incluye dedicatoria } \\
\text { manuscrita en la } \\
\text { portada de éstas, } \\
\text { firmada en } 1889: \\
\text { "Dedica este recuerdo } \\
\text { a su afectuoso amigo } \\
\text { el maestro compositor } \\
\text { D. Amancio Amorós". } \\
\text { Almacén de música, } \\
\text { pianos e instrumentos } \\
\text { de Anselmo López, } \\
6 \text { pp. } \\
\end{array}$ \\
\hline $\begin{array}{c}\text { [Nicolas R.] Espadero } \\
(1832-1890)\end{array}$ & ¡Partez ingrate! & Romanza sin palabras & $5 \mathrm{pp}$ \\
\hline $\begin{array}{c}\text { Henri] Kowalski } \\
(1841-1916) \\
\end{array}$ & $\begin{array}{c}\text { Marche Hongroise, op. } \\
13\end{array}$ & Marcha & Zozaya, 8 pp. \\
\hline $\begin{array}{c}\text { [Gustav] Lange } \\
(1830-1889)\end{array}$ & Fleurs Fanées, op. 48 & Melodía para piano & Zozaya, 5 pp. \\
\hline $\begin{array}{c}\text { [Giuseppe] Verdi } \\
\text { (transcrita para piano } \\
\text { por Le Carpentier, } \\
\text { Antoine) }\end{array}$ & Un ballo in Maschera & Fantasía para piano & Zozaya, 7 pp. \\
\hline $\begin{array}{c}\text { [Félix] Godefroid } \\
(1818-1897)\end{array}$ & Canción Criolla, op. 119 & Capricho & Zozaya, 5 pp. \\
\hline $\begin{array}{c}\text { [Félix] Godefroid } \\
\text { (transcrita para piano por } \\
\text { Gottschalk) }\end{array}$ & La melancolía & Estudio característico & Zozaya, 8 pp. \\
\hline $\begin{array}{c}\text { [Louis Moreau] } \\
\text { Gottschalk }\end{array}$ & $\begin{array}{l}\text { Últimos momentos de } \\
\text { un poeta }\end{array}$ & Meditación & Zozaya, 6 pp. \\
\hline
\end{tabular}

${ }^{29}$ Las obras editadas por Benito Zozaya aparecieron en La Correspondencia Musical: Semanario Artístico y Biblioteca Musical. 


\begin{tabular}{|c|c|c|c|}
\hline$(1829-1869)$ & $\begin{array}{c}\text { Recuerdos de Andalucía, } \\
\text { op. } 22 \\
\end{array}$ & Capricho de concierto & Zozaya, 10 pp. \\
\hline & Pasquinade, op. 59 & Capricho & Zozaya, 8 pp. \\
\hline & Acuérdate, op. 26 & Meditación para piano & Zozaya, 7 pp. \\
\hline & La Savane & Balada criolla & Zozaya, 8 pp. \\
\hline [Louis Moreau] & El Manzanillo, op. 11 & - & Zozaya, 10 pp. \\
\hline Gottschalk (1829-1869) & Dernière Espérance & Meditación religiosa & Zozaya, 7 pp. \\
\hline [Oscar De la] Cinna $(i ?)$ & $\begin{array}{l}\text { Zambra jitana }[\text { sic], op. } \\
330\end{array}$ & Pensamiento poético & Zozaya, 6 pp. \\
\hline & Estudiantina, op. 287 & Pensamiento poético & Zozaya, 6 pp \\
\hline $\begin{array}{c}\text { [Antonio] Peña y Goñi } \\
(1846-1896)\end{array}$ & ¡Guipúzcoa mía! & Nostalgia & Zozaya, 5 pp. \\
\hline $\begin{array}{c}\text { [Carlos Alfredo] } \\
\text { Peyrellade (1840-1908) }\end{array}$ & Ecos tropicales, op. 12 & Capricho cubano & $\begin{array}{c}\text { Anselmo López } \\
\text { Sucesor de Edelmann } \\
\text { y Cia, La Habana, } \\
12 \text { pp. }\end{array}$ \\
\hline $\begin{array}{l}\text { [Francisco Asenjo] } \\
\text { Barbieri (arreglada y } \\
\text { transcrita por Peña y } \\
\text { Goñi) }\end{array}$ & $\begin{array}{c}\text { Gran Fantasía sobre } \\
\text { motivos de la zarzuela } \\
\text { Pan y Toros }\end{array}$ & Fantasía & $16 \mathrm{pp}$. \\
\hline $\begin{array}{c}\text { [Miguel] Santonja } \\
(1858-?)\end{array}$ & Pavana & Pavana & Zozaya, 6 pp. \\
\hline [Giuseppe] Verdi & $\begin{array}{c}\text { Sinfonía de Juana de } \\
\text { Arco }\end{array}$ & Sinfonía & Zozaya, 10 pp. \\
\hline \multirow{6}{*}{$\begin{array}{l}\text { [Gaspar] Villate } \\
(1851-1891)\end{array}$} & Marcha Fúnebre & Marcha & Zozaya, 4 pp. \\
\hline & \multirow{5}{*}{ Baldassarre (ópera) } & Gran Marcia & \multirow{5}{*}{ Zozaya, 6 pp. } \\
\hline & & Pastorale $7 \mathrm{pp}$. & \\
\hline & & Preludio 6 pp. & \\
\hline & & Marcia Assiria 6 pp. & \\
\hline & & Danza d'Ossiris 6 pp. & \\
\hline
\end{tabular}

El orden en que aparecen las obras en las dos colecciones parece aleatorio. En el Álbum Musical los autores son mayoritariamente europeos, hay una representación de autores valencianos y catalanes y, se incluyen obras de dos compositoras, Concha Díaz Castro y Blanca Llisó y Martínez que no aparecen en el Diccionario de la Música Española e Hispanoamericana. La mayor parte de las obras son reducciones de zarzuela y bailes como polcas, mazurcas y valses ${ }^{30}$. El Álbum Musical incluye reducciones para piano y canto y piano de cuatro números editados de la zarzuela de Amancio Amorós Los

\footnotetext{
${ }^{30}$ Ricardo Miranda, "A tocar, señoritas, una mirada al repertorio mexicano para piano durante el siglo XIX”, Música Iberoamericana de salón, Actas del Congreso Iberoamericano de Musicología, coord. José Peñín (Caracas: Fundación Vicente Emilio Sojo, 2000), vol. 1, p. 145, alude a un extenso repertorio con piezas específicamente denominadas de salón (valses, mazurcas, polkas, habaneras, galops), como las localizadas en el Álbum Musical de Amancio Amorós.
} 
dos esclavos (Terceto, Escena y Vals, Guaracha, Romanza de tiple y Habanera, dúo de tiple y tenor cómico).

El Álbum Pianístico contiene entre otras, algunas obras de compositores cubanos (Ignacio Cervantes, Nicolás Ruiz Espadero, Carlos Peyrallade y Gaspar Villate). Los géneros representados en esta colección son sobre todo romanzas, barcarolas y caprichos. La primera pieza de este álbum es el capricho para piano de Amorós Violetas y Mariposas.

Probablemente en la década de los ochenta o noventa del siglo XIX Amorós compuso sus primeras obras, entre ellas el citado capricho para piano Violetas y Mariposas, op. 1 y las mazurcas para piano: en Re bemol Mayor, en Sol Mayor, en Re menor y en Fa Mayor, obras en las que revela su conocimiento de la técnica pianística, con un lenguaje virtuosístico que puede relacionarse con las obras para piano de Chopin. Se desconoce la fecha exacta de composición de estas obras, cuya cronología aproximada he calculado por diversos indicios. El capricho Violetas y Mariposas fue editado por Salvador Prosper, cuya editorial se fundó en 1840 y que tuvo una tienda de música en Valencia al menos hasta 1893 en la calle San Vicente, $99^{31}$.

Las tres primeras mazurcas citadas fueron publicadas en la Ilustración Musical Hispanoamericana (números 50, 53 y 76 de 1890 y 1891) y son mencionadas en una carta que Amorós remitió a Felipe Pedrell en septiembre de $1896^{32}$. La Mazurca en Fa Mayor se editó en 1894 en el volumen 1 de la Biblioteca Musical Valenciana que dirigía el propio Amancio Amorós. Otras obras para piano, quizás tempranas, de las que

\footnotetext{
${ }^{31}$ Carlos J. Gosálvez Lara, La edición musical española hasta 1936 (Madrid: AEDOM, 1995), p. 111. Véase también Biblioteca Sacro Musical, 15-XI-1893, p. 102.

${ }^{32}$ Entre ambos compositores existió una relación amistosa que se mantuvo al menos hasta 1915, como muestra el epistolario Pedrell, E:Bc, M 964. Véase Apéndice 18, Cartas de Amancio Amorós a Felipe Pedrell (1896-1915).
} 
desconozco la fecha de composición, fueron los valses Por ella y El Baile, el nocturno Desengaño, el pensamiento poético Vendrá, Idilio y Escenas poéticas ${ }^{33}$.

También de la década de los ochenta del siglo XIX es parte de la producción camerística de Amorós, y en concreto, seis obras: el Trío para violín, piano y armónium (1881), el nocturno para piano y armónium Trists recorts (1882), la marcha religiosa Gloria a España (1882), una Colección de ocho piezas para piano y armónium sobre motivos populares valencianos (1883), y dos quintetos para cuerda y piano, Idilio y Andante Marcial (en los que sustituyó el violoncello por el violón). Se conserva además un borrador del que hubiera sido su Cuarteto para cuerda $n^{o} 1$, op. 21, que no finalizó ${ }^{34}$. Todas estas obras, manuscritas y conservadas en la Biblioteca de Catalunya, fueron compuestas antes de la fundación de la Sociedad de Cuartetos valenciana, creada en 1890.

En 1883 la Real Sociedad Económica de Amigos del País de Valencia organizó un concurso dentro la Exposición Regional de Agricultura, Industria y Artes en el Jardín del Real de Valencia y Amorós presentó su Misa en mi menor para coro de voces blancas, armónium, piano y quinteto de cuerda, que le fue premiada con la Medalla de segunda clase de mérito. Esta misa se estrenó el 13 de noviembre de 1887 en la inauguración de la iglesia de las Adoratrices de Valencia ${ }^{35}$.

\footnotetext{
33 E:Mba, legajo 5-2-2, Expediente de nombramiento de Amancio Amorós como Académico Correspondiente (1921).

${ }^{34}$ Original manuscrito conservado en $E: B c, \mathrm{M} 1275$.

${ }^{35}$ En la actualidad el archivo de esta sociedad no conserva ningún ejemplar de esta misa, que no he podido localizar. Anónimo, "Exposición Regional de Agricultura, Industria y Artes", Almanaque de las Provincias para 1884, pp. 219-239; E:VAseap, C. 226, XX-Comisión exposiciones no 12, Memoria sobre la Exposición Regional de Agricultura, Industria y artes celebrada en Valencia (1883); E:VAseap, C. 227, XX-Comisión exposiciones $\mathrm{n}^{0}$ 16, Reglamento-programa de la Exposición Regional (1883); E:VAseap, C. 227, XX-Comisión exposiciones $\mathrm{n}^{\circ} 18$, Registro de entrega de diplomas y medallas de la Exposición Regional (1883); E:VAseap, C. 230, XX-Comisión-exposiciones no 2.2, Documentación relativa a los premios concedidos por el jurado de la Exposición Regional (1883); E:VAseap, C. 227, XX-Comisión exposiciones $\mathrm{n}^{\circ} 23$, Relación de obras que los catedráticos del Instituto y Escuela de Bellas Artes y un profesor de la Escuela Normal de esta ciudad presentan a la Exposición Regional (1883); E:Mba, legajo
} 
La Misa en Re menor para solistas, coro de voces graves y orquesta, fue compuesta entre 1882 y 1900, según consta en la portada del manuscrito autógrafo, y fue estrenada en la solemne función religiosa del 6 de septiembre de 1900 en la Parroquia de San Bartolomé Apóstol de Agullent, dentro de la celebración del Tercer Centenario del Milagro de San Vicente Ferrer; en el estreno intervino la orquesta "Primitiva" de Alcoy".

En 1885 Amorós compuso su zarzuela en cuatro actos Navegación Submarina, que no llegó a estrenarse "por retirarla los mismos autores, consecuencia de ciertas intrigas entre bastiones, como sucede con frecuencia”37. En enero de 1886 sí estrenó su zarzuela en tres actos Los dos esclavos en el Teatro Ruzafa. La obra, con letra de Antonio Roig Civera, consta de quince números y la acción se sitúa en Cuba a principios del siglo XIX. La prensa anunció la obra antes de su estreno:

Los ensayos de la nueva obra Los dos esclavos, original de dos paisanos nuestros, y cuyo estreno tendrá efecto el día 8 de los corrientes, y al efecto han aumentado el coro y el personal de la orquesta, y se están terminando algunas decoraciones, que de seguro han de agradar.

Tanto a los autores de esta producción como a los artistas encargados de interpretarla, deseámosles muchos aplausos.

Para aquella noche es muy crecido el número de localidades que hay despachadas ${ }^{38}$.

En fecha desconocida Amorós compuso varias obras teatrales que no se estrenaron, y que, excepto la parodia El tío Sappo, en la actualidad están desaparecidas:

5-2-2, Expediente de nombramiento de Amancio Amorós como Académico Correspondiente (1921); Almanaque de las Provincias para 1888, pp. 273; Martínez Aloy, Geografía General, p. 825.

36 Anónimo, Programa de las Fiestas cívico-religiosas de Agullent. Tercer Centenario del Milagro obrado en dicho pueblo por la intercesión de su patrono San Vicente Ferrer, 1900.

37 E:Mba, legajo 5-2-2, Expediente de nombramiento de Amancio Amorós como Académico Correspondiente (1921).

${ }^{38}$ El Mercantil Valenciano, 6-I-1886. 
Viva España, "obra de actualidad cuando se escribió", Chepeta, "de asunto regional" El Majo ${ }^{40}$

De 1887 es la Salve Solemne de Amorós a seis voces y gran orquesta estrenada en la Basílica Metropolitana de Valencia durante la celebración de las fiestas de la Virgen de los Desamparados. En el acto participó "lo más selecto del profesorado lírico de

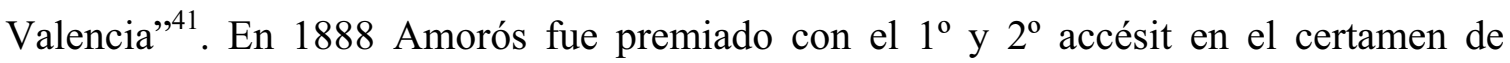
composición para orquesta convocado por Lo Rat Penat, dentro de Los Juegos Florales, aunque no consta el título de las obras premiadas ${ }^{42}$.

En la polifacética personalidad de Amorós hay que destacar también, desde su juventud, su dedicación a la docencia. Amancio Amorós fue el primer profesor de piano y solfeo de la Institución para la Enseñanza de la Mujer de Valencia al menos desde 1888, y fue vocal de la Junta Directiva de esa institución ${ }^{43}$. Esta actividad la compaginó con la dirección del coro del colegio-convento de las Adoratrices de Valencia al menos desde 1887 hasta $1899^{44}$. El músico dedicó a este centro parte de su producción religiosa e impulsó la composición colectiva Las Siete Palabras, obra de varios valencianos, que se interpretó en la capilla del convento de la Adoratrices en la Semana Santa, al menos durante tres años consecutivos $(1889,1890,1891)$. La prensa nacional elogió el papel de

\footnotetext{
${ }^{39}$ El Almanaque de las Provincias para 1909, p. 366 cita una Jepeta, comedia lírico-dramática en verso, dividida en tres cuadros, original de L. Cebrián Mezquita, premiada en los Juegos Florales de Lo Rat Penat de 1902 y dedicada a Francisco Badenes Dalmau.

40 E:Mba, legajo 5-2-2, Expediente de nombramiento de Amancio Amorós como Académico Correspondiente (1921).

${ }^{41} E: M b a$, legajo 5-2-2, Expediente de nombramiento de Amancio Amorós como Académico Correspondiente (1921); Las Provincias, 7 y 8-V-1887.

${ }^{42}$ Anónimo, "Lo Rat Penat", Almanaque de las Provincias para 1888, p. 291.

${ }^{43}$ Ilustración Musical Hispanoamericana, 30-XII-1888, p. 184; Anónimo, "Institución para la Enseñanza de la Mujer", Almanaque de las Provincias para 1895, p. 284.

${ }^{44}$ Anónimo, "Una iglesia nueva y otra reformada", Almanaque de las Provincias para 1888, pp. 272-273; Boletín Musical, 28-II-1899, p. 1430.
} 
Amorós como organizador, compositor y director ${ }^{45}$. Al parecer la obra siguió interpretándose cada año, excepto en 1893, fecha en la que por motivos desconocidos no se interpretó:

Este año, por ciertas causas, no se han podido celebrar las ya conocidas Siete Palabras de los maestros valencianos señores Giner, Plasencia, Ximénez, Chulvi, Fornet, Soriano y Amorós, obras que sentimos no haber podido admirar sus bellezas este año, por ser composiciones que nos gustaban mucho y eran de los principales compositores $^{46}$.

En ca. 1889-1891 Amorós publicó sus Elementos de Solfeo, método que tuvo una amplia repercusión y del que se hicieron al menos diez ediciones ${ }^{47}$. La labor docente de Amorós será abordada con mayor amplitud en el Capítulo 3. En 1891 la prensa alabó el papel de Amorós como escritor musical por las especiales circunstancias que reunía su método de solfeo:

De otro profesor tenemos que ocuparnos en el sentido de escritor musical. Método de solfeo se titula el trabajo publicado por el Sr. D. Amancio Amorós, y cuyo método, tan filosóficamente dispuesto, como sencillo y gradualmente ordenado con el fin de simplificar el estudio y la comprensión del mecanismo del arte musical, son circunstancias todas que explican de una manera clara y evidente la práctica y conocimiento de la enseñanza aplicada al método de un modo racional e inductivo. Justísimos aplausos ha merecido el Método del Sr. Amorós, pero merecidos y deducidos todos ellos de las especiales circunstancias que aquel reune, como hijas del estudio e incansable laboriosidad del autor, que a condiciones excepcionales de sentimiento artístico reúne la no menos recomendable de una modestia excesiva, modestia que más pronto hoy es perjudicial que beneficiosa, dada la índole de nuestra sociedad ${ }^{48}$.

\footnotetext{
45 Ilustración Musical Hispanoamericana, 7-V-1889, p. 72, 30-V-1890, pp. 270-271 y 31-IV-1891, p. 522.

${ }^{46}$ Biblioteca Sacro Musical, 1-IV-1893, p. 38.

${ }^{47}$ Esta información consta en el ejemplar de $E: V A b v$, E. López-Chavarri/3365.

${ }^{48}$ Revista contemporánea, 83 (1891), p. 381.
} 


\subsection{Amorós y la Renaixença valenciana}

Amancio Amorós fue una figura destacada dentro del movimiento cultural de la Renaixença valenciana, que revalorizó la lengua y el folklore valencianos. En Amancio Amorós destacó su preocupación por la recopilación y utilización de cantos y bailes populares de Valencia, lo que permite conectarlo con el movimiento regionalista de la Renaixença que buscó definir una cultura típicamente valenciana. Son varias las obras en las que se aprecia esta práctica que explicaré más en detalle en el Capítulo 5. El compositor fue socio de Lo Rat Penat, entidad clave en la Renaixença valenciana, desde los primeros años de su creación, dio a conocer muchas de sus obras en las veladas que organizaba esta sociedad, y entregó las correspondientes partituras a la sección de música (véase en Capítulo 1, Sociedades culturales con actividad musical) ${ }^{49}$ para que formasen parte de una biblioteca musical valenciana:

Esta sección [de Literatura] y la de Música han celebrado semanalmente las reuniones literario-musicales, en las que tan grata distracción encuentran los socios del Rat Penat, y en las que dieron a conocer sus inspiradas poesías la Srta. Doña Magdalena García Bravo, los Sres. Lorente, Pascual y Genís, Pizcuela, Ferrer y Bigné, Iranzo y Simón, Rodríguez Guzmán, Labaila, Arroyo, Llombart, Orga, Bodría, Puig, Corteza, Milego, Fambuena, Puerto, Peydró, Oltra, Mora, Alonso; ejecutando escogidas piezas bajo la dirección de D. Salvador Giner, los Sres. Penella, Jordá, Payá, Goérlich, Peydró, Baixauli, Amorós, Berga, Domínguez, Mateu, y el Orfeón Valenciano que dirige el Sr. Penella.

La sección de Música, con la actividad y buen celo que distingue a sus individuos, ha dado a conocer a la sociedad las obras siguientes, compuestas expresamente para que formen parte de la biblioteca musical valenciana que reune: Himne a València, letra del Sr. Labaila y música del reputado maestro D. Salvador Giner; La Tórtola Viuda de los Sres. Iranzo y Penella; La Cançó del bresol, de los mismos; Albada de los Sres. Labaila y Jordá; Está ausent de los Sres. Millás y Peydró; Me muich y Vora Mar de los Sres. Iranzo y Peydró; Gemechs del cor de los Sres. Oltra y Amorós; A la Reina de la festa, marcha premiada en los últimos Juegos Florales de D. Francisco J. Blasco; y la Cançó dels excursionistes del Rat Penat, obra de D. Teodoro Lorente y D. Salvador Giner ${ }^{50}$.

\footnotetext{
49 Almanaque de las Provincias para 1882, p. 230; Almanaque de las Provincias para 1883, p. 140; Almanaque de las Provincias para 1884, p. 309; Almanaque de las Provincias para 1899, pp. 129-130.

${ }^{50}$ Almanaque de las Provincias para 1882, pp. 229-230.
} 
Amancio Amorós fue presidente de la sección de música de la sociedad Lo Rat Penat, por primera vez, entre 1883 y 1884. Esta institución organizaba cada año un certamen de composición dentro de los festejos de la Feria de Julio de Valencia, en el que se quería que la música popular fuera la base principal de inspiración creativa ${ }^{51}$. En este contexto Amancio Amorós obtuvo el Tercer premio en los Juegos Florales organizados por Lo Rat Penat en 1882 por su nocturno Trists recorts, op. 25 y su Col.lecció de huit peces per a piano $i$ harmònium sobre motius populars valencians [Colección de ocho piezas para piano y armónium sobre motivos populares valencianos], op. 37 recibió, en 1883, el Premio a la Batuta Artística en el concurso organizado por la misma sociedad ${ }^{52}$. En 1885 Amancio Amorós y Juan Bautista Plasencia estrenaron tres piezas de esta Col.lecció en una velada literario-musical organizada por Lo Rat Penat:

Los Srs. Amorós i Plasència donaren a conéixer tres números dels huit quadros que sobre motius d'aires populars premià Lo Rat Penat en los últims Jocs Florals, obra que fou molt ben rebuda per l'auditori, qui felicità ab sos aplausos i demanà nova audició a son autor lo Sr. Amorós ${ }^{53}$.

Amorós fue nombrado "mantenedor" de los Juegos Florales organizados por Lo Rat Penat en 1884, junto con Antonio Rodríguez de Cepeda, Teodoro Llorente, Jaume Colell, Josep Arroyo Almela e Ignacio Pinazo. Sin embargo en abril de ese año 1884

\footnotetext{
${ }^{51}$ La Feria de Julio englobaba los Juegos Florales y otros certámenes de composición musical y literaria. Existen pocos estudios históricos sobre la Feria de Julio de Valencia, oficialmente conocida como "Gran Feria de Valencia", creada en 1871. Sus orígenes se remontan a las Corregudes de Sant Jaume [Corridas de San Jaime] que se acompañaban se diversos actos religiosos y gastronómicos, también conocidos como "Fira de Sant Jaume". Autores como Gil-Manuel Hernández y Vicente Ariño consideran la Feria de Julio valenciana como una creación de la burguesía valenciana para incentivar el comercio en la ciudad. Véase Gil-Manuel Hernández i Martí, La Feria de Julio de Valencia (Valencia: Carena, 1998), pp. 8, 25, 72; Vicente Ariño, "El calendario festivo", en $H V$, p. 524.

${ }^{52}$ Revista de Valencia, 2 (1882), p. 429; Almanaque de las Provincias para 1883, p. 143.

${ }^{53}$ Lo Rat Penat: periodich lliterari quincenal, 15-III-1885, p. 48. [Los señores Amorós y Plasencia dieron a conocer tres números de los ocho cuadros, que sobre aires populares premió Lo Rat Penat en los últimos Juegos Florales, obra muy bien recibida por el auditorio, quien felicitó con sus aplausos y pidió nueva audición a su autor, el Sr. Amorós].
} 
hubo en Valencia un brote de peste de cólera y no se celebraron los actos previstos dentro de la Feria de Julio ${ }^{54}$. Los Juegos Florales aplazados se celebraron el 16 de marzo de 1885 en el Teatro Principal y en esta ocasión Amancio Amorós actuó como "mantenedor" junto con Félix Pizcueta, Antonio Rodríguez de Cepeda y Teodoro Llorente ${ }^{55}$.

\section{2. Época de madurez (1890-1914)}

\section{1. Amancio Amorós, figura esencial en la vida musical valenciana}

El periodo 1890-1914 marca un punto de inflexión en la vida de Amorós. El músico mantuvo una intensa actividad a inicios de los noventa y, además de continuar trabajando en el campo de la composición y de la docencia, buscó nuevos caminos en su actividad profesional, influyendo decisivamente en la creación y evolución de las más importantes instituciones musicales de Valencia.

En la década de los 90 del siglo XIX Amorós siguió componiendo diversas obras en el espíritu de Renaixença valenciana, como la Sinfonía para gran orquesta, compuesta sobre aires populares de Valencia y su reino, op. 69 (1890), en la que cita temas populares, y la barcarola para canto y piano Lo cant del Mariner (1895) con texto en valenciano de Antonio Roig Civera, que se publicó en el $n^{\circ} 3$ de la Biblioteca Musical Valenciana. Amorós ocupó de nuevo la presidencia de la sección de música de Lo Rat Penat entre 1892 y 1895, aunque la falta de un local adecuado posiblemente hizo que durante bastantes años (al menos entre 1893 y 1895), no se pudiesen celebrar las sesiones de inauguración de curso ni las reuniones literario-musicales que habitualmente venía

\footnotetext{
${ }^{54}$ Almanaque de las Provincias para 1885, pp. 145-146.

${ }^{55}$ Almanaque de las Provincias para 1886, p. 315.
} 
celebrando la entidad desde su creación ${ }^{56}$. Sí seguían celebrándose, en cambio, los certámenes de composición. En 1894 Amorós participó como jurado en el concurso de composición de ese año, cuyas bases subrayaron la importancia de crear música descriptiva que reflejase costumbres valencianas y estuviera basada en melodías populares de la tierra. Los concursantes debían adjuntar a la partitura el asunto o programa en el que se hubiesen inspirado:

Próximo a celebrarse ese torneo de la literatura y de la música, que con tanta solemnidad repite anualmente durante las ferias de Julio aquella Sociedad valencianista, ha publicado ya el cartel anunciador. Por lo que al certamen de música se refiere helo aquí:

Un objecte d'art a l'autor del poema simfònic per a banda, inspirat en algun fet, llegenda o quadro de costums valencianes, quals principals motius estiguen basats en melodies populars d'esta terra. La partitura deu anar acompanyada dels corresponents datos sobre l'assunt en que s'haja inspirat l'autor'.

Todas las obras que se presenten habrán de ser inéditas y se dirigirán al Secretario de esta Sociedad, antes de la doce de la tarde del día $1^{\circ}$ de Julio próximo. La Sociedad queda propietaria de las obras de música $^{58}$.

El traslado de la sede de Lo Rat Penat en marzo de 1896 a la calle Embajador

Vich de Valencia se celebró con una solemne sesión inaugural en la que Amancio Amorós participó como pianista junto a los instrumentistas Manuel Penella, José $\mathrm{M}^{\mathrm{a}}$ Úbeda e Higinio Vives ${ }^{59}$.

En 1890 Amorós fundó la Academia Musical Amorós, en la que se prepararían profesores y profesoras de solfeo y piano, maestros de coros, concertadores, y

\footnotetext{
${ }^{56}$ Anónimo, "Lo Rat Penat", Almanaque de las Provincias para 1893, p. 117; Gil, Lo Rat Penat, p. 143; Anónimo, "Lo Rat Penat", Almanaque de las Provincias para 1894, pp. 129-132; Anónimo, "Lo Rat Penat", Almanaque de las Provincias para 1895, pp. 215-218; Anónimo, "Lo Rat Penat", Almanaque de las Provincias para 1897, p. 91.

${ }^{57}$ Traduzco literalmente las frases del valenciano: [Un objeto de arte al autor del poema sinfónico para banda, inspirado en algún hecho, leyenda o cuadro de costumbres valencianas, donde los principales motivos estén basados en melodías populares de esta tierra. La partitura debe ir acompañada de los datos correspondientes sobre el asunto que haya inspirado al autor]. Las bases de la convocatoria no especifican el objeto de arte con el que sería premiado el autor.
}

${ }^{58}$ Boletín Musical, 15-V-1894, p. 242.

${ }^{59}$ Sala, Historia de Lo Rat, p. 111. 
compositores, que seguía funcionando al menos en $1893^{60}$. En esta Academia, como puede observarse en la Ilustración 9, se impartían clases elementales y superiores de Solfeo, Piano, Armonía y Composición ${ }^{61}$. Este mismo año 1893 Amorós ingresó como profesor honorario de Solfeo y Armonía del Conservatorio de Música de Valencia y desde las páginas del Boletín Musical felicitó a Giusseppe Verdi en la conmemoración de su ochenta aniversario con estas palabras:

Dichoso ¡oh gran Verdi! que al cumplir los 80 años de tu natalicio, conservas el sagrado fuego de la inspiración y la asombrosa fecundidad del hombre sabio y honrado ${ }^{62}$.

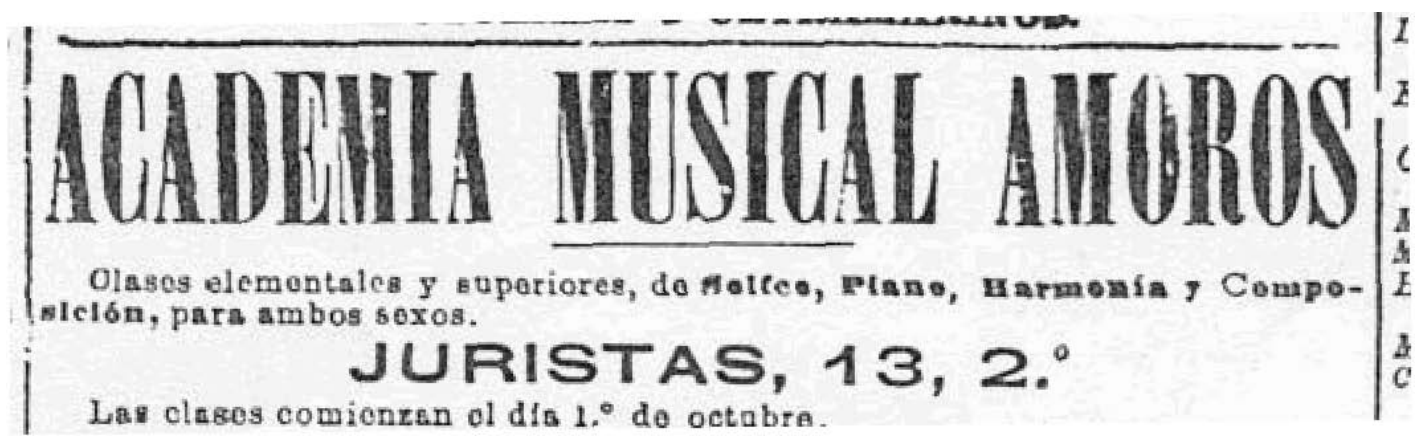

Ilustración 9

Anuncio de la Academia Musical Amorós.

Las Provincias, 23-IX-1893.

En 1890 el Conservatorio de Música de Valencia celebró el Décimo Aniversario

de su fundación $\mathrm{y}$, entre otros eventos, convocó un Certamen Internacional al que

\footnotetext{
${ }^{60}$ El Mercantil Valenciano, 26-XI-1890.

${ }^{61}$ Las Provincias, 23-IX-1893. La iniciativa pedagógica de Amorós podemos compararla con la de otros músicos españoles, cuyo reconocido prestigio avalaba la creación, a finales del XIX y principios del XX, de academias particulares de música en diversas capitales de provincia. En Valladolid, Cavia Naya, "Un músico del siglo XIX", pp. 212-213, señala a Hilario Prádanos como fundador en 1887 de una academia de música, cuyo objetivo era formar profesores de música y profesionales de la interpretación; Alén, "La Música en Galicia”, p. 86, comenta la academia creada por Manuel Sánchez Yánez en La Coruña.
}

${ }^{62}$ Boletín Musical, 9-X-1893, p. 431. 
Amorós presentó su Himno a Santa Cecilia, op. 68, que obtuvo el segundo accésit (véase el Apéndice 4) ${ }^{63}$.

En estos años hay que situar la melodía para canto y piano Recuerdo de amor con letra del propio Amorós, dedicada a su hija Ma Consuelo y cuyo manuscrito autógrafo firmó con el pseudónimo Marco Antonio Verzenni. La Ilustración 10 muestra un autógrafo de Amorós en el que el compositor ensayó distintas combinaciones de su nombre y apellidos antes de decidir dicho pseudónimo. Amorós envió esta melodía para canto y piano a Felipe Pedrell en septiembre de $1896^{64}$. El original se conserva en la Biblioteca de Catalunya y se publicó posteriormente en el $\mathrm{n}^{\mathrm{o}} 214$ de la Ilustración Musical Hispanoamericana (1896).

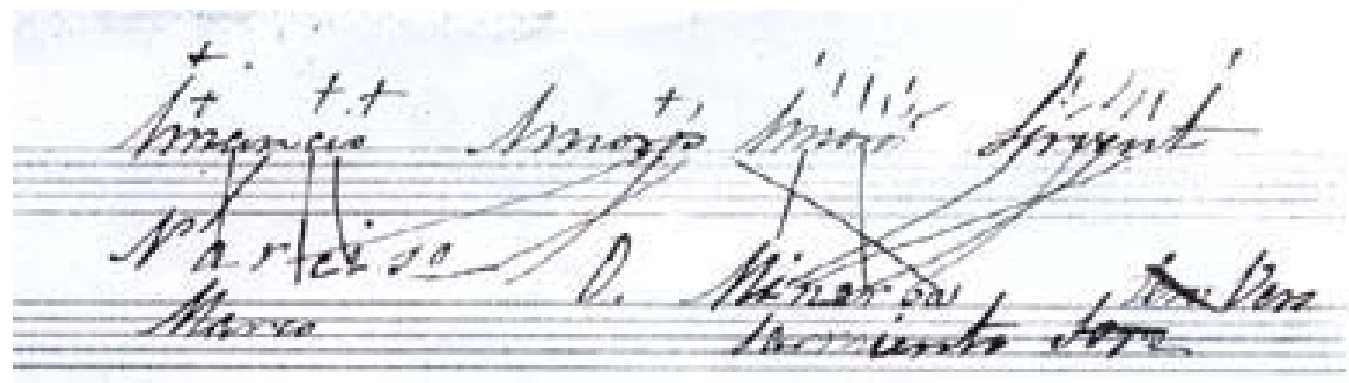

Ilustración 10

Autógrafo de Amancio Amorós explorando combinaciones de su nombre y apellidos para formar el pseudónimo "Marco Antonio Verzenni".

$E: B c, \mathrm{M} 1311$.

\footnotetext{
${ }^{63}$ El Conservatorio de Música de Valencia convocó cuatro premios ordinarios: 1) Poema sinfónico para piano, violines primeros y segundos, violas, violoncellos y contrabajo, inspirado en el libro sexto del Paraiso perdido de Milton; 2) Dúos para tiple y barítono con acompañamiento de cuarteto y piano; 3 ) Piezas para piano; 4) Coro para voces de tiple, niñas y niños con acompañamiento de piano, armónium y cuarteto de cuerda. Además se convocaron otros premios extraordinarios: 1) Premio concedido por la reina regente "Cuartetos a cuerda sola de música di camera"; 2) Premio concedido por la infanta Isabel "Piezas de concierto para arpa"; 3) Premio concedido por la junta directiva y claustro de profesores del Conservatorio de Valencia "Himnos a Santa Cecilia". Amorós presentó su Himno a Santa Cecilia con el lema "Santa Cecilia prega, prega per mi", El Mercantil Valenciano, 1-I-1890; Ilustración Musical Hispanoamericana, 15-VI-1890, p. 280; E:VAcm, Acta de la Junta Directiva del Conservatorio de Música de Valencia, 23-V-1889; Anónimo, "Conservatorio de Música. La fiesta de hoy”, Las Provincias, 20-V-1890; Anónimo, "La fiesta del Conservatorio de Música”, en Las Provincias, 21-V-1890.
}

${ }^{64}$ Carta de Amancio Amorós a Felipe Pedrell, 29-IX-1896, E:Bc, M 964. 
Las cartas que Amorós envió a Felipe Pedrell entre 1894 y 1915 muestran la relación amistosa y profesional que existió entre ambos compositores (véase Capítulo 4 y Apéndice 18). Amorós aceptó la recomendación de Pedrell de apoyar su Schola Musica Sacra, que se publicó entre 1894 y 1896 y, en efecto, fue uno de los suscriptores de la colección (véase Apéndice 19) ${ }^{65}$.

La implicación de Amorós en la vida musical valenciana hizo que formara parte de jurados en muchos concursos musicales y exámenes de oposición a plazas musicales. En 1891 fue uno de los calificadores en el certamen de bandas convocado por el Ayuntamiento de Valencia ${ }^{66}$. El certamen musical se convocaba desde 1886 en la Feria de Julio de Valencia. En 1891, además de Amorós, estuvieron en el jurado Igual, Valls, Blasco, Soriano, Bellver, Marco, Coronado, Campos y Massó. Ese año la obra obligada para las bandas militares fue Cleopatra de Mancinelli y para las bandas civiles Tutti in Maschera de Pedrotti. La prensa del momento nos ofrece una crónica del evento:

Este año, como ya hemos dicho, se han destinado dos días para dicha fiesta. Ayer correspndió a las músicas militares y esta tarde a las civiles, que son:

La Lira de Sagunto, Casino Artístico-Musical de Torrente, Nueva de Bocairente, Patronato de la Juventud Obrera y Asociación de Católicos, éstas dos últimas de esta capital.

A las cinco de la tarde fueron entrando fueron entrando las músicas militares, ejecutando bonitas marchas en el redondel. En éste, al pie de la presidencia, había un tablado donde las citadas músicas tenían que tocar, que se comunicaba con la plataforma destinada al jurado. Formaban éste el presidente de la comisión Sr. Igual, y los señores Valls, Coronado, Soriano, Blasco, Marco, Amorós, Campos y Massó. El Sr. Guirao, que había sido designado por los músicos mayores, renunció al cargo de jurado.

Se procedió al sorteo del turno con el que habían de tocar las músicas, que se dejó sin efecto por no haber tenido intervención los directores de aquellas, por lo que hubo de procederse a nueva elección, que dio este resultado:

\footnotetext{
${ }^{65}$ La Hispaniae Schola Musica Sacra se editó en ocho volúmenes dedicados, el primero, a Cristóbal Morales; el segundo, a Francisco Guerrero; el tercero, cuarto, séptimo y octavo, a Antonio de Cabezón; el quinto a Juan Ginés Pérez, y el sexto, a Fray Tomás de Santa María, Francisco Guerrero y Victoria. Véase Josep Pavia, "Pervivencia de la obra de Felip Pedrell en la musicografía española: Tesoro Sacro Musical', Recerca Musicologica, 11-12 (1991-1992), p. 278.

${ }^{66}$ Blasco, La música en Valencia, p. 86.
} 
$1^{\circ}$ Alba de Tormes, compuesta de 34 plazas, dirigida por el $\mathrm{Sr}$. Rodríguez.

$2^{\circ}$ Mallorca, formada por 54 individuos, que dirige el $\mathrm{Sr}$. Rueda.

$3^{\circ}$ Vizcaya, consta de 44 plazas, y la dirige el Sr. Rovira.

$4^{\circ}$ Guadalajara, que la componen 52 plazas, y se halla dirigida por el Sr. Soler.

Romero.

$5^{\circ}$ Tetuán, consta de 50 plazas, siendo su director el $\mathrm{Sr}$.

Por este orden fueron subiendo al tablado las músicas para ejecutar la obra obligada del concurso, que era la sinfonía Cleopatra de Mancinelli. Al terminar su cometido eran saludadas por el público con estrepitosos aplausos.

Después de esta primera parte de concurso ejecutaron por el mismo orden la obra de libre elección para cada música, según dijimos ayer. También fueron muy aplaudidas.

Ya estaba muy avanzado el crepúsculo vespertino, cuando las cinco músicas empezaron a reunirse para ejecutar la obra de conjunto El cuarto sitio de Bilbao, amenizado con fuegos de artificio simulando el disparo de bombas, toques de corneta y de campana y otros detalles. Dirigió la citada composición el inteligente músico mayor retirado Sr. Marín, saliendo aquella muy ajustada [...].

Esta tarde, con motivo del concurso de las músicas civiles, se repetirá la expresada obra. La composición que aquellas interpretarán es la sinfonía Tutti in Maschera, de Pedrotti.

Los premios adjudicados designados son: $1^{\circ} 1500$ pesetas; $2^{\circ}$ $1000 ; 3^{\circ} 500 ; 4^{\circ}$ un objeto de arte; $5^{\circ}$ mención honorífica.

También se adjudicará un premio de 250 pesetas a la banda civil de la provincia que se presente con mayor número de plazas, instrumental más perfecto y mejor uniformada $[\ldots]^{67}$.

Desde 1887 Amorós tuvo una importante relación profesional con el convento de

las Adoratrices de Valencia en la calle Hernán Cortés (Ilustración 20) en el que fue

director musical. En la Semana Santa de 1893, el coro de las religiosas Adoratrices interpretó el jueves Santo una Misa de Amorós como muestra la siguiente crónica:

Se cantó el jueves por las religiosas, bajo la dirección de su profesor D. Amancio Amorós, una misa del mismo. Viernes, motetes, propios del día. Hoy sábado se cantará Misa de Arribas, Regina Caeli de González. Mañana domingo, a las nueve y media, la Misa de Calahorra y el Regina Caeli del día anterior ${ }^{68}$.

\footnotetext{
${ }^{67}$ El Mercantil Valenciano, 30-VII-1891.

${ }^{68}$ Biblioteca Sacro Musical, 1-IV-1893, p. 38. La revista Biblioteca Sacro Musical ofrece una detallada muestra de la celebración de los Oficios de Semana Santa en iglesias, capillas y conventos de la capital valenciana.
} 
En mayo del mismo 1893, en la función de las Cuarenta Horas de las Adoratrices "un nutrido coro de tiples bajo la dirección del profesor de la casa, interpretó selectas composiciones, en su mayoría debidas al citado maestro [Amorós], a quien felicitamos por el éxito obtenido en dichas funciones" ${ }^{, 69}$.

Durante las navidades del mismo año 1893 las religiosas interpretaron en distintas funciones una Pastorela de González, Barba y Prado, la Misa de González, Te Deum de Giner, Santo Dios de Amancio Amorós, Tantum Ergo de Pedrell, todas ellas ejecutadas con acompañamiento de piano y armónium ${ }^{70}$. Su motete Tota pulchra a siete voces y gran orquesta (1893) en cambio, no llegó a estrenarse ${ }^{71}$.

En 1899, con motivo de la celebración de las Cuarenta Horas en las Adoratrices se interpretaron obras de Amancio Amorós junto con otras de Salvador Giner, José Ma Úbeda y Felipe Pedrell, y piezas de Gounod y de Juan Bautista Comes. Este repertorio fue una interesante mezcla de composiciones nuevas y tradicionales de autores autóctonos, junto con otras de españoles y extranjeros. La prensa elogió las obras de Amorós:

La capilla de música, formada por las acogidas en dicho convento, bajo la dirección del reputado maestro D. Amancio Amorós, ha interpretado selectas composiciones de los maestros Giner, Úbeda, Pedrell y Amorós. De éste último se ejecutaron un trisagio y el $O$ salutaris hostia. En cuanto al primero, ha compuesto el señor Amorós dos números musicales apropiados a la letra: para el Santo, un coral a tres voces, cuyo interés estriba en la agradable combinación de los timbres argentinos de las cantoras, que produce buen efecto, y para el Gloria, sin perder su carácter también coral, ha hecho un trabajo de factura más complicada, pues hace intervenir a los solistas, si bien prudencialmente, para no desvirtuar dicho carácter.

El $O$ salutaris, que se cantó después, es una composición inspirada, de forma amplia, escrita para soprano y coro, acompañada lo mismo que la anterior, del piano y armónium.

\footnotetext{
${ }^{69}$ Biblioteca Sacro Musical, 15-V-1893, p. 51.

${ }^{70}$ Biblioteca Sacro Musical, 15-I-1893, p. 15. Actualmente la obra Santo Dios de Amancio Amorós está en paradero desconocido.

71 E:Mba, legajo 5-2-2, Expediente de nombramiento de Amancio Amorós como Académico Correspondiente (1921).
} 
$\mathrm{Su}$ interpretación fue muy esmerada. Las cantoras hicieron una labor que se distinguió por su afinación y ajuste.

También cantaron con exquisita afinación e igualdad de ajuste el hermoso coro Ave Verum, de Gounod, que tiene una expresión angélica y encaja muy bien para las argentinas y femeniles voces de las educandas.

A esta obra siguió un Credidi de Amorós (Amancio), de forma solemne, resplandeciendo en todos los versículos una inspiración elevada. La clásica Letanía de Comes, también tuvo, como la composición anterior, una interpretación muy esmerada ${ }^{72}$.

En mayo de 1893 se estrenó en Agullent (Valencia) el himno Venid Peregrinos de Amorós para coro popular con acompañamiento de banda de música, que sirvió para amenizar la peregrinación a la ermita de San Vicente Ferrer de la localidad. La romería fue presidida por el Arzobispo de Valencia, Ciriaco María Sancha, a quien Amorós dedicó su himno (véase Capítulo 5, Amorós Compositor).

En 1894, el mismo año en que se inició la Hispaniae Schola Musica Sacra de Pedrell, comenzó también a publicarse la Biblioteca Musical Valenciana, de la que Amorós fue director técnico. Como he comentado anteriormente Amancio Amorós ocupó la presidencia de la sección de Música de Lo Rat Penat entre 1892 y 1895. Quizás la sección de música de esta institución disponía de un fondo musical, que la prensa denominó biblioteca musical valenciana, constituido por las partituras que los compositores vinculados a la entidad fueron depositando desde los primeros años de creación ${ }^{73}$. Amancio Amorós quiso impulsar en 1894 una publicación periódica bimensual que denominó Biblioteca Musical Valenciana en la que se divulgaron obras de autores valencianos como Salvador Giner, Eduardo Ximénez, Francisco Javier Blasco, José $\mathrm{M}^{\mathrm{a}}$ Úbeda, Roberto Segura, Juan Bautista Plasencia y del propio Amorós (ver

\footnotetext{
72 Boletín Musical, 28-II-1899, p. 1430.

${ }^{73}$ Véase Almanaque de las Provincias para 1882, pp. 229-230.
} 


\section{Capítulo 4 Actividad Musicológica y Apéndice 17) ${ }^{74}$. La Ilustración Musical}

Hispanoamericana anunciaba así su aparición:

Con el título de Biblioteca Musical Valenciana se ha inaugurado en la ciudad del Turia un Álbum de salón compuesto exclusivamente de composiciones musicales de autores valencianos, cuya biblioteca publicará un volumen cada bimestre. En el primero correspondiente al mes de noviembre y al presente aparecen las siguientes composiciones [...]. Las composiciones son dignas de los firmantes, distinguidos maestros valencianos, bien conocidos de nuestros lectores ${ }^{75}$.

Manuel Martí, responsable de la Academia Martí, aparecía en la portada como propietario de la edición. La publicación tuvo una vida efímera, ya que dejó de publicarse en 1895 por motivos que todavía desconozco, pero coincide precisamente con el cambio en la presidencia de la sección de música de Lo Rat Penat ${ }^{76}$.

En 1897 Amorós compuso el salmo Beatus Vir, a siete voces, órgano, violoncello y contrabajo que, según las fuentes consultadas, fue escrito expresamente para la celebración del Centenario del Beato Arzobispo Juan de Ribera ${ }^{77}$. En esta fecha, Vicente Ripollés, maestro de capilla del Real Colegio de Corpus Christi de Valencia, publicó su Memoria sobre la reforma de la Música religiosa en la Capilla de Corpus Christi de Valencia. Las medidas propuestas por Ripollés para restaurar la música religiosa se

\footnotetext{
${ }^{74}$ Boletín Musical, 15-XI-1894, p. 347; Boletín Musical, 30-XI-1894, p. 354; Boletín Musical, 30-VIII1895, p. 492; Las Provincias, 11-X-1894; Las Provincias, 31-X-1894.

75 Ilustración Musical Hispanoamericana, 15-XII-1894, p. 182.

${ }^{76}$ La Academia Martí una academia preparatoria para carreras especiales y de $2^{\text {a }}$ Enseñanza y debe su nombre al médico valenciano Manuel Martí. Véase Almanaque de las Provincias para 1893, p. 228. Según Peláez Malagón en su estudio sobre las revistas ilustradas valencianas en el siglo XIX se editaron ocho volúmenes de la Biblioteca Musical Valenciana, pero éste es un dato erróneo, como mostraré en el Capítulo 4, Actividad Musicológica. José Enrique Peláez, "Las revistas ilustradas valencianas en el siglo XIX. Estudio, comentario y catálogo de las publicaciones periódicas lustradas de la época 1890-1900". Artículo online www. Tebeosfera.com/libris/RevistasValencianas, consultado el 10-IV-2009.
}

77 Según consta en E:Mba, legajo 5-2-2, Expediente de nombramiento de Amancio Amorós como Académico Correspondiente (1921). Probablemente se refiera a la beatificación de San Juan de Ribera (1532-1611) en 1796. 
inspiraron en las Constituciones del Beato Juan de Ribera, fundador del Real Colegio de Corpus Christi.

Amorós perteneció a la Asociación de Profesores Músicos de Santa Cecilia desde su fundación en 1897, y en ella fue sucesivamente Secretario (1897-1903), Vicepresidente (1903-1909) y Presidente (1909-1924) de la Junta Directiva. El 22 de enero de 1897 la Asociación de Santa Cecilia celebró su Primera Asamblea y se procedió al nombramiento de la Junta Directiva de la Asociación. La Junta la integraron: Salvador Giner (Presidente), Vicente Ripollés (Vicepresidente), Amancio Amorós (Secretario), Antonio Pastor (Vicesecretario), José Medina y Matías Guillén (Visitadores), José Ma Úbeda (Tesorero) y el presbítero Miguel Sarrió (Consiliario) ${ }^{78}$.

En 1900 Amancio Amorós, entonces secretario de la Asociación, anunció en junta la fundación de un Círculo Musical bajo la protección de Santa Cecilia, que tendría como objetivo la promoción del arte musical, en particular el religioso, y mejorar la fraternidad entre los profesores músicos ${ }^{79}$. El Círculo Musical se creó finalmente en 1900, pero al margen de la Asociación ${ }^{80}$. Amancio Amorós formó parte del Círculo Musical desde sus inicios, dentro de la comisión de compositores (véase Capítulo 1 sobre la Actividad Musical en Valencia, Sociedades culturales con actividad musical) ${ }^{81}$.

Ese mismo año 1900 compuso el motete Cantemus Domino a solo y gran coro, para las fiestas del Tercer Centenario de San Vicente Ferrer que se celebraban en su

\footnotetext{
${ }^{78}$ Las Provincias, 17-II-1897; La Música Religiosa en España, 2/15 (1897), p. 238; Arturo Rey Marzal, "Relieves de la Semana. La patrona de los Músicos", La Semana Gráfica, 6-XII-1930; Loras, La Asociación, pp. 3-9. El cardenal Ciriaco $\mathrm{M}^{\mathrm{a}}$ Sancha concedió 100 días de indulgencia a cada uno de los asociados y fieles que, con limosnas o de cualquier otro modo, contribuyeran a los fines de la Asociación.

79 Loras, La Asociación, pp. 16-18. Anteriormente, como las bajas eran muchas, los miembros de la Asociación pensaron fusionarla con la de Profesores Músicos de San Vicente.

${ }^{80}$ Loras, La Asociación, p. 18.

${ }^{81}$ Boletín Musical, 30-III-1900, p. 1687.
} 
pueblo natal, Agullent (Valencia). La obra fue interpretada por el tenor solista Alonso, la orquesta "Primitiva” de Alcoy y los profesores Andrés Breva, Trávez y Domínguez ${ }^{82}$.

En 1902, la coral Capella Manacor de Palma de Mallorca acudió a Valencia, invitada por su Círculo de Bellas Artes, para dar un concierto, ocasión que aprovecho la comisión del IV Centenario de la fundación de la Universidad de Valencia para incluir las actuaciones de la coral en su programa festivo ${ }^{83}$. La Capella visitó varias sociedades culturales, entre ellas Lo Rat Penat. Amorós, que entonces era presidente de la sección de Música, compuso ex profeso un Coral a cuatro voces, con letra de José Bodría dedicado a la sociedad coral mallorquina:

La visita que con el fin que ya anunciamos hizo anoche la "Capella" de Manacor a la sociedad valencianista Lo Rat Penat, resultó, como no podía menos, dada la significación de ambas sociedades, un acto de cariño fraternal entre Mallorca y Valencia, y puso de manifiesto el latente, pero indudable cariño que existe entre los antiguos reinos de la Corona de Aragón.

A las seis en punto entró la Capella en la casa-social de Lo Rat Penat, siendo recibida por los numerosos socios que allí se hallaban congregados con una estruendosa salva de aplausos, el presidente de aquella, Sr. Puerto, dio las gracias y con sentidas frases expresó el cariño y hermandad entre Mallorca y Valencia.

[...] Inmediatamente los orfeonistas entonaron el Himno de la Capella, cantando asimismo magistralmente L'emigrant, de Vives, y la Serenata, de Otto, y la Bona nit. El inspirado poeta Sr. Bodría leyó unos sentidos versos dedicados a la Capella; y el profesor de este conservatorio y presidente de la sección de música de Lo Rat Penat, D. Amancio Amorós, entregó al Sr. Pont, con cariñosa dedicatoria, un

\footnotetext{
${ }^{82}$ Anónimo, Programa de las Fiestas, sp.

${ }^{83}$ La Coral llegó el día 23 de octubre de 1902 y les dieron la bienvenida los concejales del Ayuntamiento Ávalos y Olmos y varias delegaciones del Círculo de Bellas Artes, de Lo Rat Penat, de la Unión Musical y de los orfeones El Micalet, La Vega y otras. Los componentes de la Capella eran 80 hombres y muchachos, además del director y sacerdote Juan Antonio Pont; el segundo director Ramón Galmés; el presidente de su junta protectora Fausto Puerto y los vocales Juan Amor y Mateo Bonet. El 25 de octubre dieron en el Teatro Apolo su primer concierto con este programa: Primera Parte: $1^{\circ}$ Serenata de Otto; $2^{\circ}$ Balada Gallega, Montes; $3^{\circ}$ Lo compte Arnau (leyenda), Morera; $4^{\circ}$ Cançó de Nadal, Comella; $5^{\circ}$ D. Juan y D. Ramón, Pedrell; $6^{\circ}$ Xiula el fuet (humorística), Grieg; $7^{\circ}$ La pastoreta, Vives. Segunda Parte (sacra): $1^{\circ}$ Jesu dulcis memoria, Victoria; $2^{\circ}$ Ave Verum Corpus, J. S. Bach; $3^{\circ}$ Credo a seis voces, de la Misa del Papa Marcelo, Palestrina. Tercera Parte: $1^{\circ}$ La festa del poble, Giner; $2^{\circ}$ La sesta, Noguera; $3^{\circ}$ Cançó del aucells, Mollet; $4^{\circ}$ Ivernenca, Noguera; 5० Canción de niños (humorística), Grieg; $6^{\circ}$ La Balanguera (popular mallorquina), Noguera. Al día siguiente ofreció su segundo concierto en el teatro Principal. Para asegurar el lleno hubo precios reducidos. La Coral además actuó en un par de misas fúnebres, un concierto en las Escuelas Pías y un recital en el salón de audiciones del Conservatorio de Valencia. La Correspondencia de Valencia, 23, 27 y 29-X-1902; Las Provincias, 24, 25, 26 y 27-X-1902, La Voz de Valencia, 24, 25, 26, 28 y 30-X-1902, El Mercantil Valenciano, 28-X-1902.
} 
coral a cuatro voces, compuesto ex profeso para dicha Sociedad, con letra de J. Bodría ${ }^{84}$.

En 1902 Amancio Amorós ocupó por oposición la plaza de profesor de solfeo y armonía, vacante en el Conservatorio valenciano y fue además profesor sustituto de Salvador Giner en las clases de composición desde 1906 a 1910. También ejerció como secretario de la Junta de Profesores entre 1903 y 1907 y Tesorero de la Junta General de septiembre a diciembre de 1910 (fecha en la que se disolvió esta Junta General) ${ }^{85}$.

La actividad docente en el conservatorio valenciano absorbió por completo a Amorós, que en esta etapa de su vida escribió gran parte de sus obras didácticas y en especial los métodos de Solfeo, que alcanzaron varias ediciones y se adoptaron en muchas academias, colegios y centros de enseñanza. En la primera década del siglo XX publicó sus Nociones Teóricas de Solfeo para primero, segundo y tercer curso y las Lecciones Manuscritas Graduadas (Segundo y Tercer curso). El archivo del Conservatorio Superior de Música de Valencia conserva además tres lecciones manuscritas e inéditas de solfeo a una y dos voces con acompañamiento de armónium y piano (sf) de Amancio Amorós de las que presento una edición crítica en el Apéndice $6^{86}$. En la Biblioteca de Catalunya se conserva manuscrito e incompleto un Tratado de Composición de Amorós al que me referiré en el Capítulo 3.

En 1903 Amancio Amorós Sirvent formó parte del tribunal que debía elegir al director de la recién creada Banda Municipal de Valencia. El tribunal estuvo constituido además por Salvador Giner (presidente), Juan Cantó Francés (profesor del Conservatorio

\footnotetext{
${ }^{84}$ Las Provincias, 30-X-1902. La citada obra de Amorós no ha sido localizada en la actualidad.

${ }^{85}$ E:VAcm, Acta de la Junta Directiva del Conservatorio de Música de Valencia, 27-VI-1902; E:VAcm, Actas de la Junta Directiva del Conservatorio de Música de Valencia, 16-X-1906, 13-X-1907, 17-X1907, 29-III-1908, 2-V-1907, 29-III-1908; E:VAcm, Actas de la Junta General del Conservatorio de Música de Valencia, 24-II-1907, 3-III-1907, 4-IV-1908.

${ }^{86} E: V A c m, \mathrm{SF}-\mathrm{I} / 1-3$. Faltan las particellas del armónium y piano de la lección n ${ }^{\mathrm{o}} 3$.
} 
de Música de Madrid), Bartolomé Pérez Casas (director de la Banda de Alabarderos), y

José Alcarria López (director de la Banda del Regimiento de Guarnición en Valencia) ${ }^{87}$.

La oposición a la plaza de director de la Banda Municipal de Valencia constó de unos

ejercicios escritos, un ejercicio práctico y una prueba oral, como muestran las siguientes

bases:

Aprobado por el Exmo. Ayuntamiento de esta ciudad, proveer por oposición la plaza de Director de la Banda de Música Municipal, se hace saber por medio de este anuncio, que las oposiciones comenzarán el día 4 del próximo mes de mayo, con sujeción al programa, condiciones y requisitos que se insertan a continuación:

Ejercicios escritos: $1^{\circ}$ Hacer una composición que deberá tener de 80 a 100 compases como mínimo. Podrá ser escrito en tres pentagramas. El jurado propondrá a última hora el carácter que deberá tener la obra, para la cual se dará un tema o fragmento de frase. $2^{\circ}$ Numerar y realizar a cuatro voces un bajo dado. $3^{\circ}$ Transcribir para gran banda un fragmento de una obra moderna de partitura de orquesta. $4^{\circ}$ Transcribir para gran banda un fragmento escrito para piano de 25 a 30 compases.

Ejercicio práctico de dirección: Colocar la articulación e imponer el colorido a una pieza inédita escrita para banda, pudiendo emplear el tiempo que el tribunal crea suficiente en esta operación que se verificará en clausura. Esta pieza será la misma que dirigirá el opositor, haciendo observar a sus subordinados la misma articulación y colorido impuesto por él.

Ejercicio Oral: Explicación del mecanismo de cada instrumento y sus funciones peculiares dentro de cada cuerda. Conocimientos generales de la historia de la música: de los grandes compositores, desarrollo del arte, apreciación de las escuelas alemana, italiana y francesa, y diferencia que existe entre las bandas de las naciones anteriormente dichas y las españolas. Criterio peculiar del opositor acerca de estas materias. Juicio crítico acerca de las corrientes modernas sobre el gusto artístico-musical ${ }^{88}$.

También en 1903 Amorós fue nombrado Vicepresidente de la Asociación de

Profesores Músicos de Santa Cecilia. En este año las obras elegidas para la festividad de

Santa Cecilia se ejecutaron con órgano, violoncello y contrabajo para reducir gastos, ya

${ }^{87}$ El Ayuntamiento designó para formar parte de este tribunal a José $\mathrm{M}^{\mathrm{a}}$ Úbeda (director del Conservatorio) o en su defecto, un profesor del centro. Como Úbeda se negó a aceptar este cargo, el claustro de profesores del Conservatorio de Valencia designó a Amancio Amorós; E:VAcm, Acta del Claustro de profesores del Conservatorio de Música de Valencia, 1-III-1903. E:VAa, Sección I, sub. LL Banda Municipal, en proceso de catalogación, 45 cajas (1901-1942), caja 2, Libro de Actas Comisión especial de creación de una Banda Municipal Banda Municipal, 31-III-1902.

${ }^{88}$ Boletín Oficial de la provincia de Valencia, 10-IV-1903, pp. 2-3. E:Vaa, Sección I, sub. LL Banda Municipal, en proceso de catalogación, 45 cajas (1901-1942), caja 2, Libro de Actas Comisión especial de creación de una Banda Municipal, 31-III-1903. 
que la asociación atravesaba una difícil situación económica ${ }^{89}$. Posiblemente varias de las obras religiosas de Amorós, especialmente sus motetes y trisagios para voces solistas, coro y acompañamiento de órgano, violón y contrabajo (Quam dilecta tabernacula tua, Ave Maria, Credidi de $4^{\circ}$ tono, Trisagio a la Santísima Trinidad) se estrenaron en las misas y celebraciones de esta asociación, puesto que requerían menos instrumentistas, y esto permitía abaratar gastos.

En 1904 Amancio Amorós participó junto con Salvador Giner y José Bellver en el tribunal para las oposiciones a la cátedra de violín del Conservatorio de Valencia. El tribunal propuso nombrar profesor interino a Luis Sánchez ${ }^{90}$. Dos años después, la Junta Directiva acordó de nuevo convocar a oposición la plaza de profesor numerario de violín, con la disconformidad de Amancio Amorós y José Bellver ${ }^{91}$.

Amorós formó parte en 1908, junto con José Valls, José María Úbeda y Ramón Martínez, de la Comisión creada para establecer las bases del premio Infanta Isabel (hija de la reina Isabel II), que concedía el Conservatorio de Música de Valencia. Este premio consistía en una Medalla de Oro y un Diploma firmado por la Infanta Isabel (La Chata) ${ }^{92}$. Para concursar en Piano, Violín, Violonchelo y Canto se habían de interpretar una obra de libre elección, una por sorteo entre tres y una obligada; en Órgano había de interpretarse una obra de libre elección y superarse diversas pruebas (repentización,

\footnotetext{
${ }^{89}$ Loras, La Asociación, pp. 18-19.

${ }^{90}$ E:VAcm, Acta del Claustro de profesores del Conservatorio de Música de Valencia, 30-X-1904.

${ }^{91}$ E:VAcm, Acta de la Junta Directiva del Conservatorio de Música de Valencia, 28-XII-1906; E:VAcm, Acta del Claustro de profesores del Conservatorio de Música de Valencia, 12-X-1907. La oposición se celebró el 12-X-1907 y se nombró a Benjamín Lapiedra profesor numerario de violín.

92 E:VAcm, Acta de la Junta Directiva del Conservatorio Claustro del Conservatorio de Música de Valencia, 14-VI-1908.
} 
improvisación, transporte y ejecución de un bajo cifrado y composición, de un cuarteto de cuerda y una cantata, en castellano o valenciano, con acompañamiento de orquesta) ${ }^{93}$.

En 1909 Amancio Amorós, José Valls y José Bellver renunciaron a estar en el tribunal de oposiciones para una plaza de profesor de música de la Escuela Normal de Alicante por discrepancias con Manuel Penella, que también tenía que formar parte del tribunal $^{94}$. Ese mismo año Amancio Amorós ocupó la presidencia de la Asociación de Profesores Músicos de Santa Cecilia, en sustitución de Salvador Giner. La Junta la integraban además Salvador Giner (presidente honorario), Francisco Bellver (secretario), Juan Bautista Pastor (vicesecretario), José Rodrigo (tesorero), Francisco Peñarroja (vicepresidente), Francisco Gilabert, Francisco Llorens y Ángel Fabra (visitadores). En 1913 Amorós fue reelegido nuevamente presidente. Las novedades que se produjeron fueron pocas. La nueva Junta de 1913 propuso crear una biblioteca para propagar la lectura entre los asociados y la adquisición de "cedulitas de propaganda" para repartir en misas y otras celebraciones. A partir de 1912 aumentaron los coros de voces graves, de voces blancas y coros mixtos, formados por socios de la entidad, que ya existían desde 1908 y que Amorós utilizó para el estreno de su Misa Ceciliana ${ }^{95}$. Para acabar con el déficit económico crónico de la Asociación, el cantante Manuel Irurita Almandor propuso en 1913 nombrar un "clavario", que junto con la Directiva, presidiera la festividad de Santa Cecilia y ayudara económicamente a la Asociación. En 1915 Amorós propuso que los socios llevaran una medalla de plata con la imagen de Santa Cecilia, al

\footnotetext{
93 E:VAcm, Acta del Claustro de profesores del Conservatorio de Música de Valencia, 28-IX-1908. Según Fontestad se fijaron las obras obligadas para celebrar el concurso a finales de mayo de 1909, pero es posible que el concurso se suspendiera como la mayoría de Concursos previstos en la Exposición Regional de 1909 por las circunstancias políticas y no hubo más convocatorias del Concurso Infanta Isabel. Fontestad, El Conservatorio de Música, p. 571.

${ }^{94}$ E:VAcm, Acta del Claustro de profesores del Conservatorio de Música de Valencia, 27-I-1909.

${ }^{95}$ Loras, La Asociación, pp. 21-25.
} 
igual que hacían otras asociaciones ${ }^{96}$. La situación económica de la Asociación mejoró a partir de 1915 en lo que respecta a socios.

\section{2. Amorós y la Comisión de Música Sagrada de Valencia}

Amorós ingresó como miembro de la Comisión de Música Sagrada de Valencia entre 1909 y 1912 (desconozco la fecha exacta de su incorporación) y permaneció en ella hasta 1925 (véase Tabla 21) ${ }^{97}$. En Valencia, como en otras diócesis españolas, se creó en abril de 1904 una Comisión de Música Sagrada para vigilar el cumplimiento de los postulados del Motu Proprio.

Tabla 21. Miembros de la Comisión de Música Sagrada de Valencia en 1913. Fuente: $B O A V, 1679$ (16-IV-1913), p. 187.

\begin{tabular}{|c|c|c|}
\hline Cargos en la Comisión & Nombre & Ocupación profesional \\
\hline Presidente & José Vila & Canónigo Doctoral \\
\hline Vocal & Mariano Baixauli & - \\
\hline Vocal & Juan Bautista Pastor Pérez & $\begin{array}{l}\text { Beneficiado. Maestro de Capilla } \\
\text { de la Catedral }\end{array}$ \\
\hline Vocal & Vicente Ripollés Pérez & $\begin{array}{l}\text { Beneficiado. Maestro de canto } \\
\text { coral de la Catedral }\end{array}$ \\
\hline Vocal & Francisco Tito Pérez & $\begin{array}{l}\text { Beneficiado. Organista sustituto } \\
\text { de la Catedral }\end{array}$ \\
\hline Vocal & Francisco Peñarroja & $\begin{array}{c}\text { Maestro de Capilla del Colegio } \\
\text { del Corpus Christi }\end{array}$ \\
\hline Vocal & Amancio Amorós Sirvent & $\begin{array}{l}\text { Profesor del Conservatorio de } \\
\text { Valencia }\end{array}$ \\
\hline Vocal & Juan Cortés Cortés & $\begin{array}{c}\text { Organista del Colegio del Corpus } \\
\text { Christi }\end{array}$ \\
\hline Vocal & Eduardo López-Chavarri Marco & $\begin{array}{c}\text { Profesor del Conservatorio de } \\
\text { Valencia }\end{array}$ \\
\hline Secretario & Juan Bautista Redó Guimerá & $\begin{array}{l}\text { Beneficiado, Sochantre de la } \\
\text { Catedral }\end{array}$ \\
\hline
\end{tabular}

\footnotetext{
${ }^{96}$ La medalla la diseñó el hijo del presidente, José Amorós Barra. Las medallas podían ser de plata o de aluminio y se vendieron a 8 pesetas las de plata y a 2 las de aluminio, Miquel Crusanfort i Sabater, Medallas conmemoratives del Països Catalans $i$ de la Corona Catalana-Aragonesa, s. XV-XX (Barcelona: Institut d'Estudis Catalans, 2006), pp. 186, 532-533.

${ }^{97}$ Habían causado baja por defunción José Ma Úbeda y Eduardo Serrano en 1909, Salvador Giner en 1911 y Roque Chabás en 1912; Almanaque Eclesiástico de la Diócesis de Valencia (1913), p. 298.
} 
Antes de su ingreso en la Comisión de Música Sagrada de Valencia, Amorós ya era un compositor conocido y aceptado por sus miembros. En 1905 había obtenido censura favorable para la interpretación de sus obras: Acepta Virgen Pura; O Salutaris Hostia a tres voces; la "salutación al Patriarca San José", Recibid mil parabienes (sf) y los "Gozos al Patriarca San José", Pues sois Santo sin igual (sf), todas ellas publicadas en la revista valenciana Biblioteca Sacro Musical ${ }^{98}$. Ildefonso Alier editó en la colección Obras Religiosas españolas, además de las publicadas en la revista Biblioteca Sacro Musical, el Ave Maria a solo y coro, O salutaris Hostia a solo y coro, Quam dilecta tabernacula tua a solo, coro y órgano y Credidi a cuatro voces iguales con acompañamiento de orquesta y órgano ${ }^{99}$.

Amancio Amorós participó en el Tercer Congreso Nacional de Música Sagrada celebrado en Barcelona entre el 21 y 24 de noviembre de 1912, en representación de la diócesis de Valencia ${ }^{100}$. Los responsables de este Tercer Congreso Nacional de Música Sagrada fueron Felipe Pedrell, Gregorio $M^{a}$ Suñol, Vicente $M^{a}$ Gibert, Antonio Nicolau, Domingo Mas i Serracant, José Mas Vidal, Luis Millet y José Cumellas Ribó, quienes formaron la subcomisión para redactar el Reglamento del Congreso y los temas que debían estudiarse ${ }^{101}$.

\footnotetext{
${ }^{98}$ Biblioteca Sacro Musical, 15-VIII-1893, p. 73.

${ }^{99}$ No he encontrado referencias sobre si fueron también estas otras obras aceptadas por la Comisión de Música Sagrada.

${ }^{100}$ Amorós asistió al Congreso de Barcelona junto con José Vila (canónigo doctoral), Vicente Ripollés (beneficiado director de canto litúrgico), y Juan Bautista Pastor (beneficiado, maestro de capilla), Mariano Baixauli (jesuita), Francisco Peñarroja (presbítero), Miguel María Cavanillas, Luis Gallego y Eduardo López-Chavarri (vocales).

${ }^{101}$ Tercer Congreso, pp. 4-5. La sesión inaugural tuvo lugar el 21 de noviembre en el Palau de la Música, con la presencia de autoridades eclesiásticas y musicales europeas y españolas. La Schola Cantorum y la Schola Puerorum del Seminario de Barcelona, dirigidas por Gregori Suñol cantaron el Veni Creator Spiritus que sirvió para inaugurar las sesiones. Véase Aviñoa, "La música religiosa", p. 191. Este congreso estuvo organizado en tres secciones: $1^{\text {a }}$ Canto gregoriano, cuyo responsable fue M. Sablayrolles, $2^{\mathrm{a}}$ Música Figurada, a cargo de Lluís Romeo y $3^{\mathrm{a}}$ Propaganda y Organización, a cargo de Pedrell.
} 
Entre los acuerdos que se tomaron en este Tercer Congreso estuvo la creación de la Asociación Ceciliana Española y de la primera Escuela Superior de Música Sagrada ${ }^{102}$. También se abogó por la enseñanza obligatoria de la música sagrada en los centros de formación eclesiástica, por implantar el canto gregoriano en las oposiciones a maestro de capilla, fomentar el canto colectivo entre los fieles, favorecer melodías populares de expresión religiosa y utilizar como único instrumento el órgano litúrgico ${ }^{103}$. En este contexto debe situarse la composición de la Misa Ceciliana (1912) de Amorós, compuesta para celebrar la fiesta anual que la Asociación Santa Cecilia dedicó a su patrona ese año, y que se interpretó con los coros de la Asociación Santa Cecilia de Valencia $^{104}$. Al coincidir la festividad de Santa Cecilia con la celebración del Tercer Congreso Nacional de Música Sagrada en Barcelona, con participación de muchos asociados valencianos, la fiesta de la patrona de la música se celebró en Valencia el 29 de diciembre de 1912, en la Real Capilla del Milagro, y la Misa Ceciliana de Amorós se estrenó durante la celebración. El coro de la Asociación Santa Cecilia se reforzó para la ocasión con miembros del Ateneo Musical y con las capillas de la Catedral y del Real Colegio del Patriarca de Valencia ${ }^{105}$.

Durante el periodo en el que Amorós formó parte de la Comisión de Música Sagrada de Valencia, intentó solucionar varios problemas que seguían latentes (véase Capítulo 1, apartado Música religiosa).

En diciembre de 1916 fue nombrado Arzobispo de Valencia José Ma Salvador Barreda, quien confirmó en su cargo a Amancio Amorós como miembro de la Comisión

\footnotetext{
${ }^{102}$ La Junta Directiva de la Asociación Ceciliana Española estuvo constituida por: Vicente Ripollés (presidente), Julio Valdés y Felipe Pedrell (vicepresidentes $1^{\circ}$ y $2^{\circ}$ ), Francisco Agüeras, Francisco de P. Viñaspre, Luis Romeo, Juan B. Elústiza, Bernardo Gabiola (vocales). Tercer Congreso, p. 242.

${ }^{103}$ Tercer Congreso, pp. 225-231.

${ }^{104}$ Loras, La Asociación, p. 25.

${ }^{105}$ Las Provincias, 30-XII-1912.
} 
de Música Sagrada de Valencia ${ }^{106}$. El compositor mantuvo el cargo hasta su muerte en $1925^{107}$.

\section{Nombramientos, honores y últimos años (1915-1925)}

En 1915 Amancio Amorós fue miembro del jurado en las oposiciones a una cátedra de Armonía del Real Conservatorio de Música de Madrid ${ }^{108}$ y en febrero de 1920 ingresó como socio en la Sociedad Filarmónica de Valencia ${ }^{109}$. Desde 1917 presidió varias veladas literario-musicales del Centro Escolar y Mercantil en honor a Santa Cecilia (Ilustración 11). Al finalizar éstas, Amancio Amorós elogiaba la labor de los jóvenes músicos del centro y los animaba a seguir el camino emprendido ${ }^{110}$.

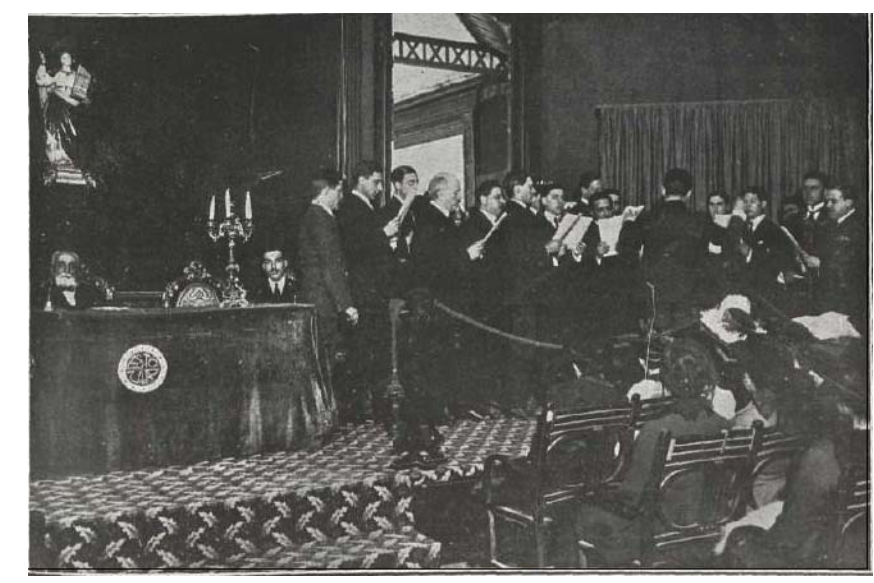

Ilustración 11

Amancio Amorós (bajo la imagen de Santa Cecilia) en una velada musical del Centro Escolar y Mercantil (1917). Oro de ley, 29-IV-1917, p. 221.

${ }^{106}$ BOAV, 1835 (15-VII-1919), p. 237.

107 Según Oriola Velló la Comisión de Música Sagrada valenciana se mantuvo durante bastante años inoperante (el último informe lo emitió en 1913), aunque no llegó a desaparecer; Oriola "L'article 24 de Pius X", p. 354.

${ }^{108}$ E:VAcm, Acta de la Junta de Gobierno del Conservatorio de Música de Valencia, 31-III-1915; E:Mba, legajo 5-2-2, Expediente de nombramiento de Amancio Amorós como Académico Correspondiente (1921).

109 Salvá, “La Sociedad Filarmónica”, pp. 86-87; Anónimo, Sociedad Filarmónica de Valencia, pp. 1719.

${ }^{110}$ Oro de ley, 29-IV-1917, p. 211; Oro de ley, 6-V-1917, pp. 220-222; Oro de ley, 10-II-1918, p. 103. 
Amancio Amorós fue director del Conservatorio de Valencia desde septiembre de 1919 hasta febrero de $1924^{111}$. Accedió al cargo tras la dimisión de Ramón Martínez y al principio lo ejerció con carácter interino, por ser el profesor con más antigüedad en el centro. Fue confirmado en el cargo de director por Real Orden de 14 de octubre de 1920 con una gratificación anual de 1000 pesetas $^{112}$. Amorós dio solución a los problemas económicos del centro, lo incorporó a las enseñanzas del Estado y redactó el nuevo Reglamento Orgánico del Conservatorio de 1921 (véase Capítulo 3, Actividad Docente).

Durante la etapa de Amorós como director del centro, Joaquín Rodrigo asistía esporádicamente, como oyente, a las clases de historia de la música de Eduardo LópezChavarri Marco, y recordaba en sus escritos a Amancio Amorós como un personaje serio y arrogante:

Me invitó a asistir a sus clases de Historia de la Música hasta que, un buen día, mientras estábamos entre Barricadas Misteriosas de Couperin y El canto de los cisnes de Rameau, se presentó el estirado y adusto D. Amancio Amorós, decimonónico director del Conservatorio valenciano que, al preguntarme en qué curso estaba y contestarle que yo era tan sólo oyente, me dijo formalmente: "Aquí no queremos oyentes, sino alumnos aunque no oigan"113.

Desde 1921 Amorós fue miembro del Centro de Cultura Valenciana, institución creada en 1915 con apoyo de la Diputación y el Ayuntamiento de Valencia ${ }^{114}$. En el

111 E:VAcm, Acta del Claustro de profesores del Conservatorio de Música de Valencia, 17-IX-1919, E:VAcm, Acta del Claustro de profesores del Conservatorio de Música de Valencia, 12-XII-1924; véase además López-Chavarri, Cien años de música, p. 134; Pena y Anglés, Diccionario de la Música, p. 65; López-Chavarri, Cien años de historia, p. 41; Adam, "Amorós Sirvent, Amancio", p. 28; Sobrino, “Amorós Sirvent, Amancio", p. 420.

112 E:VAcm, Tomas de posesión y ceses del profesorado del Conservatorio de Música y Declamación de Valencia, 1920-1960, p. 1; Real Orden de 14-X-1920 confirmando la plantilla que se indica del profesorado del Conservatorio de Música y Declamación de Valencia, Gaceta de Madrid, 16-X-1920, p. 238.

${ }^{113}$ Antonio Iglesias (ed.), Escritos de Joaquín Rodrigo (Madrid: Editorial Alpuerto, 1999), p. 115.

114 El "Centro de Cultura Valenciana" derivó posteriormente en la "Real Academia de Cultura Valenciana". Véase Anónimo, "Centro de Cultura Valenciana", Almanaque de las Provincias para 1916, pp. 137-140. 
Centro de Cultura Valenciana había distintos tipos de miembros, denominados “directores" (véase Capítulo 1, Sociedades culturales con actividad musical). En junio de 1920 se crearon los directores artistas, también llamados "directores consiliarios de arte", para los cultivadores de las Bellas Artes, en cualquiera de sus manifestaciones que hubiesen mostrado su amor a la historia de Valencia y a esa categoría perteneció Amancio Amorós ${ }^{115}$. La Junta del Centro de Cultura y en su nombre el decano, José Martínez Aloy propuso el 30 de marzo de 1921 a Amancio Amorós como "Director de Arte". Tras ser sometida la propuesta a votación, fue aprobada por unanimidad ${ }^{116}$. Amancio Amorós remitió una carta de agradecimiento a Martínez Aloy el 7 de abril de 1921:

Recibido el oficio en el cual se me comunica el haber sido honrado con el nombramiento de Director de Arte de ese tan culto Centro, a propuesta de Vuestra Excelencia, digno Director decano del mismo, complázcame en hacer constar mi más sentido agradecimiento por tal distinción, así como por haber sido favorecido con las interesantes obras publicadas por esa Institución, las cuales acusan en parte la vida cultural e intensa que lleva ese valentino centro, al cual, desde hoy, me creo obligado a ofrecer mi más modesta pero entusiasta cooperación.

Lo que tengo el honor de poner en conocimiento de Vuestra Excelencia, a quien Dios guarde muchos años ${ }^{117}$.

En junio de 1921, el “Ateneo Musical” de Valencia mostró su agradecimiento al

Centro de Cultura Valenciana por el nombramiento como "director de Arte" de Amancio

Amorós:

Tengo el gusto de poner en su conocimiento que en Junta directiva, celebrada el cinco del actual, se acordó constara en acta el agradecimiento de esta entidad y la distinción con que mira esa entidad cultural el arte músico, dando ingreso como directores de Arte a los Sres. D. Amancio Amorós, D. Vicente Ripollés, D. Ricardo Benavent y D. Eduardo López-Chavarri, personas de gran prestigio y cultura.

Les felicitamos por su elección y nombramiento de los referidos directores $[\ldots]^{118}$.

\footnotetext{
${ }^{115}$ Anónimo, “Los L años del Centro”, pp. 11-12.

${ }^{116}$ E:Vaac, Acta de la sesión de la Junta del Centro de Cultura Valenciana, 30-III-1921, p. 3.

${ }^{117}$ E:Vaac, Carta de Amancio Amorós al Centro de Cultura Valenciana, 7-IV- 1921.
} 
Según los Estatutos del Centro de Cultura Valenciana los directores de número quedaban obligados a leer antes de seis meses, en la Junta en que tomaran posesión un discurso, cuyo tema podían elegir a su gusto. Los Estatutos del Centro de Cultura Valenciana de 1928 en el capítulo 3, referente a las obligaciones de los directores, en su art. 15, dice así:

Los elegidos para Directores de número tomarán posesión en Junta pública, a cuyo efecto remitirán al Centro el discurso de que se habla en el artículo siguiente, en el término de seis meses, pasados los cuales sin hacerlo, se les prevendrá que, de no presentarlo dentro de los siguientes, declarase caducado su nombramiento y se procederá a nueva elección ${ }^{119}$.

En 1921, sin embargo, se dispuso que los "directores" de todas clases del Centro pudieran verificar su recepción solemne cuando lo estimaran oportuno, al parecer sin perder sus derechos si no lo hacían en seis meses:

La serie de doce directores consiliarios de Arte debe estar formada por artistas que de una manera muy acentuada logren imprimir a sus producciones las características regionales o se hayan distinguido en trabajos de investigación conducentes al esclarecimiento de la Historia del Arte Valenciano en cualquiera de sus manifestaciones.

Los directores de todas clases del Centro de Cultura entran en ejercicio de sus derechos desde el momento en que aceptan sus respectivos nombramientos, pero esto no es obstáculo para que se verifiquen solemnemente las recepciones de aquellos cuando lo estimen oportuno, de acuerdo con la Junta Administrativa ${ }^{120}$.

${ }^{118}$ E:Vaac, Legajo Directores Consiliarios (1921), Carta del Ateneo Musical de Valencia al Centro de Cultura Valenciana, 8-VI-1921.

119 Capítulo III, art. 15 del Reglamento del Centro de Cultura Valenciana, en Anales del Centro de Cultura Valenciana, 1 (1928), p. 4.

120 E:Vaac, Legajo Directores Consiliarios (1921). Disposiciones Reglamentarias. Véase también Reglamento del Centro. Capítulo III, artículo 15, Obligaciones de los directores, en Anales del Centro de Cultura Valenciana, 1 (1928), pp. 4 -5. 
No he podido constatar si Amorós llegó a presentar su discurso de ingreso en el Centro de Cultura Valenciana. El archivo de esta institución no conserva ningún discurso suyo y la prensa del momento no hace referencia a su lectura de presentación ${ }^{121}$.

En 1918 la Real Academia de Bellas Artes de San Fernando de Madrid propuso que las obras teóricas de Amorós Elementos de Solfeo, Nociones Teóricas de Solfeo y Lecciones Manuscritas Graduadas fueran declaradas de utilidad para la enseñanza del solfeo:

Se dio cuenta de una orden del Sr. Director General de Bellas Artes remitiendo instancia a D. Amancio Amorós Sirvent, profesor del Conservatorio de Música de Valencia, en solicitud de que sea declarada de utilidad para la enseñanza y de mérito en su carrera las obras de que es autor tituladas Nociones Teóricas de Solfeo, Elementos de Solfeo y Lecciones Manuscritas Graduadas ${ }^{122}$.

Con el informe favorable de Pedro Fontanilla, la propuesta fue aprobada por la

Sección de Música de la Real Academia en 1918:

El Sr. Fontanilla leyó el informe que por acuerdo de la Sección [de Música] había redactado acerca de las obras tituladas Nociones Teóricas de Solfeo, Elementos de Solfeo y Lecciones Manuscritas Graduadas de que es autor D. Amancio Amorós, profesor del Conservatorio de Valencia. La Sección aprobó el informe ${ }^{123}$.

\footnotetext{
${ }^{121}$ En un principio podría pensarse que los socios no numerarios estuvieran exentos de la obligación de presentar discurso. Sin embargo tengo constancia de los discursos presentados por los "directores de arte o directores artistas" Ricardo Benavent en 1920 y Eduardo López-Chavarri Marco en 1921 en el Salón de actos del Conservatorio de Valencia. El discurso de presentación de Benavent llevaba por título "Compositores Valencianos". Ricardo Benavent "pronunció un discurso en el que desenvolvió con claridad y datos abundantísimos el juicio crítico de los compositores valencianos que florecieron en las últimas décadas del siglo pasado, y de algunos de los que hoy se destacan, reconociendo lo más selecto de las obras de Plasencia, Valls, Ximénez, Giner, Úbeda, Espí, Amorós, Chavarri, Ripollés, Guzmán, Pastor y Peñarroja". En el discurso de López-Chavarri titulado "La música y el espíritu valenciano" se ensalzó "el alma valenciana y el espíritu musical de nuestra raza, que supo en otros tiempos llenar el mundo y luego, adormeciéndose ha olvidado su glorioso pretérito". Ripollés leyó también su discurso en 1921 "Les Epístoles farcides de Navidad y San Esteban", E:Vaac, Acta de la sesión de la Junta del Centro de Cultura Valenciana, 10-VII-1920 y 4-V-1921; Anónimo, "Centro de Cultura Valenciana”, Almanaque de las Provincias para 1923, pp. 115-116.
}

${ }^{122}$ E: Mba, Acta de la sesión celebrada por la Sección de Música de la Academia de Bellas Artes de San Fernando de Madrid, 13-V-1918.

${ }^{123}$ E: Mba, Acta de la sesión celebrada por la Sección de Música de la Academia de Bellas Artes de San Fernando de Madrid, 21-X-1918. 
Esta aprobación suponía la consagración, por las más altas instancias académicas del país, de la ingente labor docente desempeñada por Amancio Amorós a lo largo de su carrera profesional.

El 16 de junio de 1921 Amancio Amorós fue nombrado Académico Correspondiente por Valencia de la Real Academia de San Fernando de Madrid, a propuesta de los académicos Pedro Fontanilla, Narciso Sentenach y Joaquín Larregla ${ }^{124}$. El proceso de nombramiento fue el siguiente: los académicos propusieron a Amorós como Académico Correspondiente el 16 de mayo de 1921, presentando un informe con sus méritos. El informe se leyó en Junta en tres ocasiones antes de ser sometido a votación $^{125}$. El 16 de junio de 1921 se votó la propuesta, que fue aceptada por unanimidad:

Reunidos los señores que se expresan al margen del acta anterior, leí los artículos de los Estatutos y Reglamento que se refieren a la elección de Académicos Correspondientes, así como las propuestas y los méritos de los tres candidatos que son los señores D. Antonio García Boiza, D. Amancio Amorós y D. Manuel Izquierdo Ordóñez, los cuales fueron votados sucesivamente, resultando los tres elegidos por unanimidad, acordándose remitirles la credencial y el Diploma ${ }^{126}$.

\footnotetext{
124 E:Mba, legajo 5-2-2, Expediente de nombramiento de Amancio Amorós como Académico Correspondiente (1921). Los Académicos correspondientes estarán en comunicación directa y frecuente con la Academia, a la cual deberán participar todo cuanto sobre Bellas Artes se ejecute o publique en los puntos de su respectiva residencia. [...] Igualmente darían noticias de los descubrimientos artísticos y de los científicos que tengan relación con las Artes, de la creación de museos, archivos o bibliotecas musicales, organización de orfeones o sociedades corales, formación de colecciones de objetos de arte [...] y cuanto pueda interesar a las Artes y a los artistas. Capítulo II, artículo 48 del Reglamento interior de la Real Academia de Bellas Artes de San Fernando (Madrid: Imprenta de S. Francisco de Sales, 1914), pp. 19-20; el reglamento lo consulté dentro del legajo 4-51-3 del E: Mba; véanse también Anuario de la Real Academia de Bellas Artes de San Fernando, 1921 (p. 156), 1922 (p. 157), 1923 (p. 159), 1924 (p. 160), 1925 (p. 161) (Madrid: Establecimiento Tipográfico Nieto y Compañía).

${ }^{125}$ E: Mba, Actas de las Sesiones de la Real Academia de Bellas Artes de San Fernando de Madrid, 16-V1921, p. 274; 23-V-1921, p. 280; 30-V-1921, p. 288; 6-VI-1921, p. 291.

${ }^{126}$ E: Mba, Acta de la sesión extraordinaria celebrada por la Academia el día 16 de junio de 1921 para la elección de tres correspondientes, p. 303.
} 
Amorós fue además condecorado por el Gobierno Francés con el título de Oficial de Instrucción Pública y Bellas Artes ${ }^{127}$.

En diciembre de 1922 Amorós formó parte del jurado para premiar la música del Himno Oficial de la Coronación, con motivo de la Coronación Pontificia de la Virgen de los Desamparados en Valencia. Fueron también parte del jurado Eduardo López-Chavarri Marco, Juan Bautista Pastor, Vicente Ripollés y el jesuita Mariano Baixauli. Con anterioridad se había convocado otro concurso para la presentación de letras para el mismo himno ${ }^{128}$.

En 1922 la Asociación de profesores Músicos de Santa Cecilia celebró sus Bodas de Plata y la música de Amorós sirvió para amenizar los actos litúrgicos en la festividad de Santa Cecilia ${ }^{129}$.

En 1924 Amorós seguía siendo director del Conservatorio de Valencia, aunque su mermada salud le había obligado a solicitar varios meses de licencia por enfermedad. Ese mismo año se trasladó con su mujer a San Cugat del Vallés (Barcelona), lugar de residencia en aquellos años de su hijo José Vicente Amorós Barra ${ }^{130}$. En octubre de ese

\footnotetext{
${ }^{127}$ El Mercantil Valenciano, 17-II-1925. Desconozco los detalles de este nombramiento como Oficial de Instrucción Pública.

${ }^{128}$ Los participantes en el concurso de la letra del Himno Oficial de la Coronación tenían que "haber nacido en alguna de las actuales provincias de Alicante, Castellón o Valencia". La composición, con libertad de metro, debía estar escrita en valenciano. Los músicos concursantes, sin embargo, podían haber nacido en cualquier provincia española. Las bases de la convocatoria decían: "Para las tres estrofas de un mismo metro destinadas al coro, se escribirá una misma y sola melodía que ha de ser necesariamente unisonal. La música destinada a las estrofas que sirven de copla, será la misma en ambas y se escribirá a cuatro voces mixtas, pero de tal manera que la parte superior pueda cantarse por el pueblo, sin auxilio de las voces restantes. Debiéndose cantar el himno en su totalidad por el pueblo, los concursantes procurarán contenerse en su composición dentro de los límites extremos de Do hasta Mi bemol y tendrán en cuenta que toda la obra ha de cantarse seguida de principio a fin y sin intermedio alguno en el acompañamiento". Se presentaron treinta y tres composiciones y el fallo del jurado fue hecho público el 22 de marzo de 1923, Luis Romeo, organista de la catedral de Vich fue el compositor premiado. Véase Las Provincias, 10-V-1981.

${ }^{129}$ Loras, La Asociación, p. 28.

${ }^{130}$ José Vicente Amorós Barra (Valencia 1887-Barcelona 1970) estudió armonía y composición con su padre y aprendió a tocar el violín, el piano y el violonchelo. Estudió también Bellas Artes y Filosofía y Letras en la Universidad de Valencia. Desde 1914 fue Catedrático de Arqueología, Epigrafía y Numismática en la Universidad de Barcelona. Amorós Barra fue nombrado Académico Correspondiente
} 
mismo año falleció su esposa, $\mathrm{M}^{\mathrm{a}}$ del Consuelo Barra Escat, lo que supuso un duro golpe

para el compositor que, con una salud muy deteriorada, presentó su dimisión como

director del Conservatorio de Valencia al Director General de Bellas Artes en noviembre

de 1924.

Nos quedan algunos testimonios gráficos de los últimos años de Amancio Amorós, gracias al archivo personal de su nieta Margarita Amorós Portolés (Ilustraciones $12-15)$.

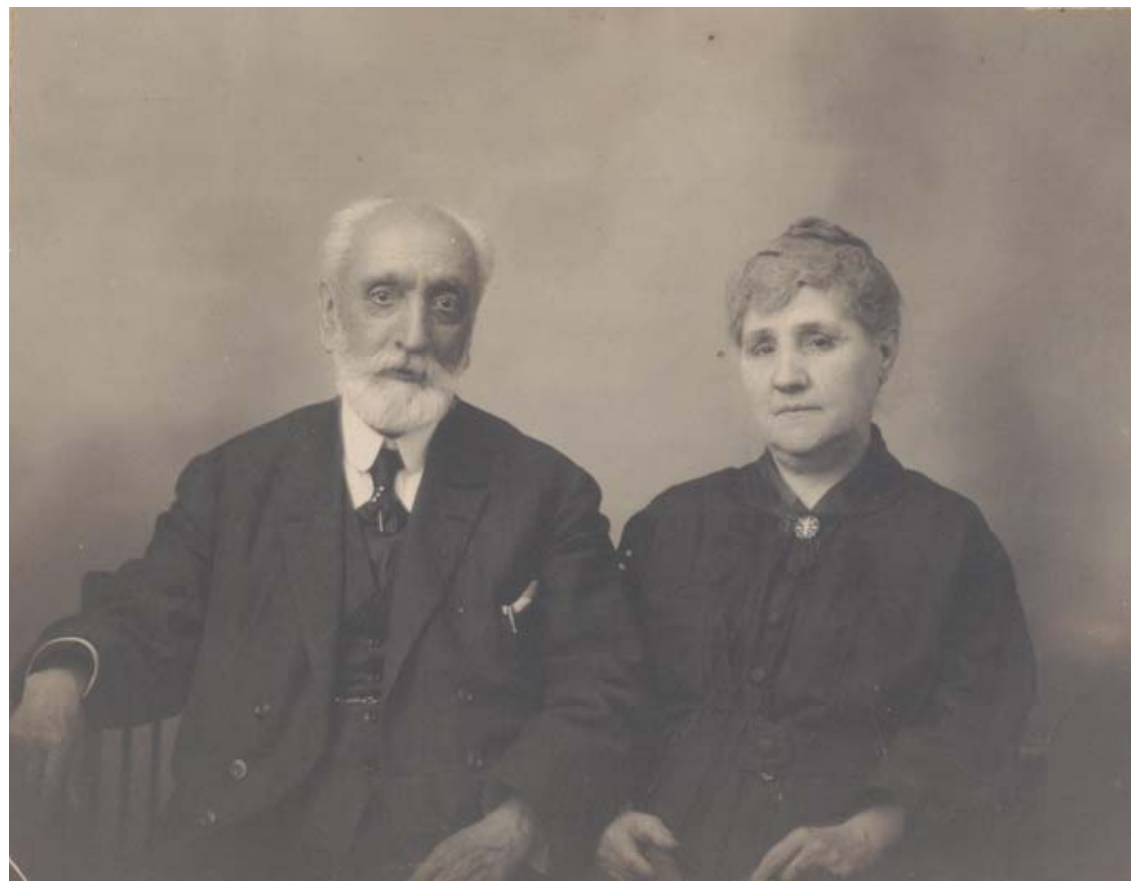

Ilustración 12

Amancio Amorós y su esposa Consuelo Barra (1924). Archivo familiar de Margarita Amorós Portolés.

del Centro de Cultura Valenciana el 21-X-1921, E:Vaac, Acta de la sesión celebrada por el Centro de Cultura Valenciana, 21-X-1921. Véase también Galbis, "Amorós Barra, José Vicente", en DMEH, vol. 1 (1999), p. 421. Amorós Barra se casó con Teresa Portolés Ferrer, natural de Calanda (Teruel) y tuvieron cuatro hijos, los únicos nietos de Amancio Amorós. Los tres primeros aparecen en el Padrón Municipal de Sant Cugat del Vallés: $\mathrm{M}^{\mathrm{a}}$ Teresa Amorós Portolés (21-I-1916); Consuelo Amorós Portolés (13-VIII1918) y José Luis Amorós Portolés (19-XII-1920). La familia Amorós Barra vivió unos tres años aproximadamente en San Cugat de Vallés, por recomendación médica, ante la enfermedad del único nieto varón de Amancio Amorós, José Luis Amorós Portolés. La casa de San Cugat del Vallés estaba situada en la calle Villà 28. Posteriormente la familia Amorós Barra volvió a trasladarse a Barcelona. E:Ban (que conserva parte de los fondos históricos del Archivo Municipal de Sant Cugat), Archivo 5 Sant Cugat, Fons 1, Administració Local 1924, 2. 7; 2/104, caja 104, Padrón de Habitantes 1926, 2. 7; 4/104, 5/104 caja 104. La hija pequeña del matrimonio fue Margarita Amorós Portolés, que nació en Barcelona en 1929 y es la única nieta de Amancio Amorós que todavía vive. 


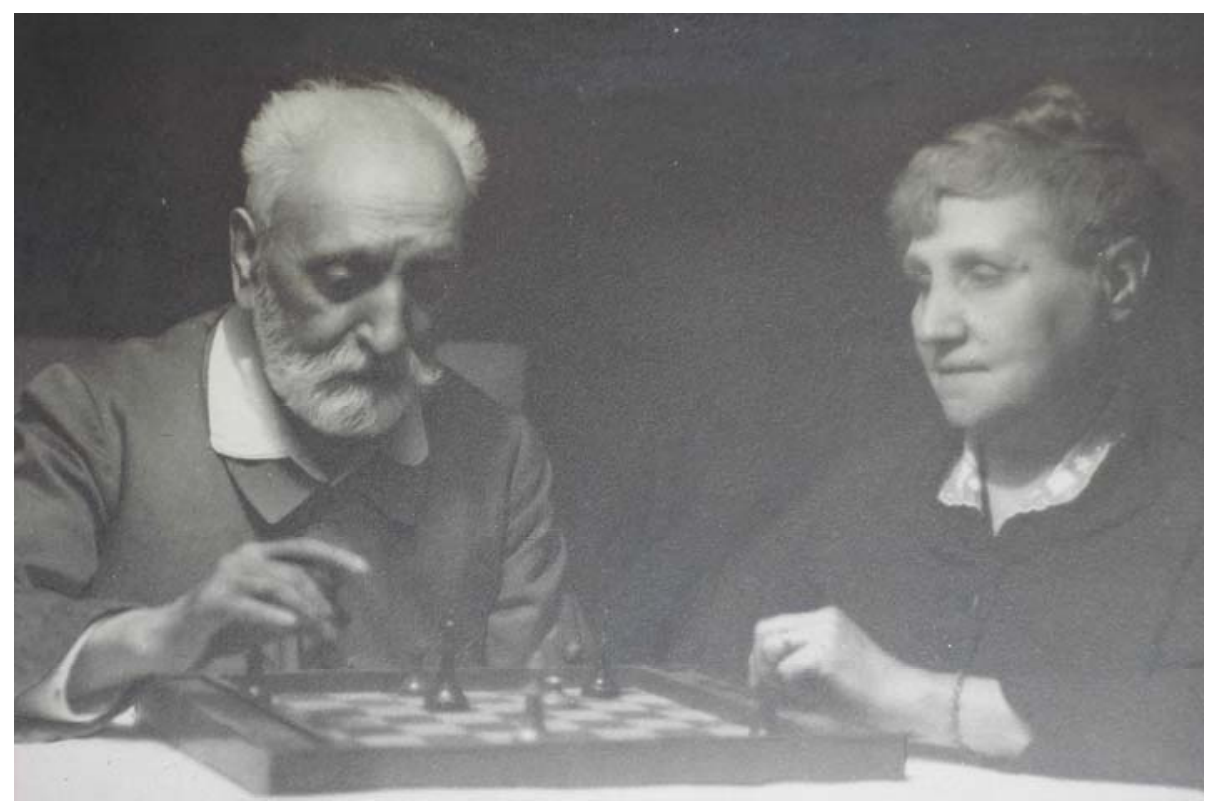

Ilustración 13

Amancio Amorós jugando al ajedrez y su esposa Consuelo Barra (1924). Archivo familiar de Margarita Amorós Portolés.

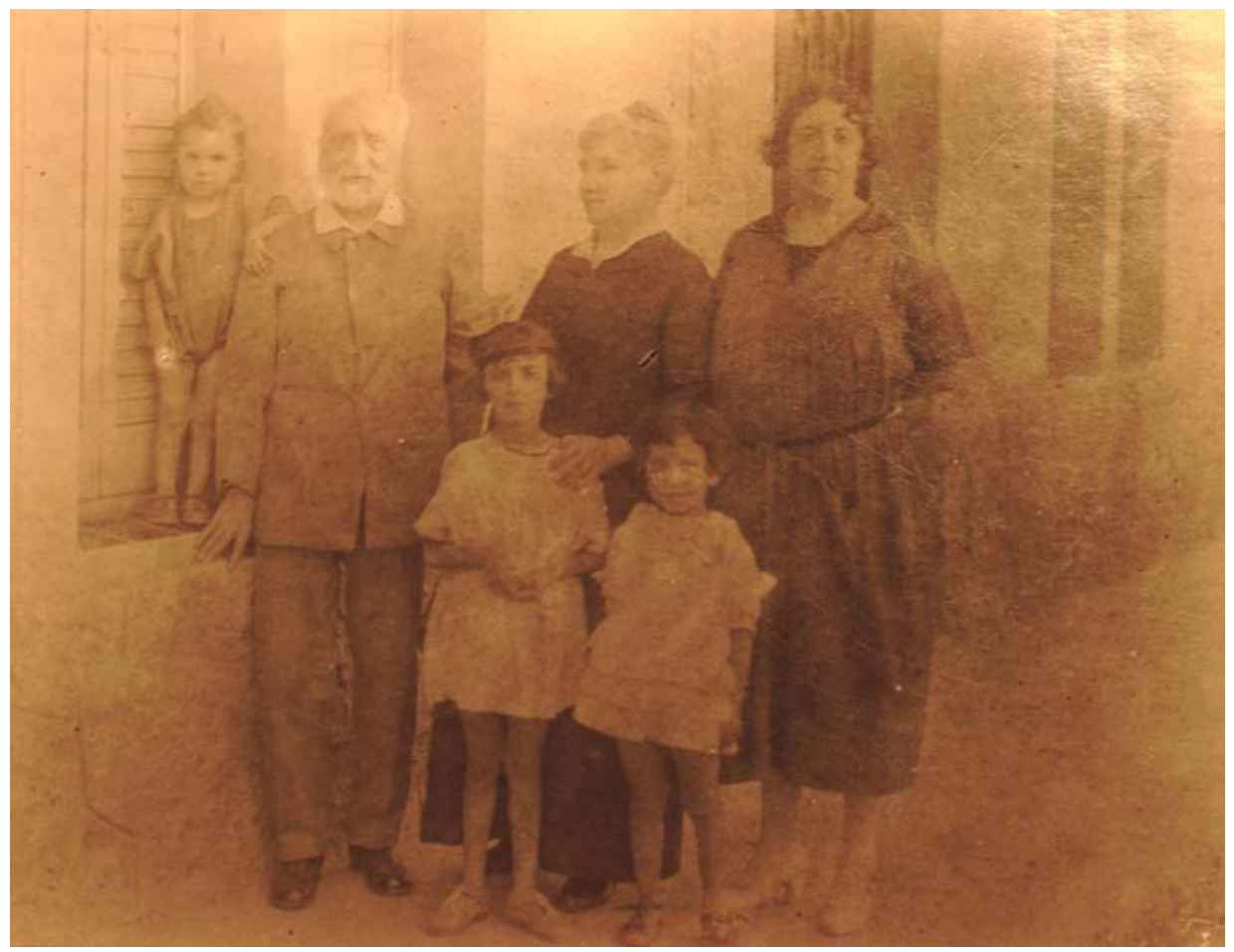

Ilustración 14

Amancio Amorós, Consuelo Barra, Teresa Portolés

José Amorós, Teresa Amorós y Consuelo Amorós (1924).

Archivo familiar de Margarita Amorós Portolés. 


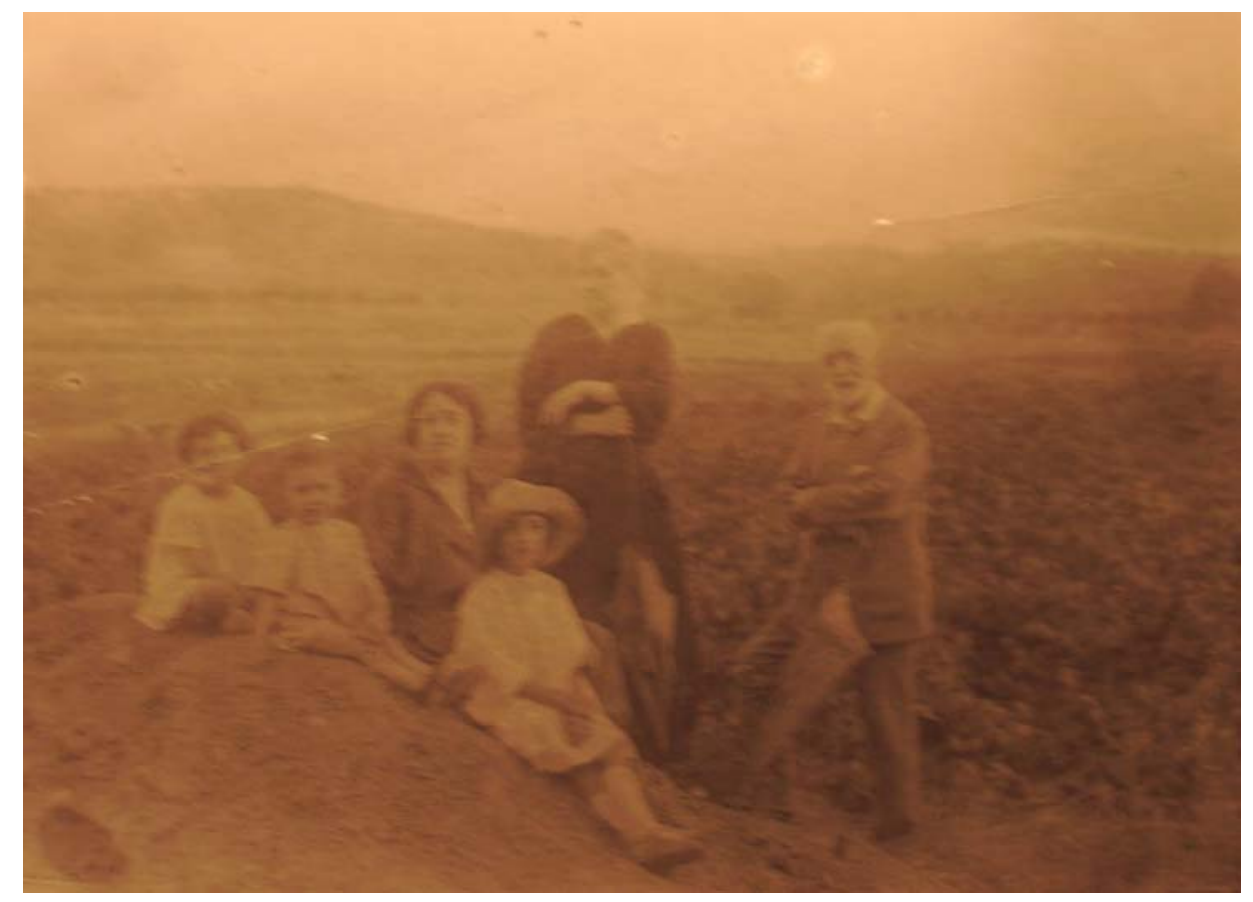

Ilustración 15

Teresa Portolés, Consuelo Barra, Amancio Amorós

Teresa Amorós, José Amorós y Consuelo Amorós (1924).

Archivo familiar de Margarita Amorós Portolés.

Amancio Amorós murió a las 13:00 horas del 5 de febrero de 1925, a los setenta años de edad por una neoplasia intestinal, en el domicilio familiar de su hijo José Vicente, en San Cugat del Vallés (Barcelona) y fue enterrado en el antiguo cementerio de esa localidad, situado en el monasterio de Sant Cugat (Ilustración 16) ${ }^{131}$. Días antes de fallecer se leyó su testamento ante José Valls i Girals, notario de Rubí (Barcelona) ${ }^{132}$.

\footnotetext{
${ }^{131}$ Registro Civil de Sant Cugat del Vallés (Barcelona), Certificado de Defunción de Amancio Amorós Sirvent, Libro de Defunciones, tomo 22, p. 130. E:Ban, Archivo 5 Sant Cugat, Fons 1, Administración Local, Padrón de Habitantes 1925, 2. 7; 3/104, caja 104. Relación de altas y bajas.

${ }^{132}$ En mayo de 2009 solicité al Archivo Histórico de Terrassa copia del testamento de Amancio Amorós, pero no pude obtenerla, por no haber transcurrido todavía cien años desde el fallecimiento del compositor.
} 


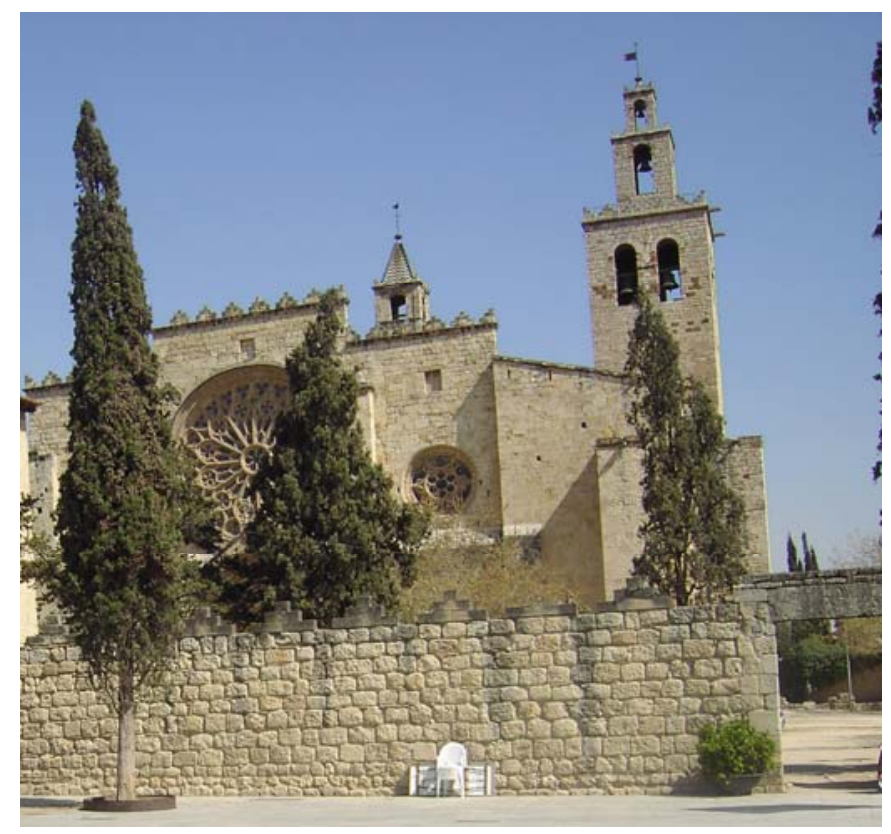

Ilustración 16

Monasterio de San Cugat.

Foto Elena Micó.

La prensa barcelonesa anunció, antes que la valenciana, la desaparición de

Amancio Amorós y recordó cariñosamente su figura con estas palabras:

En Sant Cugat del Vallés ha fallecido D. Amancio Amorós Sirvent, ex director del Conservatorio de Música y Declamación de Valencia. Persona dotada de no común cultura, con un don de gentes que le captaba enseguida la simpatía de cuantos le trataban, deja, al morir, un recuerdo imborrable en sus amigos y conocidos.

A la familia doliente, y en especial a su hijo D. José Vicente Amorós, docto catedrático de esta Universidad, expresamos nuestro sentimiento por la desgracia que ha sufrido ${ }^{133}$.

Martínez Aloy, decano del Centro de Cultura de Valencia, comunicó a la Junta de esta institución el fallecimiento de su "director de Arte D. Amancio Amorós" a quien dedicó sentidas palabras:

${ }^{133}$ La Vanguardia, 10- II-1925, p. 10. 
Al ilustre compañero e insigne compositor quien deja un gran número de composiciones musicales, su Teoría del Solfeo y una labor de cultura en la Dirección del Conservatorio de Música y Declamación de esta ciudad, cargo que honró por su talento y laboriosidad ${ }^{134}$.

Diversas instituciones valenciana celebraron actos religiosos en memoria de Amancio Amorós (Ilustración 17). Por ejemplo, hubo misas en su memoria en el Real Colegio de Corpus Christi el 18 de febrero de 1925 y la Asociación de Profesores Músicos de Santa Cecilia de Valencia organizó una misa funeral el 26 del mismo mes ${ }^{135}$.

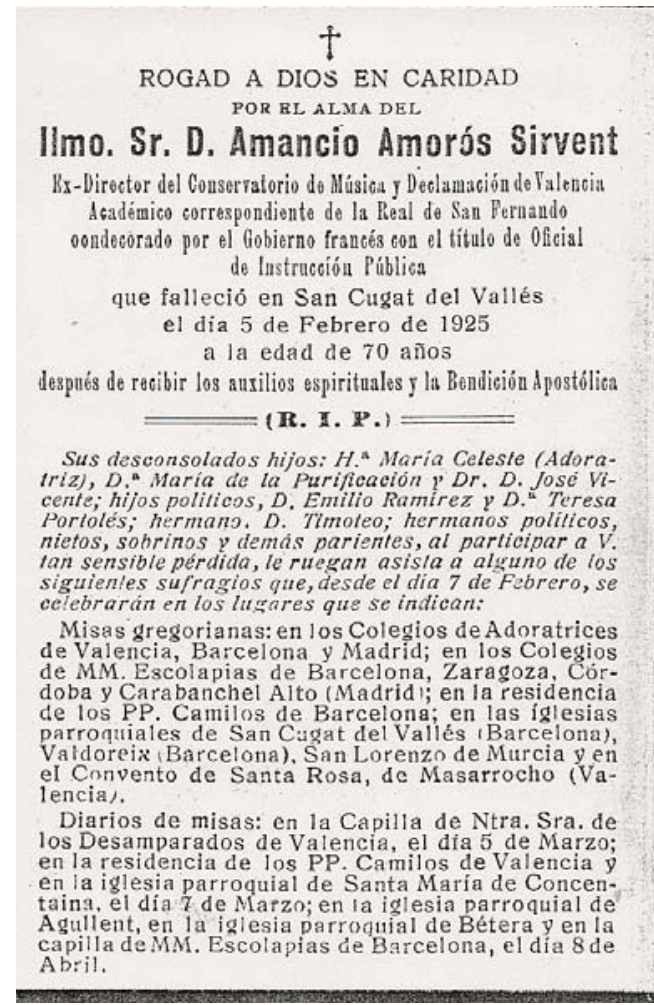

Ilustración 17

Esquela de Amancio Amorós, 1925.

Archivo familiar de Margarita Amorós Portolés.

${ }^{134}$ E:Vaac, Acta de la sesión de la Junta del Centro de Cultura Valenciana, 12-II-1925. La Junta del Centro de Cultura Valenciana acordó constase en acta "el sentimiento de la institución por la pérdida de tan ilustre compañero y telefonear estos acuerdos a su hijo Sr. Amorós, Catedrático de Arqueología en la Universidad de Barcelona y director correspondiente del Centro de Cultura Valenciana”.

${ }^{135}$ El Mercantil Valenciano, 17-II-1925; Loras, La Asociación, p. 29. 
${ }^{137}$ Sobrino, "Amorós Sirvent, Amancio", p. 420.

${ }^{138}$ Leopoldo Querol, que estudió en el Conservatorio de música de Valencia y Filosofía y Letras en la Universidad de Valencia mostró preferencia por la investigación musical. En 1927 leyó su tesis doctoral sobre el Cancionero de Uppsala. Compaginó su actividad como concertista de piano con la dedicación a la enseñanza desde su puesto como catedrático de francés en el Instituto Ramiro de Maeztu de Madrid desde 1930 hasta 1967. Uno de sus compositores preferidos fue Chopin, del que ejecutó toda su obra en diversos ciclos de conciertos por varias ciudades españolas y portuguesas. Ofreció además varias conferencias sobre compositores en la Real Academia de Bellas Artes de San Carlos. Véase Vicente Galbis, "Querol, Leopoldo", en DMEH, vol. 8 (2000), pp. 1035-1038; Bernardo Adam Ferrero, "Querol, Leopoldo", en 1000 Músicos Valencianos, pp. 662-663.

139 Ciego al poco tiempo de nacer, Cuesta se educó en el Instituto Nacional de Ciegos y en el Conservatorio de Valencia. En esta última institución, en la que estuvo entre 1902 y 1909, aprendió de Giner, Úbeda, Valls y Amorós, entre otros. Fue compañero de los pianistas José Iturbi y Leopoldo Querol, y conoció a través de ellos las novedades musicales procedentes de Europa. Sus primeras obras estaban influidas por la música de salón, la zarzuela y la música para banda. Más tarde, Su estilo evolucionó hacia un nacionalismo moderno. Partiendo en muchas ocasiones de los cantos populares, supo captar su esencia y crear obras muy personales. José Climent, "Cuesta, Francisco", en DMEH, vol. 4 (1999), p. 295.

${ }^{140}$ Izquierdo fue director y compositor valenciano. Estudió en el Conservatorio de Valencia violín, composición y piano. Posteriormente se trasladó a Madrid para ampliar sus estudios y fue violinista en diversas orquestas españolas. Dirigió entre 1924 y 1951 la Orquesta Sinfónica de Valencia y otras agrupaciones como la Orquesta Municipal de Valencia, la Coral Polifónica Valentina, la orquesta de Radio Valencia, la Orquesta del Conservatorio de Valencia y la Banda La Artesana de Catarroja. Compartió su actividad concertística con la pedagógica en el Conservatorio de Valencia. Como compositor merecen reseñarse sus zarzuelas, enmarcadas dentro de la música regionalista valenciana. Vicente Galbis López, “Izquierdo Romeu, José Manuel”, en DMEH, vol. 6 (2000), pp. 515-517.

${ }^{141}$ El compositor y organista José Ma Alcácer estudió en el Conservatorio de Valencia piano con Juan Cortés y armonía con Amancio Amorós. A los quince años obtuvo por oposición la plaza de organista del Seminario Conciliar de Valencia. Compuso música sacra, litúrgica y paralitúrgica, incluyendo canciones religiosas para el culto, misas polifónicas, salmos recogidos en su gran obra El Salterio, motetes y canciones espirituales polifónicas, villancicos, música para órgano y música para autos sacramentales. 
nacional ensalzó la labor de Amancio Amorós como maestro de varias generaciones de músicos dentro de la escuela valenciana:

Valencia no da sólo pintores y escritores, produce también músicos, y a la extensa lista de músicos valencianos de mérito (descendientes de la escuela valenciana de los Ortells, Valls, Lorente), en la que sobresalen el venerable D. Amancio Amorós, maestro de varias generaciones de músicos (discípulo de Giner), Chavarri, Salvador Martí, el eminente Iturbi, Terán, Fuster, la célebre Bori, José Serrano, Lleó, hay que añadir el nombre ya ilustre, de Pepita Roca $[\ldots]^{142}$.

\section{La biblioteca personal de Amancio Amorós}

La biblioteca personal de Amorós, custodiada actualmente en la Biblioteca de Catalunya, fue entregada a esta institución en depósito, en 1930, por José Vicente Amorós Barra, hijo del compositor, junto con las obras musicales del mismo. Sin contar las composiciones manuscritas, la biblioteca de Amorós consta de 240 obras, entre las que se incluyen tratados didácticos, partituras de distintos géneros (propias y de otros autores), publicaciones periódicas del momento y actas de congresos (ver Gráfico 1).

Gráfico 1. Volúmenes de la Biblioteca personal de Amancio Amorós depositados en 1930 en la Biblioteca de Catalunya. En el gráfico no se incluyen las partituras manuscritas. Fuente: E:Bc, Libro de Registro $n^{\circ} 24$ (1930-31).

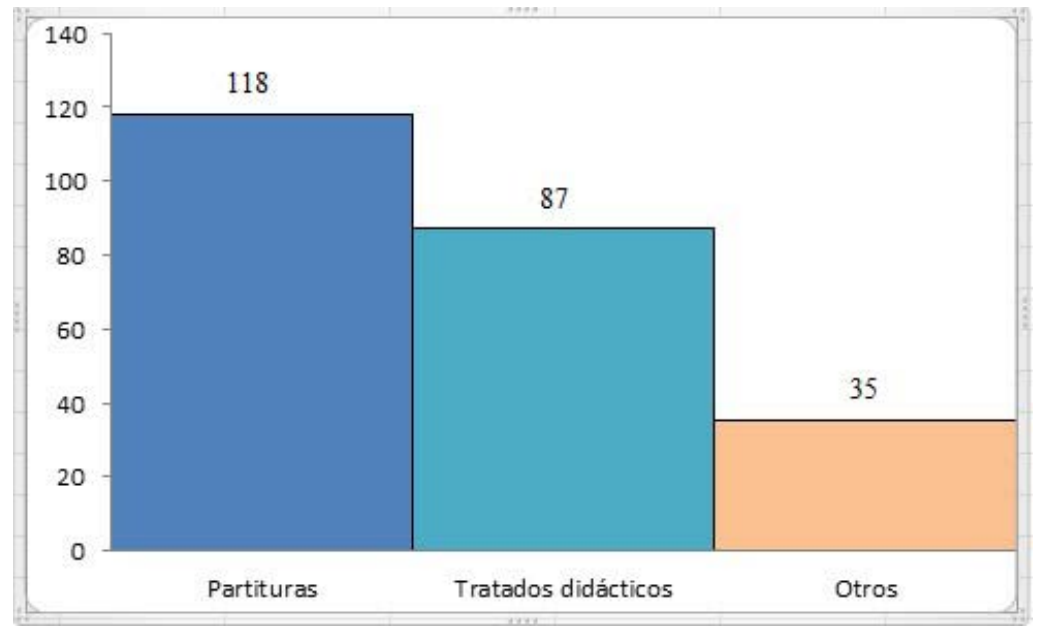

Jesús Ma Muneta, “Alcácer Martínez, José María”, en DMEH, vol. 1 (1999), p. 217; Andrés Temprano, "Panorama actual de la música religiosa en España. José Ma Alcácer”, Tesoro Sacro Musical, 43 (1972), pp. 42-47; Adam, “Alcácer Martínez, José María”, en 1000 Músicos Valencianos, pp. 96-97.

${ }^{142}$ El País, 19-II-1916. Consulta online 10-V-2010 desde la www. hemerotecadigital.bne.es. 
La colección probablemente no contiene lo que fue la biblioteca completa del autor, pero resulta interesante para conocer las preferencias y gustos estéticos de Amancio Amorós. El grupo de obras didácticas incluye tratados de armonía, contrapunto, instrumentación, orquestación, composición, estética, métodos de solfeo y teoría musical y métodos para piano; entre las partituras las hay de música escénica, sinfónica, cámara, canto y piano, piano solo y música religiosa (véase Gráfico 2); un tercer grupo de obras está constituido por 35 volúmenes con discursos, conferencias, actas de congresos, ensayos, estudios críticos y algunas publicaciones periódicas del momento (Revista Musical Hispano-Americana de 1914-1917, Hispaniae Schola Musica Sacra, vol. 1, entre otras). El inventario completo de esta biblioteca puede verse en el Apéndice 1.

Entre los métodos para piano de la Biblioteca Amorós aparecen dos de su profesor de piano, Roberto Segura: El método elemental de piano y Agilidad e independencia de los dedos ${ }^{143}$, pero ningún otro de autores españoles. Sorprende que no haya más tratados de piano cuando Amorós era pianista y a partir de la segunda década del siglo XIX se publicaron en España varios métodos dedicados al estudio de este instrumento ${ }^{144}$. El Curso elemental de piano del propio Amorós tampoco se encuentra en su legado, lo que confirma que la colección no contiene todo lo que el compositor llegó a tener; este método elemental de piano no llegó a publicarse, como se indica en el informe de

\footnotetext{
${ }^{143}$ Segura dividió su Método elemental de piano en dos partes; el claustro de profesores del conservatorio valenciano lo adoptó como texto oficial y aprobó la aplicación de las dos partes para primero y segundo cursos. Agilidad e independencia de los dedos se incorporó como obra de texto para cuarto curso de piano en el Conservatorio valenciano en la década de los noventa del siglo XIX. Véase Fontestad, El Conservatorio de Música, pp. 402, 417.

${ }^{144}$ Vega, "Métodos españoles", p. 132; véase también Ana María Vega Toscano, "La escuela española de piano en el siglo XIX: Métodos, estudios y otros ejemplos de literatura pedagógica", Música Iberoamericana de salón, Actas del Congreso Iberoamericano de Musicología, coord. José Peñín (Caracas: Fundación Vicente Emilio Sojo, 2000), vol 1, pp. 93-130.
} 
presentación de Amorós como Académico correspondiente de la Real Academia de Bellas Artes de San Fernando ${ }^{145}$.

Gráfico 2. Partituras musicales de la Biblioteca de Amancio Amorós depositadas en la Biblioteca de Catalunya.

Fuente: E:Bc, Libro de Registro $n^{\circ} 24$ (1930-31).

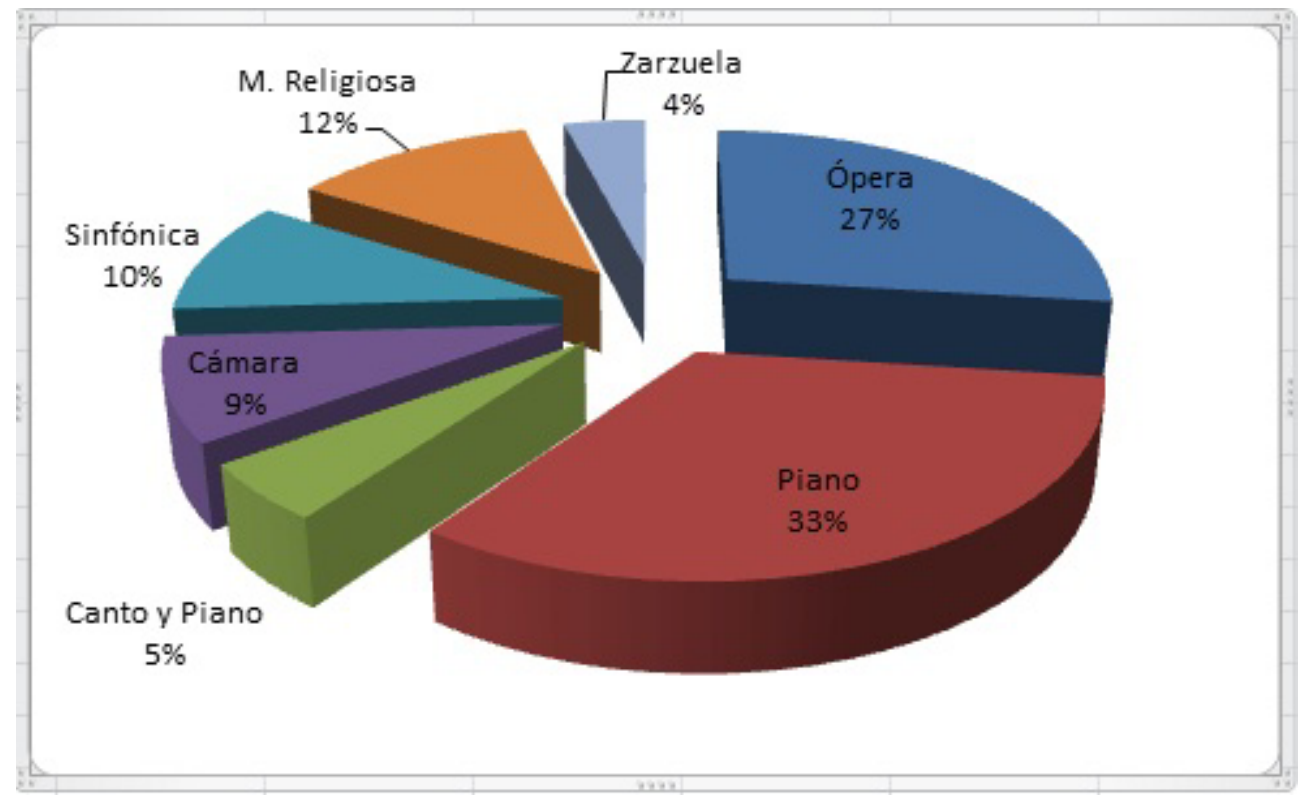

Entre las partituras del legado Amorós, los géneros musicales más representados son el pianístico y el operístico. Hay obras de pianistas ya consagrados (en particular Chopin) y dos álbumes para piano ya mencionados anteriormente, el Álbum Musical y el Álbum pianístico, en los que abundan las transcripciones para piano de temas de zarzuelas de los autores más conocidos de la segunda mitad del siglo XIX.

La práctica totalidad de óperas conservadas en la biblioteca de Amorós son del romanticismo, destacando autores como Meyerbeer y Wagner, aunque también están representados Gounod, Bellini, Donizetti, Rossini, Verdi, Puccini, Pacini y Pedrell (ver Gráfico 3).

145 E:Mba, legajo 5-2-2, Expediente de nombramiento de Amancio Amorós como Académico Correspondiente (1921). 


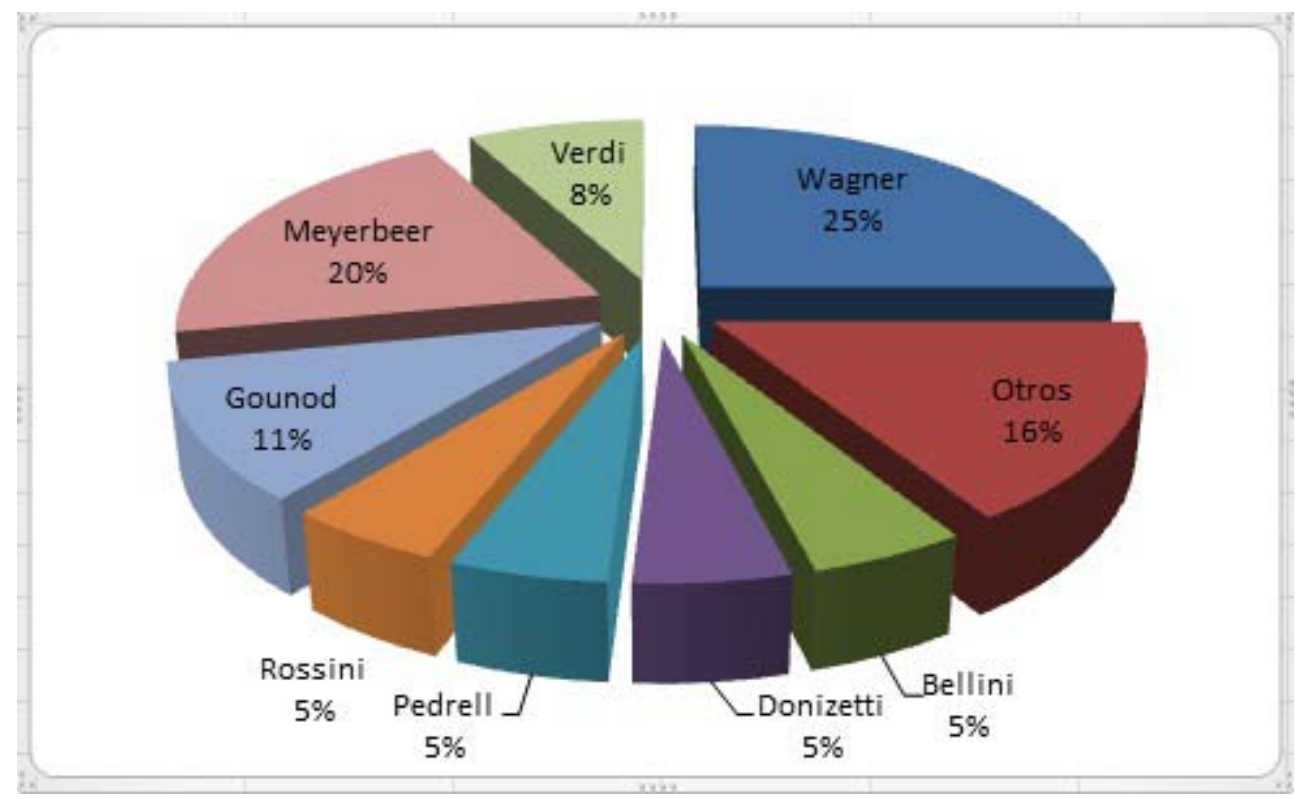

La gran cantidad de óperas de Wagner que Amorós poseía (un total de 9) así como los libros de Ricardo Benavent La obra de Wagner y de Joaquín Marsillach, Ricardo Wagner. Ensayo biográfico-crítico, que estaban en su biblioteca, sugieren que el compositor tenía una especial inclinación por Wagner. De hecho, la zarzuela Los dos esclavos de Amorós fue criticada por el excesivo uso de detalles armónicos y de instrumentación que impedían percibir claramente la melodía, lo que quizás refleja una cierta plasmación de la influencia wagneriana en la música de Amorós.

Sólo dos zarzuelas aparecen en la colección: Los Sobrinos del Capitán Grant y Los dos esclavos, del propio Amorós ${ }^{146}$. El legado Amorós incluye también obras orquestales, como las oberturas y las nueve sinfonías de Beethoven, un concierto de Chopin, sinfonías de Mendelsshon y sinfonías de Meyerbeer y la obra coral de [Emilio]

\footnotetext{
${ }^{146}$ La zarzuela Los Sobrinos del Capitán Grant era la que estaba en cartel en el Teatro Ruzafa de Valencia hasta que Amorós estrenó el 8-I-1886 su zarzuela Los dos esclavos.
} 
Ramírez Cuadros Murcianos, pero no obras sinfónicas de autores valencianos ${ }^{147}$. En lo que respecta al género camerístico, no está representado ningún autor español, aunque en la colección hay varios cuartetos de Mozart y Beethoven, un septeto de Beethoven, y obras de Grieg, además de piezas de Debussy y Ravel.

En el legado Amorós hay obras para canto y piano de Salvador Giner, Manuel Chulvi, Tosti, Ramón Martínez y Jimeno, y composiciones religiosas de autores renacentistas (Palestrina) y románticos (Gounod, Tebaldini, Perosi y Varinette).

147 Encabo, "Los Cuadros Murcianos", pp. 122, 124, destaca de Emilio Ramírez su faceta como investigador y recopilador de cantos populares de la Región de Murcia. La obra Cuadros Murcianos estrenada el 27 de noviembre de 1946 en el Teatro Romea de Murcia está dividida en tres cuadros: "La Romería de la Fuensanta", "Nocturno Huertano" y "La Parranda". 

CAPÍTULO 3

ACTIVIDAD DOCENTE DE AMANCIO AMORÓS 



\section{Centros valencianos en los que trabajó Amorós}

Una parte importante de la actividad musical de Amorós se centró en la docencia.

En Valencia Amorós fue el primer profesor de Piano y Solfeo en la Institución para la Enseñanza de la Mujer (1888-1901), maestro de capilla del convento de las Adoratrices (al menos entre 1887 y 1899), director y fundador de la Academia Musical Amorós (1890-1893), profesor del Colegio-Seminario Andresiano de las Escuelas Pías (1906), y figura clave en el Conservatorio de Música de Valencia (1881-1924), donde ejerció como sustituto de piano entre 1881 y 1884, profesor honorario de Solfeo y Armonía desde 1893, profesor numerario por oposición desde 1902 y Director desde 1919 (véase Ilustración 18).

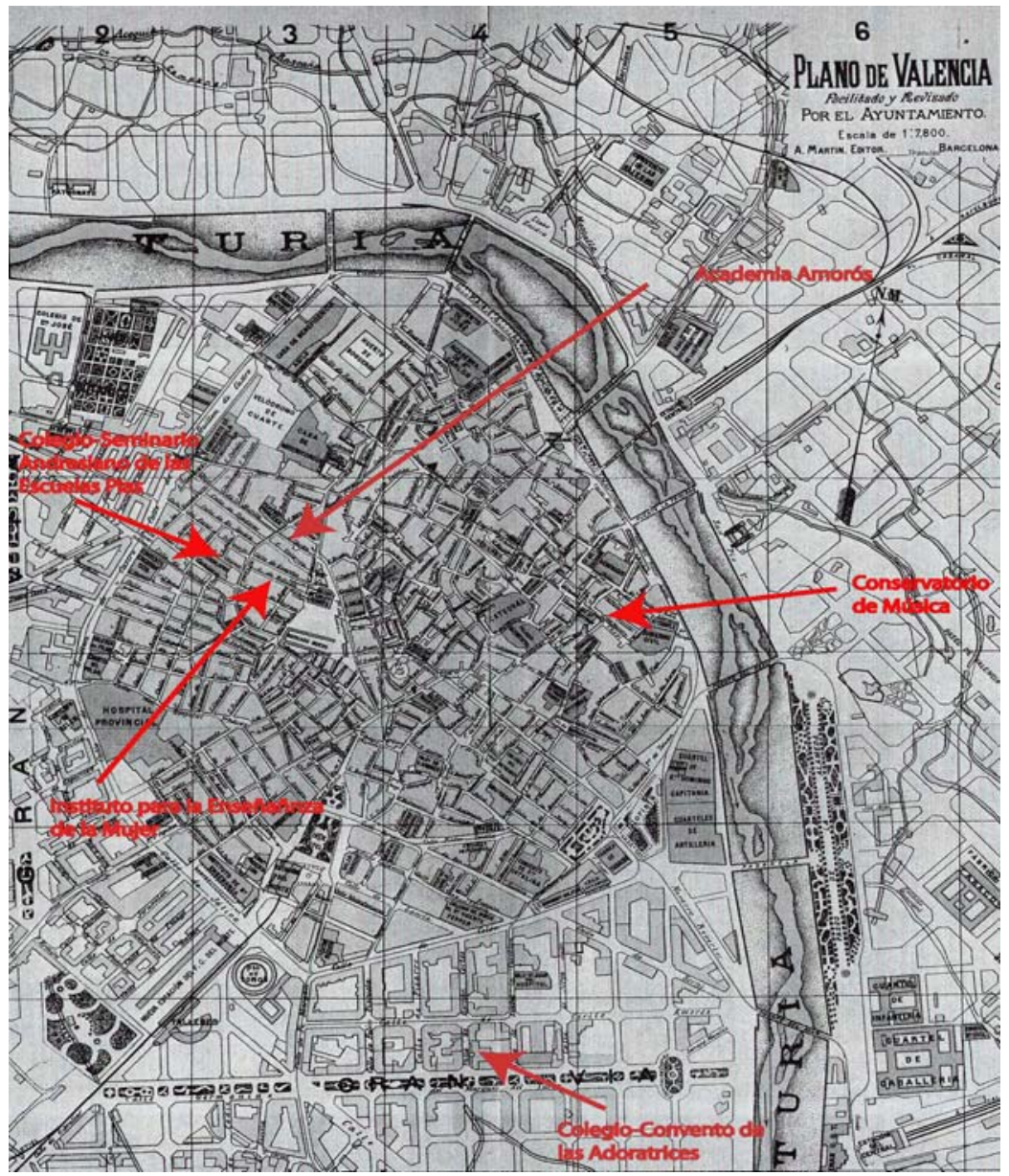

Ilustración 18

Plano de situación de los centros en los que Amorós fue profesor (1881-1925). 


\section{1. Institución para la Enseñanza de la Mujer de Valencia (1888-1901)}

Siguiendo el ejemplo de la Institución Libre de Enseñanza, importante institución radicada en Madrid y fundada en 1876 por Giner de los Ríos, en Valencia surgió en 1888 el Instituto para la Enseñanza de la Mujer ${ }^{1}$. Este Instituto tuvo su origen en la antigua Escuela de Comercio para Señoras, fundada a su vez el 11 de junio de 1883 por la Real Sociedad Económica de Amigos del País de Valencia, cuyas clases comenzaron a impartirse el 23 de noviembre de $1884^{2}$. La Escuela de Comercio tuvo una favorable acogida en Valencia, por lo que en 1888 la Real Sociedad Económica de Amigos del País amplió sus enseñanzas y cambió su denominación, que pasó a ser Institución para la Enseñanza de la Mujer ${ }^{3}$. En ella se ofrecieron distintas opciones de formación para

\footnotetext{
${ }^{1}$ J. A. Blasco Carrascosa, El Krausime Valencià (València: Institució Alfons El Magnànim, 1982), pp. 39-42. Véase también J. A. Blasco Carrascosa, La Institución Libre de Enseñanza en Valencia: Eduardo Soler Pérez. Vida, Obra y pensamiento, Tesis Doctoral (Valencia: Universidad de Valencia, 1980). El Krausismo español fue la corriente ideológica que estuvo vigente en España entre 1854 y 1936. Fue introducido en España por algunos intelectuales de clase media y en especial por Julián Sanz del Río (1814-1869) que habían estudiado en universidades alemanas. Estaba basado en las teorías del filósofo alemán Friedrich Krause (1781-1832) y surgió por oposición al pensamiento intelectual tradicional del régimen conservador de la Restauración. Véase Leticia Sánchez de Andrés, "El pensamiento estético del Krausismo español”, Revista de Musicología, 28/2 (2005), pp. 961-976.
}

${ }^{2}$ E:VAseap, C. 255, III-Educación $\mathrm{n}^{\mathrm{o}} 8$, Folleto relativo al espìritu que anima y al funcionamiento de la Institución para la Enseñanza de la Mujer (1891); E:VAseap, C. 246, X-Contabilidad no 11, Libramiento de pago de ciertas cantidades en concepto de subvenciones para el Conservatorio de Música y Escuela de Comercio (1888); E:VAa, Sección III, Sub. G Instrucción Pública, Clase II (Enseñanza Superior) Subclase C, Escuelas Especiales (1850-1900), n 1, La Sociedad Económica de Amigos del País, solicita una subvención para establecer en esta capital una escuela de comercio para señoras (1883); $E$ : $V A a$, Sección III, Sub. G Instrucción Pública, Clase II (Enseñanza Superior), Subclase C, Escuelas Especiales (1850-1900), n n 1, La sociedad de Amigos del País solicita la subvención de 2000 pesetas en favor de la escuela de comercio para señoras (1886). El Instituto para la Enseñanza de la Mujer estuvo situada en la calle Juan Villarrasa $\mathrm{n}^{\mathrm{o}} 12,2^{\mathrm{a}}$ de Valencia. Anónimo, "Instituto para la Enseñanza de la Mujer", Almanaque de las Provincias para 1895, pp. 279-284. La creación de la Institución Libre de Enseñanza se enmarca en el espíritu regeneracionista de cambio de siglo, que consideró la educación en lugar destacado. Para Joaquín Costa (1846-1911) una de las medidas prioritarias para la renovación del país era renovar las instituciones docentes, según los dictados de la pedagogía moderna. Costa se apoyó en la Institución Libre de Enseñanza, que planteaba una profunda renovación pedagógica, en la que la música adquiría una nueva valoración (al menos teóricamente), como señaló Giner de los Ríos en el discurso de inauguración del curso 1880/81 de la Institución Libre de Enseñanza. Véase el discurso citado en José Luis Abellán, Historia del pensamiento español (Madrid: Espasa Calpe, 1996), pp. 431-432.

${ }^{3}$ E:VAseap, C. 258 , III-Educación $\mathrm{n}^{\mathrm{o}}$ 1, Documentación relativa a la constitución de la Institución de la Enseñanza de la Mujer y su Reglamento (1892). La documentación relativa a la constitución de la Institución de la Enseñanza de la Mujer afirma: "Se reorganiza la escuela de comercio para señoras fundada por la Sociedad para constituir la Institución para la Enseñanza de la Mujer, conservando el patronato bajo el cual se estableció”; Juan A. Oliver, La educación de la mujer en Valencia (Valencia: Manuel Pau, 1913), pp. 3-4; Blasco Carrascosa, El Krausime Valencià, p. 42. 
mujeres: Escuela de Institutrices, Escuela de Comercio, Escuela de Idiomas, Escuela Preparatoria, Escuela de Cultura General y Escuela de Bellas Artes. En las tres últimas se impartía música ${ }^{4}$. Amancio Amorós fue profesor de Piano, Solfeo y Canto en la Escuela de Bellas Artes entre 1888 y $1901^{5}$.

La Institución para la Enseñanza de la Mujer insistió en la importancia de los estudios musicales, que podían llegar a convertirse en una profesión para la mujer, una de las pocas consentidas en esa época, y no sólo en un adorno como se había considerado tradicionalmente:

Rectificada la errónea opinión que consideraba como de mero adorno la cultura artística, no hay necesidad de insistir sobre la importancia que estos estudios ofrecen, ya como base de una honrosa profesión, ya como medio de educar y elevar el gusto y el sentimiento ${ }^{6}$.

El profesorado de este centro de enseñanza sólo recibía una pequeña compensación económica en muestra de agradecimiento. Juan A. Oliver, redactor del Reglamento de la Escuela de Comercio, y de la propuesta para nombrar profesores, insistió en la cualidad vocacional que habían de tener los docentes:

\footnotetext{
4 E:VAseap, C. 255, III-Educación $\mathrm{n}^{\circ} 8$, Folleto relativo al espíritu que anima y al funcionamiento de la Institución para la Enseñanza de la Mujer (1891). La Escuela Preparatoria preparaba a las alumnas que tuvieran que ingresar en las restantes escuelas y ampliar la instrucción primaria. Impartía asignaturas como religión o moral, lectura, escritura y ortografía, elementos de gramática castellana, nociones de aritmética, sistema métrico decimal y geometría, rudimentos de geografía e historia, nociones de higiene doméstica, principios de literatura, derecho usual, francés, dibujo y música. En la Escuela de Cultura General se incluían tres cursos de música. La Escuela de Bellas Artes estuvo dividida en las secciones de dibujo y música, y esta última incluía las enseñanzas de solfeo, piano y canto. La Escuela de Institutrices incluía, además de las asignaturas de la Escuela de Cultura General, pedagogía teórica y práctica y contabilidad y "su doble utilidad, no sólo proporciona un medio decoroso de vivir, que hoy no aprovechan más que señoritas extranjeras, sino que es de suma conveniencia para la vida familiar". La Escuela de Comercio, que había sido el origen de la institución, fue la más concurrida, después de la Escuela Preparatoria. La Escuela de Idiomas impartía francés, inglés, alemán, italiano, portugués, ruso, sueco y latín.
}

${ }^{5}$ Ilustración Musical Hispanoamericana, 30-XII-1888, p. 184; Anónimo, "Instituto para la Enseñanza de la Mujer", Almanaque de las Provincias para 1895, pp. 279-284; E:VAu, "Institución para la enseñanza de la mujer. Prospecto para el curso de 1900 a 1901”, Sección Enseñanza Media, caja 24, legajo 11.

6 El folleto informativo de esta Institución para el curso 1891-1892, se conserva en E:VAseap, C. 255, III-Educación $n^{\circ} 8$. 
He de confesar con toda sinceridad que lo que más me preocupó en dicho trabajo fue lo referente al profesorado; porque he creído siempre que para llenar éste su importantísima función, necesita unir a una devoción austera, una paciencia inquebrantable, un sincero amor a la juventud y a la patria, una profunda confianza y un verdadero desinterés. Y estas cualidades ni se adquieren con dinero ni por medio de exámenes u oposiciones ${ }^{7}$.

En la apertura del curso académico 1888-89 de la Escuela de Comercio, Amancio Amorós dirigió la parte musical:

El día 18 celebró solemne apertura de curso la Escuela de Comercio para señoras amenizando los intermedios de esta sesión un doble cuarteto de instrumentos de cuerda, piano y armónium, ejecutando distinguidos profesores selectas composiciones musicales [...]. Todo fue muy aplaudido, tanto por el mérito de las obras como por la esmerada interpretación que alcanzaron bajo la segura batuta del profesor de aquella escuela D. Amancio Amorós ${ }^{8}$.

El programa que se ofreció a todos los socios de la escuela incluyó la Serenata para quinteto de cuerda, piano y armónium, de Pedrell; L'ultimo addio, de Giner; la Canción de cuna, de Schumann; el Scherzo, de Plasencia y la serenata Non ti destare, de López Almagro, cantada por Eugenio Amorós, hermano de Amancio Amorós. Los intérpretes fueron Andrés Goñi, José Rodríguez, Vicente Peydró, Manuel Soriano, Luis Gallego, José Bellver y Juan Bautista Plasencia ${ }^{9}$.

En 1913 el Ayuntamiento de Valencia suprimió la subvención que venía otorgando a la Institución para la Enseñanza de la Mujer desde que ésta se había establecido. La Institución recurrió esta decisión ante el Gobernador Civil de la provincia y buscó el apoyo de casi todas las sociedades de Valencia y de personas independientes. Se presentó un escrito al Ayuntamiento de Valencia solicitando el restablecimiento de la subvención y éste, en sesión de 24 de febrero de 1913 acordó, en efecto, concederlo:

\footnotetext{
${ }^{7}$ Oliver, La educación de la mujer, pp. 17-18.

${ }^{8}$ Ilustración Musical Hispanoamericana, 30-XII-1888, p. 184.

${ }^{9}$ Las Provincias, 18-XI-1888.
} 
Se conceda a esa Institución para la Enseñanza de la Mujer, como auxilio y en compensación al servicio que presta admitiendo en ese Centro las alumnas que el Ayuntamiento le designa con matrícula gratuita, 4000 pesetas anuales, que deberán ser abonadas con cargo a capítulo de imprevistos, por no haberse tenido en cuenta esta atención al formar el presupuesto del corriente año ${ }^{10}$.

\section{2. Colegio-Convento de las Adoratrices (1887-1899)}

Amancio Amorós fue maestro director de la Capilla Musical en el Convento de las Adoratrices de Valencia al menos entre 1887 y $1899^{11}$. En 1845 Micaela Desmaisieres y López de Dicastillo, vizcondesa de Jorbalán (Madrid, 1809-Valencia, 1865) fundó en Madrid una casa de acogida para ayudar y reeducar a prostitutas; los buenos resultados obtenidos le llevaron a crear la Congregación de Adoratrices Esclavas del Santísimo Sacramento y de la Caridad, cuyas constituciones fueron aprobadas por el Arzobispo de Toledo en abril de $1858^{12}$. A partir de este momento los prelados de distintas diócesis solicitaron a la vizcondesa la fundación en sus diócesis de centros semejantes al de Madrid. La fundadora dejó ya instituidas las Casas-Colegios de Madrid, Zaragoza (1856), Valencia (1858), Barcelona (1861), Burgos (1863), Pinto, la filial de Madrid (1864) y Santander (1865) y falleció en Valencia en $1865^{13}$.

La Casa-Colegio de las Adoratrices de Valencia fue promovida por el sacerdote Juan María de Dios Montañés, quien propuso a la fundadora de la Congregación que instituyera el nuevo centro. Éste se situó en la casa-convento de San Gregorio, cedida por el Ayuntamiento de Valencia y fue inaugurado el 1 de noviembre de 1858 con una misa

\footnotetext{
${ }^{10}$ Oliver, La educación de la mujer, pp. 55- 69.

${ }^{11}$ Anónimo, “Una iglesia nueva y otra reformada”, pp. 272-273; Boletín Musical, 28-II-1899, p. 1430.

${ }^{12}$ En 1841, a la muerte de su madre, la vizcondesa decidió consagrar su vida a Dios y desde entonces fue conocida como madre Sacramento.

${ }^{13}$ Ignacio Vegas, Alma de oración y de apostolado. Santa María Micaela del Santísimo Sacramento (Madrid: Talleres Gráficos de Ediciones Castilla, S. A., 1965), pp. 13 y 35.
} 
cantada, procesión y un banquete al que se invitó al Ayuntamiento y otras autoridades (Ilustración 19) $)^{14}$.

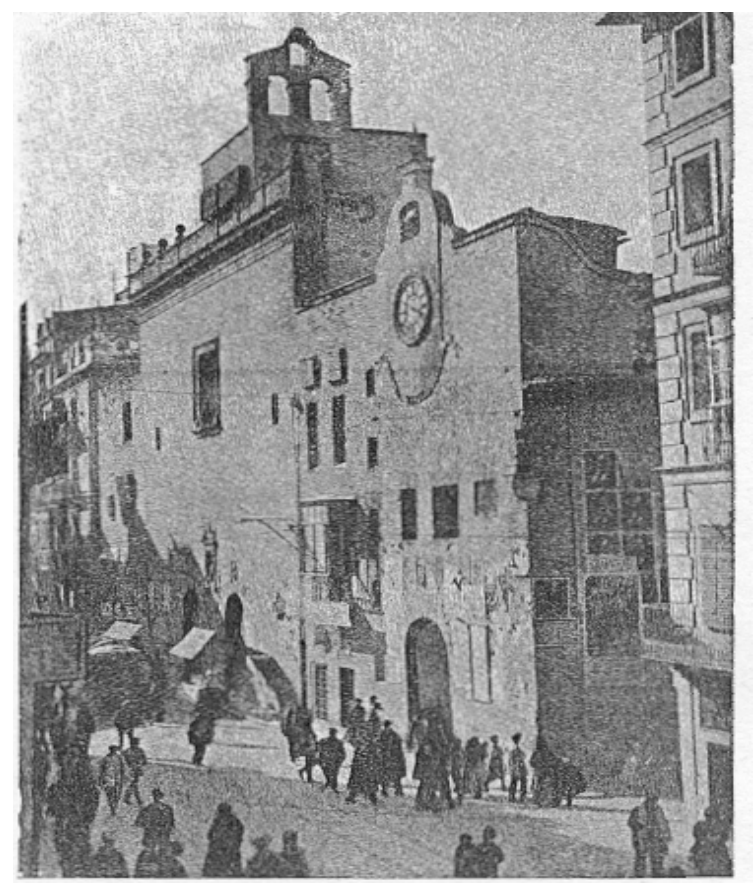

Ilustración 19

Casa de las Adoratrices y Convento de San Gregorio de Valencia, derribados en 1913. Martínez Aloy, Geografía General, p. 825.

Veinte años después, el reducido espacio del local y la falta de condiciones higiénicas, hizo que el valenciano Cirilo Amorós adquiriese un solar en la calle Hernán Cortés (esquina Gran Vía), donde se situó el nuevo convento-colegio que constaba de dos plantas y se levantó una iglesia neogótica, que fue bendecida el 13 de noviembre de 1887 (véase Ilustración 20). Amancio Amorós estrenó para la ocasión su Misa en mi menor para coro de voces blancas, armónium, piano y quinteto de cuerda:

\footnotetext{
${ }^{14}$ Boix, Manual del viajero, pp. 164-165. Anteriormente en esa casa el carmelita descalzo Francisco del Niño Jesús había comenzado a recoger jóvenes para formarlas, pero el desorden, la indisciplina y la falta de dirección llevaron su intento al fracaso, Vegas, Alma de oración y de apostolado, p. 90; Martínez Aloy, Geografia General, pp. 823-824. La superiora del nuevo centro valenciano fue la Hermana Corazón de Jesús y el Colegio se inauguró con 43 colegialas, Vegas, Alma de oración, pp. 89-91. La fundadora de la Adoratrices viajó a Valencia para ayudar a la congregación de la ciudad en la epidemia de cólera de 1865, y allí murió víctima de dicha enfermedad el 24 de agosto.
} 
Bendecido el nuevo templo según los ritos canónicos, celebróse la primera función el domingo 13 de noviembre, con asistencia del Exmo. Sr. Cardenal-Arzobispo, y de las autoridades superiores del orden civil y militar. Para asistir a ella, vino de Madrid la reverendísima madre superiora general de las Hermanas Adoratrices y otras monjas, entre ellas algunas de sus mejores cantoras, que tomaron parte en la nueva misa, compuesta por el maestro D. Amancio Amorós, y que se estrenó en esta solemnidad ${ }^{15}$.

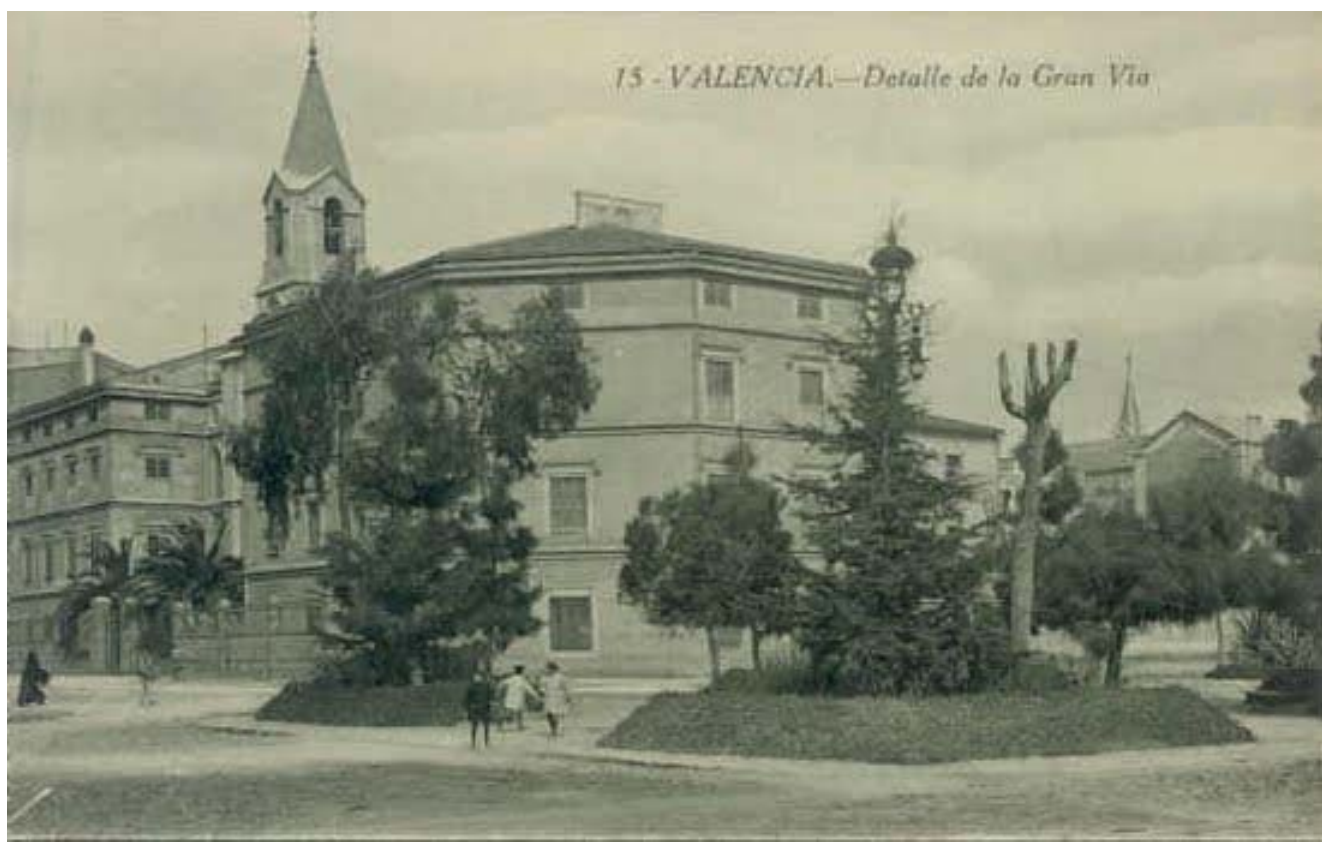

Ilustración 20

Convento de las Madres Adoratrices, postal de los años 20 (siglo XX) Valencia, Gran Vía Marqués del Turia, esquina Hernán Cortés.

En 1889, 1890 y 1891 las colegialas de las Adoratrices interpretaron Las Siete

Palabras, obra compuesta por varios músicos valencianos, al parecer por iniciativa de

Amancio Amorós, que además dirigió los conciertos (véase Tabla 22). La prensa recogió

elogiosamente la interpretación de la obra:

Las Siete Palabras cantadas este año [1889] en el Convento de las Adoratrices, han revestido una novedad que quisiéramos sirviera de estímulo a nuestros paisanos para alentarles en el difícil trabajo de la composición. El Sr. Amancio Amorós, iniciador del acontecimiento, merece los más sinceros elogios por haber realizado un pensamiento, que si bien para su logro han colaborado varios profesores, cábele la honra de llevar la mayor parte del trabajo, además de haber contribuido a la composición de la primera palabra, lugar ingrato que se ha

\footnotetext{
${ }^{15}$ Martínez Aloy, Geografía General, pp. 822-825; Anónimo, “Una iglesia nueva y otra reformada”, pp.
} $272-273$. 
reservado como persona excesivamente modesta que es [...]. Como decíamos, del iniciador, Sr. Amorós es la primera palabra Pater dimite illis. El piano lo tocaba el Sr. Bellver y el armónium el Sr. Fornet (hijo), dirigiendo a ambos y a las colegialas D. Amancio.

[...] Del maestro de capilla de la Basílica, D. Manuel Chulvi es la segunda palabra. Comienza con un inspiradísimo preludio de carácter marcadamente religioso, hecho a conciencia, revelando la clase de instrumento que más acertadamente cultiva su autor. Sigue un coro que preludia el tema, luego una tiple que después de algunos compases forma dúo con una mezzo-soprano, dúo que concierta luego con el coro que canta otra vez algunos compases del preludio.

El Sr. Chulvi no ha podido sustraerse a la influencia moderna de la música, y quizás sin advertirlo sigue la corriente. Hay momentos en el dúo que nos recuerdan compases de un celebrado racconto.

La tercera palabra Ecce filius tuus, es del joven D. Juan Plasencia. Hacemos constar la palabra joven, porque tenemos la seguridad de que las personas que hayan oído su última producción, más bien le creerán un hombre encanecido en los trabajos de la composición que no, como dejamos apuntado un joven.

El género empleado no puede ser más del día; pocos compases anteceden a un unisonal fugado que hábilmente maneja el Sr. Plasencia, termina este movimiento con un crescendo, que al llegar al centro disminuye progresivamente y es donde, en nuestro nuestro concepto, hay más inspiración. Sigue una parte comentada admirablemente, cerrando otra vez con el movimiento fugado del principio, que se repite dos veces antes de terminar.

La apología de esta composición está hecha en pocas palabras: es una pequeña joya de valor incalculable.

La cuarta y quinta palabra son del maestro don Manuel Soriano. La cuarta, compuesta este año, es delicadísima; parece una sola voz. Está escrita a conciencia del objeto a que se la destina, así que, más que una voz de mujer, Soriano ha concebido notas para un ángel. La quinta ya la conocíamos. La componen dos partes que se repiten durante la ejecución; una unisonal y otra de armoniosos acordes que alternan con la primera. Este último es más característicamente religioso. Ambos demuestran una inspiración y entendimiento nada vulgares.

Las dificultades de la sexta palabra, composición del Sr. D. José Fornet, demuestran la afición que tiene a lo difícil tan celebrado maestro.

A los cuatro o cinco compases se inicia un hermosísimo dúo siguiéndole el coro marcando las frases del Consumatum est, preludia luego el tema que recoge un dúo de tiple y mezzo-soprano que van desarrollando en toda su extensión, recogiendo los últimos compases otra vez el dúo, esta vez con algunos tiempos casi fugados, sumamente difíciles y que han sido vencidos con suma presición.

El Sr. Fornet en este número ha hecho gala de su talento y sus profundos conocimientos en la clásica música sagrada, pero con bastantes ribetes dramáticos y grandes tendencias hacia esta última, que si quisiera cultivar lo haría con abundante fruto.

La séptima palabra ha sido confiada al maestro D. Salvador Giner. Revela en esta composición su autor el gusto moderno, que indudablemente parece predominar hoy, o sea al fugado, que está repertido en este pezzo con suma discreción.

Recordamos un aire hermosísimo que finaliza los últimos compases, hábilmente concertados con el coro. Hay un movimiento combinado que imita la tempestad donde el coro está colocado con ajuste notabilísimo ${ }^{16}$.

\footnotetext{
${ }^{16}$ Ilustración Musical Hispanoamericana, 7-V-1889, p. 72.
} 
Tabla 22. Compositores de Las Siete Palabras, con texto de José Bau, interpretadas en el Convento de las Adoratrices de Valencia en 1889.

Fuente: Ilustración Musical Hispanoamericana, 7-V-1889, p. 72.

\begin{tabular}{|c|c|}
\hline Primera Palabra: Pater dimite illis & Amancio Amorós \\
\hline Segunda Palabra & Manuel Chulvi ${ }^{17}$ \\
\hline Tercera Palabra: Ecce filius tuus & Juan Plasencia $^{18}$ \\
\hline Cuarta Palabra & Manuel Soriano \\
\hline Quinta Palabra & Manuel Soriano \\
\hline Sexta Palabra & José Fornet $^{20}$ \\
\hline Séptima Palabra & Salvador Giner $^{21}$ \\
\hline
\end{tabular}

Los cronistas de la época elogiaron la buena factura de la primera palabra, compuesta por Amorós, y su enorme mérito por haber dirigido a las colegialas de las Adoratrices, que no sabían solfeo:

\footnotetext{
${ }^{17}$ Manuel Chulvi Jover (1848-1923), organista y compositor, se formó en el seminario conciliar de Valencia y recibió el presbiterado en 1873. Fue organista y profesor de canto del mismo seminario y organista de la parroquia de El Salvador de Valencia. En 1879 consiguió la plaza de organista de la Catedral de Valencia y desde 1889 regentó la plaza de maestro, vacante por la renuncia de Guzmán al ingresar en el monasterio de Montserrat. Chulvi ocupó este cargo hasta la toma de posesión del nuevo maestro Juan Bautista Pastor Pérez. Véase José Climent, "Chulvi Jover, Manuel", en DMEH, vol. 3 (1999), pp. 692-693.
}

18 Juan Bautista Plasencia Aznar (1862-1897), compositor y organista, estudió en el Conservatorio de Valencia. Obtuvo la plaza de organista de San Bartolomé y poco tiempo después, la del Real Colegio del Corpus Christi-Patriarca. Compuso obras religiosas y profanas. Véase $\mathrm{M}^{\mathrm{a}}$ Cruz López Carranza, "Plasencia Aznar, Juan Bautista", en DMEH, vol. 8 (2001), p. 857.

${ }^{19}$ Manuel Soriano (Valencia sf- México 1899), profesor del conservatorio de Valencia. Véase Adam, "Soriano, Manuel", p. 769.

${ }^{20}$ José Fornet Senís (1836-1915) fue compositor y organista, formado musicalmente en el colegio del Patriarca de Valencia. En este centro perfeccionó sus estudios de piano y órgano siendo alumno de Juan Bautista Plasencia. A partir de 1864 pasó a ser organista de la iglesia de San Nicolás de Valencia. En la faceta como instrumentista obtuvo gran fama como improvisador. Compaginó su actividad religiosa con su tarea como pianista de salón. Fue también uno de los profesores particulares más solicitado por la burguesía valenciana. La mayoría de la producción de Fornet que está localizada es de carácter religioso. Véase Vicente Galbis López, "Fornet Senís, José”, en DMEH, vol. 5 (1999), p. 223.

${ }^{21}$ Giner fue discípulo de Pascual Pérez Gascón. Fue un compositor de sólida formación técnica, tenía un gran dominio de la armonía y del contrapunto, facilidad melódica y hábil manejo de la orquestación. Merece destacarse su presencia activa en la vida musical valenciana de la época, dando consejos o enseñando o participando en la fundación de instituciones básicas para la música valenciana como la Banda Municipal o bien apoyando otras como el Conservatorio, la Sociedad Coral El Micalet o el Certamen de Bandas de Música del que fue jurado durante varios años. Giner ejerció una notable influencia debido a dos factores: la popularidad de sus obras y su magisterio directo en el conservatorio. Véase Vicente Galbis López, “Giner, Salvador”, en DMEH, vol. 1 (1999), pp. 642-647 y Bernardo Adam Ferrero, "Giner, Salvador”, en 1000 Músicos Valencianos, p. 384. 
Imposible es retener en la imaginación las diversas clases de música cantada, pues cada autor sigue su escuela especial; nuestro buen deseo sería poder decir en detalle, compás por compás, cuanto hemos escuchado. Esto nos es imposible y los maestros que han vertido sobre el pentagrama su inspiración, nos perdonarán las grandes omisiones que nos vemos precisados a hacer.

El trabajo del Sr. Amorós empieza por un coro de unisonales que cantan el tema, unisonales que empiezan luego otro tiempo, terminándolo con acordes de una factura armónica deliciosa. En otro tiempo entra una sola voz (tiple) que al terminar concierta con los unisonales, que como antes vuelven a cerrar con acordes. La última parte la forma la tiple que tiene un movimiento fugado con los coros, terminando la palabra con el tema cantado por todo el coro, como al principio.

El carácter general es altamente dramático, género que el Sr. Amorós cultiva con valimiento, como ya lo tiene revelado en admirables composiciones suyas. Lástima grande que el carácter de la composición presente sea tal, que por su índole no podamos escuchar de nuevo, hasta el año próximo. El Sr. Amorós debe escribir música, pero no exclusivamente para audiciones anuales, pues de este modo nos priva de poder saborear las bellezas que concibe y que con tanta facilidad derrama sobre la pauta.

[...] Convienen cuantos han tenido el placer de asistir a esta solemnidad, que pocas veces se escuchará función religiosa de la circunstancias de la de ayer y pásmense al saber que los coros que han interpretado las composiciones, desconocen totalmente la música. Es cierto, ni una sola nota saben y el bellísimo resultado obtenido se debe a las vigilias del iniciador del pensamiento, D. Amancio Amorós, que con una paciencia digna de los mejores elogios, ha conseguido un éxito más notable por el concepto de haber luchado con unos elementos que naturalmente eran refractarios al arte.

Y no es sólo que hayan cantado, es que además han modelado como verdaderas artistas y todo de memoria.

Las religiosas adoratrices contarán este día como uno de los más faustos desde que se inauguró la casa-iglesia de la calle Hernán Cortés ${ }^{22}$.

En 1890 y 1891 Amorós organizó de nuevo la interpretación de Las Siete Palabras en las Adoratrices, al parecer con el añadido de una pieza de Eduardo Ximénez $^{23}$. En la Ilustración 21 incluyo los autores de la música y texto de las Siete Palabras. Amorós fue de nuevo elogiado por su labor:

\footnotetext{
${ }^{22}$ Ilustración Musical Hispanoamericana, 7-V-1889, p. 72.

${ }^{23}$ Eduardo Ximénez Cos (1824-1900), discípulo de Pascual Pérez Gascón, con quien estudió piano y órgano, fue organista de la parroquia valenciana de Santo Tomás. Compuso obras religiosas y zarzuelas y fue un pionero de la investigación folclórica valenciana. Véase Galbis, La música escénica, pp. 410-411. La Ilustración Musical Hispanoamericana no hace referencia en años posteriores a la interpretación de la obra.
} 
Pertenece la celebrada música de esta composición a los distinguidos profesores Amorós, Chulvi, Plasencia, Jiménez, Soriano, Fornet y Giner, y la letra al profesor de Filosofía y Letras, Enrique Bau.

Ocupándose en la ejecución de esta composición musical escribíanos nuestro diligente e ilustrado corresponsal en Valencia:

La interpretación de esta hermosa composición estuvo a cargo del coro de monjas, acompañada a piano y armónium por los Sres. Bellver y Fayos.

Los que pudieron conseguir entrar en el templo, puesto que el acto se celebró a puerta cerrada, pasaron las tres horas que duró la función, como transportados a las celestes mansiones. Aquello no podía ser interpretado por las jóvenes reclusas que ignoran en qué espacio de la pauta se escribe una nota. La unidad del conjunto, el sonido de las voces, claro, redondo y natural en los pasajes unisonales, combinado en los armónicos cuando la composición se descompone en diferentes cuerdas y la parte a solo sostiene un motivo que flota como nave gallarda por aquel océano de luz, era conmovedor y deleitaba el espíritu que parecía elevarse por entre una atmósfera de sonidos misteriosos a las regiones más puras de lo desconocido.

La función terminó con una plegaria escrita por el señor Giner, cuyos dulces y doloridos acentos se destacaban por entre las ráfagas del huracán y el retumbo del trueno, que fueron simulados con mucha propiedad.

El Sr. Amorós puede estar orgulloso del gran partido que ha sacado de las jóvenes educandas, lo cual representa un trabajo ímprobo y largo, así como las religiosas del citado convento que cuentan con un profesor de tanta valía. Asimismo ha demostrado el Sr. Amorós estar animado de los mejores deseos en pro del profesorado a quienes ha confiado el encargo de escribir estas composiciones, que han sido correspondidas por aquellos, demostrando así el compañerismo que reina entre todos ${ }^{24}$.

${ }^{24}$ Ilustración Musical Hispanoamericana, 30-V-1890, pp. 270-271. 


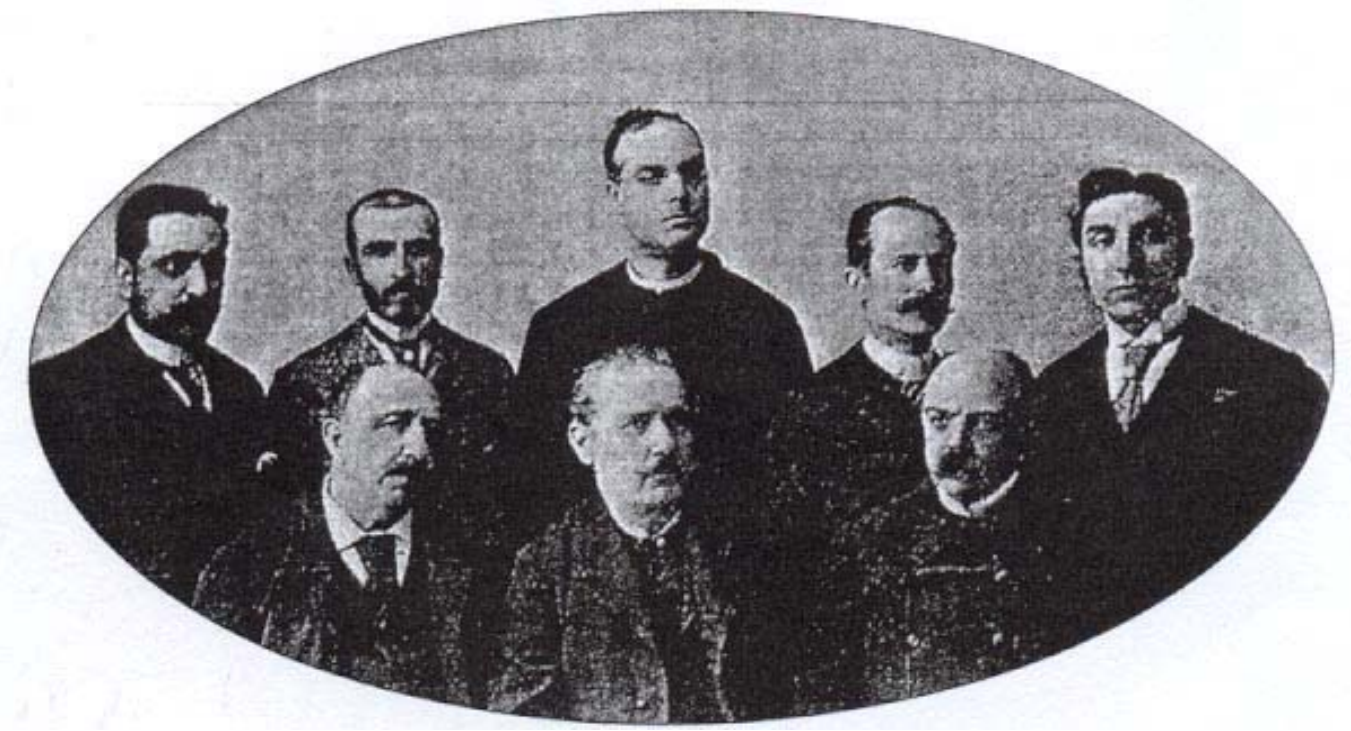

Ilustración 21

Autores de la música y texto de las Siete Palabras (1890). $\begin{array}{ccc}\text { Amancio Amorós } & \text { Enrique Bau } \\ \text { Eduardo Ximénez } & \begin{array}{c}\text { Manuel Chulvi } \\ \text { Salvador Giner }\end{array} & \begin{array}{c}\text { Manuel Soriano Juan Bautista Plasencia } \\ \text { José Fornet }\end{array}\end{array}$

Ilustración Musical Hispanoamericana, 57 (1890), pp. 270-271.

[1891]

La Semana Santa ha sido poco fecunda para el arte, habiéndose celebrado los oficios divinos sin que la música religiosa haya sido desempolvada de los archivos. Únicamente revistió gran solemnidad el acto de las Siete Palabras, celebrado en el Convento de Adoratrices. Bajo la acertada dirección del eximio profesor de aquel convento D. Amancio Amorós, cantáronse las obras de los Sres. Fornet, Soriano, Ximénez, Plasencia, Chulvi, Amorós y Giner, consiguiendo las jóvenes cantoras transportar al oyente con aquellas páginas de dolor, que pueden considerarse como los Siete Poemas de la Redención, a las celestes mansiones de lo desconocido. Aquel coro de ángeles cuyos acentos sublimes iban envueltos entre las ondas sonoras y que flotaban como suspiros misteriosos bajo las atrevidas arcadas del sagrado recinto, supo imprimir a todos los tiempos de las mencionadas obras el carácter propio de la festividad que recuerda al hombre el cruento sacrificio del Calvario ${ }^{25}$.

En la Capilla de las Adoratrices dirigió también Amorós obras sacras de Gounod,

Perossi, Bach, Beethoven, Saint-Saëns y de los españoles Pedrell, Ripollés, Chulvi,

${ }^{25}$ Ilustración Musical Hispanomericana, 31-IV-1891, p. 522. 


\section{Almagro y Plasencia ${ }^{26}$. Su papel como director de coro en esta institución fue elogiado con motivo del aniversario de la inauguración de la iglesia de la Congregación en 1892:}

En el colegio de las Adoratrices, con motivo de celebrar el aniversario de la inauguración de la iglesia, tuvo lugar una solemne fiesta religiosa, en la cual se ejecutó la gran misa Santa Cecilia de Gounod por el excelente coro de mujeres que de una manera magistral instruye el reputado profesor D. Amancio Amorós, acompañada a piano y armónium. Ha sido muy celebrado el éxito obtenido ${ }^{27}$.

\section{Para celebrar la Navidad en 1893, la Capilla de las Adoratrices de Valencia} interpretó una misa compuesta por De Diego para las Adoratrices de Bilbao. Amorós dirigió en esa ocasión a veintiséis coristas. La colorista orquestación incluía acompañamiento de piano y armónium, panderetas, castañuelas, triángulo y tambor:

El coro de educandas, que el distinguido e infatigable maestro D. Amancio Amorós instruye con sin igual aprovechamiento, ejecutó una misa pastoril que merece especial mención.

Pertenece esta obra a De Diego, natural de Bilbao, escrita expresamente para la casa de las Adoratrices de aquella capital vasca y estrenada el pasado año en Madrid con lisonjero éxito.

Dicha misa está reducida a voces, con acompañamiento de piano y armónium, panderetas, castañuelas, triángulo, tambor $\mathrm{e}$ imitaciones al ruiseñor, y el mejor elogio que de su mérito podemos hacer, es afirmar que en su género es de lo mejor y más nuevo que se ha escrito.

Su peculiar fisonomía, perfectamente apropiada a la jubilosa fiesta que conmemora, resulta característica y agradable, sin perder por ello el sabor profundamente religioso, compatible en un todo con la naturaleza de la obra.

En los Kiries, tras un preludio del piano y armónium, siguen las voces de solo con algún toque de coro imitando el rezo, en cuyo epílogo entra toda la masa coral, de sorprendente efecto. El Gloria es otra de las mejores partes que contiene la partitura, es de inspiración vigorosa y brillante, lo mismo que el Credo, a solo y masa coral. En el Sanctus, la entrada del Hosanna es de buen estilo y el Agnus bien trabajado, aunque algo monótono por la repetición del motivo, finalizando después del texto con todos los instrumentos pastoriles.

De la ejecución nada hemos de mencionar, que no sea para aplaudir el esmero y la precisión con que fue interpretada, tanto en su totalidad, como en los solos, dúos y tercetos, coreados por 26 coristas, cuyo estilo acusaba la dirección de su profesor, el maestro Amorós, cuya reputación artística no es en balde encomiada, el cual tomaba parte, además, pulsando el órgano de modo magistral ${ }^{28}$.

\footnotetext{
${ }^{26}$ Sobrino, “Amorós Sirvent, Amancio”, p. 420.

${ }^{27}$ Boletín Musical, 30-XI-1892, p. 32.

${ }^{28}$ Boletín Musical, 31-XII-1893, p. 474.
} 
En 1899, con motivo de la celebración de las Cuarenta Horas en las Adoratrices se interpretaron obras de Amancio Amorós y la prensa valenciana destacó el buen trabajo de Amancio Amorós y la magnífica interpretación del coro de voces blancas que cantaron con "exquisita afinación y ajuste"29.

\section{3. Academia Musical Amorós (1890-1893)}

Este centro docente, creado por Amancio Amorós en 1890, se anunció inicialmente en la prensa como "Academia preparatoria de profesores de solfeo y piano, maestros de coro, concertadores y compositores de ambos sexos" (Ilustración 22). La competencia profesional de Amancio Amorós fue expresamente reconocida en la prensa al comenzar la actividad de la Academia:

A primeros del mes próximo [diciembre 1890] se abrirá en esta ciudad una Academia preparatoria de profesores y profesoras de solfeo y piano, maestros de coros, concertadores, y compositores. La dirección correrá a cargo del distinguido profesor D. Amancio Amorós, cuya competencia en estos estudios es sobrada sabida para que nos detengamos en encomiarla. De las distintas clases que abrazará la nueva academia se encargarán reputados profesores ${ }^{30}$.

La Academia fue inaugurada el 1 de diciembre de 1890 y estuvo situada inicialmente en la calle de las Monjas, $17,2^{\circ}$, muy próxima al domicilio familiar de Amorós. En 1893 ya se denominaba Academia Musical Amorós, y su sede pasó a estar en la calle Juristas, $13,2^{\circ}$.

\footnotetext{
${ }^{29}$ Boletín Musical, 28-II-1899, p. 1430.

${ }^{30}$ El Mercantil Valenciano, 20-XI-1890.
} 


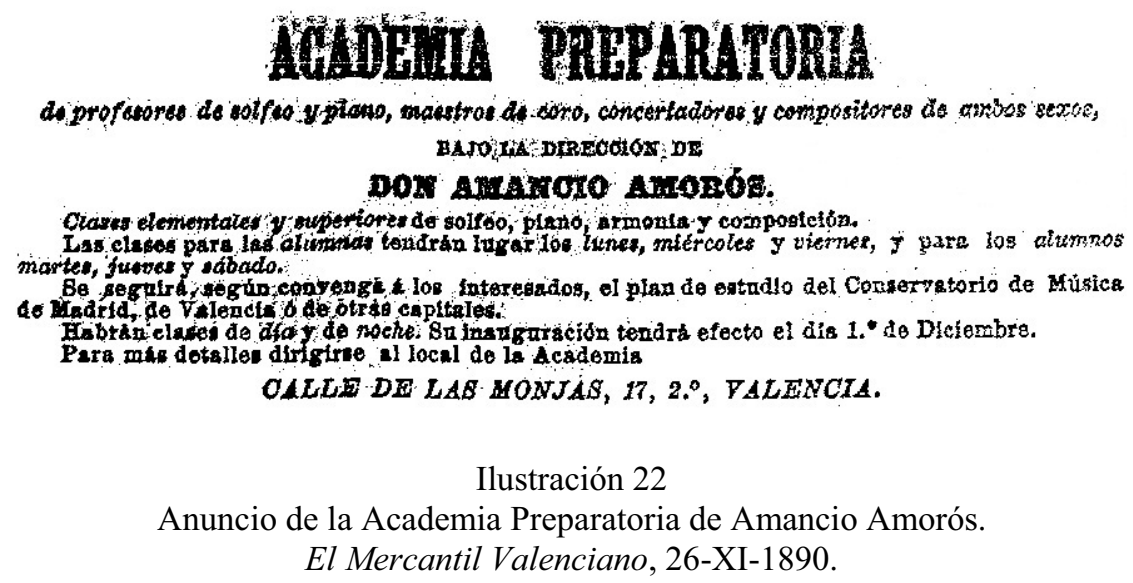

En el centro se impartían clases elementales y superiores de Solfeo, Piano, Armonía y Composición, aunque no he localizado quiénes eran los profesores. Las clases para las alumnas eran los lunes, miércoles y viernes, y para los alumnos, los martes, jueves y sábados. La Academia ofrecía clases diurnas o nocturnas y, según conviniese a los interesados, se adaptaba al plan de estudios de los Conservatorios de Música de Madrid, Valencia u otras capitales ${ }^{31}$. He documentado actividad en la Academia Amorós al menos hasta 1893, posiblemente su ingreso como profesor de Solfeo y Armonía en el Conservatorio de Valencia impediría que se pudiera ocupar de su academia privada ${ }^{32}$.

\section{4. Colegio-Seminario Andresiano de las Escuelas Pías de Valencia (1906)}

En 1763 el P. Benito Feliu fundó, con apoyo del arzobispo de Valencia Andrés Mayoral, el Seminario o Colegio Andresiano, con sede en el colegio de las Escuelas Pías de San Joaquín "para la buena educación de la nobleza española y de conocido nacimiento" y para instruir en piedad y letras a la juventud ${ }^{33}$. Aunque la sede

\footnotetext{
${ }^{31}$ El Mercantil Valenciano, 26-XI-1890.

${ }^{32}$ Las Provincias, 23-IX-1893.

33 Solemne Institución del Seminario o Colegio Andresiano, establecido por el Ilustrísimo y Reverendísimo Señor D. Andrés Mayoral, Arzobispo de Valencia en MDCCLXIII, bajo la dirección de los padres de la Escuela Pía, para la buena Educación de la Nobleza española y de conocido nacimiento (Valencia: Thomas Santos, 1763).
} 
arquitectónica era la misma para ambas instituciones, el Seminario Andresiano tenía sus propias Constituciones ${ }^{34}$. Andrés Mayoral levantó un amplio edificio, que incluía además una iglesia, y lo separó en dos secciones, según el nivel social de los alumnos. Destinó los pisos altos al internado o Seminario que llamó “Andresiano" y la planta baja a escuela pública de niños, conocida como "Escuelas de la Plaza", que eran escuelas gratuitas para alumnos de procedencia humilde y encargó la dirección de esta fundación a los Padres Escolapios $^{35}$.

El plan de estudios del Seminario se ajustaba al plan general vigente en los institutos de segunda enseñanza. Los seminaristas estudiaban latín y gramática castellana, historia, moral y religión, caligrafía y aritmética, matemáticas, dibujo lineal, geografía, lengua francesa y música. Justo Fuster y Roberto Segura, con quienes Amancio Amorós estudió, fueron profesores de piano de esta institución ${ }^{36}$.

Amancio Amorós fue profesor de música en el Seminario del Colegio Andresiano (centro donde todo parece indicar que él había estudiado), al menos en 1906. Es posible que accediese al centro en sustitución de Roberto Segura, que falleció en 1902. En 1906 Amorós dirigió la zarzuela El taumaturgo de Nápoles (con música de Roberto Segura y

34 Faubell, Diccionario Enciclopédico, pp. 836, 838, Vicente Faubell, "Renovación pedagógica e Ilustración en la España del siglo XVIII", en Anales de la Real Sociedad Económica de Amigos del País de Valencia (1997-98), pp. 234, 241.

${ }^{35}$ Los Escolapios crearon en 1738 el Colegio de las Escuelas Pías y desde 1763 dirigirán también el Colegio Andresiano donde se impartían estudios de primaria y secundaria. Mayoral creó también otro Establecimiento al que llamó "Casa Enseñanza” que destinó a la educación de las niñas. Éste tuvo la misma disposición que el de los niños. El segundo piso lo destino a "Colegio para educación y recogimiento de doncellas de distinguido nacimiento" y los pisos principal y bajo para la enseñanza gratuita de niñas pobres. Confió la dirección del centro a una superiora (Catalina Lucena) y la enseñanza a varias maestras que debían llevar una vida casi monástica. Vicente Calabuig y Carra, La Casa Enseñanza. Fundación del Arzobispo Mayoral (Valencia: Imprenta de Emilio Pascual, 1897), pp. 9-10; Àngels Martínez Bonafé, Ensenyament, burguesía i liberalisme (Valencia: Diputació Provincial, 1985), p. 15; Cándido Ruiz Rodrigo e Irene Palacio Lis, Pauperismo y educación, siglos XVIII y XIX: apuntes para una historia de la educación social en España (Valencia: Universitat de València, 1995), pp. 64-65; Vicente León Navarro, "Rafael Lasala y Lócela, Obispo auxiliar de Valencia. Su postura ante la extinción de los jesuitas", Revista de Historia Moderna, 17 (1998-1999), p. 362.

${ }^{36}$ Boix, Manual del viajero, pp. 184-185, 351. Ruiz de Lihory, La Música en Valencia, p. 264 y Saldoni, Diccionario biográfico, vol. 3 (1880), pp. 16-17. 
texto de José Félix ${ }^{37}$ ) y los juguetes cómicos Aprobados y Suspensos y El Ordenanza, que se representaron durante los días de carnaval en el salón de actos del Colegio Andresiano:

En el gran salón de actos que los Rdos. PP. Escolapios tienen en el Colegio Andresiano de esta ciudad, se improvisó un teatrito durante los días de Carnaval, en que los colegiales han representado con verdadera vis cómica, la bonita zarzuela, titulada El Taumaturgo de Nápoles, original del P. José Félix, con música del inolvidable maestro Segura y los juguetes cómicos Aprobados y Suspensos y El Ordenanza. En la parte escénica estuvieron los jóvenes actores a envidiable altura y la parte musical la desempeñaron con exquisito gusto y afinación.

Los números musicales fueron acompañados a piano $\mathrm{y}$ armónium, bajo la inteligente dirección del Sr. Amorós, profesor del citado Colegio ${ }^{38}$.

\section{5. Conservatorio de Valencia (1881-1924)}

Amorós fue profesor del Conservatorio de Música y Declamación de Valencia entre 1881 y 1924. Enseñó Piano, Solfeo, Armonía y Composición y ocupó en el centro los cargos de secretario de la Junta de Profesores ${ }^{39}$ (16-I-1903 /22-II-1907), Secretario de la Junta General (16-I-1903 y reelegido el 19-I-1905), Tesorero de la Junta Directiva (309-1910 / 27-12-1910), Director (1919-1924) y Presidente de la Junta Económica (1921$1924)^{40}$

\footnotetext{
${ }^{37}$ El taumaturgo de Nápoles, zarzuela en dos actos, con letra de José Félix y música de Roberto Segura, Valencia, Escuelas Pías, 1890, reducción para voz, piano y armonio. Roberto Segura se dedicó a la composición de obras escénicas, que el mismo autor denomina "juguetes líricos o zarzuelas infantiles", de ahí que estén dedicadas a un público infantil. El libretista que más asiduamente colaboró con Roberto Segura fue el padre José Félix (1850-1918), profesor de las Escuelas Pías. Véase Alemany, Metodología de la técnica, p. 238.

${ }^{38}$ Biblioteca Sacro Musical, 1-III-1906, p. 19. La zarzuela El Taumaturgo de Nápoles fue representada por los alumnos del Colegio Andresiano en 1900, bajo la dirección del profesor del centro Roberto Segura, en ocasión del homenaje que rindieron las Escuelas Pías de Valencia al Arzobispo de Florencia Alfonso $\mathrm{M}^{\mathrm{a}}$ Mistrangelo en su visita a la ciudad, Véase, Colegio de las Escuelas Pías, Reseña de la visita del Excelentísimo y Reverendísimo Alfonso $M^{a}$ Mistrangelo, Prepósito General de las Escuelas Pías, al Colegio Andresiano de Valencia: año 1900 (1901).

${ }^{39}$ E:VAcm, Actas del Claustro de profesores del Conservatorio de Música de Valencia, 16-1-1903, 22-II1907.

${ }^{40}$ E:VAcm, Acta del Claustro de profesores del Conservatorio de Música de Valencia, 15-II-1903; Acta de la Junta General del Conservatorio de Música de Valencia, 30-IX-1910, Acta de la Junta Económica del Conservatorio de Música de Valencia, 21-III-1921.
} 
A su llegada al Conservatorio Amorós fue profesor sustituto de piano entre 1881 y $1884^{41}$ y, al menos desde 1893 , fue profesor honorario de Solfeo y Armonía ${ }^{42}$. El ingreso de Amorós en 1881 como profesor de piano se produjo a propuesta del anterior profesor de piano José Valls, que se ausentó de Valencia en $1881^{43}$. Según Eduardo Serrano, corresponsal de La Ilustración Musical Hispanoamericana en Valencia, "su notable constancia en el cumplimiento de las obligaciones que contrae, hacen de Amorós un perfecto profesor de piano" 44 .

El 26 de junio de 1902 Amorós ganó por oposición la plaza vacante de profesor de Solfeo y Armonía ${ }^{45}$. Salvador Giner y José Ma Úbeda fijaron en marzo de 1902 las bases de la convocatoria para la provisión de plazas de Solfeo, Armonía y Violín. Para Armonía se exigía:

$1^{\circ}$ Presentar un programa razonado de los tres cursos en los que se divide la asignatura, por disposición reglamentaria.

$2^{\circ}$ Realizar a cuatro voces un bajete dado y poner acompañamiento de piano a una melodía. Todo ello en hora y media de tiempo.

\footnotetext{
${ }^{41}$ En el currículo que acompaña a su expediente como académico correspondiente de la Real Academia de Bellas Artes de San Fernando de Madrid se menciona que ejerció de profesor auxiliar de piano en el Conservatorio de Valencia durante cuatro cursos, E:Mba, "Académicos Correspondientes", legajo 5-2-1 (1921); Fontestad, El Conservatorio de Música, p. 801.

42 Boletín Musical, 9-X-1893, p. 431. Según el Reglamento del Conservatorio de Valencia de 1884, la Junta de Profesores la constituían profesores numerarios y profesores auxiliares. Además en la sección tercera del capítulo XI de este reglamento añade: "La Junta general podrá nombrar Profesor Honorario a cualquier persona que se distinga por los conocimientos en el arte de la Música en cualquiera de sus manifestaciones". Los profesores honorarios podían además presidir los exámenes de fin de curso. Véase Reglamento Orgánico del Conservatorio de Música de Valencia de 1884, pp. 11-16.

43 E:VAcm, Acta del Claustro de profesores del Conservatorio de Música de Valencia, 7-X-1881. Fontestad afirma erróneamente que Amorós fue profesor numerario de piano por oposición desde el 27-61902. Amorós fue profesor auxiliar de piano durante cuatro años pero nunca numerario de piano; las oposiciones convocadas en junio de 1902 fueron para cubrir una vacante de Solfeo y Armonía. E:Mba, “Académicos Correspondientes", legajo 5-2-2 (1921).

${ }^{44}$ Serrano, “Amancio Amorós”, p. 478.

${ }^{45}$ E:VAcm, Acta de la Junta Directiva del Conservatorio de Música de Valencia, 27-VI-1902.
} 
$3^{\circ}$ Explicar públicamente a un alumno, sobre un bajete puesto en la pizarra (el cual sólo contendrá elementos pertenecientes al primer curso) los acordes que la numeración determina, el movimiento de las voces en estos acordes, las posiciones que los acordes pueden tener y las cadencias, y explicar en las mismas condiciones sobre un bajete y melodía que contengan elementos pertenecientes al segundo y tercer curso, las modulaciones, el fraseo, las notas extrañas, a los acordes que deban regir, los retardos posibles, la nota pedal y ritmo de la frase armónica que deba acompañar a la frase melódica.

\section{Para Solfeo se pedía:}

$1^{\circ}$ Presentar un programa razonado de todas las materias que comprenda la asignatura de Solfeo, proponiendo aquellas mejoras que a juicio del opositor deban introducirse en la práctica de esta enseñanza.

$2^{\circ}$ Presentar tres programas parciales, uno para cada curso de los tres en que está dividida la enseñanza en este conservatorio. $\left(1^{\mathrm{o}}, 2^{\mathrm{o}} \text { y } 3^{\mathrm{o}}\right)^{46}$

$3^{\circ}$ Dar lección teórica y práctica a tres alumnos de cada curso

Además de Amorós, se presentaron a la plaza de Solfeo y Armonía otros dos opositores: Eugenio Úbeda y José Fayos. El tribunal, formado por Gonzalo Salvá (Presidente), Pedro Varvaró (Secretario) y los vocales José Ma Úbeda, Salvador Giner, Roberto Segura, José Valls, Manuel Coronado y Ramón Martínez, acordó por unanimidad proponer a Amancio Amorós para ocupar la plaza:

En la ciudad de Valencia, a los veintiséis días del mes de junio de 1902, reunidos los señores que componen el claustro de profesores al margen anotados y constituidos en Tribunal bajo la presidencia del que lo es del Conservatorio, D. Gonzalo Salvá, al objeto de juzgar los ejercicios de oposiciones a cátedra de profesor de Solfeo y Armonía vacante en esta Escuela, y cumplidos todos los requisitos que determinan los Estatutos de la misma para estos casos, por el señor presidente se anunció que daba principio el acto.

Llamado por el señor presidente se presentó D. Amancio Amorós, presentando dos programas de Solfeo, según las condiciones primera y segunda de la convocatoria. Acto seguido dio lección teórica y práctica a los tres alumnos de primera, segundo y tercer curso de solfeo, según la base tercera. A seguido [sic] fue llamado Eugenio Úbeda que igualmente que el anterior presentó el programa y el plan de estudios según las bases anteriormente citadas. Seguidamente dio lección a tres alumnos de solfeo, como dispone la base tercera. Por último se llamó a D. José Fayos, que asimismo entregó el programa y el plan de estudios dando igual que los anteriores, lección de solfeo a los tres alumnos de solfeo, primero, segundo y tercer curso.

${ }^{46}$ E:VAcm, Actas del Claustro de profesores del Conservatorio de Música de Valencia, 21-III-1902 y 20V-1902. 
Armonía:

Que llamado D. Amancio Amorós, que hizo entrega del programa a que se refiere la base primera. Acto seguido cumplieron el mismo requisito los opositores D. Eugenio Úbeda y D. José Fayos. Para llevarse a efecto la base segunda se les asignaron tres locales y transcurrido el tiempo marcado hicieron entrega de bajete y melodía. Después fue llamado D. Amancio Amorós que practicó los ejercicios de la base tercera en una hora y veinte minutos. Asimismo se llamó a D. Eugenio Úbeda que realizó el mismo ejercicio en una hora. Por último se presentó D. José Fayos que llevó a efecto el ejercicio mencionado en una hora y veinticinco minutos. Terminados los ejercicios con arreglo al programa, el tribunal se retiró para dar lectura al plan de estudios y abierta discusión sobre los mismos, así como de los ejercicios practicados. Y reuniendo todas las condiciones exigidas en la convocatoria, el tribunal por unanimidad acordó proponer a la Junta Directiva para desempeñar la plaza de profesor de Solfeo y Armonía vacante en esta Escuela a D. Amancio Amorós. Con lo cual dio terminado el acto, extendiéndose la presente acta que es firmada a continuación por todos los señores del tribunal de quien yo, el secretario del claustro certifico.

Conservatorio de Música de Valencia.

26 de junio de $1902^{47}$.

En 1904 Amancio Amorós propuso crear un $4^{\circ}$ curso de Armonía, no existente hasta entonces, que podrían simultanear con $1^{\circ}$ de Composición los alumnos que obtuviesen sobresaliente en $3^{\text {er }}$ curso de Armonía ${ }^{48}$.

En 1910 el Conservatorio valenciano convocó un concurso para proveer nuevas plazas de profesores numerarios ${ }^{49}$. Mientras éstas se cubrían, fueron designados como profesores interinos Juan Colom Sales en Declamación, Eduardo López-Chavarri Marco en Estética e Historia de la Música y Vicente Ripollés Pérez en Conjunto Vocal e Instrumental $^{50}$. La Junta Directiva del Conservatorio encargó a Ripollés impartir además la asignatura de Nociones de Armonía ${ }^{51}$, lo que dio lugar a que Amancio Amorós, el

\footnotetext{
${ }^{47}$ E:VAcm, Acta de la Junta Directiva del Conservatorio de Música de Valencia, 27-VI-1902.

${ }^{48}$ E:VAcm, Acta del Claustro de profesores del Conservatorio de Música de Valencia, 1-VI-1904.

49 E:VAcm, Acta de la Junta Directiva del Conservatorio de Música de Valencia, 26-IX-1910 y Acta del Claustro de profesores del Conservatorio de Música de Valencia, 25-IX-1910.

${ }^{50}$ E:VAcm, Acta de la Junta Directiva del Conservatorio de Música de Valencia, 15-X-1910.

${ }^{51}$ E:VAcm, Acta de la Junta Directiva del Conservatorio de Música de Valencia, 26-IX-1910 y Acta del Claustro de profesores del Conservatorio de Música de Valencia, 25-IX-1910.
} 
titular de la materia, presentara una reclamación ante la Junta Directiva del

Conservatorio, en la que decía:

Extrañeza me ha causado la noticia de haber sido nombrado profesor de Nociones de Armonía de este Conservatorio D. Vicente Ripollés, profesor de Conjunto e interino de Composición. [...] Protesto enérgicamente de tal nombramiento: $1^{\circ}$ Por pertenecerme de derecho dicha asignatura como profesor de número que soy de Armonía por oposición, ya que al crearse las Nociones de Armonía siempre se consideraron como una adición a la clase de Armonía. Esto lo demuestra el no haberse anunciado su provisión ni a oposición, ni al concurso; y $2^{\circ}$ Porque el Reglamento vigente del Conservatorio, en este caso concreto, no faculta, según mi leal saber y entender, a la Dirección para extender nombramiento alguno por sí y ante sí.

En este estado de cosas, me dirijo respetuosamente a Vd. para que se digne dar cuenta de lo anteriormente expuesto a la Junta Directiva, para que ésta, con su ilustrado criterio y estricta justicia, resuelva este enojoso asunto, tan deprimente para $\mathrm{mi}^{52}$.

Ramón Martínez (director del centro entre 1910 y 1919) alegó que Nociones de Armonía era una asignatura de nueva creación, y que el artículo 54 del Reglamento Orgánico del Conservatorio le facultaba para proveer profesores en aquellas plazas que no los tuvieran, pero delegó la resolución del caso en el claustro de profesores. Amorós retiró su reclamación en el claustro celebrado el 22 de octubre de 1910 para no entorpecer la marcha del centro ni crear dificultades ${ }^{53}$.

Desde octubre de 1906 Amorós se hizo cargo también de las clases de Composición del Conservatorio valenciano, en sustitución de Salvador Giner, que dimitió como director del centro y presentó su renuncia como profesor de composición por motivos de salud ${ }^{54}$. La Junta General no quería aceptar la renuncia de Giner, pero éste la mantuvo y en abril de 1908 obtuvo una licencia ilimitada, manteniendo todos los derechos y prerrogativas inherentes al cargo que había ocupado. Amorós rogó al nuevo

\footnotetext{
${ }^{52}$ E:VAcm, Acta de la Junta Directiva del Conservatorio de Música de Valencia, 20-X-1910.

${ }^{53}$ E:VAcm, Acta de la Junta Directiva del Conservatorio de Música de Valencia, 20-X-1910; E:VAcm, Acta de la Junta Profesores del Conservatorio de Música de Valencia, 22-X-1910.

${ }^{54}$ En este tiempo José Valls asumió la dirección del conservatorio valenciano. E:VAcm, Libro Actas de Exámenes Ordinarios y Extraordinarios 1908-1912, curso 1909-1910.
} 
director (José Valls), que insistiera siempre que hubiera ocasión para que Giner volviese a ocupar su cátedra de composición ${ }^{55}$, pero este músico ya no volvió a ocuparla y falleció en 1911. Amorós siguió como profesor de composición hasta el curso 1909-10 ${ }^{56}$ y formó parte de la comisión encargada de organizar un certamen nacional literario-musical para honrar la memoria de Salvador Giner tras su muerte. En este concurso se fomentaron estudios sobre Giner y nuevas composiciones, como consta en las bases de la convocatoria:

$1^{\circ}$ Estudio crítico del Maestro Giner como músico y como pedagogo: Música religiosa, música profana, método de enseñanza y resultado del mismo.

$2^{\circ}$ Biografía del Maestro Giner.

$3^{\circ}$ Composición de una Marcha para gran orquesta que contenga de 16 a 24 compases inspirada en los cantos populares. Como mérito en el estudio crítico se tendrá en cuenta el que reúna mayor imparcialidad en la crítica, mayor número de obras analizadas y a la vez sea el más técnico. En el segundo trabajo se considerará como de más mérito la biografía que aporte más datos y reúna mejores condiciones literarias. Por último, será preferente la Marcha que, además de las condiciones indicadas, reúna mayor sencillez melódicaarmónica y mayor majestuosidad. El autor además de la partitura general presentará la obra reducida para quinteto de cuerda, piano y armónium $^{57}$.

En 1916 Amorós presentó un nuevo plan de estudios para la asignatura de Armonía (véase Apéndice 16$)^{58}$.

Acceso de Amorós a la dirección del Conservatorio (1919)

Amancio Amorós fue director del Conservatorio de Valencia desde septiembre de 1919 hasta febrero de $1924^{59}$. Accedió al cargo tras la dimisión de Ramón Martínez, que

\footnotetext{
${ }^{55}$ E:VAcm, Acta de la Junta General del Conservatorio de Música de Valencia, 8-IV-1908.

${ }^{56}$ E:VAcm, Actas de la Junta Directiva del Conservatorio de Música de Valencia, 16-X-1906, 13-X1907, 17-X-1907, 29-III-1908, 2-V-1907, 29-III-1908; E:VAcm, Actas de la Junta General del Conservatorio de Música de Valencia, 24-II-1907, 3-III-1907, 4-IV-1908.

${ }^{57}$ E:VAcm, Actas del Claustro de profesores del Conservatorio de Música de Valencia, 12-XI-1911, 3XII-1912 y 7-I-1912.

58 E:VAcm, Acta de la Junta de Gobierno del Conservatorio de Música de Valencia, 29-X-1916.
} 
había sido director desde 1910 y había conseguido numerosos contactos con personas influyentes $^{60}$. En agosto de 1919, Ramón Martínez convocó a la Junta de Profesores por "un asunto grave de orden interior" $"$. Durante mucho tiempo el alquiler del local que ocupaba el Conservatorio no se había pagado y Pedro Gómez, el propietario de la casa que ocupaba el centro, iba a proceder al desahucio aunque se pagase la cantidad contratada. El claustro de profesores consideró que la gestión económica de Ramón Martínez no había sido transparente y denunció varias irregularidades: desde 1917 Martínez no había convocado a la Junta Económica para presentar balance de gastos e ingresos, creó a espaldas de sus compañeros el cargo de "escribiente" (secretaria) que el Reglamento vigente no contemplaba y dejó de ingresar el dinero procedente de la expedición de títulos. La desconfianza de los profesores hacia su director era patente, como recoge el Acta del 23 de agosto de 1919: Valencia:
Los infraescritos profesores del Conservatorio de Música de Considerando el tremendo fracaso económico de la Dirección, causa única de la situación angustiosa creada a la institución Conservatorio que hoy se ve arrojada de su casa social por débitos al propietario de la finca.
Considerando que ingresaron a su tiempo cantidades suficientes para el pago de esos débitos.
Considerando que a esas cantidades se les dio destino no dispuesto por el Claustro como es la creación clandestina de una plaza de escribiente que no existe ni en el antiguo ni en el nuevo Reglamento restando así a caja del centro la cantidad de 1000 pesetas, que la dirección a espaldas del Claustro, señaló a la favorecida con aquel destino.
Considerando que en el curso anterior según confesión propia ante la Junta, el director dejó de ingresar 750 pesetas de expedición de títulos. Considerando que ha dos años no se ha presentado la liquidación de ingresos y gastos, no constituyéndose en tiempo oportuno la Junta Económica que manda el nuevo Reglamento.
Proponen al Claustro:

59 E:VAcm, Acta del Claustro de profesores del Conservatorio de Música de Valencia, 17-IX-1919, E:VAcm, Acta del Claustro de profesores del Conservatorio de Música de Valencia, 12-XII-1924; LópezChavarri, Cien años de música, p. 134; Pena y Anglés, Diccionario de la Música, p. 65; López-Chavarri, Cien años de historia, p. 41; Adam, "Amorós Sirvent, Amancio", p. 28; Sobrino, "Amorós Sirvent, Amancio", p. 420.

${ }^{60}$ E:VAcm, Acta de la Junta de Gobierno del Conservatorio de Música de Valencia, 25-IX-1917.

${ }^{61}$ E:VAcm, Acta del Claustro de profesores del Conservatorio de Música de Valencia, 23-VIII-1919. 
Primero: Se retira en absoluto la confianza que se depositó en la Dirección.

Segundo: Se dispone que la Dirección ingrese en Caja 750 pesetas de los títulos del curso anterior y 600 pesetas de los de este curso.

Tercero: Ingreso en Caja por el Director, Secretario y Oficial de las cantidades cobradas en concepto de expedientes y de cuantos pertenezcan a la Junta Económica.

Cuarto: Que en un plazo de siete días, entreguen la Dirección y Secretaria las cantidades supradichas y las llaves de Secretaria a la Junta Económica, mas la cantidad cobrada ayer al Municipio consistente en mil quinientas veintisiete pesetas y cincuenta céntimos.

Quinto: Que se consideren en funciones los nuevos cargos desde el día 20 de julio pasado, tomando las cuentas de los dos años anteriores la Junta Económica ${ }^{62}$.

El mismo 23 de agosto de 1919 Ramón Martínez presentó su dimisión como Director del Conservatorio al Ministerio de Instrucción Pública y Bellas Artes y se comprometió a ingresar las cantidades adeudadas, aunque no a corto plazo ${ }^{63}$. El Director General de Bellas Artes, Mariano Benlliure, aceptó la dimisión de Martínez y encargó la dirección del centro (con carácter interino) al profesor más antiguo, que entonces era Amancio Amorós ${ }^{64}$. Amorós fue confirmado en su cargo de Director por Real Orden de 14 de octubre de 1920 con una gratificación anual de 1000 pesetas $^{65}$. La nueva Junta Directiva quedó constituida por Amancio Amorós (Director), Francisco Peñarroja (Vicedirector), Eduardo López-Chavarri (Secretario) y Juan Cortés (Cajero), quienes tomaron posesión de sus cargos el 21 de septiembre de $1920^{66}$ :

\footnotetext{
${ }^{62}$ E:VAcm, Acta del Claustro de profesores del Conservatorio de Música de Valencia, 23-VIII-1919.

${ }^{63}$ E:VAcm, Acta del Claustro de profesores del Conservatorio de Música de Valencia, 23-VIII-1919.

${ }^{64}$ E:VAcm, Acta del Claustro de profesores del Conservatorio de Música de Valencia, 17-IX-1919.

${ }^{65}$ E:VAcm, Tomas de posesión y ceses del profesorado del Conservatorio de Música y Declamación de Valencia, 1920-1960, p. 1; Real Orden de 14-X-1920 confirmando la plantilla que se indica del profesorado del Conservatorio de Música y Declamación de Valencia, Gaceta de Madrid, 16-X-1920, p. 238.

${ }^{66}$ E:VAcm, Acta del Claustro de profesores del Conservatorio de Música de Valencia, 21-IX-1920. La vacante de vocal que dejó Amorós en la Junta Económica fue ocupada por el profesor José Bellver, E:VAcm, Acta del Claustro de profesores del Conservatorio de Música de Valencia, 17-IX-1920.
} 
S. M. el Rey (q. D. g.) ha tenido a bien confirmar en los cargos de Director, Vicedirector, Secretario, y Cajero-Contador del expresado Centro a los señores D. Amancio Amorós Sirvent, D. Francisco Peñarroja Martínez, D. Eduardo López-Chavarri Marco, y D. Juan Cortés Cortés respectivamente, los cuales percibirán: el primero, 1000 pesetas anuales para gastos de representación; 500 el segundo por el mismos concepto, y asimismo 500 pesetas anuales de gratificación los dos últimos, con derecho al percibo de dichas cantidades desde el día 1 de Abril del año actual.

De Real Orden lo digo a V. I. para su conocimiento y efectos, Dios guarde a V. I. muchos años.

Madrid, 14 de Octubre de $1920^{67}$.

Principales logros de Amorós como director del centro (1919-1924)

a) Solución de los problemas económicos del centro

Una de las primeras actuaciones de Amorós como director fue buscar solución a los problemas económicos del centro y pagar el alquiler del local que éste ocupaba. El claustro gestionó con la Sociedad Unión Musical de Valencia, a través de su gerente Manuel Villar, un préstamo de 3000 pesetas sin plazos de devolución ni intereses de capital. Con esta cantidad y las 1364 pesetas que Martínez aportó al renunciar a su cargo de director, se pagaron las 4290 pesetas que se debían al dueño del edificio del Conservatorio, Pedro Gómez ${ }^{68}$. Además el claustro de profesores, con Amorós al frente, solicitó una revisión de libros y documentos del centro al Colegio Pericial Mercantil de Valencia $^{69}$. En el informe emitido por esta institución se subrayaron varias irregularidades, como raspaduras en los libros de cuentas del Conservatorio y sustitución de varias cantidades. Se consideró responsable al Oficial de Secretaría del Conservatorio, José Garrido, a quien se hizo comparecer en claustro de profesores. Garrido declaró que tanto las raspaduras como la sustitución de cifras las había efectuado por mandato del

\footnotetext{
${ }^{67}$ Real Orden de 14-X-1920 confirmando la plantilla que se indica del profesorado del Conservatorio de Música y Declamación de Valencia, Gaceta de Madrid, 16-X-1920, p. 238.

${ }^{68}$ E:VAcm, Acta del Claustro de profesores del Conservatorio de Música de Valencia, 17-IX-1919.

${ }^{69}$ E:VAcm, Acta del Claustro de profesores del Conservatorio de Música de Valencia, 23-X-1919.
} 
director, Ramón Martínez ${ }^{70}$. Días más tarde, Ramón Martínez admitió su responsabilidad, pero aún así, acusó a otros compañeros y afirmó:

Que se confesaba moralmente responsable de todas las irregularidades existentes como director entonces del Conservatorio y como tal admitía la responsabilidad de pagar las cantidades que resulten del Informe pero debía advertir a la Junta que existen otros responsables morales, como los señores secretarios que han actuado en este tiempo de manera especial el Sr. Fornet, que tuvo a su cargo la Tesorería y su autor material, que debe ser el Oficial de secretaría. Afirmó que de las cantidades a que alude el Informe, él no tenía ninguna ${ }^{71}$.

El profesor de piano Juan Cortés, durante el claustro, formuló varias preguntas a

Ramón Martínez, pero éste respondía con excusas y hacía recaer la responsabilidad en el Oficial de Secretaría, José Garrido, a quien también se hizo comparecer. La situación que se vivió en ese claustro fue muy desagradable. El profesorado protestó por las "palabras violentas" que Ramón Martínez y José Garrido utilizaron en su defensa y propuso que Ramón Martínez pagara de momento las cantidades correspondientes a derechos de exámenes y expedientes, y que una comisión investigadora, formada por Amancio Amorós, Francisco Peñarroja y Juan Cortés, revisara las cantidades restantes a pagar $^{72}$. Ramón Martínez pagó inicialmente 3746 pesetas $^{73}$. La comisión investigadora revisó las cuentas desde el 10 de octubre de 1910 hasta el 23 de agosto de 1919, y consiguió que Ramón Martínez se comprometiera a reintegrar otras 7635 pesetas, lo que hacía un total de 11381 pesetas a devolver ${ }^{74}$.

\footnotetext{
${ }^{70} \mathrm{El}$ informe menciona que faltaban dos cantidades de 8079'25 y 5213'01 pesetas.

${ }^{71}$ E:VAcm, Acta del Claustro de profesores del Conservatorio de Música de Valencia, 1-XI-1919.

${ }^{72}$ E:VAcm, Acta del Claustro de profesores del Conservatorio de Música de Valencia, 1-XI-1919.

${ }^{73}$ Esta cantidad respondía a las siguientes partidas: 1) Derechos de examen y expedientes: 2566; 2) Cantidad asignada por la dirección a la ayudante de secretaria Josefa Sanchis: 1166 pesetas; 3) Cantidad que falta en la cuenta del último libramiento del Ayuntamiento cobrado por Martínez: 14 pesetas. E:VAcm, Acta del Claustro de profesores del Conservatorio de Música de Valencia, 6-XI-1919.

${ }^{74}$ E:VAcm, Actas del Claustro de profesores del Conservatorio de Música de Valencia, 3-IV-1920, 9-IV1920. Martínez siempre defendió su inocencia y en sus declaraciones dejó claro que se hacía cargo de
} 
El 21 de marzo de 1921 quedó constituida la nueva Junta Económica del Conservatorio, integrada por Amancio Amorós Sirvent (Director), Juan Cortés Cortés (Contador), Benjamín Lapiedra, Lamberto Alonso (Vocales) y Eduardo López-Chavarri Marco (Secretario) ${ }^{75}$. Esta Comisión presentó en 1922 el balance económico del centro desde el 23 de agosto de 1919, fecha de la dimisión de Ramón Martínez, hasta octubre de 1922. Según se lee en el acta correspondiente:

[...] quedando la Junta Económica gratamente impresionada por la multitud de datos y comprobantes que, con exceso, ha presentado el Cajero contador Sr. Cortés [...] por lo bien ordenadas y justificadas con que han sido presentadas dichas cuentas ${ }^{76}$.

b) Gestiones para incorporar el Conservatorio de Música de Valencia al Estado

Por el Real Decreto de 16 de noviembre de 1917 el Conservatorio de Música de Valencia quedó autorizado a incorporarse a las enseñanzas del Estado, pero fue en 1920, siendo director Amancio Amorós, cuando el Consejo de Ministros aprobó el proyecto de presupuestos del Ministerio de Instrucción Pública con el que se subvencionaría económicamente el centro, que quedaba así integrado por completo en las enseñanzas del Estado $^{77}$.

Antes de que culminaran las gestiones de incorporación del Conservatorio de Valencia al Estado, Amorós hubo de viajar en varias ocasiones a Madrid con ese reintegrar el dinero al centro no por creerse culpable, sino por ser el máximo responsable del centro. De hecho, Martínez fue de nuevo director del conservatorio diez años después.

75 E:VAcm, Actas de la Junta Económica del Conservatorio de Música de Valencia, 21-III-1921, 10-III1922, 15-X-1922, 16-X-1922, 17-X-1922. En marzo de 1922 el Ayuntamiento hizo entrega de 7000 pesetas en Papel de Resultas al cinco por ciento de interés, por los tres últimos trimestres, que se destinarían a cubrir el alquiler de la casa en la que estaba el Conservatorio. La Junta Económica acordó la venta de este papel para hacer frente al pago del alquiler del centro. El beneficio neto obtenido de la venta fue de 5237’90 pesetas. El primer trimestre de 1922 fue Amancio Amorós el que pagó de su propio dinero el alquiler del centro.

${ }^{76}$ E:VAcm, Acta de la Junta Económica del Conservatorio de Música de Valencia, 17-X-1922.

${ }^{77}$ E:VAcm, Acta del Claustro de profesores del Conservatorio de Música de Valencia, 30-IX-1920. 
motivo $^{78}$. En septiembre de 1920 lo hizo con el Vicedirector, Francisco Peñarroja. Ante el

delicado estado de salud de Peñarroja (que falleció a mediados de octubre de 1920) ${ }^{79}$,

Amorós designó al profesor de piano Juan Cortés para que le acompañase a la capital ${ }^{80}$.

Las primeras gestiones en Madrid tuvieron éxito y en el claustro del conservatorio

valenciano de 30 de septiembre de 1920 se leyó un telegrama de Mariano Benlliure,

Director General de Bellas Artes, en el que notificaba la aprobación por el Consejo de

Ministros de la incorporación oficial del Conservatorio de Valencia a las enseñanzas del

Estado $^{81}$. El proyecto de Decreto para la aprobación del centro decía así:

Por Real Decreto de 16 de noviembre de 1917, conformándose V. M. con las razones expuestas por el Ministro de Instrucción Pública y Bellas Artes, y de acuerdo con el Consejo de Ministros y con el dictamen del de Instrucción Pública, se declararon incorporadas a las Enseñanzas del Estado las que a la sazón se cursaban en el Conservatorio de Música de Valencia, disponiéndose al mismo tiempo que en el próximo proyecto de presupuesto de gastos de este Ministerio se propusiese al Parlamento la inclusión de los créditos correspondientes a los servicios y atenciones del citado Conservatorio, el cual seguirá corriendo a cargo de la Diputación provincial y del Ayuntamiento de la capital citada, en tanto las Cortes no votasen los oportunos recursos.

Realizadas al cabo de tres años de su expresión en la GACETA las condiciones exigidas para que el Estado se haga cargo del referido Centro de enseñanza, el natural afán de ver convertida en realidad la pretensión tanto tiempo acariciada por un legítimo interés, se apresuró a remitir a este Ministerio la plantilla del Profesorado que actualmente figura adscrito al Conservatorio de Valencia.

De su cotejo con la plantilla existente al tiempo de publicarse el Real Decreto de 16 de Noviembre de 1917, resulta en la de ahora un exceso de enseñanzas y de personal, por lo tanto, que el Ministro que suscribe se ve en la imposibilidad de aceptar íntegramente y en las condiciones propuestas, no sólo por el deber a que se cree obligado de no incorporar a la enseñanza oficial más que aquella de índole local que se tuvo presente para la resolución adoptada, sino también por la forma en que poco a poco fueron aumentándose las obligaciones que al Estado iban a transferírsele, creando cátedras y plazas de supernumerarios que se adjudicaron sin oposiciones ni concursos, en un régimen de libre elección, de seguro bien orientada y escrupulosamente

\footnotetext{
${ }^{78}$ E:VAcm, Actas del Claustro de profesores del Conservatorio de Música de Valencia, 14-III-1920 y 9IX-1920.

${ }^{79}$ E:VAcm, Acta del Claustro de profesores del Conservatorio de Música de Valencia, 31-X-1920.

${ }^{80}$ E:VAcm, Acta del Claustro de profesores del Conservatorio de Música de Valencia, 21-IX-1920.

${ }^{81}$ E:VAcm, Acta del Claustro de profesores del Conservatorio de Música de Valencia, 30-IX-1920.
} 
recta, pero que el Estado no puede consagrar con arbitraria gracia, que supondría el abandono de otras garantías oficialmente establecidas.

El crédito votado por las Cortes para el Conservatorio de Valencia de fijo alcanza a subvenir sus actuales pretensiones; mas cifrado en forma global y sin plantilla determinada, lo cual supone manifiestamente una autorización del Parlamento, cuyo uso y cuantía depende del criterio ministerial, éste, en el caso presente, y armonizando los intereses del Tesoro con los de las enseñanzas de que se trata, sólo estima justificado el aumento de Profesores para aquellas ya existentes en la citada fecha de 16 de Noviembre de 1917 que así lo requieran por el número de su matrícula, con lo cual asimismo se armonizan la voluntad de las Cortes, bien manifestada en las autorización antes citada, y su expreso mandato de conservar en rango superior al Conservatorio de Música y Declamación de Madrid ${ }^{82}$.

El Gobierno dispuso un crédito de 69.000 pesetas para atender a los gastos del Conservatorio valenciano:

De conformidad con las razones expuestas por el Ministro de Instrucción Pública y Bellas Artes, y de acuerdo con el Consejo de Ministros.

Vengo a decretar lo siguiente:

Artículo $1^{\circ}$. Votado por las Cortes del Reino un crédito de 69.000 pesetas para atender a los gastos del Conservatorio de Música de Valencia, incorporado a las Enseñanzas del Estado por Real Decreto de 16 de noviembre de 1917, serán confirmados en sus cargos respectivos los actuales Profesores adscritos a la plantilla existente en el mencionado Centro en la referida fecha de su incorporación oficial, con el sueldo anual de 4000 pesetas, que percibirán desde abril del presente año, en que comenzó a regir la vigente ley de Presupuestos.

Para las acumulaciones que existen en la actualidad se fijará la gratificación correspondiente dentro del crédito presupuesto $[\ldots]^{83}$.

En octubre de 1920 se instituyó el cargo de Habilitador del Personal y Material del Centro, que sería el responsable de elaborar las nóminas y ordenar los pagos del Ministerio de Instrucción Pública al personal del conservatorio valenciano. Fue nombrado para el puesto el abogado Ricardo Brugada Mira y como sustituto el profesor de piano Juan Cortés:

\footnotetext{
${ }^{82}$ Proyecto de Decreto de 8-X-1920 relativo a la plantilla del profesorado y personal administrativo y subalterno del Conservatorio de Música y Declamación de Valencia, Gaceta de Madrid, 9-X-1920, p. 159. Vicente Cabeza de Vaca y Fernández de Córdova, ministro de Instrucción Pública y Bellas Artes, presentó el 8 de octubre de 1920 (con la autorización del Consejo de Ministros y el de Instrucción Pública y Bellas Artes) este proyecto de Decreto para su aprobación.

${ }^{83}$ Real Decreto de 8-X-1920 relativo a la plantilla del profesorado y personal administrativo $y$ subalterno del Conservatorio de Música y Declamación de Valencia, Gaceta de Madrid, 9-X-1920, p. 159.
} 
Se procede a la elección del Habilitador del Personal y material de este Centro Docente y sustituto a fin de que pueda el que se designe redactar las nóminas de los haberes del mismo y hacer efectivos los libramientos que se expidan, por la Ordenación de Pagos del Ministerio de Instrucción Pública y Bellas Artes, de la Intervención de Hacienda de esta provincia ${ }^{84}$.

El 14 de octubre de 1920 Amorós fue confirmado en el cargo de profesor numerario de la asignatura de solfeo y armonía, con un sueldo de 4000 pesetas por la primera y 2000 pesetas de gratificación por la segunda ${ }^{85}$. Poco después, el claustro acordó que las clases del Conservatorio de Valencia se celebrarían a diario, ajustándose al modelo del Conservatorio de Madrid, mientras no se estableciera el reglamento definitivo de aquel ${ }^{86}$. En el 1921 se aprobó el nuevo Reglamento Orgánico del Centro en cumplimiento del Real Decreto de 8 de octubre de $1920^{87}$.

En enero de 1924 la revista madrileña La Enseñanza publicó un informe del Consejo de Instrucción Pública y Bellas Artes que cuestionaba la continuidad del Conservatorio de Valencia como centro oficial. Se consideraba que había un reparto desproporcionado en los presupuestos nacionales destinados a la Arquitectura, Pintura, Escultura, Grabado y Música. Para el Conservatorio de Madrid, se proponía reducir el profesorado y suprimir los gastos de representación de los cargos directivos. Se recomendaba además dejar sin efecto la incorporación oficial del Conservatorio de Música de Valencia y de la Escuela de Música de Córdoba y desestimar todas las

\footnotetext{
${ }^{84}$ E:VAcm, Acta del Claustro de profesores del Conservatorio de Música de Valencia, 20-X-1920.

${ }^{85}$ E:VAcm, Tomas de posesión y ceses del profesorado del Conservatorio de Música y Declamación de Valencia, 1920-1960, p. 1. Real Orden de 14-X-1920 confirmando la plantilla que se indica del profesorado del Conservatorio de Música y Declamación de Valencia, Gaceta de Madrid, 16-X-1920, p. 238.

${ }^{86}$ E:VAcm, Acta del Claustro de profesores del Conservatorio de Música de Valencia, 31-X-1920.

${ }^{87}$ E:VAcm, Acta del Claustro de profesores del Conservatorio de Música de Valencia, 6-V-1921. Por el momento no he podido consultar este Reglamento en el Archivo del Conservatorio Profesional de Música de Valencia. Según me informó en 2008 y 2009 Rodrigo Madrid, director del archivo, la documentación histórica del mismo está guardada en cajas no accesibles para los investigadores hasta que finalice la rehabilitación que se está llevando a cabo en este edificio.
} 
peticiones de los pequeños conservatorios provinciales que, como los de Murcia y Oviedo, querían también ser oficiales ${ }^{88}$.

Amorós comentó al claustro de profesores la propuesta del Consejo de Instrucción Pública y viajó a Madrid junto con Cortés y Tomás para intentar solucionar el problema $^{89}$. El 12 de febrero de 1924 José Bellver, por enfermedad de Amorós, presidió el claustro y explicó la entrevista que Amorós, Cortés y Tomás habían mantenido con el Director General de Bellas Artes, que aclaró que la propuesta no tenía carácter ejecutivo, sino meramente consultivo, y que tenía la seguridad de que no prosperaría. Amorós y sus compañeros fueron recibidos además por Miguel Primo de Rivera, presidente del Directorio Militar, quien les dijo:

Que a Valencia nadie le quitaba nada y menos el Conservatorio del maestro Giner, cuya memoria se complacía en recordar $^{90}$

En efecto, la supresión de la oficialidad en el Conservatorio de Valencia fue sólo una alarma injustificada, y el centro continuó con normalidad en los años siguientes.

c) Consolidación y mejora del profesorado

En cumplimiento del artículo $1^{\circ}$ del Real Decreto de 8 de octubre de $1920^{91}$, la plantilla de profesores del Conservatorio de Música de Valencia quedó integrada por un

\footnotetext{
${ }^{88}$ Anónimo, La Enseñanza, 19-I-1924, pp. 90-91.

${ }^{89}$ E:VAcm, Acta del Claustro de profesores del Conservatorio de Música de Valencia, 25-I-1924.

${ }^{90}$ E:VAcm, Acta del Claustro de profesores del Conservatorio de Música de Valencia, 12-II-1924.

91 Real Decreto de 8-X-1920 relativo a la plantilla del profesorado y personal administrativo y subalterno del Conservatorio de Música y Declamación de Valencia, Gaceta de Madrid, 9-X-1920, p. 159. Artículo $2^{\circ}$. Por la Junta de Profesores ya confirmados con arreglo al artículo anterior, se propondrá al Ministerio de Instrucción Pública y Bellas Artes el aumento del Profesorado que estime oportuno para aquellas cátedras cuya matrícula así lo requiera, o por otras causas, cuyos justificantes se acompañarán a la propuesta. Artículo $3^{\circ}$. Se autoriza al Ministro de Instrucción Pública y Bellas Artes para que, una vez hecha la propuesta a que se refiere el artículo anterior, nombre, con carácter de Auxiliares interinos, a los encargados de desempeñar las cátedras señaladas en aquella, ínterin no se proceda a su definitiva provisión, debiendo recaer los nombramientos en personas de reconocida y acreditada competencia, cuya
} 
profesor numerario de Solfeo con la enseñanza "acumulada" de Armonía, uno de Canto, cuatro de Piano, uno de Violín, uno de Composición y Nociones de Armonía, y uno de Estética e Historia de la Música (véase Tabla 23).

Tabla 23. Profesores numerarios del Conservatorio de Música de Valencia en 1920.

Fuentes: Real Orden de 14-X-1920 confirmando la plantilla que se indica del profesorado del Conservatorio de Música y Declamación de Valencia, Gaceta de Madrid, 16-X-1920, p. 238; E:VAcm, Libro de Actas del Claustro de profesores del Conservatorio de Música de Valencia, 21-IX, 20-X y 31-X1920.

\begin{tabular}{|c|c|}
\hline Asignatura & Profesores Numerarios \\
\hline \hline Solfeo y Armonía & Amancio Amorós Sirvent \\
\hline Canto & Lamberto Alonso Torres \\
& \\
\hline Piano & $\begin{array}{c}\text { José Bellver Abella } \\
\text { Ramón Martínez Carrasco } \\
\text { Juan Cortés Cortés } \\
\text { Antonio Fornet Quilis }\end{array}$ \\
\hline Violín & Benjamín Lapiedra Cherp \\
\hline Composición y Nociones de Armonía & Francisco Peñarroja Martínez \\
\hline Estética e Historia de la Música & Eduardo López-Chavarri Marco \\
\hline
\end{tabular}

Ante la demanda de algunas especialidades que contaban con un gran número de alumnos, Amorós propuso en varias ocasiones al Ministerio de Instrucción Pública y Bellas Artes nombrar profesores auxiliares interinos de Solfeo, Piano, Armonía y Estética e Historia de la Música. La plantilla de profesores auxiliares aumentó, en efecto, por Real Orden de 27 de noviembre de 1920, y por un Real Decreto de 27 de diciembre de 1920 se dotaron también con carácter interino dos nuevas plazas de profesores de Piano y una de Solfeo (ver Tabla 24) $)^{92}$.

La muerte de Francisco Peñarroja en 1920 dejó vacante la plaza de profesor de Composición con la "acumulada" de Nociones de Armonía. A propuesta de Amorós fue nombrado para ocupar la vacante Vicente Ripollés, con un sueldo anual de 4000 pesetas

remuneración se fijará con cargo al crédito de 69.000 pesetas consignado en el concepto $8^{\circ}$, artículo $1^{\circ}$, capítulo 13, de la vigente ley de Presupuestos.

${ }^{92}$ E:VAcm, Acta del Claustro de profesores del Conservatorio de Música de Valencia, 31-X-1920. 
por la plaza de Composición, más 2000 de gratificación por la "acumulada" de Nociones de Armonía ${ }^{93}$.

Tabla 24. Profesores auxiliares interinos del Conservatorio de Música de Valencia en 1920. Fuentes: Real Orden de 27-XI-1920 nombrando profesores auxiliares del Conservatorio de Música y Declamación de Valencia, Gaceta de Madrid, 4-XII-1920, p. 977. Real Orden de 27-XII-1920 nombrando con carácter interino profesores auxiliares del Conservatorio de Música y Declamación de Valencia, Gaceta de Madrid, 8-I-1921, pp. 98-99.

\begin{tabular}{|c|c|}
\hline Asignatura & Profesores Auxiliares Interinos \\
\hline Solfeo & Tomás Aldás Conesa \\
& Elena Rosat Solera \\
\hline \multirow{3}{*}{ Piano } & Piedad Estévanez Munoz \\
& José Alonso Valls \\
& Juan Bautista Tomás Andrés \\
& Antonio Fornet Asensi \\
& Consuelo Lapiedra Cherp \\
\hline Estética e Historia de la Música & Manuel Palau Boix \\
\hline
\end{tabular}

En mayo de 1921 salieron a concurso varias plazas de profesores vacantes en el Conservatorio de Valencia:

Aprobada por Reales Ordenes de 27 de noviembre y 27 de diciembre próximo pasado, la plantilla de Profesores auxiliares del Conservatorio de Música y Declamación de Valencia, y en armonía con lo dispuesto en el artículo $3^{\circ}$ del Real Decreto de 8 de octubre de 1920, S. M. el Rey (q. D. g.) ha tenido a bien disponer que las plazas de Profesores auxiliares que figuran en la referida plantilla, se anuncien, para su propiedad a concurso entre Artistas de reconocida y acreditada competencia, siendo condición preferente el desempeñar o haber desempeñado plaza igual a la vacante ${ }^{94}$.

\section{Dimisión de Amorós como Director del Conservatorio}

Desde febrero de 1924 de Amancio Amorós no asistió por enfermedad a varias juntas del claustro del Conservatorio de Valencia, y durante el periodo en el que estuvo

\footnotetext{
93 Real Orden de 27-XI-1920 nombrando a D. Vicente Ripollés y Pérez profesor interino del Conservatorio de Música y Declamación de Valencia, Gaceta de Madrid, 8-XII-1920, p. 1029.

${ }^{94}$ Real Orden de 12-V-1921 disponiendo se convoquen plazas de profesores auxiliares vacantes en el Conservatorio de Música y Declamación de Valencia, Gaceta de Madrid, 16-V-1921, p. 603.
} 
de baja, José Bellver actuó como director sustituto ${ }^{95}$. En octubre de 1924 Amorós solicitó y obtuvo prórroga de un mes de su licencia por enfermedad ${ }^{96}$.

También en octubre de 1924 la muerte de su esposa supuso un duro golpe para el compositor que, con una salud muy deteriorada, presentó su dimisión como Director del Conservatorio de Valencia en noviembre de 1924. La renuncia fue aceptada el 5 de diciembre:

S. M. el Rey (q. D. g.) ha tenido a bien aceptar la renuncia que del cargo de Director del Conservatorio de Música y Declamación de Valencia ha presentado el Profesor de dicho Centro D. Amancio Amorós ${ }^{97}$.

El 14 de noviembre de 1924 Amorós dirigió una emotiva carta de despedida a los profesores y alumnos del Conservatorio:

Queridísimos compañeros y queridísimos discípulos:

La irrebatible fuerza de las circunstancias, me obliga a separarme de vosotros. Es preciso, pues mi salud y mi actual vida me ponen en el durísimo trance de cortar, de poner fin a lo que siempre ha sido para mi alma un máximo placer: convivir con vosotros en la plenitud del trabajo, ser una parte entusiasta, animosa de ese, mi siempre queridísimo Conservatorio. Con hondísimo dolor os dejo: a vosotros, mis compañeros que tanto me ayudasteis para hacer de nuestro Conservatorio un organismo tan importante y respetado como hoy es, a vosotros, mis alumnos que con tanto entusiasmo veníais a aprender en nuestras clases y que con vuestra firme voluntad y saber tanto habéis enaltecido el buen nombre de nuestro Centro.

Pena grande, sí, pero también tiene mi alma un íntimo contentamiento, dulcísimo alivio, al pensar que toda mi labor ahíaunque modestísima haya sido- fue sincera, amorosa, entusiasta; y que de la bondad de vuestro corazón ha de nacer hacia mí, hasta el fin de mi existencia, un hálito de recuerdos conmiseradotes para el que fue, ante todo, para vosotros un hermano y amigo verdadero, pues todo lo hizo-

\footnotetext{
95 E:VAcm, Actas del Claustro de profesores del Conservatorio de Música de Valencia, 12-02-1924, 2504-1924, 23-06-1924, 25-09-1924, 14-10-1924.

${ }^{96}$ Real Orden de 17-X-1920, concediendo un mes de prórroga a la licencia que, por enfermo, viene disfrutando D. Amancio Amorós Sirvent, Director y Profesor del Conservatorio de Música y Declamación de Valencia, Gaceta de Madrid, 19-X-1924, p. 326. En esta Real Orden se dispuso conceder a Amorós prórroga de un mes, los quince primeros días con medio sueldo y los otros quince sin él, de conformidad con el artículo 33 del Reglamento.

${ }^{97}$ Real Orden de 2-XII-1924 aceptando a D. Amancio Amorós la renuncia del cargo de Director del Conservatorio de Música y Declamación de Valencia, Gaceta de Madrid, 5-XII-1924, p. 1103.
} 
bien o mal, que mi talento es pobre- creyendo fuera un bien para todos los que constituimos esta nuestra amadísima Casa del Arte.

Si algún mal hubo en mi labor- sin duda inconscientemente hecho- perdonadlo, que es de grandes corazones olvidar lo que hizo malo el que desaparece. Si algún bien hubo, que quede ello en vuestro recuerdo, pues yo, ahora, en mi, no tengo más que memoria de vuestras delicadezas y bondades y de vuestros aciertos.

Seguid, mis queridísimos compañeros, mis amadísimos discípulos, enalteciendo cada vez más el nombre sagrado de nuestro Conservatorio, al que tanto debemos. Y procurad animosamente, ya que en tan buen cariño queda todo, que pronto sea el mejor entre los mejores en todo orden y en toda empresa. Vuestro siempre $^{98}$.

El claustro de profesores se dio oficialmente por enterado de la aceptación de la dimisión de Amorós en diciembre de 1924. El profesor Manzanares pidió que constara en acta el sentimiento que este hecho producía y que se colocara un retrato de Amorós en el sitio que el nuevo director estimara oportuno. Este retrato se instaló realmente y seguía en la sede del Conservatorio Profesional de Música de Valencia, situado en la plaza de San Esteban, hasta hace unos años (Ilustración 23) 99.

\footnotetext{
${ }^{98}$ Libro de Actas del Claustro de profesores del Conservatorio de Música de Valencia desde el 20 de octubre de 1920 hasta el 21 de abril de 1928, hojas sueltas, 14-XI-1924. Carta de Amorós dirigida al claustro de profesores y alumnos del Conservatorio de Música y Declamación de Valencia.

${ }^{99}$ E:VAcm, Acta del Claustro de profesores del Conservatorio de Música de Valencia, 12-XII-1924. En la actualidad, con el traslado del Conservatorio a su nueva sede de la plaza Viriato, desconozco si el retrato de Amorós sigue o no en el centro.
} 


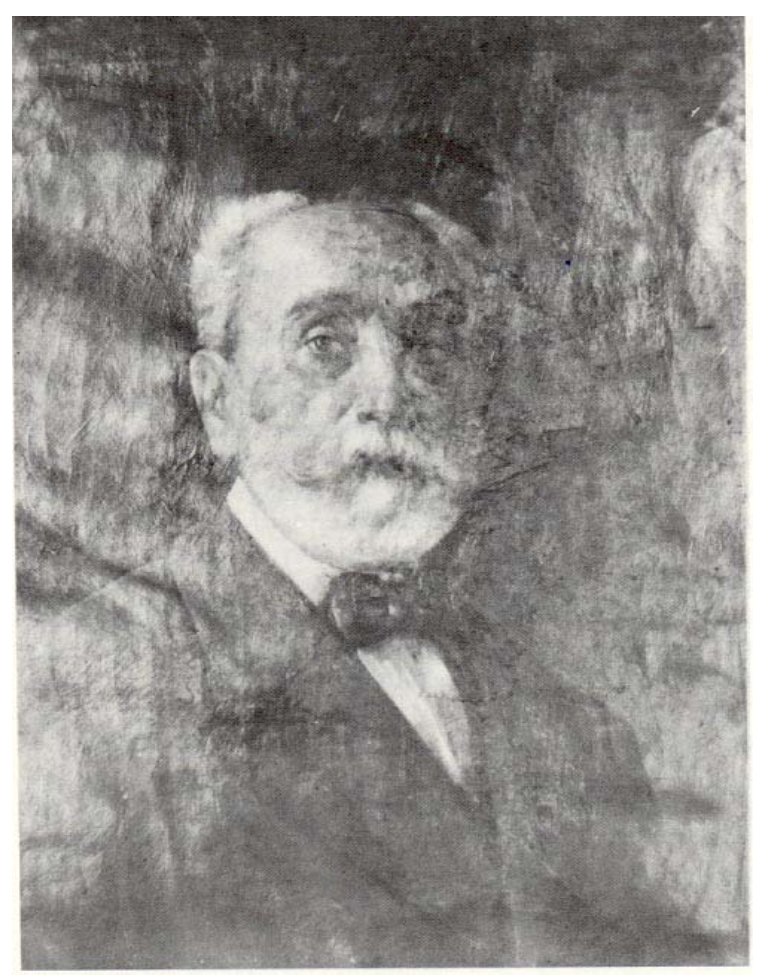

Ilustración 23

Amancio Amorós Sirvent, óleo (autor desconocido) ${ }^{100}$.

Vicente Tena, Obras musicales de Amancio Amorós, inédito.

Tras la dimisión de Amorós, José Bellver Abellá fue propuesto por unanimidad como nuevo director del Conservatorio de Valencia ${ }^{101}$. Bellver agradeció públicamente a los profesores Cortés y Tomás la ayuda que habían prestado a Amorós:

Deseaba de todos sus compañeros que otorgaran un voto de gracias para los señores Secretario y Cajero contador, por la eficaz ayuda prestada al que hasta ahora Director, D. Amancio Amorós y esperando añadió, que todos le ayudaran en su difícil cometido ${ }^{102}$.

\footnotetext{
${ }^{100}$ Podría tratarse de un óleo de Gonzalo Salvá, véase Gonzalo Salvá, "A propósito de unos cuadros del Conservatorio”, Almanaque de las Provincias para 1948, pp. 197-198.

${ }^{101}$ Real Orden de 13-XII-1924, nombrando Director del Conservatorio de Música y Declamación de Valencia al profesor numerario D. José Bellver Abellá, Gaceta de Madrid, 24-XII-1924, p. 1369.

${ }^{102}$ Cortés y Tomás declararon que así como por su ancianidad y estado achacoso, habían procurado aliviar al Sr. Amorós en las cargas de la Dirección, en tanto cuanto ello fue posible. E:VAcm, Acta del Claustro de profesores del Conservatorio de Música de Valencia, 12-XII-1924.
} 


\section{Obras didácticas de Amancio Amorós}

La actividad docente de Amancio Amorós en diversas instituciones le llevó a elaborar una serie de obras teóricas dedicadas al solfeo, la armonía, la composición y el piano, varias de ellas editadas en Valencia entre 1889 y 1925. Los ejemplares que he consultado se encuentran mayoritariamente de la Biblioteca de Catalunya y forman parte de la biblioteca personal del propio Amorós, depositada allí por José Vicente Amorós Barra, hijo del compositor, en 1930. El Apéndice 5 incluye una tabla con las obras didácticas escritas por Amorós y algunos archivos y bibliotecas que conservan ejemplares. Las obras localizadas y de atribución segura a Amancio Amorós son las dedicadas al Solfeo: Elementos de Solfeo (ca. 1889-1891), Teoría General del Solfeo (1896), Nociones Teóricas de Solfeo (1908-1909), Lecciones Manuscritas Graduadas (1910) y Lecciones de Solfeo manuscrito a una y dos voces con acompañamiento de piano y armónium (sf). Hay otras obras de atribución segura pero no localizadas, como su Método elemental de piano (sf). De atribución dudosa es el Tratado de Composición (sf), que se conserva manuscrito e incompleto en la Biblioteca de Catalunya. Las obras que llegaron a publicarse son cuatro: Elementos de Solfeo, Teoría General del Solfeo, Nociones Teóricas de Solfeo y Lecciones Manuscritas Graduadas. Estos tratados de solfeo se reeditaron en varias ocasiones y con ellos ejerció Amorós una influencia directa en la educación musical del momento. Los materiales melódicos y combinaciones rítmicas que utiliza en Elementos de Solfeo y las Lecciones Manuscritas Graduadas para cursos superiores (segundo y tercero), son diferentes en cada caso. El contenido y algunos ejemplos musicales que Amorós utiliza en sus Nociones Teóricas de Solfeo son los mismos que aparecieron en su Teoría General del Solfeo, y en este caso se observa una reutilización de materiales por razones comerciales. 
A propósito de la reedición, en 1914, de Elementos de Solfeo y Lecciones

Manuscritas Graduadas para segundo y tercer curso, Adolfo Salazar, en la sección

"Edición Musical" de la Revista Musical Hispano-Americana, emitió un juicio crítico

favorable y valoró esas obras por su verdadero valor didáctico para la enseñanza musical, mientras arremetía contra otros teóricos del solfeo:

Las publicaciones de solfeo se suceden con tal rapidez y es tan fecunda la edición española en obras de este género, que nos preguntamos si sus autores se sentirán estimulados por alguna nueva idea de vital importancia que los impulse a desarrollarla en la forma que cada cual crea más conveniente. Pero desgraciadamente, no es así.

La mayoría de los métodos de solfeo parecen cortados por el mismo patrón y apenas se diferencian en alguna minucia. Y no es que haya llegado a tan inconmensurable altura que sea imposible introducir en ellos alguna reforma; por el contrario, la inmensa mayoría nos parecen deficientísimos en el magno problema de poner al discípulo en la atmósfera musical contemporánea. Lo primero que salta a la vista, es la diferencia de extensión existente entre todos ellos, y así ocurre el preguntarse a qué consideraciones se habrán atenido sus autores para computar el tiempo necesario a cada una de las diferentes partes del solfeo: por lo regular, se multiplican hasta el infinito una serie de lecciones de tal vulgaridad melódica y combinaciones rítmicas y de intervalos, tan antiestéticamente dispuestas, que es forzoso que el discípulo haya de plantearse el dilema de o que de aquellas combinaciones no ocurren jamás en la música, o si ocurren es con mejor tino y acierto que en esas lecciones. Encontramos en muchas de ellas un completo olvido del estilo vocal, rasgos pianísticos y antiguallas tales como los puntillos más allá de las barras de compás, completamente en desuso los maravillosos torniquetes ya horizontales, ya en pie que desde hace largos años han desaparecido de las partituras. Si su objeto es el de mostrar los signos que representaban ciertos giros melódicos, ¿por qué no indicarlos todos con todas sus particularidades? La razón, es que no es este un problema de fácil solución; más fácil es mostrarles desde lejos y pasar enseguida a otra cosa.

Se arguye como defensa de la horripilante fealdad de casi todas las lecciones, que así no se aprenden de memoria. ¡Cómo si no fuera de capital importancia desarrollar desde luego esta parte importantísima en la educación musical! Y puesto que no se considera de importancia el valor melódico de los ejercicios ¿cabe dudar de que la mayoría de los métodos de solfeo no contribuyen ni aun remotamente a un desarrollo de la comprensión del discípulo en materia de la dificultad significativa de las ideas? Así no es extraño oír vaguedades tales, como la de la pérdida de la melodía en nuestros tiempos, etc; ya que para tantas gentes ésta aparece y se esfuma en cuanto el sentimiento final, fuertemente machacado en lo métodos, se amplifica y vuela más libremente libertado de las férreas trabas, con las que hasta hace poco se creía imprescindible aprisionarle. Ese es un punto capital en el solfeo y que brilla, desgraciadamente, por su ausencia, y es la flojedad de todos los métodos en materia de modulación. No es que no se estudien las alteraciones, algunos métodos hasta hacen ejercicios con el bemol y ejercicios con el sostenido según tenemos a la vista, pero lo hacen bien agarrados a la barandilla, temerosos de un resbalón que nos haga ir a pasar a los pícaros tonos 
distantes. No se procura el ennoblecimiento de una melodía rica en alteraciones, cantable dentro de una amplia base final, semejándose más con sus interpolaciones de claves, ritmos fantásticos a un steeplechase que a un ejercicio artístico. Así el discípulo será capaz, una vez ejercitado, de hacer toda clase de gargarismos y juegos malabares; lo que no es probable es que cante con sentido un adagio de Bach o que se de cuenta de la significación de una obra contemporánea. Nada hemos de hablar de completo abandono de las cuestiones modales; así se ve a mucha gente quedarse estupefacta al oír hablar de otros modos que el mayor y el menor con su correspondiente sensible. ¿Cómo concebir una conclusión lógica sin ese pícaro semitono por algún lado? Rara vez leemos reseñas como la del señor Gáscue en el número de julio de esta Revista. Y es que o se hacen colecciones ex profeso, o la canción popular con sus particularidades modales no halla acogida en los métodos de solfeo. Se ha argüido algunas veces al articulista que alguna de las indicaciones que se hacen, no tienen lugar en un método de solfeo, sino que son peculiares a los métodos de canto, creyendo positivamente que el solfeo tiene solamente por obligación poner al discípulo en disposición de descifrar todo lo que se ponga ante la vista, pero no de descifrarlo bien, esto es, con sentido musical.

En fin, ese garrapateo musical progresivo que se nos da en muchos métodos manuscritos, sería bien pronto inútil si se ejercitare al educando desde un principio en el arte de la copia, como se hace con la caligrafía en las escuelas, y si se hiciese comprender a los músicos en agraz que bien está que compliquen sus composiciones, todo lo que se les antoje, dentro siempre del terreno musical, sin añadirles dificultades que suponen una crasa falta de estimación en el precioso tiempo de los demás. Naturalmente, nada de lo antedicho reza con el método del Sr. Amorós, culto profesor del Conservatorio de Valencia. Por el contrario, sus Elementos de Solfeo son una obra de verdadero valor didáctico, y en este sentido es de toda justicia recomendarla a los neófitos del Arte Musical ${ }^{103}$.

El reconocimiento que Amorós obtuvo por estas obras pedagógicas quedó patente cuando en 1918 la Real Academia de Bellas Artes de San Fernando de Madrid declaró los Elementos de Solfeo, Nociones Teóricas de Solfeo y Lecciones Manuscritas Graduadas de utilidad para la enseñanza del solfeo y de mérito en la carrera de Amancio Amorós ${ }^{104}$.

\footnotetext{
${ }^{103}$ Adolfo Salazar, Revista Musical Hispano-Americana, enero (1915), pp. 15-16.

${ }^{104}$ E:Mba, Acta de la sesión celebrada por la Sección de Música de la Academia de Bellas Artes de San Fernando de Madrid, 13-V- 1918 y 21-X-1918.
} 


\section{1. Elementos de Solfeo (ca. 1889-91)}

La primera edición de los Elementos de Solfeo, localizada en la Biblioteca Nacional de Madrid, apareció ca. 1889-91, con prólogo de Salvador Giner ${ }^{105}$. En las ediciones posteriores aparece además un dictamen de Felipe Pedrell ${ }^{106}$. Este tratado de Amorós está dedicado a la Junta Directiva del Conservatorio de Música de Valencia (véase Ilustración 24) $^{107}$.

La primera edición de la obra salió con un precio oficial de 10 pesetas. La prensa anunció en 1894 la segunda edición de Elementos de Solfeo y comentó el éxito obtenido por Amancio Amorós con esta obra didáctica, y adelantó la publicación de la Teoría General del Solfeo que saldría a la luz finalmente en 1896:

El conocido profesor músico D. Amancio Amorós ha publicado la segunda edición de sus Elementos de Solfeo, obra didáctica que ha tenido general aceptación y sirve de texto en muchos centros de enseñanza de Valencia y en otros puntos de España y América, prueba evidente de que la obra del joven compositor responde a las exigencias de la enseñanza. Así lo han declarado autoridades tan competentes como D. Salvador Giner y D. Felipe Pedrell en los informes emitidos acerca del valor didáctico de los Elementos de Solfeo del señor Amorós.

En breve publicará dicho señor otra obra de suma utilidad y de aplicación general a todos los métodos de solfeo, tanto elementales como superiores. Tal será la Teoría general del Solfeo, en forma de diálogo, y que estará ilustrada con ejemplos en el texto ${ }^{108}$.

\footnotetext{
${ }^{105}$ El ejemplar manejado de ca. 1889-91 no contiene ninguna referencia editorial. Blasco, La música en Valencia, p. 96, afirmó en 1896 que el método Elementos de Solfeo se editó en 1889. Sobrino, "Amoros Sirvent, Amancio", p. 420, en cambio, afirma que este método de solfeo vio la luz en 1890. Los datos editoriales que maneja la Biblioteca Nacional de Madrid [Valencia: Imp. de Salvador Cabedo, 1891] no coinciden con los de Ramón Sobrino [Valencia: Laviña, 1890]. El ejemplar de la Biblioteca Nacional conserva una anotación manuscrita que dice así: "Registrada con el no 377 al folio 49 del libro diario y en el talonario provisional con el $\mathrm{n}^{\mathrm{o}} 377$ al folio 195, Valencia, 13 de abril de 1892, el jefe de registro [firma], Vicente Hiruvella". Aparece también en la portada la firma manuscrita de Amancio Amorós y los sellos de la "Biblioteca Ua de Valencia" y del "Ministerio de Fomento, entrada 9 de may. 92". A pie de página se lee: "Se halla de venta en Valencia, en los almacenes de música de los Sres. Laviña, Bajada de San Francisco, 29; S. Vicente, 99 y en los prales. establecimtos. de música de España”.

106 Amancio Amorós, Elementos de Solfeo, con un prólogo de D. Salvador Giner, Director del Conservatorio de Música de Valencia, y el dictamen de la obra por D. Felipe Pedrell, profesor de la Escuela Nacional de Música y Declamación (Valencia: Tipografía Moderna Miguel Gimeno, $3^{\mathrm{a}}$ ed., 1901).

${ }^{107}$ Serrano, “Amancio Amorós”, p. 479.

108 Las Provincias, 13-II-1894.
} 


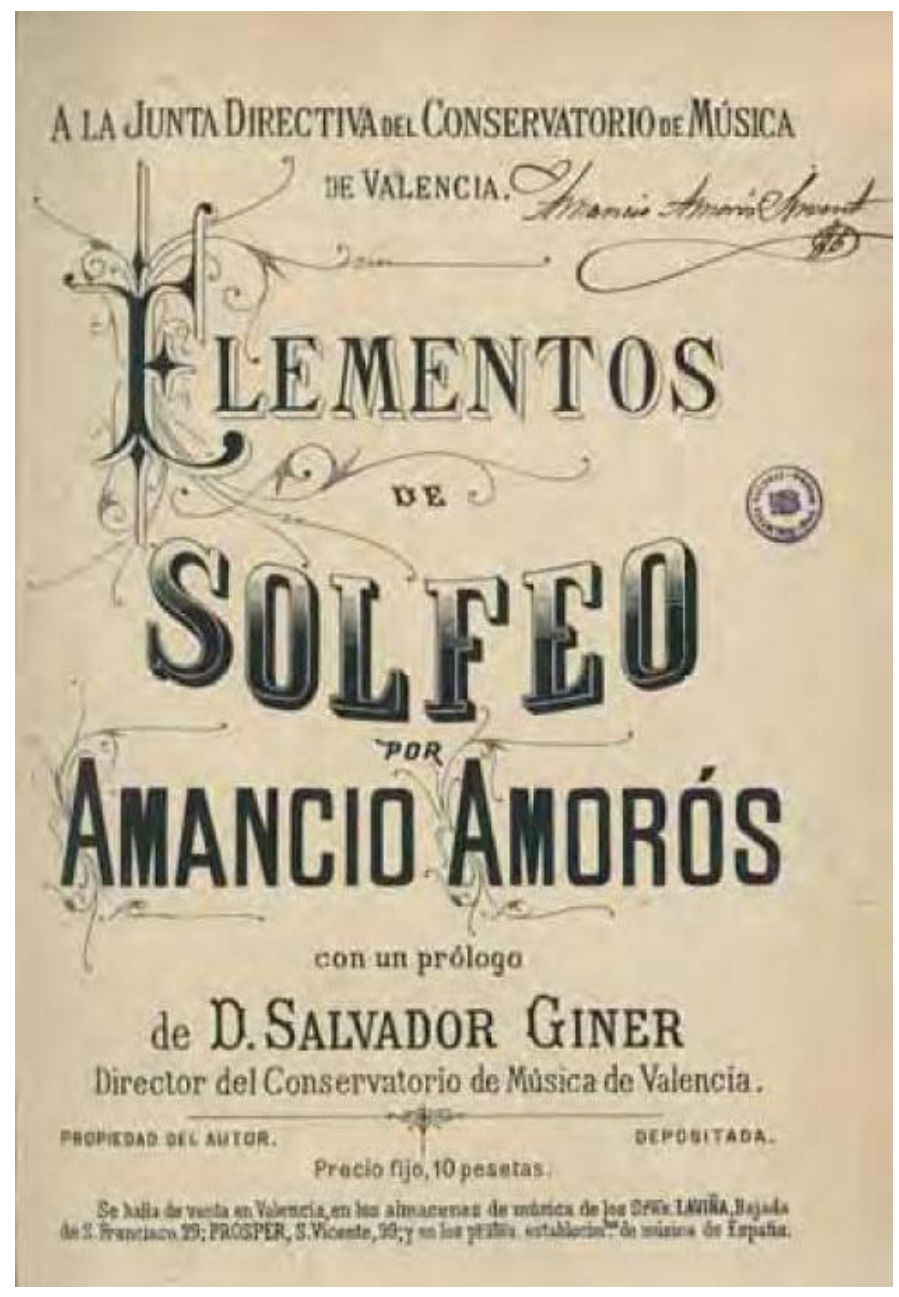

Ilustración 24

Amancio Amorós, Elementos de Solfeo, $1^{\mathrm{a}}$ ed. (ca. 1889-91). $E: M n, \mathrm{M} / 2622$.

Los Elementos de Solfeo de Amorós tuvieron una magnífica acogida y la obra alcanzó al menos las diez ediciones ${ }^{109}$. El propio Amorós, en las aclaraciones a la décima edición, consideraba que con esta obra y con sus posteriores métodos de solfeo y teoría, había analizado todos los conceptos que debían estudiarse en la materia:

Coincidiendo esta décima edición con nuestras ya publicadas obras Nociones Teóricas de Solfeo, Teoría General del Solfeo y Lecciones Manuscritas Graduadas (segundo y tercer curso de solfeo) y con ellas haber completado las materias que de esta asignatura generalmente se estudian en los centros docentes, hemos omitido la Adición que contenían las otras ediciones, por considerarla innecesaria $^{110}$.

\footnotetext{
${ }^{109}$ Un ejemplar de la $10^{\text {a }}$ ed., sf, se conserva en $E: V a b v$, E. López-Chavarri/3365.

${ }^{110}$ Amorós, Elementos de Solfeo, $10^{\mathrm{a}}$ ed., sf.
} 
Amorós recomendaba en sus Elementos de Solfeo:

Sólo cuando el discípulo haya vencido todas las dificultades que encierra este Método, y tenga un conocimiento exacto de todas las materias que contiene la Adición, tanto en la parte práctica como en la teórica, podrá dedicarse al estudio de algún instrumento, alternando con los estudios superiores de Solfeo ${ }^{111}$.

En el Conservatorio de Valencia la asignatura de Solfeo estaba dividida en esa época en tres cursos. Para primer curso se empleó desde 1879 el Método de solfeo y principios de canto, aplicables en las escuelas y colegios (1857) del valenciano Pascual Pérez Gascón (véase Apéndice 14) ${ }^{112}$. Para $2^{\circ}$ y $3^{\text {er }}$ curso de solfeo se utilizó el Método completo de Eslava (la $2^{\mathrm{a}}$ parte para $2^{\mathrm{o}}$ curso y las partes $3^{\mathrm{a}}$ y $4^{\mathrm{a}}$ para $3^{\circ}$ ). A partir del curso 1897-1898 se utilizó el Método Completo de Eslava para los tres cursos de solfeo ${ }^{113}$.

En 1901, José Ma Úbeda, Director del Conservatorio de Valencia, presentó a la Junta de Profesores los Elementos de Solfeo de Amorós "para su examen y aprobación". Ramón Martínez y Manuel Coronado quedaron encargados de revisar y estudiar la obra y en enero de 1902 emitieron un dictamen favorable. En febrero de ese mismo año los Elementos de Solfeo de Amorós se incluyeron como obra de texto del Conservatorio de

\footnotetext{
${ }^{111}$ Amorós, Elementos de Solfeo, $3^{\mathrm{a}}$ ed., 1901, p. 71.

${ }^{112}$ El Método de solfeo y principios de canto, dedicado por Pérez Gascón a la Real Sociedad Económica de Amigos del País de Valencia, consta de treinta y ocho carteles, veinticinco de los cuales contienen la parte elemental y los trece restantes varios cantos para coro a dos y tres voces. La parte teórica de este método está redactada en forma de diálogo. El Método de Solfeo y principios de canto de Pérez Gascón coincide con el método de solfeo de Eslava en el orden de aparición de las claves, tonalidades, compases y dificultades métricas. La progresión de dificultades melódicas es más pedagógica y completa en el Método de Solfeo y principios de canto de Pascual Pérez Gascón. Véase Loras, Estudio de los métodos, p. 548.
}

${ }^{113}$ Boletín Musical, 10-XI-1897, p. 1062. 
Valencia, donde estuvieron vigentes al menos hasta 1914 para el primer curso de solfeo, sustituyendo a la primera parte del Método de Eslava ${ }^{114}$.

Amorós dividió esta obra teórico práctica en tres cuadernos, el precio de cada cuaderno era de 2 pesetas y el de la obra completa 6 pesetas. No he localizado ninguno de estos cuadernos, en las ediciones localizadas aparece la obra completa ${ }^{115}$. Los Elementos de Solfeo de Amorós constan de cien lecciones en clave de sol en las que destaca la preocupación por la medida y la entonación, plasmada en numerosos ejercicios con distintas combinaciones rítmicas y entonación de todos los intervalos. La tesitura que abarcan las lecciones va del $\mathrm{Do}^{3} \mathrm{al} \mathrm{Fa}^{4}$, en la tonalidad de Do Mayor ${ }^{116}$. En el Apéndice 7 presento esquemáticamente los contenidos de esta obra. Amorós comienza con la lectura de las notas sin entonación ni medida, después inserta ejercicios de entonación de intervalos y progresivamente incorpora las figuras musicales.

Amorós dejó de utilizar, como también lo había hecho Hilarión Eslava en su Método completo de solfeo sin acompañamiento (1845), las denominaciones mensurales de breves, semibreves, mínimas y semínimas, y utilizó ya los nombres de redonda, blanca y negra. Amorós abandonó también la denominación de compás mayor o menor, y los nombres de "espera", "pausa", "media pausa", "aspiración” o "suspiro", indicando que lo lógico sería denominarlos "figuras de silencio""117.

\footnotetext{
${ }^{114}$ E:VAcm, Actas del Claustro de profesores del Conservatorio de Música de Valencia, 25-X-1901, 12-I1902; 8-X-1911; Acta de la Junta Directiva del Conservatorio de Música de Valencia, 8-II-1902; Acta de la Junta de Gobierno del Conservatorio de Música de Valencia, 7-IX-1912. En 1914 se volvió a publicar incluyendo en el título: de texto en el Conservatorio de Música. Véase "Bibliografía Valenciana", Almanaque de las Provincias para 1915, p. 256. Sobre el método de Solfeo de Eslava véase Preciado, "Don Hilarión Eslava", pp. 215-263 y Apéndice 15.

115 "Elementos de Solfeo. Obra teórico práctica. Dividida en tres cuadernos. La obra completa, 6 ptas. Precio de cada cuaderno, 2 ptas", véase Amancio Amorós, Nociones Teóricas de Solfeo, $3^{\text {er }}$ Curso, (Valencia: Tipografía Moderna Miguel Gimeno, $1^{a}$ ed., 1909).

${ }^{116}$ Se ha utilizado el sistema de identificación de octavas franco belga, $\mathrm{La} 440 \mathrm{~Hz}=\mathrm{La}^{3}$.

${ }^{117}$ Amorós, Elementos de Solfeo, $3^{\mathrm{a}}$ ed., 1901, pp. 6 y 8.
} 
Elementos de Solfeo introduce el compás de 3/4 y ejercicios de entonación de todos

los intervalos mayores y menores alterando la nota inferior y superior con un sostenido o

bemol (una destreza que no aparece en la primera parte del Método de Eslava). En los

Elementos de Solfeo Amorós cuidó la presentación, utilizó poco texto para sus

explicaciones teóricas y muchos ejemplos, aportó ejercicios para evitar que los alumnos

memorizaran las lecciones, graduó las dificultades y trató de presentar los contenidos con

claridad metódica y razonada:

Toda obra, y en particular las destinadas a la enseñanza (y de éstas, las elementales), ha de entrañar precisamente fondo y forma en las materias que en ella se expongan, es decir, buen caudal de conocimientos acumulados en ella, y éstos presentados con claridad metódica y razonada: éste pues, ha sido precisamente el ideal que hemos perseguido al escribir esta obra. ¿Lo hemos conseguido? ${ }^{118}$.

El contenido de los Elementos de Solfeo de Amorós se ajustaba al programa de

Solfeo vigente a nivel nacional en 1876 para el primer año (véase Tabla 25).

Tabla 25. Programa Oficial de Solfeo de la Escuela Nacional de Música (1876).

Fuente: Memoria presentada por la Escuela de Música y Declamación de España en la Exposición internacional de Filadelfia. España, Instrucción pública (Madrid: J. A. García, 1876), pp. 255-256.

\begin{tabular}{|c|}
\hline PRIMER AÑO \\
\hline $\begin{array}{l}\text { Normas preliminares en que se hacen las definiciones de lo que es solfeo, conocimiento de las notas, } \\
\text { figuras, silencios, pentagramas, líneas adicionales, claves, compás, intervalos mayores y menores, } \\
\text { escala diatónica. }\end{array}$ \\
\hline Ejercicios y lecciones prácticas de intervalos conjuntos y disjuntos. \\
\hline $\begin{array}{l}\text { Movimientos del compás, llamados también aires, puntillos hasta en la corchea, silencios hasta de } \\
\text { semicorchea, síncopa hasta la corchea inclusive, ligadura, calderón compases de compasillo, } 2 / 4 \text { y } 3 / 4 \text {, } \\
\text { sostenidos, bemoles, becuadros, y su práctica, sólo de grado en distancias de medio tono. }\end{array}$ \\
\hline $\begin{array}{c}\text { En las lecciones prácticas de este año, sólo se hace uso del tono de Do en clave de sol, y en las } \\
\text { combinaciones de medida, hasta la semicorchea inclusive y su silencio. }\end{array}$ \\
\hline SEGUNDO AÑO \\
\hline Conocimiento de los tonos y modos, compases binarios 3/8, 6/8, 9/8 y $12 / 8$. \\
\hline Claves de Fa en cuarta línea y Do en primera. \\
\hline Apoyaturas y mordentes, doble puntillo, seisillos, intervalos aumentados y disminuidos. \\
\hline $\begin{array}{l}\text { En las lecciones prácticas no se hace uso más que de los tonos siguientes: la menor y hasta los que tienen } \\
\text { tres sostenidos y tres bemoles, mayores y menores, y en las combinaciones de medida hasta la semifusa. }\end{array}$ \\
\hline Lectura a primera vista de lecciones manuscritas. \\
\hline TERCER AÑO \\
\hline Práctica de los tonos restantes. \\
\hline Clave de Do en segunda, tercera y cuarta y Fa en tercera. \\
\hline Dobles alteraciones. \\
\hline
\end{tabular}

${ }_{118}$ Amorós, Elementos de Solfeo, $3^{\text {a }}$ ed., 1901, sp. 
Además de las cien lecciones de solfeo, los Elementos de Solfeo contienen un anexo teórico en el que se explican los diferentes tipos de escalas, semitonos, intervalos, figuras, compases de $3 / 8,6 / 8,9 / 8$ y $12 / 8$, apoyaturas y mordentes, valores irregulares y el concepto de clave, con ejemplos de cada uno de estos conceptos ${ }^{119}$. Con los Elementos de Solfeo Amorós se proponía preparar a los alumnos que quisieran iniciar estudios de Canto o de algún instrumento, especialmente Arpa, Órgano y Piano:

No han sido enunciar ninguna revelación, sino que por medio de la exposición de la teoría, de los numerosos ejercicios de lectura, entonación y ritmo, y de las melodías que contiene esta obra, sirva modestamente de introducción, preparación o base elemental, pero sólida, a los estudios superiores de solfeo [...] y además, para poner a los principiantes, incluso a los de tierna edad (dada la poca extensión de sonidos que recorren las melodías de que se compone la obra), en disposición de dedicarse al estudio del canto o de algún instrumento, y, en particular, a los que se dediquen al estudio del arpa, órgano o piano $^{120}$.

La obra consiguió plenamente sus propósitos, según Salvador Giner en el prólogo

a la $3^{\mathrm{a}}$ edición de 1901:

Los Elementos de Solfeo escritos por D. Amancio Amorós [...] el gran acopio de ejercicios rítmicos y de entonación, y la bien calculada ordenación de los mismos, son garantía de que, practicados bajo una buena dirección, han de formar, precisamente, la sólida base del que aspire a ser un buen solfista ${ }^{121}$.

Felipe Pedrell elogió expresamente los Elementos de Solfeo de Amorós con estas

palabras, en la misma edición de 1901:

El gran acopio de ejercicios rítmicos y de entonación contenidos en estos Elementos de Solfeo, que acaba de dar la luz en una segunda tirada-edición el joven y distinguido compositor D. Amancio Amorós, la bien ordenada presentación de los mismos, la fluidez de las melodías compuestas con objeto de estucar y formar el gusto de los principiantes y la claridad en la exposición de la teoría que forma la

\footnotetext{
${ }^{119}$ Estos conceptos son tratados en la segunda parte del Método Completo de Eslava.

${ }^{120}$ Amorós, Elementos de Solfeo, $3^{\mathrm{a}}$ ed., 1901, sp.

${ }^{121}$ Amorós, Elementos de Solfeo, $3^{\mathrm{a}}$ ed., 1901, sp.
} 
base de este estudio son buena garantía de que la obra iba a difundirse [...]. Las lecciones, propiamente dichas, de este método de solfeo, alternan con ejercicios de lectura y toda una serie de ejercicios particulares dedicados a la práctica y aplicación razonada de los conocimientos adquiridos [...]. En resumen la obra del Sr. Amorós es una de las mejores en su género escritas últimamente en España ${ }^{122}$.

El método Elementos de Solfeo fue premiado en la Exposición Artística, Industrial y Agrícola del Ayuntamiento de Valencia de 1894 y en la Franco Hispana de Zaragoza de $1908^{123}$. En 1918 la sección de Música de la Real Academia de Bellas Artes de San Fernando de Madrid declaró los Elementos de Solfeo de utilidad para la enseñanza del solfeo y de mérito en la carrera del autor ${ }^{124}$.

En agosto de 1892 se anunció en el Boletín Musical de Valencia un Método Elemental para solfeo de Amancio Amorós con prólogo de Salvador Giner que Fontestad consideró como obra diferente a los Elementos de Solfeo $^{125}$. En realidad, considero que el anuncio se refería a los Elementos de Solfeo, el único tratado elemental de solfeo escrito por el autor" ${ }^{126}$. La aparición del título Método Elemental en la sección "Novedades Musicales" del Boletín Musical probablemente fue una manera de dar publicidad a los Elementos de Solfeo, que tuvieron una gran aceptación en la enseñanza del momento. Este mismo año (1892), Amorós solicitó a la Real Academia de Bellas Artes de San Fernando de Madrid que sus Elementos de Solfeo fuesen declarados de utilidad pública para la enseñanza del solfeo ${ }^{127}$. En 1915, la prensa del momento valoró los Elementos de

\footnotetext{
${ }^{122}$ Amorós, Elementos de Solfeo, $3^{\mathrm{a}}$ ed., 1901, sp.

123 Amancio Amorós, Nociones Teóricas de Solfeo (Valencia: Tipografía Moderna Miguel Gimeno, $1^{\mathrm{a}}$ ed., 1908).

${ }^{124}$ E: Mba, Actas de la sesión celebrada por la Sección de Música de la Academia de Bellas Artes de San Fernando de Madrid, 13-V-1918 y 21-X-1918.

125 Boletín Musical, 31-VIII-1892, p. 12. Fontestad, El Conservatorio de Música, p. 394.

${ }^{126}$ En el informe que acompaña su nombramiento como Académico Correspondiente sólo menciona un
método elemental de solfeo; E: $M b a$, legajo 5-2-2, Expediente de nombramiento de Amancio Amorós
como Académico Correspondiente (1921).
}

${ }^{127}$ Diario oficial de avisos de Madrid, 19-VI-1892. 
Solfeo como obra de verdadero valor didáctico, "recomendable a todos los que quisieran ejercitarse en el Arte Musical”"128.

\section{2. Teoría General del Solfeo (1896)}

En 1896, cuando Amorós era profesor honorario de solfeo en el Conservatorio de Música de Valencia, salió a la luz la primera edición de su Teoría General del Solfeo razonada en forma de diálogo y con un programa teórico de la asignatura (véase Ilustración 25) ${ }^{130}$. Amorós publicó esta obra varios años después de sus Elementos de Solfeo y con ella pretendía ofrecer contenidos más completos que llegaran a un mayor número de usuarios. La obra se divide en tres partes (equivalentes a años o cursos) y cada una de ellas contiene numerosos ejemplos, impresos en papel color rosa, a los que Amorós remite desde el texto principal ${ }^{131}$ :

La primera parte contiene todo lo que afecta sólo al sonido, la segunda lo correspondiente al tiempo, y la tercera lo que participa del sonido y del tiempo a la vez. Respecto a la teoría comprendida en toda la obra, hemos procurado exponerla todo lo más clara y razonada que nos ha sido posible.

El texto correspondiente a las tres partes, va seguido de los ejemplos que lo ilustran, con el fin de que, en esta forma, sirva indistintamente a los que, sin verificar el estudio práctico del solfeo, desean conocer el tecnicismo y significado de las palabras y signos empleados en la música moderna, y a los que se dedican al estudio de la música como afición o como profesión ${ }^{132}$.

\footnotetext{
${ }^{128}$ Revista Musical Hispano-americana, enero (1915), p. 16.

${ }^{129}$ El ejemplar manejado se conserva en E:Bc, Libro de Registro $n^{\circ} 24$ (1930-31), $\mathrm{n}^{\mathrm{o}}$ de entrada 123898.
} Amorós dedicó la obra a su hijo, José Vicente Amorós Barra.

${ }^{130}$ Amancio Amorós, Teoría General del Solfeo, razonada en forma de diálogo y con un programa teórico de la asignatura ordenado según el plan de enseñanza de la Escuela Nacional de Música y Declamación, del Conservatorio de Música de Valencia y de otros centros docentes de España y del Extranjero (Valencia: Manuel Alufre, $1^{\mathrm{a}}$ ed., 1896).

${ }^{131}$ La Teoría General del Solfeo tiene un total de 129 páginas. Amorós presenta los ejemplos de la p. 41 a la 66 y de la 107 a la 129.

${ }^{132}$ Amorós, Teoría General, $1^{\mathrm{a}}$ ed., 1896, p. 8. 


\section{AMANGIO AMRORÓs}

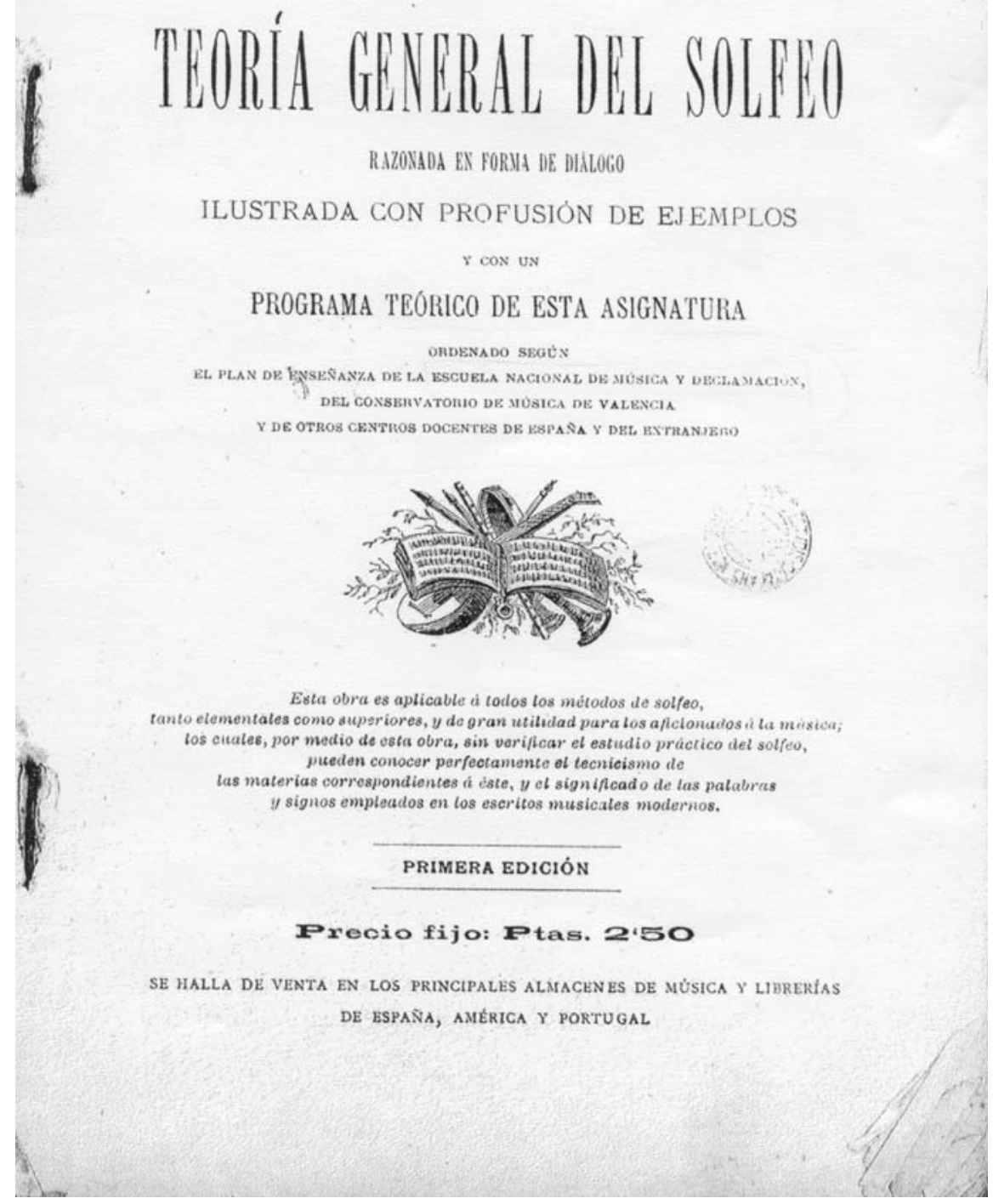

Ilustración 25

Amancio Amorós, Teoría General del Solfeo, $1^{\mathrm{a}}$ ed. (1896).

$E: B c, \mathrm{M} 428512$.

La Teoría General del Solfeo (1896) estructura las materias según el plan de enseñanza de la Escuela Nacional de Música y Declamación de Madrid, del Conservatorio de Valencia y de otros centros docentes de España y el extranjero (véase Tabla 26 y Apéndice 8). 
Tabla 26. Programa Oficial de Solfeo de la Escuela Nacional de Música (1898) ${ }^{133}$. Fuente: Boletín Musical, 20-VIII-1898, p. 1283.

\begin{tabular}{|c|}
\hline PRIMER AÑO \\
\hline Nociones preliminares. \\
\hline Definición de solfeo. \\
\hline $\begin{array}{c}\text { Conocimiento de las notas, figuras, silencios, pentagrama, líneas adicionales, claves, compás, intervalos } \\
\text { mayores y menores, escala diatónica. }\end{array}$ \\
\hline Ejercicios y lecciones prácticas de intervalos conjuntos y disjuntos. \\
\hline $\begin{array}{l}\text { Movimientos del compás, llamados aires, puntillos hasta la corchea, silencios hasta los de semicorchea } \\
\text { inclusive, ligadura, calderón, compases de compasillo } 2 / 4 \text { y } 3 / 4 \text {, sostenido, bemol, becuadro, y su práctica, } \\
\text { sólo de grado en distancias de medio tono. }\end{array}$ \\
\hline $\begin{array}{c}\text { En las lecciones prácticas de este año, sólo se hace uso del tono de Do en clave de sol, y en las } \\
\text { combinaciones de medida, hasta la semicorchea inclusive y su silencio. }\end{array}$ \\
\hline Lectura a primera vista de lecciones manuscritas. \\
\hline SEGUNDO AÑO \\
\hline Conocimiento de los tonos y modos, compases binarios $3 / 8,6 / 8,9 / 8$ y $12 / 8$. \\
\hline Claves de Fa en cuarta línea y Do en primera. \\
\hline Apoyaturas y mordentes, doble puntillo, seisillos, intervalos aumentados y disminuidos. \\
\hline $\begin{array}{c}\text { En las lecciones prácticas no se hace uso más que de los tonos siguientes: la menor y hasta los que tienen } \\
\text { tres bemoles, y en las combinaciones de medida hasta la semifusa. }\end{array}$ \\
\hline Lectura a primera vista de lecciones manuscritas. \\
\hline TERCER AÑO \\
\hline Práctica de los tonos restantes. \\
\hline Clave de Do en segunda, tercera y cuarta y Fa en tercera. \\
\hline Dobles alteraciones. \\
\hline Combinaciones irregulares de medida. \\
\hline Géneros. \\
\hline Transportes. \\
\hline Compases de $6 / 4,7 / 4,5 / 4,5 / 8,10 / 8$ \\
\hline $\begin{array}{c}\text { Conocimientos de las principales abreviaturas, de las figuras y compases antiguos, y tablas de los } \\
\text { intervalos y sus inversiones. }\end{array}$ \\
\hline Lectura a primera vista de lecciones y manuscritos. \\
\hline
\end{tabular}

La materia del primer y tercer año está dividida en "dos grupos con el objeto que cada grupo pueda servir de curso en los Colegios y otros centros de enseñanza donde el estudio de la música se verifica, no como profesión, sino simplemente como una de tantas asignaturas de adorno"134. De manera que Amorós divide la materia de la siguiente forma:

para un curso de preparación (primer año, primer grupo)

primer curso (primer año, segundo grupo)

${ }^{133}$ Las obras de texto vigentes en la Escuela Nacional de Música en 1898 eran los métodos de Eslava, Moré y Gil, Pinilla y Llanos. Boletín Musical, 20-VIII-1898, p. 1283.

${ }^{134}$ Amorós, Teoría General, p. 8. 


\begin{abstract}
segundo curso (segundo año)
tercer curso (tercer año, primer grupo)

curso de ampliación (tercer año, segundo grupo) $)^{135}$
\end{abstract}

La Teoría General del Solfeo de Amorós, escrita en forma de preguntas y respuestas tuvo una acogida muy positiva:

El atildado y conspicuo maestro D. Amancio Amorós, cuya competencia en materia de música es universalmente reconocida, y cuyas obras son justamente admiradas, nos ha remitido un ejemplar de su Teoría General del Solfeo, obra completísima, razonada en forma de dialogo e ilustrada con profusión de ejemplos.

La obra del señor Amorós, que creemos de absoluta necesidad a cuantos piensen dedicarse al estudio de la música, es de una importancia tal, que no basta una ojeada a la ligera para poder hacerse cargo de ella. Nosotros la examinaremos más a fondo con objeto de consagrarle un artículo, pues bien lo merece una producción que, en nuestro concepto, es la más completa en su clase.

Felicitamos al Sr. Amorós por la nueva y docta producción y deseamos continúe proporcionando a la enseñanza libros tan útiles como el presente ${ }^{136}$.

La Teoría General del Solfeo de Amorós agotó su primera edición, sin embargo, aparentemente no tuvo ediciones posteriores, al menos en este formato ${ }^{137}$. Posiblemente en su bajo impacto influyó la existencia de obras de características similares de dos profesores del conservatorio valenciano, Teoría General del Solfeo (1896) de Antonio Marco Benlloch ${ }^{138}$ y los tratados Teoría de la Música (1879) y Teoría del Solfeo (1897) de Manuel Coronado Cervera. En 1908 Amorós presentó al claustro de profesores del

\footnotetext{
${ }^{135}$ Amorós, Teoría General, pp. 117-129.

${ }^{136}$ Gaceta Musical y de Teatros, 16-V-1897, p. 8.

137 E:Mba, legajo 5-2-2, Expediente de nombramiento de Amancio Amorós como Académico Correspondiente (1921).

${ }^{138}$ La obra Teoría General del Solfeo de Antonio Marco Benlloch fue adoptada como obra de texto en el Conservatorio de Valencia al menos durante el curso 1897-98, véase Boletín Musical, 10-XI-1897, p. 1062.
} 
Conservatorio de Música de Valencia una "Teoría general del solfeo dividida en tres secciones, cuya última parte estaba todavía en imprenta"139.

Posiblemente la obra presentada era Nociones Teóricas de Solfeo (1908-1909), y no la Teoría General del Solfeo. Todo hace pensar que las Nociones Teóricas de Solfeo son la reordenación de su Teoría General del Solfeo. El nuevo formato en tres volúmenes obedecería a razones comerciales ya que, como consta en otra obra del autor, la Teoría General del Solfeo era obra de texto en el Conservatorio valenciano al menos desde $1909^{140}$ :

Obras de texto del mismo autor en el Conservatorio de Música de Valencia. Teoría General del Solfeo. Esta obra es de aplicación a todos los métodos prácticos, elementales y superiores de solfeo, $2^{\prime} 50^{141}$.

\section{3. Nociones Teóricas de Solfeo (1908-1909)}

El tratado teórico Nociones Teóricas de Solfeo consta tres volúmenes distintos, para primer, segundo y tercer curso (véanse Apéndices 9, 10 y 11). La primera edición de los volúmenes primero y segundo es de 1908 y la del tercer volumen es de 1909. Los ejemplares de los tres cursos de Nociones Teóricas del Solfeo conservados en la Biblioteca de Catalunya contienen correcciones del propio Amorós y una reordenación de

\footnotetext{
${ }^{139}$ E:VAcm, Acta del claustro de profesores del Conservatorio de Música de Valencia, 27-XI-1907. Esta acta, aunque fechada en 1907, está en las correspondientes a 1908 por lo que pienso que hay un error en la fecha. La Teoría General del Solfeo se editó como obra conjunta en 1896. En 1908 Amorós publicó sus Nociones Teóricas de Solfeo, para primer y segundo curso y el tercer curso de estas Nociones Teóricas de Solfeo se editó en 1909.

${ }^{140}$ La posible reedición de su Teoría General del Solfeo en formato y título diferente explicaría el contenido de las actas de la Junta de profesores del Conservatorio de Música de Valencia de 27-XI-1907 y 8 -X-1910.

${ }^{141}$ El texto citado aparece en la contraportada del tercer curso de las Nociones Teóricas de Solfeo de Amorós (1909).
} 
las lecciones con vistas a una posterior edición de la obra (véanse Ilustraciones 26, 27 y $28)^{142}$

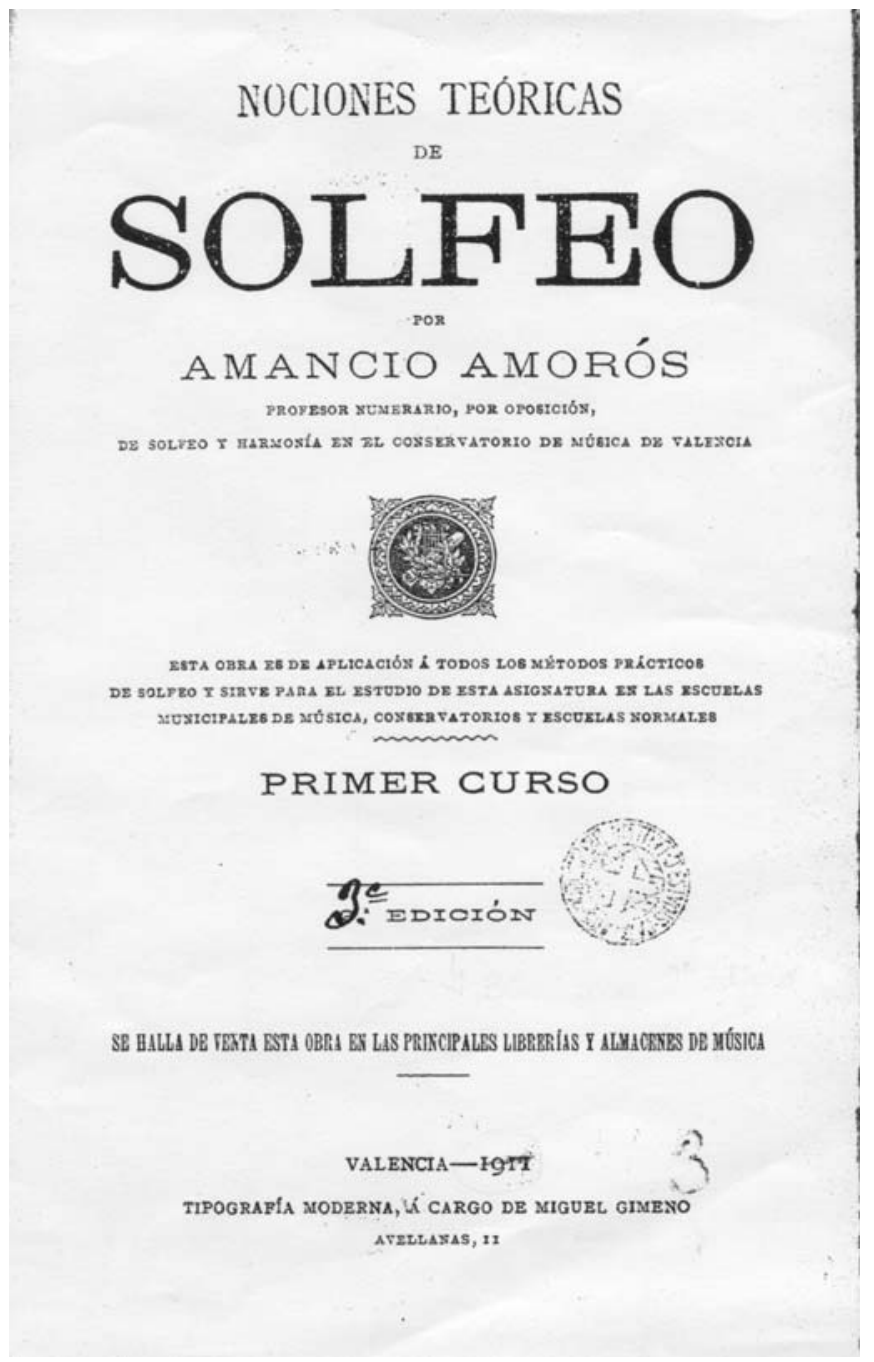

Ilustración 26

Amancio Amorós, Nociones Teóricas de Solfeo, primer curso, $2^{\mathrm{a}}$ ed. (1911). $E: B c, \mathrm{~F} 78-8-1917$.

El primer curso de estas Nociones Teóricas de Solfeo fue el que tuvo mayor repercusión y se reeditó en cuatro ocasiones (1911, 1916, 1925 y 1927). Los cursos segundo y tercero se reeditaron sólo en una ocasión, el segundo en 1916 y el tercero en 1924. Las Nociones Teóricas del Solfeo fueron declaradas en 1918 de utilidad para la

${ }^{142}$ E:Bc, F78-8-1917; Libro de Registro $n^{\circ} 24$ (1930-31), $\mathrm{n}^{\circ}$ de entrada 123866. 
enseñanza y de mérito en la carrera del Autor por la Real Academia de Bellas Artes de San Fernando y por la Comisión permanente del Consejo de Instrucción Pública ${ }^{143}$.

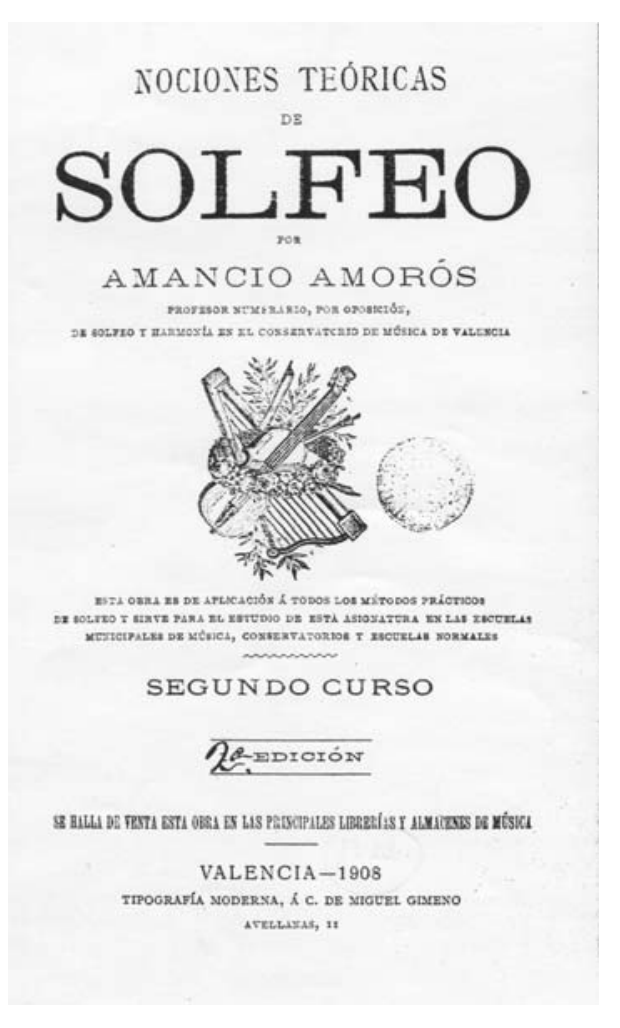

Ilustración 27

Amancio Amorós, Nociones Teóricas de Solfeo, segundo curso, $1^{\text {a }}$ ed. (1908).

$E: B c, \mathrm{~F} 78-8-1917$.

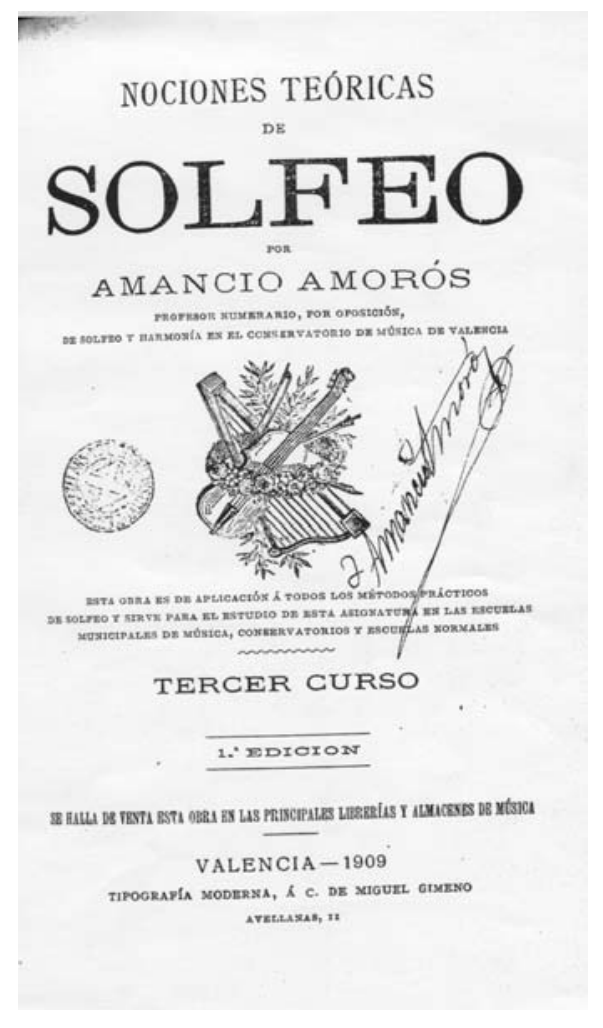

Ilustración 28

Amancio Amorós, Nociones Teóricas de Solfeo, tercer curso, $1^{\mathrm{a}}$ ed. (1909).

$E: B c, \mathrm{~F} 78-8-1917$.

Como en su Teoría General del Solfeo, en las Nociones Teóricas de Solfeo Amorós expuso la materia en forma de preguntas y respuestas. Aunque predomina el texto literario, Amorós insertó en las Nociones ejemplos musicales para ilustrar los conceptos teóricos. Las Nociones Teóricas de Solfeo podían utilizarse como textos complementarios de las Lecciones Manuscritas Graduadas, para segundo y tercer curso. El propio Amorós en sus Lecciones Manuscritas Graduadas aconseja:

\footnotetext{
${ }^{143}$ E:Mba, Actas de la sesiones celebradas por la Sección de Música de la Academia de Bellas Artes de San Fernando de Madrid, 13-V-1918 y 21-X-1918.
} 
Véase la teoría correspondiente a este tono en el $2^{\circ}$ curso de las Nociones Teóricas de Solfeo del mismo autor o en otra obra equivalente. Hágase lo propio siempre que en las lecciones de esta obra se encuentre alguna materia nueva ${ }^{144}$.

En las Nociones Teóricas de Solfeo Amorós no utiliza pentagramas de manera que los alumnos que no sabían aún leer música pudiesen aprender los conceptos, ver Ilustraciones 29 y 30 .

\section{LECCIÓN $\left.5\right|^{\mathrm{a}} \boldsymbol{2}$ \\ De la inversión de intervalos}

P. Qué es invertir un intervalo?

R. Invertir un intervalo es cambiar de posición las notas que lo forman, colocando la nota inferior encima de la superior ó viceversa. Ej.:

Intervalo propuesto: \& Inversiones. Mi-Do, subiendo. $\left\{6{ }^{a}\right.$

Do-mi, subiendo, 3. ${ }^{\text {? }}$ (Do-Mi, bajando. ?6

Ilustración 29

Amancio Amorós, Nociones Teóricas de Solfeo, $2^{\circ}$ curso, p. 11.

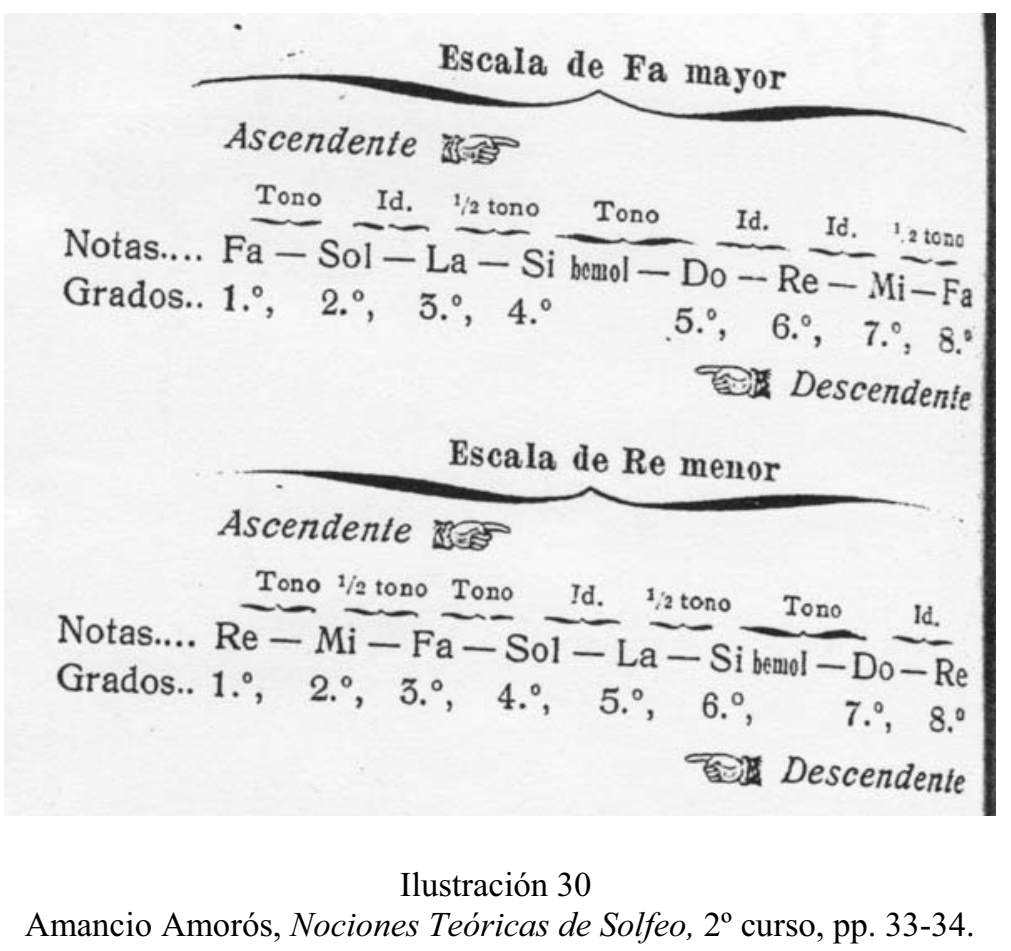

${ }^{144}$ Amancio Amorós, Lecciones Manuscritas Graduadas, $2^{\circ}$ curso (Valencia: Casa Dotesio, $1^{\mathrm{a}}$ ed., 1910), p. 4 . 
Amorós hizo donación en 1910 a la Biblioteca del Conservatorio de Valencia de los tres cursos de Nociones Teóricas de Solfeo, aunque tal y como se redactó el acta del claustro correspondiente, podría parecer que se trataba de su obra Teoría del Solfeo:

El señor Amorós regaló para la Biblioteca de este centro la Teoría del Solfeo, primero, segundo y tercer curso y la segunda parte de su método práctico ${ }^{145}$.

\section{4. Lecciones Manuscritas Graduadas (1910)}

El tratado de Solfeo Lecciones Manuscritas Graduadas se editó por primera vez en 1910 y se reeditó al menos en dos ocasiones más (1914 y otra sin fecha). He localizado los volúmenes correspondientes al segundo $\mathrm{y}$ tercer curso (véanse Ilustraciones 31 y 32) ${ }^{146}$. Con estas Lecciones Manuscritas Graduadas Amorós se propuso ofrecer de nuevo un método práctico de solfeo, únicamente con ejemplos musicales, y remitió para la teoría a las Nociones Teóricas de Solfeo ${ }^{147}$. El objetivo perseguido por Amorós, según lo expresó en el segundo curso de Lecciones Manuscritas Graduadas fue:

\footnotetext{
${ }^{145}$ E:VAcm, Acta de la Junta de profesores del Conservatorio de Música de Valencia, 8-X-1910. El acta menciona una teoría del solfeo, pero no la Teoría General del Solfeo. Me inclino a pensar que lo que Amorós regaló al centro en esa ocasión fueron los tres cursos de las Nociones Teóricas de Solfeo ya que su Teoría General del Solfeo se editó como una obra conjunta. La "segunda parte de su método práctico" que menciona el acta se correspondería probablemente con el segundo curso de las Lecciones Manuscritas Graduadas (1910).

146 E:Mba, legajo 5-2-2, Expediente de nombramiento de Amancio Amorós como Académico Correspondiente (1921); Sobrino, "Amorós Sirvent, Amancio", p. 420, menciona este tratado como Curso de Solfeo manuscrito editado por la Unión Musical Española. No he localizado el primer curso de estas Lecciones Manuscritas Graduadas. Tal vez Amorós considerase sus Tres lecciones de solfeo manuscrito a una y dos voces con acompañamiento de armónium y piano (sf), como la primera parte de este tratado. La Biblioteca de Catalunya conserva un ejemplar del segundo curso de Lecciones Manuscritas Graduadas con correcciones para una nueva edición. E:Bc, F 78-8-1917; Libro de Registro $n^{o} 24$ (1930$31), \mathrm{n}^{\circ}$ de entrada 123938. Al lado del título se añadió a lápiz "Curso $2^{\circ}$ y $3^{\circ}$ ". E: Msa, conserva el ejemplar reeditado en 1914 del $2^{\circ}$ curso, Me-24202-3/401.
}

${ }^{147}$ Amorós, Lecciones Manuscritas, $2^{\circ}$ curso, p. 4; Amorós Lecciones Manuscritas, $3^{\text {er }}$ curso, p. 8. 
Aportar a la enseñanza de tan interesante asignatura algo práctico y pedagógico de lo mucho que hemos podido observar en nuestra ya larga práctica de la enseñanza musical ${ }^{148}$.

\section{SEGUNDO CURSO DE SOLFEO}

\section{[ecciones :}

\section{Manuscritas Graduadas}

\section{por Amancio oxtmorós}

Profesor numerario, por oposicion.

Se soffeo y harmonia en el Conservatorio Se Inúsica Se Valencia.
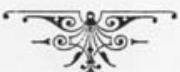

$x^{2} x^{2}$

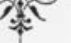

Fijo: 3 pesetas

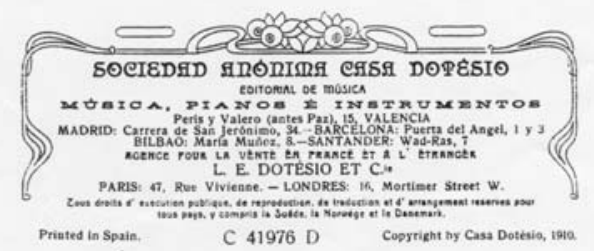

Ilustración 31

Amancio Amorós, Lecciones Manuscritas Graduadas, segundo curso, $1^{\mathrm{a}}$ ed. (1910). $E: B c, 73-F o l-C 4 / 35$.

\footnotetext{
${ }^{148}$ Amorós, Lecciones Manuscritas, $2^{\circ}$ curso, p. 1.
} 


\section{= [ecciones :}

\section{Manuscritas Graduađas}

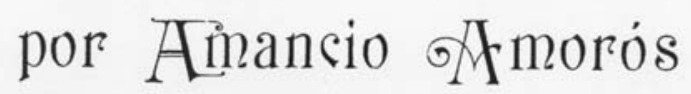

Profesor numerario, por oposición

Se soffeo y fiarmonía en el Conservatorio ठe Inúsica ठe Vafencia
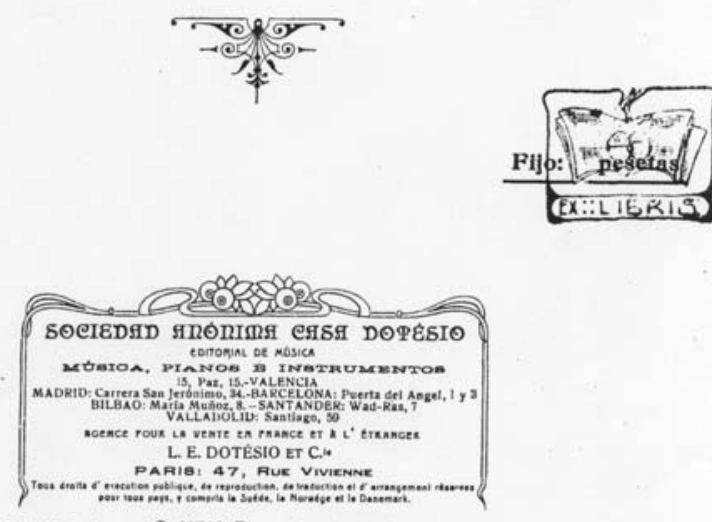

Pristed in Spain C 42718 D Copyrizat by Cas Doteteio, 192

Ilustración 32

Amancio Amorós, Lecciones Manuscritas Graduadas, tercer curso, $2^{\mathrm{a}}$ ed. (1914). E:Msa, Me-24202-3/401.

Las cuarenta y cinco lecciones del segundo curso Lecciones Manuscritas Graduadas se desarrollan en una tesitura de $\mathrm{Do}^{1}$ a $\mathrm{Re}^{5}$, y en ellas Amorós utilizó básicamente las claves de Sol, Fa en $4^{\mathrm{a}}$ y Do en $1^{\mathrm{a}}$ (véase Apéndice 12). La complejidad de esta obra era mucho mayor que la de los Elementos de Solfeo, concebidos como un método elemental para iniciar al alumnado en la práctica del solfeo. En las Lecciones Manuscritas Graduadas no hay ningún ejercicio de solfeo rítmico ni de entonación (que, 
en cambio, sí se incluyen en los Elementos de Solfeo). Según Loras, Amorós fue el primer autor que introdujo ejemplos prácticos del triple y cuádruple puntillo ${ }^{149}$.

En 1911 las Lecciones Manuscritas Graduadas fueron adoptadas como libro de texto para tercer curso de solfeo en el Conservatorio de Música de Valencia ${ }^{150}$. Amorós quería con esta obra cubrir carencias de otros métodos de solfeo:

En el Tercer curso de solfeo Lecciones Manuscritas Graduadas hemos procurado reunir, además de la gradación referente al conocimiento y práctica de las claves, tonos, compases, etc., algunas materias que en muchos métodos de gran extensión se han omitido; las cuales no hemos dudado en exponer en esta obra por el interés que en sí encierran, y, además, como consecuencia lógica del plan que ordenadamente hemos venido desarrollando desde la publicación de las obras antes anunciadas hasta la presente ${ }^{151}$.

El tercer curso de las Lecciones Manuscritas Graduadas contiene 50 lecciones, con una extensión que abarca del $\mathrm{La}^{1}$ al $\mathrm{Do}^{5}$, entre las que Amorós inserta ejercicios comparativos de varios compases (véase Ilustración 33). Este volumen sigue las mismas pautas que el segundo, pero todavía con mayor complejidad, y dificultades métricas y de entonación (véase Apéndice 13). A partir de la lección 41, en aquellas lecciones en las que utiliza varias claves, Amorós indica "se ejecutarán las notas observando la relación de sonido que en aquellas representen"152.

\footnotetext{
${ }^{149}$ Reguart en sus Elementos musicales (1839) habló del cuádruple puntillo pero sin poner ejemplos; en 1860 Manent en su Método teórico-práctico musical habló del triple puntillo y Lladó ese mismo año, puso ejemplos del triple puntillo (pero no del cuádruple) en su Método analítico para el estudio del solfeo. En 1888, Sabatés en su Curso completo de solfeo vuelve a mencionar el triple puntillo. Véase Loras, Estudio de los métodos, pp. 494-495.

${ }^{150}$ E:VAcm, Acta de la Junta de profesores del Conservatorio de Música de Valencia, 8-X-1911. El acta dice textualmente: "Los manuscritos de Amorós eran obra de texto para tercer curso de solfeo".

${ }^{151}$ Amorós, prólogo a las Lecciones Manuscritas, tercer curso, 1914, p. 4.

152 Amorós, Lecciones Manuscritas, tercer curso, 1914, p. 36.
} 
Las Lecciones Manuscritas Graduadas fueron declaradas en 1918 de utilidad para la enseñanza y de mérito en la carrera del Autor por la Real Academia de Bellas Artes de San Fernando y por la Comisión permanente del Consejo de Instrucción Pública ${ }^{153}$.

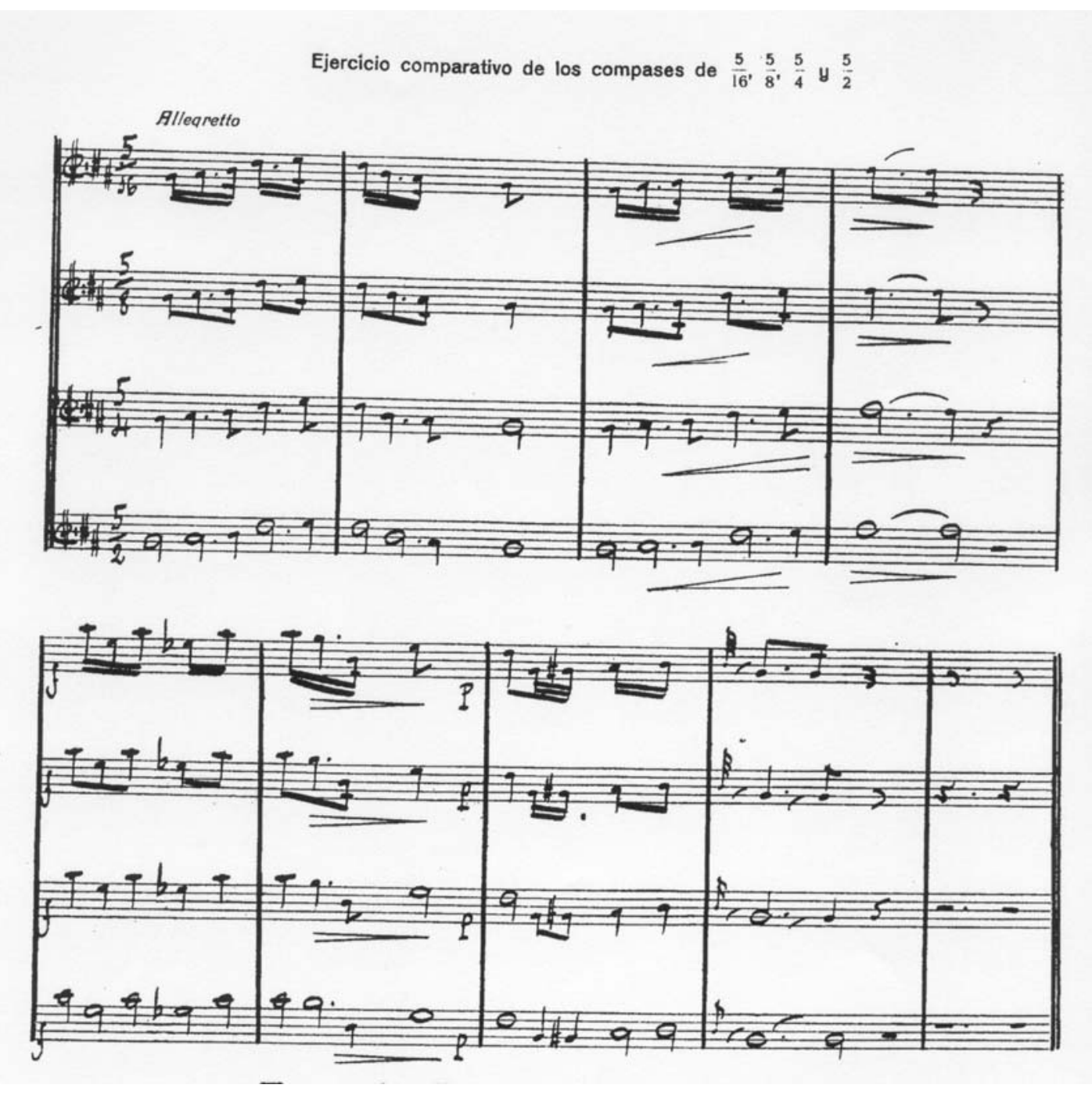

Ilustración 33

Amancio Amorós, Lecciones Manuscritas Graduadas, $3^{\text {er }}$ curso, p. 38.

${ }^{153}$ E:Mba, Actas de la sesiones celebradas por la Sección de Música de la Academia de Bellas Artes de San Fernando de Madrid, 13-V-1918 y 21-X-1918. 


\section{5. Lecciones de Solfeo manuscrito a una y dos voces $(\mathrm{sf})^{154}$}

En el Archivo del Conservatorio Superior de Música de Valencia he localizado tres lecciones de solfeo con acompañamiento de armónium y piano (sf) de Amorós que se conservan manuscritas e inéditas: Solfeo a dos voces $n^{o} 1$, Lección de solfeo $n^{\circ} 2$, Solfeo a dos voces $n^{o} 3^{155}$. Cada una de estas lecciones queda constituida por la partitura general y las particellas manuscritas, destinadas al armónium, piano y a cada una de las voces ${ }^{156}$.

La finalidad de estas lecciones era su interpretación en las audiciones celebradas anualmente en el salón de actos del Conservatorio de Valencia ${ }^{157}$. Según Fontestad, en estas audiciones participaban entre diecisiete y cuarenta y seis alumnos de la asignatura de solfeo, de ahí que se conserven varias particellas de cada parte ${ }^{158}$. Estas lecciones de solfeo no utilizan material de los métodos de solfeo del autor, son de nueva creación. Presento una edición de las mismas en el Apéndice 6.

\section{6. Obras didácticas de armonía, piano y composición}

Programa de Amancio Amorós para la asignatura de Armonía del Conservatorio de Música de Valencia (1916)

En 1916 Amorós presentó en el Conservatorio de Valencia su nuevo plan de estudios para la asignatura de Armonía ${ }^{159}$ (Véase Apéndice 16). Dividía la materia en tres

\footnotetext{
${ }^{154}$ El título editorial no consta en el original. He agrupado estas tres lecciones manuscritas bajo la denominación de Lecciones de Solfeo manuscrito a una y dos voces.

${ }^{155}$ E: $V A c m$, SF- I/1-3. Faltan las particellas del armónium y piano de la Lección $n^{o} 3$. Hay también varias lecciones de solfeo manuscrito de Salvador Giner (SF- II/8-13), Emilio Masó (SF- I/7), otras anónimas y algunos estudios de Ambrosio Thomas y de Hilarión Eslava.

${ }^{156}$ Solfeo a dos voces $n^{o} 1,1$ partitura (6 pp.), $1^{\mathrm{a}}$ voz (9 papeles, $2 \mathrm{pp}$. cada uno), $2^{\mathrm{a}}$ voz (9 papeles, $2 \mathrm{pp}$. cada uno), armónium (2 pp.), piano (2 pp.); Lección de solfeo $n^{\circ} 2,1$ partitura (8 pp.), 2 particellas de piano (3 pp.), armónium (2 pp.), 14 particellas de voces (coro); Solfeo a dos voces $n^{o} 3$, 1 partitura (11 pp.), tiples primeras ( 9 papeles, 2 pp.), tiples segundas (9 papeles, 2 pp.), faltan papeles de armónium y piano.

${ }^{157}$ Boletín Musical, 30-I-1895, p. 377.

${ }^{158}$ Fontestad, El Conservatorio de Música, p. 453.

${ }^{159}$ E:VAcm, Acta de la Junta de Gobierno del Conservatorio de Música de Valencia, 29-X-1916.
} 
cursos, el último para ampliar y profundizar en todo lo estudiado en cursos anteriores. La programación de Amorós resulta densa si la comparamos con la división de Armonía en cuatro cursos que en esa época hacían los profesores del Conservatorio de Música y Declamación de Madrid, Valentín de Arín y Pedro Fontanilla en su tratado Estudios de Harmonía, Lecciones Teórico-prácticas ${ }^{160}$. El primer curso de Amorós correspondía aproximadamente con el primer y segundo curso de Arín y Fontanilla, y el segundo curso de Amorós equivalía a los cursos tercero y cuarto de los profesores de armonía de Conservatorio de Madrid.

\section{Método elemental de piano $(\mathrm{sf})$}

Amancio Amorós es autor de un Método elemental de piano, fruto de la experiencia acumulada por Amorós desde su juventud como profesor particular de piano de alumnos de las clases acomodadas valencianas y posteriormente en varias instituciones valencianas como el Conservatorio, la Institución para la Enseñanza de la Mujer o la Academia Amorós. El Método elemental de piano no llegó nunca a editarse y tampoco se conserva manuscrito en el legado Amorós conservado en la Biblioteca de Catalunya $^{161}$. La información que me permite afirmar esta hipótesis es la ofrecida por el expediente de nombramiento de Amorós como Académico Correspondiente de la Real Academia de Bellas Artes de San Fernando Madrid que menciona "Obras didácticas inéditas: Método elemental de piano"162.

\footnotetext{
${ }^{160}$ Valentín de Arín y Pedro Fontanilla, Estudios de Harmonía, Lecciones Teórico-Prácticas para el uso de las clases del Conservatorio de Música y Declamación, Curso Primero (1905), Segundo (1910), Tercero (1910), Cuarto (1910) (Madrid: A. Pontones litógrafo).

${ }^{161}$ Sobrino, “Amorós Sirvent, Amancio" p. 420, afirma que este método fue editado en Valencia por Casa Dotesio, pero el Método elemental de piano de Amorós no llegó a editarse.

162 E:Mba, legajo 5-2-2, Expediente de nombramiento de Amancio Amorós como Académico Correspondiente (1921).
} 
Un posible tratado de composición de Amorós (sf)

El legado Amorós incluye un Tratado de Composición anónimo, incompleto y manuscrito, cuya autoría está por determinar ${ }^{163}$. En un principio podría pensarse que este Tratado de Composición fuese obra de Amorós, pero también podría haber sido escrito por Salvador Giner. Manuel Sancho mencionó la existencia de un Tratado de Composición que Giner dejó inacabado, manuscrito e inédito ${ }^{164}$. Amorós sustituyó a Giner en las clases de composición del Conservatorio de Valencia entre 1906 y 1910, así que es posible que el tratado fuera obra de Giner y hubiera acabado en manos de Amorós. Lo que se conserva de este tratado está dividido en tres capítulos:

1. Elementos del discurso, sobre las características que debe presentar la frase musical.

2. Del periodo.

3. Estructuras de las piezas instrumentales, vocales e instrumentales de música religiosa y vocales e instrumentales de música dramática.

${ }^{163} E: B c, \mathrm{M} 1303$.

164 “Queda fuera de dudas, sin embargo, que Giner redactó para el Conservatorio un tratado de armonía y composición, obra que no llegó a completar al sobrevenirle la muerte y que, por tanto, quedó inédita"; véase Sancho, El compositor Salvador Giner, pp. 84-85. No he podido localizar el Tratado de Giner para establecer una posible comparación entre ambos y (si es que eran dos tratados diferentes) tampoco he podido constatar la noticia, aparecida según Sancho en La Época (Madrid) el 20-III-1901. 
CAPÍTULO 4

ACTIVIDAD MUSICOLÓGICA DE AMANCIO AMORÓS 



\section{Relación entre Amancio Amorós y Felipe Pedrell}

Entre Amancio Amorós y Felipe Pedrell hubo, además de admiración profesional mutua, una relación amistosa que puede documentarse gracias a la correspondencia del fondo Pedrell conservada en la Biblioteca de Catalunya y al artículo de Amancio Amorós "Impresiones", publicado dentro de los Escritos heortásticos (1911) dedicados a Felipe Pedrell en la conmemoración de su 70 aniversario, por "los amigos de siempre, los entusiastas consecuentes y convencidos"1.

\section{1. "Impresiones": un homenaje de Amorós a Pedrell}

En la polifacética personalidad de Amancio Amorós hay que mencionar su faceta de escritor e impulsor de publicaciones musicales. La admiración que Amorós sentía por Pedrell quedó de manifiesto en su artículo "Impresiones", publicado dentro de los Escritos heortásticos al Maestro Pedrell, ver Apéndice $20^{2}$. Amorós participó en este homenaje junto con importantes músicos y musicólogos, como Eduardo López-Chavarri Marco, Rafael Mitjana, Camile Bellaigue, Giovanni Tebaldini, Luis Millet, Vicente Ripollés, Henri Collet, Hugo Riemann y Dom Maur Sablayrolles, entre otros ${ }^{3}$.

\footnotetext{
${ }^{1}$ Escritos heortásticos al Maestro Pedrell, p. V. El padre Nemesio Otaño promovió un homenaje que Tortosa, ciudad natal de Pedrell, hizo a Felipe Pedrell durante los días 28, 29 y 30 de octubre de 1911. Otaño organizó y dirigió además la publicación de la obra Escritos heortásticos en honor a Pedrell. Véase Música Sacro-Hispana, 4/11 (1911), monográfico dedicado a Pedrell, "como adhesión al grandioso homenaje iniciado en su honor por el Orfeó Tortosí”. Otaño obtuvo del Papa Pío X una distinción para Pedrell y la Santa Sede y varios prelados españoles enviaron escritos alabando la personalidad de Pedrell, por su protección a la música religiosa. Véase López-Calo, “Felip Pedrell”, p. 177.

${ }^{2}$ La etimología de la palabra "Heortástico" muestra los siguientes componentes griegos: Eo $\rho \tau \eta,-\eta \varsigma$, fiesta, solemnidad, día de fiesta, diversión y $\Sigma \tau \imath \chi o \varsigma,-o v$, verso, línea. El significado de la palabra podría traducirse como versos festivos o relativos a una festividad.

3 Sobre estos músicos véase Díaz y Galbis, "López-Chavarri Marco, Eduardo”, pp. 1043-1047; Emilio Casares, "Mitjana, Rafael”, en DMEH, vol. 7 (2000), pp. 623-624; Gustave Ferrari/Malcolm Turner, "Bellaigue, Camille", en TNG, vol. 3 (2002), p. 186; Vicente M ${ }^{\text {a }}$ de Gibert, "Camille Bellaigue", La Vanguardia, 6-XII-1930, p. 5; Sergio Lattes, "Tebaldini, Giovanni”, en TNG, vol. 25 (2002), p. 188; Lluís Millet i Loras, "Millet i Pagès, Lluís", en DMEH, vol. 7 (2000), pp. 576-581; Andrea Bombi, "Ripollés Pérez, Vicente", en DMV, vol. 2 (2006), pp. 344-346; Picó, "La aportación musicológica", pp. 287-288; Jacinthe Harbec/ Nicole Paiement, "Collet, Henri”, en TNG, vol. 6 (2002), pp. 121-122; Brian Hyer/ Alexander Reihding, "Riemann, Hugo", en TNG, vol. 21 (2002), pp. 362-366.
} 
La estructura de los Escritos heortásticos es como sigue:

1) Preliminares: prólogo de Nemesio Otaño, Breve de Pío X y cartas de adhesión y manifestaciones de Dom André Mocquereau, Enrico Bossi (director del Liceo Musical de Bolonia), Gius Terrabugio (profesor), Camille Bellaigue (crítico musical) y distintos obispos y arzobispos de varias diócesis españolas.

2) Escritos heortásticos:

a) Sobre la personalidad y la obra en general de Pedrell.

b) Sobre la obra erudita de investigación en general y reparación de lo tradicional en lo particular.

c) Sobre la lírica nacionalizada y el drama lírico.

3) Escritos heortásticos varios.

4) Escritos históricos o técnicos.

5) Suplemento con notas biográficas, bibliográficas e índices ${ }^{4}$.

La Tabla 27 muestra el detalle de los autores que participaron en el volumen y los títulos de sus aportaciones. El artículo "Impresiones" de Amorós se insertó en el apartado de la "obra erudita de investigación en general y reparación de lo tradicional en particular” y giró en torno a tres ideas básicas: 1) Circunstancias en las que se conocieron Amancio Amorós y Felipe Pedrell; 2) Amorós y la Ilustración Musical Hispanoamericana; 3) Pedrell y la ópera nacional.

\footnotetext{
${ }^{4}$ Escritos heortásticos, vol. 2, pp. 53-57.
} 
Tabla 27. Escritos heortásticos al Maestro Pedrell.

Fuente: Escritos heortásticos, 1911.

\begin{tabular}{|c|c|}
\hline Autores & Artículo \\
\hline \multicolumn{2}{|c|}{ Sobre la personalidad y obra en general } \\
\hline Campa, Gustavo & "El Maestro Pedrell" \\
\hline Caramanchel, Ricardo Catarineu & $\begin{array}{c}\text { "Ópera española: Felipe Pedrell, su vida y sus } \\
\text { obras" }\end{array}$ \\
\hline López-Chavarri, Eduardo & $\begin{array}{l}\text { "Felipe Pedrell et son oeuvre dans l'art } \\
\text { musical" }\end{array}$ \\
\hline Collet, Henri & $\begin{array}{c}\text { "Felipe Pedrell et la musique espagnole } \\
\text { moderne" }\end{array}$ \\
\hline Goberna, Roberto & $\begin{array}{c}\text { "Felipe Pedrell: su personalidad y su obra en } \\
\text { general (Pedrell crítico: Pedrell conferenciante } \\
\text { y obra docente)" }\end{array}$ \\
\hline Jordán de Urríes, José & "Pedrell como conferenciante: Recuerdos" \\
\hline Mestre y Noé, Francisco & "L'homenatge a Pedrell" \\
\hline Morera y Galicia, Magín & "Entre amigos" \\
\hline \multicolumn{2}{|c|}{$\begin{array}{l}\text { Sobre la obra erudita de investigación en general y reparación de lo tradicional en } \\
\text { particular }\end{array}$} \\
\hline Amorós, Amancio & "Impresiones", \\
\hline Chabás, Roque & "En Felip Pedrell" \\
\hline Ortiz, Ramón & "Anécdota" \\
\hline Ripollés, Vicente & $\begin{array}{c}\text { "La obra del maestro Pedrell en la restauración } \\
\text { de la música religiosa" }\end{array}$ \\
\hline Viñaspre, Francisco de P. & $\begin{array}{l}\text { "Modesto y sincero homenaje al maestro } \\
\text { Pedrell" }\end{array}$ \\
\hline \multicolumn{2}{|c|}{ Sobre la lírica nacionalizada y el drama lírico } \\
\hline Bellaigue, Camille & $\begin{array}{c}\text { "Un opera national espagnol: Los Pirineos } \\
\text { Un Tristán espagnol: La Celestina de Felipe } \\
\text { Pedrell" }\end{array}$ \\
\hline Bonaventura, Arnaldo & $\begin{array}{l}\text { "La Celestina: Tragicomedia lírica de Calixto y } \\
\text { Melibea, música del maestro Felipe Pedrell"" }\end{array}$ \\
\hline Calvocoressi, Michel Dimitri & "M. Felipe Pedrell et le drame lyrique espagnol" \\
\hline López-Chavarri, Eduardo & "El nacionalismo en la música española" \\
\hline Curzón, Henri & $\begin{array}{l}\text { "Une nouvelle ouvre de Felipe Pedrell: La } \\
\text { Celestina" }\end{array}$ \\
\hline Dagnino, Edoardo & $\begin{array}{l}\text { "L'opera di Pedrell nel movimento musicale } \\
\text { moderno" }\end{array}$ \\
\hline Galli, Amintore & "Diffusione dell'opera" \\
\hline Gasco, Alberto & $\begin{array}{l}\text { "Un grande compositore musicale spagnuolo: } \\
\text { Felipe Pedrell" }\end{array}$ \\
\hline Gibert, Vicente $\mathrm{M}^{\mathrm{a}}$ de & "La Glosa" \\
\hline Millet, Luis & "La Celestina, del mestre Felip Pedrell" \\
\hline Mitjana, Rafael & $\begin{array}{c}\text { "Los Pirineos } \\
\text { Música del Porvenir. La Celestina } \\
\text { Felipe Pedrell et Les Pyrénées" }\end{array}$ \\
\hline Ortiz y San Pelayo, Félix & "Pedrell" \\
\hline Tebaldini, Giovanni & "Fillipo Pedrell ed il dramma lirico espagnuolo" \\
\hline Urgellés, Manuel & "Pedrell, fundador de la ópera nacional" \\
\hline \multicolumn{2}{|c|}{ Escritos heortásticos varios } \\
\hline Bonaventura, Arnaldo & “Omaggio a Filippo Pedrell" \\
\hline Guinot, Salvador & "Per Pedrell" \\
\hline Landerer, José & "El criterio del arte musical" \\
\hline Lliurat, F. & “L’energia d'En Pedrell”' \\
\hline
\end{tabular}




\begin{tabular}{|c|c|}
\hline Nin, J. Joaquín & "Vida y Gloria" \\
\hline Oliva y Milà, Joan & "Ramón Lull" \\
\hline Rofas, Cosme & "El maestro Pedrell" \\
\hline Sebastián Besora, Enrique & "Pedrell y Tortosa" \\
\hline Serrano, Andrés & "Las fuentes de inspiración de Pedrell" \\
\hline \multicolumn{2}{|c|}{ Escritos Históricos o Técnicos } \\
\hline Radiciotti, Giuseppe & $\begin{array}{l}\text { "Due musicisti spagnoli del secolo XVI in } \\
\text { relacione con la Corte di Urbino" }\end{array}$ \\
\hline Riemann, Hugo & “Giebt es Doppel-Harmonien?" \\
\hline Sablayrolles, Dom Maur & "Une notation grégorienne espagnole" \\
\hline Suñol, Gregori M ${ }^{\mathrm{a}}$ & "Font de bellesa" \\
\hline
\end{tabular}

Circunstancias en las que se conocieron Amancio Amorós y Felipe Pedrell

Amorós conoció a Pedrell en Valencia en 1876. La Real Sociedad Económica de Amigos del País de Valencia, para conmemorar el centenario de creación de la entidad, convocó un concurso de composición al que Pedrell presentó cuatro obras: el motete Bone Pastor a cuatro voces, gran orquesta y órgano, un Te Deum a cuatro voces, coro, gran orquesta, órgano y arpas, una Misa de Requiem a cuatro voces en estilo a cappella y una Misa solemne de Gloria a tres voces a solo (soprano, tenor, bajo), coro, gran orquesta, órgano y arpa. Estas obras, escritas según el propio Pedrell "en el espacio de un mes y medio", fueron premiadas por unanimidad y se interpretaron en junio de 1876 bajo la dirección del propio Pedrell ${ }^{6}$. Amorós era, en 1876, un joven de 22 años que empezaba a interesarse por la composición y, según se desprende de sus propias palabras, las obras de Pedrell le causaron una profunda admiración:

Por el año 1876, celebró un concurso musical la Sociedad de Amigos del País de Valencia en conmemoración del centenario de dicha corporación.

El nombre de Pedrell sonó en mis oídos por primera vez. El jurado calificador de las obras presentadas a dicho certamen había premiado, por unanimidad, un Motete, un Te Deum, una Misa de Requiem y otra de Gloria, de D. Felipe Pedrell. Al indagar que los ensayos de estas obras iban a ser dirigidos por el autor, sentí vivísimos deseos de presenciarlos. [...] En aquella época yo había terminado los

\footnotetext{
${ }^{5}$ Felipe Pedrell, Jornadas de Arte (París: Ed. Garnier, 1911), p. 87.

${ }^{6}$ E:VAseap, C. $201, \mathrm{n}^{\circ} 1$, C. $201, \mathrm{n}^{\circ} 2$; C. $202, \mathrm{n}^{\circ} 1$, C. $202, \mathrm{n}^{\circ} 2$, Obras musicales premiadas por la Sociedad en el Certamen extraordinario conmemorativo de su primer centenario (1876); Ranch, "La música", p. 63.
} 
estudios de piano y estaba consagrado al estudio de la composición. El efecto que me produjeron las obras de referencia fue como una revelación. ¡Con qué devoción y recogimiento de espíritu las oía! [...]. Recuerdo que al final de uno de los ensayos, no pude menos de exclamar [...] ¡Ésta es la verdadera música religiosa! [...]. Entre las mil enhorabuenas, abrazos y apretones de manos que le dieron al músico premiado se confundieron los míos: con esto quedó sellada mi admiración hacia el maestro Pedrell ${ }^{7}$.

Estas obras religiosas de Pedrell, que causaron la admiración del joven Amancio Amorós, presentaban las características propias de la música religiosa de la segunda mitad del siglo XIX, con un gran acompañamiento orquestal, que López-Calo califica como "estilo eslaviano", y que después el propio Pedrell rechazó y criticó. Con estas obras, compuestas antes de su viaje a Italia en 1876-77, Pedrell cerró un periodo de su vida como compositor de música religiosa ${ }^{9}$. La opinión de Pedrell respecto a las obras religiosas que estrenó en Valencia en 1876 era la siguiente:

Salvo la Misa de Requiem que hoy mismo se hallaría dentro de las prescripciones del Motu Proprio, las demás son obras de cierto carácter religioso, un tanto dramatizado, que hoy rechazaría (y de hecho rechazo sin remisión), porque habiendo predicado, después de aquella fecha, en pro de la rehabilitación y enaltecimiento de la música verdaderamente litúrgica, tanto antigua como moderna, me hallaría en contradicción conmigo mismo y la dignificación que reclama el cultivo de esta manifestación del arte, la más sublime por excelencia, tanto por lo que atañe a la dignidad del arte por cuanto por lo que reclama la liturgia.

En la Misa en cuestión se ponen en música textos que sólo debe pronunciar o entonar el celebrante, se dramatizan humanamente, con demasía reprobables, así la Misa, como el Motete y el Te Deum; podrían salvarse, quizá, algunos fragmentos que acusan, como vago recuerdo, las influencias nacidas en la edad infantil en el coro de la capilla donde recibí mis primeras impresiones musicales. Mas con esto no quiero decir que las tres composiciones no sean reprobables. Lo son, en efecto, y como tales, repito, las rechazo por completo y $\sin$ resquemores de ninguna clase ${ }^{10}$.

\footnotetext{
${ }^{7}$ Amorós, “Impresiones”, p. 259.

${ }^{8}$ Estilo del que eran representantes en España Hilarión Eslava y Mariano García, entre otros.

${ }^{9}$ López-Calo, "Felip Pedrell”, p. 5.

${ }^{10}$ Pedrell, Jornadas de Arte, pp. 88-89.
} 
López-Calo sitúa el inicio del cambio de ideas respecto a lo que sería la esencia de la música religiosa en el viaje de Pedrell a Italia en 1876. A partir de 1882 Pedrell se centró en otras actividades distintas a la composición ${ }^{11}$.

Amorós y la Ilustración Musical Hispanoamericana (1888-1896)

La Ilustración Musical Hispanoamericana fue una publicación quincenal dirigida por Felipe Pedrell que se editó entre enero de 1888 y diciembre de $1896^{12}$ y desapareció, según palabras del propio Pedrell, por la "incultura musical reinante"13. Según Amorós, su amistad con Pedrell surgió a partir de la publicación de la Ilustración Musical Hispanoamericana:

De la publicación de la Ilustración Musical HispanoAmericana nació mi amistad con D. Felipe Pedrell. Consultas sobre arte que le hice; obras mías que se publicaron en dicha revista; juicios críticos de mis obras, que se dignó emitir y publicar, todo ello fue motivo más que suficiente para existir entre los dos una corriente de simpatía y una honrosa satisfacción para mí, al ser atendido por tan distinguido músico.

Pedrell, al dirigir la mencionada revista, se propuso, quién lo duda, hacer de ella una obra de cultura y de ilustración musical. Todos sus esfuerzos se dirigieron a conseguir dicho fin. ¿Obtuvo el resultado que se propuso? El mismo maestro contesta cumplidamente en el capítulo XX de su reciente obra titulada Jornadas de Arte. En dicha obra hace constar la "Calle de Amargura" (perdone el maestro el símil) que sufrió en los nueve años de existencia que tuvo la Ilustración ${ }^{14}$.

\footnotetext{
${ }^{11}$ López-Calo, “Felip Pedrell”, pp. 164-177.

${ }^{12}$ La Ilustración publicaba veinticuatro números anuales que salían los días 15 y 30 de cada mes. Cada número estaba constituido por ocho páginas de texto en las que se insertaban artículos de literatura musical en general, artículos biográficos y críticos, un "Boletín de la Quincena", que contenía una sección de bibliografía musical, y noticias artísticas de España y del extranjero. El texto se ilustraba con retratos de personalidades musicales (nacionales y extranjeras) y grabados. Con cada número se repartían ocho páginas de música en papel satinado; cuatro de ellas de "Música escogida" para piano, canto y piano, piano y violín, música coral, etc. Las cuatro páginas restantes estaban destinadas a una "Sección Especial", con música fácil y bailable para piano, Valses, Schotisch, Mazurcas, Rigodones, Habaneras, Tangos, Minuetos, Gavotas, etc. Se dedicaba una página especial a las mujeres suscriptoras con grabados de figurines de París. También se publicaba un Álbum musical anual formado por unas cincuenta piezas con distinto grado de dificultad. Ilustración Musical Hispanoamericana, 1892-1893, prospecto para 1894, sin paginar.

${ }^{13}$ Pedrell, Jornadas de Arte, p. 201.

${ }^{14}$ Amorós, "Impresiones”, p. 260.
} 
El propio Pedrell comentó que la publicación de la Ilustración Musical Hispanoamericana le había acarreado más de un disgusto, porque muchos compositores querían controlar lo que se decía sobre ellos, pero poniéndolo en boca de Pedrell:

\begin{abstract}
La cuestión de los retratos de los vivos, y las musiquitas que ellos suelen componer para admiración de la clientela, con vistas a la posteridad, nos llena de desazones a todos los que intervenimos en eso de ilustrar musicalmente a los hispanoamericanos. Todo el mundo quiere contemplarse en efigie, acompañado del texto autobiográfico trazado por el interesado, por supuesto, pero... firmado por mí, para que el "qué honor para la familia" resulte y se agradezca. Todo el mundo ha compuesto o ha cometido el crimen de componer una mazurca [...] y hay que contentar [...] a la clientela, al corresponsal, al repartidor [...], de lo contrario las listas de alzas y bajas de subscripción se registran unos barosismos tan terribles que llenan de espasmo á los epicentros editoriales. Hay que contentar a todos, a los que quieren música seria, y a los que sólo tienen tragaderas para la bazofia musical $[\ldots]^{15}$.
\end{abstract}

La Ilustración Musical Hispanoamericana editó algunas obras de Amorós. En los números 50, 53 y $76(1890,1891)$ se publicaron tres de sus mazurcas para piano $(\operatorname{Re} b$ Mayor, Sol Mayor y Re menor) y en el número 214 (1896) su melodía para canto y piano Recuerdo de Amor, y además en esta publicación apareció el perfil biográfico y el retrato del compositor ${ }^{16}$. Después de leer el texto de Pedrell afirmando que "todo el mundo ha compuesto o ha cometido el crimen de componer una mazurca", sorprende que Amorós presumiera de las obras suyas que aparecieron en la Ilustración.

\title{
Pedrell, Amorós y la ópera nacional
}

La preocupación por el tema de la ópera nacional fue una constante en el siglo XIX y en esta polémica se vieron inmersos muchos intelectuales y músicos del momento $^{17}$.

\footnotetext{
${ }^{15}$ Pedrell, Jornadas de Arte, p. 198.

${ }^{16}$ Ilustración Musical Hispanoamericana, 15-III-1891 (pp. 477-479), 30-III-1891 (p. 489).

${ }^{17}$ Casares, "La música del siglo XIX español. Conceptos fundamentales", pp. 103-122; Celsa Alonso, "La música española y el espíritu del 98", Cuadernos de Música Iberoamericana, 5 (1998), pp. 88-89;
} 
En su artículo "Impresiones", Amorós aludió al españolismo de la música de Pedrell y, sobre todo, de sus óperas. Entre 1867 y 1904 Pedrell compuso diez óperas, de las que, al parecer, Amorós estuvo al corriente:

Sin duda alguna, él es una de las primeras figuras europeas por sus vastos conocimientos, por su laboriosidad, por sus convicciones artísticas y por su españolismo, demostrado éste constantemente en la cátedra, en el periódico, en sus trabajos de investigación, en su música religiosa o de salón, en la sinfónica y especialmente en la de ópera. Hay que ojear las partituras de sus obras El último Abencerraje, Los Pirineos y La Celestina para convencerse de mi aserto. En estas óperas se respira un ambiente español tan dignificado, que contrasta notablemente con las producciones de otros autores que... cobran muy buenos trimestres.

Quien así obra, honra a su patria y se honra a sí mismo. ¡Loor al sabio y eminente maestro español Felipe Pedrell! ${ }^{18}$.

La recepción del ideario pedrelliano en España ha sido analizada por Francesc Bonastre $^{19}$. En 1891 Francesc Virella i Casañes, Rafael Mitjana, Josep Roca i Roca, Francesc Alió, Narcís Verdaguer y Francesc Miquel i Badia coincidieron en afirmar que Pedrell en Los Pirineos había explorado y asimilado nuestros cantos populares en sus diversas manifestaciones ${ }^{20}$. También Amorós, en "Impresiones", alude al ambiente español que se respiraba en las óperas El último Abencerraje, Los Pirineos y La Celestina, que contrapone a las producciones de otros autores de quienes dice "que cobran muy buenos trimestres”. Es posible que entre los autores que Amorós criticaba así

Ramón Sobrino, "La ópera española entre 1850 y 1874: Bases para una revisión crítica", en La ópera en España e Hispanoamérica, eds. Emilio Casares y Álvaro Torrente, 2 vols. (Madrid: ICCMU, 2002), vol. 2, pp. 77-142.

${ }^{18}$ Amorós, "Impresiones", p. 260.

${ }^{19}$ Francesc Bonastre, "Els Pirineus en el panorama de la música hispànica", Recerca Musicològica, 14-15 (2004-2005), pp. 258-259; Francesc Bonastre, "El nacionalisme musical de Felip Pedrell: reflexions a l'entorn de Por nuestra música", Recerca Musicologica, 11-12 (1991-1992), pp. 17-26; Francesc Bonastre, "El planteamiento operístico de Pedrell", en La ópera en España e Hispanoamérica, eds. Emilio Casares y Álvaro Torrente, 2 vols. (Madrid: ICCMU, 2002), vol. 2, pp. 187-197.

${ }^{20}$ Bonastre, "Els Pirineus", pp. 259-265. 
sin citar sus nombres, estuviera Ruperto Chapí, que, según Iberni, era la única personalidad que podía hacer sombra a Pedrell ${ }^{21}$.

\section{2. Epistolario entre Felipe Pedrell y Amancio Amorós}

El fondo Pedrell de la Biblioteca de Catalunya conserva siete cartas que Amancio Amorós dirigió a Pedrell entre 1894 y 1915 (véase Apéndice 18). El legado Amorós Sirvent, conservado en la misma Biblioteca, no incluye ningún documento epistolar y Margarita Amorós Portolés, nieta de Amancio Amorós, tampoco conserva ninguna carta de su abuelo.

Entre Amancio Amorós y Felipe Pedrell hubo, además de admiración profesional, una relación amistosa. En una de sus cartas a Pedrell no fechadas (quizás de finales de 1894 por los acontecimientos que en ella se narran), Amorós muestra su opinión sobre el polémico tema de la ópera nacional y transmite su preocupación por la mala situación que atravesaba el género operístico en España. Amorós se congratulaba del inminente estreno de la trilogía Los Pirineos en el Teatro Real ${ }^{22}$ :

Con alegría he recibido la noticia que Vd. me comunica, de que sus Pirineos van en el Real, en la primera quincena de diciembre. A Dios ruego así suceda, para bien de Vd. y de la ópera española.

Ahora dos años, cuando se había de haber estrenado su Trilogía, Serrano y yo pensábamos haberle dado a usted una sorpresa, asistiendo a los ensayos últimos y a la primera representación de su grandiosa obra. Este año, Dios dirá, amigo Pedrel1 ${ }^{23}$.

\footnotetext{
${ }^{21}$ Según Mitjana, Chapí componía sin descanso obras que no siempre escribía con el cuidado que la verdadera obra de arte exige. Su habilidad en la instrumentación y la profusión de recursos técnicos disimulaban las cualidades que faltaban. Cit. en Luis G. Iberni, "Felip Pedrell y Ruperto Chapí", Recerca Musicològica, 11-12 (1991-1992), pp. 335 y 341.

${ }^{22}$ Hacía dos años que la ópera Los Pirineos debería haberse estrenado en el Teatro Real. El 23 de septiembre de 1891 Pedrell presentó la partitura de Los Pirineos para participar en un concurso convocado para compositores operísticos españoles. Los ganadores recibirían una compensación económica y la representación de su obra en el Teatro Real. Pedrell ganó el concurso y el 30 de marzo de 1892 se acordó que la trilogía Los Pirineos fuera representada. Felip Pedrell, a finales de 1894, animado por la promesa de representación de Los Pirineos en el Teatro Real de Madrid, abandonó Barcelona y se instaló en Madrid, donde obtuvo la cátedra de conjunto vocal del Conservatorio que dejó vacante Mariano Vázquez, véase Luis G. Iberni, "Felip Pedrell y Ruperto Chapí", p. 337. Según Bonastre, "Els Pirineus", pp. 256-257, ni fue representada la ópera, ni Pedrell cobró el premio económico.
}

${ }^{23}$ Carta de Amancio Amorós a Felipe Pedrell (sf, ca. 1894). E:Bc, M 964. Ver Apéndice 18, carta nº 7. 
Amorós, en esta misma carta no fechada, criticó la situación de la enseñanza musical en Valencia y en particular en su Conservatorio. Amancio Amorós parece sorprenderse de la cantidad de alumnos que el conservatorio valenciano convertía en "maestros de música", y califica el centro valenciano como "conservatorio mercantil de música":

[...] el asombroso número de ¡maestros de...... música! que confecciona el llamado Conservatorio de Música de Valencia (léase Conservatorio mercantil de música, con alguna pequeña y honrosa excepción) va presentando mal cariz la enseñanza musical, que es de lo único que se sacaba un poco de partido en esta [...].

Celebro mucho vaya Vd. a Madrid a dar unas cuantas conferencias. Bueno sería que nos diera alguna en esta desgraciada Valencia, que buena falta nos hace ${ }^{24}$.

En 1894 Pedrell puso en marcha un nuevo proyecto, la Hispaniae Schola Musica Sacra, opera varia (saecul. XV, XVI, XVII et XVIII) diligenter excerpta, accurate revisa, sedulo concinnata con el propósito de "dar a conocer el rico tesoro artístico que los antiguos compositores españoles nos dejaron por herencia"25. Parece ser que Pedrell pidió a Amancio Amorós que apoyara la nueva publicación, según se desprende de la citada carta de Amorós sin fecha: "Amigo Sr. Pedrell: adherido, como Vd. desea a la

${ }^{24}$ Carta de Amancio Amorós a Felipe Pedrell (sf, ca. 1894). E:Bc, M 964. Ver Apéndice 18, carta 7. El Conservatorio de Valencia pasó de tener 172 alumnos matriculados en 1879 a 254 en el curso 1891-92. Había dos tipos de alumnado, el de pago, que abonaba sus correspondientes cuotas, y los becados por el Ayuntamiento y la Diputación de Valencia. El Conservatorio valenciano no estaba legitimado en 1894 para expedir titulaciones oficiales, pero sí podía conceder títulos de aptitud. El porcentaje de suspensos era muy escaso y el de sobresalientes había aumentado considerablemente en el periodo 1879-1891/92. Había cada vez mayor benevolencia en las calificaciones, lo que Fontestad atribuye, entre otras razones, a la dependencia económica de las cuotas del alumnado; véase Fontestad, El Conservatorio de Música, pp. $253,263,266,592$.

${ }^{25}$ Ilustración Musical Hispanoamericana, 30-III-1896, p. 42. El coleccionador redactor era Pedrell, los editores Pujol y $\mathrm{C}^{\mathrm{a}}$ de Barcelona y el grabador e impresor Breitkopf-Härtel. A pesar del poco favor con que fue recibida la obra por parte de algunos, según Ripollés, Pedrell presentó en ocho volúmenes las figuras de Morales, Francisco Guerrero, Ginés Pérez, Tomás de Santa Maria, Antonio de Cabezón. Véase Vicente Ripollés, "La obra del Maestro Pedrell en la restauración de la música religiosa", en Escritos heortásticos, pp. 240-242. 
publicación que me recomienda [... $]^{\prime 26}$. El nombre de Amancio Amorós aparece, en efecto, en las cubiertas de la Hispaniae Schola Musica Sacra en la lista de los suscriptores (véase Apéndice 19).

Ya he mencionado antes los elogios que Pedrell dedicó a Amorós por las obras pedagógicas de éste ${ }^{27}$. En varias de las cartas dirigidas por Amorós a Pedrell, el primero comenta obras didácticas propias, como la Teoría General de Solfeo, las Nociones Teóricas de Solfeo y las Lecciones Manuscritas Graduadas. La Teoría General de Solfeo de Amorós, editada en Valencia en 1896, incluía un programa teórico de la asignatura de Solfeo ordenado según el plan de enseñanza de la Escuela Nacional de Música y Declamación. Desde 1894, Pedrell se incorporó como docente en la Escuela Nacional de Música y Declamación de Madrid ${ }^{28}$ y en 1895 ocupó la cátedra de Conjunto Vocal e ingresó en la Real Academia de Bellas Artes de San Fernando ${ }^{29}$. En una carta fechada en septiembre de 1896, Amancio Amorós parece pedir consejo a Pedrell y esperar su respuesta para la publicación de su Teoría General del Solfeo en 1896:

Por más que creo no me habrá Vd. olvidado, me parece oportuno, como ya estamos a últimos de Septiembre, recordarle el asunto de mi Teoría, y decirle que espero órdenes de $\mathrm{Vd}^{30}$.

\footnotetext{
${ }^{26}$ Carta de Amancio Amorós a Felipe Pedrell (sf, ca. 1894). E:Bc, M 964. Ver Apéndice 18, carta 7. Con toda probabilidad Pedrell explicaría a Amorós, como lo hizo con Villaba, los planes que tenía para su obra Hispaniae Schola Musica Sacra; véase $\mathrm{M}^{\mathrm{a}}$ Antonia Virgili, "Felipe Pedrell y el músico vallisoletano Luis Villalba: correspondencia inédita", Recerca Musicologica, 1 (1981), p. 155.

${ }^{27}$ Pedrell prologó la segunda edición del método Elementos de Solfeo (1891) de Amorós. Ver más detalles en Capítulo 3.

${ }^{28}$ El Real Conservatorio de Música de Madrid recibió el nombre de Escuela Nacional de Música a raíz del Decreto de 15-XII-1868, denominación que mantuvo hasta 1900. Emilio Rey García, "Historia del Conservatorio", en Real Conservatorio Superior de Música http://www.educa.madrid.org/web/csm.realconservatorio.madrid/con-historia.htm, página web consultada el 15-VI-2008; Felipe Pedrell, Emporio científico e histórico de organología musical antigua española (Barcelona: Juan Gili, 1901), p. 4.

${ }^{29}$ Florentino Pérez Embid, Enciclopedia de la cultura española (Madrid: Editora Nacional, 1962), p. 704.

${ }^{30}$ Carta de Amancio Amorós a Felipe Pedrell, 29-IX-1896. E:Bc, M 964. Ver Apéndice 18, carta 1.
} 
En la misma carta, Amorós remitió a Pedrell algunas de sus composiciones para su publicación en el Álbum musical de la Ilustración Musical Hispanoamericana:

Muy Sr. mío y amigo de toda mi consideración: como le prometí en nuestra última grata entrevista, le remito en este mismo correo una cosita (pequeña melodía para canto y piano) con destino a la Ilustración, si es del gusto de Vd. para el objeto ${ }^{31}$.

En la Ilustración Musical Hispanoamericana se publicaron, como ya he comentado en otros capítulos, varias obras de Amorós, como las mazurcas en Re b Mayor (1890), Sol Mayor (1890) y Re menor (1891). La “cosita (pequeña melodía para canto y piano)" a la que alude Amancio Amorós es la canción para canto y piano, op. 103 cuyo ejemplar manuscrito se conserva en el legado Amorós de la Biblioteca de Catalunya, que se publicó en la Ilustración Musical Hispanoamericana (1896) con el título Recuerdo de Amor. La letra es del propio Amorós, quien buscó posibles combinaciones en su nombre y apellidos para elaborar un pseudónimo que finalmente fue Marco Antonio Verzenni ${ }^{32}$.

Muestra del afecto y agradecimiento que Amorós sintió por Pedrell son varias cartas en las que Amorós refleja su preocupación por el estado de salud del propio Pedrell y de Carmen, su única hija ${ }^{33}$. En una de 1912, Amorós da el pésame a Pedrell por el fallecimiento de Carmen:

Mi distinguido y buen amigo: el domingo pasado supe, por D. José Miravalls, la gran desgracia que a Vd. le aflige con la pérdida de su queridísima y única hija. A dicho amigo le encargué le hiciera a Vd. una visita y le diera un fuerte abrazo de mi parte, ya que personalmente, como creía, no lo puedo realizar.

Cónstele amigo, Sr. Pedrell, que la pena de Vd. la siento como propia, pues como padre que soy, la puedo apreciar con todas sus consecuencias.

\footnotetext{
${ }^{31}$ Carta de Amancio Amorós a Felipe Pedrell, 29-IX-1896. E:Bc, M 964. Ver Apéndice 18, carta no 1.

${ }^{32} E: B c, \mathrm{M} 1311$.

${ }^{33}$ Ver Apéndice 18, $\operatorname{cartas} n^{\text {os }} 2,3$ y 4.
} 
A Dios ruego que le dé toda la resignación cristiana para poder soportar tan rudo golpe, y por la que fue su idolatrada hija, elevase al Cielo mis oraciones para el descanso de su alma ${ }^{34}$.

En septiembre de 1915 Amorós agradeció a Felipe Pedrell la ayuda que al parecer éste había prestado a sus hijos en Barcelona:

Le dedico mi ratito de escritura para manifestarle mi agradecimiento por el interés que tiene por mis hijos, poniéndoles en contacto con personas buenas y cultas. óptimos frutos ${ }^{35}$.

Mucho me alegraré que las gestiones con Miró le den a Vd.

Amorós parece haber estado directamente informado de los consejos que Pedrell dio al Padre José Antonio de San Sebastián ó Padre Donostia (1886-1956) para que se dedicase a la música religiosa:

Mucho me alegro de las noticias que me da de ese P. José Antonio de San Sebastián. Seguramente que se realizará la profecía de Vd. Es muy lógico que lo incline al Oratorio y al lied franciscano. Un religioso de disposición musical (claro está) debe sentir mejor estas dos clases de trabajo que las composiciones profanas, sean del género que sean. Siento mucho no haber tratado a dicho P[adre] en mi estancia en $\mathrm{esa}^{36}$.

Unos días después Amorós envió y dedicó a Pedrell sus tratados didácticos que denominó “Teorías y Prácticas", refiriéndose seguramente a los tres cursos de Nociones Teóricas de Solfeo y Lecciones Manuscritas Graduadas (ver Capítulo 3):

Me he permitido dedicar a Vd. mis obras teóricas y prácticas de solfeo o sea el A. B. C. del músico, por si se digna en sus ratos de aburrimiento echar una ojeada sobre las referidas obras ${ }^{37}$.

\footnotetext{
${ }^{34}$ Carta de Amancio Amorós a Felipe Pedrell, 19-XI-1912. E:Bc, M 964. Ver Apéndice 18, carta no 4.

${ }^{35}$ Carta de Amancio Amorós a Felipe Pedrell, 26-X-1915. E:Bc, M 964. Ver Apéndice 18, carta $n^{\circ} 5$. Desconozco qué tipo de contactos pudo ofrecer Pedrell a los hijos de Amorós. El tercero de ellos, José Vicente Amorós Barra, llegó a ser desde 1914 Catedrático de Arqueología, Epigrafía y Numismática de la Universidad de Barcelona, E:Vaac, Actas de la Junta del Centro de Cultura Valenciana, 21-IX-1915 y 7 VI-1918.

${ }^{36}$ Carta de Amancio Amorós a Felipe Pedrell, 26-IX-1915. E:Bc, M 964. Ver Apéndice 18, carta ${ }^{\circ} 5$.

${ }^{37}$ Carta de Amancio Amorós a Felipe Pedrell, 29-IX-1915. E:Bc, M 964. Ver Apéndice 18, carta nº 6.
} 
La experiencia negativa de Amorós con el editor valenciano Antonio Sánchez

Ferrís le llevó a alertar a Pedrell, con estas palabras:

Supongo que Pepe le habrá dicho sobre Sanchez Ferrís lo bastante para Vd. ponerse en acecho. Por mi parte, le aconsejo que no ultime ningún trato con dicho individuo si no cobra anticipadamente el importe del negocio que sea ${ }^{38}$.

En algunas de sus cartas a Pedrell, Amorós mostró la relación que mantuvo con diversas figuras del panorama musical español del momento, como José Miravalls, Vicente Ripollés, Enrique Granados y José Serrano ${ }^{39}$.

\section{Creación de la Biblioteca Musical Valenciana (1894-1895)}

En 1894 Amorós fundó la Biblioteca Musical Valenciana, revista dedicada exclusivamente a la publicación de obras de autores valencianos para piano, baile y canto, que incluía además anuncios de instrumentos musicales, de métodos de solfeo y de profesores de solfeo y piano $^{40}$. La prensa valenciana anunciaba así su aparición:

Bajo la dirección del reputado maestro, nuestro amigo D. Amancio Amorós, se anuncia la aparición de una Biblioteca Musical Valenciana, en la que se insertarán obras de todos los géneros, para piano, canto y piano, piano y armónium, de profesores valencianos, publicándose 6 volúmenes anuales, repartidos por bimestres, y principiando desde el presente mes de noviembre ${ }^{41}$.

También la Ilustración Musical Hispanoamericana se hizo eco de la nueva publicación $^{42}$. Hasta ahora se creía que la Biblioteca Musical Valenciana surgió en 1895,

\footnotetext{
${ }^{38}$ Carta de Amancio Amorós a Pedrell, 29-X-1915. E:Bc, M 964. Ver Apéndice 18, carta nº 6.

${ }^{39}$ Ver Apéndice 18, cartas $n^{\text {os }} 3,4$ y 7.

${ }^{40}$ Las Provincias, 11-X-1894.

${ }^{41}$ Boletín Musical, 15-XI-1894, p. 347.

${ }^{42}$ Ilustración Musical Hispanoamericana, 15-XII-1894, p. 182.
} 
como había indicado Francisco Javier Blasco en su obra La Música en Valencia (1896), cuyos datos han sido repetidos después por otros autores ${ }^{43}$. Estaba previsto publicar cada año seis tomos elegantemente impresos de la Biblioteca Musical Valenciana, que contendrían de 96 a 120 páginas de música selecta en conjunto ${ }^{44}$. Cada número contenía veinte páginas de música y una de anuncios. Las composiciones publicadas en esta colección pertenecían a los géneros de moda en la música de salón valenciano y, en orden de importancia numérica, se pueden resumir en: obras para canto y piano $(39 \%$, incluyendo una romanza, una balada, dos melodías y una barcarola), piezas para piano (39\%), obras para piano y armonio (15\%) y obras para piano a cuatro manos $(7 \%)$, véase Apéndice 17.

A continuación describiré la localización de los tres números encontrados y las características de la Biblioteca Musical Valenciana. En la Tabla 28 muestro las obras que se publicaron en los volúmenes 1,2 y 3 .

\section{1. Ejemplares localizados de la Biblioteca Musical Valenciana}

Hasta el momento he podido localizar tres números de la Biblioteca Musical Valenciana, los números 1 (noviembre de 1894), 2 (enero de 1895) y 3 (marzo de 1895), conservados en el Archivo de la Real Academia de Bellas Artes de San Fernando, la Hemeroteca Municipal de Valencia, la Biblioteca Valenciana (San Miguel de los Reyes) de Valencia y la Biblioteca de Catalunya. El nº 1 contenía obras de Salvador Giner, José $\mathrm{M}^{\mathrm{a}}$ Úbeda, Roberto Segura y Amancio Amorós ${ }^{45}$.

\footnotetext{
${ }^{43}$ Blasco, La música en Valencia, p. 97.

${ }^{44}$ Las Provincias, 31-X-1894.

${ }^{45}$ El primer cuaderno de la Biblioteca Musical Valenciana, que he podido localizar en E:Bc, 2010-Fol-C 32/3 y E:Mba, dentro del fondo Leopoldo Querol (1899-1985), se publicó en noviembre de 1894, sin embargo Francisco J. Blasco en 1896 afirmó erróneamente que la publicación empezó en 1895 y sólo se publicaron tres volúmenes. Blasco, La música en Valencia, p. 97; véase también Boletín Musical, 30-XI1894, p. 354.
} 
El volumen $\mathrm{n}^{\mathrm{o}}$ 2, enero (1895) de la Biblioteca Musical Valenciana publicó obras de Manuel Chulvi, Manuel Penella Raga, Francisco Javier Blasco, Eduardo Ximénez Cos y Juan Bautista Plasencia ${ }^{46}$. El volumen $n^{\text {o }} 3$ incluyó obras de Amancio Amorós, Roberto Segura y Manuel Penella Raga ${ }^{47}$.

La canción para canto y piano de Manuel Penella Raga, La Tórtola Viuda (1880), con letra de Víctor Iranzo Simón, apareció también publicada en la Biblioteca Musical Valenciana según se menciona en la misma partitura, aunque en un volumen hoy no localizado $^{48}$. La localización de esta pieza de Manuel Penella sugiere que pudieron haber sido al menos cuatro los volúmenes de la Biblioteca Musical Valenciana que vieron la luz ${ }^{49}$.

Por circunstancias todavía no aclaradas la Biblioteca Musical Valenciana desapareció en 1895, como se hizo constar en agosto de ese mismo año en la revista valenciana Boletín Musical:

Caducada la Biblioteca Musical Valenciana, que veía la luz pública en esta capital bajo la dirección de Amancio Amorós, se han puesto a la venta todos los volúmenes publicados, tanto en colección como en números sueltos y a precio de suscripción en Casa Laviña, almacenes de música e instrumentos ${ }^{50}$.

\footnotetext{
${ }^{46}$ He localizado el segundo cuaderno de la Biblioteca Musical Valenciana en E:Bc, 2010-Fol-C 32/2 y E:VAm, $5 / 1515 \mathrm{NC}$.

${ }^{47}$ El volumen $\mathrm{n}^{\circ} 3$ lo he localizado en $E: B c, 2010-\mathrm{Fol}-\mathrm{C} 32 / 20$ y E:VAbv, NP 77-79/F270; véase Boletín Musical, 30-III-1895, p. 412.

${ }^{48}$ En la actualidad, ésta se conserva en un ejemplar encuadernado junto con otras piezas para canto y piano en E:VAbv, E. López-Chavarri/4010, Manuel Penella Raga, Cants de ma terra: La Tórtola Viuda, cansoneta llemosina, $\mathrm{n}^{\mathrm{o}}$ 1, letra de Victor Iranzo. 1 partitura vocal (3 pp.); $34 \mathrm{~cm}$., editada en la Biblioteca Musical Valenciana.

49 Peláez, "Las revistas ilustradas", en www. Tebeosfera.com/libris/RevistasValencianas, consultado el 10-IV-2009, afirma que aparecieron ocho volúmenes de la Biblioteca Musical Valenciana.

${ }^{50}$ Boletín Musical, 30-VIII-1895, p. 492.
} 


\section{2. Características de la Biblioteca Musical Valenciana}

El título y subtítulo completo Biblioteca Musical Valenciana. Álbum de salón se mantienen en los tres números localizados, al igual que la decoración de la cubierta. En la parte superior izquierda, sobre un friso en el que se lee Biblioteca Musical Valenciana, aparecen el escudo de la ciudad de Valencia y una lira, y sobre éstos, un murciélago. El conjunto se adorna con motivos vegetales que simulan hojas de laurel (Ilustración 34$)^{51}$.

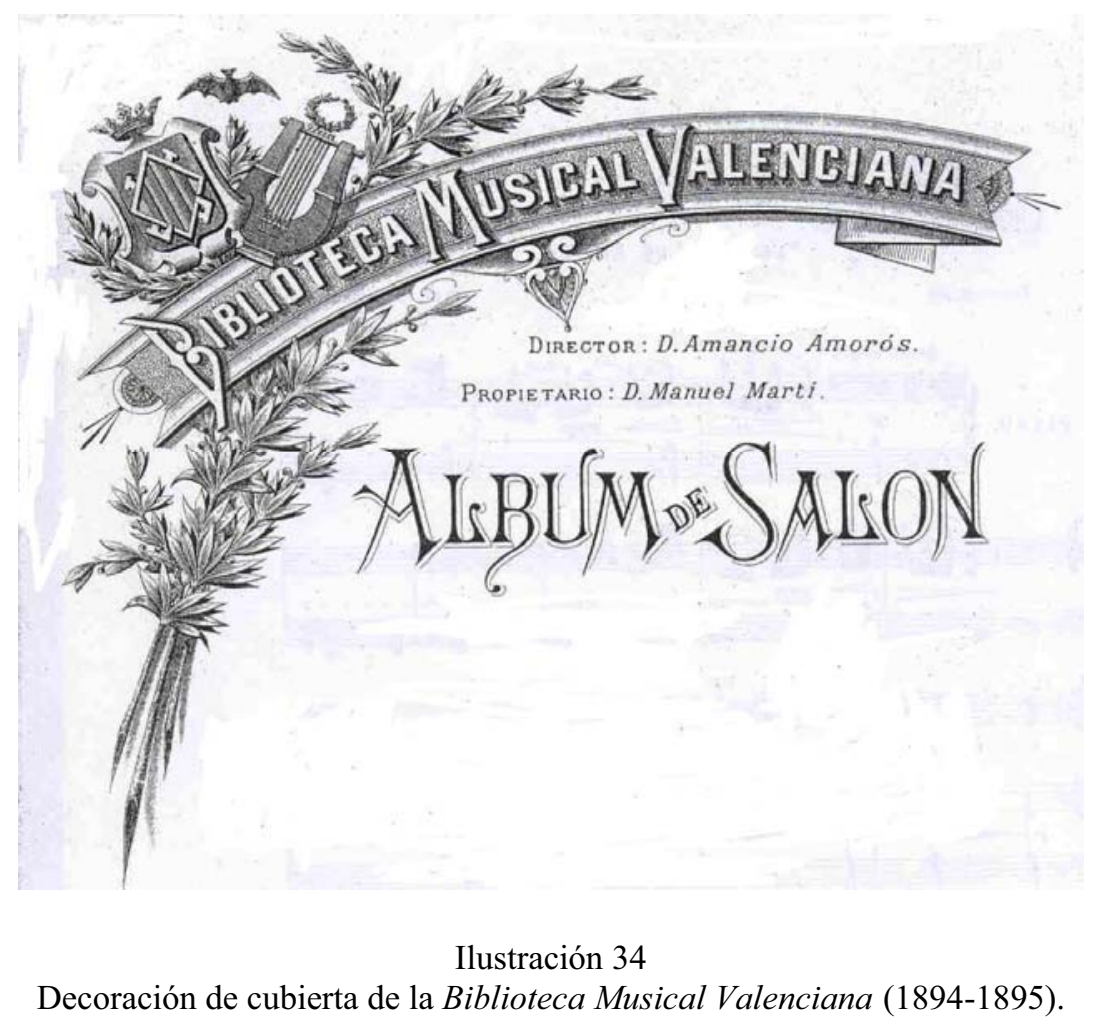

El formato de la publicación era de 32 × $22 \mathrm{~cm}$. Cada número consta de veinte páginas musicales con numeración continuada. La Biblioteca Musical Valenciana se imprimió, según Peláez Malagón, en la imprenta José Doménech, aunque no he podido

\footnotetext{
${ }^{51}$ Sobre la presencia del murciélago ("rat penat") en el escudo de Valencia, véase Luis Tramoyeres Blasco, "Lo Rat Penat en el escudo de Valencia", en Boletín de la Academia de la Historia, 38 (1901), pp. 438-445.
} 
constatar esta afirmación ${ }^{52}$. Las suscripciones y pagos de la Biblioteca Musical Valenciana se establecieron en el almacén de música de Carmelo Sánchez Laviña, que estaba situado en la Bajada de San Francisco 29 de Valencia ${ }^{53}$. Este almacén de música e instrumentos era una empresa familiar fundada en 1846 como "Casa Laviña", regentada por los hermanos Ramón y Carmelo Sánchez Laviña, y se dedicó también a tareas editoriales $^{54}$. Según un anuncio publicado en el Boletín Musical, Antonio Sánchez Ferrís fue el sucesor de Casa Laviña y su empresa continuó en la misma dirección postal (Ilustración 35) ${ }^{55}$.

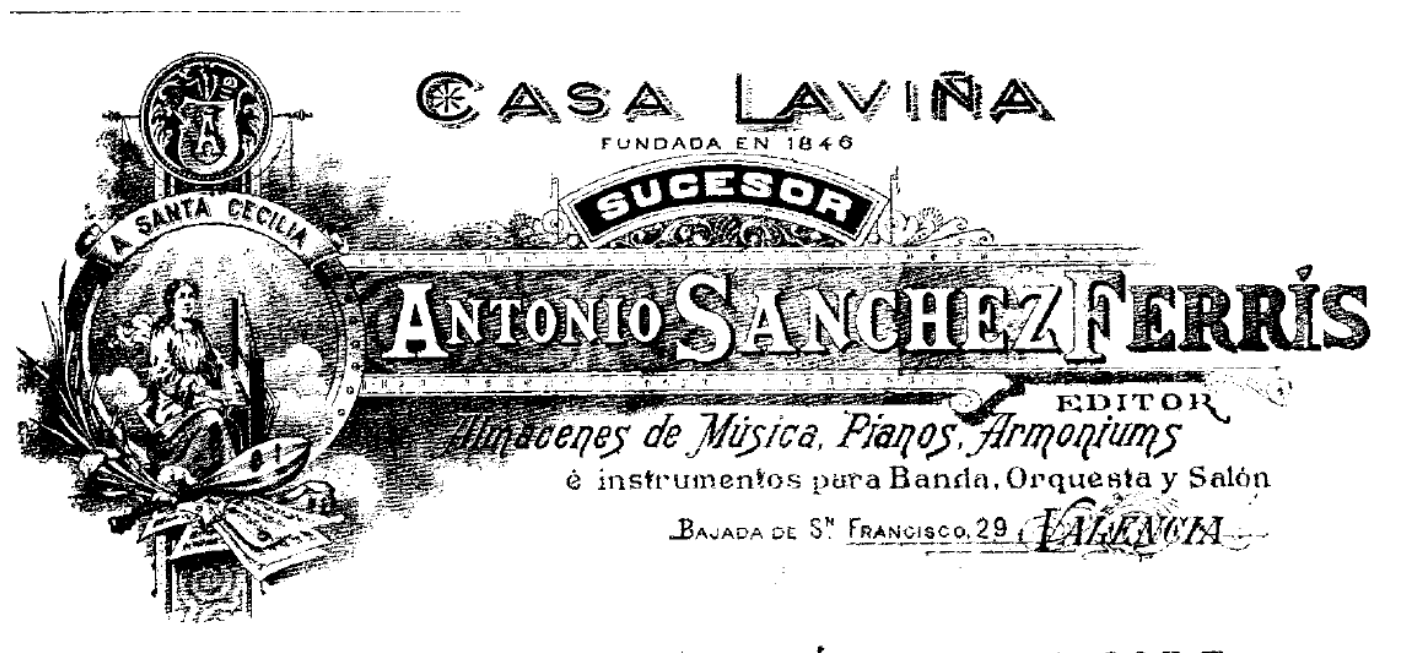

Ilustración 35

Anuncio de Casa Laviña, sucesor Antonio Sánchez Ferrís. Boletín Musical, 20-VIII-1899.

El precio de cada volumen suelto de la Biblioteca Musical Valenciana en España era de 4 pesetas para los no suscriptores y 2'50 pesetas para los suscriptores:

\footnotetext{
${ }^{52}$ Peláez, "Las revistas ilustradas".

${ }^{53}$ Boletín Musical, 15-II-1895, p. 392.

${ }^{54}$ Amorós, Elementos de Solfeo, $1^{\text {a }}$ ed., ca. 1889-91.

${ }^{55}$ Boletín Musical, 20-VIII-1899, sp.
} 
Precio en España de 15 pesetas año, 5 pesetas cuatrimestre, 2,50 bimestre y precio para no suscriptores de 4 pesetas. En el almacén del S. Sánchez Laviña se admiten suscripciones ${ }^{56}$.

Las obras se vendían también sueltas y la publicación en la Biblioteca Musical Valenciana serviría para anunciarlas. La administración de la publicación se situó en la Academia Martí, situada en la calle Cabilleros 16 de Valencia. El director y propietario de esta Academia era Manuel Martí Sanchis, doctor en Ciencias y Medicina ${ }^{57}$.

A finales del siglo XIX proliferaron las ediciones para voz y piano publicadas en forma de "bibliotecas musicales" o a través de suplementos musicales ${ }^{58}$. La Biblioteca Musical Valenciana. Álbum de salón de Amorós respondía a la moda imperante del momento que demandaba canciones líricas, obras para piano o piano y armónium, para el deleite de la burguesía y de músicos aficionados ${ }^{59}$.

Una publicación periódica musical valenciana que pudo servir de referente a Amancio Amorós fue El Jardín Musical, dirigida por Manuel Penella Raga, que se imprimió entre 1875 y 1880. Esta revista, distribuida por el Comercio de Música de Salvador Prosper y Casa Laviña, editó también obras para piano y canto y piano de compositores valencianos, muchas de ellas del propio Manuel Penella ${ }^{60}$.

\footnotetext{
${ }^{56}$ Boletín Musical, 15-XI-1894, p. 347.

${ }^{57}$ Biblioteca Musical Valenciana, vol. 2 (1895), contraportada. La Academia Martí se fundó en 1883 y gozó de gran prestigio en Valencia. Era una academia preparatoria para carreras especiales y de $2^{\mathrm{a}}$ Enseñanza y la prensa aseguraba que los alumnos de Universidad e Instituto que repasaban en este centro obtenían excelentes resultados. Véase Almanaque de las Provincias para 1893, p. 228.
}

\footnotetext{
${ }^{58}$ Alonso, La Canción lírica, p. 456.

${ }^{59}$ En el repertorio de salón de la Valencia decimonónica había tres tipos fundamentales de obras: 1) las arias, dúos y conjuntos operísticos, a los que podía añadirse alguna romanza de zarzuela, o canción popular en valenciano; 2) piezas para piano o piano a cuatro manos: reducciones de oberturas de ópera, fantasías y variaciones sobre motivos de ópera o zarzuela, bailes (polkas, mazurcas, valses, caprichos, marchas) y formas más íntimas (romanzas, nocturnos, barcarolas, etc); y 3) música para dos o tres instrumentos, en los que estaba muy presente el armonio, como uno de los instrumentos más importantes del salón burgués valenciano, véase Sancho, Romanticimo, p. 215; Virgili, "El pensamiento musical”, p. 33 .

${ }^{60}$ Blasco, La música en Valencia, p. 96.
} 
En el periodo 1894-95 Amorós era presidente de Lo Rat Penat, institución que fue uno de los principales cauces de manifestación de la Renaixença valenciana. En esta entidad colaboraron muchos artistas valencianos de la época cuyas obras se publicaron en la Biblioteca Musical Valenciana. La prensa del momento subrayó que las obras distribuidas en la Biblioteca Musical Valenciana tendrían distintos grados de dificultad, pero que se publicarían sobre todo las de dificultad media y se darían a conocer obras de "distinguidos autores valencianos no conocidas muchas de ellas" $"$. En efecto, las obras publicadas, salvo alguna excepción, eran de nivel elemental y medio.

Tabla 28. Obras publicadas en la Biblioteca Musical Valenciana, revista dirigida por Amancio Amorós.

Fuente: Biblioteca Musical Valenciana. Álbum de salón, vols. 1-3 (1894-1895).

\begin{tabular}{|c|c|c|c|c|c|c|}
\hline $\begin{array}{l}\text { Autor } \\
\text { Música }\end{array}$ & $\begin{array}{l}\text { Autor } \\
\text { Letra }\end{array}$ & $\begin{array}{l}\text { Título } \\
\text { Subtítulo }\end{array}$ & $\begin{array}{l}\text { Forma/ } \\
\text { Plantilla }\end{array}$ & $\begin{array}{l}\text { Fecha } \\
\text { edición }\end{array}$ & Página & Observaciones \\
\hline \multicolumn{7}{|c|}{ Volumen 1 (noviembre 1894) } \\
\hline $\begin{array}{l}\text { Salvador } \\
\text { Giner }\end{array}$ & $\begin{array}{l}\text { Antonio } \\
\text { Chocomeli }\end{array}$ & $\begin{array}{l}\text { El rayo de } \\
\text { sol, Balada } \\
\text { de Blanca }\end{array}$ & Canto y piano & \multirow{4}{*}{$\begin{array}{c}\text { Noviembre } \\
1894\end{array}$} & 1 & $\begin{array}{l}\text { Del melodrama } \\
\text { El Rayo de sol }\end{array}$ \\
\hline $\begin{array}{l}\text { José } \mathrm{M}^{\mathrm{a}} \\
\text { Úbeda }\end{array}$ & - & Ilusión & $\begin{array}{l}\text { Melodía para } \\
\text { piano y } \\
\text { armónium }\end{array}$ & & 8 & $1 ' 50$ pesetas \\
\hline $\begin{array}{l}\text { Roberto } \\
\text { Segura }\end{array}$ & - & Cunera & $\begin{array}{l}\text { Canzonetta } \\
\text { para piano }\end{array}$ & & 14 & $\begin{array}{c}\text { "Escrita expresamente } \\
\text { para el ejercicio de } \\
\text { lectura a primera vista en } \\
\text { los concursos de alumnas } \\
\text { (91 al 92) del } \\
\text { Conservatorio de Música } \\
\text { de Valencia". } \\
\text { 0'50 pesetas }\end{array}$ \\
\hline $\begin{array}{l}\text { Amancio } \\
\text { Amorós }\end{array}$ & - & $\begin{array}{c}\text { Mazurca en } \\
\text { Fa Mayor }\end{array}$ & Mazurca & & 16 & $\begin{array}{c}\text { 1'25 pesetas } \\
\text { “A mi distinguida } \\
\text { discípula Srta D D Dolores } \\
\text { Peñaranda Lima”. } \\
\text { La partitura contiene en } \\
\text { el margen superior } \\
\text { izquierdo una dedicatoria } \\
\text { autógrafa de Amorós al } \\
\text { pianista L. Querol }\end{array}$ \\
\hline
\end{tabular}

\footnotetext{
${ }^{61}$ Las Provincias, 31-X-1894.
} 


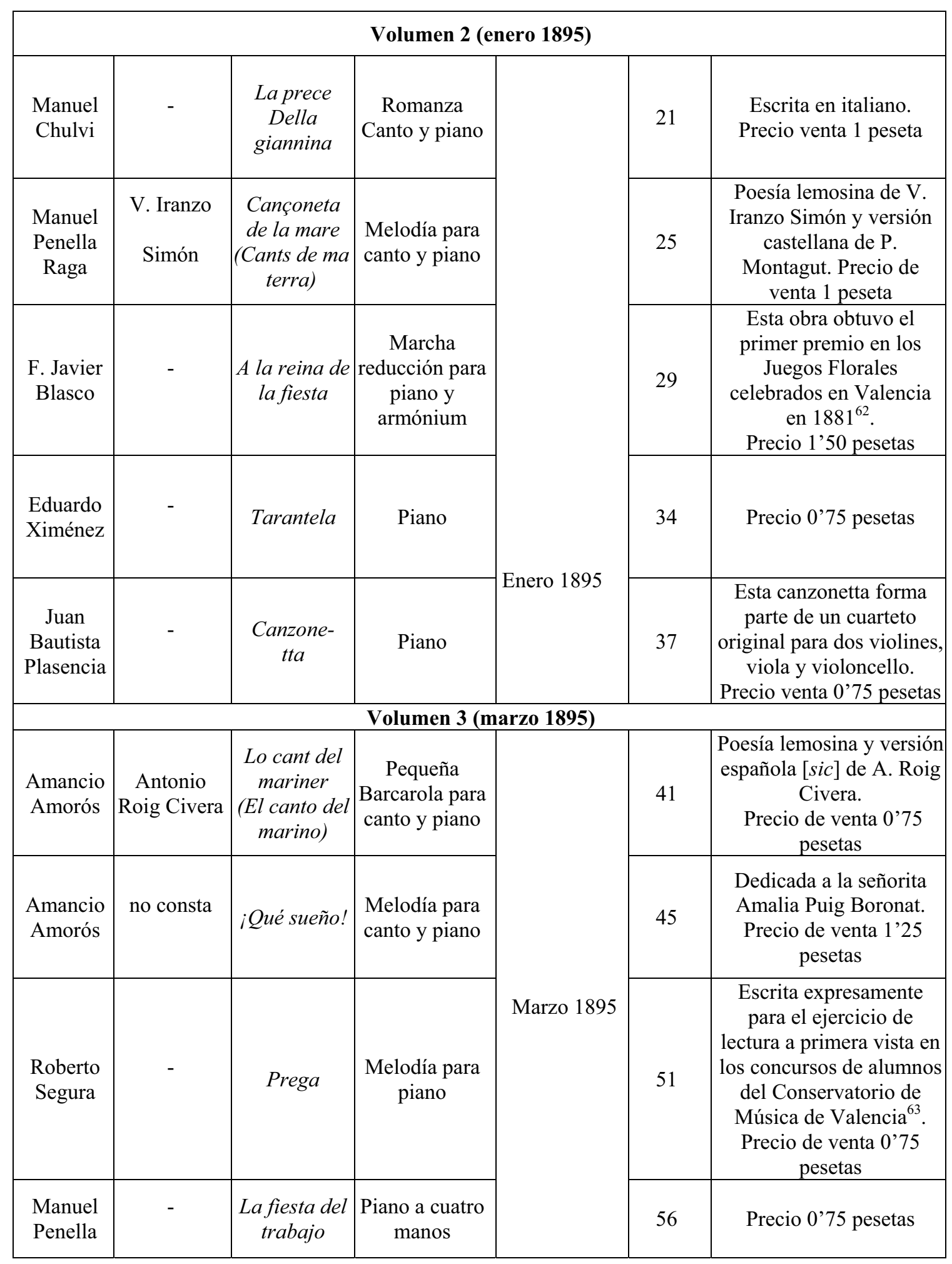

${ }^{62}$ Posteriormente fue ampliada para concierto por su autor y publicada con el título Amor, Fe y Patria. Véase Ruiz de Lihory, "Blasco, F. Javier”, p. 186.

${ }^{63}$ Curso 1891-92. 


\section{3. Obras publicadas en la Biblioteca Musical Valenciana}

A continuación presento un breve estudio del contenido de la Biblioteca Musical Valenciana, agrupando las piezas por géneros. Se trata de piezas breves de salón muy similares a muchas otras difundidas en la época, y a las que el propio Amorós también publicó $^{64}$. Amancio Amorós da cauce en esta revista a la creación de salón valenciana que no parece distar mucho del repertorio de salón internacional destinado a aficionados. Las obras de Amancio Amorós, publicadas en la colección serán analizadas en el Capítulo 5.

Obras para canto y piano

Cinco son las piezas para canto y piano publicadas en los volúmenes localizados de la Biblioteca Musical Valenciana. De ellas dos están en castellano (Balada de Blanca, ¡Qué sueño!), dos en valenciano (Lo cant del mariner, La cançoneta de la mare) y una en italiano (La prece della Giannina). La Renaixença valenciana fomentó la revitalización de la lengua y poesía vernáculas. La pequeña barcarola Lo cant del mariner de Amancio Amorós con letra de Antonio Roig Civera y la Cançoneta de la mare de Manuel Penella con letra de Víctor Iranzo Simón hay que situarlas en este contexto. En ambos casos la edición presenta la traducción de la poesía "lemosina" al castellano. Según Celsa Alonso, cantar en francés o italiano era signo de elegancia durante la Restauración. Eran frecuentes las traducciones al italiano de canciones, melodías o baladas con versos originales en catalán o castellano ${ }^{65}$. La prece della Giannina de Manuel Chulvi ${ }^{66}$ (18481923) con texto en italiano, sin embargo, no está traducida.

\footnotetext{
${ }^{64}$ Alonso, "Los salones”, pp. 167, 192-195.

${ }^{65}$ Alonso, La canción lírica, p. 457.

${ }^{66}$ Manuel Chulvi fue organista y profesor de canto del Seminario Conciliar de Valencia. En 1879 consiguió la plaza de organista de la catedral de Valencia y desde 1889 ocupó la plaza de maestro,
} 
La Balada de Blanca en re menor de Salvador Giner, con letra de Antonio Chocomeli es una reducción para canto y piano de un número de la zarzuela El Rayo de Sol $(1883)^{67}$. Se trata de una estructura monotemática bipartita con dos estrofas de ocho versos endecasílabos (véase Tabla 29). En la primera parte se establece un diálogo entre la parte vocal y el piano. A partir del compás 22 el piano duplica la línea melódica. En la segunda sección interviene además un coro de doncellas que sigue reforzando la línea melódica. La barcarola Lo cant del mariner de Amorós, en Re Mayor, presenta una estructura estrófica. En ambos casos se trata de obras sencillas para estudiantes o aficionados en las que el piano se subordina a la voz.

Tabla 29. Salvador Giner, Balada de Blanca del melodrama El Rayo de Sol (1894). Esquema analítico.

Fuente: Biblioteca Musical Valenciana. Álbum de salón, $\mathrm{n}^{\circ} 1$.

\begin{tabular}{|c|c|c|c|c|}
\hline Secciones & Compases & $\begin{array}{c}\text { Aspectos } \\
\text { Armónicos }\end{array}$ & $\begin{array}{l}\text { Material } \\
\text { temático }\end{array}$ & Compás/Tempo \\
\hline Introducción & $1-8$ & Re m & $\begin{array}{c}\text { Elementos } \\
\text { Rítmicos de A }\end{array}$ & \multirow{4}{*}{$\begin{array}{c}3 / 8 \\
\text { Andante } \\
\text { Sostenuto }\end{array}$} \\
\hline \multirow[t]{2}{*}{$1^{\mathrm{a}}$} & $9-37$ & $\begin{array}{l}\text { Re m-si b M- } \\
\text { Mi b M-Re M }\end{array}$ & $\mathrm{A}$ & \\
\hline & $38-47$ & $\mathrm{Re} M \rightarrow \mathrm{V}$ & Elementos de A & \\
\hline \multirow[t]{2}{*}{$2^{\mathrm{a}}$} & $48-71$ & $\begin{array}{l}\text { Re m-si b M- } \\
\text { Mi b M-Re M }\end{array}$ & A & \\
\hline & $72-88$ & Re $M$ & CODA & Allegretto \\
\hline
\end{tabular}

La romanza La prece della Giannina de Manuel Chulvi, con letra en italiano de autor anónimo, guarda una relación más estrecha con el italianismo operístico ${ }^{68}$. Su textura de melodía acompañada dista mucho de tener el carácter alegre y ritmo vivo propio de las canciones populares. Presenta una estructura bipartita con dos temas

vacante por renuncia de Guzmán al ingresar en el monasterio de Montserrat. Véase Climent, "Chulvi, Manuel”, pp. 692-693.

${ }^{67}$ La zarzuela se estrenó en 1883 en el Teatro Principal de Valencia por la compañía de zarzuela dirigida por Eugenio Fernández. Véase Almanaque de las Provincias para 1884, pp. 65-66.

${ }^{68}$ Esta romanza no aparece en el catálogo elaborado por Climent para la voz "Chulvi, Manuel”, pp. 692693. 
claramente definidos (véase Tabla 30). La línea melódica de la voz abarca desde el $\mathrm{Re}^{3}$ hasta el $\mathrm{Si}^{4}$. El piano se limita a acompañar a la voz, y utiliza preferentemente figuraciones de tresillos de corchea en compás de 3/4. Armónicamente la primera sección de la romanza esta en Do menor con pequeñas modulaciones, algunas de ellas sin preparación (Sol Mayor, Re b Mayor, Mi b Mayor), contrastando con la segunda sección en Do Mayor.

Tabla 30. Manuel Chulvi, La prece della giannina (sf). Esquema analítico. Fuente: Biblioteca Musical Valenciana. Álbum de salón, $\mathrm{n}^{\circ} 2$.

\begin{tabular}{|c|c|c|c|c|}
\hline Secciones & Compases & $\begin{array}{c}\text { Aspectos } \\
\text { Armónicos }\end{array}$ & $\begin{array}{l}\text { Material } \\
\text { temático }\end{array}$ & Compás/Tempo \\
\hline Introducción & $1-10$ & Do $m$ & Elementos de A & \multirow{2}{*}{$\begin{array}{c}3 / 4 \\
\text { Andante } \\
\text { Sostenuto }\end{array}$} \\
\hline $1^{\mathrm{a}}$ & $11-35$ & $\begin{array}{c}\text { Do m- Sol M-Do m- } \\
\text { Do M }\end{array}$ & A & \\
\hline $2^{\mathrm{a}}$ & $36-52$ & Do $\mathrm{M}$ & $\mathrm{B}$ & $\begin{array}{l}\text { Poco piu } \\
\text { mosso }\end{array}$ \\
\hline Repite introducción & $53-62$ & Do $\mathrm{m}$ & Elementos de $\mathrm{A}$ & Andante Sostenuto \\
\hline \multicolumn{5}{|c|}{ Repite $1^{\mathrm{a}}$ y $2^{\mathrm{a}}$ sección con la $2^{\mathrm{a}}$ letra } \\
\hline Coda & $63-73$ & Do $\mathrm{M}$ & Fermata & Poco piu mosso \\
\hline
\end{tabular}

La Cançoneta de la mare de Manuel Penella ${ }^{69}$, en Sol Mayor con letra en valenciano de Victor Iranzo Simón ${ }^{70}$ está estructurada en tres partes claramente diferenciadas por cambios de compás, tonalidad y tempo, que dan lugar a los temas A, B, y C (véase Tabla 31). La línea melódica es sencilla y el papel del piano es de apoyo armónico, aunque adquiere protagonismo en la $3^{\mathrm{a}}$ sección, con un diseño ascendentedescendente de seisillo de semicorcheas que contribuye a realzar el significado del suave vaivén de una madre al mecer a su niño en la cuna.

\footnotetext{
${ }^{69}$ Galbis, “Penella Raga, Manuel”, pp. 574-575, esta obra aparece con el título Junt a la cambra (1885).

${ }^{70}$ Iranzo Simón era uno de los mejores poetas del siglo XIX valenciano, según Verger. Incluso en el "estilo floralesco" que inevitablemente aparece en su obra, intenta huír de los recursos fáciles de la retórica del momento practicada por los poetas de la generación anterior que Verger denomina "isabelinos". Véase Eduard J. Verger, "La poesia valenciana de la Restauració (1874-1902)", en La Ilustració poètica metropolitana \& continental, Versos $i$ altres escrits, Articles $i$ notes de crítica literaria. Artículo online perso.wanadoo. es/lipmic/verger/, consultado el 10-IV-2009.
} 
Tabla 31. Manuel Penella Raga, Cançoneta de la mare. Esquema analítico.

Fuente: Biblioteca Musical Valenciana. Álbum de salón, $\mathrm{n}^{\circ} 2$.

\begin{tabular}{|c|c|c|c|c|}
\hline Secciones & Compases & $\begin{array}{c}\text { Aspectos } \\
\text { Armónicos }\end{array}$ & $\begin{array}{c}\text { Material } \\
\text { temático }\end{array}$ & Compás/Tempo \\
\hline \hline Introducción & $1-8$ & Sol M & A & $\begin{array}{c}3 / 4 \\
\text { Allegretto }\end{array}$ \\
\hline $1^{\mathrm{a}}$ & $9-34$ & Do M & B & $2 / 4$ \\
\hline $2^{\mathrm{a}}$ & $35-54$ & Sol M & C & Poco más animado \\
\hline $3^{\mathrm{a}}$ & $55-74$ & \multicolumn{2}{|c}{} \\
\hline
\end{tabular}

\section{Obras para piano y piano a cuatro manos}

Las cinco obras para piano localizadas en la Biblioteca Musical Valenciana son piezas sencillas, para aficionados o estudiantes. El Conservatorio de Valencia convocaba anualmente concursos para otorgar premios en distintas asignaturas. Roberto Segura, profesor de piano de este centro entre 1879 y 1902, escribió la canzonetta para piano Cunera y la melodía para piano Prega para que sirviesen como ejercicios de lectura a primera vista en el curso 1891-92. Cunera iba destinada al concurso de alumnas y Prega al de alumnos ${ }^{71}$. En los 57 compases de Cunera (véase Tabla 32), la mano derecha lleva la melodía y la izquierda un simple acompañamiento de arpegios con pulsación de corchea; la repetición del tema A es una variación rítmica de la melodía octavada en semicorcheas. Prega está estructurada en dos secciones con un solo tema, que aparece en la primera sección en la mano derecha, y en la segunda sección en la mano izquierda con un acompañamiento que sigue la pulsación de corchea (véase Tabla 33). La pieza acaba en Si b Mayor, aunque con acordes prestados del relativo menor (Sol b Mayor y Mi b menor).

\footnotetext{
${ }^{71}$ La obra aparece recogida en el catálogo realizado por Galbis, "Segura Villalba, Roberto”, p. 911.
} 
Tabla 32. Roberto Segura, Cunera (Canzonetta para piano). Esquema analítico. Fuente: Biblioteca Musical Valenciana. Álbum de salón, $\mathrm{n}^{\circ} 1$

\begin{tabular}{|c|c|c|c|c|}
\hline Secciones & Compases & $\begin{array}{c}\text { Aspectos } \\
\text { Armónicos }\end{array}$ & $\begin{array}{l}\text { Material } \\
\text { temático }\end{array}$ & Compás/Tempo \\
\hline \multirow{2}{*}{$1^{\mathrm{a}}$} & $1-12$ & Sol m & $\mathrm{A}$ & \multirow{4}{*}{$\begin{array}{c}3 / 4 \\
\text { Andantino }\end{array}$} \\
\hline & $13-22$ & Mi b M & $\mathrm{B}$ & \\
\hline \multirow[t]{2}{*}{$2^{\mathrm{a}}$} & $23-37$ & Sol m & $\begin{array}{c}\text { A } \\
\text { variado }\end{array}$ & \\
\hline & $38-49$ & Sol M & $\mathrm{B}$ & \\
\hline Coda & $50-57$ & Sol $\mathrm{m} \rightarrow$ Sol M & & Lento \\
\hline
\end{tabular}

Tabla 33. Roberto Segura, Prega (1891-92). Esquema analítico.

Fuente: Biblioteca Musical Valenciana. Álbum de salón, no 2.

\begin{tabular}{|c|c|c|c|c|}
\hline Secciones & Compases & $\begin{array}{c}\text { Aspectos } \\
\text { Armónicos }\end{array}$ & $\begin{array}{l}\text { Material } \\
\text { temático }\end{array}$ & Compás/Tempo \\
\hline Introducción & $1-11$ & Sib M $\rightarrow$ V & \multirow{2}{*}{ A } & \multirow{5}{*}{$\begin{array}{c}3 / 4 \\
\text { Lento }\end{array}$} \\
\hline \multirow[b]{2}{*}{$1^{\mathrm{a}}$} & $12-30$ & Sib M- Sol m & & \\
\hline & $31-37$ & Sol $\mathrm{m} \rightarrow$ Reb M (V) & $\begin{array}{l}\text { Transición } \\
\text { (elementos } \\
\text { introducción) }\end{array}$ & \\
\hline \multirow[t]{2}{*}{$2^{\mathrm{a}}$} & \multirow[t]{2}{*}{$38-68$} & $\begin{array}{c}\text { Reb M-Sib m-Sib } \\
\text { M (V) }\end{array}$ & \multirow[t]{2}{*}{$\mathrm{A}$} & \\
\hline & & Sib M & & \\
\hline
\end{tabular}

La Tarantela de Ximénez ${ }^{72}$ es una danza estructurada en tres secciones (véase Tabla 34) y sostenida rítmicamente por figuraciones de corcheas en $6 / 8$ y de negra y corchea. Armónicamente es una pieza muy sencilla, en La menor y La Mayor.

Tabla 34. Eduardo Ximénez, Tarantela. Esquema analítico. Fuente: Biblioteca Musical Valenciana. Álbum de salón, $\mathrm{n}^{\mathrm{0}} 2$.

\begin{tabular}{|c|c|c|c|c|}
\hline Secciones & Compases & $\begin{array}{c}\text { Aspectos } \\
\text { Armónicos }\end{array}$ & $\begin{array}{c}\text { Material } \\
\text { temático }\end{array}$ & Compás/Tempo \\
\hline \hline $1^{\mathrm{a}}$ & $1-40$ & $\mathrm{La} \mathrm{m}$ & $\mathrm{A}$ & \multirow{2}{*}{$6 / 8$} \\
\hline $2^{\mathrm{a}}$ & $41-63$ & $\mathrm{La} \mathrm{M}$ & $\mathrm{B}$ & \multirow{2}{*}{ Allegro } \\
\hline $3^{\mathrm{a}}$ & $3-40$ & $\mathrm{La} \mathrm{m}$ & $\mathrm{A}$ & \multirow{2}{*}{ La m } \\
\hline Coda & $64-74$ & $\mathrm{n}$ & \\
\hline
\end{tabular}

\footnotetext{
${ }^{72}$ Esta obra no aparece en el inventario realizado por Galbis para la voz "Jiménez Cos, Eduardo", en DMEH, vol. 6 (2000), pp. 575-576.
} 
La Canzonetta de Juan Bautista Plasencia es la transcripción para piano de una pieza que formaba parte de un cuarteto original para dos violines, viola y violoncello ${ }^{73}$. La pieza tiene tres temas (véase Tabla 35). El tema A, en Re menor, tiene un carácter marcial, con figuraciones de corchea o corchea con puntillo y semicorchea en $2 / 4$. Los temas $\mathrm{B}$ y $\mathrm{C}$, con carácter de divertimento, tienen figuraciones de semicorcheas $\mathrm{y}$, en algunos compases, progresiones melódicas, que dan paso de nuevo al tema A.

Tabla 35. Juan Bautista Plasencia, Canzonetta. Esquema analítico.

Fuente: Biblioteca Musical Valenciana. Álbum de salón, $\mathrm{n}^{\mathrm{o}} 2$.

\begin{tabular}{|c|c|c|c|c|}
\hline Secciones & Extensión & $\begin{array}{c}\text { Aspectos } \\
\text { Armónicos }\end{array}$ & $\begin{array}{l}\text { Material } \\
\text { temático }\end{array}$ & Compás/Tempo \\
\hline \multirow{3}{*}{$1^{\mathrm{a}}$} & $1-24$ & Re m & $\overline{\mathrm{A}}$ & \multirow{6}{*}{$\begin{array}{c}\text { 2/4 } \\
\text { Andante }\end{array}$} \\
\hline & $25-34$ & La M & $\mathrm{B}$ & \\
\hline & $35-58$ & Re m & $\mathrm{A}$ & \\
\hline \multirow[t]{2}{*}{$2^{\mathrm{a}}$} & $59-90$ & $\begin{array}{c}\mathrm{La} \mathrm{M}- \\
\text { inestabilidad } \rightarrow \mathrm{V}(\mathrm{La})\end{array}$ & $\mathrm{C}$ & \\
\hline & $91-101$ & La M & $\mathrm{B}$ & \\
\hline \multicolumn{4}{|c|}{ Repetición $1^{\mathrm{a}}$ sección } & \\
\hline
\end{tabular}

La fiesta del trabajo de Manuel Penella Raga es una pieza breve en tiempo de marcha en 2/4 para piano a cuatro manos, en forma de rondó ABACA y coda final (véase Tabla 36) ${ }^{74}$. Tras una breve introducción de carácter rítmico, en figuraciones ternarias, se inicia el tema A en Sol Mayor en octavas paralelas, con figuraciones ternarias y arpegiadas, al que le sigue, desde el compás 21, el tema B de carácter armónico. A partir del compás 71 aparece el tema $\mathrm{C}$ en Do Mayor, de carácter más rítmico, que interpreta la mano izquierda del primer pianista y es duplicado por terceras y sextas en las otras voces.

\footnotetext{
${ }^{73}$ El título de esta obra aparece en el catálogo incluido en Carranza, "Plasencia Aznar, Juan Bautista", p. 857.

${ }^{74}$ La obra aparece recogida en el catálogo realizado por Galbis en "Penella Raga, Manuel”, p. 575.
} 
Tabla 36. Manuel Penella Raga. La fiesta del trabajo. Esquema analítico. Fuente: Biblioteca Musical Valenciana. Álbum de salón, $\mathrm{n}^{\circ} 3$.

\begin{tabular}{|c|c|c|c|c|}
\hline Secciones & Extensión & $\begin{array}{c}\text { Aspectos } \\
\text { Armónicos }\end{array}$ & $\begin{array}{l}\text { Material } \\
\text { temático }\end{array}$ & Compás \\
\hline \multirow{2}{*}{$1^{\mathrm{a}}$} & $1-4$ & \multirow{2}{*}{ Sol M } & \multirow{2}{*}{ A } & \multirow{7}{*}{$2 / 4$} \\
\hline & $5-20$ & & & \\
\hline $2^{a}$ & $21-54$ & $\operatorname{Re} M$ & $\mathrm{~B}$ & \\
\hline $3^{a}$ & $55-70$ & Sol M & $\mathrm{A}$ & \\
\hline $4^{a}$ & $71-102$ & Do M & $\mathrm{C}$ & \\
\hline $5^{\mathrm{a}}$ & $1-19$ & \multirow{2}{*}{ Sol M } & $\mathrm{A}$ & \\
\hline Coda & 103-119 & & Coda & \\
\hline
\end{tabular}

\section{Obras para piano y armónium}

La Biblioteca Musical Valenciana publicó dos obras para piano y armónium, Ilusión de José Ma Úbeda y A la Reina de la fiesta de Francisco J. Blasco.

En Ilusión ${ }^{75}$ (véase Tabla 37) están claramente definidas las funciones de cada instrumento: el armónium lleva siempre la melodía y figuraciones sencillas, mientras que el piano tiene el papel de acompañante, que es más sencillo en la primera sección (nota pedal y figuraciones de corcheas) y más virtuosístico (arpegios ascendentes y descendentes de semifusas) en la segunda sección. El armónium utiliza un registro para la sección en Sol menor y otro diferente para la parte en Sol Mayor.

Tabla 37. José Ma Úbeda Montés. ¡Ilusión!. Esquema analítico.

Fuente: Biblioteca Musical Valenciana. Álbum de salón, $\mathrm{n}^{\circ} 1$.

\begin{tabular}{|c|c|c|c|c|}
\hline Secciones & Compases & $\begin{array}{c}\text { Aspectos } \\
\text { Armónicos }\end{array}$ & $\begin{array}{c}\text { Material } \\
\text { temático }\end{array}$ & Compás/Tempo \\
\hline \hline Introducción & $1-5$ & Sol $\mathrm{m} \rightarrow \mathrm{V}$ & & $\begin{array}{c}2 / 4 \\
\text { Andante } \\
\text { tranquilo }\end{array}$ \\
\hline \multirow{2}{*}{$1^{\mathrm{a}}$} & $6-23$ & Sol $\mathrm{m}$ & $\mathrm{A}$ & Poco piu mosso \\
\cline { 2 - 2 } $2^{\mathrm{a}}$ & $24-41$ & Sol M & $\mathrm{B}$ & $1^{\mathrm{o}}$ tempo \\
\cline { 2 - 3 } Coda & $50-49$ & Sol $\mathrm{m}$ & $\begin{array}{c}\text { Elementos de } \\
\text { A }\end{array}$ & \multicolumn{2}{|c}{} \\
\hline
\end{tabular}

\footnotetext{
75 ¡Ilusión! no aparece, al menos con este título, en el catálogo elaborado por Climent, "Úbeda Montés,
} José María", pp. 545-546. 
La marcha A la Reina de la fiesta, de Francisco J. Blasco es una reducción para piano y armónium de la obra premiada en el concurso de composición de 1881, organizado por la sociedad Lo Rat Penat durante los Juegos Florales celebrados en Valencia, y que posteriormente fue ampliada por el autor para concierto, y publicada con el título Amor, Fe y Patria. La versión publicada en la Biblioteca Musical Valenciana consta de tres secciones ABA (véase Tabla 38), (Mi b M-La b M- Mi b M). La obra comienza a modo de marcha de carácter solemne en 12/8. El armónium y el piano mantienen básicamente las mismas figuraciones rítmicas. En la segunda sección el armónium interpreta la melodía principal que el piano acompaña, y luego la duplica con octavas.

Tabla 38. Francisco J. Blasco, A la Reina de la fiesta. Esquema analítico. Fuente: Biblioteca Musical Valenciana. Album de salón, $\mathrm{n}^{\circ} 2$.

\begin{tabular}{|c|c|c|c|c|}
\hline Secciones & Compases & $\begin{array}{c}\text { Aspectos } \\
\text { Armónicos }\end{array}$ & $\begin{array}{l}\text { Material } \\
\text { temático }\end{array}$ & Compás/Tempo \\
\hline $1^{\mathrm{a}}$ & $1-8$ & Mi b M & $\mathrm{A}$ & \multirow{3}{*}{$\begin{array}{c}12 / 8 \\
\text { Moderato } \\
.=84 \\
\\
(\text { el c. } 17 \text { está en } \\
6 / 8)\end{array}$} \\
\hline $2^{\mathrm{a}}$ & $9-24$ & La b M & $\mathrm{B}$ & \\
\hline $3^{a}$ & $25-33$ & Mi b M & $\mathrm{A}$ & \\
\hline
\end{tabular}



CAPÍTULO 5

AMORÓS COMPOSITOR 



\section{Coordenadas estéticas de la labor creadora de Amorós: tradición romántica, folklore valenciano y cecilianismo}

Una primera aproximación al estilo compositivo de Amancio Amorós muestra la influencia de la tradición estética del Romanticismo tardío, a la que se suman elementos nacionalistas, en conexión con el movimiento estético de la Renaixença valenciana y una influencia perceptible del estilo cecilianista en algunas de sus obras religiosas. Desde mediados del XIX comienza en España la recopilación y ordenación de temas populares, lo que supuso el inicio del estudio del folklore musical tal y como lo conocemos en la actualidad $^{1}$. Las primeras recopilaciones conocidas de material folklórico valenciano se remontan a la década de los setenta del siglo XIX, con figuras como Eduardo Ximénez (1824-1900), pionero en la investigación folklórica valenciana, José Inzenga (18281891), el jesuita Mariano Baixauli Biguer (1861-1923) y José Ruiz de Lihory (1852$1920)^{2}$

Ximénez es autor de Música de los cantos y danzas populares de Valencia y su provincia, trabajo realizado en 1873 para la Exposición Universal de Viena por encargo de la Subcomisión Provincial de Industria de Valencia. El manuscrito de esta obra, que se conserva en la Biblioteca Nacional de Madrid (M 1020) consta de 43 páginas y contiene una dedicatoria del autor a Francisco Asenjo Barbieri. Ximénez recopiló en esta obra once piezas. Siete de ellas son cantos para ser acompañados con instrumentos de cuerda: La alicantina, la jota del carrer, L'u i el dos [sic], Jota valenciana, El paño moruno, El

\footnotetext{
${ }^{1}$ Emilio Rey García y Víctor Pliego Andrés, "La recopilación de la música popular española en el siglo XIX: cien canciones en cien años", Revista de Musicología, 14 (1991), pp. 356-358.

${ }^{2}$ Con anterioridad a estos folkloristas, que desarrollaron su labor a finales del siglo XIX, cabría mencionar la figura pionera del P. Eximeno, jesuita valenciano, filósofo, matemático y estudioso de la música, que incluyó una dulzaina valenciana en el apéndice de su Dell'origine e delle regole della musica colla storia del suo progreso, decadenza, e rinnovazione, obra impresa en Roma en 1774. Miguel A. Picó Pascual, "Eduardo Ximénez Cos (1824-1900), patriarca de la investigación folklórico musical valenciana", Revista de Folklore, 274 (2003), p. 134. Fermín Pardo y Jordi Reig, "Folclore", en DMV, vol. 1 (2006), pp. 361-385, añaden las aportaciones de Gonzalo Valero Agües con su Descripción manuscrita del Baile de Torrente (1884) y de Just i Joaquim Sansalvador i Cortés con Memòria de la recerca de cançons i músiques populars al Comtat de Cocentaina, dentro de L'obra del Cançoner popular de Catalunya (1929).
} 
punt de l'Habana y Les albaes [Las alboradas]. Las cuatro piezas restantes son melodías para dulzaina: La Xàquera Vella, Danza de la magrana, El Faitó del Baile de Torrent y Melodía de Procesión. Ximénez incluye una descripción de las once piezas y de los instrumentos tradicionales valencianos (guitarra, guitarró, octavilla, cítara, dulzaina y tabalet), con dibujos, extensión y registro ${ }^{3}$.

El manuscrito de Ximénez va precedido por un prólogo de Emiliano Teixeró, que comenta la carencia de datos y antecedentes escritos sobre la música original de los cantos y danzas populares con la que se encontró Ximénez. Éste trataba de escribir la música popular original y para ello era preciso distinguir la verdadera música original de las variaciones que había introducido el pueblo. Ximénez buscó en Valencia y en los pueblos de la Vega lo que el pueblo llama Cantars d'estil, es decir, aquellos que conservaban en toda su integridad la música popular transmitida de generación en generación. Según el manuscrito consultado:

\begin{abstract}
Sucede con la música popular lo que con otras muchas tradiciones que sólo el pueblo conserva (adulteradas la mayor parte de las veces al pasar por una prolongada serie de generaciones), que es imposible determinar el momento histórico que le dio vida, ni el hecho que las motivó, ni Diago, ni Escolano, ni otros historiadores del reino de Valencia dicen una palabra en este concepto. Sin embargo, y por tradición, también todos están conformes en afirmar que la música que nos ocupa procede de los árabes: manantial fecundo de conocimientos al que se recurre con harta frecuencia en nuestro país, no sin razón en casos como el presente. Sea como quiera es lo cierto que los instrumentos con que los cantos y danzas populares se acompañan son la dulzaina, el tamboril, la guitarra y la cítara ${ }^{4}$.
\end{abstract}

\footnotetext{
${ }^{3}$ Ximénez, Música de los Cantos y danzas populares de Valencia y su provincia transmitidos al papel y coleccionados por el profesor de música valenciano Eduardo Ximénez, manuscrito, E:Mn, M 1020; véase también Picó, "Eduardo Ximénez", pp. 134-135. La Biblioteca Valenciana conserva una copia del manuscrito de Ximénez, Música de los cantos y danzas populares de Valencia y su provincia, transmitidos al papel y coleccionados por el profesor de música valenciano Sr. Eduardo Ximénez [copia y anotaciones de Eduardo López-Chavarri Marco], 14 pp. Encuadernado junto a Cantos y danzas populares de la región valenciana, coleccionados en mis excursiones y tomados por mí al oído directamente, en su mayoría [Manuscrito de Eduardo López-Chavarri Marco], E:VAbv, AELCH/pro 491.

${ }^{4}$ Emiliano Teixeró, prólogo a Música de los cantos y danzas populares de Valencia y su provincia, trnasmitidos al papel y coleccionados por el profesor de música valenciano Eduardo Ximénez [Manuscrito, copia y anotaciones de Eduardo López-Chavarri], p. 2, E:VAbv, AELCH/pro 491; Picó, "Eduardo Ximénez", pp. 134-135.
} 
José Inzenga siguió la tarea de recopilación de canciones y bailes populares por tierras valencianas a finales del siglo XIX, que publicó en su obra Cantos y bailes populares de España $(1888)^{5}$. El jesuita Mariano Baixauli reunió también una muestra de melodías de danza y de procesión de la ciudad de Valencia, que fue editada en el Cancionero Musical de la provincia de Valencia por Salvador Seguí en $1980^{6}$. Ruiz de Lihory, en La música en Valencia, premiada en los Juegos Florales de 1900 y publicada en 1903, incluyó artículos sobre folklore con descripciones y noticias de danzas como "Danza de enanos", "Danza de gigantes", "Danza de la Granada", "Albaes", "Jota Valenciana", "Baile de Torrente”, “La Xàquera Vella”, "Danzas”, "Danzas de la Ribera del Júcar” y "La Muxaranga", En este contexto de interés por el folklore valenciano es en el que Amancio Amorós compuso algunas de sus creaciones ${ }^{8}$.

En sus obras religiosas Amorós se movió entre el estilo romántico vigente a finales del siglo XIX y las influencias del cecilianismo, con un estilo más sobrio y adaptado a la liturgia, patente sobre todo en su Misa Ceciliana (1912). El cecilianismo, originado en Alemania en la segunda mitad del siglo XIX y vigente, aproximadamente, hasta la segunda década del siglo XX, tuvo su centro principal en Ratisbona y se estableció oficialmente en 1869 cuando Franz Xavier Witt (1834-1888) fundó la Sociedad General de Santa Cecilia. Los músicos y teóricos cecilianistas reaccionaron contra los excesos de la música sacra romántica (que consideraban excesivamente

\footnotetext{
5 José Inzenga, Cantos y bailes populares de España. Valencia (Madrid: A. Romero, 1888). Según Miguel A. Picó Pascual, "La recopilación de canciones y bailes populares efectuada a finales del siglo XIX por José Inzenga Castellanos en tierras valencianas y murcianas I", Revista de Folklore, 187 (1996), pp. 3-13, el trabajo de Ximénez, que nunca llegó a publicarse, fue utilizado por Inzenga en su obra dedicada a Valencia.

${ }^{6}$ Salvador Seguí, Cancionero Musical de la provincia de Valencia (Valencia: Institución Alfonso El Magnánimo, 1980), pp. 508-538.

${ }^{7}$ Picó, “La recopilación de canciones”, p. 4.

${ }^{8}$ Ya después de la muerte de Amorós, Eduardo Martínez Torner publicó en 1938 sus Danzas Valencianas (Barcelona: Centro de Estudios Históricos del País Valenciano, 1938), p. 1.
} 
operística) y reivindicaron la restauración del verdadero canto gregoriano, la recuperación de la polifonía clásica del siglo XVI y la creación de un nuevo estilo de composición musical inspirado en el canto a cappella y el contrapunto imitativo. Desde el cecilianismo se pretendía también buscar la participación de la asamblea de fieles en la liturgia por medio del canto y reformar la música para órgano, que había de ser más sobria. La reforma de la música litúrgica propugnada por los músicos cecilianistas fue fomentada por el propio papa Pío X, quien en 1903 dio a conocer su Motu Proprio "Tra le sollecitudini" en el que recoge los presupuestos de Lorenzo Perosi (1872-1956), uno de los principales compositores del movimiento ceciliano.

El Cecilianismo llegó también a España, y Amancio Amorós se vió influenciado por sus presupuestos, como refleja parte de su producción religiosa, que analizaré más adelante. El estilo ceciliano sirvió en muchos casos para renovar el lenguaje musical con recursos armónicos más avanzados y un empleo más coherente de la modalidad 9 .

\section{Música sinfónica}

Amorós compuso dos sinfonías que se conservan manuscritas en la Biblioteca de Catalunya: la Sinfonía Corina, op. 35 (1883) y la Sinfonía para gran orquesta, compuesta sobre aires populares de Valencia y su reino, op. 69 (1890), de las que presento a continuación su análisis. Una edición crítica de ambas se incluye en el volumen 2 de esta Tesis. La plantilla que Amorós utiliza en ambas sinfonías es más propia de una orquesta clásica que romántica, si tenemos en cuenta los avances que presentaba el lenguaje sinfónico europeo en época del compositor.

\footnotetext{
${ }^{9}$ Véase Legasa, "Bonifacio Iráizoz”, pp. 675-693.
} 


\section{1. Corina, op. 35 (1883)}

Para la edición crítica de Corina (véase volumen 2, edición de composiciones de Amancio Amorós) he partido de la única partitura manuscrita localizada, que se conserva en la Biblioteca de Catalunya (M 1283). Amorós utilizó una orquesta integrada por flauta y flautín, dos oboes, dos clarinetes, dos fagots, cuatro trompas, dos cornetines en la, tres trombones, figle, timbales y cuerda. La estructura de la obra puede verse esquemáticamente en la Tabla 39. Desconozco si Corina se estrenó ${ }^{10}$.

Amorós utiliza para dar título a esta sinfonía op. 69 el nombre de la poetisa griega Corina de Tanagra (Beocia) ${ }^{11}$. La obra, en Mi Mayor, sigue básicamente la forma clásica de sonata de primer movimiento. Amorós utiliza las familias instrumentales para graduar la tensión rítmica y expresiva. Inicia los temas principales con la madera, a la que añade la cuerda y pasa al tutti orquestal en las secciones de mayor intensidad. Cuando disuelve los tutti, mantiene las trompas como nexo entre la madera y la cuerda. Frecuentemente dos o tres instrumentos de madera son los protagonistas de la melodía, a los que añade generalmente violines primeros y segundos (véase Ejemplo 1).

\footnotetext{
${ }^{10}$ En el estudio de Sancho, Romanticismo, no aparece ninguna referencia a la sinfonía Corina.

${ }^{11}$ Véase Cesare Cantú, "Safo y las literatas griegas”, en Historia Universal (Madrid: Imprenta de Gaspar Roig, 1866), vol. 10, pp. 41-48. Posiblemente Amorós era un enamorado de la literatura antigua. En su parodia El tío Sappo también utilizó material de la ópera Saffo de Pacini basada en aspectos de Safo, la primera poetisa griega conocida.
} 


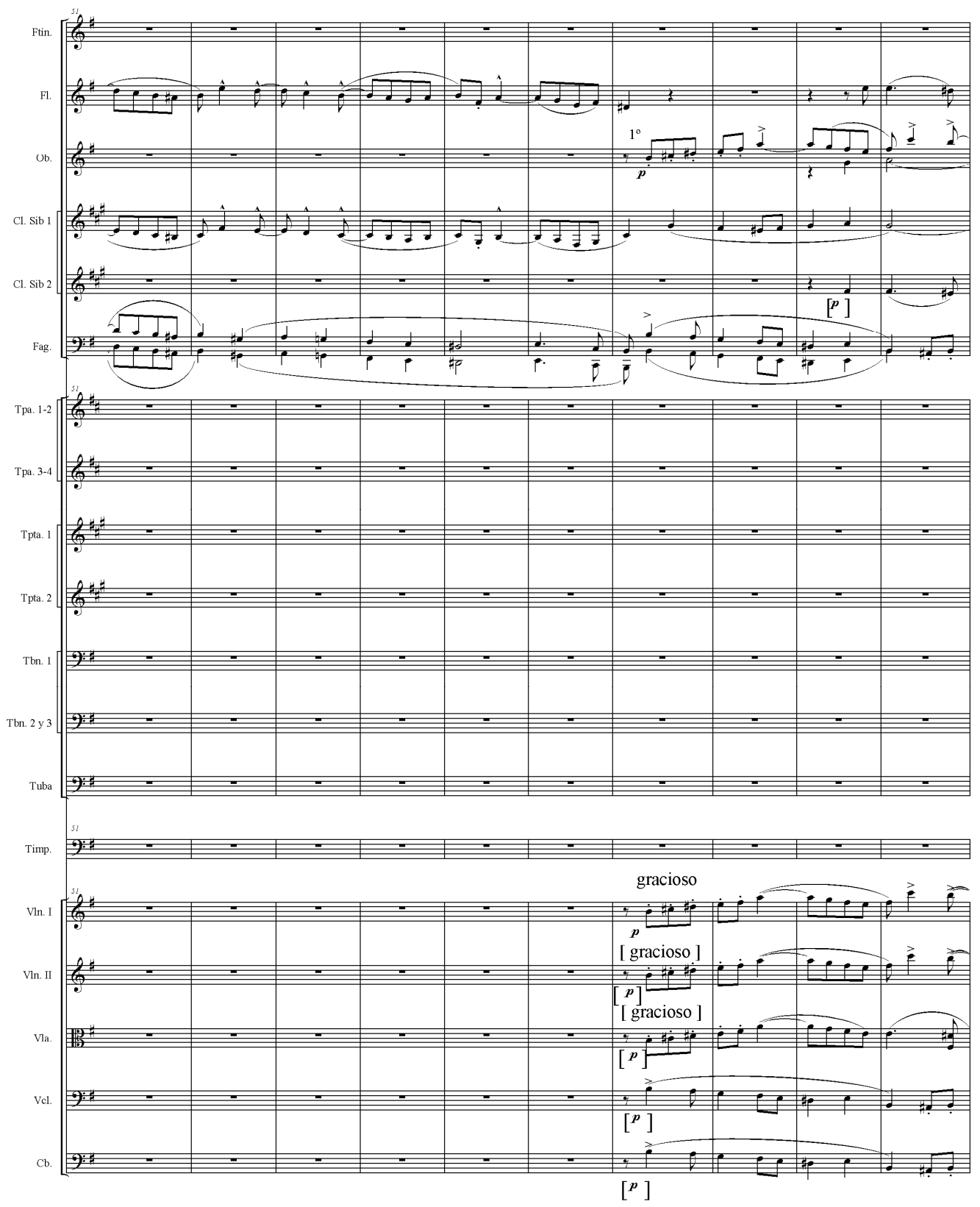

Ejemplo 1

Amancio Amorós, Corina, cc. 51-60.

Una excepción es el inicio del grupo temático $\mathrm{B}$, en el que la trompa y los violoncellos son los protagonistas de la melodía (véase Ejemplo 2). 


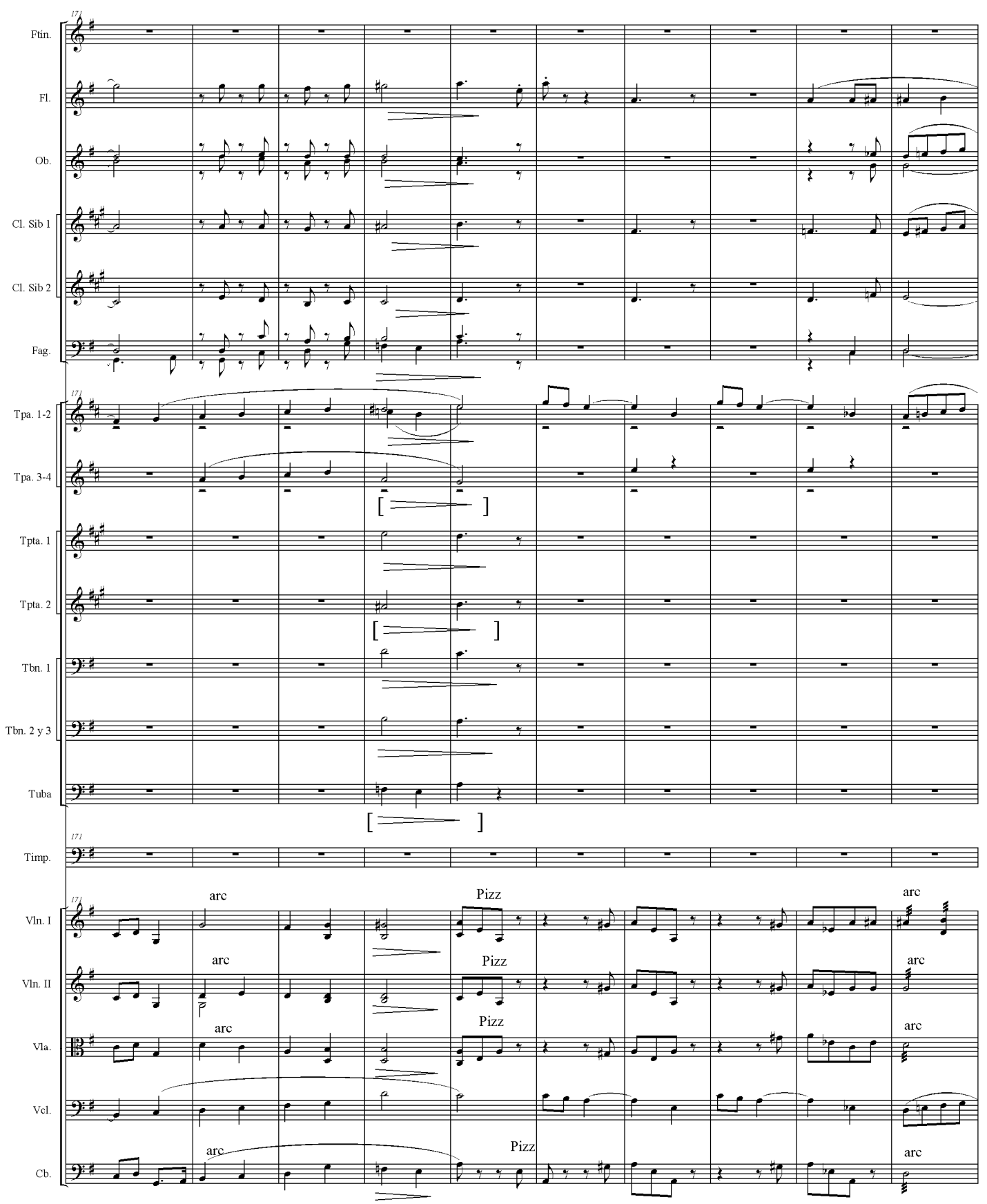

Ejemplo 2

Amancio Amorós, Corina, cc. 171-180.

Amorós utiliza muchas indicaciones expresivas que, por lo que respecta a intensidad, van desde el pianísimo hasta el fortísimo, con crescendos ocasionalmente muy largos. El tempo queda bien indicado, y aparecen muchas expresiones como mancando, gracioso, slargando, molto tenuto. La estructura fraseológica de los temas 
principales es de ocho o dieciséis compases, a menudo con cesura central. En el discurso orquestal predominan los pasajes contrapuntísticos (véase Ejemplo 3).

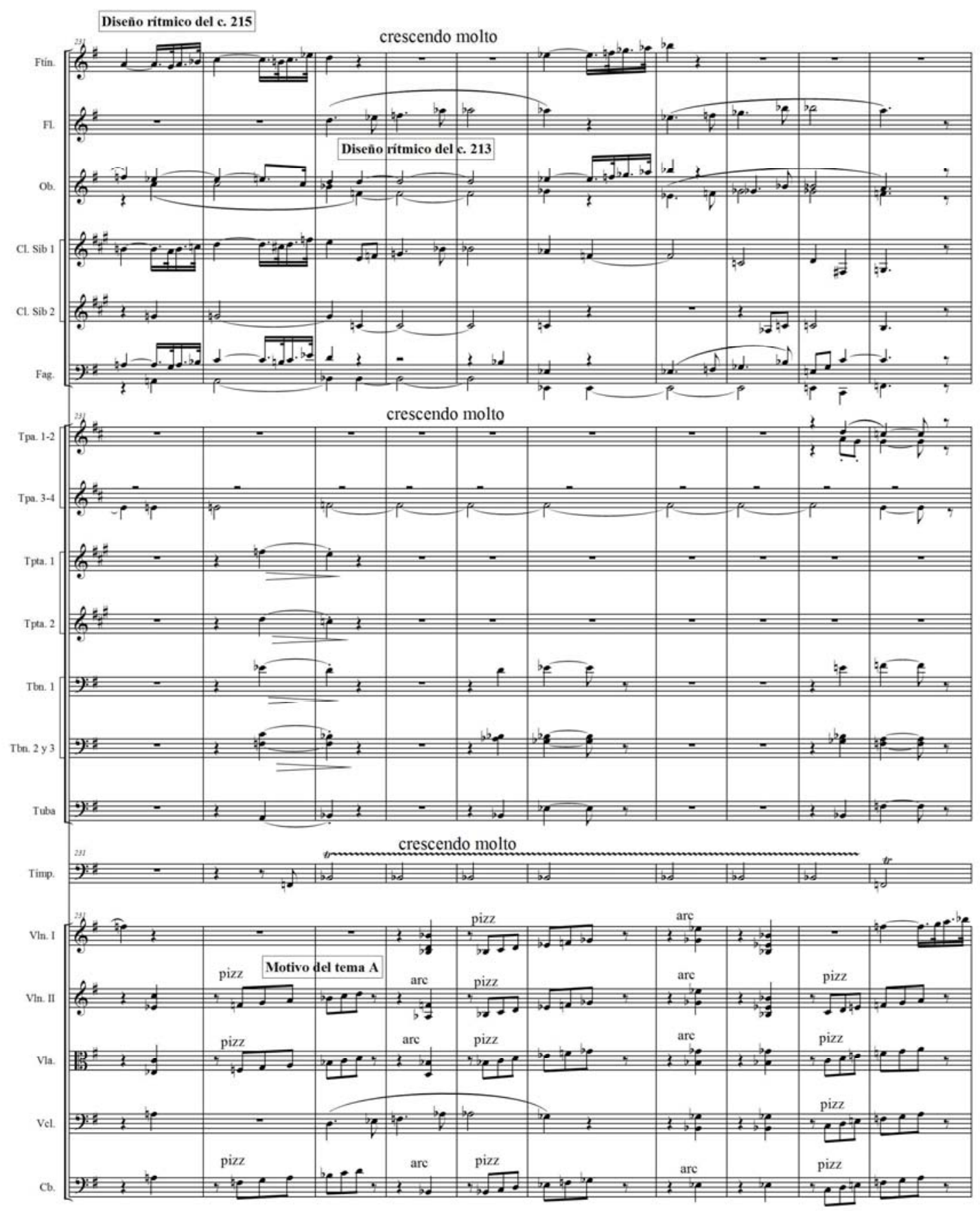

Ejemplo 3

Amancio Amorós, Corina, cc. 231-240, ejemplo representativo de pasaje contrapuntístico. 
El estilo de Corina se enmarca dentro de las características de la sinfonía de mediados del siglo XIX en España y no puede considerarse retardataria a nivel formal si tenemos en cuenta lo que se hacía en esos momentos en España. Hasta entonces las piezas instrumentales denominadas "sinfonías" eran casi siempre oberturas, y no sinfonías como las centroeuropeas, basadas en la sonata clásica ${ }^{12}$. La sinfonía de Amorós coincide con el surgimiento en España de obras sinfónicas en cuatro movimientos de Tomás Bretón (Sinfonía $n^{\circ} 1$ en Fa Mayor, 1872 y Sinfonía $n^{\circ} 2$ en Mi bemol Mayor, sf), Ruperto Chapí (Sinfonía en re menor, 1877), Pedro Miguel Marqués (Sinfonía $n^{\circ} 1$ en Si bemol Mayor, 1869) y Emilio Serrano (Sinfonía en Mi bemol Mayor, sf) ${ }^{13}$. En 1883, fecha de la sinfonía Corina de Amorós, las obras sinfónicas más frecuentes en Valencia eran danzas de salón y arreglos operísticos, por lo que el uso de formas de sonata que hace Amorós puede considerarse hasta cierto punto una novedad fruto del conocimiento de la música centroeuropea por parte del autor ${ }^{14}$.

\footnotetext{
${ }^{12}$ Según Subirá, Historia de la Música, p. 671, "la palabra sinfonía tenía un sentido equivalente al de fantasía o al de obertura"; Sobrino, "La música sinfónica", pp. 316-317.

${ }^{13}$ Sobrino, "La música sinfónica", p. 317.

${ }^{14}$ Autores valencianos coetáneos a Amorós que compusieron música orquestal fueron Salvador Giner (1832-1911); Vicente Díez Peydró (1861-1938); José Espí Ulrich (1814-1905); Manuel Penella (18471909); Eduardo Ximénez (1824-1900); Francisco Javier Blasco (1857-?); Manuel Soriano (i-1899); Manuel Galiana (1829-1855); Joan Cantó (1856-1903); José Jordá (1839-1918). Aviñoa, “L'activitat concertística", pp. 135-137.
} 
Tabla 39. Amancio Amorós. Corina, op. 35, Sinfonía para orquesta (1883). Esquema analítico. Fuente: $E: B c, \mathrm{M} 1283$.

\begin{tabular}{|c|c|c|c|c|}
\hline Secciones & Compases & $\begin{array}{l}\text { Tonalidad, } \\
\text { Función } \\
\text { Armónica }\end{array}$ & $\begin{array}{l}\text { Material } \\
\text { temático }\end{array}$ & $\begin{array}{l}\text { Tempo/ } \\
\text { compás }\end{array}$ \\
\hline Introducción & $\begin{array}{c}\mathrm{I} \\
1-48\end{array}$ & Mi menor & $\begin{array}{c}\text { Escalas } \\
\text { melódica y armónica } \\
\text { Pedal D } \\
\end{array}$ & $\begin{array}{c}\text { Moderato } \\
3 / 4\end{array}$ \\
\hline \multirow{5}{*}{ Exposición } & $\begin{array}{c}\text { A } \\
49-118\end{array}$ & Mi menor & $\begin{array}{c}\text { Grupo temático } \\
\text { A }\end{array}$ & $\begin{array}{c}\text { Allegro } \\
2 / 4\end{array}$ \\
\hline & \multirow{2}{*}{$119-167$} & $\begin{array}{c}\text { Do Mayor } \\
\text { Inestabilidad }\end{array}$ & \multirow{2}{*}{ Sección Modulante } & $\begin{array}{c}\text { Allegro } \\
2 / 4\end{array}$ \\
\hline & & Sol mayor & & $\begin{array}{c}\text { Allegro } \\
3 / 4 \\
\end{array}$ \\
\hline & $\begin{array}{c}\mathrm{B} \\
168-209\end{array}$ & Sol Mayor & $\begin{array}{c}\text { Grupo temático } \\
\text { B }\end{array}$ & $\begin{array}{c}\text { Allegro } \\
2 / 4\end{array}$ \\
\hline & $210-212$ & Sol Mayor & Pausa General & $\begin{array}{l}\text { Allegro } \\
3 / 4\end{array}$ \\
\hline \multirow{4}{*}{ Desarrollo } & $213-224$ & $\begin{array}{l}\text { Mi b Mayor } \\
\text { Fa menor } \\
\text { Sol Mayor }\end{array}$ & \multirow{3}{*}{$\begin{array}{l}\text { Mezcla motivos de la } \\
\text { exposición }\end{array}$} & \multirow{5}{*}{$\begin{array}{c}\text { Allegro } \\
2 / 4\end{array}$} \\
\hline & $225-246$ & $\begin{array}{l}\text { Re b Mayor } \\
\text { Mi b menor }\end{array}$ & & \\
\hline & $247-272$ & $\begin{array}{l}\text { Si b Mayor } \\
\text { Inestabilidad }\end{array}$ & & \\
\hline & $273-297$ & Mi menor & Pausa General & \\
\hline \multirow{3}{*}{ Reexposición } & $\begin{array}{c}\text { A } \\
298-362\end{array}$ & $\begin{array}{l}\text { Mi menor } \\
\text { Do Mayor }\end{array}$ & \multirow{3}{*}{$\begin{array}{c}\text { Grupos Temáticos } \\
\text { A y B }\end{array}$} & \\
\hline & $363-368$ & Inestabilidad & & $\begin{array}{c}\text { Allegro } \\
3 / 4\end{array}$ \\
\hline & $\begin{array}{c}\text { B } \\
369-412\end{array}$ & Mi Mayor & & $\begin{array}{c}\text { Allegro } \\
2 / 4 \\
\text { Allegro } \\
3 / 4\end{array}$ \\
\hline CODA & $\begin{array}{c}\text { CODA } \\
413-420\end{array}$ & Mi Mayor & Pedal de I & $\begin{array}{c}\text { Moderato } \\
9 / 8\end{array}$ \\
\hline
\end{tabular}


En el Moderato (Introducción) de la Sinfonía merece destacarse el protagonismo del diseño rítmico blanca-negra, que se establece como célula articuladora de esta primera parte y a nivel melódico el contraste entre las escalas armónica y melódica, con un diálogo entre cuerdas y madera, finalizando la introducción con una pedal sobre la dominante de mi menor.

El primer grupo temático de la Exposición es iniciado en el compás 49 por la flauta, clarinete y fagots (ocho compases), a los que responden las cuerdas una $5^{\mathrm{a}}$ superior (nueve compases) y finaliza sobre una cadencia perfecta V-I. En el compás 66 aparece un nuevo diseño rítmico interpretado por flautas y trompetas, que dialogan contrapuntísticamente con el violín, que realiza un motivo tomado del tema A (véase Ejemplo 4).

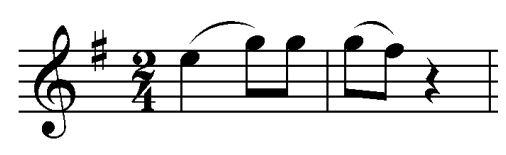

Ejemplo 4

Amancio Amorós, Corina, c. 66, diseño rítmico de flautas y trompetas.

Desde el compás 83 al 97 hay una sección de transición en la que aparecen figuraciones de semicorcheas por el viento madera y trinos en la cuerda, finalizando al unísono el tutti orquestal con figuraciones de corcheas, una intensificación dinámica y pausa con calderón. A continuación se reexpone el tema A, modificando el final con un pequeño desarrollo que busca el acorde sobre la dominante. Desde el punto de vista armónico presenta una fuerte estabilidad tonal. Del compás 119 al 167 hay una sección modulante con nuevos elementos melódicos y rítmicos que comienza con un motivo en el clarinete y el oboe en Do mayor y modula a la menor en el compás 128. 
La sección modulante finaliza con un diálogo entre la cuerda y viento madera, con apoyaturas inferior y superior sobre la pedal de la dominante; se añade a cargo de las maderas una célula rítmica por aumentación extraída del inicio de esta sección. Así pues, tenemos dos motivos contrastantes, por un lado viento madera (véanse Ejemplos 5 y 6):

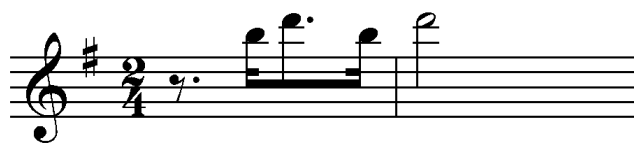

Ejemplo 5

Amancio Amorós, Corina, c. 146, viento madera.

y por otro cuerda:

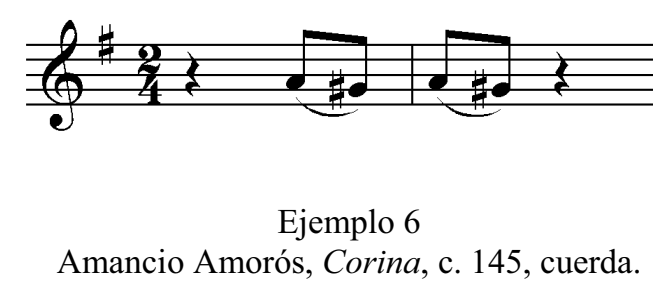

Armónicamente esta sección modulante es inestable, tomando como base un pedal de re, la tonalidad fluctúa entre los tonos de la, do y sol. En el compás 168 se inicia el grupo temático $\mathrm{B}$, con un tema más cantabile que el $\mathrm{A}$, y lo llevan trompas $\mathrm{y}$ violoncellos. Estructuralmente, el antecedente con ocho compases, sigue en Sol Mayor y en el consecuente, también con ocho compases, una séptima de dominante conduce a la menor. Una pausa general señala el final de la exposición.

El Desarrollo se inicia en el compás 213 con el motivo presentado en la sección modulante (compás 120), que a su vez sufre varias modulaciones y transformaciones. Este motivo entra en diálogo a partir del compás 228 con un motivo del tema A, entre la madera y la cuerda y es uno de los pasajes más modulantes de la obra (desde el compás 228 al 240 se pasa por Re bemol Mayor, Mi bemol menor y Fa Mayor). El desarrollo 
finaliza en un pedal de Si, acompañado de diseños de corcheas y notas tenidas para alcanzar el calderón final. En la Reexposición de los grupos temáticos A y B cabe destacar la modulación a Mi Mayor en el compás 369, tonalidad que se mantiene hasta el final de la sinfonía.

Las secciones en las que aparecen los grupos temáticos A y B presentan una armonía sencilla. En estos casos, hay pequeñas inflexiones a tonos vecinos que se realizan por cromatismo o diatónicamente (Ejemplos 7 y 8).

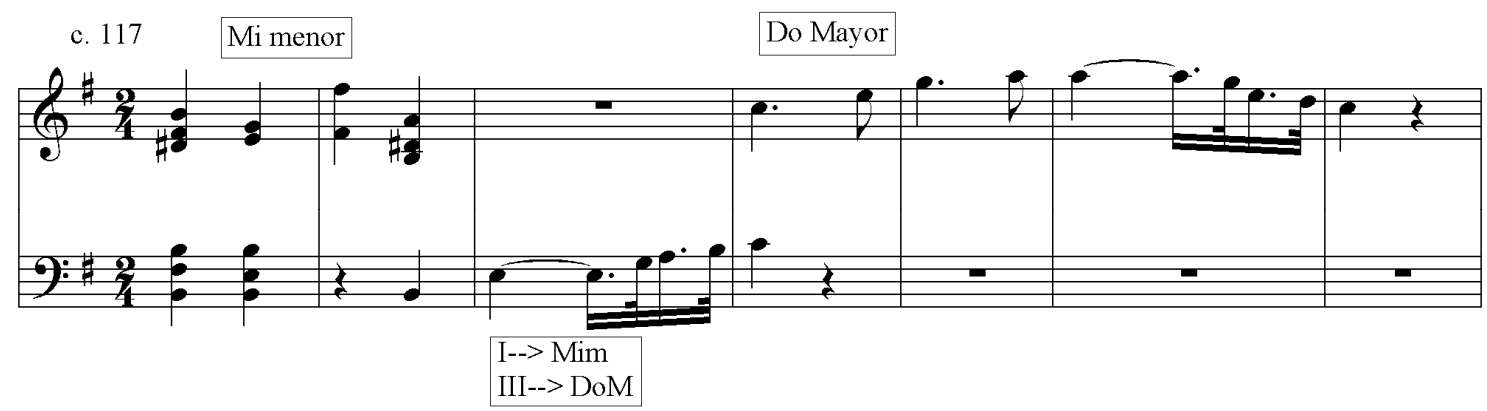

Ejemplo 7

Amancio Amorós, Corina, cc. 117-123, inflexión diatónica a tonos vecinos.

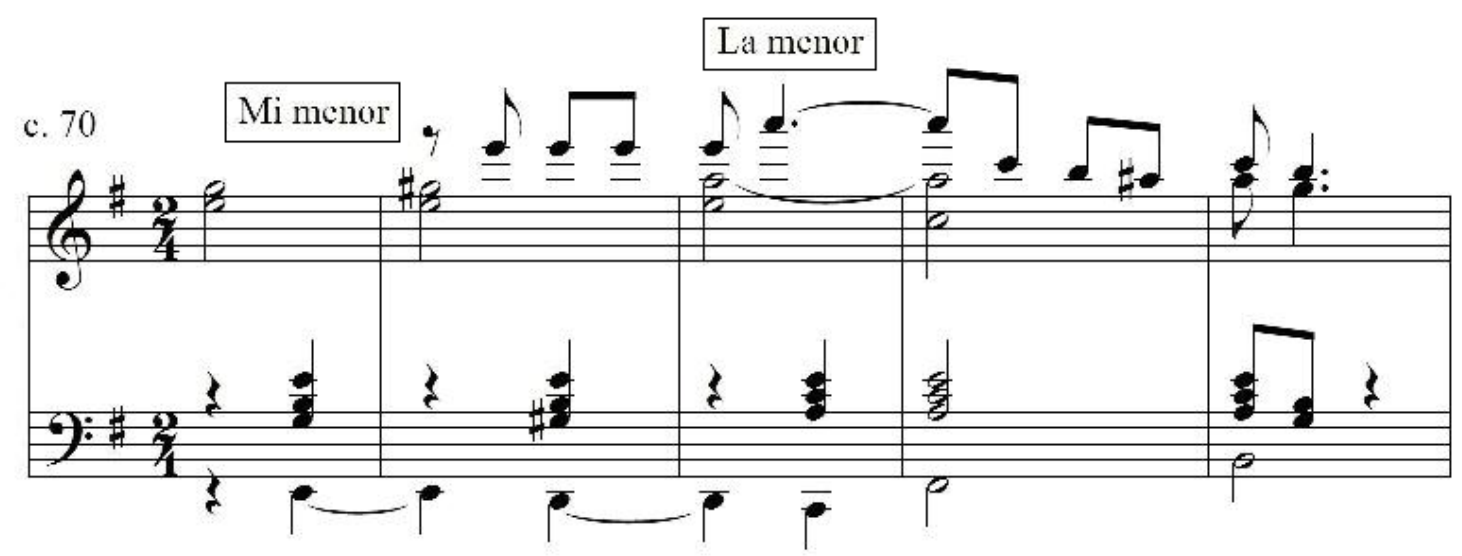

Ejemplo 8

Amancio Amorós, Corina, cc. 70-74, inflexión a la menor por cromatismo. 
Las secciones más interesantes desde el punto de vista armónico son las que unen el tema A con el B, y el desarrollo. Cabe destacar la modulación del compás 213 en el que se pasa de Sol Mayor a Mi b Mayor sin preparación alguna (Ejemplo 9), o la que se produce en el compás 224 al pasar de Sol Mayor a Re bemol Mayor mediante una cadencia rota (Ejemplo 10).

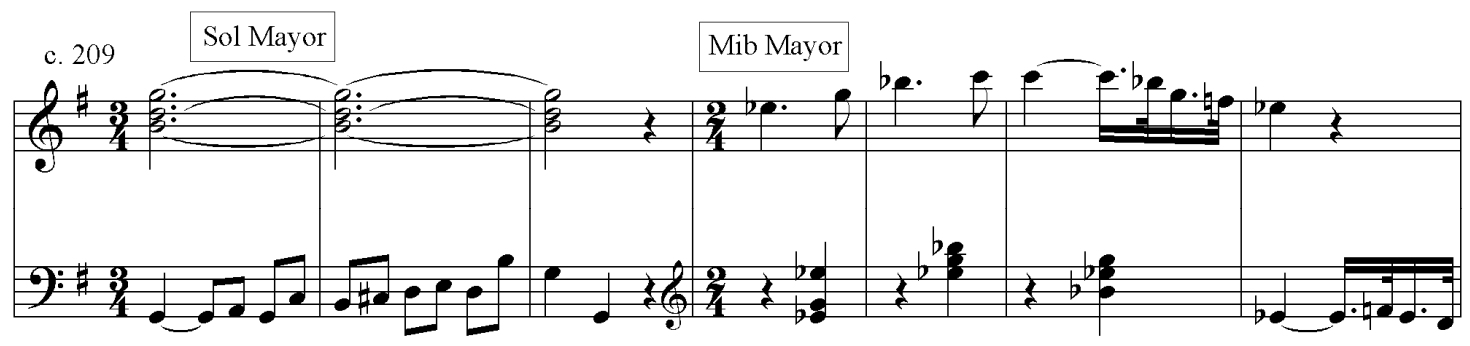

Ejemplo 9

Amancio Amorós, Corina, cc. 209-215, reducción armónica de Elena Micó.

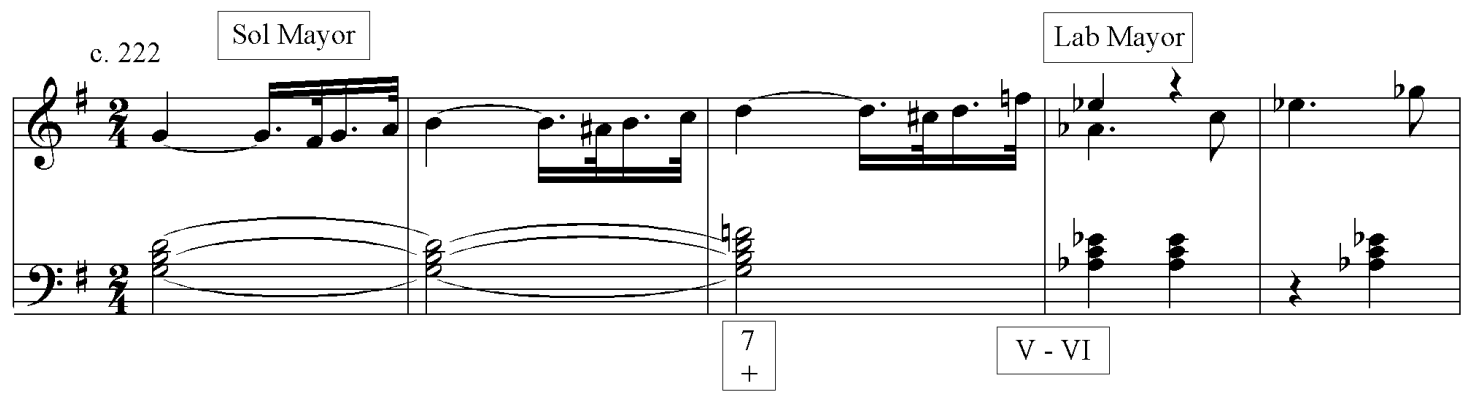

Ejemplo 10

Amancio Amorós, Corina, cc. 222-226, reducción armónica de Elena Micó.

2. 2. Sinfonía para gran orquesta, sobre aires populares de Valencia y su reino, op 69 (1890)

Para la edición crítica de la Sinfonía para gran orquesta, compuesta sobre aires populares de Valencia y su reino (1890) (véase volumen 2, edición de composiciones de Amancio Amorós) he partido de la única partitura manuscrita localizada, que se conserva en la Biblioteca de Catalunya (M 1272). En la portada de la partitura autógrafa se lee "La 
Música es el lenguaje del alma; es la armonía del universo identificada por el sonido". La Sinfonía para gran orquesta se enmarca dentro del fenómeno cultural de la Renaixença, que revalorizó los aspectos populares y autóctonos como señas de identidad del pueblo valenciano. La Renaixença valenciana, de orientación fundamentalmente literaria y poética, tuvo también una interesante proyección en diversas áreas del pensamiento y la cultura, como las artes plásticas y la música. En música se incidió especialmente en el cultivo del folklore y la lengua vernácula como medio de exaltación de la cultura valenciana $^{15}$. La Sinfonía para gran orquesta de Amorós es un magnífico ejemplo de la Renaixença musical en el campo sinfónico, y utiliza varios temas populares. Amorós había empleado ya algunos materiales de esta sinfonía en 1883 en su Colección de ocho piezas para piano y armónium sobre motivos populares valencianos (1883): La Xàquera Vella, la Danza dels nanos y la Danza valenciana de la Vall d'Albaida.

Estilísticamente la Sinfonía para gran orquesta es una obra en la línea del primer nacionalismo, y, aunque no parte de un argumento literario, está próxima a los poemas sinfónicos del valenciano Salvador Giner. Amorós, posiblemente influenciado por los poemas sinfónicos de Salvador Giner Nit d'albaes (1881), Es chopá hasta la Moma (1886) y Las fases del campo (1890), utiliza motivos folklóricos y melodías populares y los incorpora al ámbito de la música sinfónica ${ }^{16}$. Esta tradición será continuada

\footnotetext{
${ }^{15}$ Sobre los diferentes tipos de nacionalismos, regionalismos y localismos surgidos en España en el siglo XIX véase Beatriz Martínez del Fresno, "El pensamiento nacionalista en el ámbito madrileño (19001936), en De Musica Hispana et aliis. Miscelanea en honor al profesor Dr. José López-Calo, coord. Emilio Casares, Carlos Villanueva (Santiago de Compostela: Universidad de Santiago, Servicio de Publicaciones e Intercambio científico, 1990), pp. 355-356; y Celsa Alonso, "Nacionalismo", en DMEH, vol. 7 (2000), pp. 924-935.

${ }^{16}$ Sancho García opina que Giner fue el creador del poema sinfónico valenciano, Sancho, Romanticismo, pp. 64-65, 104; Sancho, El compositor Salvador Giner, pp. 92-93, 103-109. Según López-Chavarri: "Giner escribió varios poemas sinfónicos inspirados en el género de Saint-Saëns, siendo notables dos de ellos que ofrecen asunto y temas populares valencianos, Una nit d'albaes y Es chopà hasta la Moma". Cit. en Sergi Arrando i Mañez, "L'Escola de Música Valenciana, realitat o ficció", L'Anuari. Revista de recerca humanistica i científica, 6 (1995), p. 21.
} 
posteriormente en Valencia por Eduardo López-Chavarri Marco, Manuel Palau, Francisco Cuesta, José Moreno Gans y Leopoldo Magenti, entre otros ${ }^{17}$.

En su Sinfonía para gran orquesta de 1890, Amorós busca evocar un ambiente con citas folklóricas directas, pero sin llegar a una elaboración minuciosa del material folklórico $^{18}$. La obra es un año anterior al conocido texto Por nuestra Música (1891) de Felipe Pedrell, en el que éste sentó las bases para la creación de una música nacional, basada en el folklore y en el patrimonio artístico heredado de los compositores del pasado.

La Sinfonía para gran orquesta de Amorós, en un único movimiento, puede entenderse como una forma sonata con algunas peculiaridades (Tabla 40). La Exposición tiene tres grupos temáticos principales $(\mathrm{ABC})$, el Desarrollo es una reelaboración de los temas A y B, y la Reexposición sólo emplea los temas A y C. El esquema armónico subraya esta estructura, ya que la tonalidad principal es Sol Mayor, y en la reexposición los temas A y $\mathrm{C}$ están en el tono principal. Amorós utiliza tres danzas populares valencianas: Danza valenciana de la Vall d'Albaida, la Xàquera Vella y la Danza dels nanos. Los temas de estas danzas, recogidos por autores valencianos, como Eduardo Ximénez y López-Chavarri, pueden verse en los Ejemplos 26, 29, 31 y 33.

\footnotetext{
${ }^{17}$ Arrando, "L’Escola de Música", pp. 15-36, analiza opiniones de diversos autores sobre la existencia o no de una Escuela Valenciana. La negación de ésta negaría la posibilidad de la existencia de un nacionalismo en el ámbito valenciano. Arrando defiende la existencia de una escuela de música valenciana consolidada en la segunda mitad del siglo XIX con figuras como Pascual Pérez Gascón y Salvador Giner. En ese periodo, según el autor, los músicos valencianos comenzaron a concienciarse de su adscripción a una escuela con una estética colectiva y crearon una música basada en el folklore valenciano, influenciados por la estética o movimiento nacionalista, difundido en España por Felip Pedrell.

${ }^{18}$ Según Tomás Marco, Pensamiento musical y siglo XX (Madrid: Fundación Autor, 2002), p. 32, a los representantes de este primer nacionalismo, les bastaba con utilizar los temas populares e incrustar ritmos de danzas vernáculas en sus obras.
} 
La introducción y el grupo temático A, en Sol mayor, se basan en dos elementos melódicos que Amorós extrae de la Danza valenciana de la Vall d'Albaida (Ejemplos 11 y 12).

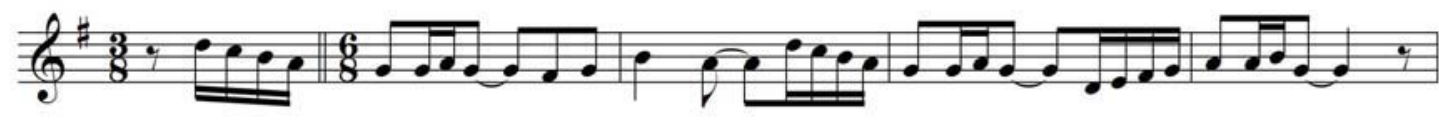

Ejemplo 11

Amancio Amorós, Sinfonía para gran orquesta, cc. 41-45. Grupo temático A, melodía 1, basada en la Danza Valenciana de la Vall d'Albaida, violín 1º.

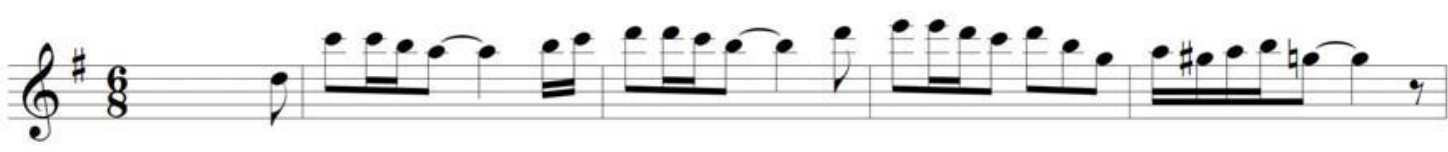

Ejemplo 12

Amancio Amorós, Sinfonía para gran orquesta, cc. 57-60. Grupo temático A, melodía 2, basada en la Danza Valenciana de la Vall d'Albaida, violín $1^{\circ}$.

La armonía de la introducción es ambigua, con mezcla de las tonalidades de Sol Mayor y Sol menor. El motivo inicial del tema A, expuesto por el oboe, está constituido por una escala descendente de cuatro semicorcheas en modo mayor, seguidas de cinco semicorcheas ascendentes en modo menor (Ejemplo 13), y después reelaborado por la orquesta.

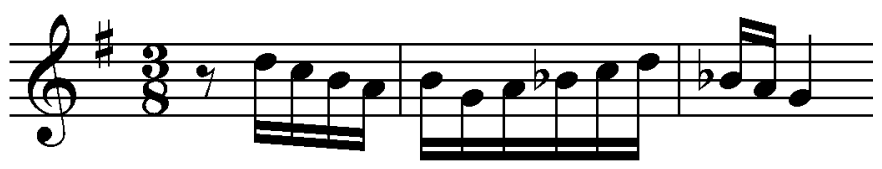

Ejemplo 13

Amancio Amorós, Sinfonía para gran orquesta, cc. 2-4. Motivo inicial del tema A, oboe. 
El material del grupo temático A tiene un carácter básicamente rítmico, y acaba en una semicadencia sobre la dominante de Sol M (compás 76).

El tema B de la Sinfonía es una recreación de la danza de la Xàquera Vella (véase melodía original en Ejemplo 26). Tras unos compases de introducción en los que se utiliza la cabeza de este tema, Amorós traza una progresión por segundas donde aparece el tema de la Xàquera Vella en Si Mayor, modificado rítmicamente (semicorchea con puntillo-fusa) y en compás de $2 / 4$. Este tema, interpretado por flauta, oboe $1^{\mathrm{o}}$ y clarinete $1^{\circ}$, tiene un carácter rítmico, con figuraciones de semicorchea con puntillo y fusa (Ejemplo 14).

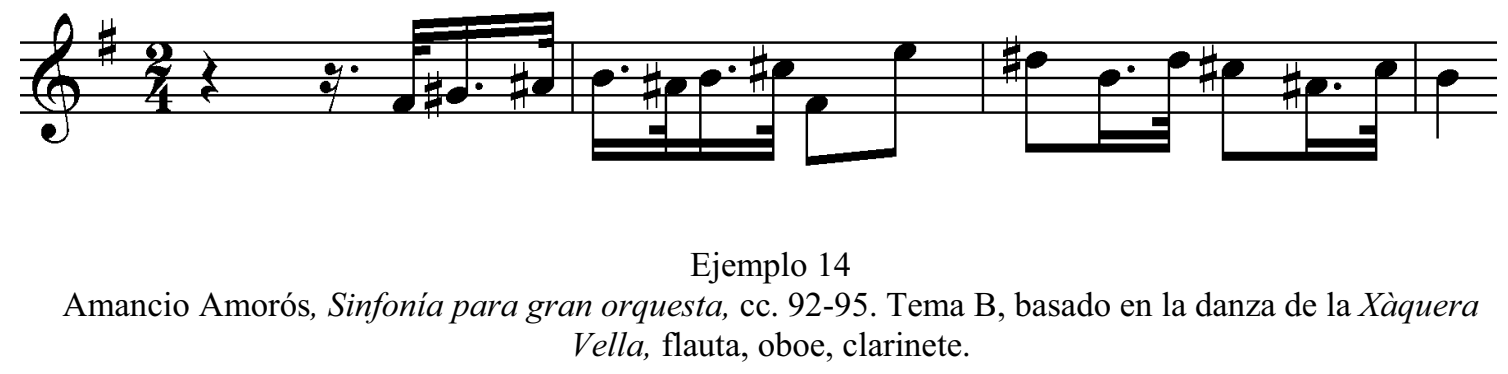

Tras unos compases de inestabilidad armónica, esta sección acaba en un acorde tutti de $7^{\mathrm{a}}$ de dominante de Re Mayor, que da paso a un nuevo material melódico (C) en el que Amorós recrea la Danza dels nanos y el fandanguet [fandanguillo] de la misma (véanse las melodías originales en los ejemplos 29 y 31). La melodía dels nanos, en Re Mayor, la exponen en el compás 117 el oboe $1^{\circ}$ y clarinete $1^{\circ}$, con acompañamiento de cuerda (Ejemplo 15). 


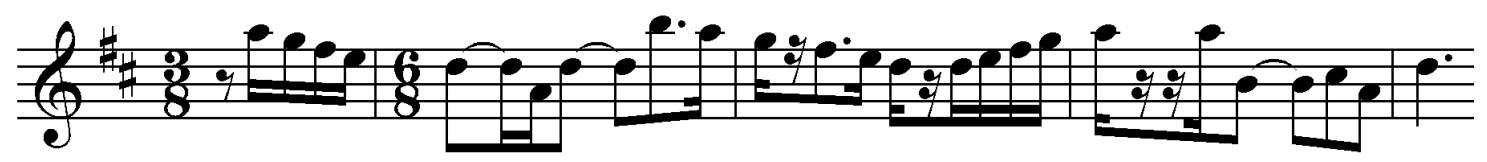

Ejemplo 15

Amancio Amorós, Sinfonía para gran orquesta, cc. 117-121. Tema C (derivado de la Danza dels nanos) oboe $1^{\mathrm{o}}$ y clarinete $1^{\mathrm{o}}$.

La melodía del fandanguet [fandanguillo], en Si menor, es interpretada por flautas, oboes, clarinetes, violines y trompeta $1^{\mathrm{a}} \mathrm{e}$ incluye una textura contrapuntística en los instrumentos graves de cada sección orquestal (Ejemplo 16).

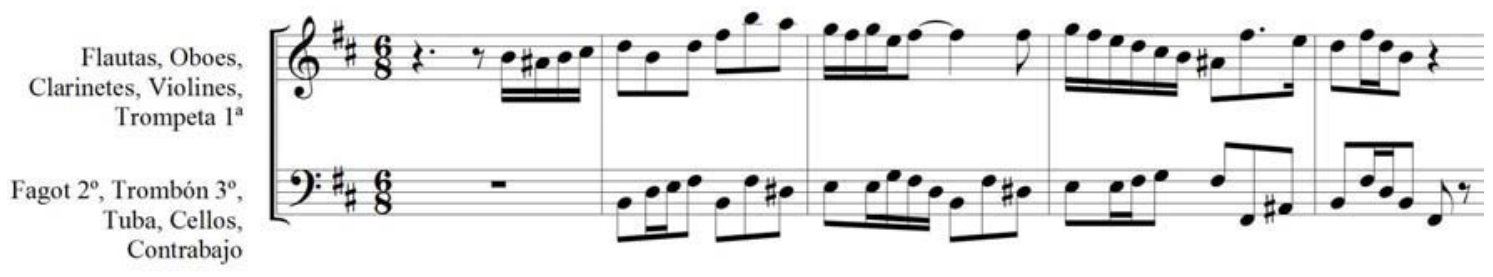

Ejemplo 16

Amancio Amorós, Sinfonía para gran orquesta, cc. 125-129. Tema C (derivado del fandanguet de la Danza dels nanos).

Entre los compases 170 y 173 del Desarrollo, Amorós utiliza un ritmo binario dentro de un compás ternario (3/8). En el compás 200 se inicia la reexposición de A y C, esta vez ambos en Sol Mayor, y una pequeña Coda de seis compases da conclusión a la sinfonía. 
Tabla 40. Amancio Amorós Sirvent, Sinfonía para gran orquesta, op. 69, compuesta sobre aires populares de Valencia y su reino (1890). Esquema analítico.

Fuente: $E: B c, \mathrm{M} 1272$.

\begin{tabular}{|c|c|c|c|c|}
\hline Secciones & Compases & $\begin{array}{l}\text { Tonalidad } \\
\text { Aspectos } \\
\text { armónicos }\end{array}$ & $\begin{array}{l}\text { Material } \\
\text { temático }\end{array}$ & Tempo/Compás \\
\hline \multirow{5}{*}{ Exposición } & $1-40$ & $\begin{array}{l}\text { Sol Mayor / } \\
\text { Sol menor }\end{array}$ & \multirow{2}{*}{ Grupo temático A } & $\begin{array}{c}\text { Larghetto } \\
3 / 8\end{array}$ \\
\hline & $41-76$ & Sol Mayor & & $\begin{array}{c}\text { Allegretto } \\
6 / 8\end{array}$ \\
\hline & $77-92$ & $\begin{array}{l}\text { Sol Mayor- } \mathrm{Si} \\
\text { menor }\end{array}$ & \multirow{2}{*}{ Grupo temático B } & Larghetto \\
\hline & $93-116$ & $\begin{array}{c}\text { Si Mayor } \\
\rightarrow \text { V7 (ReM) }\end{array}$ & & \\
\hline & $117-148$ & Re M-Si m-Re M & $\begin{array}{c}\text { Grupo } \\
\text { Temático C }\end{array}$ & $\begin{array}{c}\text { Allegretto mosso/ } \\
\text { 3/8- } 6 / 8\end{array}$ \\
\hline \multirow{2}{*}{ Desarrollo } & $149-156$ & $\begin{array}{l}\text { Re M- } \\
\mathrm{Fa} \# \mathrm{M}\end{array}$ & \multirow{2}{*}{$\begin{array}{l}\text { Variaciones de } \\
\text { A y B }\end{array}$} & $\begin{array}{c}\text { Moderato/Larghetto } \\
6 / 8-3 / 4 \\
\end{array}$ \\
\hline & $157-199$ & $\begin{array}{l}\text { Fa \# M-Sim- } \\
\text { Inestabilidad } \\
\text { Armónica }\end{array}$ & & $\begin{array}{c}\text { Allegretto/Larghetto/Piu } \\
\text { mosso } \\
3 / 8-2 / 4-3 / 8\end{array}$ \\
\hline \multirow{4}{*}{ Reexposición } & $200-234$ & Sol M & Grupo temático A & $\begin{array}{c}\text { Come prima } \\
6 / 8\end{array}$ \\
\hline & \multirow[b]{2}{*}{$235-275$} & Sol M-Mi m & \multirow[b]{2}{*}{$\begin{array}{c}\text { Grupo } \\
\text { Temático C }\end{array}$} & $\begin{array}{c}\text { Allegretto/Piu mosso } \\
6 / 8 \\
\end{array}$ \\
\hline & & $\begin{array}{l}\text { Sol M-(Lam-Si } \\
\text { M-Mi m-Re M) }\end{array}$ & & $\begin{array}{c}\text { c. } 254 \\
\text { Allegretto } \\
6 / 8\end{array}$ \\
\hline & $276-281$ & Sol M & $\begin{array}{c}\text { Escala } \\
\text { descendente tutti }\end{array}$ & $\begin{array}{c}\text { Piu mosso } \\
6 / 8\end{array}$ \\
\hline
\end{tabular}

\section{Música instrumental de cámara}

La obra camerística localizada de Amorós está constituida por seis obras, todas conservadas manuscritas en la Biblioteca de Catalunya: el Trío para violín, piano y armónium (1881); Trists recorts, nocturno para piano y armónium (1882); Gloria a España, Marcha triunfal religiosa (1882); una Col.lecció de huit peces per a piano $i$ harmònium sobre motius populars valencians [Colección de ocho piezas para piano y armónium sobre motivos populares valencianos] (1883); y dos quintetos para cuerda y piano (Idilio y Andante Marcial). Se conserva además un borrador de su Cuarteto para 
cuerda $n^{o} 1$, op. $21^{19}$ que no finalizó y la partitura manuscrita para banda de su marcha religiosa Gloria a España, escrita originalmente para armónium, piano y quinteto de cuerda en 1882. Otra obra de cámara de Amorós, en la actualidad desaparecida, fue su Gran Concierto en La bemol para violín, armónium y piano ${ }^{20}$.

Analizaré más en detalle la Col.lecció de huit peces per a piano i harmònium sobre motius populars valencians y el quinteto Idilio, de los que presento la edición en el volumen 2 de esta Tesis. El nocturno Trists recorts y la Col.lecció de huit peces per a piano $i$ harmònium sobre motius populars valencians incluyen motivos del folklore valenciano, y pueden considerarse dentro de la corriente cultural de la Renaixença. Ambas fueron presentadas a los concursos que organizó la sociedad Lo Rat Penat en 1882 y 1883, respectivamente. Trists recorts, presentado conjuntamente con la romanza Anyoranza $[$ sic] para canto y piano, también de Amorós, bajo el lema "Jo t'am oh patria meua" [sic] [Te amo, oh patria mía], ganó el primer premio en los Juegos Florales de la sociedad en 1882.

\section{1. Col.lecció de huit peces per a piano i harmònium sobre motius populars valencians, op. 37 (1883)}

La Biblioteca de Catalunya conserva dos manuscritos autógrafos de esta obra, con las signaturas M 1276 y M 1274 (véase volumen 2, edición de composiciones de Amancio Amorós). Amorós presentó en 1883 la Col.lecció de huit peces per a piano $i$ harmònium sobre motius populars valencians a un concurso de composición que organizaba anualmente la sociedad Lo Rat Penat. La obra se presentó bajo el lema “¡Oh Valencia, sultana floresta, yo te salude!", y recibió el Premio a la Batuta Artística en los

\footnotetext{
${ }^{19}$ Original manuscrito conservado en $E: B c$, M 1275.

${ }^{20}$ Obra citada por Serrano, “Amancio Amorós”, p. 479; Pedrell, Diccionario biográfico, p. 63 y Sobrino, “Amorós Sirvent, Amancio”, p. 420.
} 
Juegos organizados por la esta sociedad ese año ${ }^{21}$. En esta Col.lecció, Amorós transcribe para armónium y piano melodías de danzas y bailes tradicionales del pueblo valenciano (véase Tabla 41), como las que interpretaban las dulzainas en las procesiones, las danzas de la Ribera del Júcar y de la comarca de la Vall d'Albaida, y las ya desaparecidas en muchas localidades valencianas, de nanos $i$ gegants [enanos y gigantes], la jota de quintos y la jota valenciana conocida también como "la de l'U". La jota de quintos y el "ball de l'U" forman parte del repertorio conocido como cant valencià d'estil, que se interpretaba con acompañamiento de guitarras y guitarrons [guitarrones] y con cierta libertad rítmica respecto al acompañamiento instrumental medido ${ }^{22}$.

Tabla 41. Amancio Amorós, Col.lecció de huit peces per a piano i harmònium sobre motius populars valencians, op. 37 (1883). Esquema analítico.

Fuente: $E: B c, \mathrm{M} 1276$.

\begin{tabular}{|c|c|c|c|c|c|}
\hline $\mathbf{N}^{0}$ pieza & Título & Compases & $\begin{array}{l}\text { Material } \\
\text { temático }\end{array}$ & $\begin{array}{c}\text { Tonalidad } \\
\text { principal }\end{array}$ & Tempo/Compás \\
\hline 1 & \begin{tabular}{|c|}
\multicolumn{1}{|c|}{ Melodía } \\
característica del \\
dolçainer valencià \\
davant la processó \\
\end{tabular} & $1-73$ & A & Sol Mayor & $\begin{array}{c}\text { Largo } \\
6 / 8 \\
\end{array}$ \\
\hline \multirow{3}{*}{2} & \multirow{3}{*}{$\begin{array}{c}\text { Melodía } \\
\text { característica del } \\
\text { dolçainer valencià } \\
\text { davant la processó }\end{array}$} & $1-21$ & A & Sol Mayor & \multirow{3}{*}{$\begin{array}{c}\text { Larghetto } \\
\qquad=72\end{array}$} \\
\hline & & $22-52$ & B & Si menor & \\
\hline & & $53-77$ & A & Sol Mayor & \\
\hline 3 & $\begin{array}{c}\text { Dansa valenciana } \\
\text { de la Ribera del } \\
\text { Xúquer }\end{array}$ & $1-116$ & A & Sol Mayor & $\begin{array}{c}\text { Larghetto } \\
\qquad=96 \\
2 / 4\end{array}$ \\
\hline 4 & $\begin{array}{c}\text { Dansa dels } \\
\text { Gegants (vulgo }\end{array}$ & & & Sol Mayor & Larghetto \\
\hline
\end{tabular}

\footnotetext{
${ }^{21}$ En el certamen de composición de 1883 se convocó un premio a la mejor "Colección de cuatro o más composiciones musicales de cortas dimensiones para piano y armónium, tomadas de melodías populares del reino de Valencia". El accésit fue para Vicente Peydró. Véase Revista de Valencia, agosto 1883, pp. 377-378.

${ }^{22}$ Carles Pitarch Alfonso, El cant valencià d'estil: una aproximació conceptual $i$ històrica des de l'etnomusicologia (Aldaia: Associació de Música Tradicional d'Aldaia, 1997), p. 12; Reig, “l'U”, “l’U i dos", en $D M V$, vol. 2 (2006), pp. 517-518.
} 


\begin{tabular}{|c|c|c|c|c|c|}
\hline & Xàquera Vella) & $1-83$ & A & $\begin{array}{l}\text { Do Mayor } \\
\text { Sol Mayor }\end{array}$ & $\begin{array}{l}.=72 \\
2 / 4\end{array}$ \\
\hline \multirow{3}{*}{5} & \multirow{3}{*}{ Dansa dels nanos } & $1-49$ & A & Sol Mayor & \multirow{3}{*}{$\begin{array}{c}\text { Allegretto } \\
\text { mosso } \\
6 / 8 \\
\text { Piu mosso } \\
\text { Allegretto } \\
\text { mosso }\end{array}$} \\
\hline & & $50-59$ & B & Mi menor & \\
\hline & & $60-88$ & A & Sol Mayor & \\
\hline \multirow{3}{*}{6} & \multirow{3}{*}{$\begin{array}{c}\text { Dansa valenciana } \\
\text { de la Vall } \\
\text { d'Albaida }\end{array}$} & $1-69$ & A & Sol Mayor & $\begin{array}{c}3 / 8 \\
\text { Larghetto } \\
6 / 8 \\
\text { Allegretto }\end{array}$ \\
\hline & & $70-107$ & $\mathrm{~B}$ & Mi menor & Allegro $3 / 8$ \\
\hline & & $\begin{array}{c}42-68 \\
108-123\end{array}$ & $\begin{array}{c}\text { A } \\
\text { Coda }\end{array}$ & Sol Mayor & $\begin{array}{c}6 / 8 \\
\text { Allegretto }\end{array}$ \\
\hline \multirow{5}{*}{7} & \multirow{5}{*}{$\begin{array}{l}\text { Jota Valenciana } \\
\text { (vulgo la del dos o } \\
\text { dels quintos) }\end{array}$} & $1-29$ & A & \multirow{3}{*}{ Sol Mayor } & \multirow{5}{*}{$\begin{array}{c}\text { Moviment de jota } \\
3 / 4\end{array}$} \\
\hline & & $30-65$ & Cantar 1 & & \\
\hline & & $5-20$ & A & & \\
\hline & & $65-95$ & Cantar 2 & Sol menor & \\
\hline & & $\begin{array}{c}5-20 \\
96-122\end{array}$ & A & Sol Mayor & \\
\hline \multirow{6}{*}{8} & \multirow{6}{*}{$\begin{array}{l}\text { Jota Valenciana } \\
\text { (vulgo la de l'U) }\end{array}$} & $1-32$ & A & \multirow{6}{*}{ Modo de mi } & \multirow{6}{*}{$\begin{array}{c}\text { Moviment de jota } \\
3 / 4\end{array}$} \\
\hline & & $33-62$ & Cantar 1 & & \\
\hline & & $10-32$ & $\mathrm{~A}$ & & \\
\hline & & $63-91$ & Cantar 2 & & \\
\hline & & $10-32$ & & & \\
\hline & & $92-96$ & A & & \\
\hline
\end{tabular}


El piano y el armónium, a los que va destinada la Col.lecció de Amorós, eran frecuentes en los salones de la Valencia de la Restauración ${ }^{23}$. Amancio Amorós fue un intérprete habitual en las reuniones literario-musicales organizadas por Lo Rat Penat desde 1882 y su Col.lecció, premiada en 1883, fue interpretada con mucho éxito por el autor y por Juan Bautista Plasencia en una velada celebrada en $1885^{24}$.

\section{Melodía característica del dolçainer valencià davant la processó}

En esta primera pieza de la colección Amorós consigue un equilibrio entre armónium y piano en su presentación temática y armónica, con una armonía rica en matices y recursos: juego menor /mayor y modulaciones sin preparación (véase Ejemplo 17).

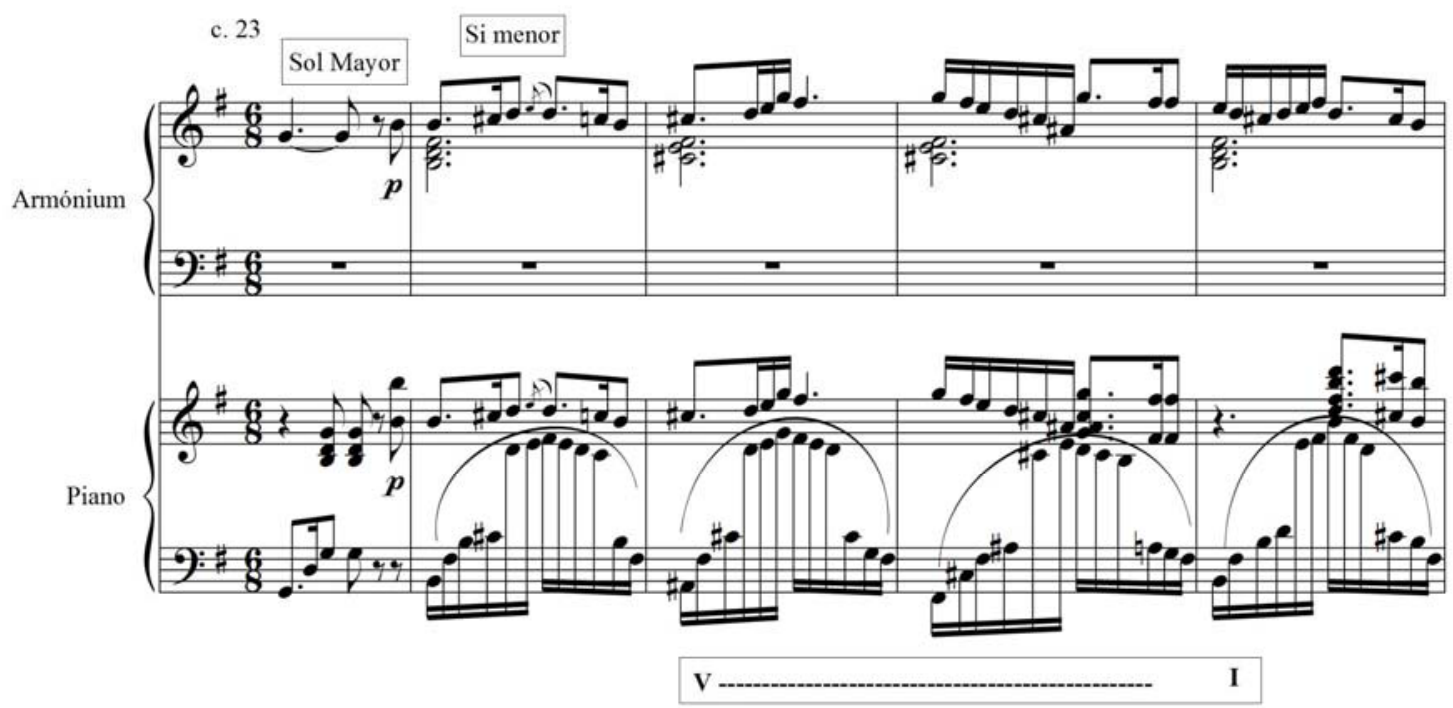

Ejemplo 17

Amorós, Col.lecció de huit peces per a piano i harmònium sobre motius populars valencians, $\mathrm{n}^{\circ} 1$, Melodía característica del dolçainer valencià davant la processó, cc. 23-27.

El tema principal es una melodía utilizada por las dulzainas valencianas para acompañar las procesiones, que expone el armónium (evocando al dulzainero), mientras el piano realiza el papel del tabalet [tambor]. A partir del compás 23, la melodía la llevan

\footnotetext{
${ }^{23}$ Sancho, Romanticismo, p. 215.

${ }^{24}$ Lo Rat Penat: periodich lliterari quincenal, 6 (15-III-1885), p. 48.
} 
al unísono el armónium y el piano. La mezcla de ambos timbres ofrece un nuevo color a este número. La melodía popular fue recogida por Eduardo Ximénez (Ejemplo 18) y la versión presentada por Amorós puede verse en el Ejemplo 19.

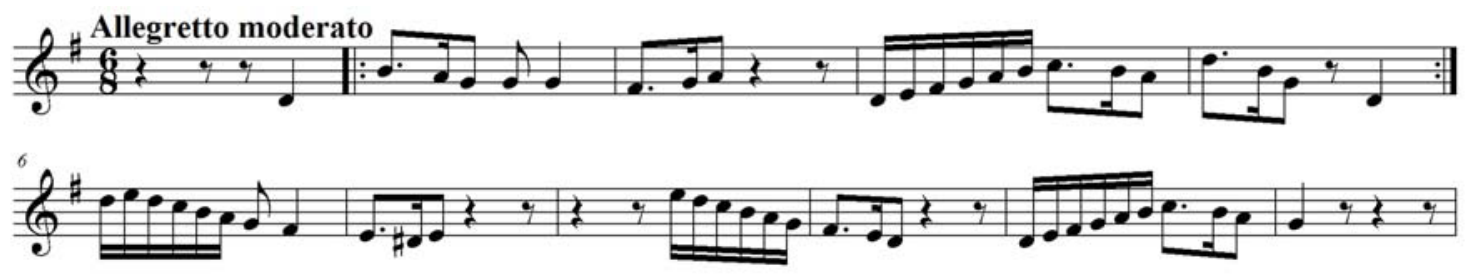

Ejemplo 18

Melodía para acompañar las imágenes en las procesiones (1873), según Ximénez ${ }^{25}$.

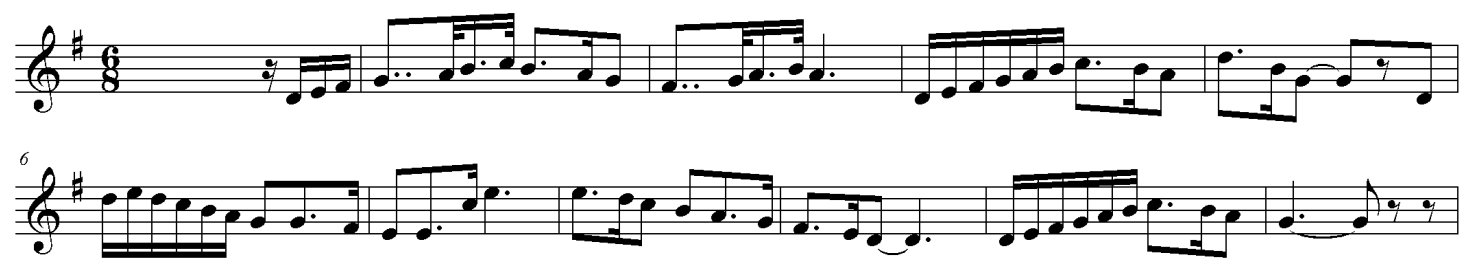

Ejemplo 19

Amancio Amorós, Col.lecció de huit peces per a piano i harmònium sobre motius populars valencians, $\mathrm{n}^{\circ} 1$, Melodía característica del dolçainer valencià davant la processó, cc. 12-22, armónium.

\section{Melodía característica del dolçainer valencià davant la processó}

Amorós presenta un tema muy simple en Sol Mayor con una modulación armónica a Si Mayor en la segunda sección. La estructura de la pieza es ABA, con el tema B rítmicamente basado en A (Ejemplos 20 y 21).

\footnotetext{
${ }^{25}$ Ximénez, "Melodía para acompañar las imágenes en las procesiones”, en Música de los cantos, p. 14. $E: V A b v$, AELCH/pro 491.
} 


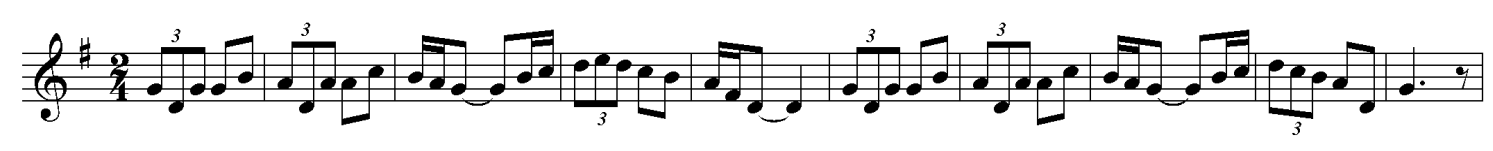

Ejemplo 20

Amancio Amorós, Col.lecció de huit peces per a piano i harmònium sobre motius populars valencians, $\mathrm{n}^{\mathrm{o}} 2$, Melodía característica del dolçainer valencià davant la processó, cc. 7-16. Tema A, armónium.

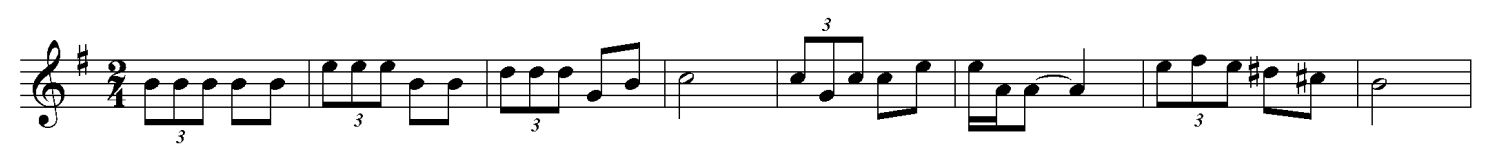

Ejemplo 21

Amancio Amorós, Col.lecció de huit peces per a piano i harmònium sobre motius populars valencians, $\mathrm{n}^{\circ}$ 2, Melodía característica del dolçainer valencià davant la processó, cc. 22-29. Tema B, armónium.

La melodía utilizada por Amorós en esta pieza, según se recoge en el título de la misma, era utilizada por el dulzainero valenciano para acompañar las procesiones. No he encontrado la transcripción de la melodía original en ningún cancionero. Es una pieza simple con escaso diálogo entre el armónium y el piano, que refuerza la melodía y complementa al armónium en la parte central (compases 30-45), pero resulta original el tratamiento imitativo de la dolçaina $i$ el tabalet [dulzaina y tambor].

\section{Dansa valenciana de la Ribera del Xúquer}

El tema que utiliza Amorós en esta danza coincide con el recopilado por Ximénez bajo el título de La Mangrana [sic], aunque Amorós no emplea este título para la pieza (Ejemplo 22). La danza de la Mangrana [de la granada], que se bailaba en la procesión del Corpus valenciano hasta el primer tercio del siglo XIX, era un baile de zíngaros en torno a una granada de gran tamaño colocada sobre una pértiga, de la que pendían cintas de colores diversos con las que los danzantes cubrían el mástil haciendo trenzados según los movimientos del baile. Finalizado el baile, se abría la granada en gajos y entre flores aparecía una caja de cristal con un cerco dorado que conservaba la hostia consagrada, 
ante la que se arrodillaban los zíngaros, representando al pueblo judío ante el Sacramento $^{26}$.

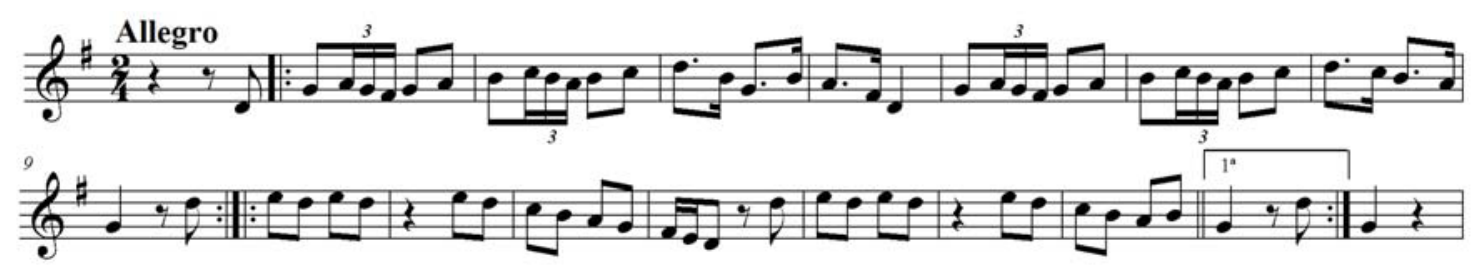

Ejemplo 22

Melodía original de la Mangrana recogida por Eduardo Ximénez ${ }^{27}$.

La versión de la melodía de la Mangrana puede verse en el Ejemplo 23.

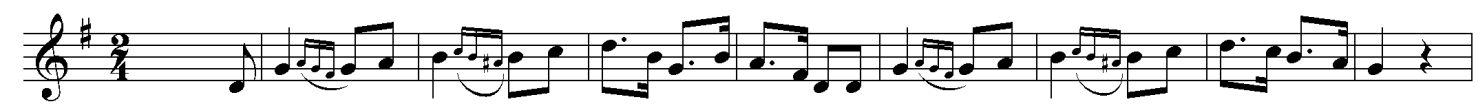

Ejemplo 23

Amancio Amorós, Col.lecció de huit peces per a piano i harmònium sobre motius populars valencians, $\mathrm{n}^{\circ}$ 3, Dansa valenciana de la Ribera del Xúquer, cc. 38-46, armónium.

La pieza de Amorós presenta un tema principal en Sol Mayor y tres variaciones. En el compás 36 realiza una enarmonía del re b por do \#, con la que busca el acorde de dominante de la dominante $\left(\mathrm{La} \mathrm{M}^{7}\right)$. La pieza es sencilla pero con gran variedad de recursos compositivos: descomposición de motivos, repeticiones, diálogos, buen ropaje armónico y juego constante de ritmos sin abandonar nunca la pulsación rítmica de corchea. Hay también muchos juegos dinámicos: la primera sección acaba de forma delicada en un pianisimo, en la parte central de la primera sección aparece un slargando como inflexión y al final de la sección aparece un decrescendo con calderón para

\footnotetext{
${ }^{26}$ Ruiz de Lihory, La Música en Valencia, pp. 130-131.

${ }^{27}$ Ximénez, "La Mangrana” [sic], en Música de los cantos, p. 13. E:VAbv, AELCH/pro 491.
} 
reexponer el tema inicial que irá diminuendo, para atacar después en un fortisimo final piu animato.

Amorós hace en este número dialogar al armónium con el piano. El primer motivo (a1) lo exponen el armónium y el piano al unísono y en octavas en los compases 1-4; la respuesta del piano es el motivo que he denominado a2 (véanse Ejemplos 24 y 25). Sigue de nuevo el motivo al (compases 9-13) una tercera menor baja (en mi menor) e igualmente octavado en armónium y piano, pero ahora el consecuente lo realiza el armónium y el diálogo se mantiene hasta el compás 38.

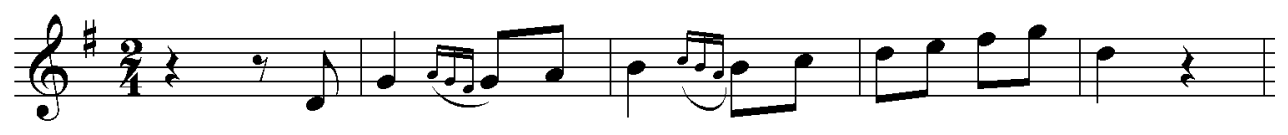

Ejemplo 24

Amancio Amorós, Col.lecció de huit peces per a piano i harmònium sobre motius populars valencians, $\mathrm{n}^{\circ}$ 3, Dansa valenciana de la Ribera del Xúquer, cc. 1-4. Motivo a1, armónium.

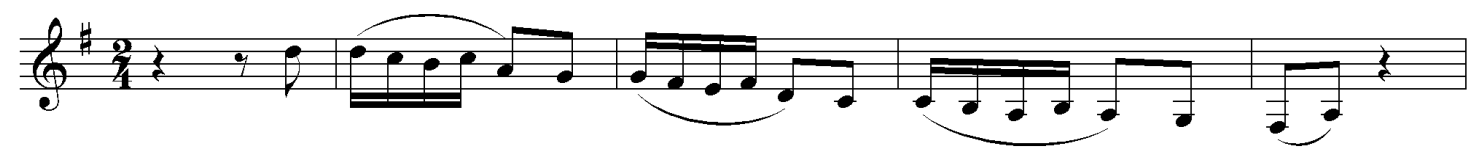

Ejemplo 25

Amancio Amorós, Col.lecció de huit peces per a piano i harmònium sobre motius populars valencians, $\mathrm{n}^{\circ}$ 3, Dansa valenciana de la Ribera del Xúquer, cc. 4-8. Motivo a2, piano.

A partir del compás 47 el motivo al sólo continúa en la mano derecha del armónium. La mano izquierda del armónium completa armonías, preferentemente terceras, mientras que la mano izquierda del piano mantiene el ritmo corchea con puntillo, semicorchea y dos corcheas. 


\section{Dansa dels gegants (vulgo Xàquera Vella)}

El tema utilizado por Amorós en este número de su Col.lecció procede de la danza popular La Xàquera Vella (Ejemplo 26). La danza dels gegants [gigantes] se baila en la procesión del Corpus valenciano. Los gegants siguen a los nanos [enanos] y preceden al séquito sagrado de la procesión del Corpus. Los gegants son cuatro parejas de gigantes que representan Europa, Asia, Africa y América y simbolizan según Ruiz de Lihory la adoración que tiene la Eucaristía en los pueblos más remotos. En Valencia, estos gigantes se hicieron en 1588, a imitación de los gigantones de Toledo. En un principio los gigantes iban delante de los timbales y clarines que preceden a la cruz procesional. Por Real Orden de 1780 se mandó que no fuesen ni enanos ni gigantes en las procesiones para evitar irreverencias. Durante 1780 y 1781 dejaron de ir en las procesiones, pero desde 1782 volvieron a ella. La marcha con que tradicionalmente desfilan los nanos y gegants [enanos y gigantes], mientras no se detienen para bailar sus respectivas danzas, es la Xàquera, una danza del siglo XVII ${ }^{28}$.

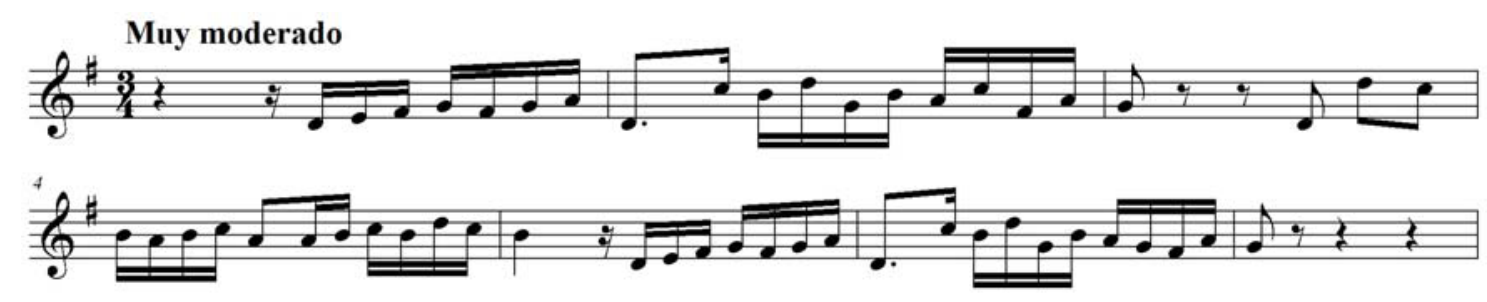

Ejemplo 26

La Xàquera Vella, melodía original recogida por Eduardo Ximénez ${ }^{29}$.

En su Dansa dels gegants, Amorós emplea en la introducción un motivo que extrae del tema principal de la danza (Ejemplo 27):

\footnotetext{
${ }^{28}$ Véase Ruiz de Lihory, La música en Valencia, pp. 125-129; Carles Pitarch Alfonso, "La festa en el Corpus Christi a València: de les Roques i els Jocs a les danses tradicionals", en El teatre en la festa valenciana, dir. Antonio Ariño (València: Consell Valencià de Cultura, 1999), pp. 181-183.

${ }^{29}$ Ximénez, "La Xàquera Vella", en Música de los cantos, p. 12. E:VAbv, AELCH/pro 491.
} 


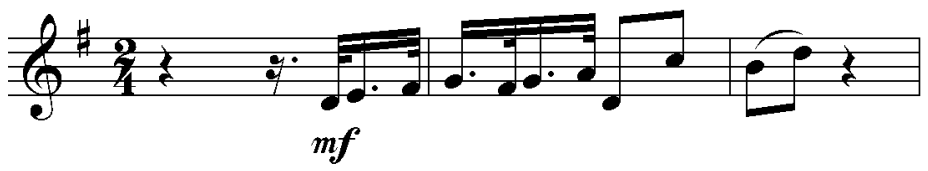

Ejemplo 27

Amancio Amorós, Col.lecció de huit peces per a piano i harmònium sobre motius populars valencians, $\mathrm{n}^{\mathrm{o}}$ 4, Dansa dels gegants (vulgo Xàquera Vella), cc. 1-2. Motivo del tema principal, armónium.

Este motivo va a ser el generador de toda la pieza, junto con otro diseño que se construye a partir del arpegio descendente de Sol mayor y mi menor (Ejemplo 28).

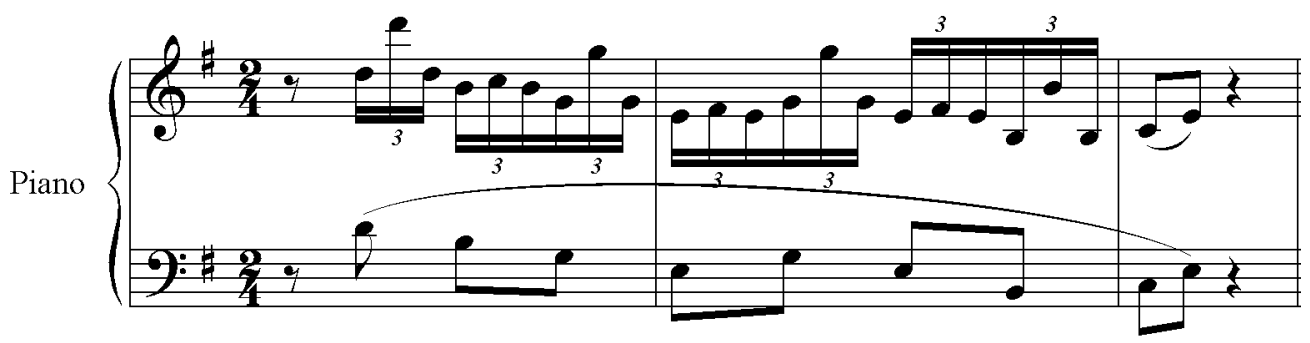

\section{Ejemplo 28}

Amancio Amorós, Col.lecció de huit peces per a piano i harmònium sobre motius populars valencians, $\mathrm{n}^{\circ} 4$, Dansa dels gegants (vulgo Xàquera Vella), cc. 2-4. Arpegio descendente, piano.

Estructuralmente la pieza presenta una sección única en Sol Mayor. El armónium expone el tema principal de la danza en su totalidad y el piano realiza el acompañamiento rítmico-armónico. Desde el compás 33 se inicia un pequeño desarrollo del tema principal y armónicamente aparecen inflexiones a Do Mayor y la menor. En la Coda se utiliza el mismo motivo que en la introducción, y después de un slargando y ritardando, la pieza termina en súbito forte al unísono octavado entre armónium y piano. 


\section{Dansa dels nanos}

En la procesión del Corpus de Valencia, después de los portadores de los guiones con el blasón de la ciudad, seis enanos bailan al son de la dulzaina y el tamboril. Los enanos representan Asia, Africa y América. Los primitivos enanos fueron sólo dos, según describe Ruiz de Lihory, pero desde 1590 pasaron a ser seis. Los enanos se colocan en dos filas, frente a frente, una de hombres y una de mujeres. Comienza la danza con un redoble del tabalet y una reverencia, y las parejas van avanzando y retrocediendo ceremoniosamente, cruzándose en forma de cadena y molinete. La melodía del dolçainer [dulzainero] se acompañaba con el repique de unos crótalos "orientales". Como casi todas las danzas procesionales valencianas, el baile de los nanos tiene dos partes diferenciadas: la danza propiamente dicha y el fandanguet [fandanguillo] ${ }^{30}$.

Amorós utiliza el tema original de la danza dels nanos que aparece en la recopilación de cantos y bailes populares realizada por Eduardo Ximénez (véanse Ejemplos 29 y 30).

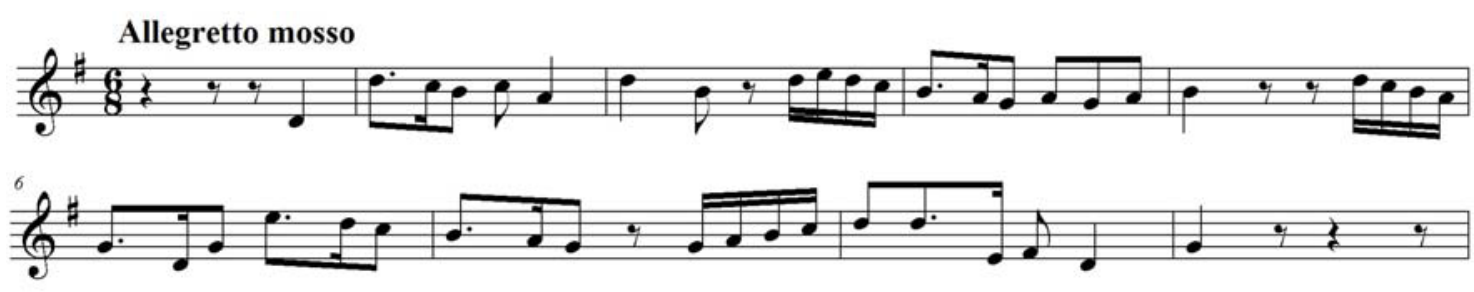

Ejemplo 29

Tema original de la Danza dels nanos [Danza de los enanos], recogida por Eduardo Ximénez ${ }^{31}$.

\footnotetext{
${ }^{30}$ Salvador Seguí y Fermín Pardo, Danzas del Corpus Valenciano, Cuadernos de Música Folklórica Valenciana, 1 (Valencia: Instituto de Etnología Valenciana, Sección de Folklore Musical, Institución Alfonso El Magnánimo, 1978), pp. 19-26.

${ }^{31}$ Ximénez, Música de los cantos, p. 12. E:VAbv, AELCH/pro 491. Pitarch, "La festa en el Corpus", pp. 181-182.
} 


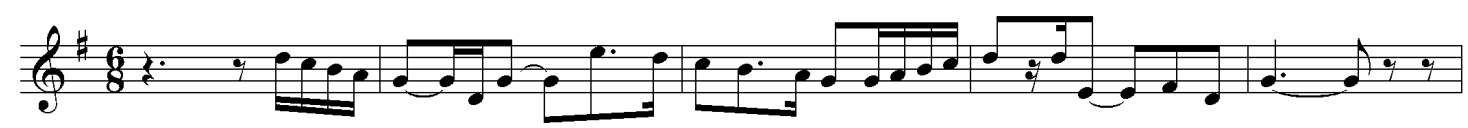

Ejemplo 30

Amancio Amorós, Col.lecció de huit peces per a piano i harmònium sobre motius populars valencians, $\mathrm{n}^{\mathrm{o}}$ 5, Dansa dels nanos, cc. 5-9. Tema A, armónium.

La Dansa dels nanos de Amorós, en Sol Mayor, sigue la típica estructura ABA.

El tema B, en Mi menor, deriva del fandanguet [fandanguillo] de la danza dels nanos.

Véase la melodía original (Ejemplo 31) y el tema de Amorós (Ejemplo 32).

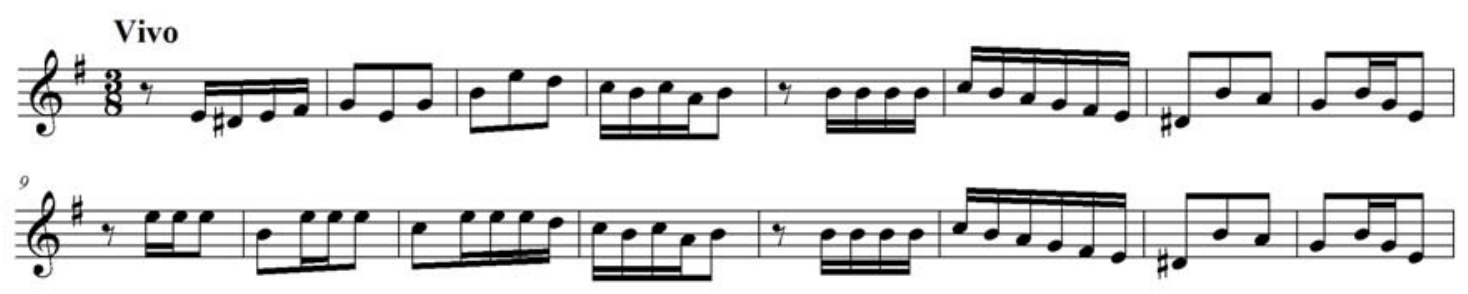

Ejemplo 31

Fandanguet de la Danza dels nanos [fandanguillo de la danza de los enanos], recogido por Eduardo Ximénez ${ }^{32}$.

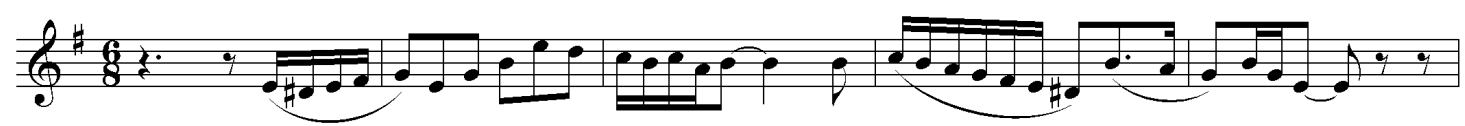

Ejemplo 32

Amorós, Col.lecció de huit peces per a piano i harmònium sobre motius populars valencians, $\mathrm{n}^{\circ} 5$, Dansa dels nanos, cc. 49-53. Tema B, armónium.

\section{Dansa valenciana de la Vall d'Albaida}

El material melódico utilizado por Amorós en esta pieza procede de la tradicional Danza valenciana de la Vall d'Albaida (véase Ejemplo 33).

\footnotetext{
${ }^{32}$ Ximénez, Música de los cantos, p. 13. E:VAbv, AELCH/pro 491; Seguí, Cancionero, p. 540.
} 


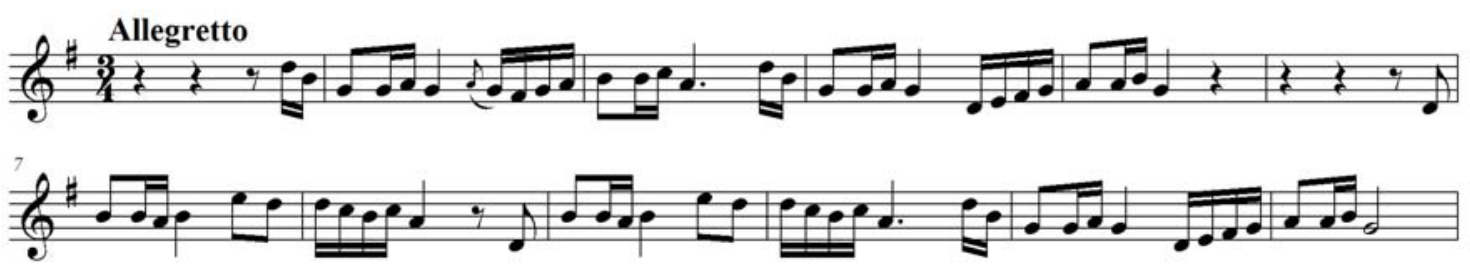

Ejemplo 33

Melodía de la Danza Valenciana de la Vall d'Albaida (ca. 1898-1900), recogida por López-Chavarri33.

López-Chavarrri recogió la melodía entre 1898-1900 y su tema principal, procedente del folklore valenciano, era ya conocido por Amorós al menos en 1883, (Ejemplo 34). Amorós, nacido en Agullent, localidad de la comarca de la Vall d'Albaida, conocía perfectamente el material melódico y rítmico utilizado en las danzas tradicionales que anualmente se bailan en esta localidad valenciana y en los pueblos vecinos. El material melódico que sigue utilizándose actualmente es el mismo, con ligeras variantes melódicas según las localidades de la comarca.

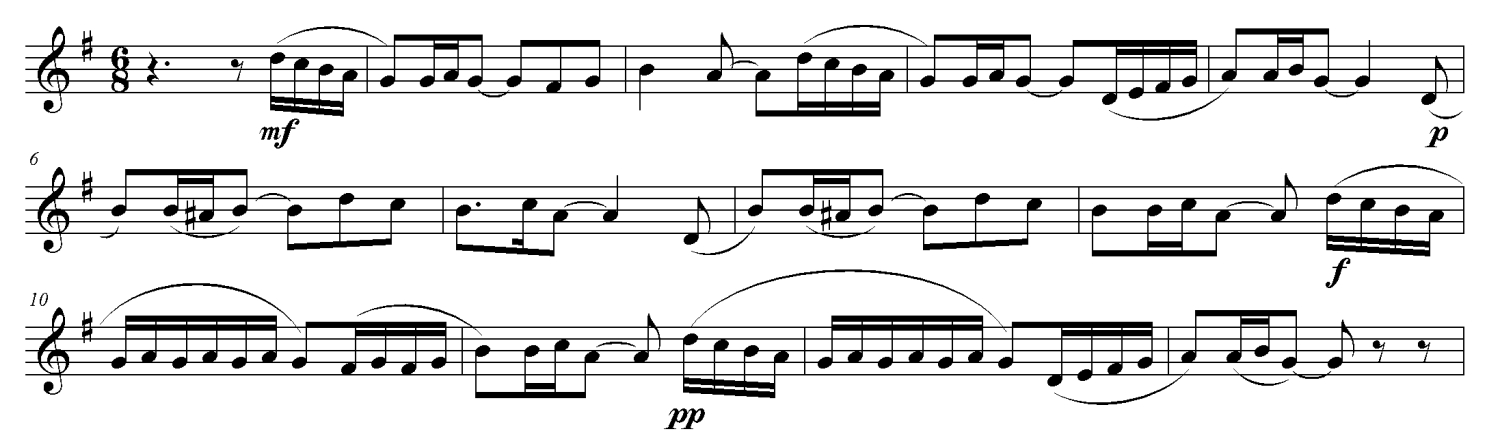

Ejemplo 34

Amancio Amorós, Col.lecció de huit peces per a piano i harmònium sobre motius populars valencians, $\mathrm{n}^{\mathrm{o}}$ 6, Dansa valenciana de la Vall d'Albaida, cc. 41-53. Tema A, armónium.

En la introducción a su Dansa valenciana, Amorós evoca con un motivo de tres compases el tema principal del baile, (Ejemplo 35) y la tonalidad fluctúa entre Sol Mayor

\footnotetext{
${ }^{33}$ López-Chavarri Marco, Cantos y danzas populares de la región valenciana, coleccionados en mis excursiones y tomados por mí al oído directamente, en su mayoría, manuscrito, p. 12. E:VAbv, AELCH/pro 491.
} 
y Sol menor, lo que le ofrece un color interesante. Este motivo es el primer compás del tema principal de la danza, pero con un tempo más lento.

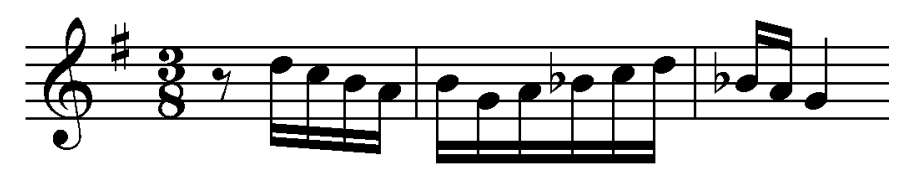

Ejemplo 35

Amancio Amorós, Col.lecció de huit peces per a piano i harmònium sobre motius populars valencians, $\mathrm{n}^{\circ}$ 6, Dansa valenciana de la Vall d'Albaida, cc. 2-4. Motivo del tema A, armónium.

Estructuralmente la pieza sigue de nuevo la forma ABA'. En la primera sección Amorós presenta el tema principal de la danza (tema A) de forma anacrúsica, en Sol Mayor y en compás de 6/8. A partir del compás 45 se desarrollan una serie de variaciones melódicas y rítmicas de ese tema. Entre los compases 53 y 56 el piano imita el ritmo del tabalet i postisses [tambor y castañuelas].

El tema $\mathrm{B}$ en $3 / 8$ y Allegro, es más rítmico que melódico, con saltos de $4^{\text {as }}$ y $5^{\text {as }}$ en stacatto (Ejemplo 36).

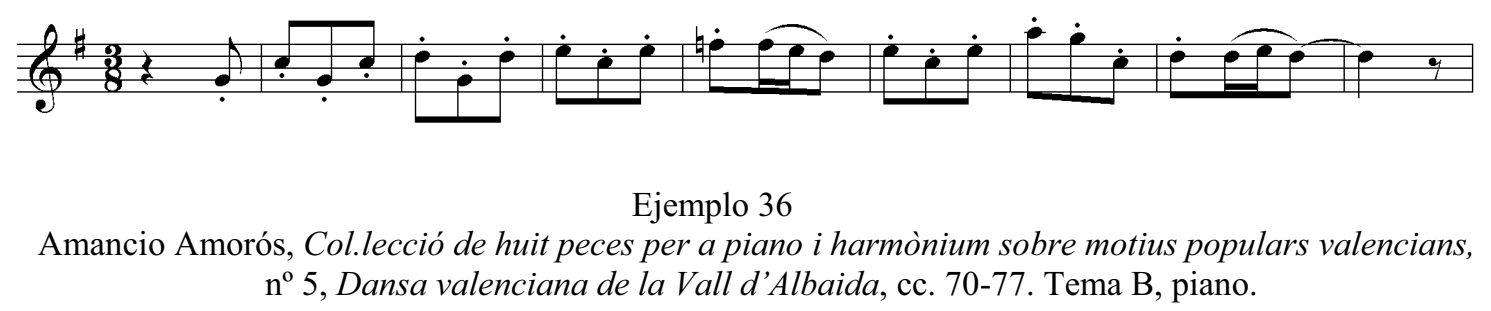

\section{Jota Valenciana (vulgo la del dos o la dels quintos)}

Las piezas $\mathrm{n}^{\mathrm{o}} 7 \mathrm{y} \mathrm{n}^{\mathrm{o}} 8$ de la Col.lecció forman parte del repertorio conocido como cant valencià d'estil, aunque prescindiendo del texto, ya que son composiciones para 
piano y armónium ${ }^{34}$. El cant d'estil es un repertorio de canto que se utiliza principalmente en rondas de tipo festivo, amorosas o de quintos llamadas "cantaes" [cantadas] (aunque también se utilizaban para el baile) y está difundido desde la comarca de la Plana de Castelló (al norte de la Comunidad Valenciana) hasta la de la Marina (al sur). Amorós denomina a estas dos piezas "jotas valencianas" y en la $\mathrm{n}^{\circ} 7$ añade "vulgo la del dos o la dels quintos" [vulgo la del dos o de los quintos] y en la $n^{\circ} 8$ "vulgo la de l'U" [la del uno], lo que viene a confirmar que aunque Amorós les llama jotas, la tradición popular siempre las ha denominado de l'U y l'U i el dos. Popularmente estos cantos también son denominados simplemente valencianes [valencianas] $^{35}$.

En la Jota de Quintos de Amorós, el armónium reproduce la parte del canto y, por ello, muestra cierta libertad rítmica que el compositor indica con un a piacere (compases 30 у 67$)^{36}$.

Los fragmentos que Amorós presenta como "Cantar 1" o "Cantar 2", se corresponderían con lo que Pitarch denomina cant pla, de tradición más antigua, y con pequeños fragmentos ornamentales al final de algunas o todas las frases del canto, ámbito melódico reducido y un registro medio en la entonación del canto ${ }^{37}$.

\footnotetext{
${ }^{34}$ No se le ha dedicado al cant valencià d'estil hasta el momento un estudio comparable al que han tenido otros repertorios populares afines, como el flamenco o la jota aragonesa.

${ }^{35}$ Según Pitarch, El cant valencià d'estil, p. 11, los cantos comprendidos en el cant d'estil son especies o variedades afandangadas. Véase también Ruiz de Lihory, La Música en Valencia, pp. 151-152.

${ }^{36}$ En el canto popular es el cantaor [cantor] quien determina la longitud de las frases; esta manera de cantar se la conoce popularmente como "cant a l'aire".

${ }^{37}$ Carles Pitarch Alfonso, "El cant valencià d'estil: conceptos para su comprensión desde una perspectiva formal, funcional e histórica", en Actas del III Congreso de la Sociedad Ibérica de Etnomusicología (Benicàsim, 1997), eds. Ramón Pelinsky y Vicent Torrent (Sabadell: La Mà de Guido, 1998), pp. 303304.
} 


\section{Jota Valenciana (vulgo la de l’U)}

La pieza $n^{0} 8$ de la Col.lecció de Amorós presenta características similares a la $\mathrm{n}^{\mathrm{o}} 7$ en cuanto a estructura formal y aspectos melódicos. La Jota Valenciana de l’U está en modo de Mi, que es propio de los fandangos del sur y confiere una armonización particular a la pieza. El acorde de Mi Mayor, aunque pueda parecer que ejerza la función de dominante de la menor tiene función de tónica. Con indicaciones como imitant a la guitarra [imitando la guitarra], Amorós alude a uno de los instrumentos con los que se marcaba el ritmo básico del acompañamiento. Frente a este acompañamiento medido, el canto presentaba una cierta libertad rítmica.

\section{2. Idilio, quinteto para cuerda y piano (sf)}

La Biblioteca de Catalunya conserva la partitura manuscrita y cinco particellas de Idilio, un quinteto para cuerda y piano con la signatura M 1278, del que presento la edición crítica en el volumen 2 de esta Tesis. Ramón Sobrino mencionó una versión para piano de esta obra titulada Escenas poéticas, $\mathrm{n}^{\mathrm{o}} 2$ Idilio, y editada por Ildefonso Alier ${ }^{38}$. El quinteto pudo haber sido estrenado en las audiciones de alumnos del Conservatorio de Música de Valencia o en alguna velada musical organizada en las sociedades culturales con las que se relacionó Amorós. En el Capítulo 3 he comentado el papel de Amorós como profesor de música en la Escuela de Comercio y en la Institución para la Enseñanza de la Mujer, instituciones dependientes de la Sociedad Económica de Amigos del País de Valencia, en las que dirigió en varias ocasiones agrupaciones de cámara. En este mismo contexto Salvador Giner compuso varias obras de cámara ${ }^{39}$.

\footnotetext{
${ }^{38}$ Sobrino, “Amorós, Amancio", p. 421. E:Bc, 2011-Fol C 4/71.

39 Sancho, El compositor Salvador Giner, pp. 85-86, menciona, por ejemplo, las siguientes obras camerísticas de Giner: Cuarteto $n^{\circ} 1$ en Sol Mayor para cuerda (1870-71); Cuarteto $n^{\circ} 2$ en Sol Mayor para cuerda (1871); Cuarteto en mi menor para cuerda (1871); Capricho para quinteto de cuerda (sf); L'ultimo addio, melodía para quinteto de cuerda (1880); Melodía para quinteto de cuerda y piano (1896); Melodía en Mi b Mayor para quinteto de cuerda, entre otros títulos.
} 
El quinteto Idilio de Amorós tiene una estructura similar a la del rondó, con secciones en las que alternan dos temas principales según el esquema ABABA (véase Tabla 42). El centro tonal de la pieza es La menor, aunque también utiliza en dos ocasiones el La Mayor, y modulaciones a Do Mayor y Fa Mayor. Las melodías las interpreta principalmente el violín $1^{\mathrm{o}}$, y en ocasiones el violín $2^{\circ}$ dobla la melodía en $8^{\mathrm{a}}$ baja. El papel del resto de la cuerda es básicamente de acompañamiento. El piano realiza diversas funciones, como refuerzo de la melodía, acompañamiento armónico y en ocasiones con pasajes solísticos.

En la primera sección de 26 compases aparece el tema A, interpretado por el violín $1^{\circ}$, acompañado por la cuerda (Ejemplo 37), al que sigue la respuesta del piano con un arpegio ascendente de Mi Mayor.

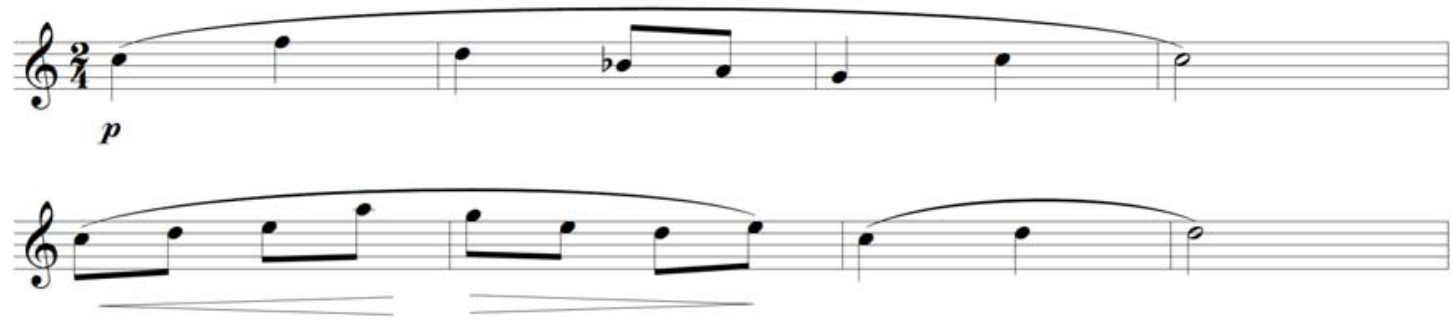

Ejemplo 37

Amorós, Idilio, cc. 98-105. Tema A, violín $1^{\circ}$.

En la segunda sección aparece por primera vez el grupo temático B en La menor, expuesto por el violín $1^{\circ}$ (Ejemplo 38), al que acompaña el resto de la cuerda. 


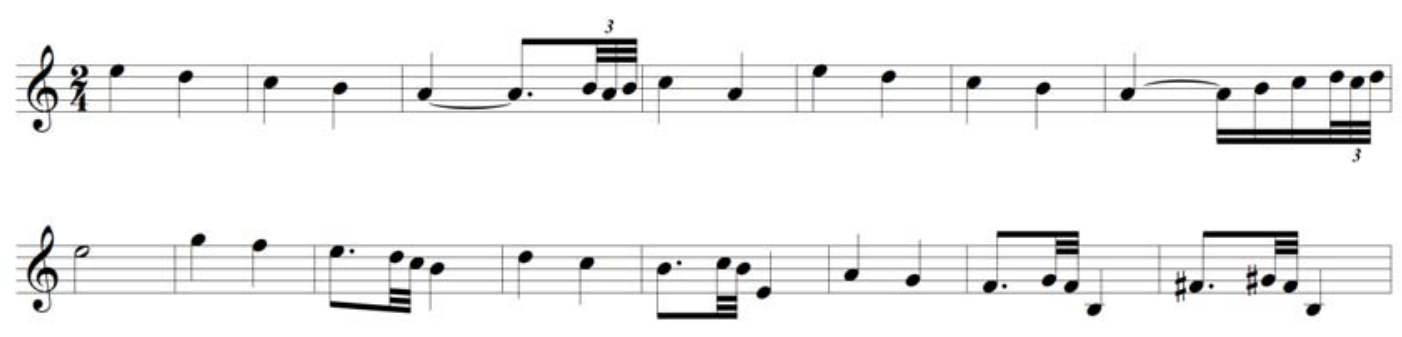

Ejemplo 38

Amorós, Idilio, cc. 27-41. Tema B, violín $1^{\text {o }}$.

Tabla 42. Amancio Amorós, Idilio (sf), quinteto para cuerda y piano. Esquema analítico. Fuente: $E: B c, \mathrm{M} 1278$.

\begin{tabular}{|c|c|c|c|c|}
\hline Secciones & Compases & Material temático & Tonalidad & Tempo/Compás \\
\hline $1^{\mathrm{a}}$ & $1-26$ & Tema A & $\begin{array}{c}\text { La menor } \\
\rightarrow \mathrm{V}\end{array}$ & $\begin{array}{c}\text { Largo } \\
2 / 4\end{array}$ \\
\hline \multirow{3}{*}{$2^{\mathrm{a}}$} & $27-59$ & \multirow{3}{*}{ Tema B } & La menor & Andante \\
\hline & $60-80$ & & $\begin{array}{l}\text { Do Mayor } \\
\rightarrow \mathrm{V} \text { (La m) }\end{array}$ & Piu mosso \\
\hline & $81-97$ & & La menor & Andante \\
\hline \multirow[b]{2}{*}{$3^{\mathrm{a}}$} & 98-113 & \multirow[b]{2}{*}{ Tema A } & Fa Mayor & Meno mosso \\
\hline & $114-145$ & & $\begin{array}{c}\text { La Mayor } \\
\rightarrow \mathrm{V}\end{array}$ & Molto mosso \\
\hline \multirow{2}{*}{$4^{a}$} & $146-162$ & \multirow[t]{2}{*}{ Tema B } & La menor & Andante \\
\hline & $163-180$ & & Do Mayor & \multirow{2}{*}{ Piu mosso } \\
\hline \multirow[b]{2}{*}{$5^{\mathrm{a}}$} & 181-195 & Tema A & \multirow[b]{2}{*}{ La Mayor } & \\
\hline & $196-213$ & Coda & & $\begin{array}{c}\text { Lento } \\
\text { Molto mosso }\end{array}$ \\
\hline
\end{tabular}

\section{Obras para canto y piano}

Hasta el momento he localizado cuatro obras para canto y piano de Amorós: la romanza Anyoranza [sic] (1882) con texto en valenciano de autor desconocido; la Canción para canto y piano (sf), con letra de Marco Antonio Verzenni ${ }^{40}$, que se publicó en 1896, en el álbum musical del número 214 de la Ilustración Musical Hispanoamericana, con el título Recuerdo de amor; Lo cant del mariner [El canto del

\footnotetext{
${ }^{40}$ Marco Antonio Verzenni parece ser un pseudónimo del mismo Amancio Amorós, formado tras estudiar varias combinaciones de su nombre y apellidos, como puede verse en $E: B c, \mathrm{M} 1311$ (véase Ilustración $10)$.
} 
marinero], pequeña barcarola con poesía en $\operatorname{lemosín}^{41}$ y traducción al castellano de Antonio Roig Civera, publicado en el $\mathrm{n}^{\circ} 3$ de la revista Biblioteca Musical Valenciana (1895) y ¡Qué sueño! (1895), melodía para canto y piano de Amorós publicada en el mismo $\mathrm{n}^{\mathrm{o}} 3$ de la Biblioteca Musical Valenciana. Otra obra para canto y piano de Amorós fue Gemechs del cor, actualmente desaparecida ${ }^{42}$. En los apartados que siguen, estudio con más detenimiento tres de las cuatro piezas para canto y piano de Amorós que he podido localizar.

\section{1. Anyoranza $[$ sic] (1882)}

Anyoranza [sic], romanza para canto y piano, según consta en la portada del manuscrito autógrafo conservado en la Biblioteca de Catalunya, M 1293, fue presentada en 1882 al concurso de composición que organizaba anualmente la sociedad valenciana Lo Rat Penat. Musicalmente es un lied ternario $\left(\mathrm{ABA}^{\prime}\right)^{43}$. El autor de la letra, escrita en valenciano, es desconocido. El texto, de carácter amoroso y sentimental, está constituido por dos estrofas de cuatro versos octosílabos que se repiten varias veces (véase Tabla 43).

$\begin{array}{ll}\begin{array}{l}\text { Quan a soles mir la lluna } \\ \text { vora'l riu que la retrata } \\ \text { una pena sent que mata } \\ \text { l'alegria del meu cor. }\end{array} & \begin{array}{l}\text { [Cuando a solas miro la luna } \\ \text { junto al río reflejada } \\ \text { siento una pena que hiere } \\ \text { la alegría de mi corazón]. }\end{array} \\ \begin{array}{l}\text { Pense en tu volguda meua, } \\ \text { quan mire en lo cel la lluna } \\ \text { i em desconsola tot d'una }\end{array} & \begin{array}{l}\text { [Pienso en tí querida mía, } \\ \text { cuando miro en el cielo la luna } \\ \text { l'enyorança de l'amor. }\end{array} \\ \text { y me desconsuela } \\ \text { la añoranza del amor]. }\end{array}$

\footnotetext{
${ }^{41}$ El termino "lemosín" se utilizó a finales del s. XIX para designar todas las variantes de la lengua catalana, evitando la denominación de catalán, valenciano o mallorquín.

${ }^{42}$ Gemechs del cor es citada por Adam, Músicos Valencianos, p. 28.

${ }^{43}$ La estructura de la romanza suele ser ternaria, aunque es habitual que el compositor no se ajuste a ninguna forma específica; véase Mariano Vázquez Tur, "Romanza”, en DMEH, vol. 9 (2002), p. 372.
} 
La pieza está escrita para una voz de registro medio-alto ${ }^{44}$ con algunos intervalos complejos para el cantante, como una quinta disminuida (compás 30), las cuartas aumentadas (compases 95 y 102) y una tercera disminuida (compases 62-63).

El piano tiene muchas notas de adorno sobretodo en la primera sección (mordentes, floreos dobles, apoyaturas) que generan gran riqueza armónica. En ocasiones Amorós utiliza resoluciones excepcionales en acordes de séptima (compases 63-67).

Tabla 43. Amancio Amorós, Anyoranza [sic] (1882). Esquema analítico. Fuente: $E: B c, \mathrm{M} 1273$.

\begin{tabular}{|c|c|c|c|c|c|}
\hline Secciones & Compases & $\begin{array}{l}\text { Material } \\
\text { temático }\end{array}$ & Texto & $\begin{array}{c}\text { Tonalidad } \\
\text { Aspectos } \\
\text { Armónicos }\end{array}$ & $\begin{array}{l}\text { Tempo/ } \\
\text { Compás }\end{array}$ \\
\hline $1^{\mathrm{a}}$ & $1-47$ & A & $\begin{array}{l}\text { Estrofa } 1 \\
(2 \text { veces })\end{array}$ & Re menor & \multirow{4}{*}{$\begin{array}{c}\text { Andante } \\
\text { moderato } \\
3 / 4\end{array}$} \\
\hline $2^{\mathrm{a}}$ & $48-76$ & B & $\begin{array}{l}\text { Estrofa } 2 \\
(2 \text { veces })\end{array}$ & $\begin{array}{c}\text { Fa Mayor } \\
\text { (Inflexión Si b } \\
\text { Mayor) }\end{array}$ & \\
\hline \multirow[t]{2}{*}{$3^{a}$} & \multirow{2}{*}{$77-106$} & \multirow[t]{2}{*}{$A^{\prime}$} & \multirow{2}{*}{$\begin{array}{l}\text { Estrofa } 1 \\
\text { Estrofa } 2\end{array}$} & Re menor & \\
\hline & & & & Re Mayor & \\
\hline
\end{tabular}

\section{2. Lo cant del Mariner (1895)}

Esta barcarola para canto y piano, con letra en valenciano traducida al castellano por Antonio Roig Civera, fue publicada en la Biblioteca Musical Valenciana, Álbum de salón, $\mathrm{n}^{\circ}$ 3, de 15 de marzo de 1895 (véase Apéndice 17). No he localizado el ejemplar manuscrito de esta obra. La pieza es de estructura estrófica y, a su vez, cada estrofa tiene una estructura tripartita:

\footnotetext{
${ }^{44}$ Amorós no indica en el manuscrito si la voz es masculina o femenina, aunque por la letra, con referencias a la amada "pense en tu volguda meua" [pienso en ti, querida mía], parece estar pensada para voz masculina que, por el registro, habría de ser tenor.
} 
1. a (Re Mayor)

2. $\mathrm{b}$ (Re menor)

3. a' (Re Mayor)

La pieza, muy sencilla, es para una voz masculina de registro medio con una extensión que no supera la octava. Predomina la línea melódica ondulada y el piano es un mero acompañamiento. El diseño rítmico, en compás de $6 / 8$ y 3/4, sigue los tópicos habituales de las barcarolas, imitando el balanceo de un barco y el vaivén de las olas. El texto contribuye a crear esta sensación: "Ya subo, ya bajo, me mece la mar [...], la nave empieza a zarpar [...] y corta el azulado cristal" ${ }^{\text {"45. }}$

\section{3. ¡Qué sueño! (1895)}

Esta obra se publicó en el no 3 de la revista Biblioteca Musical Valenciana, Álbum de salón, el 15 de marzo de 1895 y fue dedicada por Amorós a Amalia Puig Boronat, posiblemente cantante aficionada y/o alumna suya (véase Apéndice 17). Desconozco el autor de la poesía, escrita en castellano. No he encontrado la partitura manuscrita de esta pieza.

La pieza presenta una estructura durchcomponiert o de obra continua. La línea melódica vocal, con abundantes cromatismos, va describiendo el texto, con cambios de tempo para caracterizar mejor su expresividad. Las ideas presentes en el texto (negra pesadilla, pérdida de la amada y desfallecimiento del amante) son subrayadas con cromatismos reiterados (Ejemplo 39).

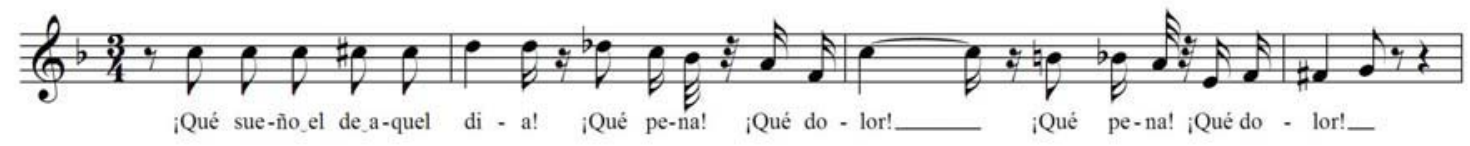

Ejemplo 39

Amorós, ;Qué sueño!, cc. 44-47.

\footnotetext{
${ }^{45}$ Sobre los rasgos generales de la barcarola, véase Mariano Vázquez Tur, "Barcarola", en DMEH, vol. 2 (1999), pp. 217-218.
} 
La obra, en re menor, hace un uso expresivo de acordes apoyatura, acordes alterados (en ocasiones como acordes de paso) y acordes de séptima disminuida que en ocasiones oscurecen el discurso tonal. Destaca el empleo del acorde de $9^{a}$ de dominante sobre Do \# menor, de gran fuerza expresiva (Ejemplo 40).

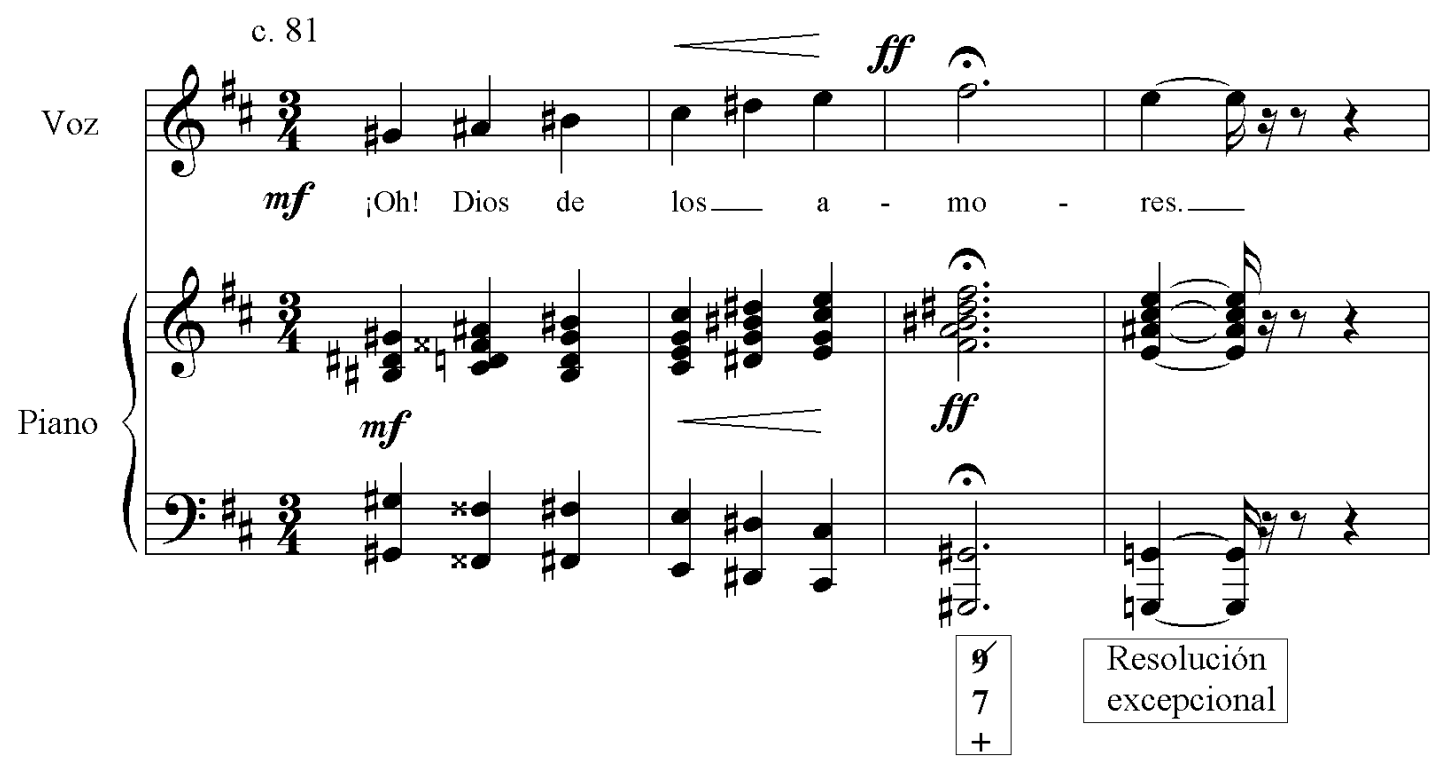

Ejemplo 40

Amorós, ¡Qué sueño!, cc. 81-84.

La línea melódica esta diseñada en función del texto y el piano juega un papel importante, aportando cambios de color cromático y acordes alterados. Esta melodía para canto y piano es cercana estilísticamente a otras obras de este mismo género de compositores valencianos contemporáneos como Eduardo Ximénez o como el gaditano Antonio Reparaz ${ }^{46}$.

\footnotetext{
${ }^{46}$ Sobre las piezas de Ximénez y Reparaz, véanse los comentarios de Alonso, La canción lírica, p. 475.
} 


\section{Obras para piano}

He localizado cinco obras para piano de Amorós: cuatro mazurcas (en Re b Mayor y Sol Mayor de 1890, Re menor de 1891 y Fa Mayor, ca. 1894) y el capricho Violetas y Mariposas (sf). Las tres primeras mazurcas fueron editadas en los números 50, 53 y 76 de la Ilustración Musical Hispanoamericana (1890 y 1891); la mazurca en Fa Mayor apareció en el vol. 1 de la publicación valenciana Biblioteca Musical Valenciana, dirigida por el propio Amancio Amorós y el capricho Violetas y Mariposas para piano fue editado por Salvador Prosper ${ }^{47}$. De ninguna de estas obras he podido localizar los originales manuscritos. Hay además reducción para piano de tres de las danzas de la Col.lecció de huit peces per a piano i harmònium sobre motius populars valencians, la Danza dels chagants [sic], la Danza dels nanos y la Danza valenciana de la Vall d'Albaida ${ }^{48}$. Amorós publicó también otras obras para piano, de las que desconozco la fecha de composición, como el vals Por ella ${ }^{49}$, el nocturno Desengaño, el pensamiento poético Vendrá, romanzas sin palabras, scherzos, fantasías sobre motivos de ópera, arreglos de sinfonías y la obra Escenas poéticas, todas en la actualidad ilocalizables ${ }^{50}$.

Las piezas para piano de Amorós son típicas del género de salón y forman parte del amplio repertorio que se interpretaba en los salones y tertulias de las clases burguesas valencianas $^{51}$. Algunas de ellas presentan rasgos virtuosísticos y dificultades técnicas que

\footnotetext{
${ }^{47}$ Según Gosálvez, La edición musical española, p. 111, la editorial Salvador Prosper apareció alrededor de 1850. El comercio de música de Salvador Prósper estuvo en funcionamiento en Valencia al menos hasta 1893, en la Calle San Vicente 99, según Biblioteca Sacro Musical, 15-XI-1893, p. 102.

${ }^{48}$ Los manuscritos de estas reducciones se conservan en $E: B c, \mathrm{M} 1276$ bis.

${ }^{49}$ Mencionado en Boletín Musical, 10-IV-1900, p. 1695.

50 E:Mba, legajo 5-2-2, Expediente de nombramiento de Amancio Amorós como Académico Correspondiente (1921). Obras citadas por Serrano, "Amancio Amorós", p. 479 y Pedrell, Diccionario biográfico, p. 63. También se da noticia de ellas en la contraportada del método Elementos de Solfeo de Amancio Amorós, que incluye las obras editadas por Amorós hasta 1901.

${ }^{51}$ La música para piano ocupó un importantísmo papel en la música privada o doméstica española del siglo XIX. El piano estuvo presente no sólo en casa de famílias acomodadas, sino también en salones, cafés y sociedades, por lo que se convirtió en el medio de difusión idóneo del resto de géneros musicales
} 
las distancian de la sencillez característica de la música para aficionados ${ }^{52}$. El compositor parece preferir las pequeñas formas y probablemente estuvo influenciado por la escuela de Chopin, inculcada por su maestro Roberto Segura (que a su vez recibió clases de Georges Mathias, uno de los alumnos más destacados de Fredéric Chopin) ${ }^{53}$. LópezChavarri situó el piano de Amorós en un conjunto de importantes compositores valencianos por recuperar:

Cuando se escriba la historia completa de la música española, sin antojeras históricas, con perspectiva periférica, el piano valenciano podrá exhibir títulos fundamentales como el Concierto Hispánico de López-Chavarri, Sonata del Sur de Esplá, sonatas de Llácer y Moreno Gans, piezas peculiares de Rodrigo, Cuesta, Magenti (causa rubor decirlo pero hay que confesarlo) para que la producción de antiguos músicos como Amancio Amorós, Ramón Martínez, Segura [...] no sigan siendo títulos de un inventario erudito o musicológico, sino repertorio y testimonio de un quehacer abundante de nuestro patrimonio filarmónico ${ }^{54}$.

A continuación describiré las principales piezas pianísticas de Amorós localizadas hasta ahora.

del momento. Muchos compositores de finales del XIX y principios del XX trabajaban para cubrir la gran demanda de partituras para piano solo, piano a cuatro manos o voz y piano. Salas, "Santiago de Masarnau", p. 197. En Barcelona, por ejemplo, se constituyó en 1873 la Asociación de Pianistas Compositores de Barcelona destinada a publicar y vender piezas para piano escritas por los asociados; véase Jaume Carbonell i Guberna, "La Música a Barcelona entre els anys 1874-1890. Condicionants del modernisme musical", Revista de Catalunya, 68 (1992), p. 81. Consuelo Carredano, "El piano", en La Música en Hispanoamérica en el siglo XIX, eds. Consuelo Carredano y Victoria Eli, vol. 6. Historia de la música en España e Hispanoamérica, dir. y coord. Juan Ángel Vela del Campo (Madrid: Fondo de Cultura Económica, 2010), pp. 221-263, describe el papel protagonista que tuvo el piano en la sociedad hispanoamericana, analiza los espacios en los que se cultivó el pianismo y el repertorio que éste produjo.

52 Casares, "La música del siglo XIX", p. 62, fue la pequeña forma y no el piano orquestal el más cultivado en España, y en él se dan tres estilos: el virtuoso, uno intermedio y el fácil, dirigido a la clase burguesa, que a través del diletantismo se aproximaba a la música.

${ }^{53}$ A nivel estético podríamos establecer cierta similitud entre la obra pianística de Amancio Amorós y la de otros autores de la segunda mitad del XIX en España, como la del pianista y compositor coetáneo José Tragó y Arana o Anselmo González del Valle, véase Ma Almudena Sánchez Martínez, "El pianista y compositor español José Tragó y Arana (1856-1934)", Revista de Musicología, 28/2 (2005), pp. 15971607; Gómez, Ecos de Asturias, pp. 34-39.

${ }^{54}$ López-Chavarri, “Concierto en el Conservatorio de Música”, p. 43. 


\section{1. Las mazurcas (1890-1894)}

La mazurca estuvo muy extendida en la España del XIX y en casi todos los cuadernos de salón era frecuente encontrar alguna mazurca, asociada en muchas ocasiones a la polka ${ }^{55}$. Las cuatro mazurcas localizadas de Amancio Amorós se ajustan a una estructura ternaria, ABA. En general, llevan como diseño rítmico el acompañamiento de tres figuras por compás (negras en 3/4) de las cuales la primera es grave (fundamental del acorde) y las otras dos forman acorde con la armonía correspondiente, con uso casi exclusivo de acordes de tónica, dominante y subdominante.

La Mazurca en Re bemol Mayor, dedicada a Isaac Albéniz ${ }^{56}$ fue publicada en el $\mathrm{n}^{\mathrm{o}} 50$ de la Ilustración Musical Hispanoamericana, del 18 de febrero de 1890 (véase volumen 2, edición de composiciones de Amancio Amorós) ${ }^{57}$. El tema A de la pieza está basado en el característico ritmo punteado de la mazurca y el tema B es una melodía cantabile y expresiva, sostenida por un ostinato de la mano izquierda con pulsaciones de negra, a modo de pedal, sobre el acorde de fa\# menor sin la tercera (ver Tabla 44). A diferencia de las otras mazurcas, ésta se inicia con una introducción en tempo lento en octavas y una pequeña fermata con arpegios ascendentes y escala descendente que busca la dominante de la tonalidad principal ( $\operatorname{Re} \mathrm{b}$ Mayor). Amorós realiza cambios a tonalidades sin preparación y modulaciones por enarmonía, como la recogida en el Ejemplo 41.

\footnotetext{
${ }^{55}$ Vázquez, El piano y su música, pp. 1066-1067. Véase una descripción de la mazurca en Felipe Pedrell, Las formas pianisticas: origenes y transformaciones de las formas instrumentales, estudiadas en los instrumentos de teclado moderno (Valencia: Manuel Villar, 1918), p. 173.

${ }^{56}$ No he localizado correspondencia entre Amorós e Isaaz Albéniz. Véase, Patrimonio Cultural de la Fundación Albéniz: Fondo Isaac Albéniz, cartas. Dirigido por la Fundación Albéniz y la Biblioteca Virtual Miguel de Cervantes. www.cervantesvirtual.com/FichaObra, página web consultada el 15-VI2008.

${ }^{57}$ Se conserva en $E: B c, 786.2 .089 .82$ ZUR FOL.
} 


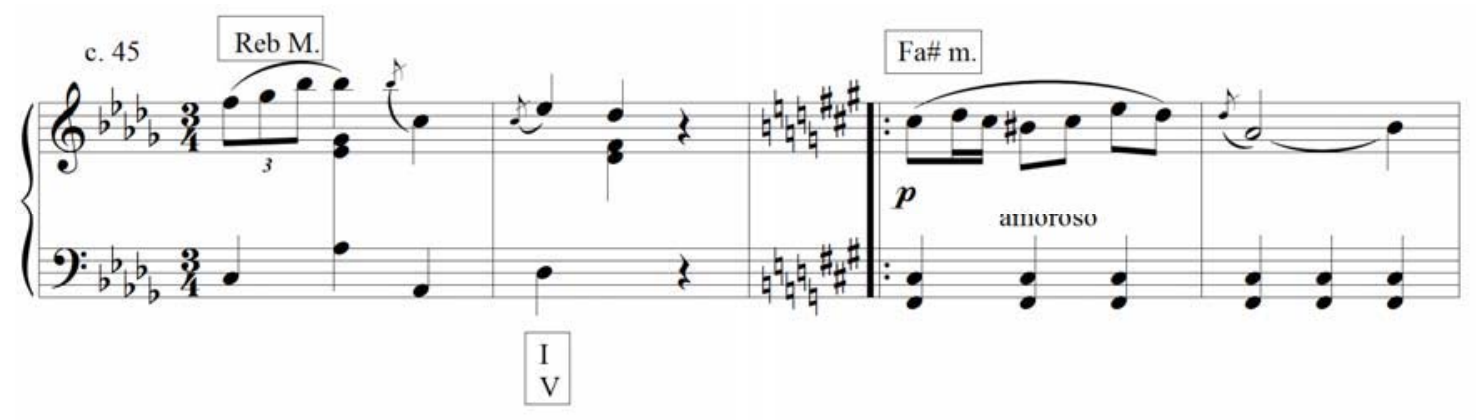

Ejemplo 41

Amorós, Mazurca en Re bemol Mayor, cc. 45-49, modulación por enarmonía.

Tabla 44. Amancio Amorós, Mazurca en Re bemol Mayor (1890). Esquema analítico. Fuente: Ilustración Musical Hispanoamericana, 18-II-1890. E:Bc, 786.2.089.82 ZUR FOL.

\begin{tabular}{|c|c|c|c|c|}
\hline Secciones & Compases & $\begin{array}{l}\text { Material } \\
\text { temático }\end{array}$ & $\begin{array}{c}\text { Tonalidad } \\
\text { Aspectos } \\
\text { armónicos }\end{array}$ & $\begin{array}{l}\text { Tempo/ } \\
\text { Compás }\end{array}$ \\
\hline Introducción & $1-7$ & & $\begin{array}{c}\text { Re b Mayor } \\
\text { V }\end{array}$ & $\begin{array}{c}\cdot=76 \\
3 / 4\end{array}$ \\
\hline $1^{\mathrm{a}}$ & $8-46$ & Tema A & $\begin{array}{l}\text { Re b Mayor } \\
\text { La b Mayor } \\
\text { Re b Mayor }\end{array}$ & \multirow{3}{*}{$\downarrow d=138$} \\
\hline $2^{\mathrm{a}}$ & $47-69$ & Tema B & $\mathrm{Fa} \#$ menor & \\
\hline $3^{\mathrm{a}}$ & $70-108$ & Tema A & $\begin{array}{l}\text { Re b Mayor } \\
\text { La b Mayor } \\
\text { Re b Mayor }\end{array}$ & \\
\hline
\end{tabular}

La Mazurca en Sol Mayor para piano (1890), editada en el álbum de la Ilustración Musical Hispanoamericana, $\mathrm{n}^{\circ}$ 53, del 2 de abril de 1890 (véase volumen 2, edición de composiciones de Amancio Amorós) ${ }^{58}$, está dedicada a una dama, C. Beltrán, cuya vinculación con el compositor desconozco (es posible que fuera alumna suya) ${ }^{59}$. Esta obra es una pieza muy simple dentro de los cánones de la mazurca del XIX (Tabla 45),

\footnotetext{
${ }^{58}$ Se conserva en la $E: B c, 786.2 .089 .82$ ZUR FOL.

59 Según Carredano, "El piano”, p. 235, la práctica de dedicar partituras de piano a las damas fue una costumbre muy extendida en la sociedad del momento.
} 
sin más pretensiones que servir como obra de estudio o para amenizar alguna tertulia musical en una casa acomodada, donde las "señoritas" mostraban la cuidada educación que habían recibido ${ }^{60}$.

En la primera sección de la mazurca, el grupo temático A puede subdividirse en aba. En a domina el ritmo punteado de la mano derecha, de carácter rítmico y bailable; en b se acentúa el segundo tiempo en la mano derecha, característica que coincide con la descripción de mazurca según Pedrell ${ }^{61}$. El tema B es una melodía más cantabile y de amplios vuelos en mano derecha, con una estructura de 8 compases (4+4). Amorós utiliza algunos cromatismos y dominantes secundarias que refuerzan las tonalidades principales (Sol Mayor y Si b Mayor); véanse Ejemplos 42 y 43.

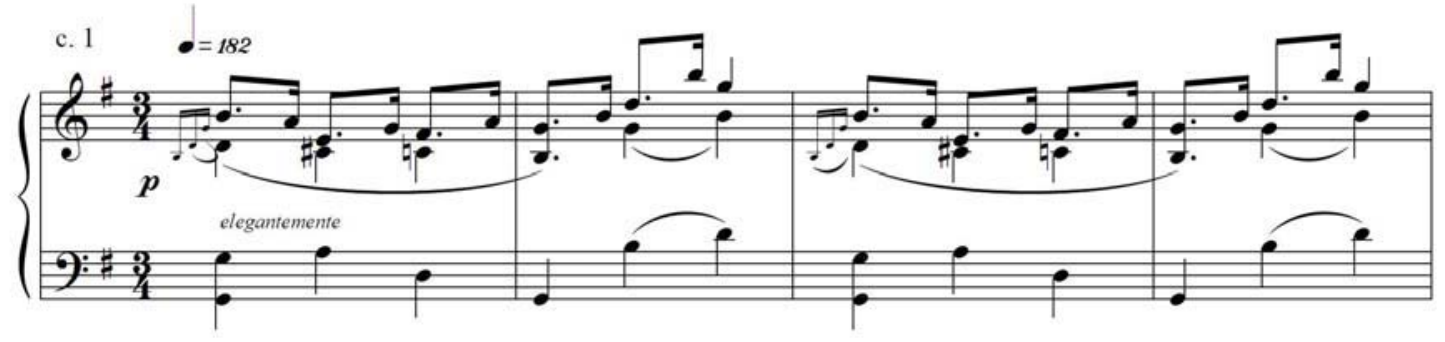

Ejemplo 42

Amorós, Mazurca en Sol Mayor, cc. 1-4, cromatismos.

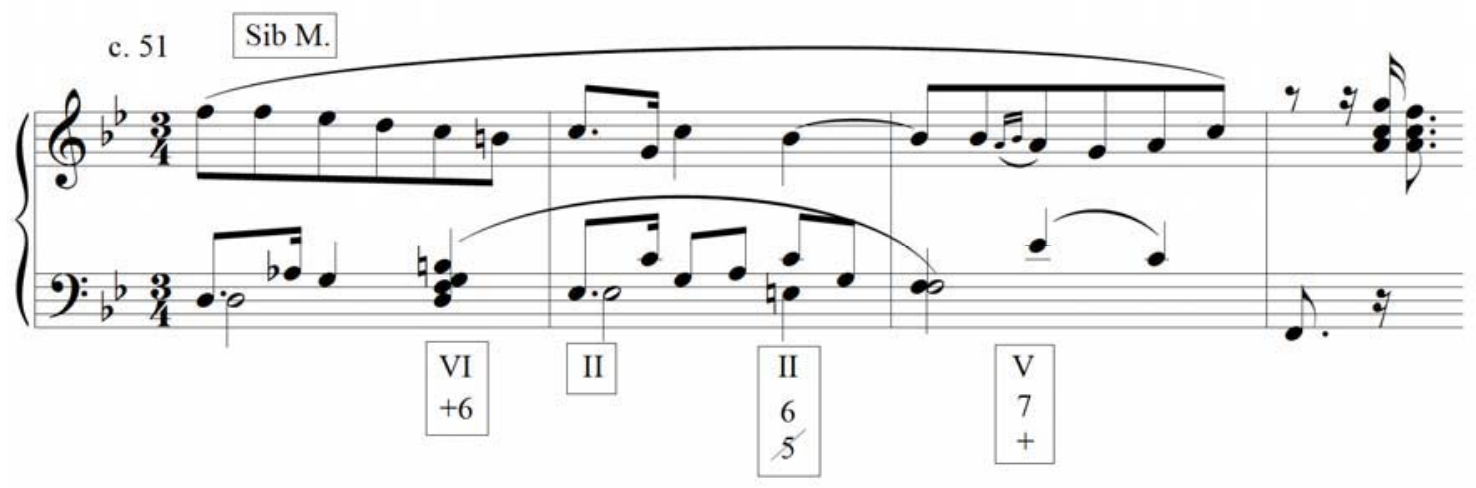

Ejemplo 43

Amorós, Mazurca en Sol Mayor, cc. 51-53, dominantes secundarias.

\footnotetext{
${ }^{60}$ Véase Miranda, “A tocar, señoritas”, pp. 153, 156.

${ }^{61}$ Pedrell, Las formas pianísticas, p. 173.
} 
Tabla 45. Amancio Amorós Sirvent, Mazurca en Sol Mayor para piano (1890). Esquema analítico. Fuentes: Ilustración Musical Hispanoamericana, 2-IV-1890; E:Bc, 786.2.089.82 ZUR FOL.

\begin{tabular}{|c|c|c|c|c|}
\hline Secciones & Compases & $\begin{array}{l}\text { Material } \\
\text { temático }\end{array}$ & $\begin{array}{c}\text { Tonalidad } \\
\text { Aspectos } \\
\text { Armónicos }\end{array}$ & $\begin{array}{l}\text { Tempo/ } \\
\text { Compás }\end{array}$ \\
\hline \multirow{3}{*}{$1^{\mathrm{a}}$} & $1-17$ & \multirow[t]{3}{*}{$\begin{array}{c}\text { Grupo temático } \\
\text { A }\end{array}$} & $\begin{array}{c}\text { Sol Mayor } \\
\text { I }\end{array}$ & \multirow{5}{*}{$\begin{array}{c}\cdot=132 \\
3 / 4\end{array}$} \\
\hline & $18-29$ & & $\begin{array}{c}\text { Re Mayor } \\
\text { I }\end{array}$ & \\
\hline & $30-46$ & & $\begin{array}{l}\text { Sol Mayor } \\
\text { I }\end{array}$ & \\
\hline \multirow[b]{2}{*}{$2^{\mathrm{a}}$} & $47-55$ & \multirow[b]{2}{*}{$\begin{array}{c}\text { Grupo temático } \\
\text { B }\end{array}$} & Sol menor & \\
\hline & $56-70$ & & $\begin{array}{c}\text { Si b Mayor } \\
\text { Cadencia } \\
\text { V-I }\end{array}$ & \\
\hline
\end{tabular}

La Mazurca en Re menor, publicada en el $n^{\circ} 76$ de La Ilustración Musical Hispanoamericana (15 de marzo de 1891) y dedicada a Felipe Pedrell, utiliza muy poco el ritmo característico de la mazurca (corchea con puntillo y semicorchea, véase volumen 2, edición de composiciones de Amancio Amorós) ${ }^{62}$. El mayor interés de la pieza está en el bajo y en dos temas bien definidos (Ejemplos 44 y 45). De las cuatro mazurcas de Amorós es la que presenta rasgos más chopinianos.

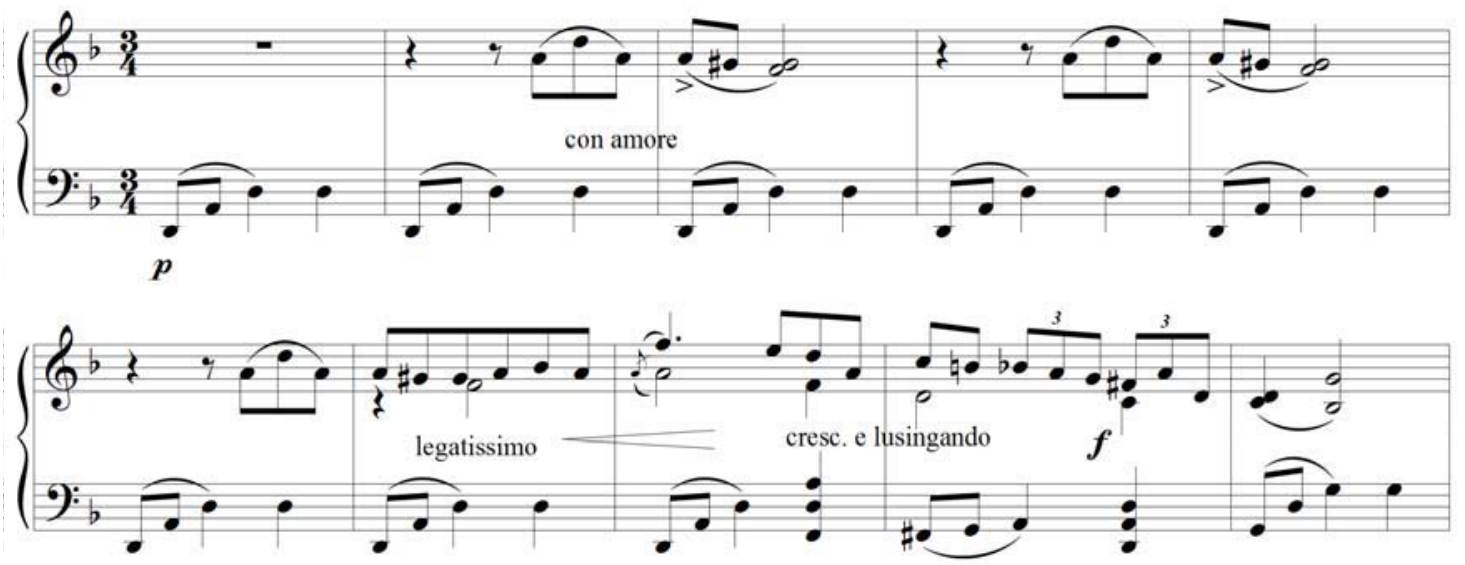

Ejemplo 44

Amorós, Mazurca en re menor, cc. 1-10, tema A.

${ }^{62}$ La mazurca se conserva en $E: B c, 786.2 .089 .82$ ZUR FOL. 

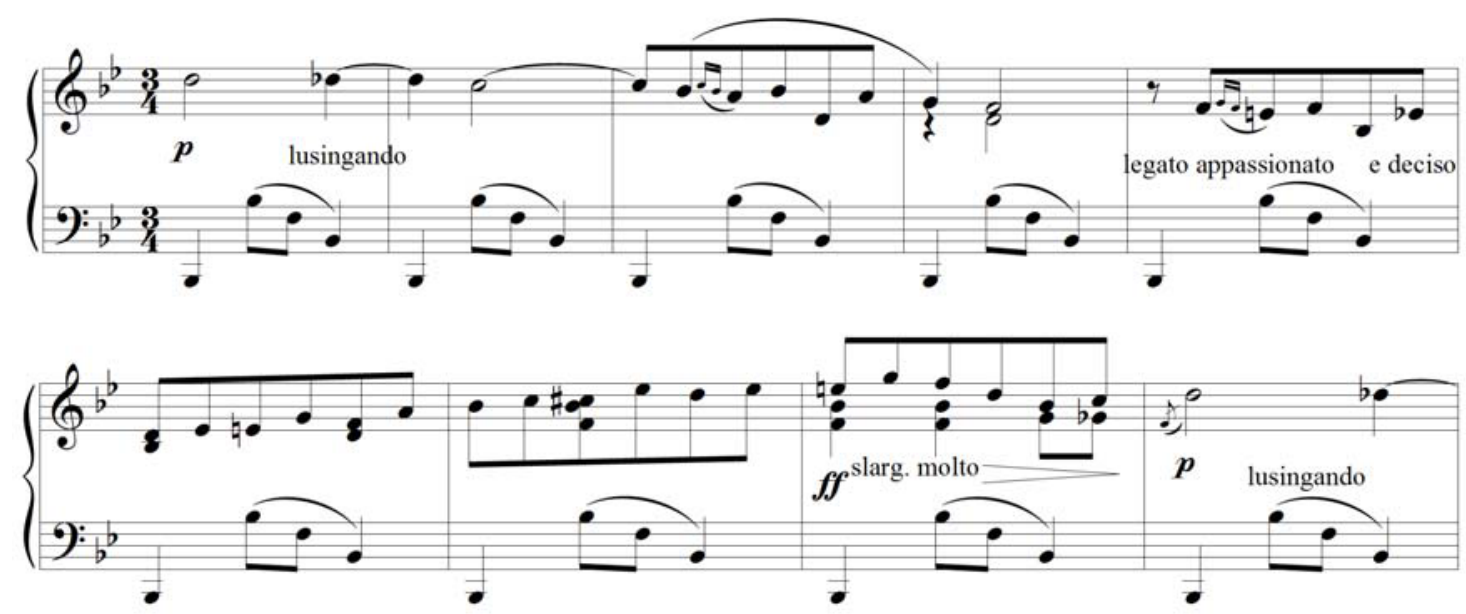

Ejemplo 45

Amorós, Mazurca en re menor, cc. 69-77, tema B.

La obra, que sigue la misma estructura ternaria que las otras mazurcas de Amorós (véase Tabla 46), presenta una mayor elaboración armónica con progresiones modulantes (compases 24-43), notas extrañas al acorde (compás 3), y cromatismos en las pequeñas fermatas que originan disonancias (compases 17, 63, 92).

Tabla 46. Amancio Amorós, Mazurca en Re menor para piano (1891). Esquema analítico. Fuente: Ilustración Musical Hispanoamericana, 15-III-1891. E:Bc, 786.2.089.82 ZUR FOL.

\begin{tabular}{|c|c|c|c|c|}
\hline Secciones & Extensión & $\begin{array}{l}\text { Material } \\
\text { temático }\end{array}$ & $\begin{array}{c}\text { Tonalidad } \\
\text { Aspectos } \\
\text { Armónicos }\end{array}$ & $\begin{array}{l}\text { Tempo/ } \\
\text { Compás }\end{array}$ \\
\hline \multirow{3}{*}{$1^{\mathrm{a}}$} & $1-23$ & \multirow{2}{*}{$\begin{array}{c}\text { Grupo temático } \\
\text { A }\end{array}$} & $\begin{array}{l}\text { Re menor } \\
\mathrm{I} \rightarrow \mathrm{IV} \rightarrow \mathrm{V} \rightarrow \mathrm{I}\end{array}$ & \multirow{6}{*}{$\begin{array}{c}\text { Allegretto } \\
3 / 4\end{array}$} \\
\hline & $24-47$ & & $\begin{array}{l}\text { Inestabilidad } \\
\text { armónica }\end{array}$ & \\
\hline & $48-68$ & $\begin{array}{l}a \\
b \\
a\end{array}$ & $\begin{array}{c}\text { Re menor } \\
\mathrm{I} \rightarrow \mathrm{IV} \rightarrow \mathrm{V} \rightarrow \mathrm{I}\end{array}$ & \\
\hline \multirow{3}{*}{$2^{\mathrm{a}}$} & $69-85$ & \multirow{3}{*}{$\begin{array}{c}\text { Grupo temático } \\
\text { B }\end{array}$} & Sol menor & \\
\hline & $86-101$ & & $\begin{array}{l}\text { Inestabilidad } \\
\text { armónica }\end{array}$ & \\
\hline & $102-118$ & & Sol menor & \\
\hline \multicolumn{5}{|c|}{ Repetición íntegra de la $1^{\mathrm{a}}$ Sección } \\
\hline
\end{tabular}


La Mazurca en Fa Mayor se editó en 1894 en el volumen 1 de la Biblioteca Musical Valenciana y fue dedicada por Amorós a su "distinguida discípula Srta Da Dolores Peñaranda Lima" (véase Apéndice 17). En el ejemplar que he manejado hay además una emotiva dedicatoria autógrafa de Amorós a su "queridísimo discípulo Leopoldo Querol [...] como recuerdo de antaño" ${ }^{\circ 3}$. El esquema de la pieza puede verse en la Tabla 47. Los dos grupos temáticos presentan células de ritmo punteado en la mano derecha y abundantes mordentes (Ejemplos 46, 47 y 48).

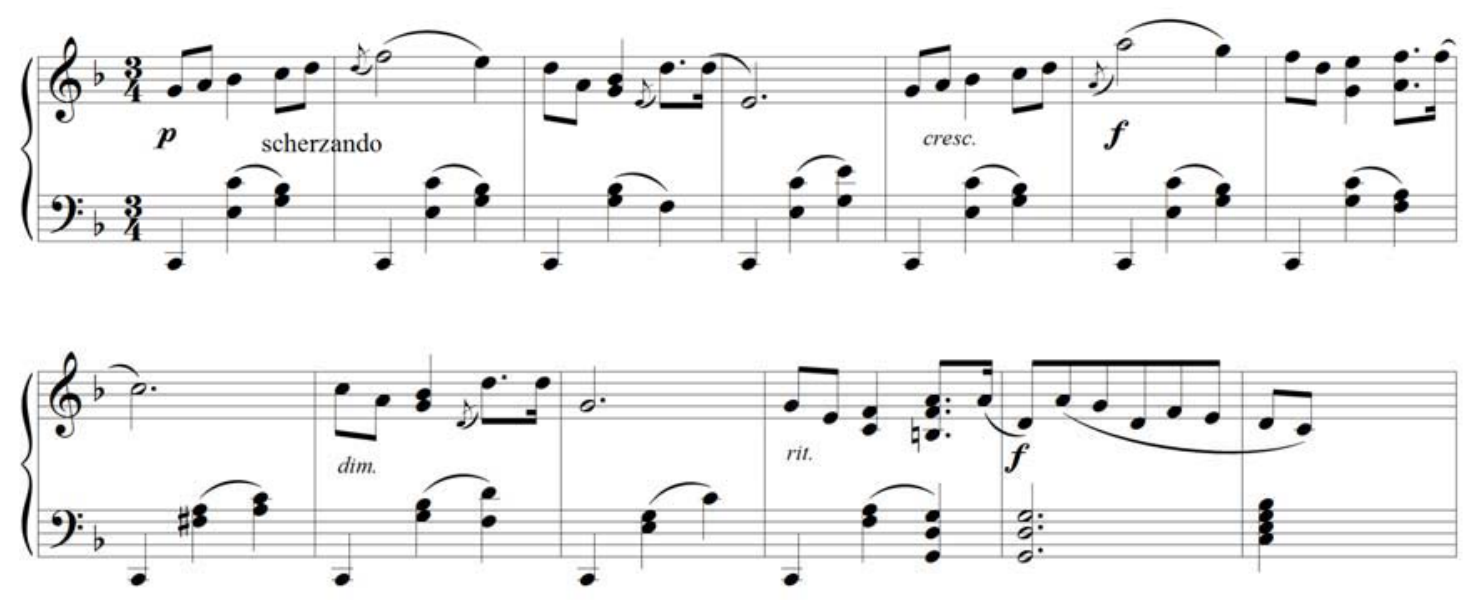

Ejemplo 46

Amorós, Mazurca en Fa Mayor, cc. 1-13, tema A.

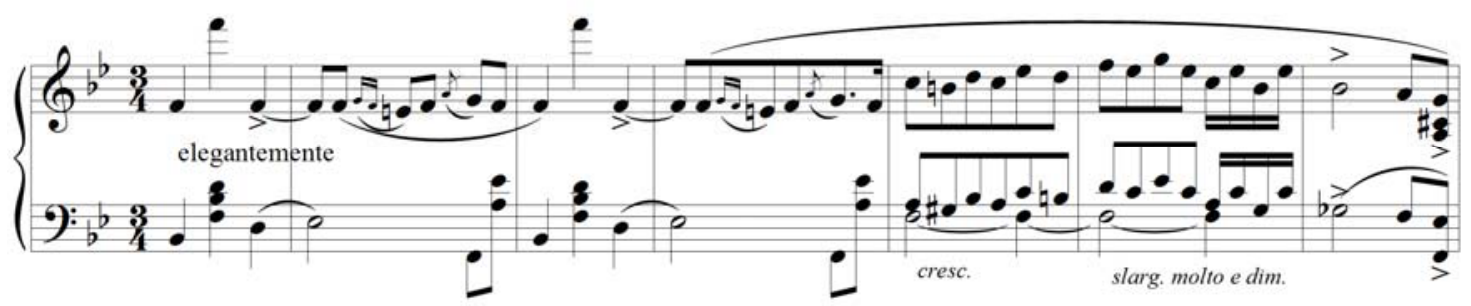

Ejemplo 47

Amorós, Mazurca en Fa Mayor, cc. 50-56, grupo temático B (b).

\footnotetext{
${ }^{63}$ He localizado el número 1 de la Biblioteca Musical Valenciana (1894) en E:Bc, 2010-Fol-C 32/3 y $E: M b a$, en el fondo del pianista Leopoldo Querol, C. XXII-12. El pianista castellonense Leopoldo Querol (1899-1985) fue alumno del Conservatorio de música de Valencia, perfeccionó sus estudios musicales en París y fue catedrático del Conservatorio Nacional de Música. Véase Capítulo 2.
} 


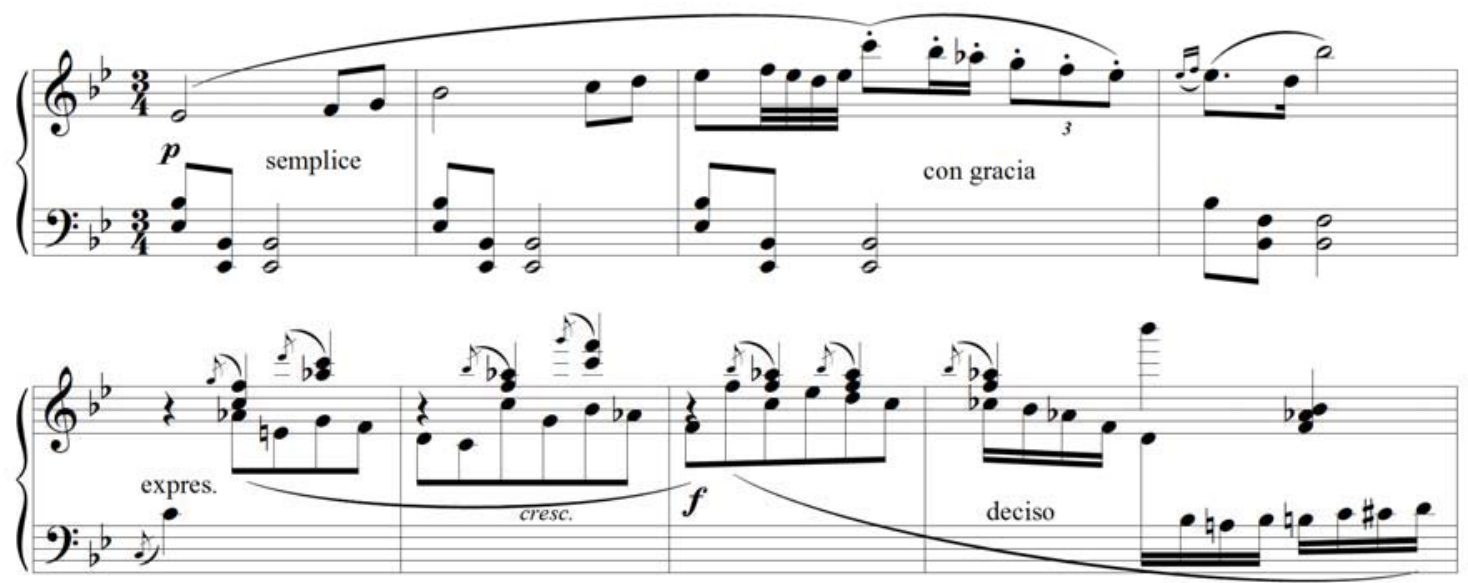

Ejemplo 48

Amorós, Mazurca en Fa Mayor, cc. 70-77, grupo temático B (c).

Tabla 47. Amancio Amorós, Mazurca en Fa Mayor. Esquema analítico. Fuente: Biblioteca Musical Valenciana. Álbum de salón, $\mathrm{n}^{\circ} 1$.

\begin{tabular}{|c|c|c|c|c|}
\hline Secciones & Extensión & $\begin{array}{l}\text { Material } \\
\text { temático }\end{array}$ & $\begin{array}{c}\text { Tonalidad } \\
\text { Aspectos } \\
\text { Armónicos }\end{array}$ & Tempo/Compás \\
\hline \multirow{3}{*}{$1^{\mathrm{a}}$} & $1-17$ & \multirow{3}{*}{$\begin{array}{c}\text { Grupo temático } \\
\text { A } \\
(\mathrm{a}-\mathrm{a}-\mathrm{a})\end{array}$} & Fa Mayor & \multirow{7}{*}{$\begin{array}{c}3 / 4 \\
\text { Allegretto } \\
\cdot=92 \\
\text { (cc. } 91 \text { y } 92 \\
\text { en } 9 / 8)\end{array}$} \\
\hline & $18-35$ & & Do Mayor & \\
\hline & $36-49$ & & Fa Mayor & \\
\hline \multirow{3}{*}{$2^{\mathrm{a}}$} & $50-69$ & \multirow{3}{*}{$\begin{array}{c}\text { Grupo temático } \\
\text { B } \\
(b-c-b)\end{array}$} & Si b Mayor & \\
\hline & $70-92$ & & Mi b Mayor & \\
\hline & $93-121$ & & Si b Mayor & \\
\hline \multicolumn{4}{|c|}{ Repetición de la $1^{\text {a }}$ sección } & \\
\hline
\end{tabular}

\section{2. El capricho Violetas y Mariposas (sf)}

El capricho de Amorós se conserva en un álbum impreso y encuadernado para piano que contiene entre otras obras, el Scherzo de la sonata $n^{o} 1$ de I. Albéniz, la Suite Espagnole de Albéniz, Pasquinade, Últimos momentos de un poeta, y Acuérdate (meditación para piano) de Gottschalk, ¡Partez Ingrate! de Nicolás Ruiz Espadero ${ }^{64}$,

\footnotetext{
${ }^{64}$ Nicolás Ruiz Espadero (1832-1890) fue uno de los músicos cubanos más relevantes del siglo XIX dentro de la corriente nacionalista e influyó notablemente en las siguientes generaciones. Es el primer músico profesional cubano formado en Cuba que alcanzó reconocimiento universal. Cecilio Tieles Ferrer, "Ruiz Espadero, Nicolás", en DMEH, vol. 9 (2002), pp. 484-488.
} 
Fleurs faneés de Gustave Lange, reducciones de zarzuela como Gran Fantasía sobre motivos de la zarzuela Pan y Toros, arreglada por Peña y Goñi, la sinfonía Juana de Arco de G. Verdi. Contiene además algunas danzas de Ignacio Cervantes ${ }^{65}$, con una dedicatoria en la portada que decía: "Dedica este recuerdo a su afectuoso amigo el maestro compositor D. Amancio Amorós $" 66$. Todo parece indicar que este álbum sería de Amancio Amorós y seguramente muestra el tipo de piezas que se escucharían en las veladas musicales de la sociedad burguesa valenciana.

Los caprichos eran piezas vocales o instrumentales, de forma libre, similares a las fantasías y de carácter humorístico o caprichoso. Es difícil establecer la frontera entre fantasía y capricho porque tales denominaciones con frecuencia eran consideradas sinónimas. En los caprichos para piano de compositores españoles del siglo XIX se distinguen dos tipos: 1) los inspirados en motivos populares españoles (jotas aragonesas, sevillanas y otras); y 2) los basados en otras fuentes. En el primer caso, el capricho suele acomodarse a la estructura de copla-estribillo. En el segundo, el margen de libertad es mucho mayor y puede dar lugar a estructuras binarias, ternarias $\mathrm{u}$ otras ideadas por el compositor, ya sea con un solo tema o con más ${ }^{67}$.

El capricho Violetas y Mariposas de Amorós responde al segundo modelo descrito y es una pieza romántica, de tinte melancólico, con estructura ternaria, dos temas y presencia del elemento virtuosístico en cadencias y fermatas (ver Tabla 48). El tema A, con una melodía muy expresiva, presenta en el acompañamiento un diseño rítmico de dos

\footnotetext{
${ }^{65}$ El compositor cubano Ignacio María Cervantes (1847-1905) es conocido sobre todo por sus obras para piano, aunque también compuso obras de otros géneros. Véase Victoria Eli, "Cervantes Kawanagh, Ignacio María”, en DMEH, vol. 3 (1999), pp. 497-500.

${ }^{66} E: B c, \mathrm{M} 4128$, Álbum pianístico.

${ }^{67}$ Para Pedrell el capricho primitivamente "era sinónimo de fantasía y designaba una pieza instrumental en imitaciones", Pedrell, Las formas pianísticas, p. 72. El término apareció en el siglo XVI como denominación de algunos madrigales italianos y tuvo un amplio desarrollo en la literatura para piano del siglo XIX, Mariano Vázquez Tur, "Capricho”, en DMEH, vol. 3 (1999), p. 141.
} 
negras en las que la primera se articula como nota más grave y base del acorde que sigue (Ejemplo 49).

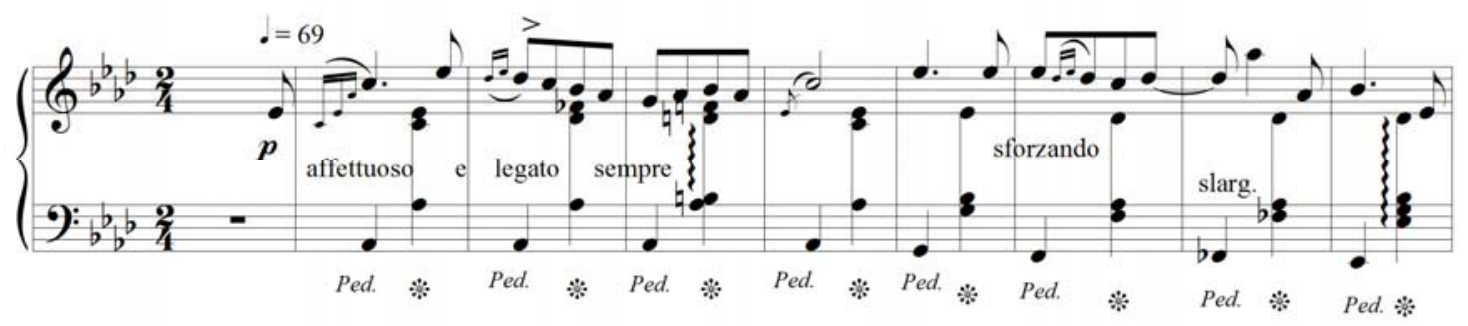

Ejemplo 49

Amorós, Violetas y Mariposas, cc. 21-28, tema A.

En la segunda sección Amorós presenta un cambio rítmico que anima la composición, con figuraciones más cortas, cambiando la pulsación a la corchea y con un persistente ritmo de tresillos (véase Ejemplo 50). La tercera sección es la reexposición de la primera, pero adornada virtuosísticamente.
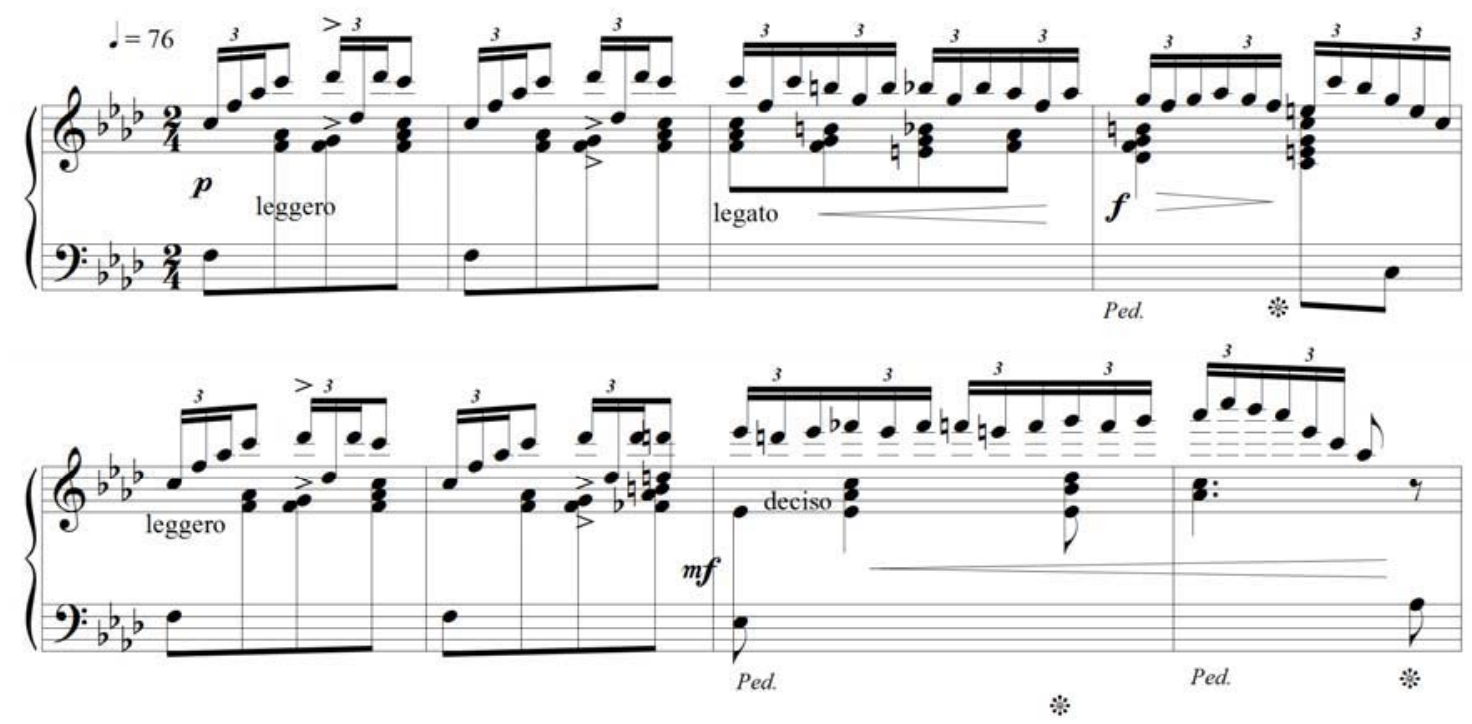

Ejemplo 50

Amorós, Violetas y Mariposas, cc. 62-69, tema B. 
En Violetas y Mariposas Amorós se muestra conocedor de la técnica pianística con un lenguaje idiomático complejo y propio del instrumento, y adentrándose en un considerable virtuosismo, con recursos como octavas paralelas, saltos interválicos importantes, ornamentación en todas las zonas del piano, notas dobles, arpegios y fermatas expresivas.

Tabla 48. Amancio Amorós, Violetas y mariposas, capricho para piano (sf). Esquema analítico. Fuente: Álbum pianistico. E:Bc, M 4128.

\begin{tabular}{|c|c|c|c|c|}
\hline Secciones & Compases & $\begin{array}{l}\text { Material } \\
\text { temático }\end{array}$ & $\begin{array}{l}\text { Tonalidad } \\
\text { Aspectos } \\
\text { armónicos }\end{array}$ & $\begin{array}{l}\text { Tempo/ } \\
\text { Compás }\end{array}$ \\
\hline Introducción & $1-20$ & $\begin{array}{c}\text { Acordes } \\
\text { desglosados }\end{array}$ & $\begin{array}{l}\text { La b } \\
\text { Mayor }\end{array}$ & \multirow{4}{*}{$\begin{array}{c}\text { Moderato } \\
2 / 4\end{array}$} \\
\hline \multirow{3}{*}{$1^{\mathrm{a}}$} & \multirow{3}{*}{ 21-61 } & \multirow{3}{*}{ Tema A } & $\begin{array}{c}\text { La b Mayor } \\
\text { I }\end{array}$ & \\
\hline & & & $\begin{array}{l}\text { Inestabilidad } \\
\text { armónica }\end{array}$ & \\
\hline & & & $\begin{array}{c}\text { La b Mayor } \\
\text { I }\end{array}$ & \\
\hline \multirow{4}{*}{$2^{\mathrm{a}}$} & \multirow{4}{*}{$62-109$} & \multirow{3}{*}{$\begin{array}{c}\text { Tema B } \\
\text { Tresillos de } \\
\text { semicorcheas en } \\
\text { progresión }\end{array}$} & $\begin{array}{c}\text { Fa menor } \\
\text { La b Mayor }\end{array}$ & \multirow{4}{*}{$\begin{array}{c}\text { Piu mosso } \\
2 / 4\end{array}$} \\
\hline & & & $\begin{array}{l}\text { Re b Mayor } \\
\text { Progresión } \\
\text { armónica } \\
\text { modulante }\end{array}$ & \\
\hline & & & & \\
\hline & & $\begin{array}{l}\text { Acordes } \\
\text { arpegiados }\end{array}$ & $\begin{array}{c}\text { Fa menor } \\
\qquad \mathrm{V} \rightarrow\end{array}$ & \\
\hline \multirow{3}{*}{$3^{\mathrm{a}}$} & \multirow{3}{*}{$110-150$} & \multirow{3}{*}{$\begin{array}{c}\text { Tema A } \\
\text { Ornamentado } \\
\text { Virtuosísti- } \\
\text { camente } \\
\end{array}$} & $\begin{array}{c}\text { La b Mayor } \\
\text { I }\end{array}$ & \multirow{4}{*}{$\begin{array}{c}\text { Moderato } \\
2 / 4\end{array}$} \\
\hline & & & $\begin{array}{c}\text { Inestabilidad } \\
\text { armónica }\end{array}$ & \\
\hline & & & $\mathrm{V}-\mathrm{I}$ & \\
\hline Coda & $151-186$ & $\begin{array}{c}\text { Elementos del } \\
\text { Tema A y B }\end{array}$ & La b Mayor & \\
\hline
\end{tabular}




\section{Música escénica}

A finales del siglo XIX y principios del XX la vida zarzuelística valenciana giraba en torno al Teatro Ruzafa, aunque, como he mencionado en el Capítulo 1, se programaban temporadas de zarzuela también en otros teatros valencianos. La música escénica de Amorós se desarrolló paralelamente junto a las producciones de otros valencianos como Salvador Giner (1832-1911), Roberto Segura (1845-1902), José Valls (1850-1909), Vicente Díez Peydró (1861-1938, conocido como Peydró), José Bellver Abells (1869-1945), José Fayos Pascual (1871-1931), José Serrano (1873-1941), José Espí Ulrich (1814-1905), José Jordá Valor (1839-1918) y Ramón Martínez Carrasco (1872-1966), entre otros ${ }^{68}$.

Hasta el momento he localizado tres obras escénicas compuestas por Amancio Amorós: las zarzuelas Navegación Submarina (1885) y Los dos esclavos (1886) y la parodia El tío Sappo (sf). Las tres obras se conservan manuscritas en la Biblioteca de Catalunya y sólo Los dos esclavos fue estrenada ${ }^{69}$. Amorós compuso además otras piezas teatrales en un acto que no he conseguido localizar por el momento: Viva España, Chepeta $^{70}$ (de asunto regional) y El Majo ${ }^{71}$.

\footnotetext{
${ }^{68}$ Sobre la producción teatral de estos autores, véase Sancho, El compositor Salvador Giner, pp. 93-98; García Franco, "El apogeo de la zarzuela", pp. 285-297.

${ }^{69}$ La zarzuela Navegación Submarina y la parodia El tio Sappo, "tropezaron con ciertas dificultades que imposibilitaron su estreno", véase Serrano, "Amancio Amorós", p. 479. Según el informe que acompaña el expediente para el nombramiento de Amorós como Académico Correspondiente de la Real Academia de San Fernando de Madrid, E:Mba, legajo 5-2-2, Expediente de nombramiento de Amancio Amorós como Académico Correspondiente (1921), en los ensayos de Navegación Submarina, Amorós era aplaudido por los actores y profesores de la orquesta, pero la obra fue retirada por los mismos autores y no llegó a estrenarse por "ciertas intrigas entre bastiones, como sucede con frecuencia".

${ }^{70}$ Desconozco si podría tratarse de la comedia lírico-dramática en verso, dividida en tres cuadros Jepeta, original de L. Cebrián Mezquita, Imp. Federico Doménech. Obra premiada en los Juegos Florales de Lo Rat Penat de 1902. Está dedicada a Francisco Badenes Dalmau. Un tomo en $4^{\circ}$, de 190 pp., Almanaque de las Provincias para 1909, p. 366.

71 E:Mba, legajo 5-2-2, Expediente de nombramiento de Amancio Amorós como Académico Correspondiente (1921). El texto manuscrito de la zarzuela cómica en un acto y cuatro cuadros $A$ les Danses d'Agullent, podría ser una zarzuela de Amancio Amorós cuya música hoy es desconocida. E:Vabv, Mss/643-20 [37 pp.].
} 


\section{1. Obras no estrenadas: Navegación submarina (1885) y El tío Sappo (sf)}

Navegación submarina (1885) es una zarzuela en cuatro actos y veintinueve números, con letra de Antonio Roig Civera. El manuscrito de la obra, conservado en la Biblioteca de Catalunya, no indica quién fue el autor del libreto, que sin embargo, sí aparece en la portada de la reducción autógrafa de la melodía y bajo armónico que conserva la Biblioteca Nacional de Madrid ${ }^{72}$.

El tío Sappo (sf), con letra de Juan Bautista Perales ${ }^{73}$, es una parodia en un acto de la ópera Saffo (1840) de Giovanni Pacini ${ }^{74}$ que probablemente hay que fechar entre 1880 y 1920, periodo de mayor cultivo y éxito del género paródico en España ${ }^{75}$. Los autores de parodias utilizaban trozos de fragmentos conocidos de óperas o zarzuelas ya consagradas o de reciente estreno como coros, arias y romanzas que resultaban familiares al público, y los utilizaban en las creaciones propias dándoles un sentido tergiversado y cómico ${ }^{76}$. La dependencia cultural y auditiva que fomentó la ópera italiana ha de tenerse en cuenta para comprender el éxito que tendrán las parodias surgidas en España en este momento ${ }^{77}$. El

\footnotetext{
${ }^{72} E: M n, M / 1761,73$ páginas en folio apaisado. Véase Nieves Iglesias Martínez [et al.], La Música en el Boletín de la Propiedad intelectual 1847-1915 (Madrid: Ministerio de Educación y Cultura, 1997), p. 296. El número de registro de la obra en este catálogo es el 7926; Iglesias, Teatro lírico español, vol. 2 (1991), p. 752.

${ }^{73}$ Véase Iglesias, Teatro lírico español, vol. 3 (1991), p. 742.

${ }^{74}$ Giovanni Pacini (1796-1867) fue un compositor italiano, autor de más de 80 óperas. Cuando su ídolo y rival Rossini abandonó el teatro napolitano hacia 1822, Pacini lo reemplazó y alcanzó gran éxito con sus operas serias: Alessandro 'nell Indie en 1824 y L'Ultimo Giorno di Pompei en 1825. En 1840 compuso la ópera Saffo, en colaboración con el libretista Salvatore Cammarano, muy influenciada por Giuseppe Verdi. En los años siguientes disfrutó de varios éxitos, incluyendo Medea (1843) y Maria d'Ingelterre (1843), también conocida como Maria Tudor. Compuso además oratorios, misas, cantatas y música instrumental. Véase Scout L. Balthazar/Michael Rose, "Pacini, Giovanni”, en The New Grove Dictionary of Opera, ed. Stanley Sadie, 4 vols. (London: MacMillan, 1996), vol. 3, pp. 808-812.

${ }^{75}$ Eduardo Huertas Vázquez, "La zarzuela paródica y sus incursiones políticas", Cuadernos de Música Iberoamericana, 2 y 3 (1996-97), p. 165; véase también Emilio Casares Rodicio, "Historia del teatro de los bufos, 1866-1881. Crónica y dramaturgia”, Cuadernos de Música Iberoamericana, 2 y 3 (1996-97), pp. 110-113.

${ }^{76}$ Huertas, "La zarzuela paródica", pp. 165-166.

${ }^{77}$ Serge Salaün, "La zarzuela híbrida y castiza”, Cuadernos de Música Iberoamericana, 2 y 3 (1996-97), p. 238.
} 
manuscrito que conserva la Biblioteca de Catalunya de El tío Sappo es una reducción para voces y piano, con muchas correcciones, por lo que parece ser un borrador. Algunos números parecen estar incompletos y la letra resulta prácticamente ilegible en el manuscrito. La trama de la obra es una historia de amor en tono de burla en la que muchos elementos quedan inconexos.

El tío Sappo consta de un solo acto, compuesto por seis números musicales, que son más breves que en Los dos esclavos y Navegación Submarina. La obra tiene una introducción para orquesta y banda. En la ópera original Saffo de Pacini, tragedia lírica en tres partes con libreto de Salvatore Cammarano, estrenada en el Teatro San Carlo de Nápoles el 29 de noviembre de 1840, los personajes principales eran cuatro: Saffo, Faone, Alcandro y Climene, y la acción transcurría en la antigua Grecia $^{78}$. En la parodia de Amorós los personajes son: Sappo, Tula, Frasco y Casta y se sitúan en la Valencia de finales de siglo XIX. El tono de burla aparece ya en el mismo título en el que la poetisa griega Saffo, queda convertida en un personaje masculino, "el tío Sappo".

Amor, engaño, venganza y muerte son el eje en torno al cual gira la acción, tanto en la obra original como en la parodia. Vocalmente los personajes de la ópera de Pacini muestran la tradición del virtuosismo belcantista de Bellini. Amorós utiliza los fragmentos que posiblemente más gustaron de la ópera Saffo repitiendo melodías, tonalidades y motivos rítmicos. El papel de Sappo coincide con el de Alcandro en la ópera original, el de Tula con el de Saffo, el de Frasco con el de Faone y el de Casta con el de Climene. En el $\mathrm{n}^{\mathrm{o}} 1$ de la parodia, Amorós utiliza los primeros 39 compases del preludio de la ópera de Pacini y el fragmento final de la cavatina de Alcandro para Sappo

\footnotetext{
${ }^{78}$ Giovanni Pacini, Saffo (Milano: Stabilimento Ricordi, sf). He manejado la edición de su biblioteca personal, depositada en la Biblioteca de Catalunya en 1930, con anotaciones a lápiz probablemente del propio compositor. Véase el argumento en Antonio Bertelé, Enciclopedia del arte lírico (Toledo: Aguilar, 1981), pp. 194-195.
} 
(acto $1^{\mathrm{o}}$, escena $2^{\mathrm{a}}$ ). El $\mathrm{n}^{\mathrm{o}} 2$ de la parodia coincide con elementos que Pacini presenta en el primer acto, escena V. En el n ${ }^{\circ} 3$ de la parodia Amorós incluye una pieza con aire de seguidillas en la que canta Sappo y éste es el único fragmento que no muestra ninguna relación con la obra original. El $n^{\circ} 4$ utiliza un fragmento del segundo acto, segunda escena de la ópera Saffo de Pacini que finaliza con el dúo entre Saffo y Climene "Di quai soavi lagrime" (que Amorós utiliza en su parodia para el dúo entre Tula y Casta). En el n ${ }^{\circ}$ 5 el material del que se sirve Amorós es el aria final de Saffo, tercer acto, escena final "L'ama ognor qual io l'amai" para Tula. Este mismo material es el que utiliza también para concluir la obra, en el nº 6 (véase Tabla 49).

Tabla 49. Materiales de la ópera Saffo de Pacini utilizados por Amancio Amorós en la parodia El tío Sappo (sf).

Fuentes: Pacini, Saffo, pp. 1-3, 11-15, 35-49, 72-78, 265-269, y Amorós, El tío Sappo, E:Bc, M 1271.

\begin{tabular}{|c|c|}
\hline Parodia El tio Sappo & Ópera Saffo \\
\hline $\mathrm{N}^{\mathrm{o}} 1$ & $\begin{array}{c}\text { Escena I Preludio de la ópera } \\
\text { Cavatina de Alcandro }\end{array}$ \\
\hline $\mathrm{N}^{\circ} 2$ & Escena V, dúo Saffo/Faone \\
\hline $\mathrm{N}^{\circ} 3$ & ? \\
\hline $\mathrm{N}^{\circ} 4$ & $\begin{array}{c}\text { II Acto, } 2^{\text {a }} \text { escena, dúo Safo/Climene } \\
\text { "Di quai soavi lagrime" }\end{array}$ \\
\hline $\mathrm{N}^{\circ} 5$ & $\begin{array}{c}\text { III Acto, escena final } \\
\text { "L’ama ognor qual io l'amai" }\end{array}$ \\
\hline
\end{tabular}

\section{2. La zarzuela Los dos esclavos, op. 50 (1886)}

La zarzuela en tres actos Los dos esclavos (1886), con letra de Antonio Roig Civera consta de quince números que presentan una estructura poliseccional con cuatro, cinco e incluso seis secciones por número ${ }^{79}$. Amorós dedicó la obra al historiador y autor

\footnotetext{
${ }^{79}$ Sobre el libretista, véase Iglesias, Teatro lírico español, vol. 1 (1991), p. 955. El dramaturgo Antonio Roig Civera (1844-1901) comenzó sus estudios en las Escuelas Pías y desarrolló sus aficiones dramáticas en el casino La Amistad de Valencia. Su primera obra fue la zarzuela Los amores de un cesante. En 1871 se representó por primera vez en el teatro Princesa su juguete bilingüe En la plasa de bous [sic] o Una hora de cuarentena. Siguieron con éxito otros titulados Els banys de les barraquetes, El cap de Holofernes, El casament de les borles, Cuestió de faldes [sic], Un chuche municipal [sic], Les botigues de la $O$ y Tres abelles y una flor $[\mathrm{sic}]$. Ya en su madurez obtuvo el título de notario. Sus últimas producciones teatrales fueron la zarzuela Los dos esclavos, con música de Amancio Amorós, y el drama
} 
dramático Juan Bautista Perales ${ }^{80}$. Tanto Los dos esclavos como Navegación submarina siguen la tipología que Casares Rodicio denomina zarzuela grande. Cada acto va precedido por un preludio y predomina el texto cantado sobre el hablado ${ }^{81}$.

Los dos esclavos de Amorós se estrenó el 8 de enero de 1886 en el teatro Ruzafa de Valencia por la Compañía de zarzuela Bayarri, dirigida por los maestros Rigoberto Cortina y Luis Reig, y también se representó el 9 de enero ${ }^{82}$. Para su estreno Rafael Díaz, empresario del Ruzafa, consideró necesario aumentar el número de cantantes del coro e instrumentistas de la orquesta:

Actívanse en el teatro de Ruzafa los ensayos de la nueva obra Los dos esclavos, original de dos paisanos nuestros, y cuyo estreno tendrá efecto el día 8 de los corrientes, y al efecto han aumentado el coro y el personal de la orquesta, y se han terminado algunas decoraciones, que de seguro han de agradar.

Tanto a los autores de esta producción, como a las artistas encargados de interpretarla, deseámosles muchos aplausos.

Para aquella noche es ya muy crecido el número de localidades que hay despachadas ${ }^{83}$.

El reparto de los papeles principales en la noche del estreno puede verse en la

Tabla 50. Además de los papeles principales había en la obra esclavos, esclavas, soldados

españoles, filibusteros, coro general y comparsas. Al finalizar la representación se

Romeu, estrenado con éxito en Sagunto y en el Teatro de Ruzafa. Véase Almanaque de las Provincias de 1901, pp. 322-323. Roig Civera trabajó en las oficinas de la compañía naviera de Viñes con flota anclada en Valencia que hacía la ruta Valencia-México-Filipinas. La compañía trasladaba mercancías y esclavos chinos en dirección a Cuba, véase Emili Casanova Herrero, "El significat del nom de la filà Ben Hulem d'Agullent (1958-2008), en 50 anys de Ben Hulem a Agullent (Agullent: Filà Ben Hulem, 2008), pp. 1011 .

${ }^{80}$ Según consta en Nieves Iglesias (dir.), Catálogo del Teatro Lírico español en la Biblioteca Nacional, (Madrid: Ministerio de Cultura. Dirección General del libro y Bibliotecas, 1991), vol. 3, p. 169.

${ }^{81}$ La zarzuela grande presenta, según Casares, los siguientes rasgos: tres actos (menos frecuentemente dos o cuatro), cada acto puede contener quince o dieciséis números de música, con cuatro, cinco o seis secciones; cada acto va precedido por un preludio que prepara el ambiente y permite que se abra el telón; predomina el texto cantado sobre el hablado; hay fuerte interrelación entre texto y música y numerosos personajes; son frecuentes los temas de carácter histórico o relacionados con la historia de España. Véase Emilio Casares, "Teatro musical, zarzuela, tonadilla, ópera, revista", en Historia de los espectáculos en España, coord. Andrés Amorós (Madrid: Castalia, 1999), p. 160.

${ }^{82}$ Almanaque de las Provincias para 1886, p. 101.

${ }^{83}$ El Mercantil Valenciano, 5-I-1886. 
homenajeó a los autores y a Amorós le regalaron una pluma de oro acompañada de una cariñosa dedicatoria firmada por Salvador Giner, José $\mathrm{M}^{\mathrm{a}}$ Úbeda, Juan Bautista Plasencia y otros. El libreto refleja la situación socio-política de la isla de Cuba antes de su independencia: el trabajo de los esclavos en los “ingenios” (fábricas de azúcar), las ideas a favor y en contra de la independencia cubana y la abolición de la esclavitud (véase Apéndice 21).

Según consta en la contraportada del libreto, el estreno fue un enorme éxito ${ }^{84}$. Las críticas del momento contradicen, sin embargo, el supuesto éxito al que se alude en el libreto. Se dijo que la música de Los dos esclavos no lució, entre otras cosas, por falta de buenos intérpretes y por un exceso de detalles armónicos y de instrumentación, que impedían percibir claramente la melodía. La envergadura de esta zarzuela hizo que fuera considerada incluso como una ópera por los abundantes "efectos de armonía y de instrumentación”, cualidades que, según el autor de la crítica, debían utilizarse en la ópera y no en la zarzuela ${ }^{85}$. A continuación transcribo algunas de las críticas aparecidas en los periódicos del momento sobre esta zarzuela:

Su música, aunque muy estudiada, resultó algo confusa y falta de inspiración, pero revelaba buenas disposiciones de su joven autor ${ }^{86}$.

Con el título Los dos esclavos se estrenó anteanoche en el teatro de Ruzafa una zarzuela en tres actos, letra del Sr. Roig Civera, y música del Sr. Amorós (D. Amancio). El numeroso público que acudió a presenciar la nueva obra se mantuvo en una prudente reserva, que solo se vio interrumpida al final de algunas escenas por movimientos de aprobación. Esta actitud de los espectadores es el mejor juicio que se puede hacer de Los dos esclavos, y ateniéndonos a la misma, tampoco puede decirse en rigor de verdad que merezca desagrado la indicada zarzuela, que, después de todo, es el primer ensayo, en lo que respecta a

\footnotetext{
${ }^{84}$ Antonio Roig, Los dos esclavos, Libreto de la zarzuela (Valencia: Imprenta Emilio Pascual, 1886).

${ }^{85}$ El Mercantil Valenciano, 10-I-1886. La hoja de méritos que acompañó el nombramiento de Amorós como Académico Correspondiente de la Real Academia de Bellas Artes de San Fernando de Madrid dice que "la prensa unánime calificó dicha obra como ópera y no como zarzuela", $E: M b a$, legajo 5-2-2, Expediente de nombramiento de Amancio Amorós como Académico Correspondiente (1921).

${ }^{86}$ Almanaque de las Provincias para 1886, p. 28.
} 
la parte musical, de un joven compositor que ha ganado justos lauros en públicos certámenes.

Lo que toca averiguar con criterio independiente y desapasionado es si esta actitud del público reconoce algún fundamento. Nosotros creemos que sí, y vamos a explicar nuestras razones.

Adolece tanto el libro como la partitura de plétora de efectismo. El Sr. Roig y Civera hubiera podido sacar más partido del asunto que sirve de base al argumento de Los dos esclavos, aprovechando para ello la mayor parte de los elementos que pone en acción: pero llevado de un desmedido afán de alcanzar efectos, ha tropezado con el escollo de no poderles dar un desenlace satisfactorio, quebrantando algunas veces la unidad de acción, tan apetecida en las obras destinadas al teatro. ¿Qué necesidad tenía de presentar de improviso al final del segundo acto un nuevo personaje, cuya intervención adivina el público? Si el objeto del Sr. Roig ha sido, como es de presumir, acrecentar el interés de la acción, este recurso era por demás inútil, porque aquel había llegado al punto más culminante que puede desearse.

Palpitan en el libro dos sentimientos notabilísimos: el amor a la patria y el amor a la mujer, bastantes de por sí, puestos en juego, para conmover al público; y en contraposición a estos sentimientos la pasión más desenfrenada que obra a impulsos de una ambición que en nada repara con tal de verse satisfecha. No están de más, antes al contrario, nos parecen muy oportunos los toques cómicos que de vez en cuando alegran el fondo sombrío del asunto.

Con semejantes medios y mayor pulcritud en el lenguaje que la que emplea el Sr. Roig, no le hubiera sido difícil conseguir un éxito satisfactorio en su nueva producción dramática, que si peca de algo, según antes hemos dicho, es de sobra de elementos.

La música de Los dos esclavos es abundante y tiene trozos inspirados, que no lucieron por falta de buenos intérpretes. Pero algunos de los números, acaso en los que el joven autor cifraba todas sus esperanzas, por el mucho trabajo que en ellos ha puesto, tienen el defecto de no presentar con claridad el concepto melódico, que aparece como sofocado por el exceso de detalles y fragmentos que le envuelven e interrumpido con bruscos cambios de tonalidad. Semejante alarde de composición, si bien revela los empujes con que se presenta el Sr. Amorós en el terreno de la música dramática, en cambio le priva de los aplausos que le hubiese tributado el público, a haber simplificado los elementos con que ha querido realzar su trabajo.

Esta moderación, este prudente uso de los efectos de armonía y de instrumentación, son más de aconsejar tratándose de una zarzuela, en cuyo género el elemento melódico debe destacarse con mayor claridad posible, quedando reservada a la ópera la resolución de los problemas que se ventilan en el campo del arte sobre la expresión musical.

Los dos esclavos tiene, además de la sinfonía, las siguientes piezas musicales: en el primer acto un coro de introducción, una romanza de tenor, un dúo de tenor y barítono, un terceto de tiples y barítono y un concertante.

En el segundo acto un coro seguido de una jota; una guaracha, un dúo de tiple y tenor y un concertante.

En el tercero un coro de introducción; una habanera, una romanza y un cuarteto.

La ejecución de Los dos esclavos dejó que desear en la parte musical, lo que nada de extraño tiene si se observa la categoría del teatro Ruzafa, que es módico en sus precios, por cuya circunstancia 
merece plácemes el empresario, que no ha titubeado en hacer algunos sacrificios para dar a conocer la citada obra ${ }^{87}$.

La editorial Schott de Maguncia publicó reducciones para piano o canto y piano de cuatro números de Los dos esclavos: el no 5 Terceto, escena y vals, el no 9 Guaracha, el $\mathrm{n}^{\mathrm{o}} 12$ Romanza para soprano y el $\mathrm{n}^{\mathrm{o}} 13$ Habanera (dúo de soprano y tenor cómico), posiblemente porque fueron los números que más gustaron al público ${ }^{88}$. Considero que fue el propio Amorós quien realizó las reducciones de estas cuatro piezas de su zarzuela Los dos esclavos, aunque por el momento no he podido constatarlo documentalmente. La “Administración lírico-dramática de Eduardo Hidalgo", establecida en Madrid, era la encargada de administrar los derechos generados por la música de esta zarzuela ${ }^{89}$. Presentaré a continuación un breve análisis de los cuatro números citados a partir de las ediciones publicadas de los mismos.

\footnotetext{
${ }^{87}$ El Mercantil Valenciano, 10-I-1886.

${ }^{88}$ Según Carmen García Mallo, "Peters y España: Edición Musical y relaciones comerciales entre 1868 y 1892", Anuario Musical, 60 (2005), pp. 38, 49-50, 145, la firma Schott fue fundada en 1770 por el clarinetista y grabador musical Bernhard Schott (1748-1809) como comercio musical en la ciudad alemana de Maguncia. Sus primeras ediciones se centraron en obras de compositores locales, en partituras para piano al gusto de la época y arreglos de óperas famosas. Los hijos de Bernhard cambiaron el nombre de la empresa a $B$. Schott's Söhne y ampliaron el negocio editorial abriendo sucursales en Amberes, París, Londres y Leipzig. En 1874 la editorial pasó a manos de Ludwing Strecker (1853-1943), empresario sin vinculación con la familia Schott. En este artículo García Mallo analiza las relaciones comerciales establecidas entre la editorial alemana Peters y algunos editores y almacenistas españoles. El editor madrileño Pablo Martín Larrouy, representante de Peters en España, mantuvo relaciones comerciales con un gran número de editores europeos, entre ellos Fils de B. Schott de Maguncia. Martín no sólo comercializaba materiales nacionales ("Música de Zarzuela", "Canciones Españolas", "Aires Nacionales") sino que procuraba obtener la exclusiva de determinadas ediciones foráneas y vendía en su establecimiento partituras que hacía traer del exterior. El transporte marítimo fue el habitual en el traslado de partituras impresas de Alemania a España. En algunos manuscritos autógrafos de Amancio Amorós, conservados en la Biblioteca de Catalunya, aparece el sello de la editorial Martín, regentada por Casimiro Martín Bessières y desde 1876 por su hijo Pablo Martín Larrouy.
}

${ }^{89}$ Los dos esclavos (libreto), E:Bc, C 400/899. 
Tabla 50. Amancio Amorós, Los dos esclavos, zarzuela en tres actos. Letra de Antonio Roig Civera. Principales personajes de la obra y reparto en su estreno (Valencia, 1886). Fuente: Libreto de la zarzuela Los dos esclavos, E:Bc, C 400/899.

\begin{tabular}{|c|c|}
\hline Personajes & Actores/ Actrices \\
\hline Lola, primera soprano & Rosa Alba \\
\hline $\begin{array}{c}\text { Alelí (negra), } \\
\text { soprano cómica }\end{array}$ & Isabel Llorens \\
\hline Isabel (Soprano) & Pilar Vidal \\
\hline Osorio, barítono & $\begin{array}{l}\text { Manuel Ogladi } \\
\text { Francisco Bru }\end{array}$ \\
\hline Fernando, tenor & Miguel Losada \\
\hline D. Jesús, primer bajo & Vicente Bayarri \\
\hline Carrasco, tenor cómico & José M. Esteve \\
\hline $\begin{array}{l}\text { Pancho (negro), } \\
\text { Tenor cómico }\end{array}$ & Rafael Queralt \\
\hline Mariano, segundo bajo & Miguel Jiménez \\
\hline Un mayoral, partiquino & Luis Soler \\
\hline
\end{tabular}

“Terceto, escena y vals" (n $\left.n^{\circ}\right)$

En la versión original de este número intervienen los personajes Lola, Alelí y Osorio, pero la reducción publicada es para piano solo, sin parte vocal. El esquema formal de la pieza puede verse en la Tabla 51. El número se divide en dos secciones, tras una introducción en la que Amorós utiliza una figuración de corchea y tresillo de semicorcheas que conferirá unidad a toda la primera sección. El tema A, en mi menor, es una melodía de carácter gracioso que se mueve por grados conjuntos y está estructurada en tres frases de ocho compases cada una. En la segunda frase, Amorós utiliza un giro melódico de tercera disminuida La\#-do natural. En el compás 32 se produce un cambio de compás 3/4 y manteniendo la misma pulsación, a nivel melódico utiliza la figuración de corchea y dos semicorcheas que en ocasiones combina contrapuntísticamente con la figuración de corchea y tresillo de semicorcheas (Tema B). La sección finaliza en una escala cromática descendente que conduce a la dominante de Sol Mayor, tonalidad que mantendrá a lo largo de la segunda sección. 
La segunda sección es un vals de estructura tripartita (CDC) con dos temas contrastantes, el primero una melodía cantabile y el segundo, con figuraciones más breves que le confieren dinamismo. En ambos casos, el final de la frase se repite una octava alta a modo de eco. Del compás 126 al 133 hay una progresión ascendente modulante que busca la dominante de Sol Mayor. El número finaliza con una Coda en la que combina varios elementos aparecidos con anterioridad. Amorós utiliza la sexta rebajada dentro del acorde de IV en el compás 196, un recurso que aparece también en otras obras del autor.

Tabla 51. Amancio Amorós. $N^{o} 5$, Terceto, escena y vals de Los dos esclavos, op. 50 (1886). Reducción para piano (Maguncia, Schott, sf). Esquema analítico. Fuente: $E: B c, \mathrm{M} 4220$.

\begin{tabular}{|c|c|c|c|c|}
\hline Secciones & Compases & Aspectos armónicos & Material temático & $\begin{array}{l}\text { Tempo/ } \\
\text { Compás }\end{array}$ \\
\hline Introducción & $1-8$ & Mi menor & Motivo rítmico & Allegretto \\
\hline \multirow{3}{*}{$1^{\mathrm{a}}$} & \multirow[t]{2}{*}{$9-31$} & \multirow[t]{2}{*}{ Mi menor } & \multirow{2}{*}{$\begin{array}{c}\mathrm{A} \\
8+8+8\end{array}$} &.$=96$ \\
\hline & & & & $2 / 4$ \\
\hline & $32-63$ & $\begin{array}{c}\text { Mi Mayor } \rightarrow \\
\text { Sol M }(\mathrm{V})\end{array}$ & B & $\begin{array}{c}\text { Stesso Tempo } \\
3 / 4\end{array}$ \\
\hline \multirow{3}{*}{$2^{\mathrm{a}}$} & $64-107$ & \multirow{4}{*}{ Sol Mayor } & $\mathrm{C}$ & \multirow{4}{*}{$\begin{array}{l}\text { Movimiento de Vals } \\
3 / 4\end{array}$} \\
\hline & $108-143$ & & $\mathrm{D}$ & \\
\hline & $144-172$ & & $\mathrm{C}$ & \\
\hline Coda & $173-203$ & & Elementos de B y D & \\
\hline
\end{tabular}

"Guaracha" (no9)

Según Olga Fernández, la guaracha es un género de canción jocosa y rápida escrita en 2/4, propio de la música folklórica popular cubana, caracterizado por su gracia, contrasentidos y corte picaresco, con texto de contenido social, que llegó a imponerse en el siglo XIX en el teatro bufo ${ }^{90}$. En la Guaracha para canto y piano de Amorós canta la

\footnotetext{
${ }^{90}$ Olga Fernández, Solo de música cubana (Quito: Abya-Yala, 2005), p. 63. El esquema rítmico de las guarachas aparece en algunas habaneras, canciones y boleros del siglo XIX, según M $\mathrm{M}^{\mathrm{a}}$ Teresa Linares, $L a$ música entre Cuba y España (Madrid: Fundación Autor, vol. 1, 1998), pp. 112-114. Véase también Argeliers León, Del canto y el tiempo (La Habana: Pueblo y Educación, 1985), p. 166, quien señaló que la guaracha surgió como canción con cuartetas diferentes en la que aparece una alternancia entre solista y coro. Consuelo Carredano y Victoria Eli, "El teatro lírico", en La música en Hispanoamérica en el siglo
} 
soprano cómica negra, Alelí, acompañada por un coro. Se utiliza un lenguaje popular y humorístico para narrar una situación jocosa con acentos rítmicos anacrúsicos, marcados en la intervención del coro, que enfatizan el tono burlón de la canción. La inserción de la guaracha queda justificada por el argumento de la zarzuela. Este número es interpretado por Alelí, una esclava negra con una manera peculiar de expresar el castellano. Entre los recursos que se utilizan está la omisión de alguna consonante entre fonemas que presentan dobles consonantes (“nega" por "negra”), la omisión de la consonante final que se sustituye por una vocal acentuada ("paseá" por "pasear", "retosá" por "retozar"). También se emplea la expresión "Guachi”, "Guacha", "Guacho”, probablemente un localismo cubano, con cierta dosis de ironía ${ }^{91}$. El texto de la guaracha compuesta por Amorós es el siguiente:

$\begin{array}{ll}\begin{array}{l}\text { La neguita y el neguito, } \\ \text { van juntos a paseá } \\ \text { CORO Guacha! Guachi!, } \\ \text { Guachi, Guacha }\end{array} & \begin{array}{l}\text { No me toques tu neguito! } \\ \text { Si no te toco yo! } \\ \text { Qué quieres tu morenito? } \\ \text { Morena dame tu amo! }\end{array} \\ \text { CORO Guacha! Guachi!, } & \text { No me toques tu neguito! } \\ \text { Guachi, Guacha } & \text { Si no te toco yo! } \\ \text { Y en el bosque o en la playa, } & \text { Que quieres tu morenito? } \\ \text { Se ponen a retosá. } & \text { Morena dame tu amo! } \\ & \\ \text { CORO Guacha! Guachi! } & \text { CORO Guacho!, Guacho! } \\ \text { Guachi, Guacha } & \text { Y el nego su codason! } \\ \text { Y en el bosque o en la playa, } & \text { Y el nego su codason! } \\ \text { Se ponen a retosá. } & \text { su codason!, su codason! } \\ & \text { su codason! su codason! }\end{array}$

CORO Guacha! Guachi!

Guachi, Guacha

\footnotetext{
$X I X$, eds. Consuelo Carredano y Victoria Eli, vol 6. Historia de la música en España e Hispanoamérica, dir. y coord. Juan Ángel Vela del Campo (Madrid: Fondo de Cultura Económica, 2010), p. 206, señalan que en las zarzuelas españolas de finales del siglo XIX era cada vez más frecuente la utilización de música popular cubana.

${ }^{91}$ Victoria Eli Rodríguez y M $\mathrm{M}^{\mathrm{a}}$ de los Ángeles Alfonso, La música entre Cuba y España. Tradición e innovación (Madrid: Fundación Autor, 1999), p. 36. La guaracha de Amorós presenta similitudes con el tango americano, que también se interpreta por personajes "negros" e imita en el texto el acento e inflexiones del habla del esclavo negro (lengua bozal).
} 
Musicalmente, la pieza presenta una estructura estrófica AA (véase Tabla 52) y el piano queda subordinado a la voz. Las frases melódicas son cortas y las notas breves, alternando el ritmo binario (dos corcheas) con el ternario (tresillo de corcheas o negras). La armonía se limita básicamente a acordes de tónica y dominante. El ritmo del acompañamiento es sincopado en la primera sección (véase Ejemplo 51). En la segunda sección Amorós utiliza una pequeña variación rítmica de una secuencia rítmica tradicional de la música cubana que es el cinquillo, que suele aparecer en la guaracha, y convierte la corchea central en dos semicorcheas (véase Ejemplo 52) ${ }^{92}$.

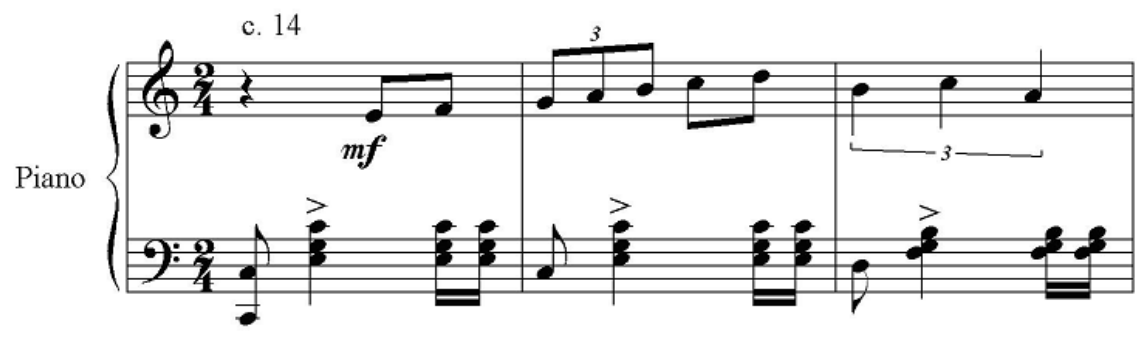

Ejemplo 51

Amancio Amorós. Guaracha de Los dos esclavos, op. 50, cc. 14-16.

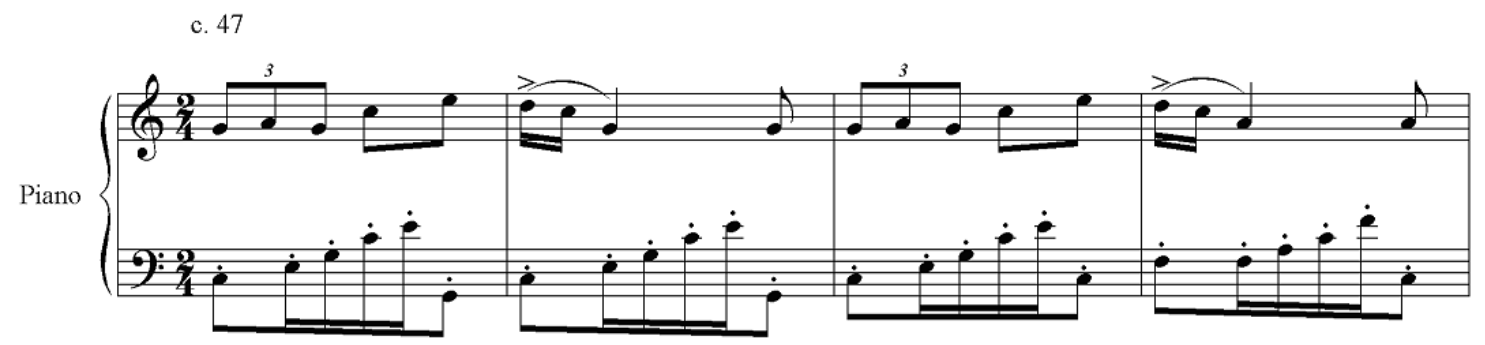

Ejemplo 52

Amancio Amorós. Guaracha de Los dos esclavos, op. 50, cc. 47-50.

\footnotetext{
${ }^{92}$ La figuración rítmica característica de la música cubana está articulada sobre un patrón conocido como ritmo de habanera (corchea con puntillo, semicorchea-dos corcheas). Este ritmo puede presentar varias combinaciones, presentes dentro de una misma especie o que den lugar a otros géneros. El caso de la guaracha es un ejemplo de esto, en donde aparece otra secuencia rítmica tradicional de la música cubana que es el cinquillo, corchea-semicorchea-corchea-semicorchea-corchea, dentro de un compás de $2 / 4$, véase Aimée Guerrero Fernández, "Presencia cubana en la zarzuela española", Revista de Musicología, 28/1(2005), p. 448.
} 
Tabla 52. Amancio Amorós. $N^{o}$ 9, Guaracha de Los dos esclavos, op. 50 (1886). Reducción para piano (Maguncia, Schott, sf). Esquema analítico.

Fuente: $E: B c, \mathrm{M} 4220$.

\begin{tabular}{|c|c|c|c|c|}
\hline Secciones & Compases & $\begin{array}{c}\text { Tonalidad } \\
\text { Aspectos } \\
\text { armónicos }\end{array}$ & $\begin{array}{c}\text { Material } \\
\text { temático }\end{array}$ & $\begin{array}{c}\text { Tempo/ } \\
\text { Compás }\end{array}$ \\
\hline \hline $1^{\mathrm{a}}$ & $1-62$ & & $\mathrm{~A}$ & \\
\cline { 1 - 2 } & \multirow{2}{*}{$2^{\mathrm{a}}$} & $63-78$ & & $\begin{array}{c}\text { Allegro giusto } \\
2 / 4\end{array}$ \\
\cline { 2 - 2 } Coda & 79 a 90 & & A & \\
\hline
\end{tabular}

"Romanza de tiple",93 ( $\left.n^{\circ} 12\right)$

La romanza era habitualmente una composición de carácter amoroso y sentimental, con estructura ternaria, o sin forma específica ${ }^{94}$. La Romanza de Amorós es de estructura tripartita (véase Tabla 53) ABA'. En ocasiones, Amorós utiliza el sexto grado rebajado, tanto en el acorde de IV como en el de II. En el tema B, armónicamente en mi menor y con un tempo más rápido respecto al tema $\mathrm{A}$, el piano desarrolla un acompañamiento con acordes sincopados y trémolos.

\footnotetext{
${ }^{93}$ En los compases 32 y 46 aparecen en la partitura mordentes indicados a lápiz, quizás añadidos por el propio Amorós.

94 Vázquez, "Romanza”, p. 372, define la romanza como una pequeña composición, inicialmente vocal y más tarde instrumental, que tiene su origen en el antiguo romance con música y en la balada popular, y suele presentar textura de melodía acompañada por un diseño rítmico de acompañamiento, en ocasiones ostinato.
} 
Tabla 53. Amancio Amorós. $N^{o} 12$, Romanza de Los dos esclavos, op. 50 (1886). Reducción para canto y piano (Maguncia, Schott, sf). Esquema analítico.

Fuente: $E: B c, \mathrm{M} 4220$.

\begin{tabular}{|c|c|c|c|c|}
\hline Secciones & Compases & $\begin{array}{c}\text { Tonalidad } \\
\text { Aspectos armónicos }\end{array}$ & Material temático & $\begin{array}{l}\text { Tempo/ } \\
\text { Compás }\end{array}$ \\
\hline Introducción & $1-15$ & Sol Mayor & Recitativo & $3 / 4$ \\
\hline $1^{\mathrm{a}}$ & $\begin{array}{c}16-24 \\
\text { a } \\
25-32 \\
\text { b } \\
33-43 \\
\text { a' } \\
\end{array}$ & Sol Mayor & A & $\begin{array}{c}\text { Andante molto } \\
\text { moderato } \\
\cdot=63\end{array}$ \\
\hline $2^{\mathrm{a}}$ & $44-62$ & $\begin{array}{l}\text { Mi menor } \\
\rightarrow V^{7}(\text { Sol M })\end{array}$ & B & $\begin{array}{c}\begin{array}{c}\text { Piu mosso } \\
.=108\end{array}\end{array}$ \\
\hline $3^{\mathrm{a}}$ & $\begin{array}{c}63-73 \\
a^{\prime}\end{array}$ & Sol Mayor & A & $\begin{array}{c}\text { Tempo come } \\
\text { prima }\end{array}$ \\
\hline Coda & $74-88$ & Sol Mayor & Motivo rítmico de $\mathrm{A}$ & \\
\hline
\end{tabular}

"Habanera, dúo de tiple y tenor cómico" (n $\left.{ }^{o} 13\right)$

En la música teatral española del siglo XIX se utilizaron géneros y especies musicales llegadas de Cuba, entre ellos la americana, la habanera, el tango americano y la guaracha, que se diferencian por el tema y el texto de las piezas ${ }^{95}$.

La habanera que Amorós incluye en su zarzuela Los dos esclavos es un dúo de tiple y tenor cómico (Alelí y Carrasco), con una melodía muy expresiva y lírica (como era habitual en las habaneras) que expresa el amor idílico entre estos dos personajes. En la habanera de Amorós no se alude al viaje a América (como solía ser frecuente en las habaneras), sino al regreso a España. Al igual que en la guaracha de Amorós, la inserción de la habanera en la zarzuela Los dos esclavos queda justificada por el argumento.

La habanera de Los dos esclavos es de estructura binaria con dos temas claramente definidos de dieciséis compases cada uno (Tabla 54). El tema A presenta un diálogo entre los dos personajes, en mi menor, con una melodía graciosa y ligera; el tema

\footnotetext{
${ }^{95}$ Eli y Alfonso, La música entre Cuba, p. 34; Linares y Núñez, La música entre Cuba y España. La ida y la vuelta, pp. 257-272; Alfonso, "Habanera", en DMEH, vol. 6 (2000), pp. 177-178.
} 
B, en Sol Mayor, es más cantabile y las dos voces cantan simultáneamente a distancia de terceras y sextas. Armónicamente es una pieza muy sencilla, en la que cabe señalar las dos cadencias rotas con el sexto grado rebajado entre los compases 69-70 y 91-92.

Tabla 54. Amancio Amorós. $N^{o} 13$, Habanera de Los dos esclavos, op. 50 (1886). Reducción para canto y piano (Maguncia, Schott, sf). Esquema analítico.

Fuente: $E: B c, \mathrm{M} 4220$.

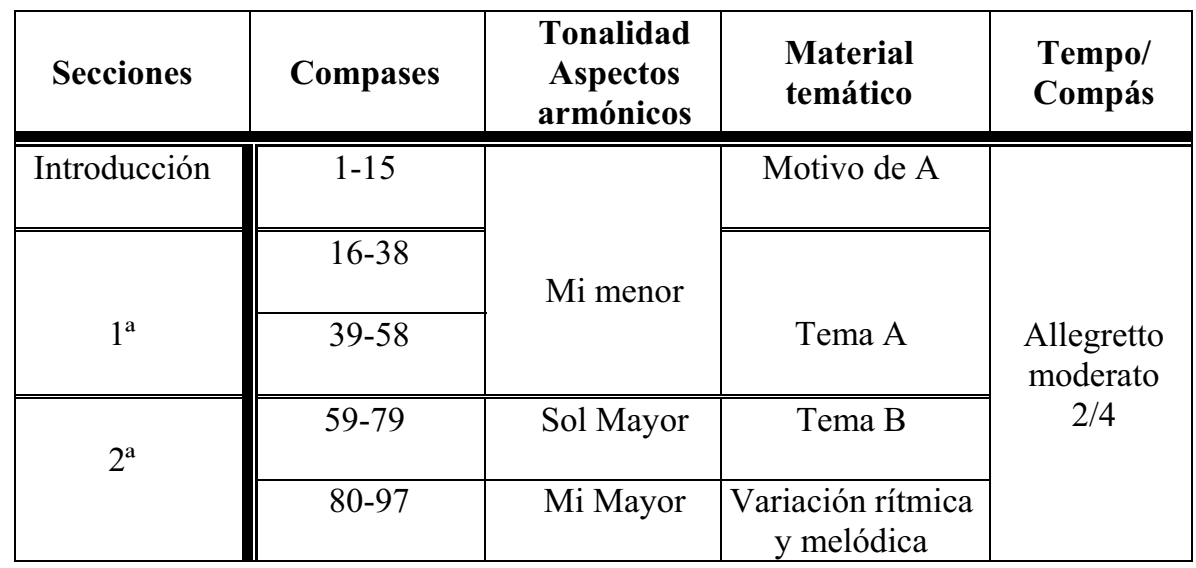

\section{Música coral profana}

Es interesante destacar la relación de Amorós con algunos de los mejores poetas valencianistas de Lo Rat Penat, como fue Josep Bodría, quien puso letra a varias de sus composiciones corales, entre ella la no localizada Serenata para tenores, barítonos y bajos compuesta por Amorós en $1896^{96}$. También ilocalizada es la obra Alborada, basada en cantos populares valencianos. La sección de correspondencia del Boletín Musical la mencionó en 1897:

Este nuevo género de cantos populares ha logrado despertar las simpatías para un género de música cuya tradición se iba olvidando y que era despreciado por el vulgo. Además, la iniciativa tomada por el señor Giner, ha sido un incentivo para mover y estimular a otros maestros compositores valencianos a ensayar este nuevo género de música popular; animados algunos de noble y digna emulación artística

\footnotetext{
96 Referencia citada en Emili Casanova Herrero, "Introducció a la història de la Banda de Música d'Agullent (1884-1984)", en 1883-2003, Agrupació Musical d'Agullent (Agullent: Caixa d'Estalvis d'Ontinyent, Obra Social, 2003), p. 57. No he podido localizar la partitura de esta Serenata.
} 
amparándose de poesías valencianas sobre asuntos populares, han dado ya alguna muestra en las tituladas: Albada de Penella, Alborada de Amorós, Amor a la Nostra Terra de Fayos, Sempre Valencians, de Mas y La plegà de les olives de Grau'

En 1902 Amorós dedicó un Coral a cuatro voces a la Sociedad Coral la Capella de Manacor, con texto también de Josep Bodría ${ }^{98}$. No he localizado esta obra de momento, pero según se lee en la prensa del momento:

\begin{abstract}
El inspirado poeta señor Bodría leyó unos sentidos versos dedicados a la Capella y el profesor de este conservatorio y presidente de la sección de música de Lo Rat Penat, D. Amancio Amoros, entregó al Sr. Pont, con cariñosa dedicatoria, un coral a cuatro voces, compuesto ex profeso para dicha Sociedad con letra del J. Bodría ${ }^{99}$.
\end{abstract}

\title{
8. Música religiosa
}

José Climent destacó a Amancio Amorós como "un compositor de Iglesia" junto con Rigoberto Cortina, José Medina, Manuel Chulvi, Vicente Perales y Facundo Domínguez. Todos estos músicos tenían en común que conocían la iglesia, sus instrumentos y su música y, aunque compusieron obras profanas (teatrales y de otros géneros) varios fueron más conocidos, según Climent, por sus trabajos religiosos que por sus composiciones profanas ${ }^{100}$.

Hasta el momento he localizado treinta composiciones religiosas de Amancio Amorós para distintas plantillas instrumentales y vocales, de las que al menos ocho llegaron a imprimirse en su época. Amorós produjo música sacra de modo ininterrumpido durante toda su carrera profesional.

\footnotetext{
${ }^{97}$ Boletín Musical, 10-V-1897, p. 913.

${ }^{98}$ La capella Manacor fue una de las principales agrupaciones corales fundada en Mallorca por Antonio Noguera Balaguer en 1897. Las Provincias, 30-X-1902.

${ }^{99}$ Anónimo, "La Capella de Manacor”, en Las Provincias, 30-X-1902.

${ }^{100}$ Climent, Historia de la música, p. 34.
} 
En la vida musical valenciana de finales del siglo XIX el éxito de la música italiana era innegable; las óperas italianas gozaron de un éxito clamoroso e incluso muchos músicos valencianos compusieron zarzuelas siguiendo las influencias de la lírica italiana. La música religiosa no quedó fuera de esta influencia y pronto comenzaron a aparecer escritos acusándola de inapropiada para el templo. El entorno en el que desarrolló Amancio Amorós su producción religiosa coincide con los intentos de recuperación de la música eclesiástica que se dieron con el movimiento cecilianista y la publicación del Motu Proprio "Tra le sollecitudini” de Pío X, que reaccionó contra la moda italianizante del momento. Este documento papal fue publicado en el Boletín del Arzobispado de Valencia en $1904^{101}$. Amorós estuvo en contacto con los reformistas de la música religiosa cuando estudiaba composición, y admiró las composiciones religiosas de Pedrell, como he indicado anteriormente.

Una de las disposiciones de Pío X fue que en todas las diócesis se creara una Comisión de Música Sacra para velar por la música que se ejecutaba en las iglesias. La Comisión de Valencia, en la que intervino Amorós al menos entre 1909 y 1925, invitó a todos los compositores valencianos a presentar ante la misma sus obras para comprobar si se ajustaban a las disposiciones del Motu Proprio ${ }^{102}$. Las obras religiosas de Amorós que en 1905 la Comisión de Música Sagrada de Valencia consideró adaptadas al espíritu y letra de las reglas del Motu Proprio fueron: Acepta Virgen Pura, O Salutaris Hostia a tres voces, Pues sois Santo sin igual "Gozos al Patriarca San José” y Recibid mil parabienes "Salutación al Patriarca San José", todas ellas publicadas en la revista valenciana Biblioteca Sacro Musical ${ }^{103}$. Ildefonso Alier editó en la colección Obras Religiosas

\footnotetext{
${ }^{101} B O A V, 1459$ (17-II-1904), pp. 49-59.

102 BOAV, 1467 (23-VI-1904), p. 182.

${ }^{103}$ Biblioteca Sacro Musical, 15-VIII-1893, sp.
} 
españolas, además de las publicadas en la revista Biblioteca Sacro Musical, el Ave Maria a solo y coro, O salutaris Hostia a solo y coro, Quam dilecta tabernacula tua a solo, coro y órgano y Credidi a cuatro voces iguales con acompañamiento de orquesta y órgano.

\section{1. La Misa Ceciliana (1912) y otras misas}

De las cuatro misas que he localizado de Amancio Amorós, la más temprana es la Misa en Re menor para solistas, coro de voces graves y orquesta, compuesta entre 1882 y $1900^{104}$, estrenada el 6 de septiembre de 1900 en la parroquia de San Bartolomé Apóstol de Agullent (Valencia) durante la celebración del tercer Centenario del Milagro de San Vicente Ferrer. En el estreno de la misa intervino la orquesta "primitiva" de Alcoy ${ }^{105}$. De 1883 es la Misa en Mi menor para coro, armónium, piano y quinteto de cuerda, premiada en la Exposición Regional organizada por la Real Sociedad Económica de Amigos del País de Valencia. En la actualidad el archivo de esta sociedad no conserva ningún ejemplar de la obra. La Misa a dúo para voces de niño con acompañamiento de violón, contrabajo y órgano no está fechada y de ella sólo se han conservado las particellas en la Biblioteca de Catalunya (M 1308).

La Misa Ceciliana de 1912, a tres voces iguales, coro popular homófono y acompañamiento de órgano, es la única misa impresa del catálogo Amorós y fue publicada por Casa Dotesio de Valencia (véase Volumen 2, edición de composiciones de Amancio Amorós) ${ }^{106}$. Esta obra fue compuesta por Amorós tras la publicación del Motu Proprio (1903) de Pío X, cuando Amorós era presidente de la Asociación de Profesores

\footnotetext{
${ }^{104}$ Según consta en la portada de la partitura manuscrita, E:Bc, M 1312.

105 Anónimo, Programa de las Fiestas.

${ }^{106}$ En la actualidad se conservan ejemplares impresos de la partitura y particellas de la Misa Ceciliana al menos en E:Mba, con una dedicatoria del autor a Bartolomé Pérez Casas (M 3086), en E:VAcp (IV/6) y en E:Msa, A-943/19. Véase Las Provincias, 30-XII-1912; Loras, La Asociación de profesores músicos, p. 25 .
} 
Músicos de Santa Cecilia. Cada año esta entidad conmemoraba la festividad de su patrona con una solemne misa. En 1912 esta Asociación pospuso la festividad de Santa Cecilia, ya que varios de sus asociados, entre ellos el propio Amorós, participaron entre el 21 y 24 de noviembre en el Tercer Congreso de Música Sagrada que se celebró en Barcelona $^{107}$. La Misa Ceciliana se estrenó el 29 de diciembre de 1912 en la Real Capilla del Milagro de Valencia y fue cantada por el coro de la Asociación de Profesores Músicos, reforzado por miembros del Ateneo Musical y de las capillas de la Catedral y del Real Colegio del Patriarca de Valencia. Una crónica publicada en la prensa describió así el estreno:

\footnotetext{
Con notable solemnidad se verificó ayer la fiesta anual que la Asociación de Profesores Músicos de Santa Cecilia bajo la advocación de Santa Cecilia, dedica a su patrona.

La festividad se celebró en la Real Capilla del Milagro y la parte musical fue solemne y digna en un todo de la fiesta religiosa.

El coro de la Asociación, reforzado por elementos del Ateneo Musical y capillas de la Catedral y del Real Colegio del Patriarca interpretó de modo notable las obras siguientes: Misa siciliana [sic], de D. Amancio Amorós; Motete de D. Juan Bautista Pastor y Plegaria del maestro Giner.

Celebró la misa el Dr. D. Juan B. Aguilar y el Dr. D. Pedro Tomás Montañana, canónigo magistral de la Colegiata de Gandía, pronunció una notable oración sagrada, ensalzando a Santa Cecilia y al divino arte de la música ${ }^{108}$.
}

La Misa Ceciliana es un ejemplo del estilo codificado por el Motu Proprio de Pío X que contrasta con la Misa en re menor del propio Amorós, en la que el compositor utiliza una amplia plantilla orquestal con influencias de la música escénica. Amorós en su Misa Ceciliana puso música a los números del Ordinario: Kyrie, Gloria, Credo, SanctusBenedictus y Agnus Dei (Tabla 55). El Kyrie y Agnus utilizan el mismo material temático, aunque en los restantes números aparecen otros materiales. En el texto se

\footnotetext{
${ }^{107}$ Con la biblioteca personal de Amorós se conservan la Crónica y Actas Oficiales de este Tercer Congreso de Música Sagrada (E:Bc, $\mathrm{n}^{\circ}$ de registro 123862).

${ }^{108}$ Las Provincias, 30-XII-1912.
} 
respeta el orden de las palabras y la acentuación original del latín. Amorós asegura la comprensión del texto cantado en latín, sin alteraciones del texto original y con predominio del canto silábico, melismas breves en las cadencias y un uso limitado del contrapunto. Las melodías se alejan de las características propias del estilo operístico italiano y en ellas predomina el diatonismo, los grados conjuntos y un ámbito interválico reducido. Amorós utiliza varios estilos de escritura vocal en esta misa. Los solos, que el Motu Proprio no excluía de manera absoluta, son breves melodías sin carácter virtuosístico que están ligadas al coro homófono ${ }^{109}$. El Motu Proprio animó a la participación activa de los fieles en la liturgia, algo que también buscó Amorós en la Misa Ceciliana, que contiene pasajes para "coro popular"110. Las secciones a tres voces son tratadas homofónicamente o en estilo contrapuntístico.

\footnotetext{
${ }^{109}$ Sobre las consecuencias del Motu Proprio en la composición musical, véase Yvan Nommick, "Sobre las implicaciones del Motu Proprio de San Pío X en materia de composición musical", Revista de Musicología, 27/1 (2004), pp. 131-132.

${ }^{110} \mathrm{M}^{\mathrm{a}}$ José Egido Langarita, "De Tra le sollecitudini (1903) a Musicam Sacram (1967)", Revista de Musicología, 27/ 1 (2004), p. 425.
} 
Tabla 55. Amancio Amorós, Misa Ceciliana (1912). Esquema analítico. Fuente: Misa Ceciliana, Valencia, Casa Dotesio (C 42395 D).

\begin{tabular}{|c|c|c|c|c|c|}
\hline Secciones & Compás & $\begin{array}{l}\text { Material } \\
\text { temático }\end{array}$ & $\begin{array}{c}\text { Aspectos } \\
\text { Armónicos }\end{array}$ & Plantilla & Textura predominante \\
\hline \multirow{3}{*}{ Kyrie } & $1-36$ & $\begin{array}{c}\text { Kyrie } \\
\text { A }\end{array}$ & Sol menor & 3 voces/ órgano & Contrapunto imitativo \\
\hline & $37-50$ & $\begin{array}{c}\text { Christe } \\
\text { B }\end{array}$ & Si b Mayor & $\begin{array}{c}\text { Coro popular/ } \\
\text { órgano }\end{array}$ & Melodía silábica \\
\hline & $51-61$ & $\begin{array}{c}\text { Kyrie } \\
\text { A }^{\prime}\end{array}$ & Sol menor & 3 voces/ órgano & Contrapunto imitativo \\
\hline \multirow{4}{*}{ Gloria } & $1-24$ & $\mathrm{C}$ & Sol Mayor & \multirow{4}{*}{$\begin{array}{c}\text { Coro popular/ } 3 \\
\text { voces/órgano }\end{array}$} & Melodía silábica \\
\hline & $25-52$ & $\mathrm{D}$ & Mi menor & & Contrapunto \\
\hline & $53-107$ & $\mathrm{E}$ & Re menor & & Melodía silábica \\
\hline & $108-145$ & $\mathrm{C}$ & Sol Mayor & & Contrapunto imitativo \\
\hline \multirow{3}{*}{ Credo } & $1-95$ & \multirow{3}{*}{$\mathrm{F}$} & $\begin{array}{c}\text { Re mayor-Fa \# } \\
\text { menor-Mi } \\
\text { Mayor }\end{array}$ & \multirow{3}{*}{$\begin{array}{l}\text { Coro popular/ } \\
\text { solistas }\end{array}$} & Melodía silábica \\
\hline & $96-147$ & & $\begin{array}{c}\text { Re Mayor } \\
\text { Si menor } \\
\text { Re Mayor }\end{array}$ & & Contrapunto imitativo \\
\hline & $148-214$ & & $\begin{array}{l}\text { Sol Mayor } \\
\text { Re mayor Re } \\
\text { menor }\end{array}$ & & $\begin{array}{l}\text { Melodía silábica/ } \\
\text { Contrapunto/ } \\
\text { Melodía silábica }\end{array}$ \\
\hline \multirow[b]{2}{*}{$\begin{array}{c}\text { Sanctus- } \\
\text { Benedictus }\end{array}$} & $1-35$ & \multirow[b]{2}{*}{ G } & Sol Mayor & \multirow[b]{2}{*}{$\begin{array}{l}\text { Coro/Solistas/ } \\
\text { órgano }\end{array}$} & \multirow[b]{2}{*}{ Melodía silábica } \\
\hline & $36-70$ & & $\begin{array}{l}\text { Mi menor } \\
\text { Sol Mayor }\end{array}$ & & \\
\hline \multirow{3}{*}{ Agnus } & $1-22$ & A & \multirow{3}{*}{$\begin{array}{l}\text { Sol menor } \rightarrow \\
\text { Sol M }\end{array}$} & \multirow{3}{*}{$\begin{array}{c}\text { Solistas/Coro } \\
\text { popular/ } \\
\text { órgano }\end{array}$} & \multirow{3}{*}{$\begin{array}{c}\text { Contrapunto/ } \\
\text { Melodía silábica }\end{array}$} \\
\hline & $23-39$ & $\mathrm{~A}^{\prime}$ & & & \\
\hline & $40-54$ & $\mathrm{~A}$ & & & \\
\hline
\end{tabular}

A nivel armónico la misa utiliza básicamente un lenguaje basado en la tradición tonal diatónica, aunque en el Kyrie y Gloria hay evocaciones modales, un recurso muy empleado por el Cecilianismo ${ }^{111}$. El tratamiento armónico de los temas principales es tonal, con empleo de notas de paso (alteradas o no), floreos y retardos para dar interés al discurso armónico. Amorós utiliza preferentemente cadencias plagales para el final de cada sección de la misa. En general, utiliza cadencias en las que aparece la sensible. En la cadencia del tema principal del Gloria utiliza la sucesión acordal II-I, recurso que imprime un carácter modal (Ejemplo 53). Amorós utiliza frecuentemente acordes de

\footnotetext{
${ }^{111}$ Véase Legasa, “Bonifacio Iráizoz”, p. 686.
} 
séptima en función de dominante secundaria para realizar inflexiones a tonos vecinos (Ejemplo 54).

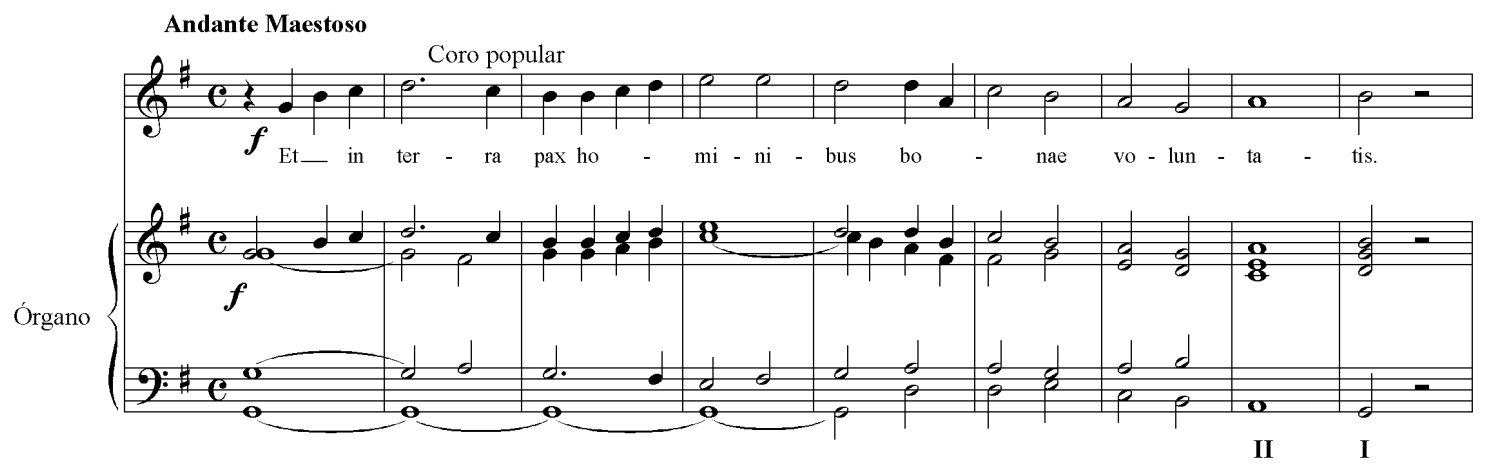

Ejemplo 53

Amorós, Misa Ceciliana, cadencia del Gloria, cc. 1-9.

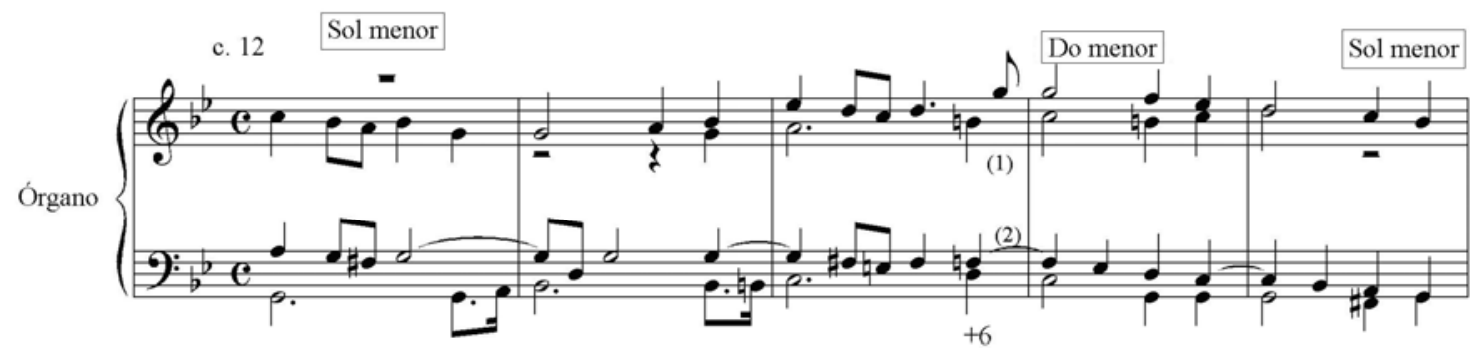

(1) Nota de paso alterada ascendentemente.

(2) Nota de paso cromática alterada, con retardo en su resolución.

Ejemplo 54

Amorós, Misa Ceciliana, Kyrie, cc. 12-16.

La parte principal del discurso musical en la Misa Ceciliana está destinada a las voces. El órgano desempeña una función de apoyo armónico aunque también, en ocasiones, refuerza las líneas melódicas y, en otras, prepara el discurso musical.

El tema principal del Kyrie (Ejemplo 55) es tratado contrapuntísticamente primero en el área de la tónica y posteriormente en el área de la dominante. El Kyrie 
concluye con una cadencia plagal IV-I, con el elemento sorpresa de utilizar un si natural que desemboca en Sol Mayor (en lugar de sol menor, como cabría esperar).

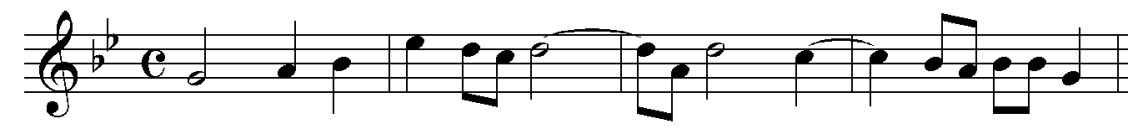

Ejemplo 55

Amorós, Misa Ceciliana, Kyrie, cc. 9-12. Tema principal en su primera aparición, $2^{\mathrm{a}}$ voz.

El material temático del Gloria es expuesto por el coro popular con un tratamiento homofónico (Ejemplo 56).

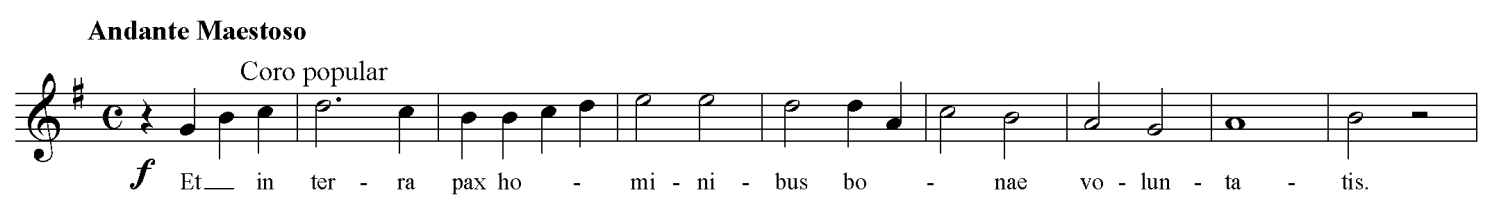

Ejemplo 56

Amorós, Misa Ceciliana, Gloria, cc. 1-9. Tema principal, coro popular.

Un nuevo elemento temático en Re Mayor da cohesión al Credo, con una melodía en la que abundan los grados conjuntos (Ejemplo 57).

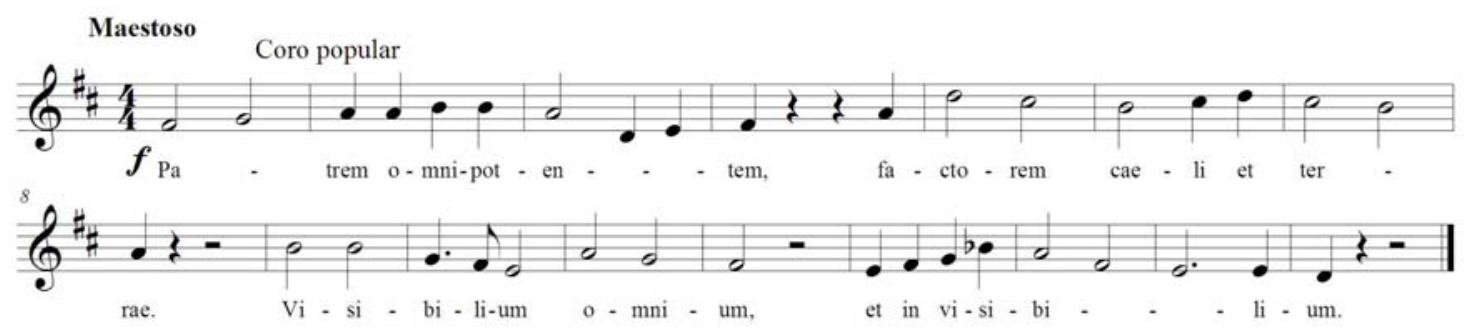

Ejemplo 57

Amorós, Misa Ceciliana, Credo, cc. 1-16. Tema principal. 
La música expresa sonora y gráficamente el significado del texto en ciertos pasajes del Credo. Por ejemplo, en los compases 57-62 la línea melódica desciende una octava desde el $\mathrm{mi}^{3}$ hasta el $\mathrm{mi}^{2}$ en descendit de caelis (Ejemplo 58).

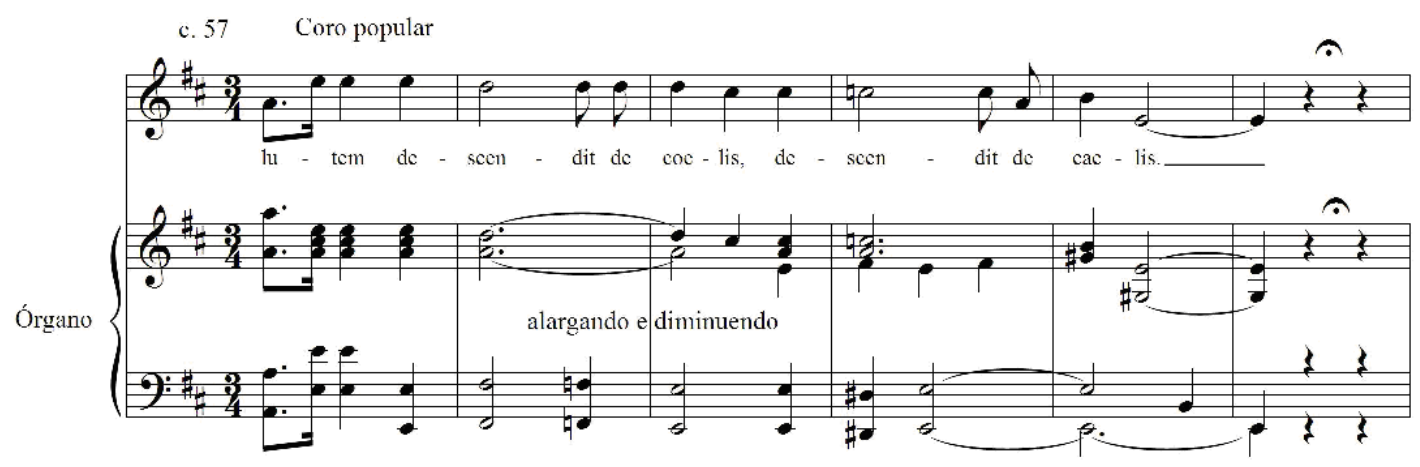

Ejemplo 58

Amorós, Misa Ceciliana, Credo, cc. 57-62.

Para destacar el significado de Crucifixus, sepultatus, Amorós utiliza también cromatismos, líneas melódicas descendentes y el registro grave del órgano (Ejemplo 59).

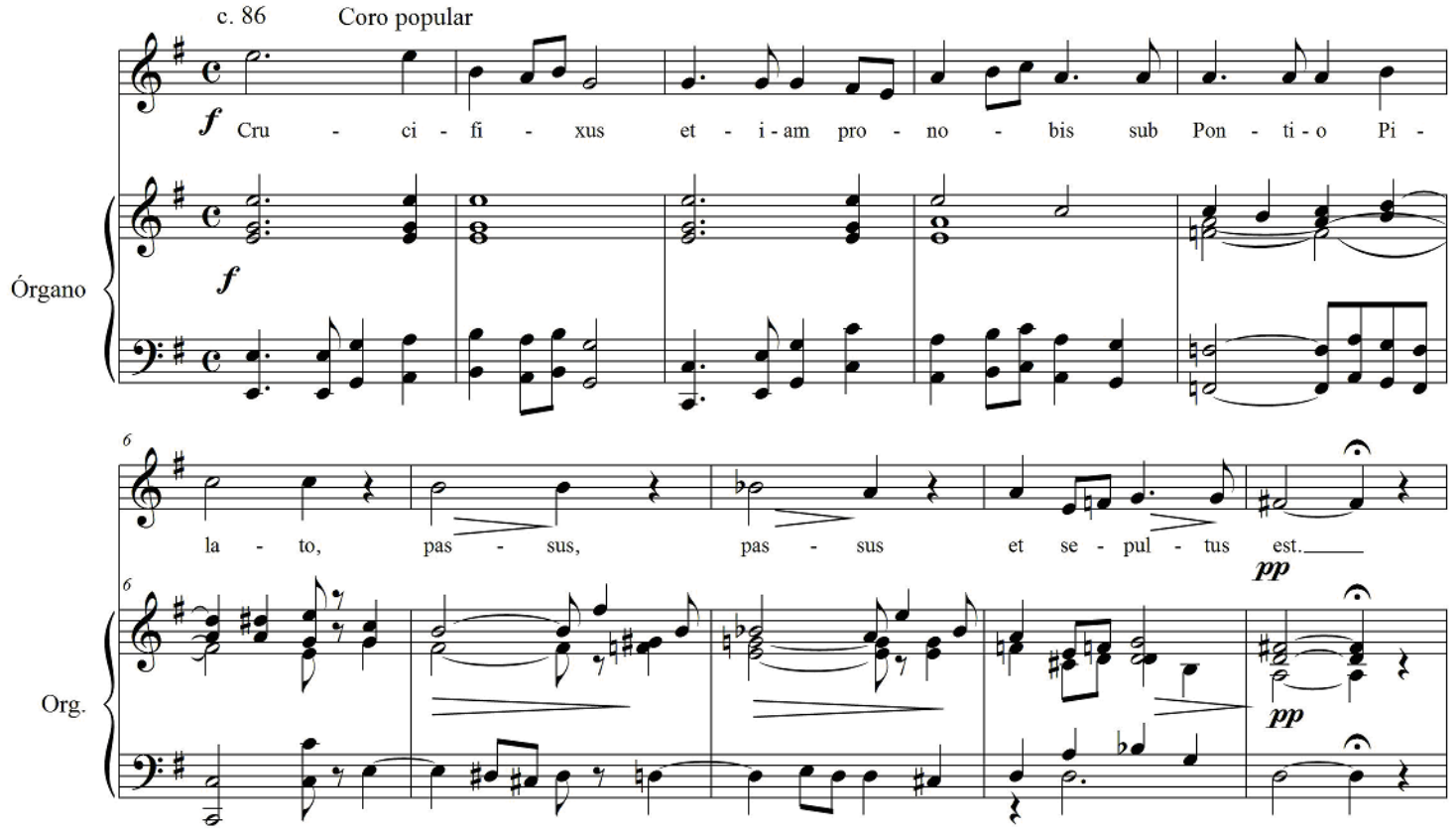

Ejemplo 59

Amorós, Misa Ceciliana, Credo, cc. 82-95, coro popular y órgano. 


\section{2. El himno Venid peregrinos, op. 88 (1893)}

Aproximadamente la mitad de la producción musical religiosa de Amorós es de dimensiones menores que las misas. Su Himno a Santa Cecilia (1890) para tiples con acompañamiento de quinteto de cuerda y arpa recibió el $2^{\circ}$ accésit al premio de la Junta y Claustro de Profesores en el Certamen Internacional convocado por el Conservatorio de Música de Valencia para celebrar su décimo aniversario ${ }^{112}$. La Biblioteca de Catalunya conserva la versión manuscrita de este himno (M 1294) y una versión para piano y armónium en cuya partitura se lee "predicción para armónium y piano del autor" ${ }^{113 "}$ (M 1293).

Otros dos himnos de Amorós son para coro popular y banda de música: Himno a la Santísima Cruz (sf), con texto de Martínez de la Rosa, dedicado a José Fuentes, de la localidad de Bétera; y Venid Peregrinos (1893), op. 88, que paso a comentar más en detalle.

Venid peregrinos (1893), op. 88, "Pequeño Himno popular religioso", con texto de José Peris Pascual, fue dedicado a San Vicente Ferrer, patrón del pueblo natal del compositor, para acompañar la peregrinación del 22 de mayo de 1893 a la ermita de San Vicente Ferrer de Agullent (pueblo natal de Amorós). En el volumen 2 presento la edición crítica de esta obra, cuyo original se conserva manuscrito en la Biblioteca de Catalunya, M 1287. Este himno llegó a editarse con el título Himno a San Vicente Ferrer, aunque no he podido localizar la versión impresa ${ }^{114}$. La prensa valenciana anunció la peregrinación de 1893 en la que se estrenó el himno y comentó los ensayos previos al acontecimiento:

\footnotetext{
${ }^{112}$ El Correo de Valencia publicó una crónica sobre este certamen internacional en mayo de 1890. Cit. López-Chavarri, Cien años de historia, pp. 139-143.

${ }^{113}$ Himno a Santa Cecilia (1890), E:Bc, M 1293.

114 E:Mba, legajo 5-2-2, Expediente de nombramiento de Amancio Amorós como Académico Correspondiente (1921).
} 
En la parroquial de Santa Catalina mártir de esta ciudad, viene ensayándose todas las noches un bonito himno popular dedicado a San Vicente Ferrer, escrito expresamente por nuestro amigo el Maestro Amorós (D. A.), para la peregrinación al ermitorio [sic] de San Vicente Ferrer en Agullent que ha de efectuarse el 22 de los corrientes.

El Excmo e Ilmo. Sr. Arzobispo de esta diócesis irá a presidir esta manifestación religiosa, que promete verse muy concurrida ${ }^{115}$.

El Ayuntamiento de Agullent, a instancias del concejal Tomás Espí Belda, constituyó una comisión organizadora de la romería de 1893, integrada por José Espí Ferri y Tomás Espí Belda ${ }^{116}$. La peregrinación estuvo presidida por el Arzobispo de Valencia, Ciriaco María Sancha y revistió un carácter especial. Al pueblo llegaron miles de peregrinos de las comarcas de la Vall d'Albaida y la Costera (véanse las crónicas periodísticas de la peregrinación en Apéndice 22) ${ }^{117}$ :

Partiendo de todos los pueblos del Valle y de la Costera, fue presidida por el Arzobispo de Valencia, su Eminencia llegó en tren a Albaida a las 10 de la mañana rodeado de numerosa e importante comitiva; desde allí caminaron durante 4 horas a pie hasta la ermita adonde arribaron $[$ sic $]$ a las dos de la tarde ${ }^{118}$.

La banda de música de Agullent amenizó esta romería. El origen de la banda se remonta a 1884, cuando el Ayuntamiento y la Sociedad Musical de Agullent firmaron un convenio para su mantenimiento ${ }^{119}$. Entre las obligaciones de la banda estaba la de participar gratuitamente en la festividad del Miracle [Milagro] de San Vicente Ferrer:

\footnotetext{
${ }^{115}$ Biblioteca Sacro Musical, 15-V-1893, p. 51.

${ }^{116}$ La comisión se encargó de invitar al Arzobispo y al gerente de los Ferrocarriles del Norte "para ver si de este modo se podía conseguir de su influencia una estación o apeadero en este pueblo". E:AGm, Libro de Actas Municipales, 13-IV-1893. Finalmente parece ser que no se consiguió el apeadero.

${ }^{117}$ El Criterio, 25-V-1893; Anónimo, "Peregrinación a Agullent", BOAV, 1115 (2-VI-1893), pp. 272-275. Otra tradicional peregrinación a esa ermita es la Romería nocturna que cada 3 de septiembre, desde 1600 , se celebra en ella. Es conocida como la "Nit de les Fogueretes" y consiste en la visita nocturna a la ermita del pueblo con antorchas y farolillos para conmemorar un milagro realizado por San Vicente Ferrer en 1600. Una vez en la ermita el pueblo entona los Gozos al santo. Véase Antoni Ariño [et al.], La Nit de les Fogueretes: romería nocturna des de 1600 (Valencia: Consell Valencià de Cultura, 1994), pp. 114-115.

${ }^{118}$ El Criterio, 25-V-1893.

${ }^{119}$ Casanova, "Introducció a la història", pp. 20-58.
} 
$1^{\circ}$ El Ayuntamiento se compromete a proporcionarles local o sea el mismo que vienen ocupando en el objeto expresado, costearles una caja de petróleo anualmente y prestarles todo el apoyo que necesiten con arreglo a las facultades de la Corporación Municipal.

$2^{\circ}$ Que en cambio de lo expuesto y agradecidos a la conducta del Ayuntamiento se comprometen dichos señores que toque la música gratuitamente y sin remuneración de ninguna clase durante las festividades del Santísimo Corpus Christi, San Bartolomé Apóstol y el día del Milagro de cada año, como asimismo acompañar con música al Ayuntamiento los días que acuerde salir por la población con el objeto de implorar la caridad pública con destino a la festividad de San Vicente Ferrer $[\ldots]^{120}$.

En el himno Venid Peregrinos, Amorós utilizó una plantilla para banda formada por flautín, requinto, clarinetes $1^{\circ}, 2^{\circ}$ y $3^{\circ}$, saxofones $1^{\circ}$ y $2^{\circ}$, fliscorno en si b $1^{\circ}$ y $2^{o}$, cornetines $1^{\circ}, 2^{\circ}$ y $3^{\circ}$, dos trompas en fa, dos “trombas" en fa o trompetas bajas ${ }^{121}$, dos bombardinos barítonos, tres trombones, dos bombardinos, tuba y percusión. La melodía del himno es muy sencilla, pensada para ser cantada por el pueblo, y abarca un ámbito de novena. Entre los compases 49 y 52 la melodía transcurre por semitonos cromáticos. La armonía es también sencilla, las distintas áreas tonales coinciden con las tres secciones (ABA) en las que se divide la obra (Tabla 56). Amorós sigue mostrando predilección por utilizar el VI rebajado (Ejemplo 60).

Tabla 56. Amancio Amorós, Venid Peregrinos “Pequeño Himno popular religioso", op. 88 (1893). Esquema analítico.

Fuente: $E: B c$, M 1287.

\begin{tabular}{|c|c|c|c|c|}
\hline Secciones & Compases & $\begin{array}{c}\text { Aspectos } \\
\text { armónicos }\end{array}$ & $\begin{array}{l}\text { Material } \\
\text { temático }\end{array}$ & $\begin{array}{l}\text { Tempo/ } \\
\text { Compás }\end{array}$ \\
\hline \multirow[b]{2}{*}{$1^{\mathrm{a}}$} & $1-7$ & Si b Mayor & Elementos de A & \multirow{2}{*}{$\begin{array}{c}\text { Tiempo de marcha } \\
\cdot=88\end{array}$} \\
\hline & $8-31$ & Si b Mayor & A & \\
\hline $2^{\mathrm{a}}$ & $36-70$ & Fa Mayor & B & $\begin{array}{c}\text { Moderato } \\
\downarrow=56\end{array}$ \\
\hline $3^{\mathrm{a}}$ & $8-74$ & Si b Mayor & A & $\begin{array}{c}\text { Tiempo de marcha } \\
\cdot=88\end{array}$ \\
\hline
\end{tabular}

120 E:AGm, "Acuerdo adoptado entre el Ayuntamiento y señores representantes de la Sociedad de música", Libro de Actas Municipales de 1884, 21v y 22r.

${ }^{121}$ Por su afinación, la tromba en Fa designa una trompeta baja. Véase Philip Bate/Stephen J. Weston, "Basse-trompette", en $T N G$, vol. 2 (2002), p. 869. 


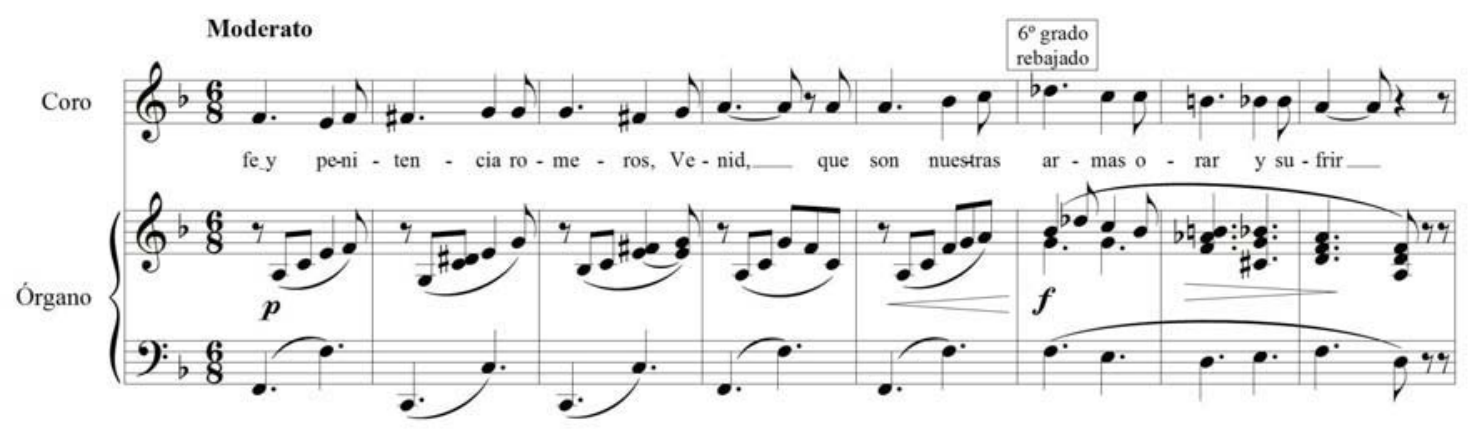

Ejemplo 60

Amorós, Venid Peregrinos, cc. 40-48.

\section{3. Motetes}

He documentado por el momento once motetes de Amorós, todos en latín, y algunos de ellos fechados entre 1884 y 1907: O sacrum convivium (1884) para voz solista, coro y orquesta; O salutaris Hostia (1891) para voz y órgano; Tota pulchra (1893) para solistas, coro y orquesta; Memoriam fecit mirabilium suorum (1898) para voz solista y orquesta; Quam dilecta tabernacula tua (1899) para solista, coro y pequeño conjunto instrumental; Cantemus Domino (1900) para voz solista, coro y orquesta; Domine dilexi decorem domus tua (1907) para voz solista y orquesta; Domine, exaudi orationem meam (sf) para coro popular y orquesta; Ave Maria (sf) para solista, coro y pequeño conjunto instrumental; $O$ salutaris Hostia (sf) para voz solista, coro y órgano y Vidi Angelum (sf) para voz y órgano, dedicado a San Vicente Ferrer ${ }^{122}$ (en la actualidad ilocalizable).

Los motetes Memoriam fecit y Cantemus Domino de Amorós se interpretaron en 1900 durante el III Centenario del Milagro de San Vicente Ferrer, celebrado en Agullent, localidad natal del compositor. En el programa de fiestas de Agullent de ese año se lee:

\footnotetext{
${ }^{122}$ La obra es citada por Ruiz de Lihory en La música en Valencia, pp. 25-26 y Sobrino, "Amorós Sirvent, Amancio", p. 420.
} 
Día 4

A las nueve, solemne función religiosa, cantándose después de tercia, bajo la dirección del laureado maestro D. Amancio Amorós, profesor honorario del Conservatorio de Música de Valencia e hijo de esta población, la misa de Santa Cecilia de Gounod, y motetes Venite ad me y Memoriam fecit de los maestros Giner y Amorós, por la orquesta primitiva de Alcoy y otros distinguidos profesores de Valencia, entre ellos los señores Andrés Breva, Trávez y Domínguez.

Día 6

A las nueve, solemne función religiosa, en la que se estrenará la Misa en re menor del ya citado maestro Amorós y los motetes Cantemus Domino del mismo y el Angelus de Massenet, tomando parte los ya indicados profesores, más el distinguido tenor Sr. Alonso, siendo el celebrante el doctor D. Constantino Tormo $[\ldots]^{123}$.

El rasgo común a todos los motetes de Amorós es su carácter sobrio que contrasta, en ocasiones, con líneas melódicas de gran lirismo, influenciadas por la música teatral, y lejanas a la simplicidad que proclamaban los reformistas de la música religiosa. Un ejemplo representativo es el motete $O$ salutaris Hostia, op. 61 (1891), a tres voces y órgano, en Fa mayor, del que presento la edición en el volumen 2 de esta Tesis. El manuscrito autógrafo de la obra se conserva en la Biblioteca de Catalunya (M 1295), y hay una copia, no autógrafa, en la Biblioteca Musical de Compositores Valencianos (1A $\mathrm{n}^{\circ} 31$ ). Ildefonso Alier editó este $O$ Salutaris en la Colección obras religiosas españolas, con errores que he corregido en mi edición ${ }^{124}$. Las partes vocales empleadas por Amorós son $1^{\mathrm{a}}$ voz, $2^{\mathrm{a}}$ voz y bajo, sin especificar si la primera y segunda voz deben cantarlas sopranos o tenores $^{125}$.

\footnotetext{
${ }^{123}$ Anónimo, Programa de las Fiestas, sp.

${ }^{124}$ En la edición impresa por Ildefonso Alier falta el antepenúltimo compás según el manuscrito autógrafo.

${ }^{125}$ O salutaris Hostia, op. 61, E: Msa, A-946/19. En la página 8 de la partitura impresa por Alier hay una nota a pie de página que dice "si cantan tiples, el bajo que cante la nota superior, y si cantan los tenores, la nota inferior.
} 
Estructuralmente la pieza se organiza en función del texto:

O Salutaris Hostia, quae caeli pandis ostium. Bella premunt hostilia. Da robur fer auxilium.
Oh, Hostia seas saludada

Tú que abres la puerta del cielo.

Las cosas hermosas cubren lo que es funesto.

Da (nos) fuerza, trae (nos) auxilio.

Tabla 57. Amancio Amorós, O salutaris Hostia, op. 61 (1891), terceto [sic] para voces y órgano. Esquema analítico.

Fuentes: E:Bc, M 1295 (autógrafo), E:Msa, A-946/ 19, E:VAbm, $1 \mathrm{~A} \mathrm{n}^{\mathrm{o}} 31$.

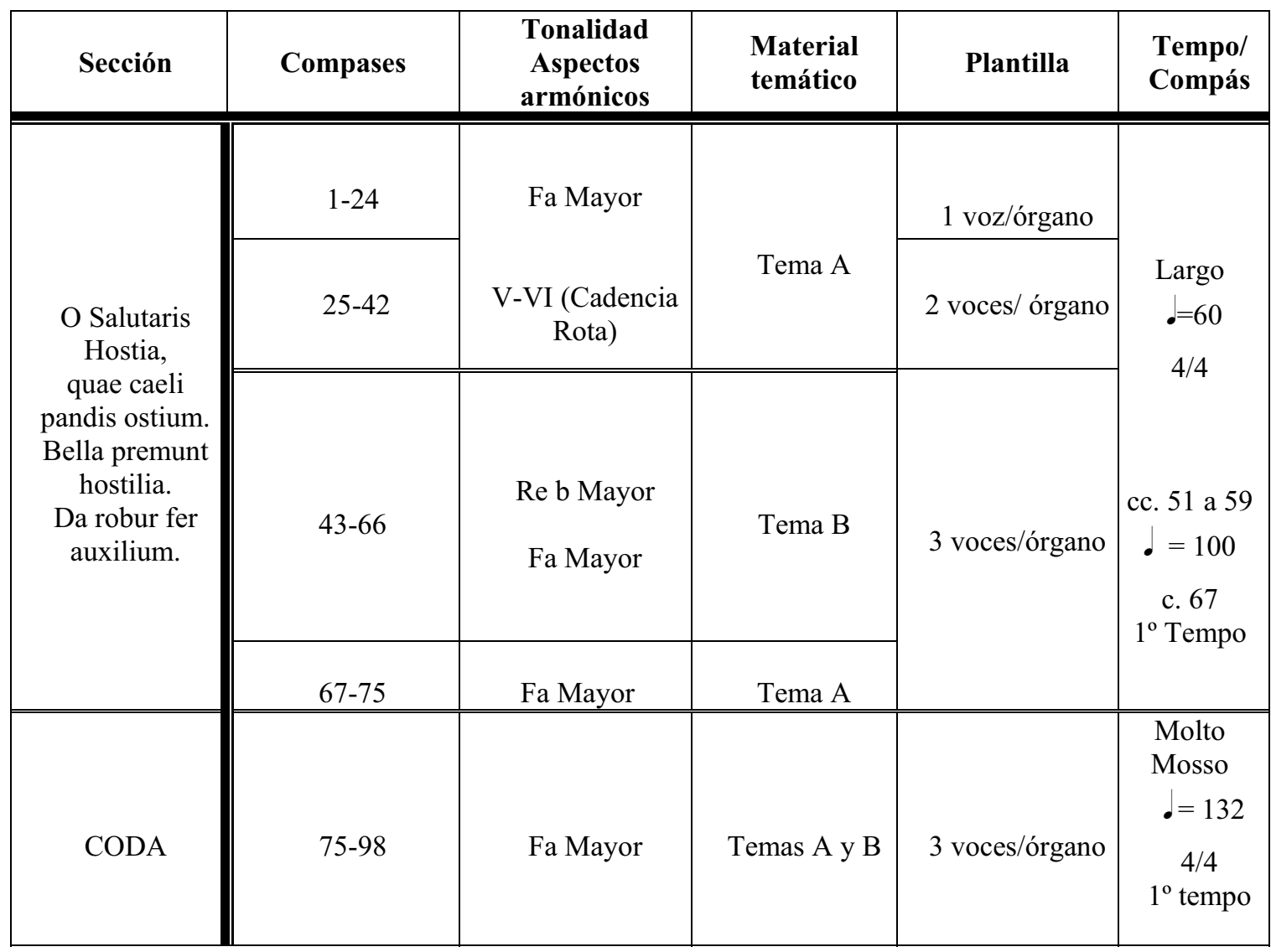

Amorós elabora una única sección musical con dos temas y la textura se va complicando sucesivamente (Tabla 57). La pieza comienza a una voz: "O salutaris Hostia/quae caeli pandis ostium" (hasta el compás 25) con la exposición del primer material temático (A) en Fa Mayor. Esta melodía, doblada por el órgano, está constituida por ocho compases y armónicamente se apoya en los grados I-V-I (Ejemplo 61). 

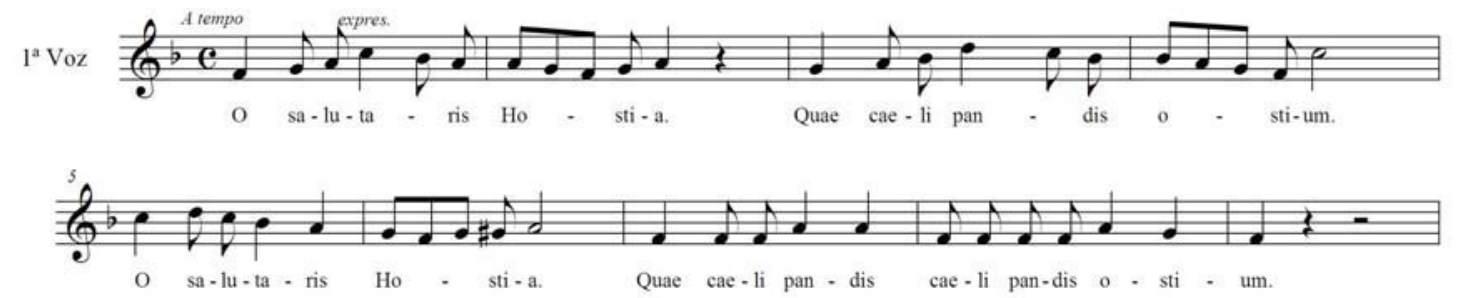

Ejemplo 61

Amorós, O salutaris Hostia, op. 61, cc. 17-25. Tema A.

A partir del compás 25 se presenta el texto completo de la estrofa, esta vez a dos voces y con un juego polifónico contrapuntístico entre ellas. La segunda voz expone el material melódico A, con sencillas y breves imitaciones de células motívicas de este material realizadas por la primera voz. Armónicamente se producen inflexiones a tonalidades vecinas, en el compás 42 se busca el acorde de $7^{\text {a }}$ de Dominante de Fa y con una resolución excepcional V-VI se llega en el compás 43 a Re bemol Mayor ${ }^{126}$ (Ejemplo $62)$.

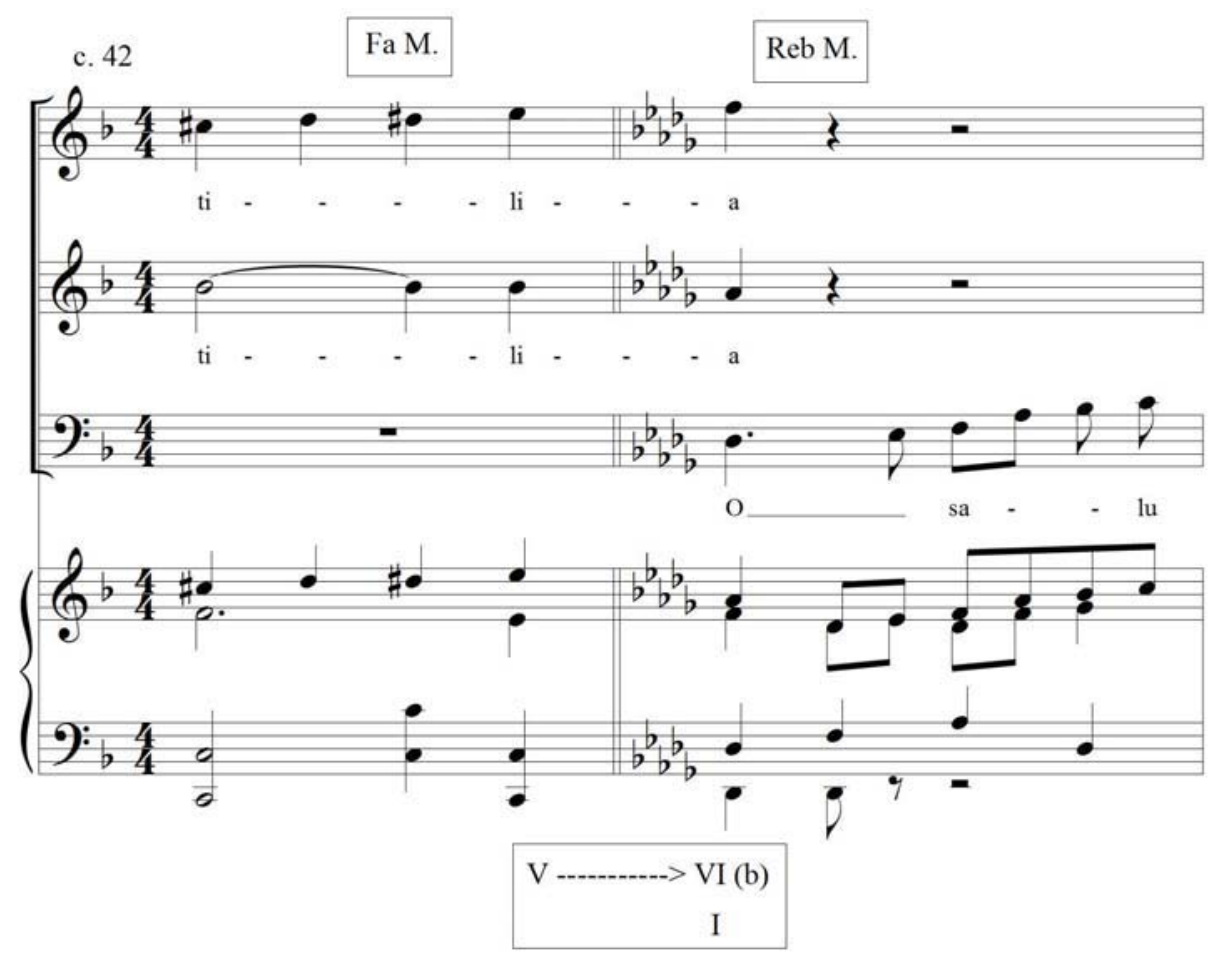

Ejemplo 62

Amorós, O salutaris Hostia, op. 61, cc. 42-43, resolución excepcional V- VI.

${ }^{126}$ La utilización del sexto grado rebajado es un recurso armónico que Amorós utilizó habitualmente. 
La textura a tres voces se introduce en el compás 43 (repetición del texto completo). El bajo expone el segundo material melódico (B) en Re bemol Mayor (véase Ejemplo 63) y coincidiendo con una textura vertical y una aplicación del texto básicamente silábica.

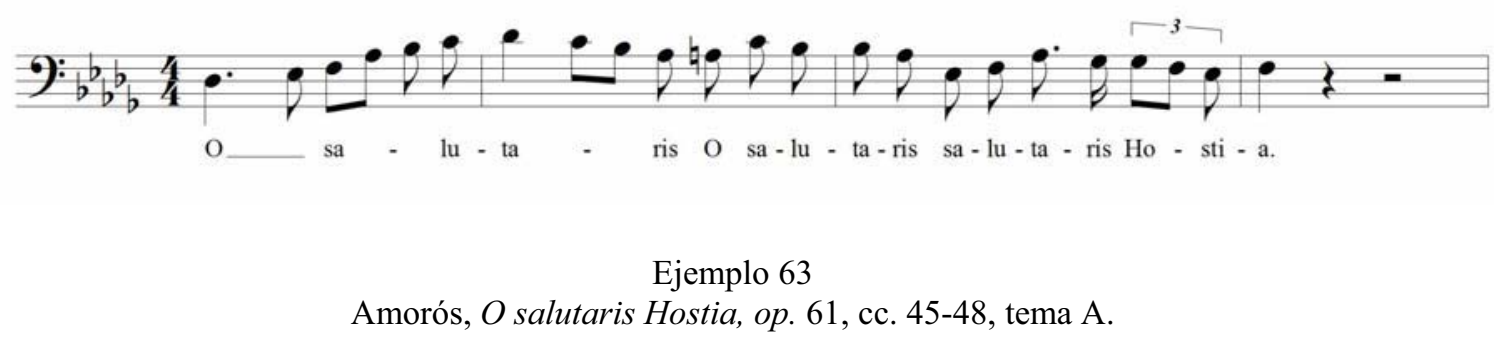

El motete finaliza con una Coda, en la que Amorós combina las dos ideas melódicas antes expuestas y realiza inflexiones a tonalidades lejanas mostrando gran atrevimiento desde el punto de vista armónico.

\section{4. Otras obras religiosas}

Además de los géneros religiosos ya comentados, Amorós compuso algunas otras piezas eclesiásticas. En la Biblioteca de Catalunya se conserva la partitura manuscrita de los Gozos a San José de Calasanz (1904). La edición impresa de los Gozos al Patriarca San José a tres voces y órgano (sf) se conserva en el Archivo Histórico de la Unión Musical Española y se editó en el volumen 1 de la Biblioteca Sacro Musical $(1891)^{127}$. Amorós compuso una Salve (1887) para dos voces solistas, coro y orquesta que se conserva manuscrita en la Biblioteca de Catalunya (M 1300). Su Tantum ergo en Si b sobre canto llano (sf) para voces iguales, coro y armónium es hoy ilocalizable ${ }^{128}$, mientras que el Trisagio a la Santísima Trinidad (sf) para coro y pequeño conjunto

\footnotetext{
${ }^{127}$ Publicación quincenal valenciana de música religiosa, que comenzó en diciembre de 1890. Ilustración Musical Hispanamericana, 28-II-1891, p. 473.

${ }^{128}$ La obra es citada por Ruiz de Lihory en La música en Valencia, p. 26 y Sobrino, “Amorós Sirvent, Amancio", p. 420.
} 
instrumental se conserva manuscrito en la Biblioteca de Catalunya. Entre los salmos compuestos por Amorós están el Beatus Vir, qui timet Dominum (1897) para dos coros, órgano, violón y contrabajo y el Credidi de $4^{\circ}$ tono (sf) para dos voces solistas, coro, órgano, violón y contrabajo ${ }^{129}$.

La marcha religiosa Gloria a España es la única obra instrumental religiosa del catálogo de Amorós. El compositor hizo dos instrumentaciones de esta obra, una para armónium, piano y quinteto de cuerda y otra para banda de música. Completa la producción religiosa de Amorós una heterogénea colección de páginas musicales con títulos diversos, como letanías, plegarias, salutaciones y letrillas. Sólo he podido averiguar las fechas de estreno de las obras religiosas de Amorós en algunas ocasiones, ya que la prensa del momento no proporciona demasiados detalles al respecto.

Comentaré brevemente dos ejemplos de este tipo de pequeñas piezas religiosas, una salutación a San José y unas letrillas a la Virgen.

La pieza Recibid mil parabienes, denominada "Salutación al Patriarca San José" (sf), fue impresa por Ildefonso Alier y se publicó también en el volumen 1 de la Biblioteca Sacro Musical (1891) ${ }^{130}$. La composición, en Do menor, es una armonización para coro popular con acompañamiento de órgano de una sencilla melodía de nueve compases, que se mueve por grados conjuntos; estructurada en dos semifrases de $4+5$ compases en 6/8, termina con una coda en $9 / 8$ (véase volumen 2, edición de composiciones de Amancio Amorós).

\footnotetext{
${ }^{129}$ Del Credidi de $4^{o}$ tono se conservan dos plantillas instrumentales, el manuscrito autógrafo para dos voces solistas, coro y órgano y el manuscrito no autógrafo de $E: V a b m, 1 \mathrm{~A} \mathrm{n}{ }^{\circ} 31$ para dos voces solistas, coro, órgano, violón y contrabajo, que coincide con la edición impresa de Ildefonso Alier.

${ }^{130}$ Según la relación de obras aparecidas en la Biblioteca Sacro Musical, 15-VIII-1893. De la impresión de Alier se conserva un ejemplar en E:Msa, A-945/20. Hay también un ejemplar manuscrito, no autógrafo en $E: V a b m, 1 \mathrm{~A} \mathrm{n}^{\circ} 31$.
} 
Las "letrillas a la Virgen" Acepta Virgen Pura (sf), se publicaron en el no 2 de la Biblioteca Sacro Musical (véase volumen 2, edición de composiciones de Amancio Amorós $)^{131}$. La obra se compuso para la congregación de Adoratrices de Valencia, probablemente entre 1889 y $1893^{132}$. Las letrillas son para voces solistas, coro de voces blancas y órgano, y constan de tres secciones: Andante maestoso (coro), Adagio (solista) y Adagio (dos voces) en Fa Mayor, La b Mayor y Re b Mayor, respectivamente. Amorós estructura estas letrillas a la Virgen en forma de rondó (véase Tabla 58).

Tabla 58. Amancio Amorós, Acepta Virgen Pura (sf). Esquema analítico. Fuente: $E: V A b m 1 \mathrm{~A}, \mathrm{n}^{\mathrm{o}} 31$.

\begin{tabular}{|c|c|c|c|c|c|}
\hline Secciones & Extensión & $\begin{array}{c}\text { Tonalidad } \\
\text { Aspectos } \\
\text { armónicos }\end{array}$ & $\begin{array}{l}\text { Material } \\
\text { temático }\end{array}$ & Tempo/Compás & Plantilla \\
\hline Introducción & $1-6$ & Fa Mayor & $\begin{array}{c}\text { Motivo del } \\
\text { tema A }\end{array}$ & \multirow{3}{*}{$\begin{array}{c}\text { Andante Maestoso } \\
6 / 8\end{array}$} & \multirow{3}{*}{ Coro } \\
\hline \multirow[t]{2}{*}{$1^{\mathrm{a}}$} & $7-26$ & \multirow{2}{*}{ Fa Mayor } & \multirow{2}{*}{$\begin{array}{c}\text { Tema A } \\
8+8+4\end{array}$} & & \\
\hline & $\begin{array}{l}27-32 \\
\text { Coda }\end{array}$ & & & & \\
\hline $2^{\mathrm{a}}$ & $33-60$ & La b Mayor & Tema B & $\begin{array}{c}\text { Adagio } \\
6 / 8\end{array}$ & 1 voz solista \\
\hline \multicolumn{5}{|c|}{ Repetición de la $1^{\mathrm{a}}$ Sección A } & Coro \\
\hline $3^{\mathrm{a}}$ & $61-96$ & Re b Mayor & Tema C & $\begin{array}{c}\text { Adagio } \\
3 / 4\end{array}$ & 2 voces \\
\hline \multicolumn{5}{|c|}{ Repetición de la $1^{\text {a }}$ Sección A } & Coro \\
\hline
\end{tabular}

\footnotetext{
${ }^{131}$ Según la relación de obras aparecidas en la Biblioteca Sacro Musical, 15-VIII-1893. He manejado una copia conservada en $E: V A b m, 1 \mathrm{~A}, \mathrm{n}^{\circ} 31$.

${ }^{132}$ Amorós dirigió el coro de voces blancas del colegio-convento de las Adoratrices al menos entre 1889 y 1899, y la obra es citada en 1893 en la Biblioteca Sacro Musical.
} 
CONCLUSIONES GENERALES 

La investigación realizada en esta Tesis Doctoral ha puesto de manifiesto la enorme importancia de Amancio Amorós (1854-1925) en la vida musical valenciana de su época, su intensa vinculación con los movimientos culturales e institucionales que se desarrollaron en esos años y sus notables aportaciones como pianista, gestor musical, pedagogo y compositor.

La irrupción de Amorós en el mundo profesional de la música coincidió con el apogeo de la Renaixença valenciana, movimiento cultural que llegó a su máximo esplendor durante la segunda mitad del siglo XIX y que buscaba recuperar la personalidad del pueblo valenciano, poniendo especial énfasis en el intento de recuperar la lengua propia. Desde el punto de vista musical, la Renaixença revalorizó la tradición popular y subrayó la necesidad de formar una conciencia musical valenciana, utilizando elementos del folklore musical en el lenguaje sinfónico, empleando asuntos populares valencianos en los libretos de zarzuelas "regionalistas" e introduciendo el valenciano en composiciones vocales (zarzuelas, piezas para canto y piano y obras corales). La sociedad Lo Rat Penat se convirtió en la plataforma aglutinadora de los renaixencistas valencianos y, en el plano musical, convocó concursos de composición durante la Feria de Julio de Valencia, en cuyas bases se exigía la creación de música descriptiva que reflejase costumbres valencianas y que estuviese basada en melodías populares de la tierra. La historiografía venía afirmando hasta ahora que los principales músicos que sustentaron la Renaixença en Valencia fueron Juan Bautista Guzmán, José María Úbeda y Salvador Giner. La investigación realizada para esta Tesis permite añadir otras figuras relevantes en la Renaixença musical valenciana, entre ellas el propio Amancio Amorós, además de Vicente Peydró (1861-1938), Eduardo Ximénez Cos (1824-1900) y Manuel Penella Raga (1847-1909). 
En vida de Amancio Amorós se produjo una profunda transformación de la enseñanza musical, hasta entonces casi exclusivamente vinculada a centros religiosos, colegios privados, capillas de música y casas particulares, que fue dando paso poco a poco a un tipo de enseñanza musical oficial, regulada estatal o municipalmente. Desde 1873 las Escuelas de Artesanos de Valencia ofrecían la posibilidad de estudiar música en su plan de enseñanza. En 1879 el Ayuntamiento valenciano mantenía tres escuelas municipales de música, con la colaboración altruista de los profesores Manuel Penella, Emilia Lacombe y Consuelo Rey, que fueron ampliadas a cuatro escuelas en 1880 a petición del profesor de solfeo Eduardo Senís. Entre las sociedades culturales y recreativas valencianas que mostraron interés por la educación musical a finales del XIX destacó la Real Sociedad Económica de Amigos del País de Valencia que, con subvenciones de la Diputación Provincial y del Ayuntamiento, puso en funcionamiento el Conservatorio de Música de Valencia, cuyo Reglamento se aprobó en 1878 y que comenzó a funcionar en 1879.

La vida teatral valenciana fue muy intensa en la etapa estudiada. El Teatro Principal siguió siendo la sede principal para las representaciones de ópera italiana durante el siglo XIX y primeras décadas del XX, aunque programaba también temporadas de “ópera española". En la primera década del siglo XX, la zarzuela triunfó en otros teatros de Valencia, como el Teatro Princesa, el Teatro Ruzafa y el Teatro Apolo. El Teatro Princesa se especializó en la zarzuela regionalista, género que Amancio Amorós cultivó en Chepeta (sf). En el Teatro Ruzafa estrenó Amancio Amorós en enero de 1886 su zarzuela Los dos esclavos. El repertorio zarzuelístico, a través de arreglos y transcripciones, fue fundamental en las veladas literario-musicales ofrecidas por las secciones de Música de diversas entidades culturales valencianas, en el repertorio de las orquestas y bandas de música y en parte del repertorio coral. 
El estudio realizado ha permitido constatar un paulatino auge de la creación y consumo de música instrumental (sinfónica y camerística) en Valencia desde aproximadamente 1875. En la capital valenciana surgieron, por ejemplo, la Sociedad de Conciertos (1878), la Orquesta Goñi (1890), la Sociedad de Cuartetos (1890), la Asociación de Profesores de Orquesta de Valencia (1902) y la Orquesta Sinfónica de Valencia (1916). En ese contexto compuso Amancio Amorós algunas significativas obras sinfónicas, como la sinfonía Corina, op. 35 (1883) y la Sinfonía para gran orquesta, compuesta sobre aires populares de Valencia y su reino, op. 69 (1890), aunque no he podido documentar si estas composiciones fueron estrenadas por orquestas valencianas.

Valencia vivió desde la segunda mitad del siglo XIX un crecimiento particularmente importante de las bandas de música, requeridas por la sociedad burguesa para subrayar actos políticos, civiles, militares y religiosos. En Valencia capital he podido documentar en época de Amancio Amorós la existencia de al menos once bandas de música diferentes: Banda La Unión, Banda de vecinos de Patraix, Banda de la Casa de la Beneficencia, La Valenciana, Banda de l'Oli, Banda de la Brigada de Bomberos, Patronato Juventud Obrera, Banda de la Asociación de Católicos, Lira Valenciana, Veteranos de la Libertad/Batallón de Veteranos y Banda Municipal de Valencia (fundada en 1903). En 1886 el Ayuntamiento de Valencia creó el certamen de Bandas de Música de Valencia, dentro de la Feria de Julio de la capital. Amancio Amorós compuso al menos tres obras que requerían la intervención de una banda: la marcha instrumental religiosa Gloria a España (1882) y los himnos A la Santísima Cruz (sf) y Venid Peregrinos para coro popular y banda (1893).

Las sociedades culturales valencianas desempeñaron un importante papel en la difusión de la música dentro de la sociedad burguesa de finales del siglo XIX y principios del XX. En las veladas literario-musicales organizadas por la sección de Música de estas 
asociaciones participaban socios aficionados y músicos profesionales. Hubo actuaciones de este tipo en la Real Sociedad Económica de Amigos del País de Valencia, el Círculo de Comercio y Fomento o Círculo Valenciano, la Academia Científico Literaria de la Juventud Católica, el Ateneo científico, Artístico y Literario de Valencia, el Ateneo Casino Obrero de Valencia, la sociedad Lo Rat Penat, El Iris, el Círculo de Bellas Artes y el Centro Escolar y Mercantil, entre otras.

Amancio Amorós estuvo directamente implicado en la vida musical que bullía en este denso tejido de asociaciones valencianas, en las que fue expresamente reconocido como pianista de técnica impecable, seguridad y limpieza en la ejecución. He documentado su participación como pianista en veladas literario-musicales organizadas por la Academia de la Juventud Católica y la sociedad Lo Rat Penat, aunque no hay que descartar que participara también en otras. Muestra de su actividad pianística son dos volúmenes de su biblioteca personal, el Álbum Musical y el Álbum Pianístico (ambos hoy en la Biblioteca de Catalunya), que contienen obras impresas para piano de mediados del siglo XIX, probablemente encuadernadas para el uso del propio Amancio Amorós, y que podrían reflejar el tipo de repertorio que interpretaba el músico en su juventud. En el Álbum Musical los autores son mayoritariamente extranjeros, aunque hay también algunos valencianos y catalanes y dos compositoras prácticamente desconocidas en la actualidad, Concha Díaz Castro y Blanca Llisó y Martínez. La mayor parte de las obras del Álbum Musical que perteneció a Amancio Amorós son reducciones de números de zarzuela y bailes como polkas, mazurcas y valses. El volumen incluye además reducciones para piano y canto y piano de cuatro números de la zarzuela Los dos esclavos de Amancio Amorós que fueron editados (Terceto, Escena y Vals, Guaracha, Romanza de tiple y Habanera, dúo de tiple y tenor cómico). El Álbum Pianístico, también conservado en la biblioteca personal de Amancio Amorós, se inicia con el capricho para 
piano de Amorós Violetas y mariposas op. 1 (sf) y contiene algunas obras de compositores cubanos (Ignacio Cervantes, Nicolás Ruiz Espadero, Carlos Peyrallade y Gaspar Villate). Los géneros representados en esta colección son mayoritariamente romanzas, barcarolas y caprichos para piano.

El desarrollo del movimiento coral valenciano en época de Amorós fue paralelo al que tuvo lugar en el resto de España. En la década de los sesenta del siglo XIX ya existían en Valencia el Orfeón Valenciano, el Orfeón Apolo y el Orfeón Ceciliano. Un estudio sistemático del Boletín Musical de Valencia me ha permitido constatar que la década 1890-1900 fue la época de máximo esplendor para la música coral valenciana. La llegada desde Cataluña de los Coros de Clavé a Valencia en junio de 1893 sirvió para confirmar y consolidar el movimiento coral valenciano. Francisco Fayos Anthony, redactor y corresponsal del Boletín Musical de Valencia en Barcelona, a través de sus escritos en prensa y de sus visitas desde 1894 a varios pueblos valencianos, animó a constituir la Asociación Coral de la Región Valenciana, que se fundó en 1895 como una confederación de varios coros. Los fines de esta asociación eran artísticos, pero también educativos y patrióticos, ya que a través de la música coral se quería educar, moralizar y dignificar al obrero, y fomentar al mismo tiempo el amor a la música y a la cultura valencianas. Fayos exhortaba a los orfeones a cantar en valenciano, y es significativo que entre los artistas que mencionó por haber compuesto obras de carácter esencialmente valenciano estuvo Amancio Amorós, con sus obras Costum de l'horta y Alborada, ambas relacionadas con los ideales de la Renaixença. Las desavenencias surgidas entre los coros integrantes de la Asociación Coral de la Región Valenciana llevaron a la disolución de la misma en 1897.

En el rico contexto musical valenciano descrito, Amancio Amorós ejerció un papel preponderante. Su vida transcurrió sin grandes sobresaltos, en un marco geográfico 
sobre todo local y regional, aunque en contacto con la realidad musical nacional, a través de sus viajes a Madrid y su correspondencia y amistad con personajes de particular relevancia, como Felipe Pedrell, entre otros. Tras sus primeros años en Agullent (18541862), Bétera (1862-1867) y Cocentaina (1867-1870), se asentó en Valencia capital, donde residió la mayor parte de su vida adulta (1871-1925). Su formación musical estuvo ligada a centros religiosos, como la parroquia de El Salvador de Cocentaina, donde empezó a estudiar órgano, o el Seminario Andresiano de las Escuelas Pías de Valencia, donde a partir de 1871 continuó su formación musical en piano con Justo Fuster y Roberto Segura; probablemente el joven Amorós también recibió clases de música en el domicilio particular de Salvador Giner en Valencia. Posteriormente (1879-1882), Amancio Amorós estudió composición con Antonio Marco y José María Úbeda en el entonces recién creado Conservatorio de Valencia. En el mismo Conservatorio desarrollaría después Amorós una activa labor como profesor y director, en una de las etapas más decisivas para el centro.

En su primera etapa profesional (1882-1889), Amancio Amorós trabajó como pianista, al tiempo que comenzó a componer. En su época de madurez (1890-1914) su implicación en la vida musical valenciana fue total, lo que le llevó a participar directamente en la gestión de diversas sociedades, como el Círculo Musical (1900) y la Asociación de Profesores Músicos de Santa Cecilia de Valencia, en la que fue socio fundador y ejerció como secretario, vicesecretario y presidente de su Junta Directiva entre 1897 y 1924. Amorós ocupó la presidencia de la Sección de Música de la emblemática sociedad Lo Rat Penat en dos ocasiones, en el periodo 1883-1884 y entre 1892 y 1895 . Fue requerido en varias ocasiones para formar parte de tribunales, como ocurrió en el Certamen de Bandas de Música de Valencia (1891), en las oposiciones para elegir el primer director de la Banda Municipal de Valencia (1903), en las oposiciones a 
la cátedra de Armonía del Conservatorio de Madrid (1915) y en el concurso para la elección del Himno de la Coronación de la Virgen de los Desamparados (1922), entre otros. También fue destacada la labor de Amorós como director de agrupaciones de cámara en conciertos para celebrar la inauguración de cursos académicos de algunas instituciones como, por ejemplo, el de la Escuela de Comercio (institución dependiente de la Real Sociedad Económica de Amigos del País de Valencia) en 1888.

En los últimos años de su vida, Amancio Amorós fue reconocido con diversos cargos honoríficos. En 1921 fue nombrado "director" o miembro de la sección de Arte del Centro de Cultura Valenciana y Académico Correspondiente por Valencia de la Real Academia de Bellas Artes de San Fernando de Madrid (este último cargo, a propuesta de los académicos Pedro Fontanilla, Narciso Sentenach y Joaquín Larregla). Amorós fue además condecorado hacia 1908 por el Gobierno Francés con el título de Oficial de Instrucción Pública y Bellas Artes. En 1924 Amancio Amorós, a causa de su enfermedad, dejó la dirección del Conservatorio de Valencia y se trasladó a vivir, junto con su esposa, a la localidad barcelonesa de San Cugat del Vallés, donde falleció en 1925.

Además de la intensa labor ya mencionada de Amancio Amorós en múltiples tareas de gestión y de su actividad como pianista y director, en su vida y obra destacan de manera sobresaliente tres grandes áreas de actuación: la actividad docente y pedagógica, la actividad musicológica y la composición musical.

La labor docente de Amancio Amorós fue ingente. En Valencia fue maestro de capilla del convento de las Adoratrices (al menos entre 1887 y 1899), primer profesor de piano y solfeo en la Institución para la Enseñanza de la Mujer (1888-1901), director y fundador de la Academia Musical Amorós (1889-1893), profesor del Colegio-Seminario Andresiano de las Escuelas Pías (1906), y figura clave en el Conservatorio de Música de Valencia (1881-1924) donde ejerció como sustituto de piano entre 1881 y 1884, profesor 
honorario de Solfeo y Armonía desde 1893, profesor numerario por oposición desde 1902 y director desde 1919. El trabajo de Amorós en el convento de las Adoratrices le llevó a organizar entre 1889 y 1891 la interpretación de Las Siete Palabras, composición colectiva en la que implicó a un grupo de compositores valencianos (Manuel Chulvi, Juan Bautista Plasencia, Eduardo Ximénez, Manuel Soriano, José Fornet y Salvador Giner) y con la que obtuvo éxito y buenas críticas. Los cronistas de la época elogiaron el extraordinario mérito de Amancio Amorós como director de esa obra colectiva y la buena factura de la Primera palabra, Pater dimite illis, compuesta por él mismo. La academia privada que fundó Amorós en 1889 se llamó inicialmente Academia Preparatoria y posteriormente Academia Musical Amorós. Funcionó al menos hasta 1893 (cuando el compositor afianzó su posición en el Conservatorio de Valencia) y en ella se impartieron clases de Solfeo, Armonía y Composición.

La vinculación de Amorós como docente del Conservatorio de Valencia (iniciada en 1881-1884 como profesor sustituto de Piano) se consolidó a partir de 1893, cuando fue nombrado profesor honorario. En 1902 el músico obtuvo por oposición la plaza vacante de profesor numerario de Solfeo y Armonía en el mismo centro. Amorós elaboró el programa de estudios de la asignatura de Armonía y entre 1906 y 1910 sustituyó a Salvador Giner como profesor de composición. La culminación de la labor de Amancio Amorós en el Conservatorio de Valencia fue su etapa como director del centro (19191924), en la que solucionó los problemas económicos del mismo, consiguió que en 1920 quedara definitivamente incorporado a las Enseñanzas del Estado, y redactó un nuevo Reglamento (1921). En 1924, cuando el Consejo de Instrucción Pública y Bellas Artes cuestionó en un informe la continuidad del Conservatorio de Valencia como centro oficial, Amancio Amorós viajó a Madrid, se entrevistó con el Director General de Instrucción Pública y consiguió mantener el centro como conservatorio oficial. 
Además de su labor de docencia y gestión en diversos centros, Amancio Amorós ejerció influencia directa en la educación musical de un extenso alumnado a través de los métodos que escribió de solfeo, armonía, piano y composición. Particularmente influyentes fueron sus métodos de solfeo, que alcanzaron varias ediciones en vida del autor y fueron adoptados en numerosas academias, colegios y centros de enseñanza de Valencia y otros lugares de España y América. Los Elementos de Solfeo de Amorós fueron el método oficial para primer curso de Solfeo en el Conservatorio de Valencia desde febrero de 1902 y sustituyeron al método de solfeo de Hilarión Eslava. La Teoría General del Solfeo y las Lecciones Manuscritas Graduadas de Amorós se adoptaron como métodos en el Conservatorio valenciano en 1909 y 1911, respectivamente. En 1918 la Real Academia de Bellas Artes de San Fernando de Madrid declaró los métodos de Amorós Elementos de Solfeo, Nociones Teóricas de Solfeo y Lecciones Manuscritas Graduadas de utilidad para la enseñanza del solfeo y de mérito en la carrera de su autor.

Un aspecto hasta ahora poco subrayado de la labor realizada por Amancio Amorós es su contribución al conocimiento y difusión de la música valenciana, particularmente a través de la Biblioteca Musical Valenciana, publicación bimensual promovida por él que salió a la luz en 1894 y 1895, coincidiendo con los dos últimos años de Amorós en la presidencia de la Sección de Música de la asociación Lo Rat Penat. Aunque hasta ahora sólo se había localizado la portada del volumen 2 de la Biblioteca Musical Valenciana, en el curso de mi investigación he encontrado y estudiado tres volúmenes completos de la revista y alguna pieza suelta publicada en otros números. En el volumen $\mathrm{n}^{\mathrm{o}} 1$ (noviembre 1894), conservado en la Biblioteca de Catalunya y el Archivo de la Real Academia de Bellas Artes de San Fernando de Madrid, se publicaron composiciones de Salvador Giner, José Ma Úbeda, Roberto Segura y el propio Amancio Amorós. El volumen no 2 (enero 1895) de la Biblioteca Musical Valenciana (conservado 
en la Hemeroteca Municipal de Valencia y Biblioteca de Catalunya) contiene composiciones de Manuel Chulvi, Manuel Penella Raga, Francisco Javier Blasco, Eduardo Ximénez Cos y Juan Bautista Plasencia. El nº 3 (localizado en la hemeroteca de la Biblioteca Valenciana y Biblioteca de Catalunya) incluyó composiciones de Amancio Amorós, Roberto Segura y Manuel Penella Raga. Las obras editadas en esta colección eran quizás algunas de las partituras que los socios de Lo Rat Penat daban a conocer en las veladas literario-musicales de la entidad y posteriormente entregaban a la misma. Se trata de repertorio de salón de dificultad media o baja, para el deleite de la burguesía y de músicos aficionados, principalmente constituido por canciones líricas y obras para piano o piano y armónium. La Biblioteca Musical Valenciana dejó de publicarse en 1895, coincidiendo con el cese de Amancio Amorós como presidente de la Sección de Música de Lo Rat Penat.

Amancio Amorós mantuvo una relación amistosa con Felipe Pedrell, que firmó el prólogo a la segunda edición de los Elementos de Solfeo de Amorós y reconoció el valor pedagógico de sus tratados. En la Biblioteca de Catalunya se conservan siete cartas dirigidas por Amorós a Pedrell (ca. 1894-1915) en las que pueden seguirse algunos temas profesionales que interesaron a ambos músicos. Por esas cartas sabemos que Amorós estaba al corriente del proyecto Hispaniae Schola Musica Sacra de Pedrell (fue además uno de los suscriptores de esta publicación) y de las conferencias que Pedrell ofrecía en Madrid, que compartía con Pedrell su preocupación por la situación que atravesaba el género operístico en España y que le comentaba su visión sobre la enseñanza musical en Valencia y en particular en su Conservatorio. En varias de las cartas, Amorós mencionó haber enviado algunas de sus obras de salón a Pedrell, le comentó aspectos de sus tratados de solfeo e incluso le pidió consejo sobre la publicación de la Teoría General del Solfeo. La admiración que Amorós sentía por Pedrell se plasmó en el artículo 
"Impresiones", que el compositor de Agullent escribió para los Escritos heortásticos, publicación colectiva de homenaje a Pedrell en su 70 aniversario, promovida por iniciativa de Nemesio Otaño. En los Escritos heortásticos participaron, además de Amancio Amorós, un nutrido grupo de relevantes compositores y musicólogos españoles e internacionales, como Eduardo López-Chavarri Marco, Rafael Mitjana, Camile Bellaigue, Giovanni Tebaldini, Luis Millet, Vicente Ripollés, Henri Collet, Hugo Riemann y Dom Maur Sablayrolles, entre otros.

Una de las aportaciones de esta Tesis Doctoral es el catálogo completo de la producción musical de Amancio Amorós. Este autor compuso más de doscientas obras, según la memoria presentada para su nombramiento como Académico Correspondiente de la Real Academia de Bellas Artes de San Fernando de Madrid, aunque en las referencias bibliográficas publicadas hasta ahora eran muy pocas las obras citadas de Amorós. La investigación realizada me ha permitido localizar cuarenta y ocho composiciones conservadas actualmente en diversos archivos y bibliotecas españolas, y documentar con cierto detalle otras diecisiete composiciones hoy perdidas. Del total de obras localizadas, dieciséis llegaron a imprimirse y el resto se conservan sólo manuscritas (algunas de ellas con varias versiones). La mayor parte de las composiciones localizadas (cuarenta y tres manuscritos autógrafos) y la biblioteca personal del compositor (240 obras) se conservan desde 1930 en la Biblioteca de Catalunya, donde fueron entregadas en depósito por José Vicente Amorós Barra, hijo de Amancio Amorós.

En esta Tesis presento una aproximación al estilo compositivo de Amancio Amorós a partir de la edición y análisis de una selección representativa de diecisiete obras suyas de diferentes géneros musicales. En conjunto, la producción de Amorós se sitúa dentro del estilo tardo-romántico europeo, con elementos nacionalistas claramente visibles en algunas obras, en conexión con el movimiento estético de la Renaixença 
valenciana (que revalorizó el folklore valenciano y la música popular como base de inspiración creativa). La Sinfonía para gran orquesta sobre aires populares de Valencia y su reino, op. 69 (1890) es un claro ejemplo de plasmación de los ideales de la Renaixença valenciana en el campo sinfónico, y en ella Amorós utiliza materiales musicales de tres danzas populares valencianas (Danza valenciana de la Vall d'Albaida, la Xàquera Vella y la Danza dels nanos).

En la música de salón, Amorós maneja las habituales pequeñas formas para piano, como puede verse en el capricho Violetas y Mariposas, op. 1 (sf) y en las cuatro mazurcas, obras en las que revela su conocimiento de la técnica pianística con un lenguaje idiomático cercano al mundo pianístico de Chopin. Algunas obras camerísticas de Amorós experimentan con rasgos nacionalistas, como es el caso de la Col.lecció de huit peces per a piano i harmònium sobre motius populars valencians (1883), en la que Amorós incorporó melodías de danzas y bailes tradicionales valencianos, como las que interpretaban las dulzainas en las procesiones, las danzas de la Ribera del Júcar y de la comarca de la "Vall d'Albaida", y las ya desaparecidas en muchas localidades valencianas de "nanos i gegants" [enanos y gigantes], la jota de quintos y la jota valenciana conocida también como "la de l’U”. Estas últimas, la jota de quintos y "la de l'U', forman parte del repertorio conocido como cant valencià d'estil. La Renaixença propugnaba utilizar la lengua valenciana como medio de exaltación de la cultura propia, y Amorós siguió esta recomendación empleando el valenciano en algunas piezas para canto y piano, como Gemechs de cor (sf), Anyoranza [sic] (1882) y Lo cant del mariner (1894), y en parte de su producción coral profana (Costum de l'horta) y escénica (Chepeta).

Amorós compuso para la escena varias zarzuelas: Chepeta, El Majo, Viva España (no localizadas), Navegación Submarina (1885), Los dos esclavos (1886) y la parodia El tío Sappo (ca. 1880-1920). La zarzuela en tres actos Los dos esclavos, con letra de 
Antonio Roig Civera, es una obra muy trabajada desde el punto de vista melódico y armónico. Estrenada en enero de 1886, llegó a ser calificada por la crítica del momento como una ópera. La editorial Schott de Maguncia (Alemania) publicó las reducciones para voz y piano de los cuatro números más populares de esta zarzuela. Coincidiendo con el cultivo del género paródico en España, Amorós compuso El tío Sappo, parodia en un acto de Saffo (1840) de Pacini. Amorós utilizó los fragmentos que posiblemente más habían gustado de Saffo, rehaciendo melodías, tonalidades y motivos rítmicos en un nuevo contexto humorístico.

Amorós contribuyó personalmente a renovar la música religiosa valenciana como miembro de la Comisión de Música Sagrada de Valencia (ca. 1909/ 1912-1925) y, aunque algunas de sus piezas religiosas siguen el estilo romántico impregnado de influencias de la ópera italiana, otras se orientan a un estilo más austero y sobrio, siguiendo los cánones recomendados por el movimiento cecilianista y por las directrices del Motu Proprio de Pío X (1903). El contraste entre los dos estilos de música religiosa citados es evidente al comparar la Misa Ceciliana (1912) de Amorós, ejemplo del estilo codificado por el Motu Proprio, con su Misa en re menor (1882-1900), en la que emplea una amplia plantilla orquestal con influencias de la música escénica.

En conjunto, la personalidad de Amancio Amorós emerge como la de un singular creador, intérprete, pedagogo y gestor musical hasta ahora injustamente olvidado, que influyó activamente en el rico tejido musical valenciano de finales del siglo XIX y comienzos del siglo XX. Seguir la pista de su biografía y obra en múltiples campos de la actividad musical abre puertas a investigaciones más detalladas sobre las que será interesante poder profundizar en el futuro. Las composiciones de Amancio Amorós son una parte significativa del patrimonio musical valenciano contemporáneo que merece la 
pena recuperar no sólo como material de estudio, sino también como repertorio vivo que puede interesar a los oyentes actuales en salas de concierto y grabaciones discográficas. 
PRINCIPALES FUENTES CONSULTADAS 



\section{Biblioteca de Catalunya $(E: B c)$}

Si no se indica lo contrario, todas son obras de Amancio Amorós.

M 1271. M 1272.

El tío Sappo, parodia de Saffo de Giovanni Pacini.

Sinfonía para gran orquesta compuesta sobre aires populares de Valencia y su reino, op. 69.

M 1273.

Anyoranza [sic], op. 24.

M 1274.

Colección de ocho piezas para piano y armónium sobre motivos populares valencianos, op. 37.

M 1275.

Trío para violín, armónium y piano, op. 20.

M 1276.

Col.lecció de huit peces per a piano $i$ harmònium sobre motius populars valencians, op. 37.

M 1276 bis.

[Tres danses valencianes per a piano] Danza del chagans [sic], Danza dels nanos, Danza valenciana de la Vall d'Albaida [ms. no autógrafo]

M 1277.

Gozos a San José de Calasanz.

M 1278.

Idilio. Quinteto de cuerda y piano.

M 1279.

Tota pulchra, para coro y orquesta.

M 1280.

M 1281.

Salve a 4 voces, op. 60.

Domine dilexi decorem domus tua, para barítono y orquesta.

M 1282.

Los dos esclavos, zarzuela en tres actos, op. 50, partitura.

M 1283.

Corina, sinfonía para orquesta, op. 35 .

M 1284.

O salutaris Hostia, coro y solo.

M 1286.

O sacrum convivivum.

M 1287.

Pequeño himno popular religioso de la peregrinación al Eremitorio de San Vicente Ferrer en Agullent. Letra de José Peris Pascual, op. 88. Banda y coro popular.

M 1288.

Trists recorts [sic], nocturno para piano y armónium, op. 25.

M 1289.

Himno popular religioso. Letra de Martínez de la Rosa. Banda y coro popular. M 1290.

Memoriam fecit. 
M 1291.

Quam dilecta tabernacula tua, op. 110.

M 1292.

Final de Las siete Palabras.

M 1293.

M 1294.

Himno a Santa Cecilia, op. 68.

Himno a Santa Cecilia, op. 68.

M 1295.

O salutaris Hostia.

M 1296.

Los dos esclavos, zarzuela en tres actos, op. 50, letra de Antonio Roig Civera, libreto.

M 1297.

[Tres Misteris] Anónimos, Misteri de Sant Cristòfol [sic], Misteri de Adan y Eva M 1298.

[sic], Misteri del Rey Herodes [sic].

Credidi de $4^{\circ}$ tono.

M 1299.

Andante Marcial.

M 1300.

Salve a dos y coro.

M 1301.

Memoriam fecit.

M 1302.

Ave Maria.

M 1303.

Tratado de composición [ms. 73 pp.]

M 1304.

O sacrum convivium.

M 1305.

Trisagio a la Santísima Trinidad.

M 1306.

Cantemus Domino, op. 121.

M 1307.

Domine exaudi orationem meam.

M 1308.

Misa a dúo para voces de niños.

M 1309.

Gloria a España, op. 27.

M 1311.

Canción para canto y piano, op. 103.

M 1312.

Misa en re menor, op. 28.

M 1313.

Navegación submarina.

M 1314.

El drama del Calvario, op. 22. 
M 1384.

Beatus Vir qui timet Dominum, op. 111.

M 1386.

Cantemus Domino, a solo y coro, op. 121.

786.2.089.82 ZUR FOL.

Mazurca en Re bemol Mayor.

Mazurca en Sol Mayor.

Mazurca en re menor.

2009-Fol-1824.

Recuerdo de amor.

M 4128.

Violetas y mariposas.

2011-Fol-C 4/71.

Escenas poéticas $\mathrm{n}^{\mathrm{0}} 2$ Idilio, op. 100.

M 4259/24.

Lo cant del mariner.

2006-Fol- C 1/ 18.

Credidi de $4^{\circ}$ tono, a solo de tenor y barítono.

784.9 Amo-fol.

$\mathrm{M} 4285 / 2$

Elementos de Solfeo, $3^{\mathrm{a}}$ ed., 1901.

Teoría General del Solfeo, $1^{\mathrm{a}}$ ed., 1896.

F78-8-1917.

Nociones Teóricas de Solfeo, primer curso, 2a ed., 1908.

Nociones Teóricas de Solfeo, segundo curso, $1^{\mathrm{a}}$ ed., 1908.

Nociones Teóricas de Solfeo, tercer curso, $1^{\mathrm{a}}$ ed., 1909.

73-Fol-C 4/35.

Lecciones Manuscritas Graduadas, segundo curso, $1^{\text {a }}$ ed., 1910.

Lecciones Manuscritas Graduadas, tercer curso, $1^{\text {a }}$ ed.,1910

M 4128

Álbum Pianístico.

M 4220.

Álbum Musical.

Libro de Registro $n^{\circ} 24$ (1930-31).

\section{Archivo Nacional de Catalunya (E:Ban)}

Archivo 5 Sant Cugat, Fons 1, Administració Local, Padrón de Habitantes.

1916-1919, 2. 7; 5/103, caja 103.

$1920,2.7 ; 7 / 103$, caja 103 .

$1924,2.7 ; 2 / 104$, caja 104

$1925,2.7 ; 3 / 104$, caja 104 .

1926, 2. 7; 4/104, 5/104 caja 104.

\section{Registro Civil de Sant Cugat del Vallés (Barcelona)}

Libro de Defunciones, tomo 22, Certificado de Defunción de Amancio Amorós Sirvent. 


\section{Archivo Histórico Municipal de Valencia (E:VAa)}

Sección primera: Gobernación. Subsección A: Estadística. Clase I: Estadística de población.

Padrón Municipal de Valencia 1875-80

Índice de varones letra "T", legajo 307.

Legajo 268.

Legajo 274.

Legajo 276.

Padrón Municipal de Valencia 1889

Índice de varones letra "A", legajo 429.

Legajo 657 .

Padrón Municipal de Valencia 1899

Índice de mujeres letra "A", legajo 509.

Índice de varones letra “A”, legajo 675.

Legajo 504.

Sección Primera: Gobernación. Subsección LL: Banda Municipal.

Clase I: Músicas municipales, subclase A. Creación, Reglamentación, Disolución (1859-1869).

$1859 \mathrm{n}^{\circ} 1$, Creación de una Música Municipal.

$1860 n^{\circ} 1$, Música de la ciudad.

$1869 \mathrm{n}^{\circ}$ 1, Creación de una banda militar de música titular del Ayuntamiento,

Acta Municipal de la sesión celebrada por el Ayuntamiento Popular de Valencia, 16-IV-1869.

Banda Municipal. En proceso de catalogación, 45 cajas (1901-1942).

1902, caja 2.

Libro de Actas Comisión especial de creación de una Banda Municipal.

Expediente sobre Reglamento de la Banda Municipal.

1903, caja 4.

Oficio de la Alcaldía comunicando al Presidente de la Comisión de Personal el nombramiento de Santiago Lope para Director de la Banda Municipal.

Sección Tercera: Fomento. Subsección G: Instrucción Pública.

Clase II: Enseñanza Superior. Subclase C. Escuelas Especiales (1850-1900).

$1883 \mathrm{n}^{\circ}$ 1, La sociedad Económica de Amigos del País, solicita una subvención para establecer en esta capital una escuela de comercio para señoras.

$1886 n^{\circ}$ 1, La sociedad de Amigos del País solicita la subvención de 2000 pesetas en favor de la escuela de comercio para señoras.

Clase III: Enseñanza Artística y Literaria. Subclase B: Escuelas de música (18651902).

$1865 \mathrm{n}^{\mathrm{o}}$ 1, Circular del Sr. Gobernador relativa a las escuelas de música existentes en esta ciudad y el estado y progreso de las mismas.

$1867 \mathrm{n}^{\circ}$ 1, Establecimiento de la sección de música en la escuela normal de niñas de esta ciudad.

1867 n 2 2, Petición de D. Manuel Penella, profesor de música en el Colegio de S. Nicolás, ofreciendo enseñanza a niños pobres de las Escuelas del Ayuntamiento. 
1880 n $^{\circ}$ 4, D. Eduardo Senís Zafrané, profesor de música solicita establecer una escuela de música y enseñar gratis los niños que le mande el Ayuntamiento si éste le concede local.

$1880 \mathrm{n}^{\mathrm{o}} 2, \mathrm{D}^{\mathrm{a}}$. Consuelo del Rey y Fernández, profesora de una de las escuelas publicas de música, solicita aumento de sueldo.

$1884 \mathrm{n}^{\circ}$ 1, Emilia Lacombe invita al Sr. Presidente de la Junta local a asistir a una velada musical.

$1892 \mathrm{n}^{\circ}$ 1, La Comisión propone al Excelentísimo Ayuntamiento se concedan algunas gratificaciones a los maestros de Música.

$1892 \mathrm{n}^{\mathbf{0}}$ 4, Salvador Escrivá Grajales pide se le conceda el ingreso en el Conservatorio de Música para cursar el segundo año de solfeo como alumno subvencionado.

$1892 \mathrm{n}^{\mathrm{o}}$ 7, Pedro Esteve y Villanueva y otros solicitan su ingreso en el Conservatorio como alumnos subvencionados por el Excelentísimo Ayuntamiento.

$1893 \mathrm{n}^{\mathrm{o}}$ 1, Se propone la concesión de una gratificación a las profesoras de las Escuelas Municipales de Música.

$1893 \mathrm{n}^{\mathrm{o}} 2, \mathrm{D}^{\mathrm{a}}$ Desamparados Mongrell ofrece presentar enseñanza gratuita de música a las alumnas pobres que le designe el Excelentísmo Ayuntamiento.

1893 n $^{\circ}$ 13, D. José Cros y Fernández solicita se concedan al nuevo Orfeón Valenciano titulado El Micalet los beneficios que disfrutaba el antiguo, consistentes en local para academias y exención del impuesto sobre licencias para serenatas.

$1894 n^{\circ}$ 4, D ${ }^{a}$ Encarnación Avellán solicita la creación de una escuela de música para niñas en el distrito del Mercado.

$1894 \mathrm{n}^{\circ}$ 6, Enrique Carrasco Navarro solicita la creación de una escuela de música.

\section{Archivo del Conservatorio Superior de Música de Valencia (E:VAcm)}

Libro de Actas de los exámenes de ingreso en el Conservatorio de Música de Valencia (1879-1883).

Libro Actas de Exámenes Ordinarios y Extraordinarios (1908-1912).

Libro de Actas de las reuniones celebradas por la Junta General (28-II-1879 a 9-VII1892).

Libro de Actas de las reuniones celebradas por la Junta General (6-I-1893 a 27-XII1910).

Libro de Actas de la Junta Directiva del Conservatorio de Música de Valencia (8-III1879 a 31-III-1908).

Libro de Actas de la Junta Directiva del Conservatorio de Música de Valencia (29-IV1908 a 23-X-1910).

Libro de Actas del Claustro de Profesores del Conservatorio de Música de Valencia (19$\mathrm{X}-1879$ a 1-IV-1908).

Libro de Actas del Claustro de Profesores del Conservatorio de Música de Valencia (4IV-1908 a 10-XI-1916).

Libro de Actas del Claustro de Profesores del Conservatorio de Música de Valencia (4-I1917 a 23-III-1920).

Libro de Actas del Claustro de Profesores del Conservatorio de Música de Valencia (20X-1920 a 21-IV-1929). 
Libro de Actas de tomas de posesión y ceses del profesorado del Conservatorio de Música de Valencia (18-X-1920 a 26-II-1960).

Libro de Actas de la Junta Económica del Conservatorio de Música de Valencia (31-X1921 a 31-XII-1983).

Libro de Actas de la Junta de Gobierno del Conservatorio de Música de Valencia (4- I1917 a 23-III-1920).

SF-I/1-3, Tres lecciones de solfeo manuscrito a una y dos voces con acompañamiento de armónium y piano de Amancio Amorós.

\section{Archivo de la Real Sociedad Económica de Amigos del País de Valencia (E:VAseap)}

Libro de Actas de la Junta de Gobierno de la Sociedad Económica (1865-1898).

Libro de Actas de la Sección de Bellas Artes de la Económica, vol. 12 (1869-1905).

1875. C. 196 VII-Varios

$\mathrm{n}^{\mathrm{o}}$ 1. Premios que ofrece la Real Sociedad Económica en el Certamen extraordinario de su primer centenario.

$\mathrm{n}^{\mathrm{o}}$ 5. Premios que ofrece la Real Sociedad Económica en el Certamen extraordinario de su primer centenario.

1876. C. 201

$\mathrm{n}^{\mathrm{o}}$ 1. Obras musicales premiadas por la Sociedad en el certamen extraordinario conmemorativo de su primer centenario. Su autor: Felipe Pedrell.

$\mathrm{n}^{\mathrm{o}}$ 2. Obras musicales premiadas por la Sociedad en el certamen extraordinario conmemorativo de su primer centenario. Su autor: Felipe Pedrell.

1876. C. 202

$\mathrm{n}^{\mathrm{o}} 1$. Obras musicales premiadas por la Sociedad en el certamen extraordinario conmemorativo de su primer centenario. Su autor: Felipe Pedrell.

$\mathrm{n}^{\mathrm{o}}$ 2. Obras musicales premiadas por la Sociedad en el certamen extraordinario conmemorativo de su primer centenario. Su autor: Felipe Pedrell.

1879. C. 211, XXI-Varios

$\mathrm{n}^{\mathrm{o}}$ 40. Comunicado del Conservatorio para la celebración de la primera de las sesiones clásicas que se celebrarán en los salones de la Económica.

1883. C. 222, III-Educación

$\mathrm{n}^{\mathrm{o}} 10$. Propuesta de premios de la Sección de Educación para 1883.

$\mathrm{n}^{\mathrm{o}}$ 11. Documentación relativa a la creación de la Escuela de Comercio para Señoras.

$\mathrm{n}^{\mathrm{o}} 16$. Documentación relativa a las escuelas públicas y privadas que existen en la ciudad de Valencia, En este mismo legajo se puede consultar el Reglamento del Ateneo casino Obrero de Valencia.

1883. C. 226, XX-Comisión exposiciones

$\mathrm{n}^{\mathrm{o}}$ 12. Memoria sobre la Exposición Regional de Agricultura, Industria y Artes celebrada en Valencia en 1883.

$\mathrm{n}^{\mathrm{o}}$ 12.1. Memoria sobre la Exposición Regional de Agricultura, Industria y Artes celebrada en Valencia en 1883.

$\mathrm{n}^{\mathrm{o}}$ 16. Reglamento-programa para la Exposición Regional de Agricultura, Industria y Artes de julio de 1883, organizada por la Sociedad Económica. 
1883. C. 227, XX-Comisión exposiciones

$\mathrm{n}^{\mathrm{o}}$ 16. Reglamento-programa de la Exposición Regional de Agricultura, Industria y Artes de Julio de 1883, organizada por la Sociedad Económica.

$\mathrm{n}^{\mathrm{o}}$ 18. Registro de entrega de diplomas y medallas de la Exposición Regional de 1883.

$\mathrm{n}^{\mathrm{o}}$ 23. Relación de obras que los Catedráticos del Instituto y Escuela de Bellas Artes y un profesor de la Escuela Normal de esta ciudad presentan a la Exposición Regional de 1883.

1883. C. 230, XX-Comisión-exposiciones

$\mathrm{n}^{\mathrm{o}}$ 2.2. Documentación relativa a los premios concedidos por el jurado de la Exposición Regional de 1883.

1884. C. 231, XII-Correspondencia de Sociedades

$\mathrm{n}^{\mathrm{o}}$ 2. Documentación relativa al reglamento por el que ha de regirse la Academia de la Juventud Católica de Valencia.

1888. C. 246, Música

$\mathrm{n}^{\mathrm{o}}$ 3. Invitación remitida por el Conservatorio a la Económica para que asista al Concierto que se efectuará en sus salones.

$\mathrm{n}^{\mathrm{o}}$ 4. Invitación remitida por el Conservatorio a la Económica para que asista a la solemne audición en honor a Santa Cecilia.

$\mathrm{n}^{\mathrm{o}} 5$. Documentación del Conservatorio y la Academia de la Juventud Católica de Valencia relativa a la cesión, a dicha Academia del salón de audiciones para una velada musical.

$\mathrm{n}^{\mathrm{o}}$ 6. Documentación relativa a conciertos celebrados por la Económica en dicho año. Incluye invitaciones y programas.

1888. C. 246, X-Contabilidad

$\mathrm{n}^{\mathrm{o}} 11$. Libramiento de pago de ciertas cantidades en concepto de subvenciones para el Conservatorio de Música y Escuela de Comercio.

1891. C. 255 , III-Educación

$\mathrm{n}^{\mathrm{o}}$ 8. Folleto relativo al espíritu que anima y al funcionamiento de la Institución para la Enseñanza de la Mujer.

1892. C. 258, III-Educación

$\mathrm{n}^{\mathrm{o}}$ 1. Documentación relativa a la constitución de la Institución para la Enseñanza de la Mujer y su Reglamento. Incluye ejemplar de dicho Reglamento.

\section{Archivo Histórico de la Universidad de Valencia (E:VAu)}

Sección Expedientes Académicos (Ex)

caja 713, legajo 13 (Expediente de reválida de José Vicente Amorós Barra). caja 932, legajo 25 (Expediente $\mathrm{M}^{\mathrm{a}}$ Purificación Amorós Barra).

caja 1214, legajo 1 (Expediente de José Vicente Amorós Barra, licenciado en Filosofía y Letras, sección de Historia, curso 1907-1908).

Sección Enseñanza Media (EM)

caja 24, legajo 11. Amorós en la Institución para la Enseñanza de la Mujer (19001901). 


\section{Archivo de la Real Academia de Cultura Valenciana, antiguo Centro de Cultura Valenciana (E:VAac)}

Actas de la Junta del Centro de Cultura Valenciana (1915-1927).

Legajo Directores Consiliarios de Arte (1921).

Carta de Amancio Amorós al Centro de Cultura Valenciana, 7-IV- 1921.

Carta del Ateneo Musical de Valencia al Centro de Cultura Valenciana, 8-VI1921.

Disposiciones Reglamentarias.

\section{Archivo del Real Colegio del Corpus Christi de Valencia (E:VAcp)}

Si no se indica lo contrario, todas son obras de Amancio Amorós.

CM-A-21.

Beatus vir qui timet Dominum [Ms], para terceto (tiple, tenor y bajo) y coro con acompañamiento de quinteto de cuerda y órgano.

CM-A-20.

Beatus vir [Ms], a 3 y 7.

EDB-311.

Corazón de Dios amable [Ms], plegaria al Corazón de Jesús para voz de Tiple o Tenor.

EDB-1334.

Recibid mil parabienes, "Salutación al Patriarca San José".

EDB-1337.

Pues sois Santo sin igual, "Gozos al Patriarca San José”.

\section{Archivo Diocesano de Valencia}

Almanaque Eclesiástico de la Diócesis de Valencia (1913-1919).

Boletín Oficial del Arzobispado de Valencia (1893, 1913-1919).

11. Biblioteca Musical de Compositores Valencianos del Ayuntamiento de Valencia $(E: V A b m)$

$1 \mathrm{~A} \mathrm{n} \mathrm{n}^{\mathrm{o}} 31$

Quam dilecta tabernacula tua.

Credidi de $4^{\circ}$ tono.

Ave Maria.

O salutaris Hostia, op. 61.

Acepta Virgen Pura.

O salutaris Hostia, a solo.

Recibid mil parabienes, "Salutación al Patriarca San José".

Pues sois Santo sin igual, "Gozos al Patriarca San José". 


\section{Biblioteca Municipal de Valencia $(E: V A m)$}

NC 5/1515. Biblioteca Musical Valenciana, vol. 2.

13. Biblioteca Valenciana (antiguo Monasterio de San Miguel de los Reyes de Valencia) $(E: V A b v)$

E. López-Chavarri/3365.

Elementos de Solfeo, $10^{\mathrm{a}} \mathrm{ed}$. (sf).

NP77-79/F83.

Nociones Teóricas de Solfeo, primer curso, $2^{\mathrm{a}}$ ed., 1911.

NP77-79/F84.

Nociones Teóricas de Solfeo, tercer curso, nueva ed.,1924.

E. López-Chavarri/3365.

Lecciones Manuscritas Graduadas, segundo curso, 1910.

E. López-Chavarri/3365.

Lecciones Manuscritas Graduadas, tercer curso, 1910.

Bas Carbonell/2924-26.

Roig Civera, Los dos esclavos (libreto).

NP77-79/F270.

Biblioteca Musical Valenciana, vol. 3 (1895).

AELCH/pro 491.

Cantos y danzas populares de la región valenciana, coleccionados en mis excursiones y tomados por mí al oído directamente en su mayoría [Manuscrito de Eduardo López-Chavarri Marco].

Mss/643-20.

A les danses d'Agullent.

14. Archivo Municipal de Agullent (Valencia) (E:AGm)

Libro de Actas Municipales (1884, 1893).

15. Archivo Parroquial de San Bartolomé Apóstol de Agullent (E:AG)

Quinque Libri, Libro IX, 55v, 16-IX-1854, no 35.

16. Archivo Parroquial de El Salvador de Cocentaina (Alicante) $(E: C O s)$

Quinque Libri (1867-1872), 12v, 19v, 20v, 39v, 40v, 53v, 201, 325v.

\section{Archivo particular de Vicente Fuentes (Bétera, Valencia)}

Himno a la Santísima Cruz.

A la Santa Pastoral. 


\section{Archivo del Real Conservatorio de Música y Declamación de Madrid (E:Mc)}

Libros de pago derechos de matrícula y exámenes (1865-1877, 1877-1887, 1887-1899, 1899-1906). Microfilm.

Actas de exámenes (1872-1880). Microfilm.

Actas de exámenes. Enseñanza Libre, Exámenes extraordinarios (1875-1879).

Actas de exámenes. Enseñanza Libre, Pagos de matrícula (1901-1909). Microfilm.

Actas de exámenes, generales y extraordinarios (1865-1878). Microfilm.

Actas de exámenes, generales y extraordinarios (1878-1880). Microfilm.

Actas de exámenes, generales y extraordinarios (1865-1878). Microfilm.

\section{Real Academia de Bellas Artes de San Fernando en Madrid (E:Mba)}

Relación general de Académicos de la Real Academia de Bellas Artes de San Fernando (1752-2010).

Académicos Correspondientes (1921)

legajo 5-101-2.

legajo 5-2-1.

legajo 5-2-2. Expediente de nombramiento de Amancio Amorós como Académico Correspondiente elaborado en 1921 por los Académicos Pedro Fontanilla, Narciso Sentenach y Joaquín Larregla.

legajo 5-118-1. Expediente de nombramiento de José Vicente Amorós Barra.

Actas de las Sesiones particulares, ordinarias, generales, extraordinarias, públicas y solemnes de la Real Academia de Bellas Artes de San Fernando (1921).

Libro de Actas de las sesiones celebradas por la Sección de Música de la Academia de Bellas Artes de San Fernando de Madrid (1902-1927), legajo 3-133.

Reglamento interior de la Real Academia de Bellas Artes de San Fernando, Madrid, Imprenta de S. Francisco de Sales, 1914, legajo 4-51-3.

Solfeo- Estudio y enseñanza

M-210. Amorós, Amancio: Lecciones Manuscritas Graduadas, tercer curso de solfeo (1914).

M-211. Amorós, Amancio: Elementos de Solfeo, $4^{\mathrm{a}}$ ed., sf.

Misas (Música)

M-3086. Amorós, Amancio: Misa Ceciliana a tres voces iguales y coro popular homófono, Madrid, Casa Dotesio [1912].

Improvisación (Música)

LQ-493. Querol Roso, Leopoldo: Impromptu para piano, Valencia, ca. 1916 (5 pp). Dedicatoria autógrafa del autor a su maestro Amancio Amorós.

Música para piano

LQ-590. Amorós, Amancio (dir.): Biblioteca Musical Valenciana, vol. 1 (1894).

FJIM-147. Blasco y Compans, Justo: Tu y yo, cantinela para canto y piano/Música de Justo Blasco y Compans, letra de J. Selgas. Mazurca en re menor/ Amancio Amorós [Partitura], Madrid, A. Romero, 1891. 2 partituras, (10 pp.). 


\section{Archivo de la Sociedad General de Autores y Editores en Madrid (E:Msa)}

Si no se indica lo contrario, todas son obras de Amancio Amorós.

A-942/19.

Ave Maria. Ildefonso Alier, ed. (I. A. 2385).

A-948/20.

Credidi de $4^{\circ}$ tono. Ildefonso Alier, ed. (I. A. 2661).

A-944/20.

Gozos al patriarca San José. Ildefonso Alier, ed. (I. A. 2340).

Me-24202-3/401.

Lecciones Manuscritas Graduadas, segundo y tercer curso. UME, ed. (C 41976

D).

A-943/19.

Misa Ceciliana. Casa Dotesio, ed. (C 42395 D).

A-946/19

O salutaris Hostia. Ildefonso Alier, ed. (I. A. 2660).

A-947/20.

O salutaris Hostia. Ildefonso Alier, ed. (I. A. 2663).

A-945/20.

Salutación al Patriarca San José. Ildefonso Alier, ed. (I. A. 2341).

\section{Biblioteca Nacional de España en Madrid (E:Mn)}

M-2622.

Elementos de Solfeo, $1^{\text {a }}$ ed., ca. 1889-1891.

$\mathrm{M}-8642$.

Elementos de Solfeo, $4^{\mathrm{a}}$ ed., sf.

M. FOLL/127/13.

Nociones Teóricas de Solfeo, primer curso, $1^{a}$ ed., 1908.

M. FOLL/127/12.

Nociones Teóricas de Solfeo, primer curso, nueva ed. Sevilla, 1927.

$\mathrm{VC} / 430 / 18$

Nociones Teóricas de Solfeo, segundo curso, $1^{\mathrm{a}}$ ed., 1908.

$\mathrm{M} / 1747$.

Teoría General del Solfeo ilustrado con profusión de ejemplos y con un programa teórico de esta asignatura ordenado según el plan de enseñanza de la Escuela Nacional de Música y Declamación, del Conservatorio de Valencia y de otros centros docentes de España y del extranjero, $1^{\mathrm{a}}$ ed., 1896. $\mathrm{M} / 2921$

Lecciones Manuscritas Graduadas, segundo curso, $1^{\mathrm{a}}$ ed., 1909.

$\mathrm{MP} / 2804 / 11$.

Lecciones Manuscritas Graduadas, tercer curso, $2^{\mathrm{a}}$ ed., 1914. $\mathrm{M} / 1761$.

Navegación Submarina. Reducción autógrafa para piano (73pp.). M 1020.

Eduardo Ximénez, Música de los Cantos y danzas populares de Valencia y su provincia transmitidos al papel y coleccionados por el profesor de música valenciano Eduardo Ximénez [Manuscrito]. 


\section{Fuentes hemerográficas}

Almanaque de las Provincias (1879-1928).

Anales de la Sociedad Económica de Amigos del País de Valencia, 1876-1882.

Anuario de la Real Academia de Bellas Artes de San Fernando (Madrid), 1921-1925.

Biblioteca Musical Valenciana (1894-1895).

Biblioteca Sacro Musical (1892, 1893, 1906).

Boletín de la Sociedad Económica de Amigos del País de Valencia, 14 (1874).

Boletín Musical, Valencia (1892-1900).

Boletín Oficial del Arzobispado de Valencia (1893, 1904-1905, 1912-1913, 1919)

Boletín-Revista de la Juventud Católica de Valencia, 1 (1880), 13 (1882), 53 (1885), 54 (1885), 56 (1886).

Crónica de la Música $(1880,1892)$.

Diario Mercantil de Valencia (1853-1863).

Diario oficial de avisos de Madrid, 19-VI-1892.

El Arte (Madrid), 18-I-1874.

El Criterio, 25-V-1893.

El Fénix, 14-XII-1845.

El imparcial, 23-XI-1917.

El jardín musical (1875).

El Mercantil Valenciano (1880-1882, 1886, 1890, 1895, 1902-1903, 1925).

El Valenciano, 13-VI-1893.

Gaceta de Madrid, 10-IX-1857.

Gaceta Musical y de Teatros (1897).

Indicador General de Valencia (1895).

Ilustración Musical Hispanoamericana, Barcelona (1888-1896).

La Correspondencia de Valencia (1902).

La Educación, 10-VI-1911.

La Época (Madrid), 20-III-1901.

La Ilustración Valenciana: ciencias, letras y artes, 15-I-1887.

La Música Ilustrada Hispano-Americana, 15-VII-1900.

La Música Religiosa en España (1896-1899).

La Opinión, 26-X-1862.

La Vanguardia, 10- II-1925.

La Verdad, 1-I-1869.

La Voz de Valencia (1902).

Las Provincias (1876, 1878, 1879, 1887, 1888, 1893, 1894, 1895, 1897, 1902, 1912).

Letras y figuras (1911).

Lo Rat Penat: periodich lliterari quincenal (1884-1885).

Oro de ley $(1917,1918,1919)$.

Revista contemporánea, 83 (1891).

Revista de Valencia, agosto 1883.

Revista Musical Hispano-Americana (1915).

Revista Musical, 11 (1911).

Tesoro Sacro Musical, 43 (1972).

Valencia Ilustrada (1878). 


\section{Fuentes jurídicas}

Boletín Oficial de la Provincia de Valencia, 10-IV-1903.

Real Decreto disponiendo que las Corporaciones provinciales que sostengan Conservatorios y Escuelas de Música y deseen que los estudios en ellos cursados tengan validez académica soliciten su incorporación al Conservatorio de Madrid, Gaceta de Madrid, 17-V-1905, p. 1108.

Real Orden de 26-IV-1911 concediendo validez académica a los estudios de Solfeo y elementales de Piano y Violín, que se cursen en el Conservatorio de Música de Valencia, como incorporado al de Madrid, Gaceta de Madrid, 29-IV-1911, p. 219.

Real Decreto de 16-XI-1917 declarando incorporado a las enseñazas del Estado el Conservatorio de Música y Declamación de Valencia, Gaceta de Madrid, 17-XI1917, p. 340.

Real Decreto de 8-X-1920 relativo a la plantilla del profesorado y personal administrativo y subalterno del Conservatorio de Música y Declamación de Valencia, Gaceta de Madrid, 9-X-1920, p. 159.

Real Orden de 14-X-1920 confirmando la plantilla que se indica del profesorado del Conservatorio de Música y Declamación de Valencia, Gaceta de Madrid, 16-X1920, p. 238.

Real Orden de 27-XI-1920 nombrando a D. Vicente Ripollés y Pérez profesor interino del Conservatorio de Música y Declamación de Valencia, en Gaceta de Madrid, 8-XII-1920, p. 1029.

Real Orden de 12-V-1921 disponiendo se convoquen plazas de profesores auxiliares vacantes en el Conservatorio de Música y Declamación de Valencia, Gaceta de Madrid, 16-V-1921, p. 603.

Real Orden de 17-X-1924 concediendo un mes de prórroga a la licencia que, por enfermo, viene disfrutando D. Amancio Amorós Sirvent, Director y Profesor del Conservatorio de Música y Declamación de Valencia, Gaceta de Madrid, 19-X1924, p. 326.

Real Orden de 13-XII-1924 nombrando Director del Conservatorio de Música y Declamación de Valencia al profesor numerario D. José Bellver Abellá, Gaceta de Madrid, 24-XII-1924, p. 1369.

Real Orden de 2-XII-1924 aceptando a D. Amancio Amorós la renuncia del cargo de Director del Conservatorio de Música y Declamación de Valencia, Gaceta de Madrid, 5-XII-1924, p. 1103. 

BIBLIOGRAFÍA 

AA.VV.: Crónica de un centenario, Valencia, Conservatorio Superior de Música de Valencia, Departamento de Solfeo y Teoría de la Música, Servicio de Publicaciones, 1983.

: Diccionari Enciclopèdic, Barcelona, Salvat, 1999.

: Escritos heortásticos al Maestro Pedrell, 2 vols., Tortosa, Casa Social del Orfeó Tortosí, 1911.

Aaron Clark, Walter: Retrato de un romántico, Madrid, Turner, 2002.

: Enrique Granados: Poet of the piano, Oxford, Oxford University Press, 2006.

Abellán, José Luis: Historia del pensamiento español: de Séneca a nuestros días, Madrid, Espasa Calpe, 1996.

Adam Ferrero, Bernardo: Las bandas de música en el mundo, Madrid, Sol, 1986.

: "Amorós Sirvent, Amancio", en Músicos Valencianos, Valencia, Proip, S. A., 1992, p. 28.

: 1000 Músicos Valencianos, Valencia, Sounds of Glory, 2003.

: “Alcácer Martínez, José María”, en 1000 músicos valencianos, Valencia, Sounds of Glory, 2003, pp. 96-97.

: "Giner, Salvador”, en 1000 Músicos Valencianos, Valencia, Sounds of Glory, 2003, p. 384.

: "Soriano, Manuel", en 1000 Músicos Valencianos, Valencia, Sounds of Glory, 2003, p. 769.

: "Úbeda Montés, José María", en 1000 Músicos Valencianos, Valencia, Sounds of Glory, 2003, pp. 809-810.

Aguilera Cerni, Vicente (dir.): Historia del Arte Valenciano, Valencia, Consorci d'editors valencians, vol. 6, 1986.

Albertí, Santiago (ed.): “Amorós Sirvent, Amancio", en Diccionari Biogràfic, 4 vols., 1966-1970, Barcelona, vol. 1 (1966), p. 118.

Alborg Escarti, Juan Luis: Realismo y Naturalismo. La novela III. A. Palacio Valdés - V. Blasco Ibáñez, Madrid, Gredos, 1999.

Alcázar, Joan del: "La primera Guerra Mundial i la Dictadura de primo de Rivera", en Història del País Valencià, coord. Ernest Belenguer, 6 vols., 1988-2006, Barcelona, Edicions 62, vol. 5 (1990), pp. 257-286. 
Aleixandre Tena, Francisca: Catálogo documental del archivo de la Real Sociedad Económica de Amigos del País de Valencia 1776-1876, Valencia, Caja de Ahorros de Valencia, 1978.

Alemany Ferrer, Victoria: Metodología de la técnica pianística y su pedagogía en Valencia, 1870-1916, Tesis Doctoral, Valencia, Universidad Politécnica de Valencia, Departamento de Comunicación Audiovisual, Documentación e Historia del Arte, 2006.

Alén Garabato, Pilar: "La Música en Galicia: del piano de salón a las masas corales”, en Galicia e América. Música, Cultura e Sociedade arredor do 98, Santiago de Compostela, Tórculo Artes Gráficas, 1999, pp. 73-101.

: "La edad de oro de las melodías gallegas (ca. 1890-1915)", en Homenaje a José García Oro, eds. M. Romaní y M Ángeles Novoa, Santiago de Compostela, Servicio de publicaciones de la Universidad de Santiago, 2002, pp. 375-382.

: "Reflexiones sobre el ambiente musical en La Coruña (1920-1980) a través del Fondo Bugallal", en Campos Interdisciplinares de la musicología, Quinto Congreso de la Sociedad Española de Musicología (Barcelona, 2000), ed. Begoña Lolo, 2 vols., Madrid, Sociedad Española de Musicología, 2002, vol. 1, pp. 213234.

: "Reflexiones sobre un siglo de música gallega (ca. 1808-1916)", Revista de Musicología, 30/1 (2007), pp. 49-102.

Alfonso, $\mathrm{M}^{\mathrm{a}}$ de los Ángeles: "Habanera", en Diccionario de la Música Española e Hispanoamericana, dir. Emilio Casares, 10 vols., Madrid, Sociedad General de Autores y Editores, 1999-2002, vol. 6 (2000), pp. 177-178.

Algarra Pardo, Victor: "La anexión de los poblados periféricos", en Historia de Valencia, dir. Antoni Furió, Valencia, Prensa Valenciana (Levante) y Universitat de València, 1999, pp. 507-510.

Alonso González, Celsa: "Los salones: un espacio musical para la España del XIX", Anuario Musical, 48 (1993), pp. 165-205.

: La canción lírica española en el siglo XIX, Madrid, Instituto Complutense de Ciencias Musicales, 1998.

: “La música española y el espíritu del 98", Cuadernos de Música Iberoamericana, 5 (1998), pp. 79-107.

: "Benavent, Ricardo", en Diccionario de la Música Española e Hispanoamericana, dir. Emilio Casares, 10 vols., Madrid, Sociedad General de Autores y Editores, 1999-2002, vol. 2 (1999), p. 352.

: "Nacionalismo", en Diccionario de la Música Española e Hispanoamericana, dir. Emilio Casares, 10 vols., Madrid, Sociedad General de Autores y Editores, 1999-2002, vol. 7 (2000), pp. 924-935. 
: "Un espacio de sociabilidad musical en la España romántica: las sociedades instructo-recreativas", Cuadernos de Música Iberoamericana, 8-9 (2001), pp. $17-40$.

Álvarez, Ángeles [et al.]: 150 Años del cuerpo de Bomberos de Valencia 1857-2007, Valencia, Ajuntament de València, 2007.

Álvarez Cañibano, Antonio: "La zarzuela en Andalucía", en La zarzuela en España e Hispanoamérica. Centro y periferia, 1800-1950, Actas del Congreso Internacional (Madrid, 1995), Cuadernos de Música Iberoamericana, 2-3 (19961997), pp. 351-362.

Amorós Sirvent, Amancio: Teoría General de Solfeo razonada en forma de diálogo y con un programa teórico de la asignatura ordenado según el plan de enseñanza de la Escuela Nacional de Música y Declamación, del Conservatorio de Música de Valencia y de otros centros docentes de España y del Extranjero, Valencia, Manuel Alufre, $1^{\text {a }}$ ed., 1896.

: Elementos de solfeo por Amancio Amorós, maestro de capilla de la Iglesia de las Adoratrices de Valencia, profesor de las Escuelas Pías e ídem Honorario del Conservatorio de Música de Valencia, con un prólogo de D. Salvador Giner, Director del Conservatorio de Música de Valencia, y el dictamen de la obra por D. Felipe Pedrell, profesor de la Escuela Nacional de Música y Declamación, Valencia, Tipografía Moderna Miguel Gimeno, $3^{\text {a }}$ ed., 1901.

: Nociones Teóricas de Solfeo por Amancio Amorós. Profesor numerario por oposición de solfeo y armonía en el Conservatorio de Música de Valencia. Esta obra es de aplicación a todos los métodos prácticos de solfeo y sirve para el estudio de esta asignatura en las escuelas municipales de música, conservatorios $y$ escuelas normales. Segundo curso, Valencia, Tipografía Moderna Miguel Gimeno, $1^{\text {a }}$ ed., 1908.

: Nociones Teóricas de Solfeo por Amancio Amorós. Profesor numerario por oposición de solfeo y armonía en el Conservatorio de Música de Valencia. Esta obra es de aplicación a todos los métodos prácticos de solfeo y sirve para el estudio de esta asignatura en las escuelas municipales de música, conservatorios $y$ escuelas normales. Tercer curso, Valencia, Tipografía Moderna Miguel Gimeno, $1^{\text {a }}$ ed., 1909.

: Lecciones Manuscritas Graduadas. Segundo curso, Valencia, Sociedad Anónima Casa Dotesio, $1^{\mathrm{a}}$ ed., 1910.

: Lecciones Manuscritas Graduadas. Tercer curso, Valencia, Sociedad Anónima Casa Dotesio, $1^{\text {a }}$ ed., 1910.

: Nociones Teóricas de Solfeo por Amancio Amorós. Profesor numerario por oposición de solfeo y armonía en el Conservatorio de Música de Valencia. Esta obra es de aplicación a todos los métodos prácticos de solfeo y sirve para el estudio de esta asignatura en las escuelas municipales de música, conservatorios 
y escuelas normales. Primer curso, Valencia, Tipografía Moderna Miguel Gimeno, $2^{\text {a }}$ ed., 1911.

: "Impresiones", en Escritos Heortásticos al Maestro Pedrell, Tortosa, Casa Social del Orfeó Tortosí, 1911, pp. 259-261.

Andrés-Viergé, Marcos: Fernando Remacha. El compositor y su obra, Madrid, Instituto Complutense de Ciencias Musicales, 1998.

Anónimo: "Academia Científico Literaria de la Juventud Católica de Valencia", Almanaque de las Provincias para 1890, pp. 245-249.

: "Academia Científico Literaria de la Juventud Católica de Valencia", Almanaque de las Provincias para 1891, pp. 305-309.

: "Bellas Artes”, La Enseñanza, 19-I-1924, pp. 90-91.

: "Centro de Cultura Valenciana", Almanaque de las Provincias para 1923, pp. 115-116.

: "Centro de Cultura Valenciana", Almanaque de las Provincias para 1916, pp. 137-140.

: “Centuria Teatral”, Almanaque de las Provincias para 1899, pp. 279- 304.

: Colegio de las Escuelas Pías, Reseña de la visita del Excelentísimo y Reverendísimo p. Alfonso $M^{a}$ Mistrangelo, Prepósito General de las Escuelas Pías, al Colegio Andresiano de Valencia: año 1900, Valencia, Imprenta de Manuel Alufre, 1901.

: "Conservatorio de Música y declamación", Almanaque de las Provincias para 1913, pp. 147-148.

: "Dos nuevos teatros en Valencia", Almanaque de las Provincias para 1916, pp. 155-156.

: "El Conservatorio de Música de Valencia", Almanaque de las Provincias para 1880, pp. 131-133.

: "El Conservatorio de Música en 1910", Almanaque de las Provincias para 1911, pp. 165-166.

: "El Conservatorio de música", Almanaque de las Provincias para 1911, pp. 237238.

: "Estadística General de la Diócesis de Valencia", Almanaque Eclesiástico de la Diócesis de Valencia (1913), p. 298.

: "Exposición Artística y Certamen Musical de El Iris", Almanaque de las Provincias para 1881, pp. 255-257. 
: "Exposición Regional de Agricultura, Industria y Artes", Almanaque de las Provincias para 1884, pp. 219-239.

: "Institución para la Enseñanza de la Mujer", Almanaque de las Provincias para 1895 , pp. 279-284.

: “La Institución coral valenciana”, Boletín Musical, 20-II-1897, p. 850.

: “Lo Rat Penat", Almanaque de las Provincias para 1880, pp. 159-162.

: “Lo Rat Penat", Almanaque de las Provincias para 1881, pp. 229-233.

: "Lo Rat Penat", Almanaque de las Provincias para 1883, pp. 139-143.

: “Lo Rat Penat", Almanaque de las Provincias para 1884, pp. 309-313.

: “Lo Rat Penat", Almanaque de las Provincias para 1886, pp. 315-318.

: "Lo Rat Penat", Almanaque de las Provincias para 1888, pp. 289-293.

: "Lo Rat Penat", Almanaque de las Provincias para 1892, pp. 266-268.

: “Lo Rat Penat", Almanaque de las Provincias para 1893, pp. 113-117.

: "Lo Rat Penat", Almanaque de las Provincias para 1894, pp. 129-132.

: “Lo Rat Penat", Almanaque de las Provincias para 1895, pp. 215-218.

: "Lo Rat Penat", Almanaque de las Provincias para 1896, pp. 121-124.

: "Lo Rat Penat", Almanaque de las Provincias para 1897, p. 91.

: "Lo Rat Penat", Almanaque de las Provincias para 1899, pp. 129-132.

: "Los L años del Centro de Cultura Valenciana, crónica de la conmemoración jubilar", Anales del Centro de Cultura Valenciana, 50 (1967), pp. 1-27.

: “Los orfeones en España”, Boletín Musical, 15-II-1895, p. 387.

: “Los Teatros en 1924”, Almanaque de las Provincias para 1924, pp. 345-350.

: "Los Teatros en Valencia", Almanaque de las Provincias para 1893, pp. 173177.

: "Los Teatros en Valencia", Almanaque de las Provincias para 1888, pp. 189194.

: "Los Teatros en Valencia", Almanaque de las Provincias para 1889, pp. 131137. 
: "Los Teatros en Valencia", Almanaque de las Provincias para 1890, pp. 307311.

: "Los Teatros en Valencia", Almanaque de las Provincias para 1899, pp. 263267.

: "Los Teatros en Valencia", Almanaque de las Provincias para 1902, pp. 379384.

: "Los Teatros en Valencia”, Almanaque de las Provincias para 1901, p. 90.

: "Los Teatros en Valencia", Almanaque de las Provincias para 1910, pp. 175, 181.

: "Los Teatros en Valencia", Almanaque de las Provincias para 1901, pp. 119123.

: "Los Teatros en Valencia", Almanaque de las Provincias para 1904, pp. 193197.

: “Los Teatros en Valencia”, Almanaque de las Provincias para 1900, pp. 89-93.

: "Los Teatros en Valencia", Almanaque de las Provincias para 1906, pp. 291295.

: "Los Teatros en Valencia", Almanaque de las Provincias para 1908, pp. 159164.

: “Teatros", Almanaque de las Provincias para 1884, pp. 65-70.

: “Teatros”, Almanaque de las Provincias para 1887, pp. 161-167.

: “Teatros”, Almanaque de las Provincias para 1916, pp. 209-216.

: “Teatros”, Almanaque de las Provincias para 1918, pp. 205-207.

: Memoria presentada por la Escuela de Música y Declamación de España en la Exposición internacional de Filadelfia. España, Instrucción pública, Madrid, J. A. García, 1876.

: Memoria del curso de 1913-1914 precedida del discurso leido por el profesor numerario de la asignatura de violín Benjamín Lapiedra Cherp en el Conservatorio de Música de Valencia, Valencia, Tipografía Moderna, 1914.

: Programa de las Fiestas Cívico-religiosas de Agullent. Tercer Centenario, Valencia, Imprenta José Ma Alpuente, 1900.

: Reglamento de la Hermandad y Congregación de Profesores Músicos bajo la protección de San Vicente Ferrer y Nuestra Señora de los Desamparados, Valencia, La Hermandad, 1863. 
: "Reglamento del Centro de Cultura Valenciana", Anales del Centro de Cultura Valenciana, 1 (1928), pp. 12-23.

: "Reglamento del Conservatorio de Música de Valencia de 1878", Anales de la Real Sociedad Económica de Amigos del País de Valencia 1878 (1882), pp. 8286.

: Reglamento Orgánico del Conservatorio de Música de Valencia de 1884, Valencia, Imprenta Nicasio Rius, 1884.

: Reglamento para el régimen y buen gobierno del Círculo Musical de Valencia, Valencia, Papelería de José Ferrándis, 1902.

: Sociedad Filarmónica de Valencia: Cincuenta años de misión artística, 19121962. Memoria, Valencia, Talleres Tipográficos de Semana Gráfica, 1962.

: Solemne Institución del Seminario o Colegio Andresiano, establecido por el Ilustrísimo y Reverendísimo Señor D. Andrés Mayoral, Arzobispo de Valencia en MDCCLXIII, bajo la dirección de los padres de la Escuela Pía, para la buena Educación de la Nobleza española y de Conocido nacimiento, Valencia, Thomas Santos, 1763.

: Tercer Congreso Nacional de Música Sagrada celebrado en Barcelona del 21 al 24 de noviembre de 1912. Crónica y actas oficiales. Barcelona, La Hormiga de Oro, 1913.

: "Una iglesia nueva y otra reformada", Almanaque de las Provincias para 1888, pp. 272-276.

Archilés, Ferran/Martí, Manuel: "La cultura política de la Renaixença”, en Historia de Valencia, dir. Antoni Furió, Valencia, Prensa Valenciana (Levante) y Universitat de València, 1999, pp. 498-500.

Arín, Valentín de/Fontanilla, Pedro: Estudios de Harmonía, Lecciones TeóricoPrácticas para el uso de las clases del Conservatorio de Música y Declamación, Curso Primero, Madrid, A. Pontones litógrafo, 1905.

: Estudios de Harmonía, Lecciones Teórico- Prácticas para el uso de las clases del Conservatorio de Música y Declamación, Curso Segundo (1910), Madrid, A. Pontones litógrafo, 1910.

: Estudios de Harmonía, Lecciones Teórico-Prácticas para el uso de las clases del Conservatorio de Música y Declamación, Curso Tercero, Madrid, A. Pontones litógrafo, 1910.

: Estudios de Harmonía, Lecciones Teórico- Prácticas para el uso de las clases del Conservatorio de Música y Declamación, Curso Cuarto, Madrid, A. Pontones litógrafo, 1910. 
Ariño, Antoni [et al.]: La Nit de les Fogueretes: romería nocturna des de 1600, Valencia, Consell Valencià de Cultura, 1994.

: "El calendario festivo", en Historia de Valencia, dir. Antoni Furió, Valencia, Prensa Valenciana (Levante) y Universitat de València, 1999, pp. 523-524.

Arrando i Mañez, Sergi: “L’Escola de Música Valenciana, realitat o fícció", L'Anuari, Revista de recerca humanistica i científica, 6 (1995), pp. 15-36.

Asensi, Elvira: "El certamen de bandas. Identidad y confrontación musical en la Valencia del siglo XIX", en

http://www.unican.es/NR/rdonlyres/0000e135/lgzsqvtnlnmwwkndfpwjphzendxsiioh/ElviraAsensiEl certamendebandasidentidadyconformaci\%C3\%B3nmusicalenlaValenciadelsigloXIX.pdf (consultado el 22-XI-2010).

Astruells Moreno, Salvador: La Banda Municipal de Valencia y su aportación a la Historia de la Música Valenciana, Valencia, Ajuntament de Valencia, 2004.

: El mestre Eduardo Felip: director $i$ compositor, Albalat de la Ribera, Ajuntament de Albalat de la Ribera, 2005.

Aviñoa, Xosé: La música i el Modernisme, Barcelona, Curial, 1985.

: Cent anys del Conservatori, Barcelona, Ajuntament de Barcelona, 1986.

: "A propòsit del consum musical tardoromàntic barceloní", Revista de Catalunya, 35 (1989), pp. 79-98.

: Jaume Pahissa: un estudi biogràfic i crític, Barcelona, Biblioteca de Catalunya, 1996.

: (dir.) Història de la Música Catalana, Valenciana i Balear, Barcelona, Edicions 62, 13 vols., 1999-2004.

: "L'activitat concertística", en Història de la Música Catalana, Valenciana $i$ Balear, dir. Xosé Aviñoa, 13 vols., Barcelona, Edicions 62, 1999-2004, vol. 3 (1999), pp. 111-146.

: "L'activitat musical", en Història de la Música Catalana, Valenciana i Balear, dir. Xosé Aviñoa, 13 vols., Barcelona, Edicions 62, 1999-2004, vol. 4 (1999), pp. 59-102.

: "La música religiosa", en Història de la Música Catalana, Valenciana i Balear, dir. Xosé Aviñoa, 13 vols., Barcelona, Edicions 62, 1999-2004, vol. 4 (1999), pp. 189-209.

: "La creació", en Història de la Música Catalana, Valenciana i Balear, dir. Xosé Aviñoa, 13 vols., Barcelona, Edicions 62, 1999-2004, vol. 4 (1999), pp. 210-256. 
: "Conservatori Superior de Música del Liceu", en Història de la Música Catalana, Valenciana i Balear, dir. Xosé Aviñoa, 13 vols., Barcelona, Edicions 62, 1999-2004, vol. 9 (2003), p. 169.

: "Escola Municipal de Música. Conservatori Municipal de Barcelona", en Història de la Música Catalana, Valenciana i Balear, dir. Xosé Aviñoa, 13 vols., Barcelona, Edicions 62, 1999-2004, vol. 9 (2003), p. 195.

: "Sociedades musicales y modernidad en Cataluña en el primer tercio del siglo XX”, Cuadernos de Música Iberoamericana, 8-9 (2001), pp. 277-286.

: "Los Congresos del Motu Proprio (1907-1928). Repercusión e influencias", Revista de Musicología, 27/1 (2004), pp. 381-399.

: "Modernisme i música: una reflexió al cap dels anys", Recerca Musicologica, 14-15 (2004-2005), pp. 107-122.

Azagra Ros, Joaquín: "La densificación de la ciudad intramuros", en Historia de Valencia, dir. Antoni Furió, Valencia, Prensa Valenciana (Levante) y Universitat de València, 1999, pp. 431-433.

: El bienio progresista en Valencia. Análisis de una situación revolucionaria a mediados del siglo XIX 1854-65, Valencia, Universitat de València, 1978.

\section{B}

Badenes Masó, Gonzalo (dir.): Historia de la Música de la Comunidad Valenciana, Valencia, Valencia, Editorial Prensa Valenciana, 1992.

Bagües, Jon: "El coralismo en España en el siglo XIX", en España en la Música de Occidente, Actas del Congreso Internacional (Salamanca, 1985), eds. Emilio Casares, José López-Calo, Ismael Fernández de la Cuesta, 2 vols., Madrid, Instituto Nacional de Artes Escénicas y de la Música, 1987, vol. 2, pp. 173-198.

Baixauli Biguer, Mariano: “La música religiosa”, Razón y Fe, 9/33 (1904), pp. 23-38.

Baldó Lacomba, Marc: "La consolidació de la cultura burgesa", en Història del País Valencià, coord. Ernest Belenguer, 6 vols., Barcelona, Edicions 62, 1988-2006, vol. 5 (1990), pp. 167-220.

: "La cultura: entre el naturalismo y el positivismo", en Historia de Valencia, dir. Antoni Furió, Valencia, Prensa Valenciana (Levante) y Universitat de València, 1999, pp. 521-522.

Balthazar, Scout L./Rose, Michael: "Pacini, Giovanni", en The New Grove Dictionary of Opera, ed. Stanley Sadie, 4 vols., London, MacMillan, vol. 3 (1996), pp. 808-812.

Barberá Soler, José Miguel, "La música en Granada durante el siglo XIX", Revista del Centro de Estudios Históricos de Granada y su reino, 7 (1993), pp. 227-250. 
Barce, Ramón: "La ópera y la zarzuela en el siglo XIX", en España en la Música de Occidente, Actas del Congreso Internacional (Salamanca, 1985), eds. Emilio Casares, José López-Calo, Ismael Fernández de la Cuesta, 2 vols., Madrid, Instituto Nacional de Artes Escénicas y de la Música, 1987, vol. 2, pp. 145-153.

: (coord.) Actualidad y futuro de la zarzuela, Madrid, Alpuerto/ Fundación Caja de Madrid, 1994.

Bas Carbonell, Manuel: "Conservatorio de Música de Valencia”, en 225 años de la Real Sociedad Económica de Amigos del País de Valencia, Valencia, Fundación Bancaja, 2003, pp. 137-141.

Bate, Philip/Weston, Stephen J.: "Basse-trompette [trombe]", en The New Grove Dictionary of Music and Musicians, Second Revised Edition, ed. Stanley Sadie, 29 vols., London, MacMillan, vol. 2 (2002), p. 869.

Belenguer, Ernest (coord.): Història del País Valencià, Barcelona, Edicions 62, 6 vols., 1988-2006.

Benito Goérlich, Daniel: La arquitectura del eclecticismo en Valencia. Vertientes de la arquitectura valenciana entre 1875-1925, Valencia, Ajuntament de València, 1983.

: "Del historicismo al modernismo: la arquitectura valenciana entre dos siglos", en Historia de Valencia, dir. Antoni Furió, Valencia, Prensa Valenciana (Levante) y Universitat de València, 1999, pp. 513-515.

Bertelé, Antonio: Enciclopedia del arte lírico, Toledo, Aguilar, 1981.

Blasco Carrascosa, Juan Ángel: La Institución Libre de Enseñanza en Valencia: Eduardo Soler Pérez. Vida, Obra y pensamiento, Tesis Doctoral, Valencia, Universidad de Valencia, 1980.

: El Krausime Valencià, València, Institució Alfons El Magnànim, 1982.

Blasco, Francisco Javier: La música en Valencia. Apuntes Históricos, Alicante, Imprenta de Sirvent y Sánchez, 1896.

Blasco, Ricard: "Lo Rat Penat: periodich 1literari quincenal (1884-1885)", Estudis romànics, 16 (1971-1975), pp. 185-231.

: "Llengua i pàtria al País Valencià durant la Renaixença", Caplletra, 4 (1988), pp. 43-67.

Boira, Josep Vicent: "Los accesos a la ciudad: caminos, carreteras, estaciones y puerto", en Historia de Valencia, dir. Antoni Furió, Valencia, Prensa Valenciana (Levante) y Universitat de València, 1999, pp. 533-536. 
: "El puerto de Valencia", en Historia de Valencia, dir. Antoni Furió, Valencia, Prensa Valenciana (Levante) y Universitat de València, 1999, pp. 457-459.

Boix, Vicente: Manual del viajero y guía de los forasteros en Valencia, Valencia, Imprenta José Rius, 1849.

Bombi, Andrea [et al.]: “Ópera”, en Diccionario de la Música Valenciana, dir. Emilio Casares, 2 vols., Madrid, Instituto Complutense de Ciencias Musicales, Institut Valencià de la Música, vol. 2 (2006), pp. 168-193.

: "Ripollés Pérez, Vicente", en Diccionario de la Música Valenciana, dir. Emilio Casares, 2 vols., Madrid, Instituto Complutense de Ciencias Musicales, Institut Valencià de la Música, vol. 2 (2006), pp. 344-346.

Bonastre i Bertràn, Francesc: "El nacionalisme musical de Felip Pedrell: reflexions a l'entorn de Por nuestra música", Recerca Musicològica, 11-12 (1991-1992), pp. $17-26$.

: "El planteamiento operístico de Pedrell", en La ópera en España $e$ Hispanoamérica, eds. Emilio Casares y Álvaro Torrente, 2 vols., Madrid, Instituto Complutense de Ciencias Musicales, 2002, vol. 2, pp. 187-197.

: "Els Pirineus en el panorama de la música hispànica", Recerca Musicològica, 14-15 (2004-2005), pp. 255-268.

Botella Jáudenes, Antonio: Memoria del Conservatorio de Música, Valencia, Imprenta V. Gay, 1892.

Braccini, Roberto: Vocabulario internacional de términos musicales, Madrid, Editorial de música española contemporánea, 1994.

Bru Casanova, José Ma: "Aproximación a Amancio Amorós y Sirvent", en Agullent 1585-1985 IV Centenari de la Segregació jurídica d'Agullent d'Ontinyent, Valencia, Caixa Estalvis d'Ontinyent, 1985, pp. 187-192.

Burdiel, Isabel: "Revolució Liberal i moderantisme burgés: 1833-1866", en Història del País Valencià, coord. Ernest Belenguer, 6 vols., Barcelona, Edicions 62, 19882006, vol. 5 (1990), pp. 77-116.

\section{C}

Calabuig y Carra, Vicente: La Casa Enseñanza. Fundación del Arzobispo Mayoral, Valencia, Imprenta de Emilio Pascual, 1897.

Cantú, Cesare: "Safo y las literatas griegas", en Historia Universal, vol. 10, Madrid, Imprenta de Gaspar Roig, 1866, pp. 41-48.

Carbonell i Guberna, Jaume: "Las sociedades corales en Cataluña. Visión historiográfica y estado de la cuestión", Revista de Musicología, 14/1-2 (1991), pp. 113-124. 
: "La Música a Barcelona entre els anys 1874-1890. Condicionants del modernisme musical”, Revista de Catalunya, 68 (1992), pp. 71-86.

: "El cant coral", en Història de la Música Catalana, Valenciana i Balear, dir. Xosé Aviñoa, 13 vols., Barcelona, Edicions 62, 1999-2004, vol. 3 (1999) pp. 147186.

Carnero, Teresa: "Los partidos dinásticos y el turnismo", en Historia de Valencia, dir. Antoni Furió, Valencia, Prensa Valenciana (Levante) y Universitat de València, 1999, pp. 479- 481.

Carranza, Ma Cruz: "Plasencia Aznar, Juan Bautista", en Diccionario de la Música Española e Hispanoamericana, dir. Emilio Casares, 10 vols., Madrid, Sociedad General de Autores y Editores, 1999-2002, vol. 8 (2001), p. 857.

Carredano, Consuelo, "El piano": en La Música en Hispanoamérica en el siglo XIX, eds. Consuelo Carredano y Victoria Eli, vol 6. Historia de la música en España e Hispanoamérica, dir. y coord. Juan Ángel Vela del Campo, Madrid, Fondo de Cultura Económica, 2010, pp. 221-263.

Carredano, Consuelo/Eli, Victoria (eds.): La música en Hispanoamérica en el siglo XIX, vol 6. Historia de la música en España e Hispanoamérica, dir. y coord. Juan Ángel Vela del Campo, Madrid, Fondo de Cultura Económica, 2010.

: "El teatro lírico", en La música en Hispanoamérica en el siglo XIX, eds. Consuelo Carredano y Victoria Eli, vol 6. Historia de la música en España e Hispanoamérica, dir. y coord. Juan Ángel Vela del Campo, Madrid, Fondo de Cultura Económica, 2010, pp. 153-218.

Carrillo, Luisa: Banda Municipal de Valencia: cien años de música, Valencia, Ajuntament de València, 2003.

Casanova Herrero, Emili: "Introducció a la història de la Banda de Música d'Agullent (1884-1984), en 1883-2003, Agrupació Musical d'Agullent, Agullent, Caixa d'Estalvis d'Ontinyent, Obra Social, 2003, pp. 20-58.

: "El significat del nom de la filà Ben Hulem d'Agullent (1958-2008), en 50 anys de Ben Hulem a Agullent, Agullent, Filà Ben Hulem, 2008, pp. 10-11.

Casares Rodicio, Emilio: "La música española hasta 1939, o la restauración musical”, en España en la Música de Occidente, Actas del Congreso Internacional (Salamanca, 1985), eds. Emilio Casares, José López-Calo, Ismael Fernández de la Cuesta, 2 vols., Madrid, Instituto Nacional de Artes Escénicas y de la Música, 1987, vol. 2, pp. 261-322.

: Francisco Asenjo Barbieri, 2 vols., Madrid, Instituto Complutense de Ciencias Musicales, 1994. 
: "La música en el siglo XIX español. Conceptos fundamentales", en La música española en el siglo XIX, eds. Emilio Casares y Celsa Alonso, Gijón, Servicio de Publicaciones de la Universidad de Oviedo, 1995, pp. 13-122.

: (dir.) La zarzuela en España e Hispanoamérica. Centro y periferia 1800-1950, Actas del Congreso Internacional (Madrid, 1995), Cuadernos de Música Iberoamericana, 2-3 (1996-1997).

: "Historia del teatro de los bufos, 1866-1881. Crónica y dramaturgia", Cuadernos de Música Iberoamericana, 2-3 (1996-97), pp. 110-113.

: "Teatro musical, zarzuela, tonadilla, ópera, revista", en Historia de los espectáculos en España, coord. Andrés Amorós, Madrid, Castalia, 1999, pp. 147172.

: Diccionario de la Música Española e Hispanoamericana, Madrid, Sociedad General de Autores y Editores, 10 vols., 1999-2002.

: “Compta Torres, Eduardo", en Diccionario de la Música Española e Hispanoamericana, dir. Emilio Casares, 10 vols., Madrid, Sociedad General de Autores y Editores, 1999-2002, vol. 3 (1999), pp. 858-859.

: "Mitjana, Rafael”, en Diccionario de la Música Española e Hispanoamericana, dir. Emilio Casares, 10 vols., Madrid, Sociedad General de Autores y Editores, 1999-2002, vol. 7 (2000), pp. 623-624.

: (dir.) Sociedades Musicales en España. Siglos XIX-XX, Actas del Curso de Musicología (Granda, 1997), Cuadernos de Música Iberoamericana, 8-9 (2001).

: (dir.) Diccionario de La Zarzuela. España e Hispanoamérica, Madrid, Instituto Complutense de Ciencias Musicales, 2002.

: Fernández Ismael y López-Calo, José (eds.): España en la Música de Occidente, Actas del Congreso Internacional (Salamanca, 1985), 2 vols., Madrid, Instituto Nacional de las Artes Escénicas y de la Música, 1987.

: y Alonso González, Celsa (eds.): La música española en el siglo XIX, Gijón, Servicio de Publicaciones de la Universidad de Oviedo, 1995.

: y Torrente, Álvaro (eds.): La ópera en España e Hispanoamérica, Actas del Congreso Internacional (Madrid, 1999), 2 vols., Madrid, Instituto Complutense de Ciencias Musicales, 2002.

Cavia Naya, Victoria: "Un músico del siglo XIX y su proyección desde la catedral de Valladolid: Hilario Prádanos", Cuadernos de Música Iberoamericana, 7 (1999), pp. 199-214.

: La vida musical de la catedral de Valladolid en el siglo XIX, Valladolid, Diputación provincial de Valladolid, 2004. 
Cerdá, Manuel (dir.): Historia del pueblo valenciano, Valencia, Caja de Ahorros de Valencia, 1988.

Cervera, David: La prensa valenciana y su aportación a la Renaixença, Valencia, Ayuntamiento de Valencia, 1976.

Clares Clares, Esperanza: "Bandas y Música en la calle: una visión a través de la prensa en las ciudades de Murcia y Cartagena (1800-1875)", Revista de Musicología, 28/1 (2005), pp. 543-562.

Climent Barber, José: “Conservatorio de Música de Valencia”, en Gran Enciclopedia de la Región Valenciana, dir. Manuel Mas, 12 vols., Valencia, Graphic 3, vol. 3 (1973), p. 230.

: Historia de la Música Contemporánea Valenciana, del Cenia al Segura, Valencia, Artes Gráficas Soler, 1978.

: Fondos Musicales de la Región Valenciana, 4 vols., Valencia, Institución Alfonso el Magnánimo, 1979-1986.

: Historia de la Música Valenciana, Valencia, Rivera Mota, 1989.

: "Antich Carbonell, Francisco", en Diccionario de la Música Española e Hispanoamericana, dir. Emilio Casares, 10 vols., Madrid, Sociedad General de Autores y Editores, 1999-2002, vol. 1 (1999), pp. 487-488.

: “Asenjo Vilar, María de la Concepción”, en Diccionario de la Música Española e Hispanoamericana, dir. Emilio Casares, 10 vols., Madrid, Sociedad General de Autores y Editores, 1999-2002, vol. 1 (1999), p. 790.

: "Chulvi Jover, Manuel", en Diccionario de la Música Española e Hispanoamericana, dir. Emilio Casares, 10 vols., Madrid, Sociedad General de Autores y Editores, 1999-2002, vol. 3 (1999), pp. 692-693.

: "Cuesta, Francisco", en Diccionario de la Música Española e Hispanoamericana, dir. Emilio Casares, 10 vols., Madrid, Sociedad General de Autores y Editores, 1999-2002, vol. 4 (1999), p. 295.

: "Úbeda Montés, José María", en Diccionario de la Música Española e Hispanoamericana, dir. Emilio Casares, 10 vols., Madrid, Sociedad General de Autores y Editores, 1999-2002, vol. 10 (2002), pp. 545-546.

Codina, Daniel: "Felip Pedrell i la música religiosa. La seva relació amb el monestir de Montserrat", Recerca Musicològica, 11-12 (1991-1992), pp. 357-361.

Collado, Josep Antoni: "El cant d'estil en l'actualitat", en Actas del III Congreso de la Sociedad Ibérica de Etnomusicología (Benicàsim, 1997), eds. Ramón Pelinsky y Vicent Torrent, Sabadell, La Mà de Guido, 1998, pp. 313-317. 
Comellas i Barri, Monserrat: El romanticisme musical a Barcelona. Els concerts Barcelona, Libros de la Frontera, 2000.

Cortés i Mir, Francesc: "La Música escènica de Felip Pedrell: Els Pirineus. La Celestina. El comte Arnau", Recerca Musicologica, 11-12 (1991-1992), pp. 63-97.

: "La música religiosa", en Història de la Música Catalana, Valenciana i Balear, dir. Xosé Aviñoa, 13 vols., Barcelona, Edicions 62, 1999-2004, vol. 3 (1999), pp. $187-253$

: "La zarzuela en Cataluña y la zarzuela en catalán", en La zarzuela en España e Hispanoamérica. Centro y periferia, 1800-1950, Actas del Congreso Internacional (Madrid, 1995), Cuadernos de Música Iberoamericana, 2-3 (19961997), pp. 289-317.

Cortizo, Ma Encina: Emilio Arrieta. De la ópera a la zarzuela, Madrid, Instituto Complutense de Ciencias Musicales, 1998.

Costa Vázquez-Mariño, Luis: “As bases do nacionalismo musical galego no entorno da música religiosa", Actas del Congreso Galicia fai dous mil anos. O feito diferencial galego, coord. Carlos Villanueva, Santiago de Compostela, Museo do Pobo Galego, 1998, vol 2, pp. 251-292.

: "Coralismo, etnicidad y nacionalismo en Galicia", Cuadernos de Música Iberoamericana, 6 (1998), pp. 49-63.

Cotarelo y Mori, Emilio: Historia de la zarzuela, Madrid, Tipografía de Archivos, 1938.

Crusanfort i Sabater, Miquel: Medalles conmemoratives del Països Catalans $i$ de la Corona Catalana-Aragonesa (s. $X V$ - $X X$ ), Barcelona, Institut d'Estudis Catalans, 2006.

Cucó, Alfons: Aspectes de la política valenciana en el segle XIX, Barcelona, Rafael Dalmau, 1965.

Cucó, Josepa: El Valencianisme polític (1874-1936), València, Cosmos, 1971.

: Músicos y festeros valencianos, Valencia, Instituto Valenciano de Artes Escénicas, Cinematografía y Música, 1993.

D

Delgado García, Fernando, "La construcción del sistema nacional de conservatorios en España (1892-1942)”, Cuadernos de Música Iberoamericana, 12 (2006), pp. 109134.

Díaz, Filiberto Abelardo: Guía Novísima de Valencia, Valencia, Imprenta de El Valenciano, 1867. 
Díaz, Gómez, Rafael: "Sosa López, Pedro", en Diccionario de la Música Española e Hispanoamericana, dir. Emilio Casares, 10 vols., Madrid, Sociedad General de Autores y Editores, 1999-2002, vol. 10 (2002), pp. 33-34.

: "Valls, José", en Diccionario de la Música Española e Hispanoamericana, dir. Emilio Casares, 10 vols., Madrid, Sociedad General de Autores y Editores, 1999-2002, vol. 10 (2002), p. 707.

\section{$\mathbf{E}$}

Egido Langarita, Ma José: "De Tra le sollecitudini (1903) a Musicam Sacram (1967)", Revista de Musicología 27/1 (2004), pp. 423-433.

Eigeldinger, Jean-Jacques: "Mathias, Georges-Amedée Saint Clair", en Chopin vu pour ses élèves, Suiza, ed. de la Baconnière, 1988, pp. 246-248.

Eli Rodríguez, Victoria: "Cervantes Kawanagh, Ignacio María”, en Diccionario de la Música Española e Hispanoamericana, dir. Emilio Casares, 10 vols., Madrid, Sociedad General de Autores y Editores, 1999-2002, vol. 3 (1999), pp. 497-500.

: y Alfonso, $\mathrm{M}^{\mathrm{a}}$ de los Ángeles: La música entre Cuba y España. Tradición e innovación, Madrid, Fundación Autor, 1999.

Emparán Boada, Gloria: "El piano en el siglo XIX español”, Cuadernos de Música. El Romanticismo Musical Español, 2 (1982), pp. 59-70.

Encabo, Enrique: "Los Cuadros Murcianos de Emilio Ramírez", Revista de Musicología, 32/2 (2009), pp. 117-127.

Eslava, Hilarión: Método completo de solfeo sin acompañamiento por D. Hilarión Eslava, Madrid, Gran Casa Editorial de B. Eslava, 1878.

Espadaler, Antón M.: Història de la literatura catalana, Barcelona, editorial Barcanova, 1993.

\section{$\mathbf{F}$}

Fayos, Francisco: “Las Sociedades Corales”, Boletín Musical, 30-XI-1893, pp. 159-160. : “El Orfeón Valenciano El Micalet”, Boletín Musical, 15-V-1894, p. 240. : “El Orfeón Valenciano El Micalet”, Boletín Musical, 30-V-1894, pp. 247-251. : "Los Orfeones Valencianos”, Boletín Musical 15-XI-1894, pp. 342-343.

: “Carta abierta", Boletín Musical, 15-XII-1894, pp. 358-360.

: "Los orfeones El Micalet y La Vega", Boletín Musical, 30-IV-1895, pp. 426428. 
: “Los Orfeones El Micalet y La Vega”, Boletín Musical, 15-V-1895, pp. 434435.

: “Los Orfeones El Micalet y La Vega”, Boletín Musical, 30-V-1895, pp. 439440.

: "Proyecto de Estatutos Generales para la Asociación Coral de la Región Valenciana", Boletín Musical, 15-VI-1895, pp. 449-450.

Faubell, Vicente: Diccionario Enciclopédico Escolapio, vol. 1, dir. Luis Ma Bandrés Rey, Madrid, Publicaciones ICCE, 1990.

: "Renovación pedagógica e Ilustración en la España del siglo XVIII", Anales de la Real Sociedad Económica de Amigos del País de Valencia 97-98 (1999), pp. 215-246.

Fernández de la Cuesta, Ismael: "La reforma del canto gregoriano en el entorno del Motu Proprio de Pío X", Revista de Musicología, 27/1 (2004), pp. 43-73.

Fernández Soria, Juan Manuel/Agulló, Carmen: Los temas educativos en las memorias del magisterio valenciano 1908-1909, Valencia, Universitat de Valencia, 2002.

Fernández, Olga: Solo de música cubana, Quito, Abya-Yala, 2005.

Ferrari, Malcolm/Turner, Gustave: "Bellaigue, Camille", en The New Growe Dictionary of Music and Musicians, Second Revised Edition, ed. Stanley Sadie, 29 vols., London, MacMillan, vol. 3 (2002), p. 186.

Fontestad Piles, Ana: El Conservatorio de Música de Valencia antecedentes, fundación y primera etapa (1879-1910), Tesis Doctoral, Valencia, Universitat de València. Departament d'Història de l'Art, 2005.

Furió, Antoni (dir.): "La Cultura de la Renaixença", en Historia de Valencia, Valencia, Prensa Valenciana (Levante) y Universitat de València, 1999, pp. 489-500.

: Historia de Valencia, Valencia, Editorial Prensa Valenciana (Levante) y Universitat de València, 1999.

\section{G}

Galbis López, Vicente: "La música instrumental y vocal de la primera mitad del siglo XIX", en Historia de la Música de la Comunidad Valenciana, Valencia, Editorial Prensa Valenciana, 1992, pp. 261-280.

: "La zarzuela en el área mediterránea", en La zarzuela en España e Hispanoamérica. Centro y periferia, 1800-1950, Actas del Congreso Internacional (Madrid, 1995), Cuadernos de Música Iberoamericana, 2-3 (199697), pp. 327-349. 
: La música escénica en Valencia: 1832-1868. Del modelo del Antiguo Régimen a la organización musical del Estado burgués, Tesis Doctoral, Valencia, Universidad de Valencia, 1998

: "La educación musical española en el siglo XIX: el caso valenciano", Eufonía, 17 (1999), pp. 79-87.

: “Amorós Barra, José Vicente", en Diccionario de la Música Española e Hispanoamericana, dir. Emilio Casares, 10 vols., Madrid, Sociedad General de Autores y Editores, 1999-2002, vol. 1 (1999), p. 421.

: “Fornet Senís, José”, en Diccionario de la Música Española e Hispanoamericana, dir. Emilio Casares, 10 vols., Madrid, Sociedad General de Autores y Editores, 1999-2002, vol. 5 (1999), p. 223.

: “Giner, Salvador", en Diccionario de la Música Española e Hispanoamericana, dir. Emilio Casares, 10 vols., Madrid, Sociedad General de Autores y Editores, 1999-2002, vol. 1 (1999), pp. 642-647.

: "Goñi Otermin, Andrés", en Diccionario de la Música Española e Hispanoamericana, dir. Emilio Casares, 10 vols., Madrid, Sociedad General de Autores y Editores, 1999-2002, vol. 5 (1999), p. 791.

: "Izquierdo Romeu, José Manuel”, en Diccionario de la Música Española e Hispanoamericana, dir. Emilio Casares, 10 vols., Madrid, Sociedad General de Autores y Editores, 1999-2002, vol. 6 (2000), pp. 515-517.

: "Jiménez Cos, Eduardo", en Diccionario de la Música Española e Hispanoamericana, dir. Emilio Casares, 10 vols., Madrid, Sociedad General de Autores y Editores, 1999-2002, vol. 6 (2000), pp. 575-579.

: "Marco Belloch, Antonio", en Diccionario de la Música Española e Hispanoamericana, dir. Emilio Casares, 10 vols., Madrid, Sociedad General de Autores y Editores, 1999-2002, vol. 7 (2000), pp. 155-156.

: "Querol, Leopoldo", en Diccionario de la Música Española e Hispanoamericana, dir. Emilio Casares, 10 vols., Madrid, Sociedad General de Autores y Editores, 1999-2002, vol. 8 (2001), pp. 1035-1038.

: "Les bandes valencianes: història, activitats i projecció social", en Historia de la Música Catalana Valenciana i Balear, dir. Xosé Aviñoa, 13 vols., Barcelona, Edicions 62, 1999-2004, vol. 6 (2001), pp. 160-205.

: "Penella Raga, Manuel", en Diccionario de la Música Española e Hispanoamericana, dir. Emilio Casares, 10 vols., Madrid, Sociedad General de Autores y Editores, 1999-2002, vol. 8 (2001), pp. 574-575.

: "Segura Villalba, Roberto", en Diccionario de la Música Española e Hispanoamericana, dir. Emilio Casares, 10 vols., Madrid, Sociedad General de Autores y Editores, 1999-2002, vol. 9 (2002), p. 911. 
: "Bandas", en Diccionario de la Música Valenciana, dir. Emilio Casares, 2 vols., Madrid, Instituto Complutense de Ciencias Musicales, Institut Valencià de la Música, vol. 1 (2006), pp. 89-97.

: "Zarzuela", en Diccionario de la Música Valenciana, dir. Emilio Casares, 2 vols., Madrid, Instituto Complutense de Ciencias Musicales, Institut Valencià de la Música, vol. 2 (2006), pp. 605-618.

: "Coros", en Diccionario de la Música Valenciana, dir. Emilio Casares, 2 vols., Madrid, Instituto Complutense de Ciencias Musicales, Institut Valencià de la Música, vol. 1 (2006), pp. 253-260.

: “Tena Meliá, Vicente Javier”, en Diccionario de la Música Valenciana, dir. Emilio Casares, 2 vols., Madrid, Instituto Complutense de Ciencias Musicales, Institut Valencià de la Música, vol. 2 (2006), p. 494.

: “Un referent per als orfeons Valencians", El Temps, 787, pp. 48-49.

: y Climent, José: "Bellver Abells, José", en Diccionario de la Música Española e Hispanoamericana, dir. Emilio Casares, 10 vols., Madrid, Sociedad General de Autores y Editores, 1999-2002, vol. 2 (1999), pp. 342-343.

Galbis López, Vicente/Díaz Gómez, Rafael: "Homenaje a la familia López-Chavarri, figuras de la historia musical valenciana", en Anales de la Real Sociedad Económica de Amigos del País de Valencia 1993-94 (1995), pp. 337-359.

: "López-Chavarri Marco, Eduardo", en Diccionario de la Música Española e Hispanoamericana, dir. Emilio Casares, 10 vols., Madrid, Sociedad General de Autores y Editores, 1999-2002, vol. 6 (2000), pp. 1043-1047.

Galiano Arlandis, Ana: "La Renaixença", en Historia de la Música de la Comunidad Valenciana, dir. Gonzalo Badenes, Valencia, Editorial Prensa Valenciana, 1992, pp. 301-320.

: "La transición del siglo XIX al XX", en Historia de la Música de la Comunidad Valenciana, dir. Gonzalo Badenes, Valencia, Editorial Prensa Valenciana, 1992, pp. 321-340.

García Caballero, María: La vida musical en Santiago a finales del siglo XIX, Santiago de Compostela, Alvarellos editora, 2008.

García del Busto, José Luis: "La generación musical de 1890", en Historia de la Música de la Comunidad Valenciana, dir. Gonzalo Badenes, Valencia, Editorial Prensa Valenciana, 1992, pp. 341-360.

García Franco, Manuel: "El apogeo de la zarzuela", en Historia de la Música de la Comunidad Valenciana, dir. Gonzalo Badenes, Valencia, Editorial Prensa Valenciana, 1992, pp. 282-300. 
García Mallo, Carmen: "Peters y España: Edición Musical y relaciones comerciales entre 1868 y 1892”, Anuario Musical, 60 (2005), pp. 115-165.

García Velasco, Mónica: "La Sociedad de cuartetos de Madrid (1863-1894)", Cuadernos de Música Iberoamericana, 8-9 (2001), pp. 149-194

Gascón Pelegrí, Vicente: Prohombres valencianos en los últimos cien años, 1878-1978, València, Caixa d'Estalvis de València, 1978.

Gay i Puigbert, Joan: “Guzmán Martínez, Juan Bautista [Manuel]”, en Diccionario de la Música Española e Hispanoamericana, dir. Emilio Casares, 10 vols., Madrid, Sociedad General de Autores y Editores, 1999-2002, vol. 6 (2000), pp. 172-173.

Gayano Lluch, Rafael: "El Conservatorio de Música y Declamación de Valencia. Apuntes Históricos", Almanaque de las Provincias para 1945, pp. 481-489.

Gibert, Vicente Ma de: “Camille Bellaigue”, La Vanguardia, 6-XII-1930, p. 5.

Gil Barberà, Joan [et al.]: Lo Rat Penat, Valencia, Consell Valencià de Cultura, 1996.

Giralt, Jesús (dir.): Gran Enciclopedia de la Música, Barcelona, Fundació Enciclopedia Catalana, 1999.

Gmeinwieser, Siegfried: "Cecilian Movement", en The New Grove Dictionary of Music and Musicians, Second Revised Edition, ed. Stanley Sadie, 29 vols., London, MacMillan, vol. 5 (2002), pp. 333-334.

Gómez Amat, Carlos: "Apuntes sobre el sinfonismo español en el siglo XIX", Cuadernos de música. El Romanticismo musical español, 2 (1982), pp. 39-47.

: Historia de la música española. Siglo XIX, Madrid, Alianza Editorial, 1984.

: "Sinfonismo y música de cámara en la España del siglo XIX", en España en la Música de Occidente, Actas del Congreso Internacional (Salamanca, 1985), eds. Emilio Casares, José López-Calo, Ismael Fernández de la Cuesta, 2 vols., Madrid, Instituto Nacional de Artes Escénicas y de la Música, 1987, pp. 211-223.

Gómez Rodríguez, José Antonio (ed.): Canciones de dentro. Música asturiana para voz y piano, Oviedo, Caja de Asturias, Fundación Príncipe de Asturias, Consejería de Cultura, 1996.

: Ecos de Asturias. Música asturiana para piano, Oviedo, Caja de Asturias, Fundación Príncipe de Asturias, Consejería de Cultura, 1997.

González, Casimiro: "La música orquestal", en Un siglo de música en la Comunidad Valenciana, Valencia, Unidad Editorial S. A., 1998, pp. 37-53.

Gosálvez Lara, Carlos J.: La edición musical española hasta 1936, Madrid, Asociación Española de Documentación Musical, 1995. 
Guarner, Lluís: La Renaixença Valenciana i Teodor Llorente, Barcelona, Edicions 62, 1985.

Guerrero Fernández, Aimée: "Presencia cubana en la zarzuela española", Revista de Musicología, 28/1, 2005, pp. 443-454.

$\mathbf{H}$

Harbec, Jacinthe/Paiement, Nicole: "Collet, Henri", en The New Growe Dictionary of Music and Musicians, Second Revised Edition, ed. Stanley Sadie, 29 vols., London, MacMillan, vol. 6 (2002), pp. 121-122.

Hernández Farinós, J. Pasqual: "Francesc Antich Carbonell”, Algudor, 3 (2004), pp. 7386.

Hernández i Martí, Gil Manuel: La Feria de Julio de Valencia, Valencia, Carena, 1998.

Hernández, Telesforo: "El impacto del ferrocarril”, en Historia de Valencia, dir. Furió, A., Valencia, Prensa Valenciana (Levante) y Universitat de València, 1999, pp. 456-457.

Herrera i Llop, Lluís-Marc: La Música a Lleida durant la Renaixença i el Modernisme, Lleida, Ajuntament de Lleida, 2002.

Herrera, José María [et al.]: Cartografía histórica de la ciudad de Valencia 1704-1910, Valencia, Ajuntament de València, 1985.

Hess, Carol: "Enric Granados y el contexto pedrelliano", Recerca Musicolòica, 14-15 (2004-2005), pp. 47-56.

Huertas Vázquez, Eduardo: "La zarzuela paródica y sus incursiones políticas", en La zarzuela en España e Hispanoamérica. Centro y periferia, 1800-1950, Actas del Congreso Internacional (Madrid, 1995), Cuadernos de Música Iberoamericana, 2-3 (1996-1997), pp. 165-181.

Hyer, Brian/Reihding, Alexander: "Riemann, Hugo", en The New Growe Dictionary of Music and Musicians, Second Revised Edition, ed. Stanley Sadie, 29 vols., London, MacMillan, vol. 21 (2002), pp. 362-366.

I

Iberni, Luis G.: "Felip Pedrell y Ruperto Chapí”, Recerca Musicològica, 11-12 (19911992), pp. 335 y 344.

: Pablo Sarasate, Madrid, Instituto Complutense de Ciencias Musicales, 1994.

: Ruperto Chapí, Madrid, Instituto Complutense de Ciencias Musicales, 2009.

Iglesias, Antonio (ed.): Escritos de Joaquín Rodrigo, Madrid, Editorial Alpuerto, 1999. 
Iglesias de Souza, Luis: Teatro lírico español, 4 vols, La Coruña, Diputación Provincial de La Coruña, 1991-1996.

Iglesias Martínez, Nieves [et al.]: La Música en el Boletín de la Propiedad intelectual 1847-1915, Madrid, Ministerio de Educación y Cultura, 1997.

: (dir.) Catálogo del Teatro Lírico español en la Biblioteca Nacional, vol. 3 (1991), Madrid, Ministerio de Educación y Ciencia, Dirección General del libro y bibliotecas, 1991.

: y Lozano Martínez, Isabel: La música del siglo XIX. Una herramienta para su descripción bibliográfica, Madrid, Biblioteca Nacional, 2008.

Inzenga, José: Cantos y bailes populares de España. Valencia, Madrid, A. Romero, 1888.

Jorba i Jorba, Manuel: "La Renaixença", en Història de la Literatura Catalana, dir. Joaquim Molas, 11 vols., Barcelona, Ed. Ariel, 1984-1988, vol. 7 (1986), pp. 939.

Juan Llovet, Elvira: Música religiosa en los pueblos del valle de Albaida (del siglo XVII hasta los inicios del siglo XX), Tesis doctoral, Valencia, Universidad de Valencia, 2009.

Justo [pseudónimo de Francisco Fayos]. Véase Fayos, Francisco.

$\mathbf{L}$

Labajo, Joaquina: "Las entidades musicales durante el periodo romántico en España", Cuadernos de Música. El Romanticismo Musical Español, 2 (1982), pp. 26-35.

Lambea, Mariano (ed.): El Motu Proprio de San Pío X y la Música (1903-2003). Actas del Simposio Internacional (Barcelona, 2003), Revista de Musicología, 27/1 (2004).

Lattes, Sergio: "Tebaldini, Giovanni", en The New Growe Dictionary of Music and Musicians, Second Revised Edition, ed. Stanley Sadie, 29 vols., London, MacMillan, vol. 25 (2002), p. 188.

Legasa, Francisco Javier: "Bonifacio Iráizoz (1883-1951) y el modernismo musical en el contexto del Motu Proprio", Príncipe de Viana, 238 (2006), pp. 675-693.

León, Argeliers: Del canto y el tiempo, La Habana, Pueblo y Educación, 1985.

León Navarro, Vicente: "Rafael Lasala y Lócela, Obispo auxiliar de Valencia. Su postura ante la extinción de los jesuitas", Revista de Historia Moderna, 17 (1998-1999), pp. 353-372. 
Linares, M ${ }^{\mathrm{a}}$ Teresa/Núñez, Faustino: La música entre Cuba y España, Madrid, Fundación Autor, 1998.

Llombart, Constantí: Excel.lències de la llengua llemosina: discurs panegirich llegit en la solemne sessió inaugurativa de Lo Rat Penat, Valencia, Emili Pasqual, 1878.

Llorens, Manuel (dir.): “Conservatorio de Música de Valencia”, en Gran Enciclopedia Valenciana, 10 vols., Valencia, Difusora de Cultura Valenciana, 1990-1991, vol. 3 (1991), p. 155.

: (dir.) "Sociedad Económica de Amigos del País de Valencia", en Gran Enciclopedia Valenciana, 10 vols., Valencia, Difusora de cultura valenciana, 1990-1991, vol. 9 (1991), p. 99.

López-Calo, José: Índices de la revista Tesoro Sacro Musical, Madrid, Sociedad Española de Musicología, 1983.

: "Felip Pedrell y la reforma de la música religiosa", Recerca Musicològica, 11-12 (1991-1992), pp. 157-209.

: "Amorós Sirvent, Eugenio", en Diccionario de la Música Española e Hispanoamericana, dir. Emilio Casares, 10 vols., Madrid, Sociedad General de Autores y Editores, 1999-2002, vol. 1 (1999), p. 421.

: "Baixauli Biguer, Mariano", en Diccionario de la Música Española e Hispanoamericana, dir. Emilio Casares, 10 vols., Madrid, Sociedad General de Autores y Editores, 1999-2002, vol. 2 (1999), pp. 61-62.

: "Cecilianismo", en Diccionario de la Música Española e Hispanoamericana, dir. Emilio Casares, 10 vols., Madrid, Sociedad General de Autores y Editores, 1999-2002, vol. 3 (1999), pp. 459-462.

: "Congresos de Música Religiosa", en Diccionario de la Música Española e Hispanoamericana, dir. Emilio Casares, 10 vols., Madrid, Sociedad General de Autores y Editores, 1999-2002, vol. 3 (1999), pp. 876-878.

: "Cien años de asociaciones de música religiosa", Cuadernos de música Iberoamericana, 8-9 (2001), pp. 287-306.

: "Hilarión Eslava (1807-1878), precursor del cecilianismo en España”, Príncipe de Viana, 238 (2006), pp. 577-607.

: Nemesio Otaño: medio siglo de música religiosa en España, Madrid, Instituto Complutense de Ciencias Musicales, 2010.

López Carranza, Ma Cruz: "Plasencia Aznar, Juan Bautista", en Diccionario de la Música Española e Hispanoamericana, dir. Emilio Casares, 10 vols., Madrid, Sociedad General de Autores y Editores, 1999-2002, vol. 8 (2001), p. 857. 
López-Chavarri Andújar, Eduardo: Cien años de Música Valenciana 1878-1978. Valencia, Caja de Ahorros de Valencia, 1978.

: Cien años de historia del Conservatorio de Valencia, Valencia, Conservatorio Superior de Música y Escuela de Arte dramático de Valencia, 1979.

: Breviario de Historia de la música valenciana, Valencia, Editorial Piles, 1985.

: 100 años del Certamen Internacional de Bandas de Música, València, Ajuntament de València, 1986.

: Compositores Valencianos del siglo XX: del Modernismo a las Vanguardias, Valencia, Generalitat Valenciana, 1992.

López-Chavarri Marco, Eduardo: "Lo ball dels nanos", en Cuentos Lírics, Valencia, Imprenta F. Doménech, 1907.

Loras Villalonga, Roberto: La Asociación de profesores músicos de Santa Cecilia desde su fundación a 2002, Valencia, Editorial Mare Nostrum, 2003.

: El Patriarca de la Música Valenciana, Valencia, Universidad Politécnica de Valencia, 2007.

: Estudio de los métodos de solfeo españoles en el siglo XIX y principios del XX, Tesis doctoral, Valencia, Universidad Politécnica de Valencia, Bellas Artes, Departamento de Comunicación Audiovisual, Documentación e Historia del Arte, 2008

Lull Martí, Enrique: Jesuitas y pedagogía: El Colegio de San José en la Valencia de los años veinte, Madrid, Universidad Pontificia Comillas, 1997.

\section{$\mathbf{M}$}

Madoz, Pascual: Diccionario Geográfico-estadístico-histórico de Alicante, Castellón y Valencia, 2 vols., Valencia, Edicions Alfons El Magnànim, 1987.

Mancebo, María Fernanda: La Universidad de Valencia: de la monarquía a la república, 1919-1939, Valencia, Universitat de Valencia, 1994.

Marco, Tomás: Pensamiento musical y siglo XX, Madrid, Fundación Autor, 2002.

Martí, Manuel: "La societat valenciana de la Restauració (1875-1814): estabilització del domini burgés i contestació renovada", en Història del País Valencià, coord. Ernest Belenguer, 6 vols., Barcelona, Edicions 62, 1988-2006, vol. 5 (1990), pp. 137-166.

Martín Tenllado, Gonzalo: La música en Málaga durante el siglo XIX. Ocón: música nacionalista en la catedral de Málaga, Granada, Universidad de Granada, 1991.

Martínez Aloy, José: Geografía General del Reino de Valencia. Provincia de Valencia, vol. 1., Barcelona, A. Martin, 1920. 
Martínez Anguita, $\mathrm{M}^{\mathrm{a}}$ Rosa: La música civil y religiosa en Jaén en el siglo XIX, Jaén, Universidad de Jaén, 1997.

: La Música y los músicos en el Jaén del siglo XIX, Jaén, Concejalía de Cultura, Servicio de Publicaciones, 2000.

Martínez Bonafé, Àngels: Ensenyament, burguesía i liberalisme, Valencia, Diputació Provincial, 1985.

Martínez del Fresno, Beatriz: "El pensamiento nacionalista en el ámbito madrileño (1900-1936). Fundamentos y paradojas", en De Musica Hispana et aliis. Miscelánea en honor al profesor Dr. José López-Calo en su $65^{\circ}$ cumpleaños, coord. Emilio Casares y Carlos Villanueva, Santiago de Compostela, Universidad de Santiago, Servicio de Publicaciones, 1990, pp. 351-397.

: "Nacionalismo e internacionalismo en la música española de la primera mitad del siglo XX", Revista de Musicología, 16/1 (1993), pp. 640-657.

: “Asturias en la obra de Manuel del Fresno (1900-1936)", en Canciones de dentro. Música asturiana para voz y piano, Oviedo, Caja de Asturias, Fundación Príncipe de Asturias, 1996, pp. 111-140

: Julio Gómez: una época de la música española, Madrid, Instituto Complutense de Ciencias Musicales, 1999.

Martínez Gallego, Francesc Andreu: "Banquete, tertulia y partido: agentes de la política urbana", en Historia de Valencia, dir. Antoni Furió, Valencia, Prensa Valenciana (Levante) y Universitat de València, 1999, pp. 442-444.

: "Vientos de progreso: la industria y el comercio a mediados del Ochocientos", en Historia de Valencia, dir. Antoni Furió, Valencia, Prensa Valenciana (Levante) y Universitat de València, 1999, pp. 460-462.

: "Entre el confort y el ocio: la sociabilidad ciudadana en la segunda mitad del siglo XIX", en Historia de Valencia, dir. Antoni Furió, Valencia, Prensa Valenciana (Levante) y Universitat de València, 1999, pp. 517-520.

Martínez Torner, Eduardo: Danzas Valencianas, Barcelona, Centro de Estudios Históricos del País Valenciano, 1938.

Micó Terol, Elena: Amancio Amorós Sirvent (1854-1925), compositor, pianista y pedagogo. Catálogo de su producción y aproximación a su estilo compositivo, Trabajo de Investigación Tutelada para la Obtención del D.E.A., dirigido por María Gembero Ustárroz (Granada, Universidad de Granada, 2004, 239 pp.).

: "Amanci Amorós Sirvent i la seua producció musical profana", Almaig, estudis i documents, 20 (2004), pp. 104-108. 
: "Amanci Amorós Sirvent: Compositor i pedagog", Actas del II Congreso de l'Institut d' estudis de la Vall d'Albaida (Ontinyent, 2004), Ontinyent, Institució Alfons El Magnànim, 2008, pp. 867-886.

Mido: “La Federación Coral Valenciana”, Boletín Musical, 20-IV-1897, p. 899.

: “La Federación Coral Valenciana”, Boletín Musical, 10-V-1897, p. 912.

Millet i Loras, Lluís: "Millet i Pagès, Lluís", en Diccionario de la Música Española e Hispanoamericana, dir. Emilio Casares, 10 vols., Madrid, Sociedad General de Autores y Editores, 1999-2002, vol. 7 (2000), pp. 576-581.

Miranda, Ricardo: "A tocar, señoritas, una mirada al repertorio mexicano para piano durante el siglo XIX”, Música Iberoamericana de salón, Actas del Congreso Iberoamericano de Musicología, coord. José Peñín, Caracas, Fundación Vicente Emilio Sojo, 2000, vol 1, pp. 131-171.

Montlleó Peris, Rosa: "La revolución Gloriosa y la Primera República", en Historia de Valencia, dir. Antoni Furió, Valencia, Prensa Valenciana (Levante) y Universitat de València, 1999, pp. 450-452.

Morales Villar, María del Coral: Los Tratados de canto en España durante el siglo XIX: técnica vocal e interpretación de la música lírica, Tesis doctoral dirigida por Emilio Ros Fábregas, Granada, Universidad de Granada, Departamento de Historia del Arte y Música, 2008.

: La agrupación lírica Francisco Alonso (1963-1973): historia de una compañia de zarzuela de Granada, Granada, Junta de Andalucía, Consejería de Cultura, 2003.

Muneta, Jesús Ma: "Alcácer Martínez, José María”, en Diccionario de la Música Española e Hispanoamericana, dir. Emilio Casares, 10 vols., Madrid, Sociedad General de Autores y Editores, 1999-2002, vol. 1 (1999), p. 217.

Muñoz, Adelaida/Cabeza Rodríguez, Antonio: "Algunos aspectos de la vida musical de Palencia en el siglo XIX: Las Bandas de Música", Revista de Musicología, 14/1-2 (1991), pp. 279-296.

\section{$\mathbf{N}$}

Nagore Ferrer, María: "Orígenes del movimiento coral en Bilbao", Revista de Musicología, 14/1-2 (1991), pp. 125-134.

: "La música coral en España en el siglo XIX”, en La música española en el siglo $X I X$, eds. Emilio Casares y Celsa Alonso, Gijón, Servicio de Publicaciones de la Universidad de Oviedo, 1995, pp. 425-462.

: "Sociedades filarmónicas y de conciertos en el Bilbao del siglo XIX", Cuadernos de Arte de la Universidad de Granada, 26 (1995), pp. 195-206. 
: "La vida zarzuelística en Bilbao (1850-1936)", en La zarzuela en España e Hispanoamérica. Centro y periferia, 1800-1950, Actas del Congreso Internacional (Madrid, 1995), Cuadernos de Música Iberoamericana, 2-3 (199697), pp. 399-408.

: "Una aportación al estudio de la reforma de la música religiosa en España: el Congreso Internacional de Música Sacra (Bilbao, 1896)”, Revista de Musicología, 20/1 (1997), pp. 605-615.

: La revolución coral. Estudio sobre la Sociedad Coral de Bilbao y el movimiento coral Europeo (1800-1936), Madrid, Instituto Complutense de Ciencias Musicales, 2001.

: "Un aspecto del asociacionismo musical en España: las sociedades corales", Cuadernos de Música Iberoamericana, 8-9 (2001), pp. 211-226.

: "Tradición y renovación en el movimiento de reforma de la música religiosa anterior al Motu Proprio", Revista de Musicología, 27/1 (2004), pp. 211-233.

: "La Escuela Municipal de Música de Pamplona: una institución pionera en el siglo XIX”, Príncipe de Viana, 238 (2006), pp. 537-560.

Ninyoles, Lluís: Conflicte lingüístic valencià, València, Eliseu Climent, 1978.

Nommick, Yvan: "Sobre las implicaciones del Motu Proprio de San Pío X en materia de composición musical”, Revista de Musicología, 27/ 1 (2004), pp. 125-136.

\section{$\mathbf{O}$}

Oleza, J./Lluch, J. (eds.): Vicente Blasco Ibáñez 1898-1998. La vuelta al siglo de un novelista. Actas del Congreso Internacional (Valencia, 1998), Valencia, Direcció General del Llibre i Coordinació Bibliotecària, 2 vols., 2000.

: "Novelas mandan. Blasco Ibáñez y la musa realista de la modernidad", en Vicente Blasco Ibáñez, 1898-1998, la vuelta al siglo de un novelista: Actas del Congreso Internacional (Valencia, 1998), Valencia, Direcció General del Llibre i Coordinació Bibliotecària, 2000, pp. 19-51.

Oliver, Antonio: Medio siglo de artistas murcianos (1900-1950), Murcia, Patronato de Cultura de la Diputación, 1952.

Oliver, Juan A: La educación de la mujer en Valencia, Valencia: Manuel Pau, 1913.

Olmedo de Cerdá, $\mathrm{M}^{\mathrm{a}}$ Francisca: Callejeando por Valencia, Valencia, Carena editors, 2003.

Oriola Velló, Frederic: "L'article 24 de Pius X: La Comissió de Música Sagrada a València (1904-1936)", Anales Valentinos, 68 (2008), pp. 341-380. 
: "La música Sagrada a la Universitat Pontifícia de València (1896-1931)", Anales valentinos, 70 (2009), pp. 371-405.

Otaño, Nemesio: "El canto de las mujeres en la iglesia”, Razón y Fe, 61/244 (1921), pp. 451-472.

Pacini, Giovanni: Saffo, Milano, Stabilimento Ricordi (sf).

Palacios Sanz, José Ignacio: “Aproximación histórica a la capilla de música en la catedral de Burgo de Osma durante el siglo XIX: de Bernardo Pérez al Motu Propio", Revista de Musicología, 14/1-2 (1991), pp. 549-560.

Pardo, Fermín/Reig, Jordi: "Folclore", en Diccionario de la Música Valenciana, dir. Emilio Casares, 2 vols., Madrid, Instituto Complutense de Ciencias Musicales, Institut Valencià de la Música, vol. 1 (2006), pp. 361-385.

Pavia, Josep: "Pervivencia de la obra de Felip Pedrell en la musicografía española: Tesoro Sacro Musical”, Recerca Musicologica, 11-12 (1991-1992), pp. 275-303.

Pedrell, Felipe (dir.): Diccionario Técnico de la Música, escrito con presencia de las obras más notables en este género, publicadas en otros países e ilustrado con 117 grabados y 51 ejemplos de música y seguido de un suplemento, Barcelona, Isidro Torres Oriol, $2^{\mathrm{a}}$ ed., 1894.

: Hispaniae Schola Musica Sacra, Opera varia (saecul. XV, XVI, XVII et XVIII) diligenter excerpta, accurate revisa, sedulo concinnata a Philippo Pedrell, 8 vols., Barcelona, Juan Bautista Pujol y Cia, 1894-1898.

: "Amorós Sirvent, Amancio", en Diccionario biográfico y bibliográfico de músicos y escritores de música españoles, portugueses e hispanoamericanos antiguos y modernos, Barcelona, Victor Berdós y Feliu, vol. 1, 1897, p. 63.

: Emporio científico e histórico de organología musical antigua española, Barcelona, Juan Gili, 1901.

: Jornadas de Arte, París, Ed. Garnier, 1911.

: Las formas pianísticas: orígenes y transformaciones de las formas instrumentales, estudiadas en los instrumentos de teclado moderno, Valencia, Manuel Villar, 1918.

Peláez Malagón, José Enrique: “Amorós Sirvent, Amancio", en Historia de la Música Catalana, Valenciana i Balear, dir. Xosé Aviñoa, 13 vols., Barcelona, Edicions 62, 1999-2004, vol. 1 (1999), p. 41.

: “Teatros”, en Diccionario de la Música Valenciana, dir. Emilio Casares, 2 vols., Madrid, Instituto Complutense de Ciencias Musicales, Institut Valencià de la Música, vol. 2 (2006), p. 485. 
: "Las revistas ilustradas valencianas en el siglo XIX. Estudio, comentario y catálogo de las publicaciones periódicas lustradas de la época 1890-1900", consultado en www. Tebeosfera.com/libris/RevistasValencianas el 10-IV-2009.

Pena, José/Anglés, Higinio: Diccionario de la música, Barcelona, Labor, 1954.

Pérez Embid, Florentino: Enciclopedia de la cultura española, 1962.

Pérez Gascón, Pascual: Método de solfeo y principios de canto aplicables en la escuela y colegios. Guía para la Enseñanza, Valencia, Imprenta de José Rius, 1857.

Pérez Gutiérrez, Mariano: Diccionario de la Música y los Músicos, Madrid, Ediciones Istmo, 1985.

: "Los Conservatorios españoles. Historia, Reglamentaciones, planes de estudio, centros, profesorado y alumnado", Música y Educación, 15/6 (1993), pp. 17-48.

Pérez Jorge, Vicente: La Música en Ontinyent, Ontinyent, Caixa d'Estalvis d'Ontinyent, 1979.

Peset Reig, Mariano [et al.]: Historia de la Universidad de Valencia. La Universitat liberal, vol. 3, València, Universitat de València, 2000.

Picó Pascual, Miguel A.: "La recopilación de canciones y bailes populares efectuada a finales del siglo XIX por José Inzenga Castellanos en tierras valencianas y murcianas I", Revista de Folklore, 187 (1996), pp. 3-13.

: "La recopilación de canciones y bailes populares efectuada a finales del siglo XIX por José Inzenga Castellanos en tierras valencianas y murcianas II", Revista de Folklore, 200 (1997), pp. 55-59.

: "Eduardo Ximénez Cos (1824-1900), patriarca de la investigación folklórico musical valenciana", Revista de Folklore, 274 (2003), pp. 134-135.

: "La aportación musicológica del canónigo Vicente Ripollés Pérez", Revista de Musicología, Actas del Simposio Internacional El Motu Proprio de San Pío X y la música (1903-2003), 27/1 (2004), pp. 287-292.

Pinero, Carmen: La enseñanza de las Bellas Artes en Valencia y su repercusión social, Valencia, Facultad de Bellas Artes, Universidad Politécnica de Valencia, 2003.

Piñón, Luis: "Los ensanches de Valencia", en Historia de Valencia, dir. Furió, A., Valencia, Prensa Valenciana (Levante) y Universitat de València, 1999, pp. 503505.

Pitarch Alfonso, Carles: "El cant valencià d'estil: conceptos para su comprensión desde una perspectiva formal, funcional e histórica", en Actas del III Congreso de la Sociedad Ibérica de Etnomusicología (Benicàsim, 1997), ed. Ramón Pelinsky y Vicent Torrent, Sabadell, La Mà de Guido, 1998, pp. 299-311. 
: El cant valencià d'estil: una aproximació conceptual $i$ històrica des de l'etnomusicologia, Aldaia, Associació de Música Tradicional d'Aldaia, 1997.

: "La festa en el Corpus Christi a València: de les Roques i els Jocs a les danses tradicionals", en El teatre en la festa valenciana, dir. Antonio Ariño, València, Consell Valencià de Cultura, 1999, pp. 173-198.

Pizcueta, Félix: "Discurs de gràcies del Sr. President en Feliu Pizcueta", en Excel.lències de la llengua llemosina: discurs panegirich llegit en la solemne sessió inaugurativa de Lo Rat Penat per Constantí Llombart, Valencia, Emili Pasqual, 1878, pp. 85-87.

Pons, Anaclet/Serna, Justo: “Ayuntamiento y negocios político", en Historia de Valencia, dir. Antoni Furió, Valencia, Prensa Valenciana (Levante) y Universitat de València, 1999, pp. 444-446.

: "La demolición de las murallas", en Historia de Valencia, dir. Antoni Furió, Valencia, Prensa Valenciana (Levante) y Universitat de València, 1999, pp. 501503.

Preciado, Dionisio: "Don Hilarión Eslava y su Método Completo de Solfeo", en Monografia de Hilarión Eslava. Primer Centenario, Pamplona, Diputación Foral de Navarra, Institución Príncipe de Viana, 1978, pp. 215-263.

Primitiu, Nicolau: Renaixença i Romanticismo, València, Edicions Acció, 1935.

\section{Q}

Querol i Gavaldà, Miquel: "Pedrell i els altres compositors i musicòlegs. Pedrell, primer historiador de la música espanyola", Recerca Musicològica, 11-12 (1991-1992), pp. 5-15.

Querol Rosso, Leopoldo: "Estilo y significación del Romanticismo de Chopin”, Archivo de Arte Valenciano, 41 (1970), pp. 42-49.

$\mathbf{R}$

Rainbow, Bernarr: "Wilhem, Guillaume Louis Bocquillon", en The New Grove Dictionary of Music and Musicians, Second Revised Edition, ed. Stanley Sadie, 29 vols., London, MacMillan, vol. 27 (2002), p. 387.

Ramos López, Pilar: "Pastorelas and the pastoral tradition in 18th-century Spanish villancicos", en Devotional Music in the Iberian World, 1450-1800: The Villancico and related genres, eds. Tess Knighton y Álvaro Torrente, Aldershot, Ashgate, 2007, pp. 283-306.

Ranch, Amparo: "La música en la Real Sociedad Económica de Amigos del País de Valencia”, Anales de la Real Sociedad Económica de Amigos del País de Valencia 1978-88 (1989), pp. 61-80. 
Reig, Jordi: "Principals trets musicals del cant d'estil", en Actas del III Congreso de la Sociedad Ibérica de Etnomusicología, (Benicàsim, 1997), eds. Ramón Pelinsky y Vicent Torrent, Sabadell, La Mà de Guido, 1998, pp. 319-330.

: "U", en Diccionario de la Música Valenciana, dir. Emilio Casares, 2 vols., Madrid, Instituto Complutense de Ciencias Musicales, Institut Valencià de la Música, vol. 2 (2006), pp. 517-518.

: "U i dos", en Diccionario de la Música Valenciana, dir. Emilio Casares, 2 vols., Madrid, Instituto Complutense de Ciencias Musicales, Institut Valencià de la Música, vol. 2 (2006), p. 518.

Revuelta González, Manuel: Compañia de Jesús en la España Contemporánea, vol. 3, Madrid, Universidad Pontificia Comillas, 1984.

Rey García, Emilio/Pliego Andrés, Víctor: "La recopilación de la música popular española en el siglo XIX: cien canciones en cien años", Revista de Musicología, 14 (1991), pp. 355-374.

Rey García, Emilio: "Historia del Conservatorio" en

http://www.educa.madrid.org/web/csm.realconservatorio.madrid/con-historia.htm (Consultado el 1-III-2010).

Rey Marzal, Arturo: "Relieves de la Semana. La patrona de los Músicos", La Semana Gráfica, 6- XII-1930.

[Ribera, Juan de]: Constituciones de la Capilla del Colegio y Seminario de Corpus Christi, Valencia, Imprenta de Antonio Bordázar, 1739.

Ricart Matas, Josep: Diccionario biográfico de la música, Barcelona, Iberia, S. A., 1966, p. 37.

Ripollés Pérez, Vicente: Memoria sobre la Reforma de la Música Religiosas en la Capilla del Real Colegio de Corpus Christi de Valencia que a la Excma. Visita presenta Don Vicente Ripollés, presbitero, maestro de capilla, Madrid, Imprenta y Litografía de la Viuda e Hijos de Terceño, 1897.

: "Dramas litúrgicos que tienen por aumento la parábola evangélica de las Virgenes prudentes et fatuae y el hecho real de la Resurrección de Jesucristo", Anales de la Real Academia de Cultura Valenciana, 1 (1928), pp. 47-80.

: "Breves anotaciones a la epístola farçida de San Esteban", Boletín de la Sociedad Castellonense de Cultura, 22 (1946)), pp. 127-166.

Roig Civera, Antonio: Los dos esclavos, Libreto de la zarzuela, Valencia, Imprenta Emilio Pascual, 1886.

Roig Condomina, Vicente: "El Ateneo Científico, Literario y Artístico de Valencia y su aportación a las artes en el último tercio del siglo XIX", Ars Longa, 6 (1995), pp. 107-114. 
: "Algunes notes sobre els inicis del Cercle de Belles Arts de València i la seua activitat en el segle XIX", Ars Longa, 7-8 (1996-97), pp. 239-245.

: "El Iris (1878-1882): Un ejemplo de Sociedad Recreativa valenciana del siglo XIX promotora del arte", Ars Longa, 9-10 (2000), pp. 239-246.

Ruiz de Lihory, José: La música en Valencia, diccionario biográfico y crítico, Valencia, Tip. Doménech, 1903.

Ruiz Monrabal, Vicente: Historia de las sociedades musicales de la Comunidad Valenciana: Les Bandes de Música i la seua Federació, 2 vols., Valencia, Federación de Sociedades Musicales de la Comunidad Valenciana, 1993.

Ruiz Rodrigo, Cándido/Palacio Lis, Irene: Pauperismo y educación, siglos XVIII y XIX: apuntes para una historia de la educación social en España, Valencia, Universitat de València, 1995.

Ruiz Torres, Pedro: “Crisi del sistema moderat i revolució democràtica 1866-1874”, en Història del País Valencià, coord. Ernest Belenguer, 6 vols., 1988-2006, Barcelona, Edicions 62, vol. 5 (1990), pp. 117-135.

\section{$\mathbf{S}$}

Sala Giner, Daniel: Història de Lo Rat Penat, dir. Federico Martínez Roda, Valencia, Lo Rat Penat, 2000.

Salas Villar, Gemma: "Santiago de Masarnau y la implantación del piano romántico en España”, Cuadernos de Música Iberoamericana, 4 (1996), pp. 197-222.

Salaün, Serge: "La zarzuela híbrida y castiza", en La zarzuela en España $e$ hispanoamérica. Centro y periferia, 1800-1950, Actas del Congreso Internacional (Madrid, 1995), Cuadernos de Música Iberoamericana, 2-3 (1996-1997), pp. 235255.

Salazar, Adolfo: La Música contemporánea en España, Madrid, Ediciones La Nave, 1930.

: "Edición Musical”, Revista Musical Hispano-americana, enero 1915, pp. 1516.

Sales, Jaime/Espí, José: "Creación de un Instituto o Escuela de Música", Boletín de la Real Sociedad Económica de Amigos del País de Valencia, 16 (1874), pp. 366368.

Saldoni, Baltasar: Diccionario biográfico-bibliográfico de efemérides de músicos españoles, Madrid, Imprenta de Antonio Pérez Dubrull, 1880.

Salvá, A. V.: "La Sociedad Filarmónica. Su vida y su estado actual", Almanaque de las Provincias para 1924, pp. 85-89. 
: “A propósito de unos cuadros del Conservatorio", en Almanaque de las Provincias para 1948, pp. 195-198.

Sánchez de Andrés, Leticia: "El pensamiento estético del Krausismo español”, Revista de Musicología, 28/2 (2005), pp. 961-976.

Sánchez Martínez, Ma Almudena: "El pianista y compositor español José Tragó y Arana (1856-1934)”, Revista de Musicología, 28/2 (2005), pp. 1597-1607.

Sánchez Sánchez, Víctor: "Tomás Bretón y el regeneracionismo. Una reflexión sobre la valoración de la música en el contexto cultural de la España de 1898", Cuadernos de Música Iberoamericana, 6 (1998), pp. 35-48.

: Tomás Bretón: un músico de la Restauración, Madrid, Instituto Complutense de Ciencias Musicales, 2002.

Sanchis Guarner, Manuel: Les generacions literàries en la Renaixença valenciana, València, Lo Rat Penat, 1968.

: Renaixença al País Valencià, Valencia, Colecció 3 i 4, 1982.

: El sector progresista de la Renaixença valenciana, Valencia, Universitat de València, 1985.

: La ciutat de València, Síntesi d'història i de geografia urbana, Valencia, Generalitat Valenciana, Consell Valencià de Cultura, 1997.

: "Democràcia i industrialització gens completes (1868-1909)", en La ciutat de València, Valencia, Generalitat Valenciana, Consell Valencià de Cultura, 1997, pp. 487-556.

Sancho García, Manuel: El compositor Salvador Giner. Vida y obra musical, Valencia, Ajuntament de València, 2002.

: El sinfonismo en Valencia durante la restauración (1878-1916), Tesis doctoral, Valencia, Universitat de València, Servei de Publicacions, 2003.

: "Los inicios del sinfonismo en Valencia: La Sociedad de Conciertos de José Valls", Revista de Musicología, 27/2 (2004), pp. 979-997.

: "Orfeonismo y canto coral en Valencia (1850-1910)", Revista de Musicología, 30/ 1 (2007), pp. 103-126.

: Romanticimo y música instrumental en Valencia (1832-1916), Valencia, Institució Alfons El Magnànim, 2007.

Seguí, Salvador: "Por las rutas de nuestro folklore musical. Un valioso legado del padre Baixauli”, Levante, 9-XII-1976. 
: Cancionero Musical de la provincia de Valencia, Valencia, Institución Alfonso el Magnánimo, Diputación Provincial de Valencia, 1980.

Seguí, Salvador/Pardo, Fermín: Danzas del Corpus Valenciano. Cuadernos de Música Folklórica Valenciana, 1 (1978).

Serrano Pla, Eduardo: Discursos leídos en las sesiones literario-musicales celebradas por la Sociedad Económica de Amigos del País de Valencia en la inauguración de los cursos $5^{\circ}, 7^{\circ}$ y $8^{\circ}$ por el socio Don Eduardo Serrano Pla, Valencia, Imprenta de Nicasio Rius, 1880.

: "Amancio Amorós”, Ilustración Musical Hispanoamericana, 15-III-1891, pp. 477- 479 .

Simbor Roig, Vicent: Els orígens de la Renaixença Valenciana, València, Institut de Filología Valenciana, 1980.

: "La Renaixença al País Valencià”, Caplletra, 4 (1988), pp. 9-41.

: "La Renaixença: entre Teodor Llorente y Constantí Llombart", en Historia de Valencia, dir. Antoni Furió, Valencia, Prensa Valenciana (Levante) y Universitat de València, 1999, pp. 492-494.

Simó, Trinidad: "Arquitectura y urbanismo, 1874-1920", en Historia del Arte Valenciano, dir. Vicente Aguilera Cerni, 6 vols., Valencia, Consorci d'editors valencians, 1986-1990, vol. 5 (1987), pp. 46-53.

Sirera, José Luis: "La cultura de principios de siglo", en Historia del País Valenciano, coord. Pedro Ruiz Torres, Madrid, Editorial Planeta, vol. 6, 1981, pp. 425-446.

: El Teatre Principal de València, València, Institució Valenciana d'Estudis i Investigació, 1986.

: Història de la literatura valenciana, Valencia, Edicions Alfons el Magnànim, 1995.

Sobrino Sánchez, Ramón: "La Música sinfónica en el siglo XIX”, en La Música española en el siglo XIX, eds. Emilio Casares y Celsa Alonso, Gijón, Servicio de Publicaciones de la Universidad de Oviedo, 1995, pp. 279-323.

: “Amorós Sirvent, Amancio", en Diccionario de la Música Española e Hispanoamericana, dir. Emilio Casares, 10 vols., Madrid, Sociedad General de Autores y Editores, 1999-2002, vol. 1 (1999), pp. 420-421.

: "Mendizábal de Sagastume, Manuel A.", en Diccionario de la Música Española e Hispanoamericana, dir. Emilio Casares, 10 vols., Madrid, Sociedad General de Autores y Editores, 1999-2002, vol. 7 (2000), pp. 433-434.

: "La Sociedad de Conciertos de Madrid, un modelo de sociedad profesional", Cuadernos de Música Iberoamericana, 8-9 (2001), pp. 125-147. 
: "Amorós Sirvent, Amancio", en Diccionario de la zarzuela. España e Iberoamérica, dir. Emilio Casares, Madrid, Instituto Complutense de Ciencias Musicales, 2002, p. 90.

: "La ópera española entre 1850 y 1874: Bases para una revisión crítica", en $L a$ ópera en España e Hispanoamérica, eds. Emilio Casares y Álvaro Torrente, 2 vols., Madrid, Instituto Complutense de Ciencias Musicales, 2002, vol. 2, pp. 77142.

: “Amorós Sirvent, Amancio", en Diccionario de la Música Valenciana, dir. Emilio Casares, 2 vols., Madrid, Instituto Complutense de Ciencias Musicales, Institut Valencià de la Música, vol. 1 (2006), pp. 47-48.

: y Cortizo, M ${ }^{\mathrm{a}}$ Encina: "Asociacionismo musical en España", Cuadernos de Música Iberoamericana, 8-9 (2001), pp. 11-16.

Solaz Albert, Rafael: Guía de las guías de Valencia, 1700-1975: fragmentos de historia popular de la ciudad, Valencia, Ayuntamiento de Valencia, 2002.

Sol-La: “La Federación Coral Valenciana”, Boletín Musical, 30-IV-1897, pp. 904-905.

Sopeña Ibáñez, Federico: Historia crítica del Conservatorio de Madrid, Madrid, Ministerio de Educación y Ciencia, Dirección General de Bellas Artes, 1967.

Suárez Pérez, Héctor-Luis: "Panorama musical del último cuarto del siglo XIX en una pequeña ciudad del Noroeste Ibérico", Revista de Musicología, 14/1-2 (1991), pp. 297-306.

Subirá, José: Historia de la Música Española e Hispanoamericana, Barcelona, Salvat, 1958.

\section{$\mathbf{T}$}

Temprano, Andrés: "Panorama actual de la música religiosa en España. José $\mathrm{M}^{\mathrm{a}}$ Alcácer”, Tesoro Sacro Musical, 43 (1972), pp. 42-47.

Tena, Vicente: Obras musicales de Amancio y Eugenio Amorós y Ramón Esplugues, Agullent, Ajuntament d'Agullent, 1978.

Tieles Ferrer, Cecilio: "Ruiz Espadero, Nicolás”, en Diccionario de la Música Española e Hispanoamericana, dir. Emilio Casares, 10 vols., Madrid, Sociedad General de Autores y Editores, 1999-2002, vol. 9 (2002), pp. 484-488.

Tomàs, Margalida: "Renaixença", en Gran Enciclopedia Catalana, dir. Jordi Carbonell, 16 vols., Barcelona, Enciclopedia Catalana S. A, 1969-1983, vol. 12 (1978), pp. 466-467.

Tormo, Enrique: "L'Art valencià del segle XX”, en Història del Pais Valencià, coord. Ernest Belenguer, 6 vols., Barcelona, Edicions 62, 1988-2006, vol. 5 (1990), pp. 411-434. 
Torres Mulas, Jacinto: "El Romanticismo musical; algunas premisas", Cuadernos de música. El romanticismo Musical Español, 2 (1982), pp. 3-13.

: "Orquestas y sociedades", en España en la Música de Occidente, Actas del Congreso Internacional (Salamanca, 1985), eds. Emilio Casares, José LópezCalo, Ismael Fernández de la Cuesta, 2 vols., Madrid, Instituto Nacional de Artes Escénicas y de la Música, 1987, vol. 2, pp. 351-368.

: Las publicaciones periódicas musicales en España (1812-1990). Estudio críticobibliográfico. Repertorio general, Madrid, Instituto de Bibliografía musical, 1991.

Tramoyeres Blasco, Luis: "Lo Rat Penat en el escudo de Valencia", Boletín de la Academia de la Historia, Valencia, vol. 38, 1901, pp. 438-445.

Uría Líbano, Fidela: Música asturiana entre 1860 y 1934. Vida, obra y catálogo de Victor Sáenz, Anselmo González del Valle, Baldomero Fernández, Oviedo, Servicio de Publicaciones del Principado de Asturias, 1997.

\section{V}

Valor Calatayud, Ernesto: "García Muñí, Enrique José”, en Diccionario de la Música Española e Hispanoamericana, dir. Emilio Casares, 10 vols., Madrid, Sociedad General de Autores y Editores, 1999-2002, vol. 5 (2001), p. 481.

Vázquez Tur, Mariano: El piano y su música en el siglo XIX en España, Santiago de Compostela, Tesis Doctoral, Universidad de Santiago, Facultad de Geografía e Historia, 1988.

: "Piano de salón y piano de concierto en la España del siglo XIX", Revista de Musicología, 14 / 1-2 (1991), pp. 225-248.

: "Barcarola", en Diccionario de la Música Española e Hispanoamericana, dir. Emilio Casares, 10 vols., Madrid, Sociedad General de Autores y Editores, 19992002, vol. 2 (1999), pp. 217-218.

: "Capricho", en Diccionario de la Música Española e Hispanoamericana, dir. Emilio Casares, 10 vols., Madrid, Sociedad General de Autores y Editores, 19992002, vol. 3 (1999), p. 141.

: "Romanza", en Diccionario de la Música Española e Hispanoamericana, dir. Emilio Casares, 10 vols., Madrid, Sociedad General de Autores y Editores, 19992002, vol. 9 (2002), p. 372.

Vega Toscano, Ana María: "Métodos españoles de piano en el siglo XIX”, Cuadernos de música Iberoamericana, 5 (1998), pp. 129-145. 
: "La escuela española de piano en el siglo XIX: Métodos, estudios y otros ejemplos de literatura pedagógica", Música Iberoamericana de salón, Actas del Congreso Iberoamericano de Musicología, coord. José Peñín, Caracas, Fundación Vicente Emilio Sojo, 2000, vol 1, pp. 93-130.

Vegas, Ignacio: Alma de oración y de apostolado. Santa María Micaela del Santísimo Sacramento, Madrid, Talleres Gráficos de Ediciones Castilla, S. A., 1965.

Verger, Eduard J.: "La poesia valenciana de la Restauració (1874-1902)", La Ilustració poètica metropolitana \& continental, Versos $i$ altres escrits, Articles $i$ notes de crítica literaria. Artículo online http://perso.wanadoo.es/lipmic/verger/, consultado en línea el 10-IV-2009.

Vidal Corella, Vicente: "El humorista Don Salvador Giner", en Las Provincias, 14-XI1971.

: El maestro Santiago Lope, Valencia, Publicaciones del Conservatorio de Música y Escuela de Arte Dramático de Valencia, 1979.

Vidal Guillen, Antonio/Torrent, Vicent: "Sociedades Musicales", en Diccionario de la Música Valenciana, dir. Emilio Casares, 2 vols., Madrid, Instituto Complutense de Ciencias Musicales, Institut Valencià de la Música, vol. 2 (2006), p. 459.

: El maestro Santiago Lope, Valencia, Conservatorio Superior de Música de Valencia, 1979.

Virgili Blanquet, $\mathrm{M}^{\mathrm{a}}$ Antonia: "Felipe Pedrell y Luis Villalba. Correspondencia inédita", Recerca Musicologica, 1 (1981), pp. 151-192.

: La música en Valladolid en el siglo XX, Valladolid, Ateneo, 1985.

: "La música religiosa en el siglo XIX español”, en La música española en el siglo $X I X$, eds. Emilio Casares y Celsa Alonso, Gijón, Servicio de Publicaciones de la Universidad de Oviedo, 1995, pp. 375-405.

: "El pensamiento musical y la estética de salón en la España del siglo XIX", Música Iberoamericana de Salón, Actas del Congreso Iberoamericano de Musicología, coord. José Peñín, Caracas, Fundación Vicente Emilio Sojo, 2000, vol. 1, pp. 11-39.

: "La reforma de la música sacra en España", La musique entre France et Espagne, dir. Luis Jambou, París, Presses de l'Université de París-Sorbonne, 2003, pp. 153-163.

: “Antecedentes y contexto ideológico de la recepción del Motu Proprio en España”, Revista de Musicología, 27/1 (2004), pp. 23-39.

: "La música religiosa en el siglo XIX español", Revista Catalana de Musicología, 2 (2004), pp. 181-202. 
: "El canto popular religioso y la reforma litúrgica en España (1850-1915)", Aisthesis, 47 (2010), pp. 175-186.

Vives, José Ma: "Coronado Cervera, Manuel”, en Diccionario de la Música Española e Hispanoamericana, dir. Emilio Casares, 10 vols., Madrid, Sociedad General de Autores y Editores, 1999-2002, vol. 3 (1999), p. 21.

\section{$\mathbf{Y}$}

Yanini Montés, Alicia: "La máquina electoral del caciquismo", en Historia de Valencia, dir. Antoni Furió, Valencia, Prensa Valenciana (Levante) y Universitat de València, 1999, pp. 481- 482.

\section{$\mathbf{Z}$}

Zamacois, Joaquín: De la Escuela Municipal de Música del año 1886 al Conservatorio Superior Municipal de Música del año 1963, Barcelona, Ayuntamiento de Barcelona, 1963. 